$0 / 19998 S D$
i19ANDIA REPORT

SAND92-2247 - UC-814

Unlimited Release

Printed September 1993

Yucca Mountain Site Characterization Project

\title{
Effect of Boundary Conditions on the Strength and Deformability of Replicas of Natural Fractures in Welded Tuff: Comparison Between Predicted and Observed Shear Behavior Using a Graphical Method
}

J. Wibowo, B. Amadei, S. Sture, R. H. Price, A. B. Robertson

\section{Prepared by}

Sandia National Laboratories

Albuquerque, Now Mexlco 87186 and Livermore, Callfornla 94550

for the United States Department of Energy

under Contract DE-ACO4-76DP00789 
"Prepared by Yucca Mountain Site Characterization Project (YMSCP) participants as part of the Civilian Radioactive Waste Management Program (CRWM). The YMSCP is managed by the Yucca Mountain Project Office of the U.S. Department of Energy, DOE Field Office, Nevada (DOE/NV). YMSCP work is sponsored by the Office of Geologic Repositories (OGR) of the DOE Office of Civilian Radioactive Waste Management (OCRWM)."

Issued by Sandia National Laboratories, operated for the United States Department of Energy by Sandia Corporation.

NOTICE: This report was prepared as an account of work sponsored by an agency of the United States Government. Neither the United States Government nor any agency thereof, nor any of their employees, nor any of their contractors, subcontractors, or their employees, makes any warranty, express $r$ implied, or assumes any legal liability or responsibility for the accuracy, completeness, or usefulness of any information, apparatus, product, or process disclosed, or represents that its use would not infringe privately owned rights. Reference herein to any specific commercial product, process, or service by trade name, trademark, manufacturer, or otherwise, does not necessarily constitute or imply its endorsement, recommendation, or favoring by the United States Government, any agency thereof or any of their contractors or subcontractors. The views and opinions expressed herein do not necessarily state or reflect those of the United States Government, any agency thereof or any of their contractors.

Printed in the United States of America. This report has been reproduced directly from the best available copy.

Available to DOE and DOE contractors from

Office of Scientific and Technical Information

PO Box 62

Oak Ridge, TN 37831

Prices available from (615) 576-8401, F'TS 626-8401

Available to the public from

National Technical Information Service

US Department of Commerce

5285 Port Royal Rd

Springfield, VA 22161

NTIS price codes

Printed copy: A10

Microfiche copy: A01 
SAND 92-2247

Unlimited Release

Printed September 1993

\title{
EFFECT OA' BOUNDARY CONDITIONS \\ ON THE STRENGTH AND DEFORMABILITY OF REPLICAS \\ OF NATURAL FRACTURES IN WELDED TUFF: \\ COMPARISON BETWEEN PREDICTED AND OBSERVED SHEAR \\ BEHAVIOR USING A GRAPHICAL METHOD
}

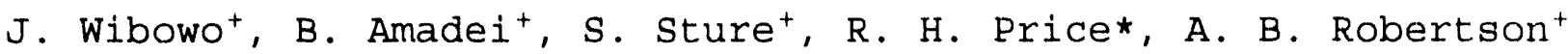 \\ +Department of Civil, Environmental, and Architectural Engineering \\ University of Colorado at Boulder \\ Boulder, Colorado 80309-0428 \\ *Geoscience Assessment and Valiuation Department \\ Sandia National Laboratories \\ Albuquerque, New Mexico 87185-5800
}

\begin{abstract}
Four series of cyclic direct-shear experiments were conducted on several replicas of three natural fractures and a laboratory-developed tensile fracture of welded tuff from Yucca Mountain to test the graphical load-displacement analysis method proposed by Saeb (1989) and Amadei and Saeb (1990). Eased on the results of shear tests conducted on several joint replicas under different levels of constant normal load ranging between 0.6 and $25.6 \mathrm{kips}(2.7$ and $113.9 \mathrm{kN})$, the shear behavior of joint replicas under constant normal stiffness ranging between 14.8 and $187.5 \mathrm{kips} / \mathrm{in}$. $(25.9$ and $328.1 \mathrm{kN} / \mathrm{cm})$ was predicted by using the graphical method. The predictions were compared to the results of actual shear tests conducted for the same range of constant normal stiffness. In general, a good agreement was found between the predicted and the observed shear behavior.
\end{abstract}

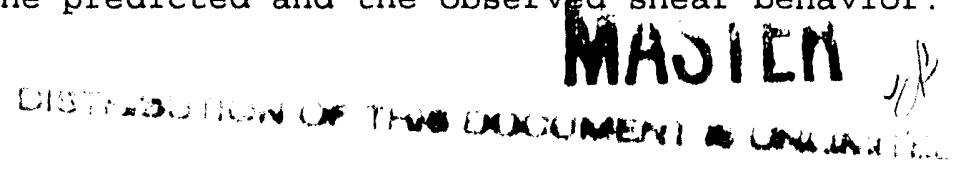


This report was prepared under the Yucca Mountain Project WBS number 1.2.4.2.1.2. The data in this report was developed subject to QA controls in QAGR S124212; the data is not qualified and is not to be used for licensing. 
1.0

2.0 PREDICTION OF FRACTURE BEHAVIOR UNDER CONSTANT NORMAL STIFFNESS

2.1 Graphical Method of Amadei and Saeb 2

2.2 Prediction

2.3 Comparison Between Predicted and Observed Behavior

2.3.1 Comparison for F4 Samples

2.3.2 Comparison for F3 Samples

2.3.3 Comparison for F2 Samples

2.34 Comparison for G2 Samples

3.0

CONCLUSIONS

4.0

REFERENCES

APPENDICES 


\section{FIGURES}

FIGURE

PAGE

Figure 1. Sample KR12F4, first-cycle forward shear:

(a) Shear load versus shear displacement,

(b) Dilatancy versus shear displacement.

(Solid lines for constant normal load tests and

dashed lines for constant stiffness tests under initial normal load $\mathrm{N}_{0}=3.6 \mathrm{kips}[16.0 \mathrm{kN}]$ or $\mathrm{N}_{0}=7.2 \mathrm{kips}[32.0 \mathrm{kN}]$ )

Figure 1c. Normal load versus normal displacement (dilatancy) for RF4 sample, before shear.

Figure 2. Sample KR12F4, first-cycle forward shear:

Normal load versus normal displacement response

curves for different levels of shear

displacement, $U$.

Figure 3. Sample KR12F4, first-cycle forward under constant stiffness $K=179.9 \mathrm{kips} / \mathrm{in} .(314.8 \mathrm{kN} / \mathrm{cm})$ and initial normal load $=7.2 \mathrm{kips}(32.0 \mathrm{kN})$.

(a) Comparison between observed and predicted dilatancy versus shear displacement curves, (b) Comparison between observed and predicted shear load versus shear displacement curves. 


\section{TABLES}

TABLE

PAGE

Table 1a. Coefficient of Correlation, Standard Error, and Coefficient of Variation for Dilatancy. Sample KR12F4 tested under initial normal load $7.2 \mathrm{kips}$ $(32.0 \mathrm{kN})$ and applied stiffness $179.9 \mathrm{kips} / \mathrm{in}$. $(314.8 \mathrm{kN} / \mathrm{cm})$.

Table 1b. Coefficient of Correlation, Standard Error, and Coefficient of Variation for Shear Load. Sample KR12F4 tested under initial normal load 7.2 kips $(32.0 \mathrm{kN})$ and applied stiffness $179.9 \mathrm{kips} / \mathrm{in}$. $(314.8 \mathrm{kN} / \mathrm{cm})$.

Table 2a. Maximum, Minimum, and Average Values of the Coefficient of Correlation, Standard Error, and Coefficient of Variation for Dilatancy.

F4 samples tested under constant normal stiffness. 12

Table 2b. Maxinum, Minimum, and Average Values of the Coefficient of Correlation, Standard Error, and Coefficient of Variation for Shear Load.

F4 samples tested under constant normal stiffness. 12

Table 3a. Maximum, Minimum, and Average Values of the Coefficient of Correlation, standard Error, and Coefficient of Variation for Dilatancy.

F3 samples tested under constant normal stiffness. 14

Table 3b. Maximum, Minimum, and Average Values of the Coefficient of Correlation, Standard Error, and Coefficient of Variation for shear Load.

F3 samples tested under constant normal stiffness. 14

Table 4a. Maximum, Minimum, and Average Values of the Coefficient of Correlation, Standard Error, and Coefficient of Variation for Dilatancy. F2 samples tested under constant normal stiffness. 16

Table 4b. Maximum, Minimum, and Average Values of the Coefficient of Correlation, Standard Error, and Coefficient of Variation for shear Load. F2 samples tested under constant normal stiffness. 16 


\section{TABLES}

(continued)

TABLE

PAGE

Table 5a. Maximum, Minimum, and Average Values of the

Coefficient of Correlation, Standard Error, and

Coefficient of Variation for Dilatancy.

G2 samples tested under constant normal stiffness. 17

Table 5b. Maximum, Minimum, and Average Values of the

Coefficient of Correlation, Standard Error, and

Coefficient of Variation for Shear Load.

G2 samples tested under constant normal stiffness. 17 


\subsection{INTRODUCTION}

The response of a rough joint to shear loading depends on its surface properties, as well as the boundary conditions that are applied by the surrounding rock mass. These boundary conditions can exist in a variety of forms and vary between constant normal load (stress), in the case of slope stability problems near the surface, to variable or constant normal stiffness in the vicinity of underground excavations. The normal stiffness applied across joint surfaces is defined as the ratio between increments in normal load and increments in normal displacement. It varies between zero for constant normal load conditions and infinity for constant normal displacement conditions. In general, the joint shear strength under constant or variable normal stiffness (non zero) is higher than the joint shear strength under constant normal load (stress). The main reason for the increase in shear strength is that under constant or variable normal stiffness boundary conditions, joint dilatancy created by joint surface roughness is inhibited and joint normal load (stress) increases as shear takes place. The effect of normal stiffness boundary conditions on the shear behavior of rock joints has been investigated theoretically or experimentally by obert et al. (1976), Leichnitz (1985), Goodman and Borle (1985), and Hutson (1987), and more recently by Archambault et al. (1990), Bandis (1990), Benmokrane et al. (1991), Ohnishi and Dharmaratne (1990) and Skinas et al. (1990).

In two recent publications, Saeb (1989) and Amadei and Saeb (1990) proposed mathematical and graphical methods to predict the behavior of a rock joint under any normal stiffness boundary condition from the results of conventional constant normal load (or stress) direct shear tests. An experimental research program was initiated to test these methods using the data collected on several fractures of welded tuff from Yucca Mountain in the southwest corner of the Nevada test site in southern Nevada, and on one fracture from Rainer Mesa. Cyclic direct shear and normal compression tests were conducted on replicas of three natural fractures and a laboratory developed tensile fracture of welded tuff. The direct shear tests 
were carried out under constant normal loads ranging between 0.6 and $25.6 \mathrm{kips}(2.7$ and $113.9 \mathrm{kN})$ and constant normal stiffnesses ranging between 14.8 and $187.5 \mathrm{kips} / \mathrm{in}$. $(25.9$ and $328.1 \mathrm{kN} / \mathrm{cm})$ with different initial normal loads. Each test consisted of five cycles of forward and reverse shear motion. The complete set of experimental results can be found in the data report by wibowo et al. (1993).

Based on the results of the direct shear experiments performed on the replicas of fractures of welded tuff under constant normal load, the shear behavior of the replicas tested under constant normal stiffness was predicted by using the above mentioned graphical method. The predictions are presented in this report and are compared to the actual shear test results with three statistical parameters for all five creles of forward and reverse shear motion.

\subsection{PREDICTION OF FRACTURE BEHAVIOR UNDER CONSTANT NORMAL STIFFNESS}

\subsection{Graphical method of Amadel and Saeb}

The graphical method proposed by Saeb (1989) and Amadei and Saeb (1990) relies on the coupling that exists between the normal Ioad versus displacement and shear load versus displacement response of a rough fracture. In order to use the graphical method, it is necessary to know the normal load versus normal displacement, shear load versus shear displacement and dilatancy versus shear displacement response curves of a given fracture at different levels of constant normal load (or stress). Using these three sets of curves, normal load versus normal displacement diagrams at different levels of shear displacement are constructed. These curves can then be used to predict the shear strength of tre fracture for any selected load path with constant or variable controlled stiffness, $K$. The applied stiffness, $K$, is defined as the ratio between an increment in normal load, dN, and an increment 
in normal displacement, $d v$. The stiffness can vary betwsen $k=0$ for the constant normal load path $(d N=0)$ and $K=\infty$ for the constant normal displacement path $(d v=0)$. A fundamental assumption inherent in the graphical method of Saeb (1989) and Amadei and Saeb (1990) is that fracture shear strengths (peak and residual) are independent of the load path. A detailed example of the method applied to hypothetical data can be found in Amadei and Saeb (1990).

\subsection{Prediction}

The aforementioned method was followed in order to predict the shear and dilatancy response of the replicas of the fractures of welded tuff tested under constant normal stiffness. Predictions were done for the forward and reverse parts of each shear cycle. The predicted response curves were then compared to those measured during the shear experiments. Three sets of response curves presented in the earlier data report (Wibowo et al., 1993) wers used in making the prediction: the shear load versus shear displacement curves, the dilatancy versus shear displacement curves, and the normal load versus normal displacement curves. Note that different sets of response curves had to be used for the forward and reverse parts for each one of the five shear cycles.

As an illustrative example, Figures $1 \mathrm{a}$ and $1 \mathrm{~b}$ show, respectively, the first-cycle forward shear load versus shear displacement and dilatancy versus shear displacement curves (solid lines) for the shear tests conducted on the F4 samples under constant normal L cads ranging between $0.7 \mathrm{kips}(3.2 \mathrm{kN})$ and $14.4 \mathrm{kips}(64.1 \mathrm{kN})$. Figure $1 \mathrm{c}$ shows the normal load versus normal displacement response for fracture F4 tested under normal compression before shear. Note that in Figure 1c, joint closing is assumed to be negative.

Using the curves shown in Figures la through 1c, the variation of the normal load with the normal displacement was plotted for different values of the shear displacement, $U$, ranging between 0 and $0.5 \mathrm{in.}(1.27 \mathrm{~cm}$ ) (see Figure 2 ). The curves in Figure 2 were 

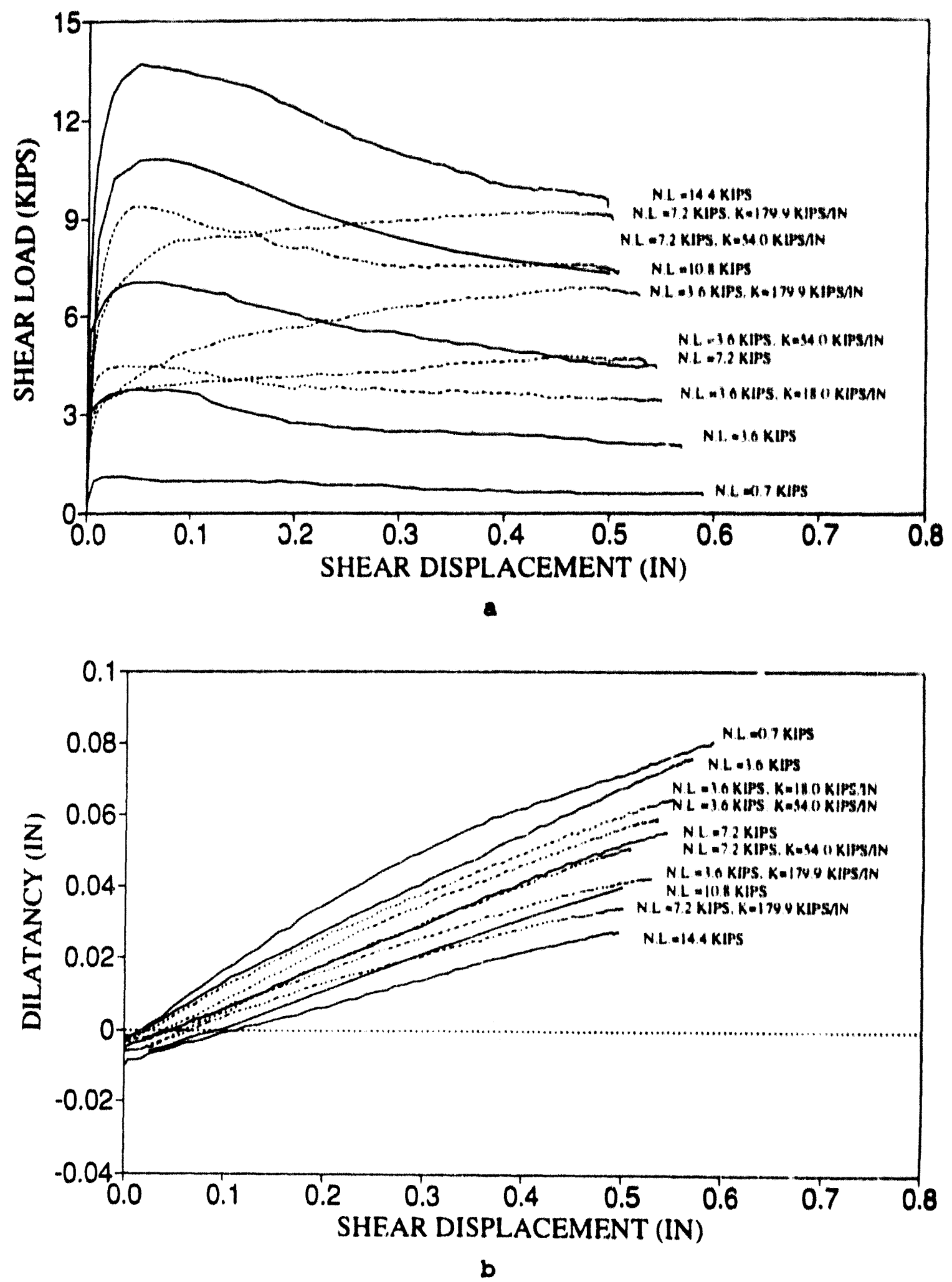

Figure 1. Sample KR12F4, f1rst-cycle forward ohear: (a) Shear load versus shear displacement, (b) Dilatancy versus shear displacement. (Sclid lines for constant normal load tests and dashed lines for constant stiffness tests under initial normal load $\mathrm{N}_{0}=3.6 \mathrm{kips}$ $[16.0 \mathrm{kN}]$ or $\left.\mathrm{N}_{0}=7.2 \mathrm{kips}(32.0 \mathrm{kN}]\right)$. 


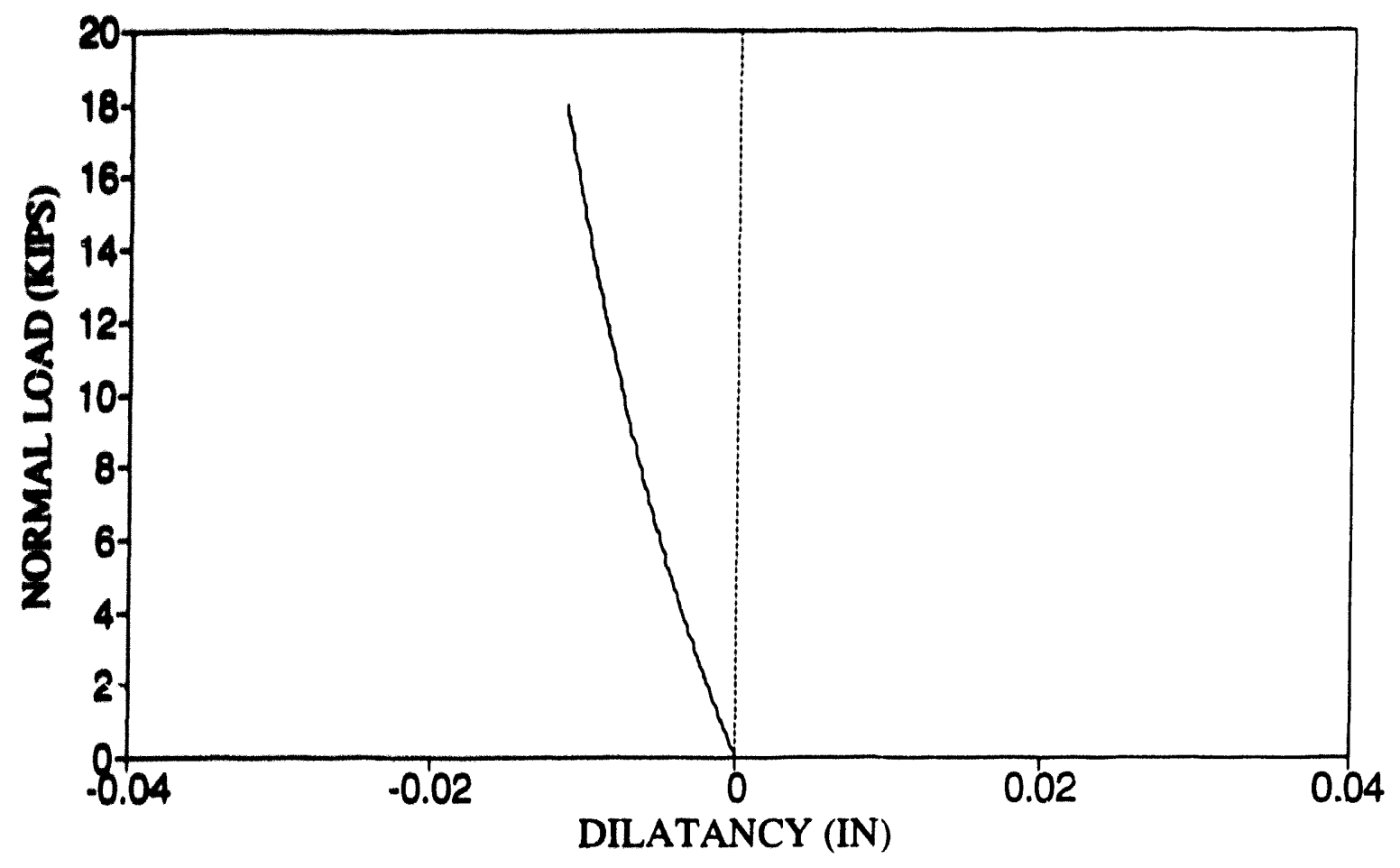

Figure 1c. Normal load vs. normal displacement (dilatancy) for RF4 sample, before shear.

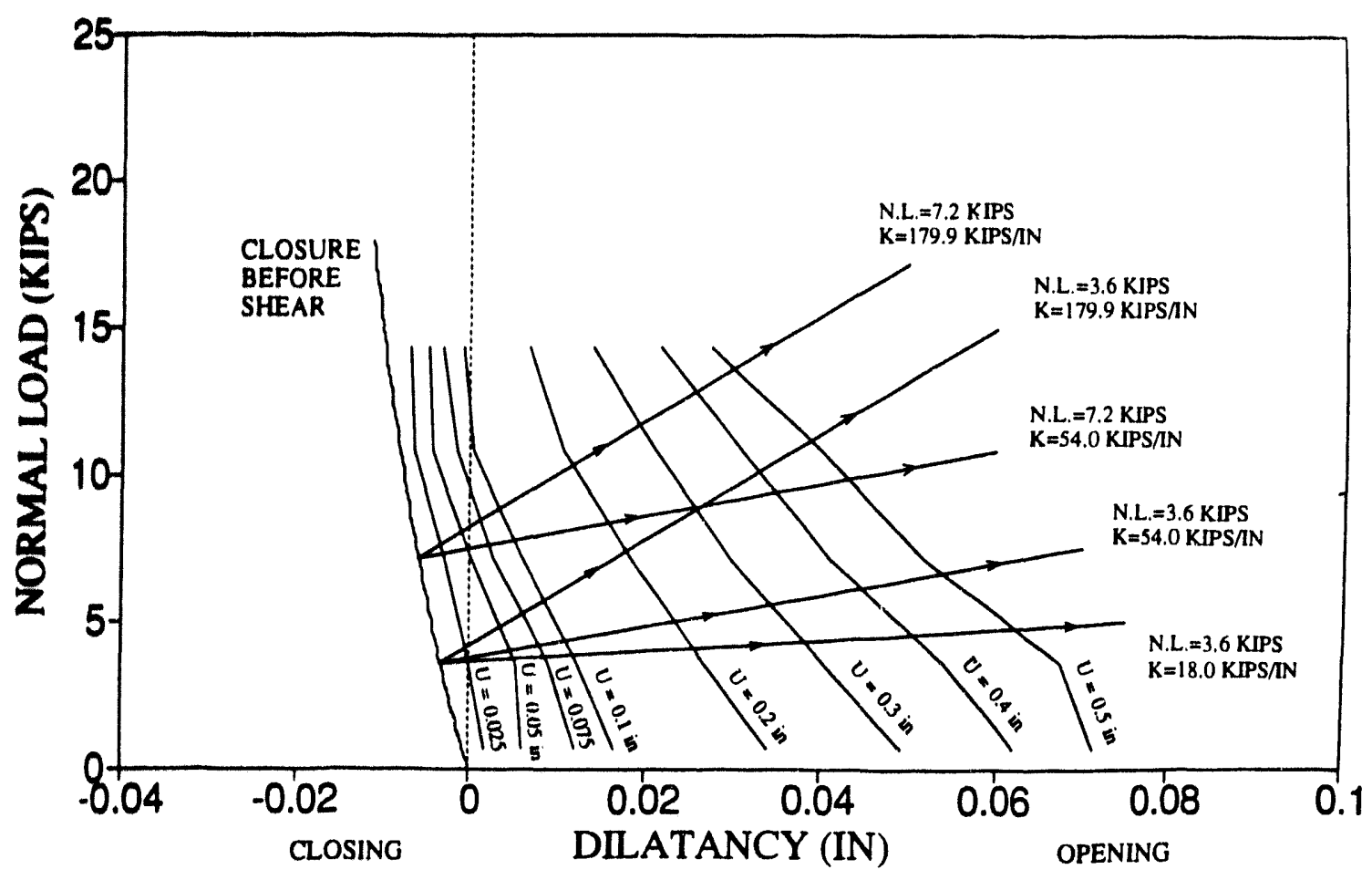

Figure 2. Sample KR12F4, first-cycle forward shear: Normal load vo. normal displacement response curves for different levels of shear displacement, $U$. 
constructed using the values of normal load and normal displacement at the points of intersection between the dilatancy curves of Figure $1 b$ and several vertical lines corresponding to arbitrary values of shear displacement. The different constant normal stiffness paths followed during testing of the F4 samples are also shown as straight lines in Figure 2. The bottom three straight lines correspond to constant stiffness experiments conducted at an initial normal load level of $\mathrm{N}_{\mathrm{o}}=3.6 \mathrm{kips}(16.0 \mathrm{kN})$ with stiffnesses of $18.8 \mathrm{kips} / \mathrm{in} .(32.9 \mathrm{kN} / \mathrm{cm}), 56.3 \mathrm{kips} / \mathrm{in} .(98.7$ $\mathrm{kN} / \mathrm{cm})$, and $179.9 \mathrm{kips}$ 'in. $(314.8 \mathrm{kN} / \mathrm{cm})$. The top two straight Iines correspond to tests conducted under an initial normal load of $\mathrm{N}_{\mathrm{o}}=7.2 \mathrm{kips}(32.0 \mathrm{kN})$ and for constant normal stiffnesses of 56.3 $\mathrm{kips} / \mathrm{in} .(98.7 \mathrm{kN} / \mathrm{cm})$ and $179.9 \mathrm{kips} / \mathrm{in} .(314.8 \mathrm{kN} / \mathrm{cm})$. The normal load versus normal displacement response curves at different levels of shear displacement for all joint samples are enclosed in Appendix A. These curves are presented for the forward and reverse parts of each shear cycle.

For each stiffness path, the shear load versus shear displacement and dilatancy versus shear displacement response curves were predicted using Figures $1 a, 1 b$, and 2 . This was done by first recording the values of normal load and shear displacement at the points of intersection of each load path with the different curves of Figure 2. Then, these values were transferred to the shear load versus shear displacement and dilatancy versus shear displacement curves in Figures $1 \mathrm{a}$ and $1 \mathrm{~b}$.

\subsection{Comparison between predicted and observed behavior}

Predicted shear load versus shear displacement and dilatancy versus shear displacement responses were compared with those measured during shear testing under constant normal stiffness. For the F4 samples, the constant normal stiffness shear test response curves (for the first cycle forward motion) are shown as dashed lines in Figures $1 \mathrm{a}$ and $1 \mathrm{~b}$. Figures $3 \mathrm{a}$ and $3 \mathrm{~b}$ show examples of comparisons between predicted and measured dilatancy versus shear displacement, 


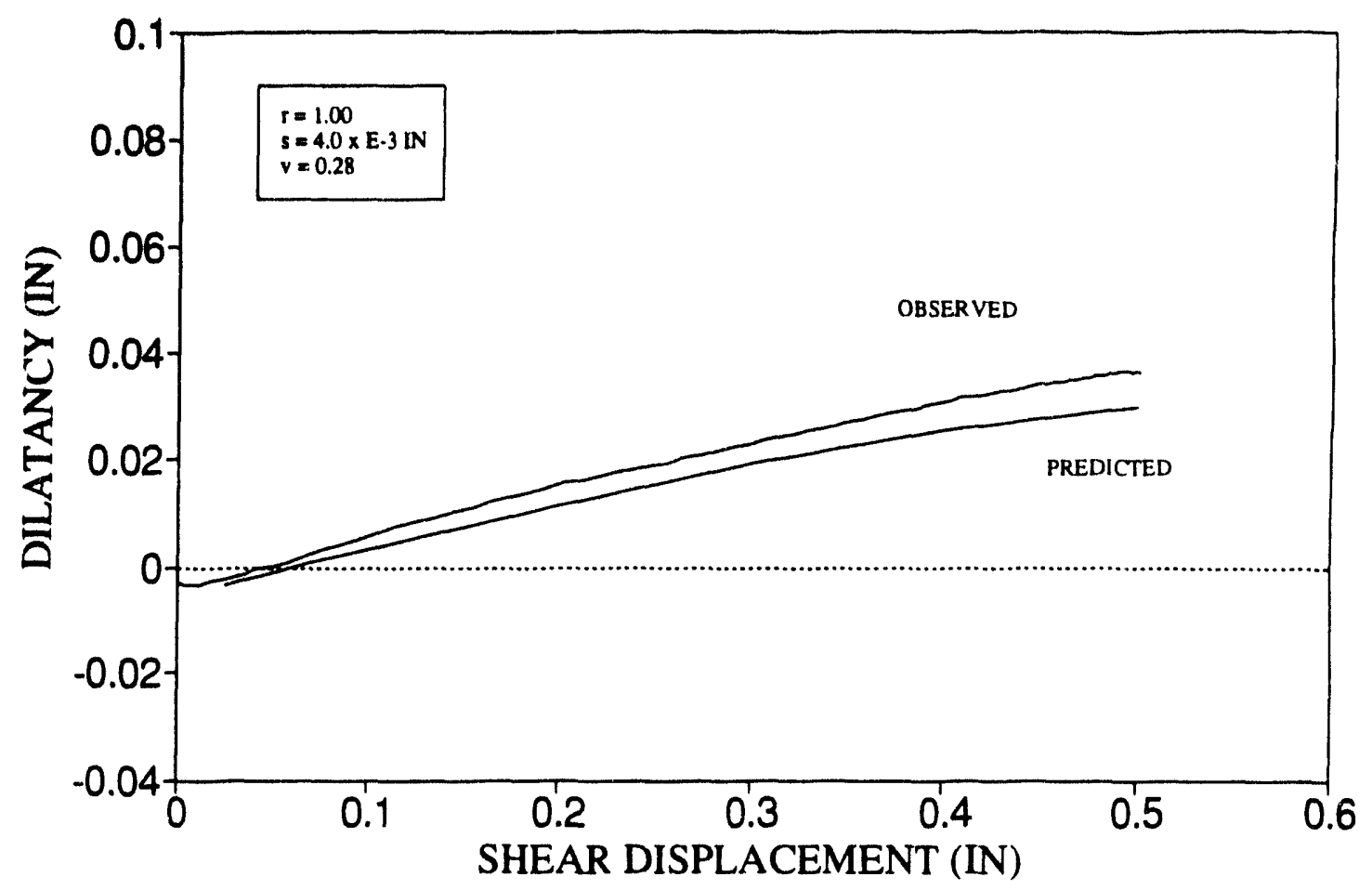

b

Figure 3. Specimen KR12F4, Eirst-cycle forward under constant stiffness $K=179.9 \mathrm{kips} / \mathrm{in} .(314.8 \mathrm{kN} / \mathrm{cm})$ and initial normal load $=7.2 \mathrm{kips}(32.0 \mathrm{kN}):$ (a) Comparison between observed and predicted dilatancy vs. shear displacement curves, (b) Comparison between observed and predicted shear load vs. shear displacement curves. 
and shear load versus shear displacement response curves, respectively, for sample KR12F4, tested under an initial load of $\mathrm{N}_{\mathrm{o}}$ $=7.2 \mathrm{kips}(32.0 \mathrm{kN})$ and a constant normal stiffness of $\mathrm{K}=179.9$ $\mathrm{kips} / \mathrm{in}$. $(314.8 \mathrm{kN} / \mathrm{cm})$. It is observed that the agreement between predicted and observed behavior is very good for this particular test. Comparisons between predicted and observed behavior for all joint samples tested under constant normal stiffness can be found in Appendix $B$. While most comparisons are good, some are not.

In order to quantify the differences between the predicted and observed responses, three statistical parameters were evaluated for each category of response curve: the coefficient of correlation, the standard error, and the coefficient of variation (Ang and Tang, 1975). The parameters are described as follows.

Let $X$ and $Y$, be the predicted and observed values of shear load or dilatancy respectively. The coefficlent of correlation, $r$, between $X$ and $Y$ is defined as

$$
r=\frac{\operatorname{Cov}(X, Y)}{\left(\sigma_{X}\right)\left(\sigma_{Y}\right)}
$$

where $\operatorname{Cov}(X, Y)$ is the covariance of $X$ and $Y$, and $\sigma_{X}$ and $\sigma_{Y}$ are the standard deviations of $X$ and $Y$, respectively. The values of $r$ range between -1 and +1 . When $r= \pm 1, X$ and $Y$ are linearly related, whereas, when $x=0, X$ and $Y$ are scattered. In other words, the magnitude of the absolute value of the correlation coefficient can be used as a measure of the degree of linear relationship existing between the observed and predicted values of shear load or dilatancy.

If, for a given value of shear displacement, $Y_{\mathfrak{c}}=X$ represents the predicted value of $Y$ (shear load or dilatancy), a measure of the scatter about the line $Y=X$ (i.e., predicted value = observed value) is given by the standard error, $s$, such that 


$$
s^{2}=\frac{1}{n-1} \sum\left(Y_{i}-Y_{e}\right)^{2}
$$

where $\mathrm{n}$ is the number of data points, and $Y_{i}$ and $Y_{c}$ are the observed and predicted values of $\mathrm{Y}$, respectively.

In order to assess whether the dispersion in the $\mathrm{X}, \mathrm{Y}$ space is large or small, the measure of dispersion relative to the central value is more useful. For this reason, the coefficient of variation, $v$, is used and is defined as follows:

$$
V=\frac{S}{\bar{Y}}
$$

where $\mathrm{s}$ is the standard error defined in equation (2), and $\bar{Y}$ is the mean value of the observed data, $Y$. The coefficient of variation is a convenient nondimensional measure of dispersion or variability. A disadvantage of this coefficient is that its usefulness diminishes when $\bar{Y}$ is close to zero.

The three statistical parameters were calculated for all normal displacement versus shear displacement and shear load versus shear displacement response curves for fractures G2, F2, F3, and F4. This was done for the forward and reverse parts of each of the five shear cycles. As an example, the values of the coefficient of correlation, standard error, and coefficient of variation $f, r$ sample KR12F4 are given in Figures $3 a$ and $3 b$ for the first shear cycle forward motion. Values of those three statistical parameters for the other cycles and reverse motion can be found in Tables la and $1 \mathrm{~b}$ for dilatancy and shear load, respectively. The complete set of values for all samples can be found in Appendix $C$.

Tables $2 a$ through $5 \mathrm{~b}$ give the minimum, maximum, and average values of the coefficient of correlation, the standard error, and the coefficient of variation for the forward and reverse parts of the 
Table 1a

Coefficient of Correlation, standard error, and Coefficient of Variation for Dilatancy. Sample KR12F4 tested under initial normal load $7.2 \mathrm{kips}(32.0 \mathrm{kN})$ and applied stiffness $179.9 \mathrm{kips} / \mathrm{in} .(314.8$ $\mathrm{kN} / \mathrm{cm})$.

\begin{tabular}{||c|c|c|c||}
\hline $\begin{array}{c}\text { Sample } \\
\text { KR12F4 }\end{array}$ & $\begin{array}{c}\text { Coefficient of } \\
\text { Correlation } \\
(\mathrm{r})\end{array}$ & $\begin{array}{c}\text { Standard } \\
\text { Error } \\
(\mathrm{s}) \\
\left(10^{-3} \text { in. }\right)\end{array}$ & $\begin{array}{c}\text { Coefficient of } \\
\text { Variation } \\
(\mathrm{v})\end{array}$ \\
\hline Forward & 1.00 & & \\
1st cycle & 1.00 & 4.0 & 0.28 \\
2nd cycle & 1.00 & 1.8 & 0.70 \\
3rd cycle & 1.00 & 2.0 & 3.42 \\
4th cycle & - & 2.5 & 1.05 \\
5th cycle & & - & - \\
\hline Reverse & 1.00 & 0.7 & 0.21 \\
1st cycle & 1.00 & 0.8 & 0.25 \\
2nd cycle & 1.00 & 0.7 & 0.12 \\
3rd cycle & 1.00 & 0.9 & 0.12 \\
4th cycle & - & - & - \\
5th cycle & & & \\
\hline
\end{tabular}

Table $1 \mathrm{~b}$

Coefficient of Correlation, Standard Error, and Coefficient of Variation for Shear Load. Sample KR12F4 tested under initial normal load $7.2 \mathrm{kips}(32.0 \mathrm{kN})$ and applied stiffness $179.9 \mathrm{kips} / \mathrm{in} .(314.8$ $\mathrm{kN} / \mathrm{cm}$ ).

\begin{tabular}{|c|c|c|c|}
\hline $\begin{array}{l}\text { Sample } \\
\text { KR12F4 }\end{array}$ & $\begin{array}{c}\text { Coefficient of } \\
\text { Correlation } \\
(r)\end{array}$ & $\begin{array}{l}\text { Standard } \\
\text { Error } \\
\text { ( s) } \\
\text { (kips) }\end{array}$ & $\begin{array}{c}\text { Coefficient of } \\
\text { Variation } \\
(\mathrm{v})\end{array}$ \\
\hline $\begin{array}{l}\text { Forward } \\
\text { 1st cycle } \\
\text { 2nd cycle } \\
3 \text { rd cycle } \\
4 \text { th cycle } \\
5 \text { th cycle }\end{array}$ & $\begin{array}{l}0.99 \\
1.00 \\
0.99 \\
0.99\end{array}$ & $\begin{array}{l}0.29 \\
0.18 \\
0.30 \\
0.39 \\
-\end{array}$ & $\begin{array}{l}0.03 \\
0.03 \\
0.06 \\
0.07 \\
-\end{array}$ \\
\hline $\begin{array}{l}\text { Reverse } \\
\text { 1st cycle } \\
\text { 2nd cycle } \\
3 \mathrm{rd} \text { cycle } \\
4 \text { th cycle } \\
5 \text { th cycle }\end{array}$ & $\begin{array}{l}0.94 \\
1.00 \\
1.00 \\
1.00 \\
-\end{array}$ & $\begin{array}{l}1.25 \\
1.14 \\
0.97 \\
0.94 \\
-\end{array}$ & $\begin{array}{l}0.18 \\
0.21 \\
0.19 \\
0.19 \\
-\end{array}$ \\
\hline
\end{tabular}


dilatancy versus shear displacement and shear load versus shear displacement curves for samples F4, F3, F2, and G2, respectively.

\subsubsection{Comparison for F4 samples.}

For the F4 samples, the coefficient of correlation for dilatancy is very large and the average values range between 0.99 and 1.00 (see Table 2a). The average values of the standard error for dilatancy vary between 0.8 and $8.0 \times 10^{-3} \mathrm{in.}(0.02$ and $0.20 \mathrm{~mm})$, and the average values of the coefficient of variation for dilatancy vary between 0.15 and 3.68. This large value of the coefficient of variation is due to a mean value of observed dilatancy $(\bar{Y}$ in equation (3]) that is close to zero for sample KR11F4. Analysis of the individual dilatancy versus shear displacement response curves for each F4 sample shows an increase in the values of the standard error and the coefficient of variation with the number of shear cycles for forward and reverse motion.

For the F4 samples, the average values of the coefficient of correlation for the shear load varies between 0.71 and 0.99 (see Table 2b). Minimum values as $l o w$ as 0.41 were also found for samples KR7F4 and KR9F4. These small values occurred because the observed and predicted shear 1 sad versus shear displacement curves are essentially parallel to the shear displacement axis. Therefore, low values of the coefficient of correlation do not always reflect poor predictions. In fact, for samples KR7F4 and KR9F4, small values of the standard error and the coefficient of variation were found, indicating that the predictions are good. In general, the average values of the standard error for the shear load vary between 0.38 and $1.53 \mathrm{kips}(1.7$ and $6.8 \mathrm{kN})$, and the average values of the coefficient of variation for the shear load vary between 0.05 and 0.27 . As for the dilatancy, analysis of the individual shear load versus shear displacement response curves for each F4 sample shows an increase in the values of the standard 
Table $2 a$

Maximum, Minimum, and Average Values of the Coefficient of Correlation, Standard Error, and Coefficient of Variation for Dilatancy. F4 samples tested under constant normal stiffness. ( $F=$ forward motion and $R=$ reverse motion for all shear cycles.)

\begin{tabular}{|c|c|c|c|c|c|c|c|c|c|}
\hline \multirow[t]{2}{*}{ Sample } & \multicolumn{3}{|c|}{$\begin{array}{c}\text { Coefficient of } \\
\text { Correlation }\end{array}$} & \multicolumn{3}{|c|}{$\begin{array}{c}\text { Standard Error } \\
\left(10^{3} \text { in. }\right)\end{array}$} & \multicolumn{3}{|c|}{$\begin{array}{l}\text { Coefficient of } \\
\text { Variation }\end{array}$} \\
\hline & $\operatorname{Max}$. & Min. & Av. & Max. & $\operatorname{Min}$ & Av. & Max. & Min. & Av. \\
\hline \multirow[t]{2}{*}{ KR7F4 } & 1.00 & 1.00 & 1.00 & 4.0 & 0.9 & 2.6 & 0.44 & 0.05 & 0.23 \\
\hline & 1.00 & 1.00 & 1.00 & 1.9 & 1.2 & 1.5 & 0.23 & 0.10 & 0.15 \\
\hline \multirow[t]{2}{*}{ KR9F4 } & 1.00 & 1.00 & 1.00 & 3.6 & 2.6 & 3.1 & 0.35 & 0.12 & 0.24 \\
\hline & 1.00 & 1.00 & 1.00 & 2.6 & 1.9 & 2.2 & 0.41 & 0.16 & 0.28 \\
\hline \multirow{2}{*}{ KR1OF4 F } & 1.00 & 0.99 & 1.00 & 4.1 & 2.6 & 3.1 & 0.87 & 0.17 & 0.46 \\
\hline & 1.00 & 0.99 & 1.00 & 9.9 & 7.1 & 8.0 & 1.35 & 0.47 & 0.92 \\
\hline \multirow{2}{*}{$\begin{array}{r}\mathrm{KR} 11 \mathrm{~F} 4 \mathrm{E} \\
\mathrm{F}\end{array}$} & 1.00 & 1.00 & 1.00 & 7.4 & 5.3 & 6.2 & 2.88 & $0 . \angle 8$ & 1.28 \\
\hline & 1.00 & 0.97 & 0.99 & 7.2 & 3.4 & 5.7 & 8.94 & 0.39 & 3.68 \\
\hline \multirow{2}{*}{$\begin{array}{rl}\mathrm{KR} 12 \mathrm{~F} 4 \mathrm{~F} & \mathrm{R}\end{array}$} & 1.00 & 1.00 & 1.00 & 4.0 & 0.9 & 2.6 & 3.42 & 0.28 & 1.36 \\
\hline & 1.00 & 1.00 & 1.00 & 0.9 & 0.7 & 0.8 & 0.25 & 0.12 & 0.18 \\
\hline
\end{tabular}

Table $2 b$

Maximum, Minimum, and Average Values of the Coefflcient of Correlation, standard Error, and Coefficient of Variation for Shear Load. F4 samples tested under constant normal stiffness. ( $F=$ forward motion and $\mathrm{R}=$ reverse motion for all stlear cycles.)

\begin{tabular}{|c|c|c|c|c|c|c|c|c|c|}
\hline \multirow[t]{2}{*}{ Sample } & \multicolumn{3}{|c|}{$\begin{array}{c}\text { Coefficient of } \\
\text { Correlation }\end{array}$} & \multicolumn{3}{|c|}{$\begin{array}{c}\text { Standard Error } \\
(\mathrm{kips})\end{array}$} & \multicolumn{3}{|c|}{$\begin{array}{c}\text { Coefficient of } \\
\text { Variation }\end{array}$} \\
\hline & Max. & Min. & Av. & $\operatorname{Max}$ & Min. & Av. & Max. & Min. & Av. \\
\hline \multirow[t]{2}{*}{ KR7F4 } & 0.98 & 0.67 & 0.88 & 0.95 & 0.62 & 0.80 & 0.35 & 0.15 & 0.27 \\
\hline & 0.95 & 0.55 & 0.71 & 0.67 & 0.58 & 0.61 & 0.21 & 0.18 & 0.20 \\
\hline \multirow[t]{2}{*}{ KR9F4 } & 0.99 & 0.41 & 0.86 & 0.89 & 0.36 & 0.67 & 0.30 & 0.09 & 0.21 \\
\hline & 0.99 & 0.87 & 0.96 & 0.67 & 0.71 & 0.69 & 0.24 & 0.17 & 0.21 \\
\hline \multirow{2}{*}{ KRIOF4 } & 1.00 & 0.98 & 0.99 & 0.67 & 0.23 & 0.38 & 0.14 & 0.07 & 0.10 \\
\hline & 1.00 & 0.96 & 0.99 & 1.07 & 0.95 & 0.99 & 0.30 & 0.22 & 0.27 \\
\hline \multirow{2}{*}{ KRIIF4 } & 0.98 & 0.90 & 0.94 & 1.80 & 1.25 & 1.53 & 0.31 & 0.21 & 0.25 \\
\hline & 0.94 & 0.70 & 0.85 & 0.62 & 0.30 & 0.52 & 0.11 & 0.05 & 0.09 \\
\hline \multirow{2}{*}{$\mathrm{KR} 12 \mathrm{~F} 4 \mathrm{~F}$} & 1.00 & 0.99 & 0.99 & 0.39 & 0.18 & 0.29 & 0.08 & 0.03 & 0.05 \\
\hline & 1.00 & 0.94 & 0.98 & 1.25 & 0.97 & 1.08 & 0.21 & 0.18 & 0.19 \\
\hline
\end{tabular}


error and the coefficient of variation with the number of shear cycles for forward and reverse motion.

\subsubsection{Comparison for F3 Samples}

For the F3 samples, the coefficient of correlation for dilatancy is very large and the average values range between 0.98 and 1.00 (see Table $3 \mathrm{a}$ ). The average values of the standard error for dilatancy vary between 3.4 and $12.2 \times 10^{-3} \mathrm{in.}(0.1$ and $0.3 \mathrm{~mm})$, and the average values of the coefficient of variation for dilatancy vary between 0.14 and 6.77 . This large value of the coefficient of variation is due to a mean value of observed dilatancy ( $\bar{Y}$ in equation [3]) close to zero for sample KRI1F3. Like the F4 sample, analysis of the individual dilatancy versus shear displacement response curves for each $F 3$ sample shows an increase in the value of the standard error and the coefficient of variation with the number of shear cycles for forward and reverse motion.

The average values of the coefficient of correlation for the shear load varies between 0.55 and 0.99 (see Table 3b). Minimum values as low as 0.04 were also found for samples KR7F3 and KR1OF3. These very small values occurred because the observed or predicted shear load versus shear displacement response curve is essentially parallel to the shear displacement axis. For samples KR7F3 and KR1OF3, relatively small values of the standard error and the coefficient of variation were found, indicating that the predictions are quite good, although the coefficients of correlation were very small. In general, the average values of the standard error for the shear load vary between 0.23 and $1.88 \mathrm{kips}$, $(1.0$ and $8.4 \mathrm{kN})$ and the average values of the coefficient of variation for the shear load vary between 0.06 and 0.55 . As for the dilatancy, analysis of the individual shear load versus shear displacement response curves for each F3 sample shows an increase in the values of the standard error and the coefficient of variation with the number of shear cycles for forward and reverse motion. 
Table $3 a$

Maximum, Minimum, and Average Values of the Coefficient of Correlation, Standard Error, and Coefficient of Variation for Dilatancy. F3 samples tested under constant normal stiffness. ( $F=$ forward motion and $R=$ reverse motion for all shear cycles.)

\begin{tabular}{|c|c|c|c|c|c|c|c|c|c|c|}
\hline \multirow{2}{*}{\multicolumn{2}{|c|}{ Sample }} & \multicolumn{3}{|c|}{$\begin{array}{c}\text { Coefficient of } \\
\text { Correlation }\end{array}$} & \multicolumn{3}{|c|}{$\begin{array}{c}\text { Standard Error } \\
\left(10^{-3} \text { in. }\right)\end{array}$} & \multicolumn{3}{|c|}{$\begin{array}{c}\text { Coefficient of } \\
\text { Variation }\end{array}$} \\
\hline & & $\operatorname{Max}$. & Min. & Av. & Max. & Min. & Av. & Max. & Min. & Av \\
\hline \multirow[t]{2}{*}{$\mathrm{KR} 7 \mathrm{~F} 3$} & $\mathrm{~F}$ & 1.00 & 0.99 & 1.00 & 6.2 & 5.1 & 5.8 & 0.27 & 0.19 & 0.24 \\
\hline & $\mathrm{R}$ & 1.00 & 1.00 & 1.00 & 5.7 & 3.1 & 4.7 & 0.32 & 0.12 & 0.24 \\
\hline \multirow[t]{2}{*}{$\mathrm{KR} 8 \mathrm{~F} 3$} & $F$ & 1.00 & 1.00 & 1.00 & 5.1 & 1.4 & 3.4 & 0.23 & 0.06 & 0.14 \\
\hline & $\mathrm{R}$ & 1.00 & 0.99 & 1.00 & 4.2 & 2.4 & 3.5 & 0.28 & 0.09 & 0.21 \\
\hline \multirow[t]{2}{*}{ KR9F3 } & $\mathrm{F}$ & 1.00 & 0.99 & 0.99 & 4.3 & 3.2 & 3.5 & 0.27 & 0.19 & 0.23 \\
\hline & $\mathrm{R}$ & 0.99 & 0.97 & 0.98 & 5.0 & 3.5 & 4.5 & 0.81 & 0.22 & 0.58 \\
\hline \multirow[t]{2}{*}{$K R 10 F 3$} & $F$ & 1.00 & 1.00 & 1.00 & 12.6 & 12.0 & 12.2 & 6.98 & 0.65 & 2.76 \\
\hline & $\mathrm{R}$ & 1.00 & 0.99 & 1.00 & 11.1 & 9.7 & 10.3 & 11.08 & 0.76 & 4.88 \\
\hline \multirow[t]{2}{*}{ KR11F3 } & $\mathrm{F}$ & 1.00 & 0.99 & 0.99 & 5.1 & 4.3 & 4.6 & 1.07 & 0.26 & 0.68 \\
\hline & $\mathrm{R}$ & 0.99 & 0.99 & 0.99 & 6.5 & 5.4 & 5.9 & 26.38 & 0.49 & 6.77 \\
\hline
\end{tabular}

Table $3 b$

Maximum, Minimum, and Average Values of the Coefficient of Correlation, Standard Error, and Coefficient of Variation for Shear Load. F3 samples tested under constant normal stiffness. ( $\mathrm{F}$ = forward motion and $\mathrm{R}$ = reverse motion for all shear cycles.)

\begin{tabular}{|c|c|c|c|c|c|c|c|c|c|c|}
\hline \multirow{2}{*}{\multicolumn{2}{|c|}{ Sample }} & \multicolumn{3}{|c|}{$\begin{array}{c}\text { Coefficient of } \\
\text { Correlation }\end{array}$} & \multicolumn{3}{|c|}{$\begin{array}{c}\text { Standard Error } \\
\text { (kips) }\end{array}$} & \multicolumn{3}{|c|}{$\begin{array}{c}\text { Coefficient of } \\
\text { Variation }\end{array}$} \\
\hline & & Max. & Min. & Av. & Max. & Min. & Av. & Max. & Min. & Av. \\
\hline KR7F3 & $\begin{array}{l}\mathrm{F} \\
\mathrm{R}\end{array}$ & $\begin{array}{l}0.92 \\
0.80\end{array}$ & $\begin{array}{l}0.04 \\
0.34\end{array}$ & $\begin{array}{l}0.57 \\
0.62\end{array}$ & $\begin{array}{l}0.61 \\
0.53\end{array}$ & $\begin{array}{l}0.36 \\
0.09\end{array}$ & $\begin{array}{l}0.49 \\
0.23\end{array}$ & $\begin{array}{l}0.31 \\
0.15\end{array}$ & $\begin{array}{l}0.12 \\
0.03\end{array}$ & $\begin{array}{l}0.23 \\
0.07\end{array}$ \\
\hline KR8F3 & $\begin{array}{l}\mathrm{F} \\
\mathrm{R}\end{array}$ & $\begin{array}{l}1.00 \\
0.96\end{array}$ & $\begin{array}{l}0.98 \\
0.92\end{array}$ & $\begin{array}{l}0.99 \\
0.95\end{array}$ & $\begin{array}{l}0.71 \\
0.94\end{array}$ & $\begin{array}{l}0.49 \\
0.53\end{array}$ & $\begin{array}{l}0.56 \\
0.67\end{array}$ & $\begin{array}{l}0.22 \\
0.25\end{array}$ & $\begin{array}{l}0.20 \\
0.20\end{array}$ & $\begin{array}{l}0.21 \\
0.23\end{array}$ \\
\hline KR9F3 & $\begin{array}{l}\mathrm{F} \\
\mathrm{R}\end{array}$ & $\begin{array}{l}1.00 \\
0.99\end{array}$ & $\begin{array}{l}0.94 \\
0.91\end{array}$ & $\begin{array}{l}0.98 \\
0.96\end{array}$ & $\begin{array}{l}2.12 \\
2.69\end{array}$ & $\begin{array}{l}1.22 \\
1.33\end{array}$ & $\begin{array}{l}1.54 \\
1.77\end{array}$ & $\begin{array}{l}0.55 \\
0.64\end{array}$ & $\begin{array}{l}0.47 \\
0.47\end{array}$ & $\begin{array}{l}0.51 \\
0.55\end{array}$ \\
\hline$K R 10 F 3$ & $\begin{array}{l}\mathrm{F} \\
\mathrm{R}\end{array}$ & $\begin{array}{l}0.93 \\
0.83\end{array}$ & $\begin{array}{l}0.27 \\
0.05\end{array}$ & $\begin{array}{l}0.57 \\
0.55\end{array}$ & $\begin{array}{l}0.71 \\
2.36\end{array}$ & $\begin{array}{l}0.11 \\
1.67\end{array}$ & $\begin{array}{l}0.36 \\
1.88\end{array}$ & $\begin{array}{l}0.10 \\
0.28\end{array}$ & $\begin{array}{l}0.02 \\
0.25\end{array}$ & $\begin{array}{l}0.06 \\
0.26\end{array}$ \\
\hline$K R 11 F 3$ & $\begin{array}{l}\mathrm{F} \\
\mathrm{R}\end{array}$ & $\begin{array}{l}1.00 \\
1.00\end{array}$ & $\begin{array}{l}0.97 \\
0.98\end{array}$ & $\begin{array}{l}0.99 \\
0.98\end{array}$ & $\begin{array}{l}0.79 \\
0.79\end{array}$ & $\begin{array}{l}0.68 \\
0.38\end{array}$ & $\begin{array}{l}0.73 \\
0.52\end{array}$ & $\begin{array}{l}0.12 \\
0.09\end{array}$ & $\begin{array}{l}0.09 \\
0.07\end{array}$ & $\begin{array}{l}0.11 \\
0.08\end{array}$ \\
\hline
\end{tabular}




\subsubsection{Comparison for F2 Samples}

The coefficient of correlation for dilatancy is very large and the average values range between 0.92 and 1.00 (see Table 4a). The average values of the standard error for dilatancy vary between 4.3 and $12.6 \times 10^{-3} \mathrm{in.}(0.1$ and $0.3 \mathrm{~mm})$ and the average values of the coefficient of variation for dilatancy vary bccween 0.19 and 7.70 . As in the case of the previous samples, this large value of the coefficient of variation is due to a mean value of observed dilatancy ( $\bar{Y}$ in equation [3]) close to zero for sample KR8F2. The values of the standard error and the coefficient of variation for dilatancy were found to increase markedly with the number of shear cycles for forward and reverse motion.

The average value of the coefficient of correlation for the shear load varies between 0.55 and 0.99 (see Table $4 \mathrm{~b}$ ). A value as low as 0.07 was found for sample KR6F2. This very small value occurred because the observed or predicted shear load versus shear displacement response curve is essentially parallel to the shear displacement axis. For this particular sample, the small values found for the standard error and the coefficient of variation indicate that the predictions are quite good, even though the coefficient of correlation is very small. The average values of the standard error for the shear load vary between 0.18 and 0.42 kips $(0.8$ and $1.9 \mathrm{kN})$ and the average values of the coefficient of variation for the shear load vary between 0.12 and 0.19 . Analysis of the incividual shear load versus shear displacement response curves for each F2 sample shows an increase in the values of the standard error and the coefficient of variation for the shear load with the number of shear cycles for forward and reverse motion.

\subsubsection{Comparison for G2 Samples}

The coefficient of correlation for dilatancy is quite large and the average values range between 0.43 and 1.00 (see Table 5a). The 
Maximum, Mininum, and Average Values of the Coefficient of Correlation, Sturdard Error, and Coefficient of Variation for Dilatancy. F2 samples tested under constant normal stiffness. ( $F=$ forward motion and $\mathrm{R}=$ reverse motion for all shear cycles.)

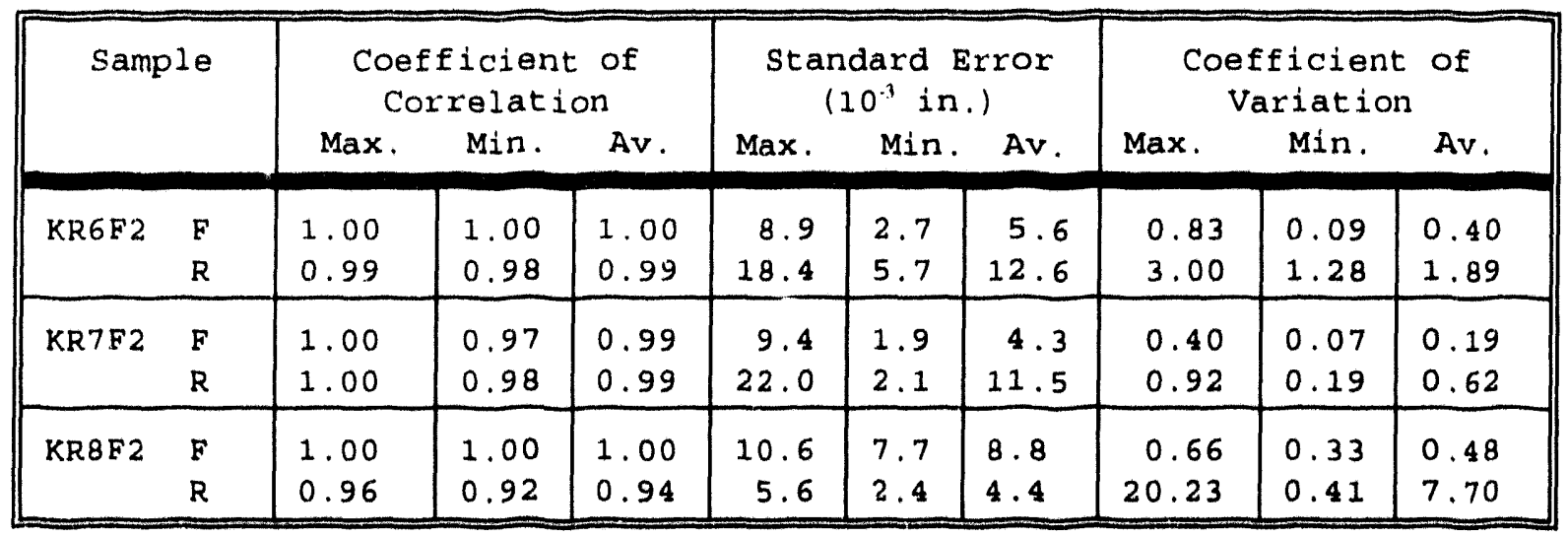

Table $4 b$

Maximum, Minimum, and Average Values of the Coefficient of Correlation, standard Error, and Coefficient of Variation for Shear Load. F2 samples tested under constant normal stiffness. $(\mathrm{F}=$ forward motion and $\mathrm{R}=$ reverse motion for all shear cycles.)

\begin{tabular}{|c|c|c|c|c|c|c|c|c|c|c|}
\hline \multirow{2}{*}{\multicolumn{2}{|c|}{ Sample }} & \multicolumn{3}{|c|}{$\begin{array}{c}\text { Coefficient of } \\
\text { Correlation }\end{array}$} & \multicolumn{3}{|c|}{$\begin{array}{c}\text { Standard Error } \\
(k i p s)\end{array}$} & \multicolumn{3}{|c|}{$\begin{array}{l}\text { Coofficient of } \\
\text { Variation }\end{array}$} \\
\hline & & $\operatorname{Max}$ & $\operatorname{Min}$ & $A v$. & Max. & Min. & Av. & $\operatorname{Max}$. & Min. & Av. \\
\hline \multirow{2}{*}{ KR6F2 } & $F$ & 0.78 & 0.07 & 0.52 & 0.41 & 0.15 & 0.27 & 0.19 & 0.10 & 0.16 \\
\hline & $\mathrm{R}$ & 0.97 & 0.89 & 0.95 & 0.22 & 0.16 & 0.19 & 0.16 & 0.11 & 0.13 \\
\hline \multirow[t]{2}{*}{$\mathrm{KR} 7 \mathrm{~F} 2$} & $\mathrm{~F}$ & 0.97 & 0.32 & 0.75 & 0.55 & 0.18 & 0.34 & 0.40 & 0.09 & 0.19 \\
\hline & $\mathrm{R}$ & 0.96 & 0.60 & 0.78 & 0.56 & 0.16 & 0.26 & 0.32 & 0.10 & 0.16 \\
\hline \multirow[t]{2}{*}{ KR8F2 } & $\mathbf{F}$ & 1.00 & 0.91 & 0.98 & 0.73 & 0.17 & 0.42 & 0.28 & 0.04 & 0.16 \\
\hline & $\mathrm{R}$ & 0.84 & 0.42 & 0.65 & 0.21 & 0.15 & 0.18 & 0.14 & 0.08 & 0.12 \\
\hline
\end{tabular}


Maximum, Minimum, and Average Values of the Coefficient of Correlation, Standard Error, and Coefficient of Variation for Dilatancy. G? samples tested under constant normal stiffness. ( $F=$ forward motion and $R=$ reverse motion for all shear cycles.)

\begin{tabular}{|c|c|c|c|c|c|c|c|c|c|c|}
\hline \multirow{2}{*}{\multicolumn{2}{|c|}{ Sample }} & \multicolumn{3}{|c|}{$\begin{array}{c}\text { Coefficient of } \\
\text { Correlation }\end{array}$} & \multicolumn{3}{|c|}{$\begin{array}{c}\text { Standard Error } \\
\left(10^{-3} \text { in. }\right)\end{array}$} & \multicolumn{3}{|c|}{$\begin{array}{l}\text { Coefficient of } \\
\text { Variation }\end{array}$} \\
\hline & & $\operatorname{Max}$ & Min. & Av. & Max. & Min. & Av. & Max. & $\operatorname{Min}$ & Av. \\
\hline \multirow[t]{2}{*}{ KR5G2 } & $F$ & 1.00 & 1.00 & 1.00 & 17.2 & 5.9 & 11.6 & 0.88 & 0.21 & 0.55 \\
\hline & $\mathbf{R}$ & 0.99 & 0.93 & 0.96 & 56.7 & 37.6 & 47.2 & 4.59 & 3.54 & 4.06 \\
\hline \multirow[t]{2}{*}{$\mathrm{KR} 6 \mathrm{G} 2$} & $F$ & 1.00 & 0.83 & 0.91 & 19.4 & 4.6 & 12.0 & 8.84 & 0.23 & 4.53 \\
\hline & $R$ & 0.64 & 0.23 & 0.43 & 27.6 & 22.4 & 25.0 & 1.12 & 0.91. & 1.02 \\
\hline
\end{tabular}

Maximum, Minimum, and Average Values of the Coefficient of Correlation, Standard Error, and Coefficient of Varlation for Shear Load. G2 samples tested under constant normal stiffness. ( $F=$ forward motion and $R=$ reverse motion for all shear cycles.)

\begin{tabular}{|c|c|c|c|c|c|c|c|c|c|c|}
\hline \multirow{2}{*}{\multicolumn{2}{|c|}{ Sample }} & \multicolumn{3}{|c|}{$\begin{array}{l}\text { Coefficient of } \\
\text { Correlation }\end{array}$} & \multicolumn{3}{|c|}{$\begin{array}{c}\text { Standard Error } \\
(\text { kips })\end{array}$} & \multicolumn{3}{|c|}{$\begin{array}{l}\text { Coefficient of } \\
\text { Variation }\end{array}$} \\
\hline & & Max. & $\operatorname{Min}$ & Av. & $\operatorname{Max}$ & $\operatorname{Min}$ & Av. & $\operatorname{Max}$. & Min. & Av. \\
\hline \multirow[t]{2}{*}{$\mathrm{KR} 5 \mathrm{G} 2$} & $F$ & 0.99 & 0.98 & 0.99 & 0.56 & 0.29 & 0.43 & 0.28 & 0.16 & 0.22 \\
\hline & $\mathbf{R}$ & 0.99 & 0.76 & 0.88 & 0.36 & 0.30 & 0.33 & 0.39 & 0.39 & 0.39 \\
\hline \multirow[t]{2}{*}{$\mathrm{KR} 6 \mathrm{G} 2$} & $F$ & 0.99 & 0.71 & 0.85 & 0.91 & 0.34 & 0.62 & 0.15 & 0.05 & 0.10 \\
\hline & $R$ & 0.99 & 0.73 & 0.86 & 1.62 & 1.22 & 1.42 & 0.38 & 0.31 & 0.35 \\
\hline
\end{tabular}


average values of the standard error for dilatancy vary between 11.6 and $47.2 \times 10^{1} \mathrm{in.}(0.3$ and $1.2 \mathrm{~mm})$ and the average values of the coefficient of variation for dilatancy vary between 0.55 and 4.53. The values of the standard error and the coefficient ot variation for dilatancy were found to increase notably with the number of shear cycles for forward and reverse motion. Because of extensive damage to the joint surfaces observed at the end of the fifth cycles, comparisons between predicted and observed behavior were done for the first and second cycles only. As observed by wibowo et al. (1993), the extensive damage can be attributed to the absence of confinement embankments along the sample periphery and the extreme roughness of the joint surfaces.

The average values of the coefficient of correlation for the shear load vary between 0.85 and 0.99 (see Table 5b). The average values of the standara error for the shear load vary between 0.33 and 1.42 kips $(1.5$ and $6.3 \mathrm{kN})$, and the average values of the coefficlent of variation for the shear load vary between 0.10 and 0.39 . Analysis of the individual shear load versus shear displacement response curves for each G2 sample shows an increase in the values of the standard error and the coefficient of variation for the shear load with the number of ahear cycles for forward and reverse motion.

\subsection{CONCLUSIONS}

Based on the results of direct shear experiments performed on replicas of four fractures of welded tuff under constant normal load boundary conditions, the shear behavior of replicas tested under constant normal atiffness boundary conditions was predicted by using the graphical method of Saeb (1989) and Amadei and Saeb (1990). The predictions were compared to the actual shear test. results from constant normal stiffness experiments. Two hundred and sixty eight comparisons between predicted and observed dilatancy and shear load responses were analyzed. Three 
statistical parameters were evaluated for each type of response curve: the coefficient of correlation, the standard error, and the coefficient of variation. Several important observations can be made:

1. In general, a good agreement was found between joint the response predicted using the Amadei and Saeb graphical method and the observed response.

2. The graphical method is straightforward and simple, and can be used to predict joint behavior under cyclic loading for a variety of loading paths and boundary conditions.

3. Differences between predictions and observations do sometimes occur. There are several possible sources for such differences.

In constructing the normal load versus dilatancy curvos for different values of shear displacement, a linear interpolation was made.

- In constructing the shear load versus shear displacement and dilatancy versus shear displacement curves for the joints under constant normal stiffness, linear interpolation was made between the shear load curves and between the dilatancy curves obtained under constant normal load.

- In making predictions using the normal load versus dilatancy curves, it was assumed that the load path had no effect on the predicted values of joint shear strength and dilatancy.

Additional errors that have been explored in the report by wibowo et al. (1993) may have contributed to the differences between predictions and observations (i.e., reproducibility and specimen installation); however, in most cases, the differences between observed and predicted shear load and dilatancy seem to be within the 
reported experimental error of $0.8 \mathrm{kips}(3.6 \mathrm{kN})$ for the shear load and $0.005 \mathrm{in.}(0.13 \mathrm{~mm})$ for the dilatancy.

4. The values of standard error and coefficient of variation were found to increase systematically with the number of cycles. The cumulative damage that occurred during shear was not accounted for in the current version of the graphical method.

\subsection{REFERENCES}

Amadei, B. and Saeb, S. 1990. Constitutive model of rock joints. Proc. Int. Conf. on Rock Joints, pp. 581-594. Loen, Norway. (NNA.920610.0033)

Ang, A. H-S and Tang, W. H. 1975. Probability concept in engineering planning and design, volume 1, basic principles. John Wiley \& Sons. (NNA.930507.0078)

Archambault, G., Fortin, M., Gill, D. E., Aubertin, M., and Ladanyi, B. 1990. Experimental investigation for an algorithm simulating the effect of variable normal stiffness on discontinuities shear strength. Proc. Int. Conf. on Rock Joints, pp. 141-148. Loen, Norway. (NNA.920610.0034)

Bandis, S. C. 1990. Mechanical properties of rock joints. Proc. Int. Conf. on Rock Joints, pp. 125-140. Loen, Norway. (NNA.920610.0035)

Benmokrane, B., Bouraoui, M., and Mouchaorab, K. S. 1991. Shearing behavior of rock discontinuities under constant or variable normal stiffness conditions. Addendum to Proc. of the 32nd U.S. Sym. in Rock Mech. Norman, Oklahoma. (NNA.930914.0072)

Goodman, R. E. and Boyle, W. 1985. Non-linear analysis for calculating the support of a rock block with dilatant joint faces. Presented at the $34 \mathrm{th}$ Geomechanics Colloquy, Salzburg, Austria.

(NNA.930802.0060)

Hutson, R. W. 1987. Preparation of duplicate rock joints and their changing dilatancy under cyclic shear. Ph.D. dissertation, Northwestern University. (NNA.920427.0048)

Leichnitz, W. 1985. Mechanical properties of rock joints. Int. J. Rock Mech. Min. Sci. Vol. 22, pp. 313-321. (NNA.900308.0332)

Obert, L., Brady, B. T., and Schmechel, F. H. 1976. The effect of normal stiffness on the shear resistance of rock. Rock Mechanics 8, pp. 57-72. (NNA.900403.0405) 
Ohnishi, Y. and Dharmaratne, P. G. R. 1990. Shear behavior of physical models of rock joints under constant normal stiffness conditions. Proc. Int. Conf. on Rock Joints, pp. 267-273. Loen, Norway. (NNA.920610.0036)

Saeb, S. 1989. Effect of boundary condition on the behavior of a dilatant rock joint. Ph.D. dissertation, Univ. of Colorado at Boulder. (NNA.900515.0007)

Skinas, C. A., Bandis, S. C., and Demiris, C.A. 1990. Experimental investigation and modeling of rock joint behavior under constant stiffness. Proc. Int. Conf. on Rock Joints, pp. 301-308. Loen, Norway. (NNA.920610.0037)

Wibowo, J., Amadei, B., Sture, S., Price, R. H., Robertson, A. B. 1993. Effect of boundary condition on the strength and deformability of replicas of natural fractures in welded tuff: Data Report. SAND 92-1853. (NNA.930907.0001) 


\section{APPENDICES}

\section{CONTENTS}

APPENDIX

DESCRIPTION

PAGE

A

Normal Load Versus Dilatancy for

Different Level of Shear Displacement

B

Comparison Between Prediction and

Observed of Dilatancy and Shear Load

C Coefficient of Correlation, standard

Error, and Coefficient of Variation
A- 1 to $A-17$

B-1 to B-134

C- 1 to $C-15$ 


\section{APPENDIX A}

\section{Normal Load Versus Dilatancy}

for Different Levels of Shear Displacement

SAMPLE DESCRIPTION

PAGE

$\begin{array}{lll}\text { RF4 } & \text { First cycle forward } & \text { A-1 } \\ \text { RF4 } & \text { First cycle reverse } & \text { A-1 } \\ \text { RF4 } & \text { Second cycle forward } & \text { A-2 } \\ \text { RF4 } & \text { Second cycle reverse } & \text { A-2 } \\ \text { RF4 } & \text { Third cycle forward } & \text { A-3 } \\ \text { RF4 } & \text { Third cycle reverse } & \text { A-3 } \\ \text { RF4 } & \text { Forth cycle forward } & \text { A-4 } \\ \text { RF4 } & \text { Forth cycle reverse } & \text { A-4 } \\ \text { RF4 } & \text { Fifth cycle forward } & \text { A-5 } \\ \text { RF4 } & \text { Fifth cycle reverse } & \text { A-5 }\end{array}$

RF3

First cycle forward

A- 6

RF3

First cycle reverse

A- 6

RF3

Second cycle forward

A -7

RF3

Second cycle reverse

A -7

RF3

Third cycle forward

A- 8

RF3

Third cycle reverse

A- 8

RF 3

Forth cycle forward

A -9

RF3

Forth cycle reverse

A- 9

RF3

Fifth cycle forward

A- 10

RF3

Fifth cycle reverse

A- 10

RF2

First cycle forward

A- 11

RF2

First cycle reverse

A- 11

RF2

second cycle forward

A -12

RF2

Second cycle reverse

A. 12

RF2

Third cycle forward

A -13

RF2

Third cycle reverse

A- 13

RF2

Forth cycle forward

A- 14 
RF2 Forth cycle reverse

A - 14

RF2 Fifth cycle forward

A -15

RF2

Fifth cycle reverse

A- 15

RG2 First cycle forward

A- 16

RG2

First cycle reverse

A- 16

$\mathrm{RG} 2$

Second cycle forward

A- 17

RG2

second cycle reverse

A- 17 


\section{JOINT - DEFORMATION \\ RF4 SPECIMEN - 1ST CYCLE FORWARD}

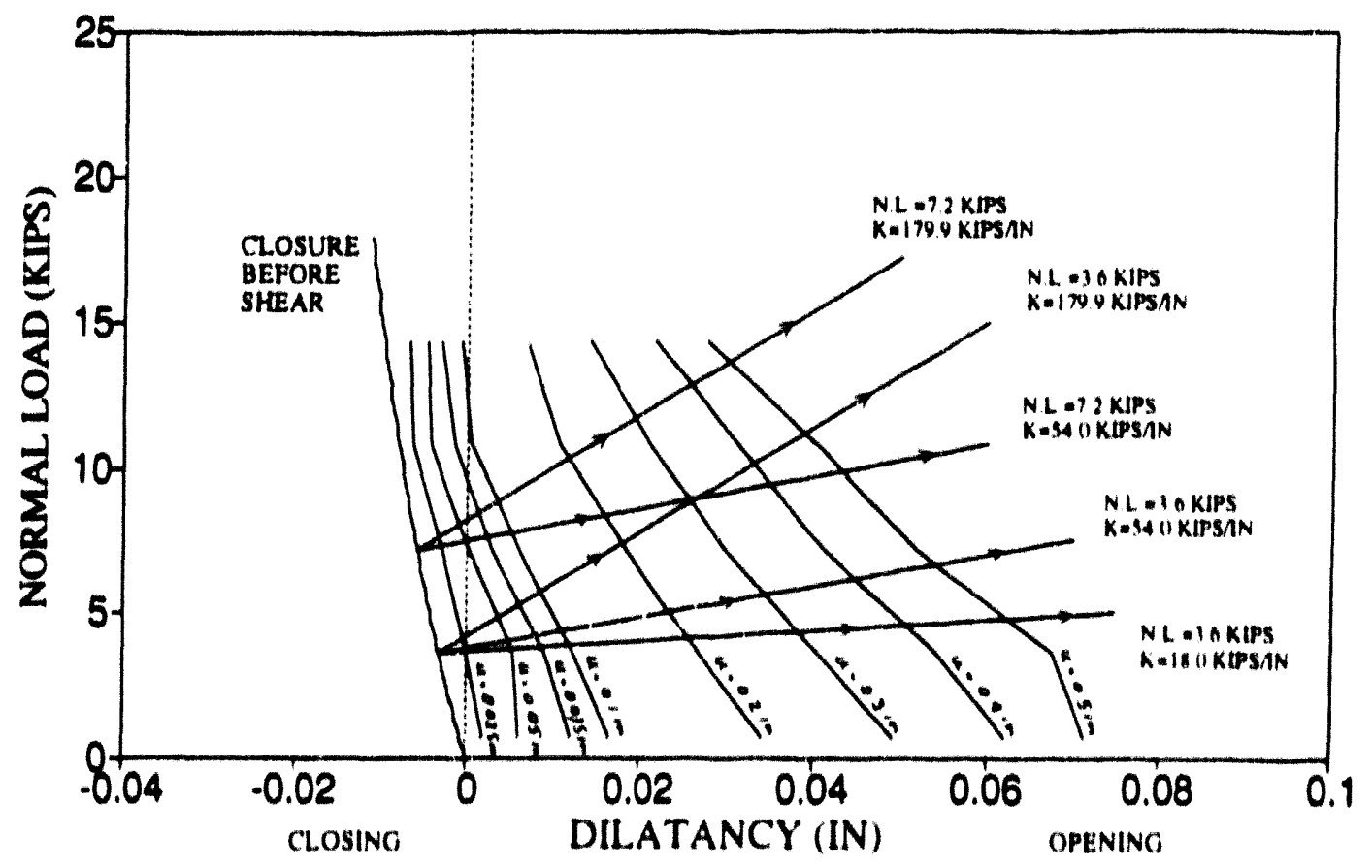

JOINT - DEFORMATION

RF4 SPECIMEN - IST CYCLE REVERSE

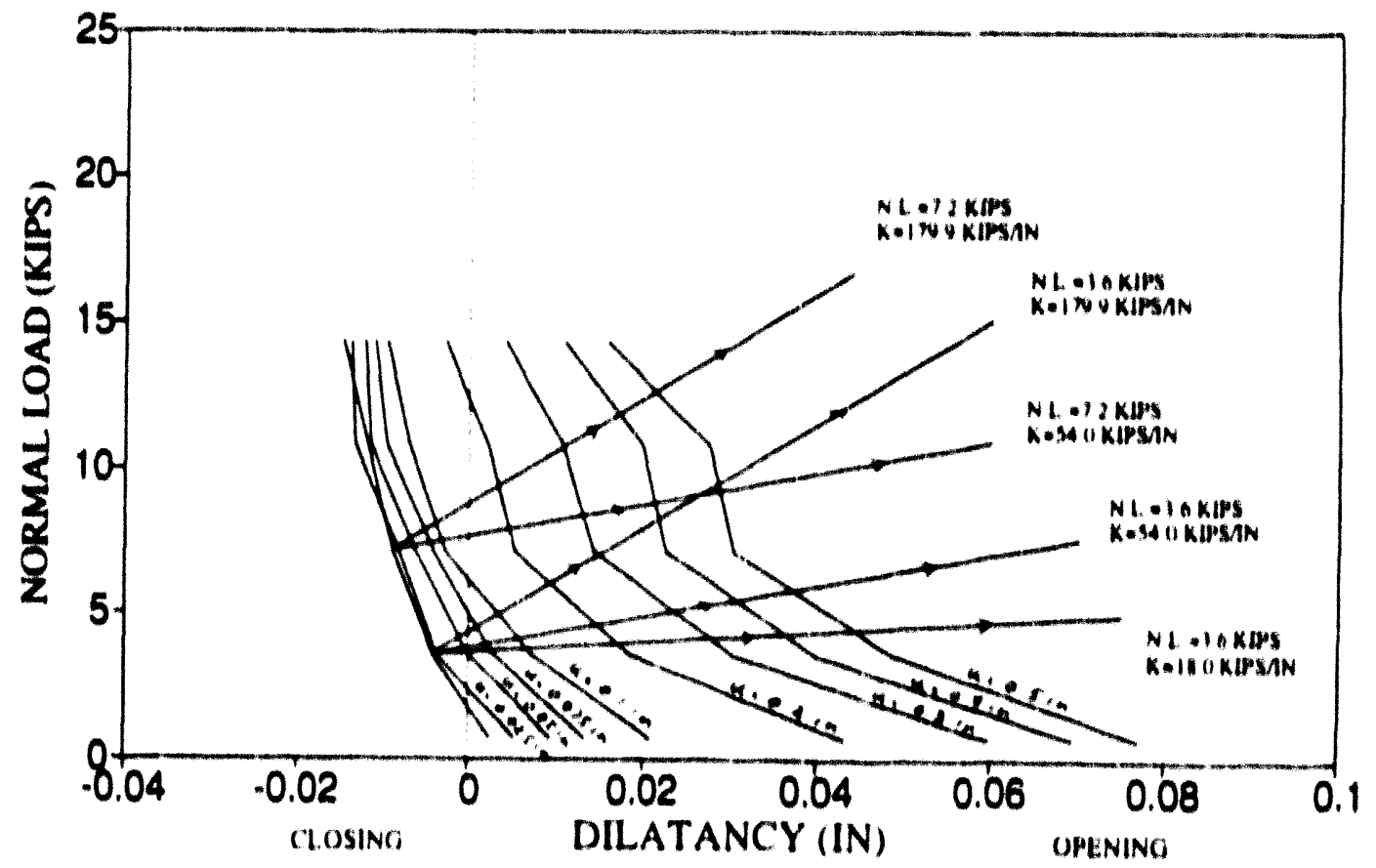



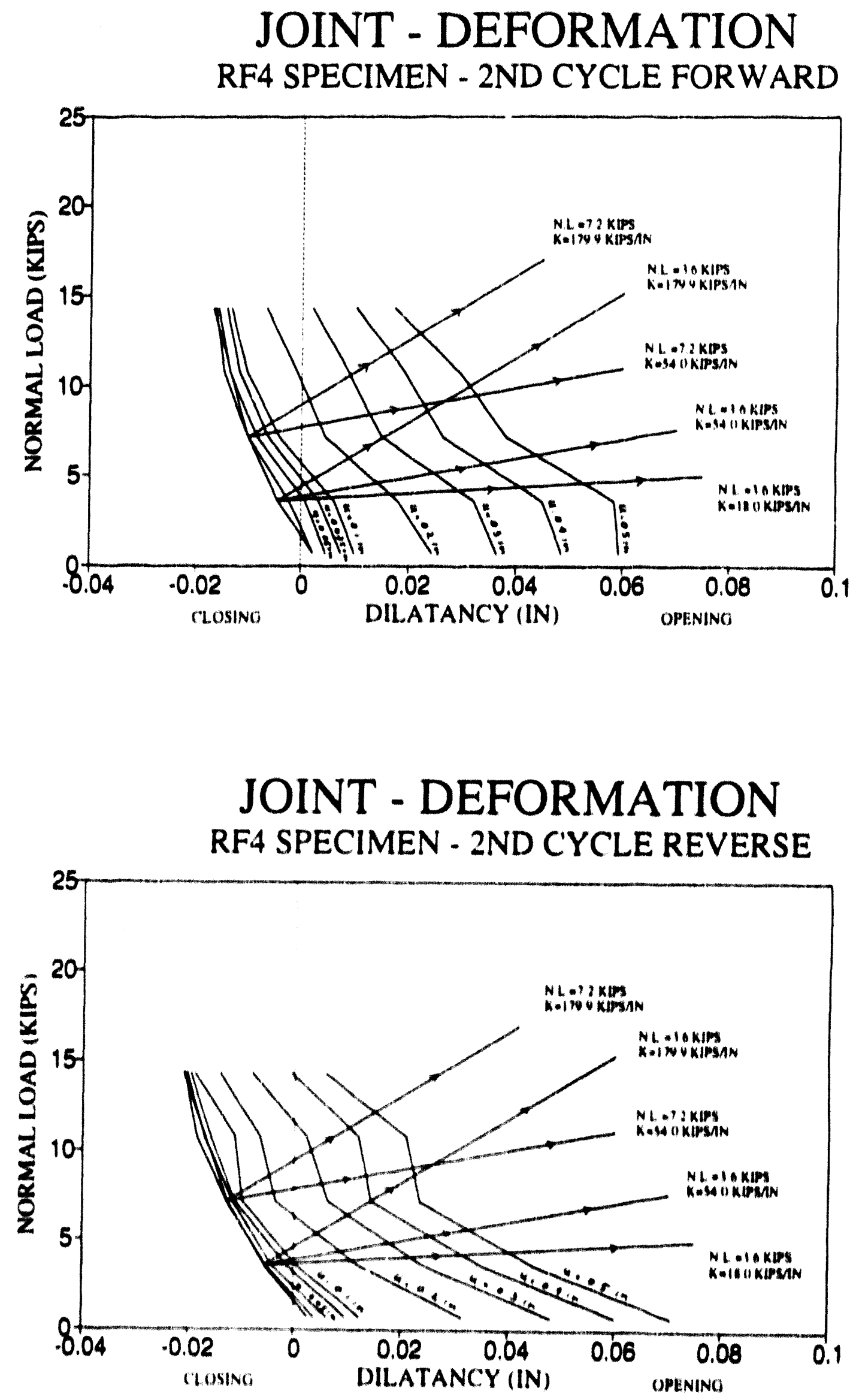


\section{JOINT - DEFORMATION RF4 SPECIMEN - 3RD CYCLE FORWARD}

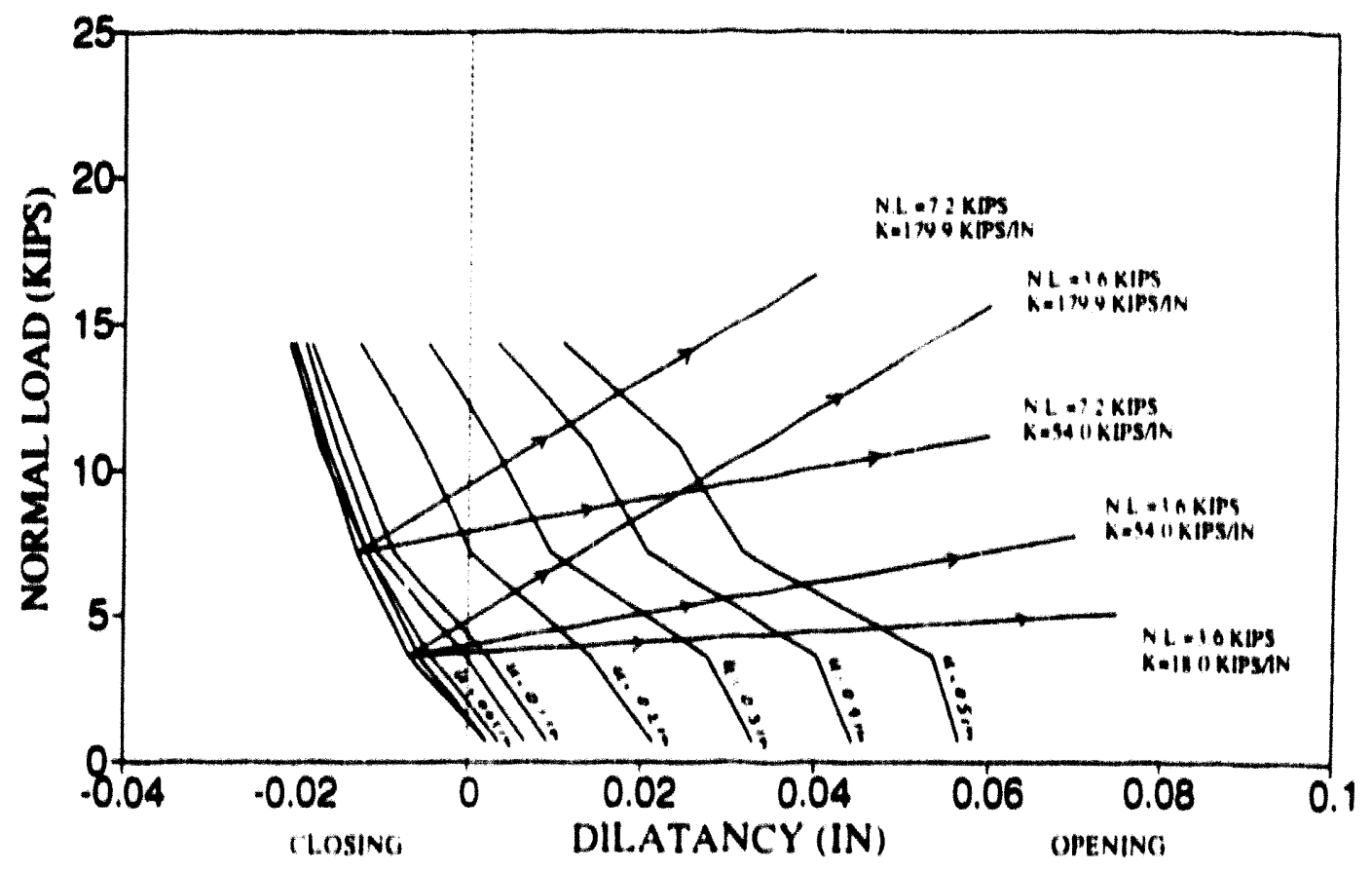

JOINT - DEFORMATION

RF4 SPECIMEN - 3RD CYCLE REVERSE

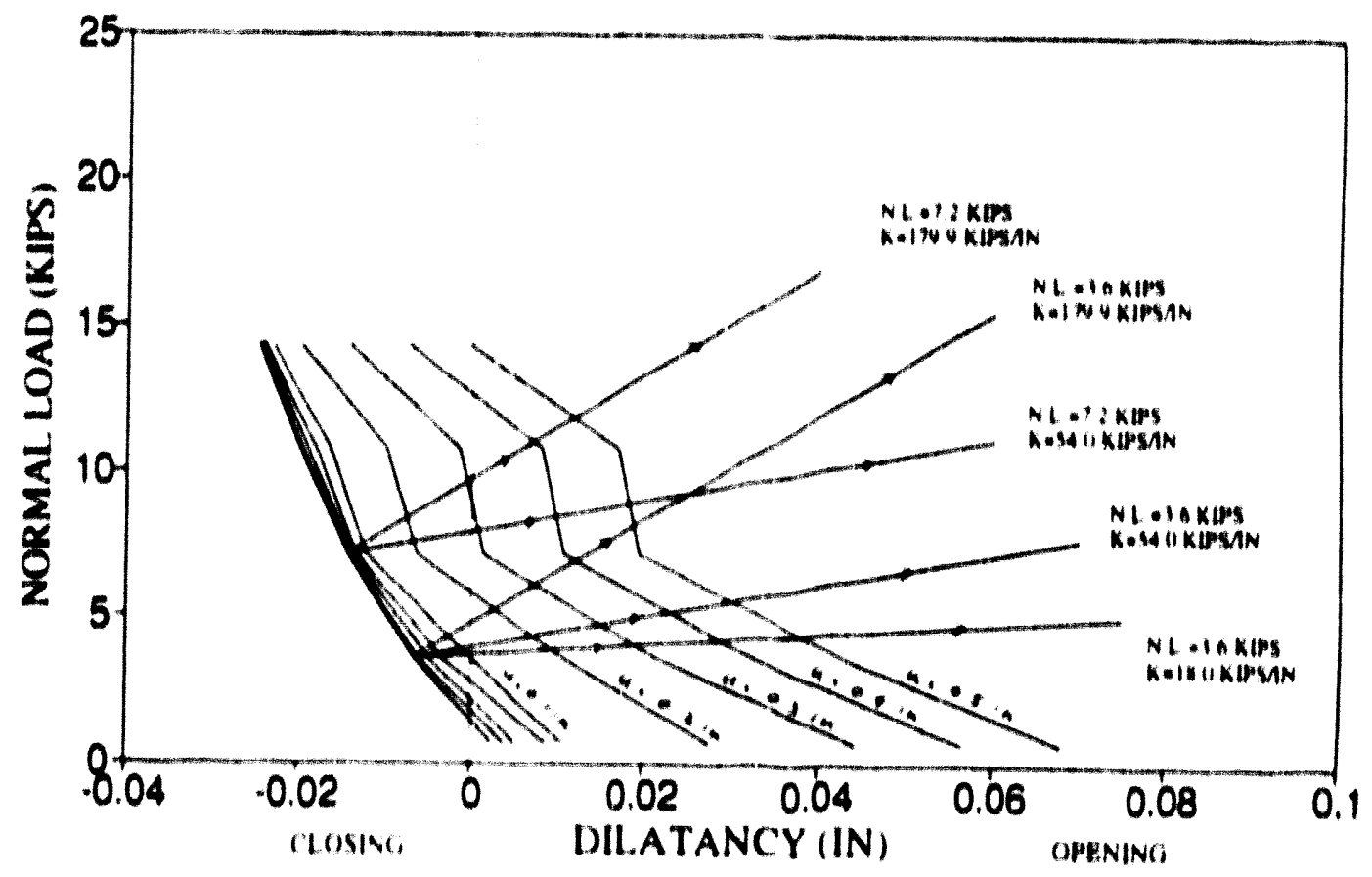




\section{JOINT - DEFORMATION RF4 SPECIMEN - 4TH CYCLE FORWARD}
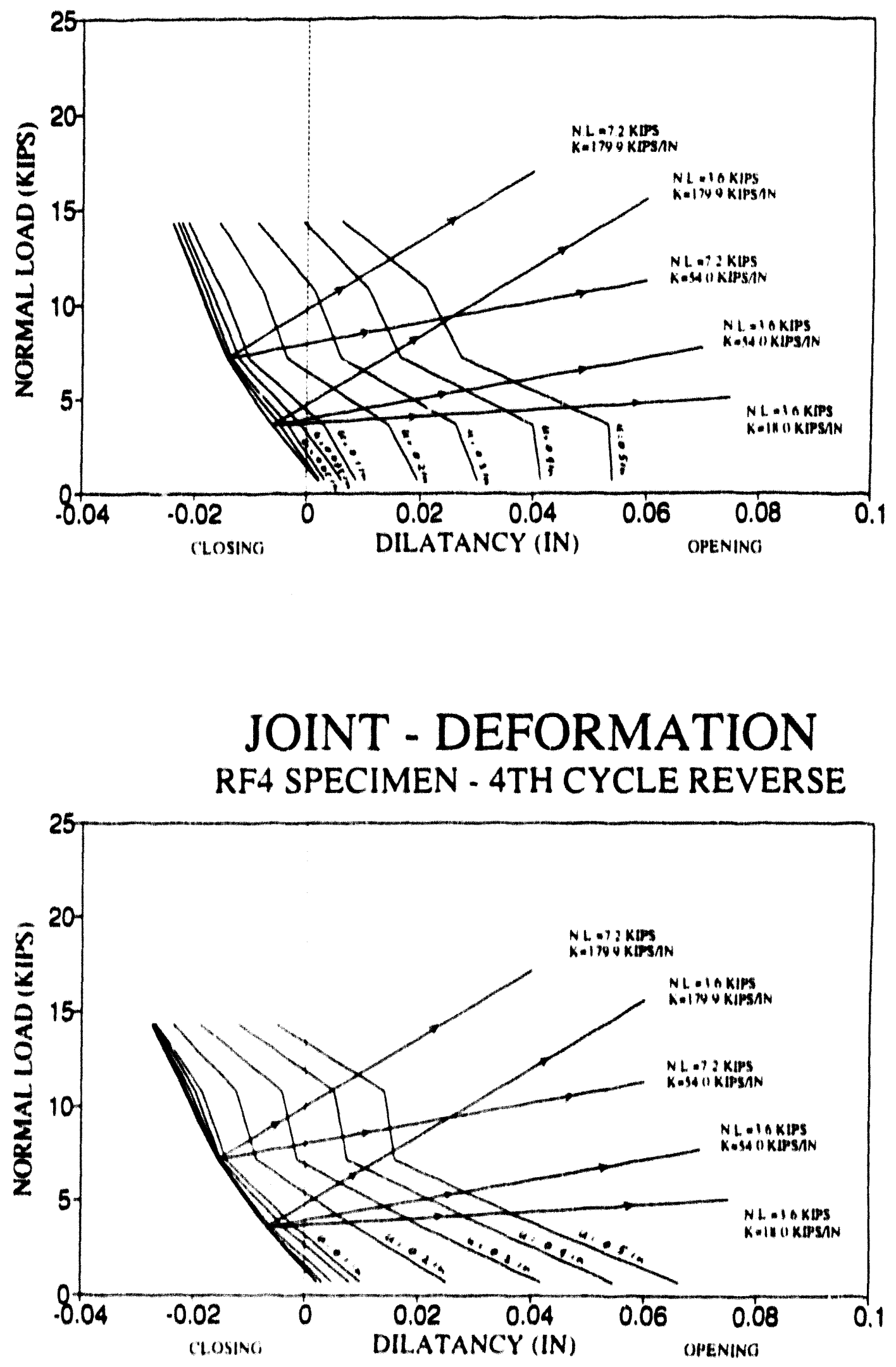


\section{JOINT - DEFORMATION \\ RF4 SPECIMEN - 5TH CYCLE FORWARD}
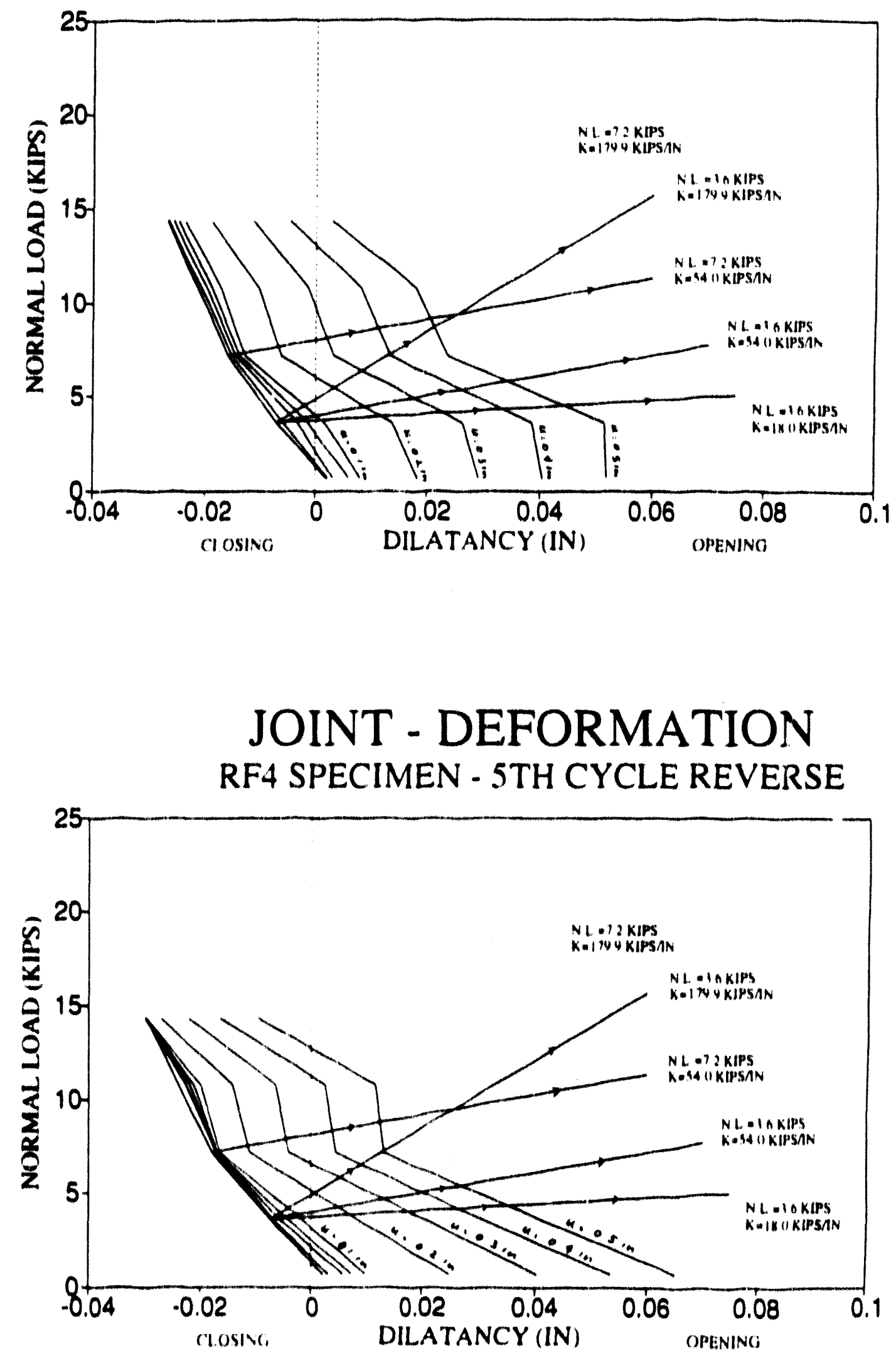


\section{JOINT - DEFORMATION}

RF3 SPECIMEN - 1ST CYCLE FORWARD

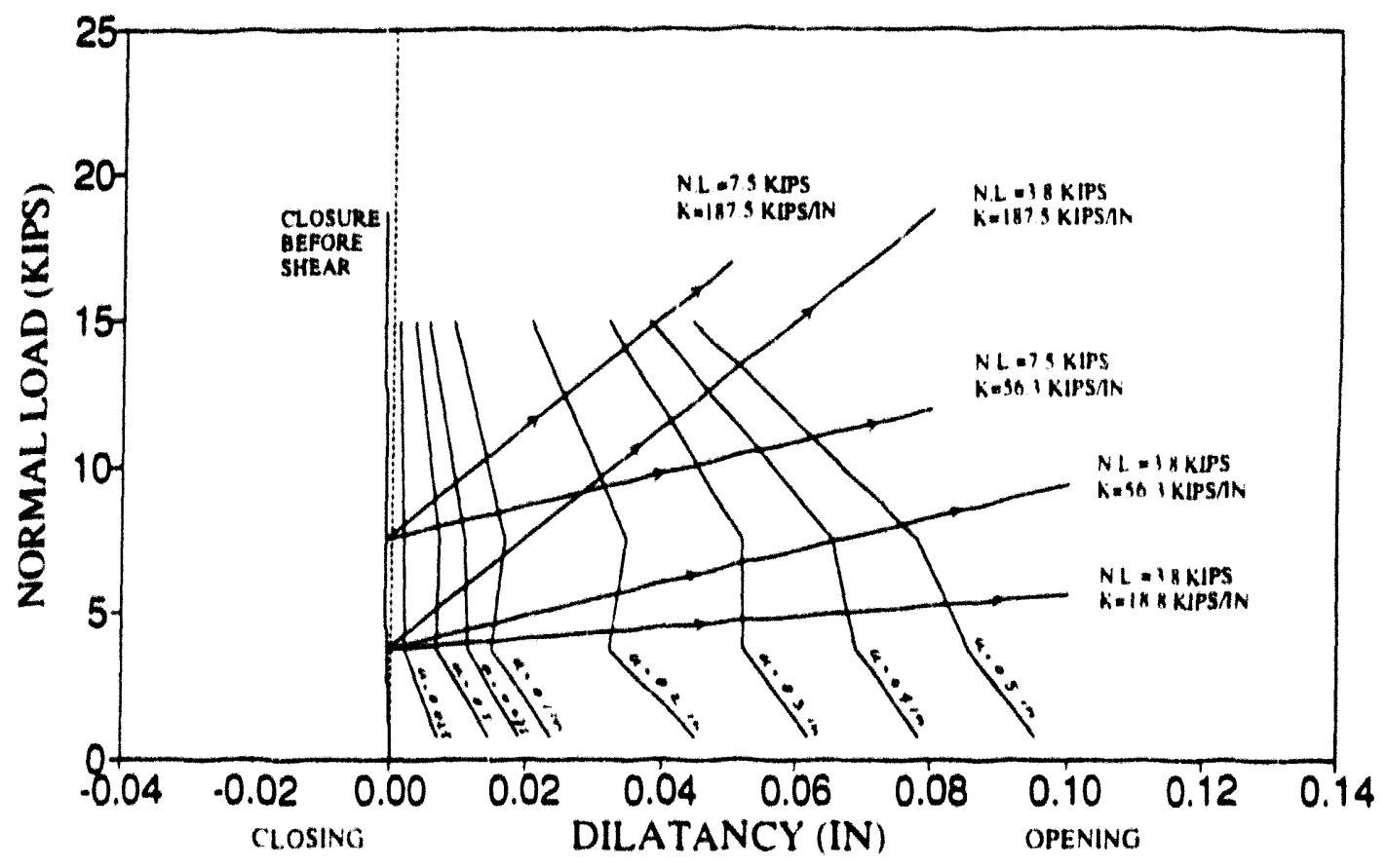

JOINT - DEFORMATION RF3 SPECIMEN - IST CYCLE REVERSE

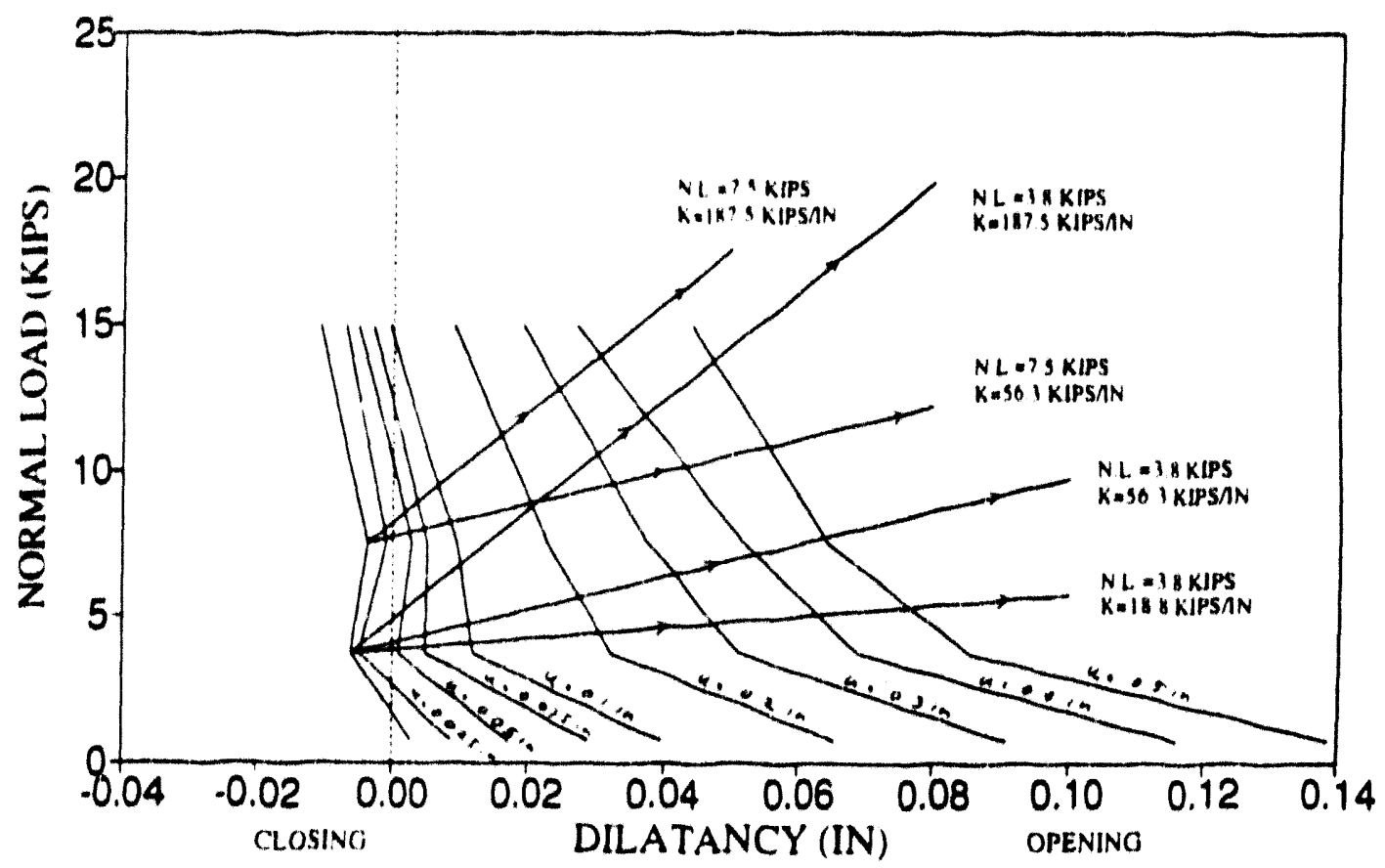




\section{JOINT - DEFORMATION RF3 SPECIMEN - 2ND CYCLE FORWARD}

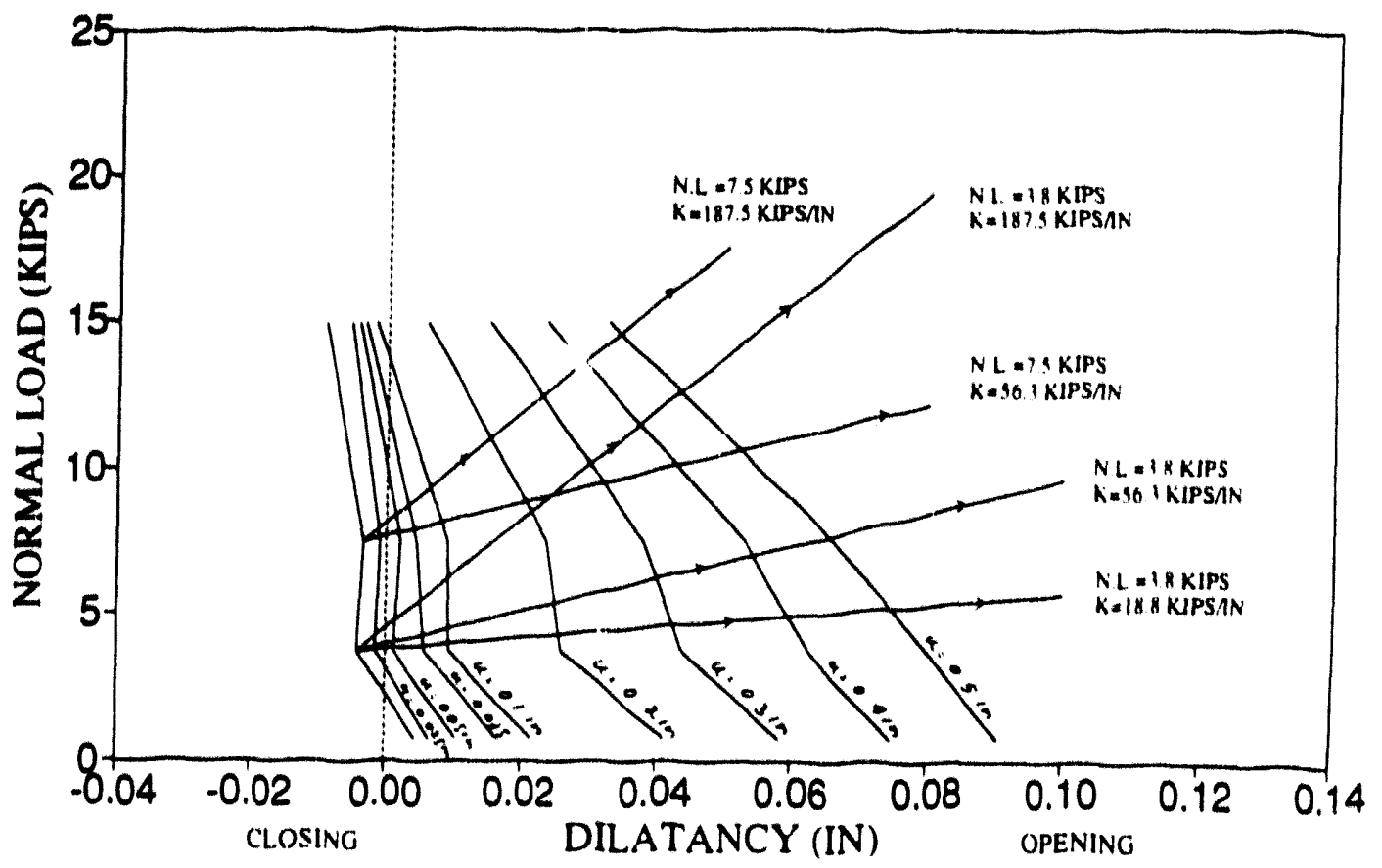

JOINT - DEFORMATION RF3 SPECIMEN - 2ND CYCLE REVERSE

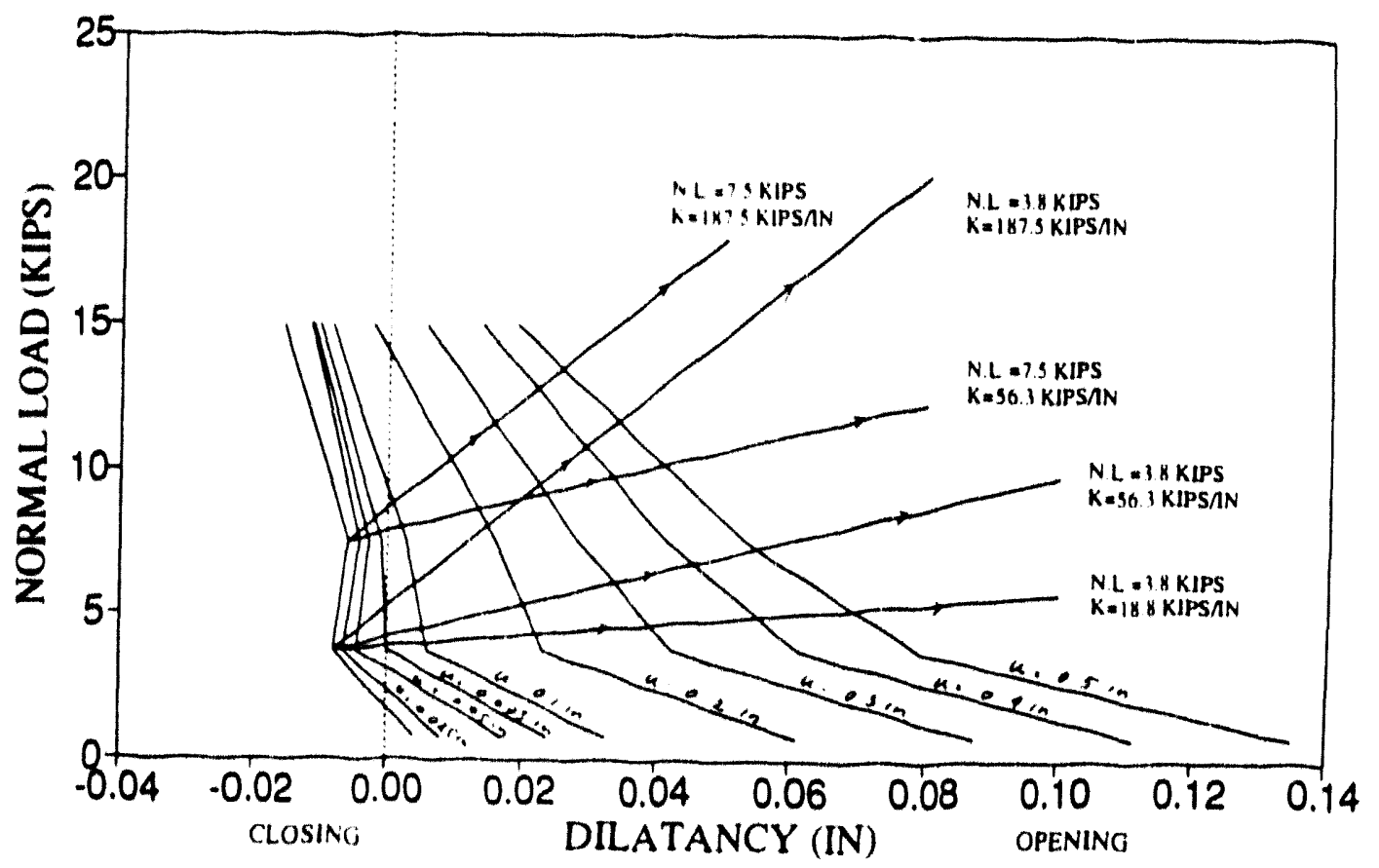


JOINT - DEFORMATION

RF3 SPECIMEN - 3RD CYCLE FORWARD

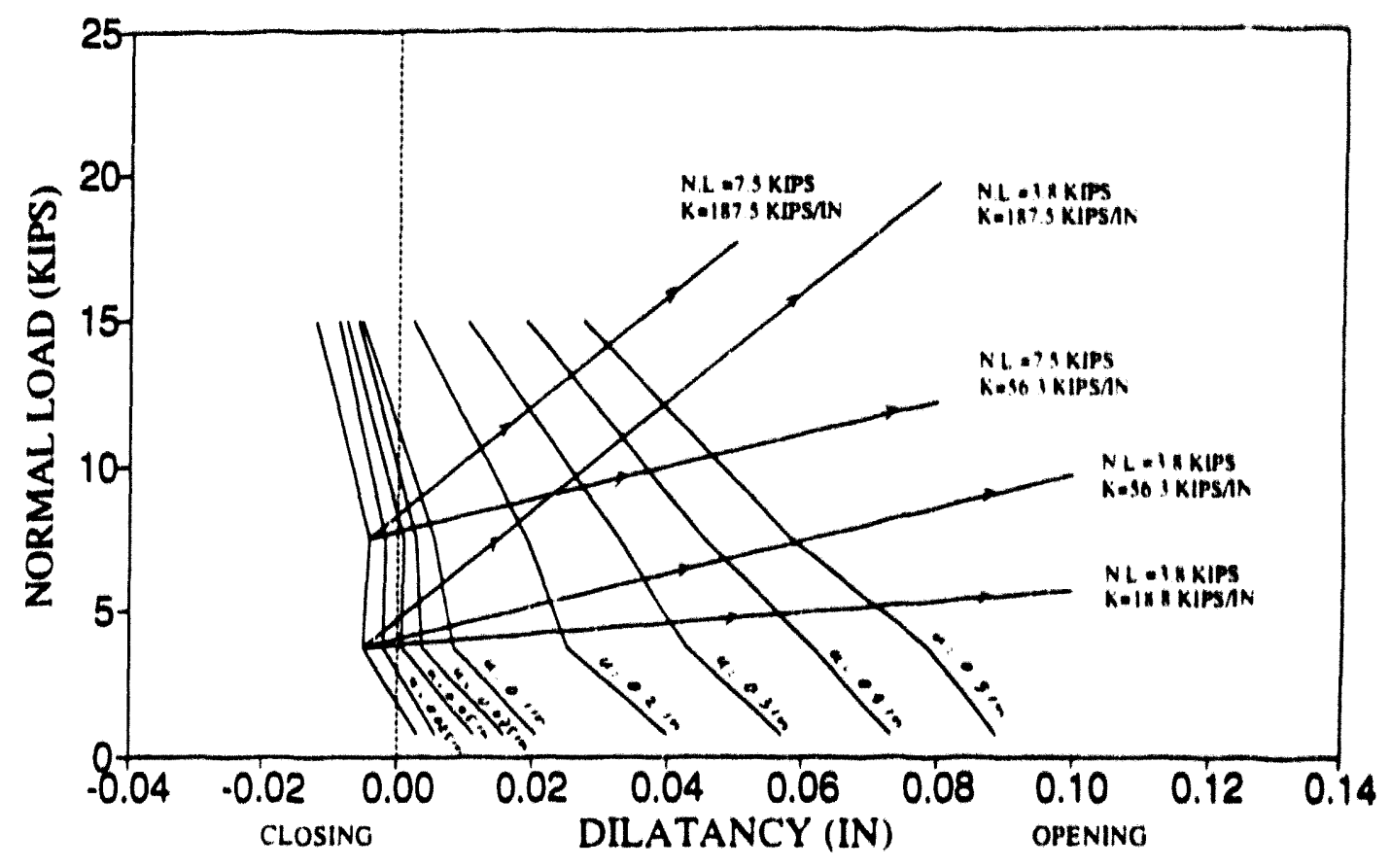

\section{JOINT - DEFORMATION}

RF3 SPECIMEN - 3RD CYCLE REVERSE

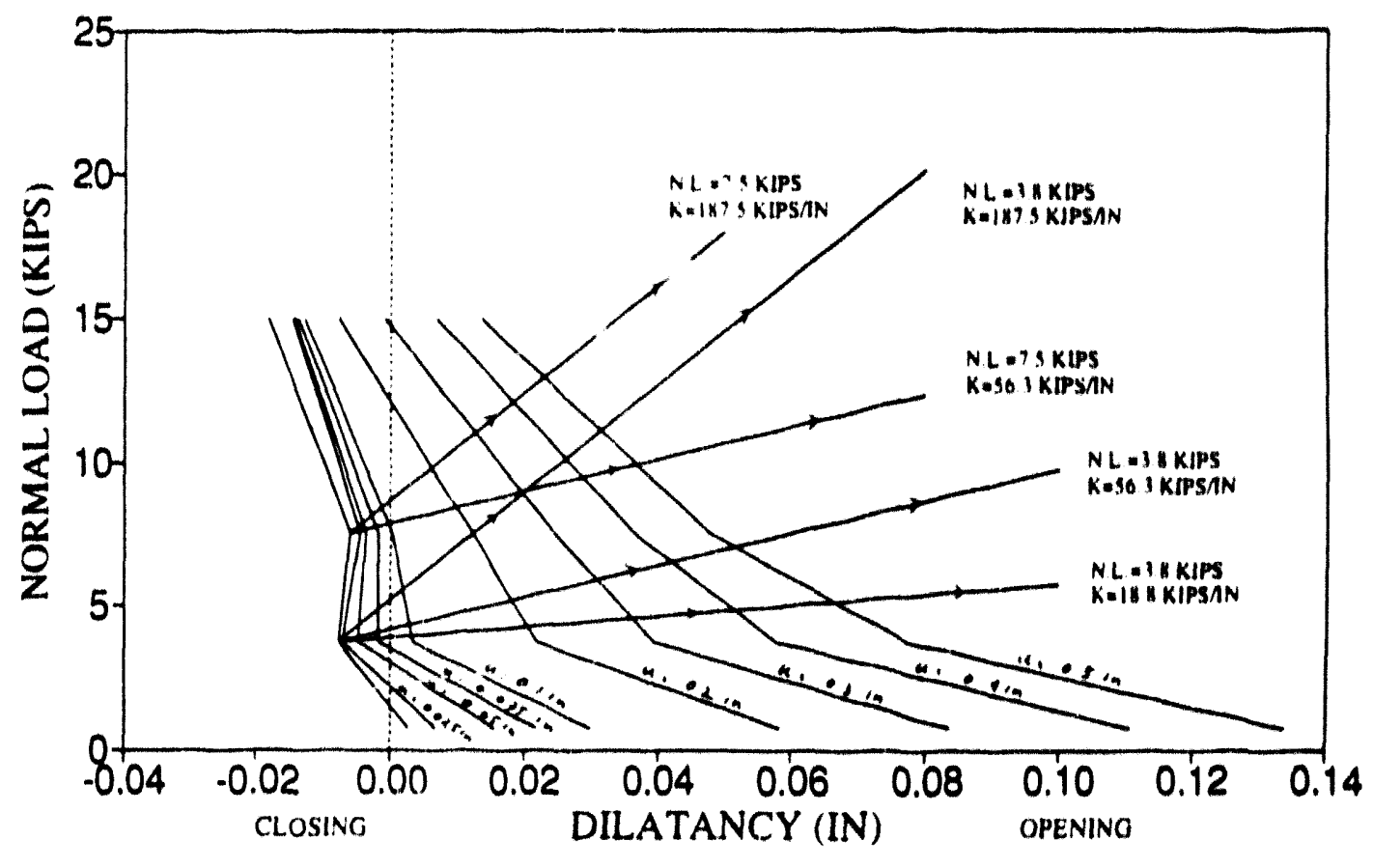




\section{JOINT - DEFORMATION RF3 SPECIMEN - 4TH CYCLE FORWARD}

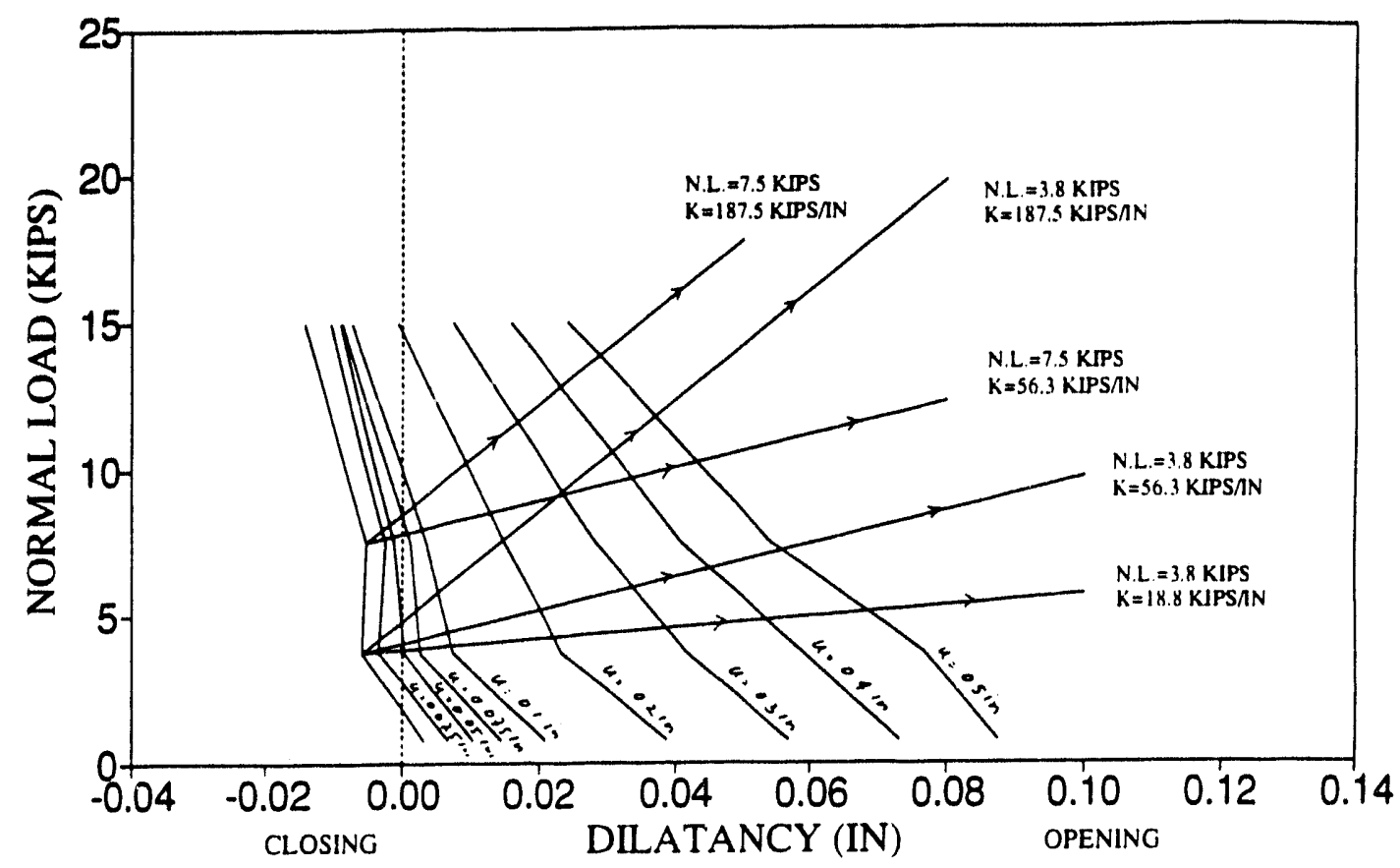

JOINT - DEFORMATION RF3 SPECIMEN - 4TH CYCLE REVERSE

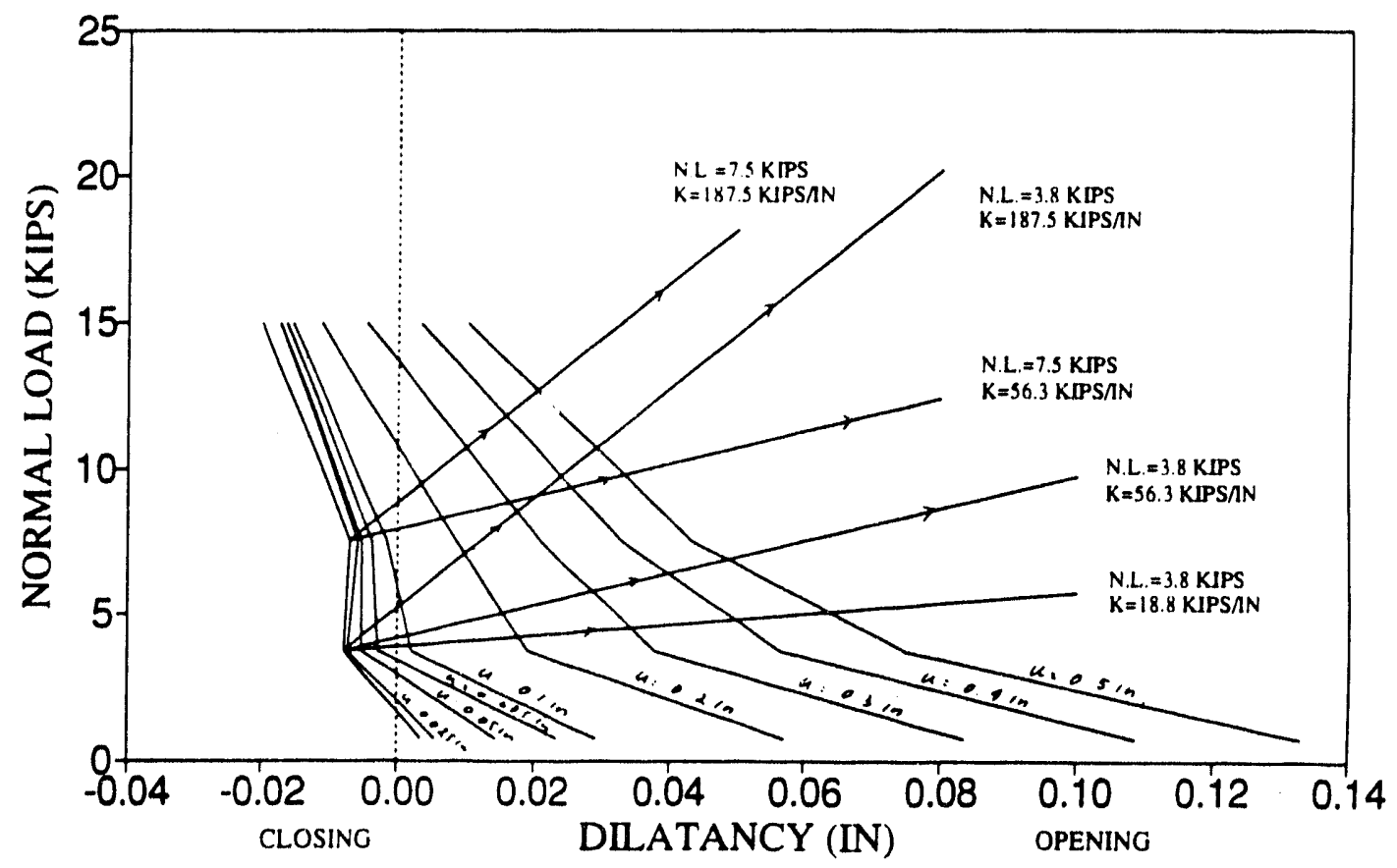




\section{JOINT - DEFORMATION}

\section{RF3 SPECIMEN - 5TH CYCLE FORWARD}

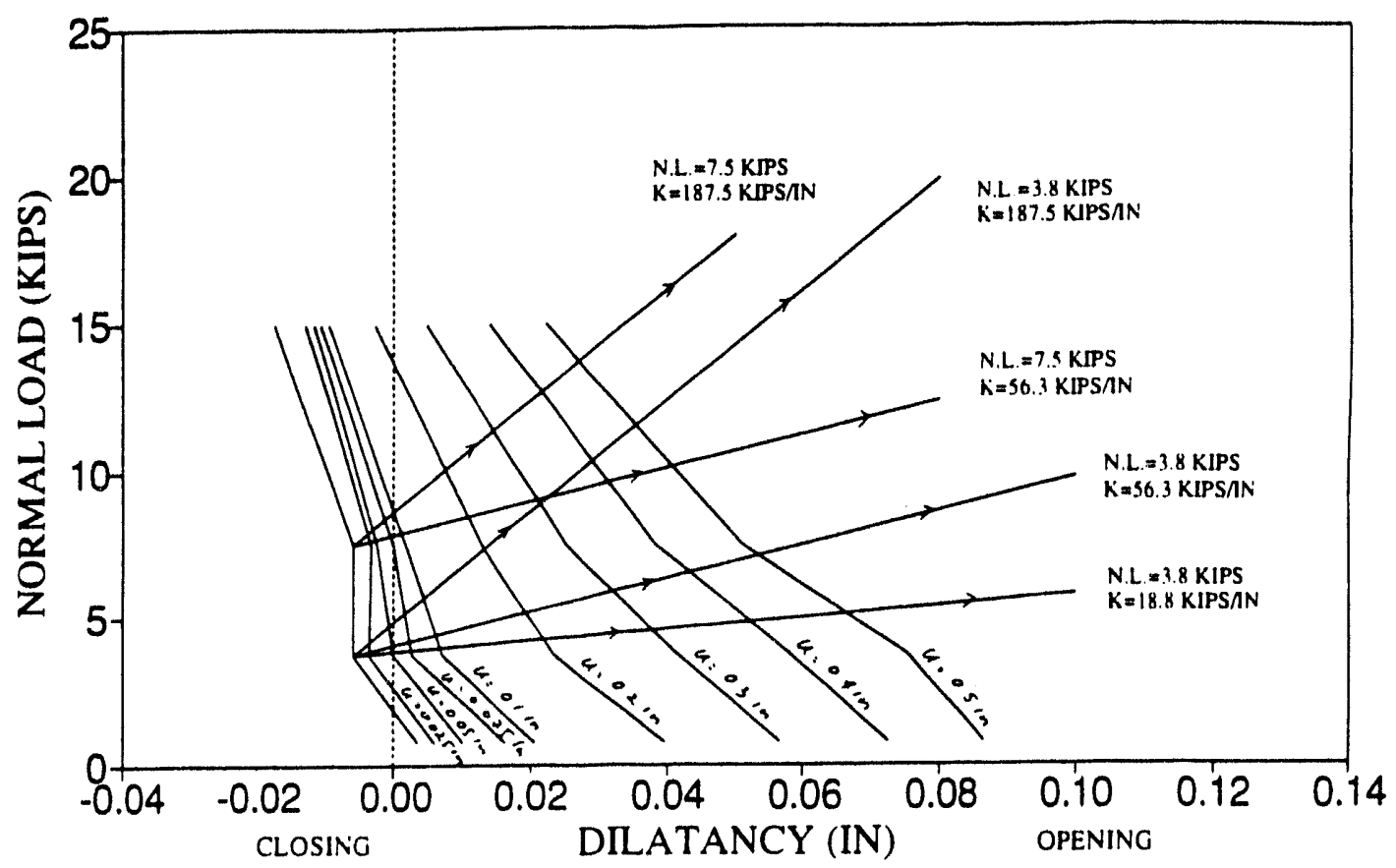

JOINT - DEFORMATION RF3 SPECIMEN - 5TH CYCLE REVERSE

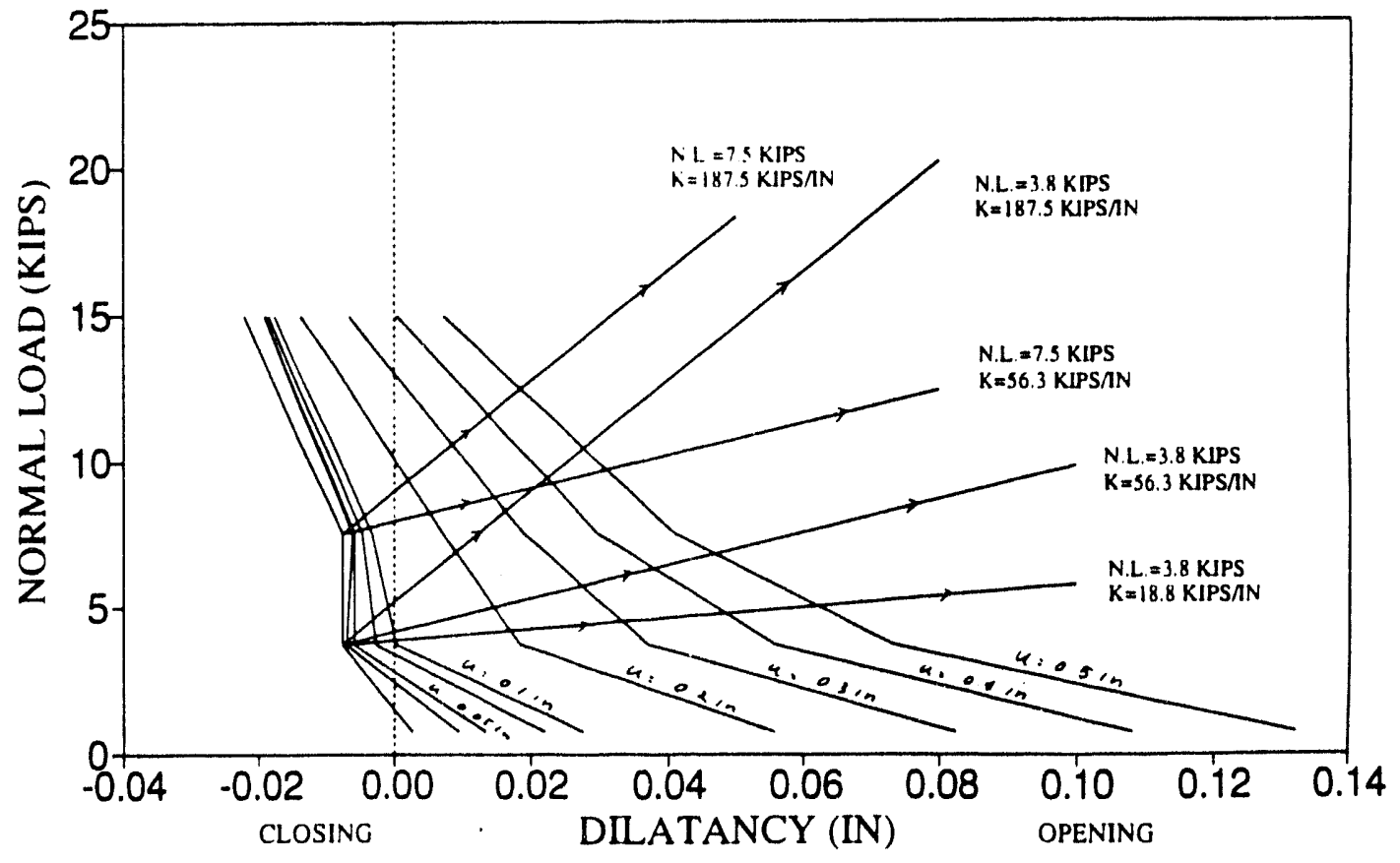




\section{JOINT - DEFORMATION}

\section{RF2 SPECIMEN - 1ST CYCLE FORWARD}

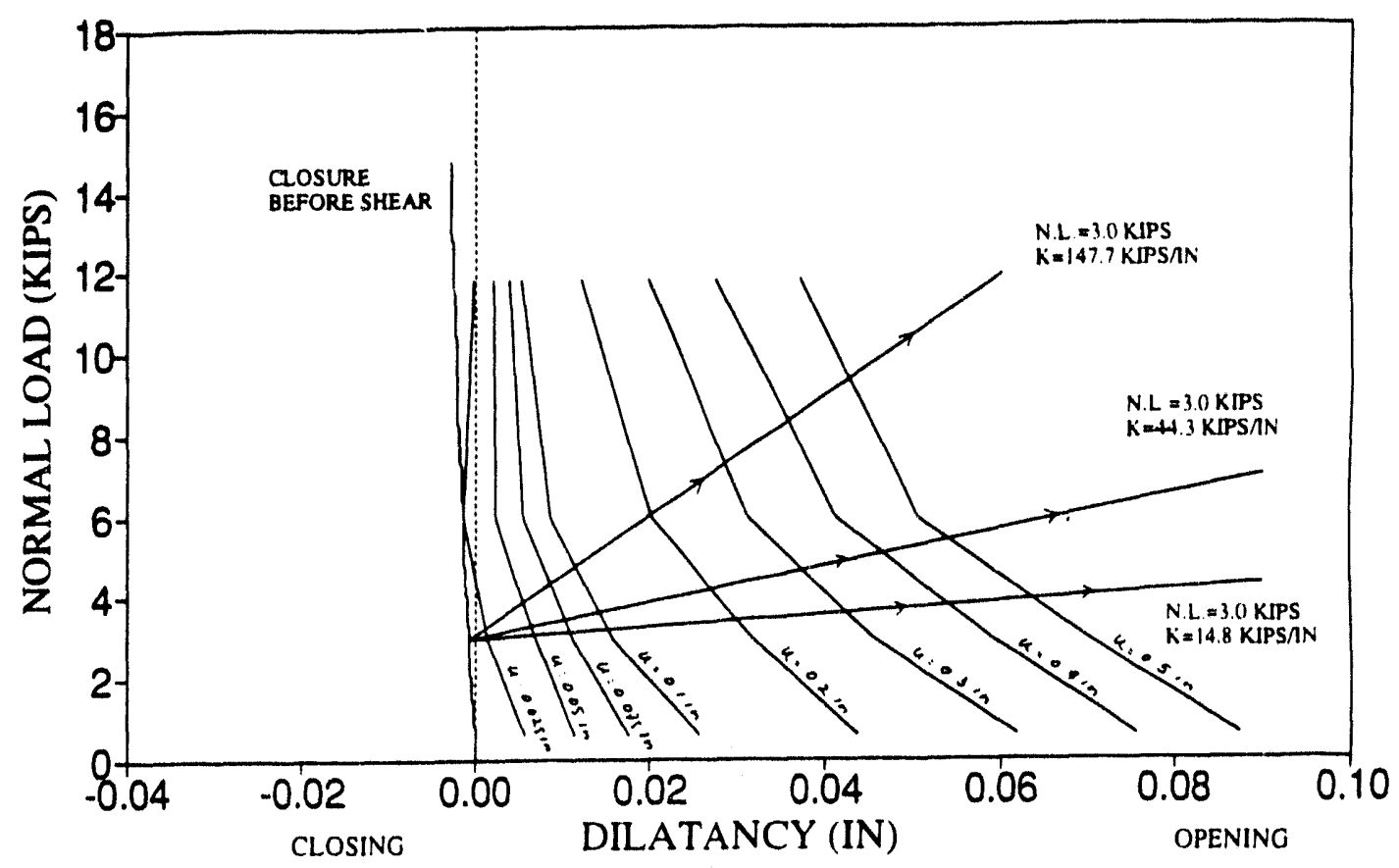

\section{JOINT - DEFORMATION}

RF2 SPECIMEN - 1ST CYCLE REVERSE

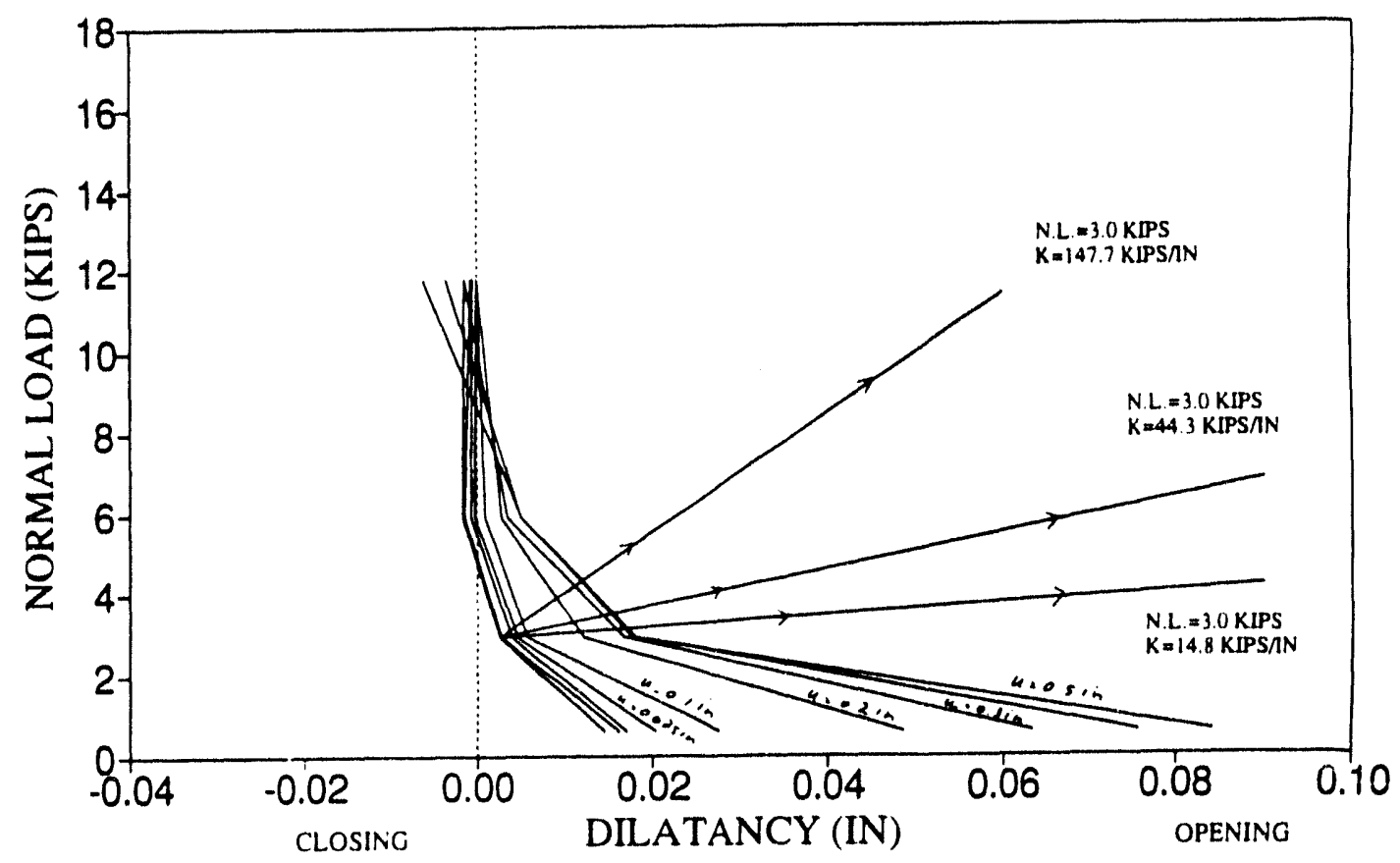




\section{JOINT - DEFORMATION RF2 SPECIMEN - 2ND CYCL.E FORWARD}

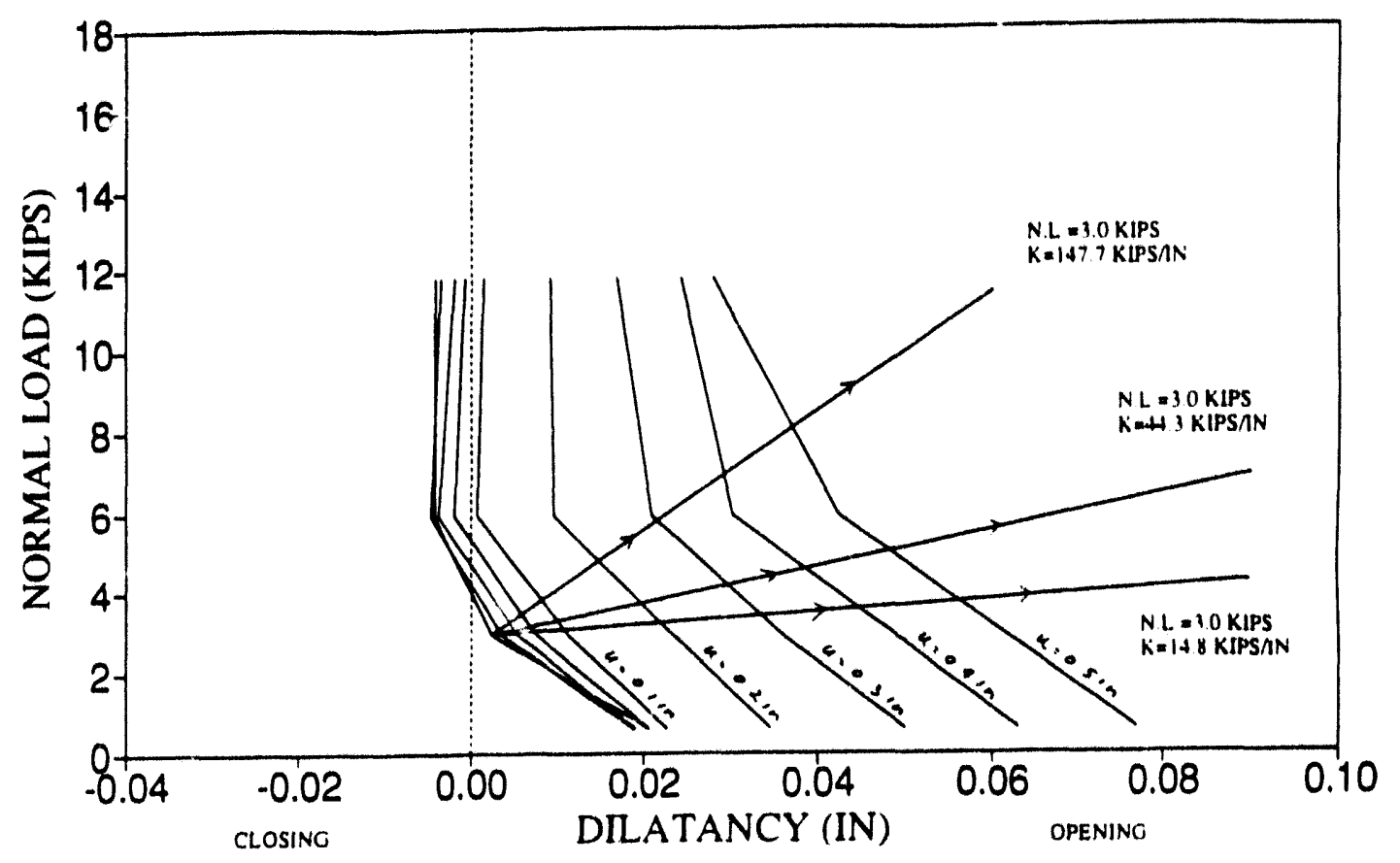

JOINT - DEFORMATION RF2 SPECIMEN - 2ND CYCLE REVERSE

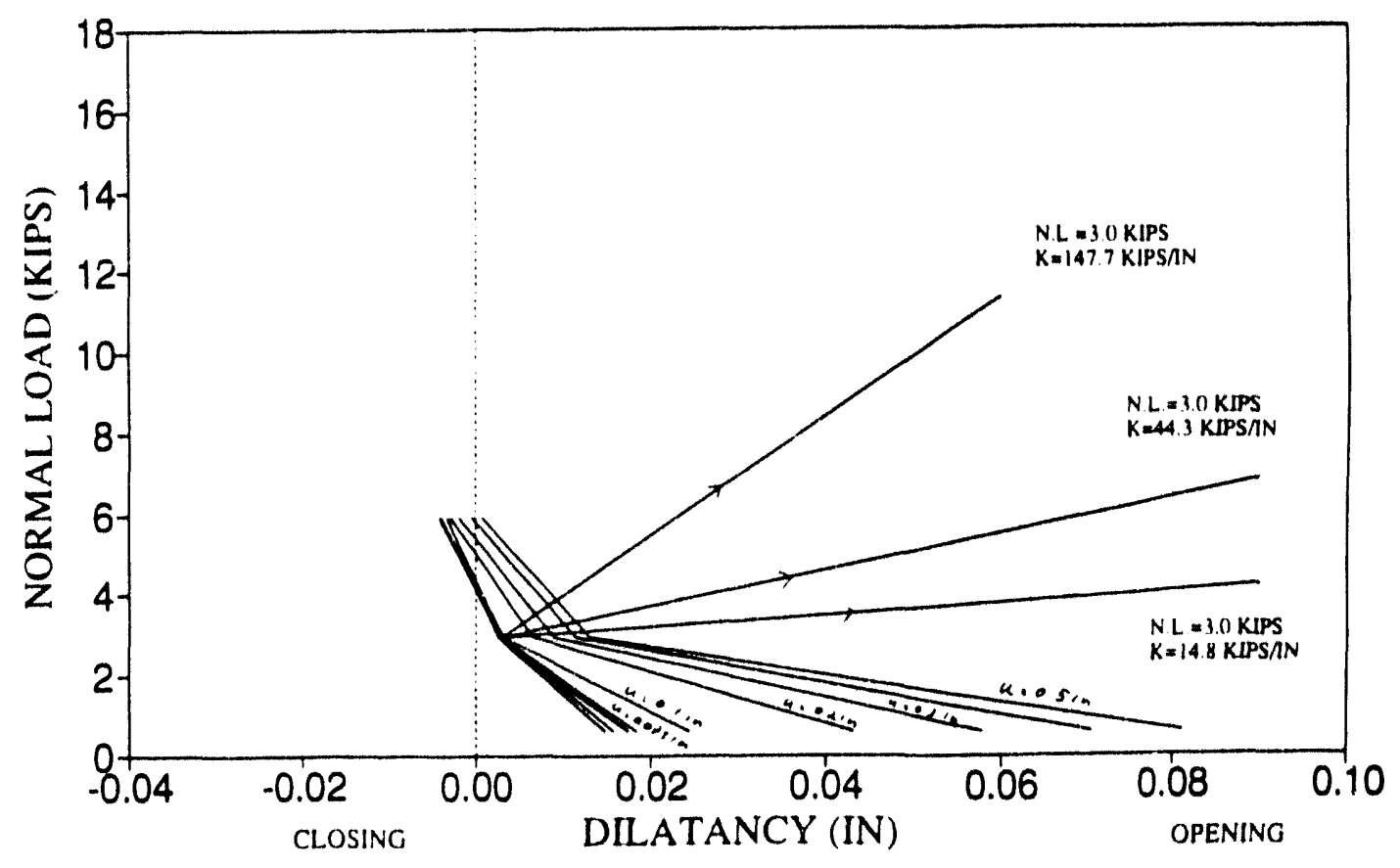




\section{JOINT - DEFORMATION}

\section{RF2 SPECIMEN - 3RD CYCLE FORWARD}

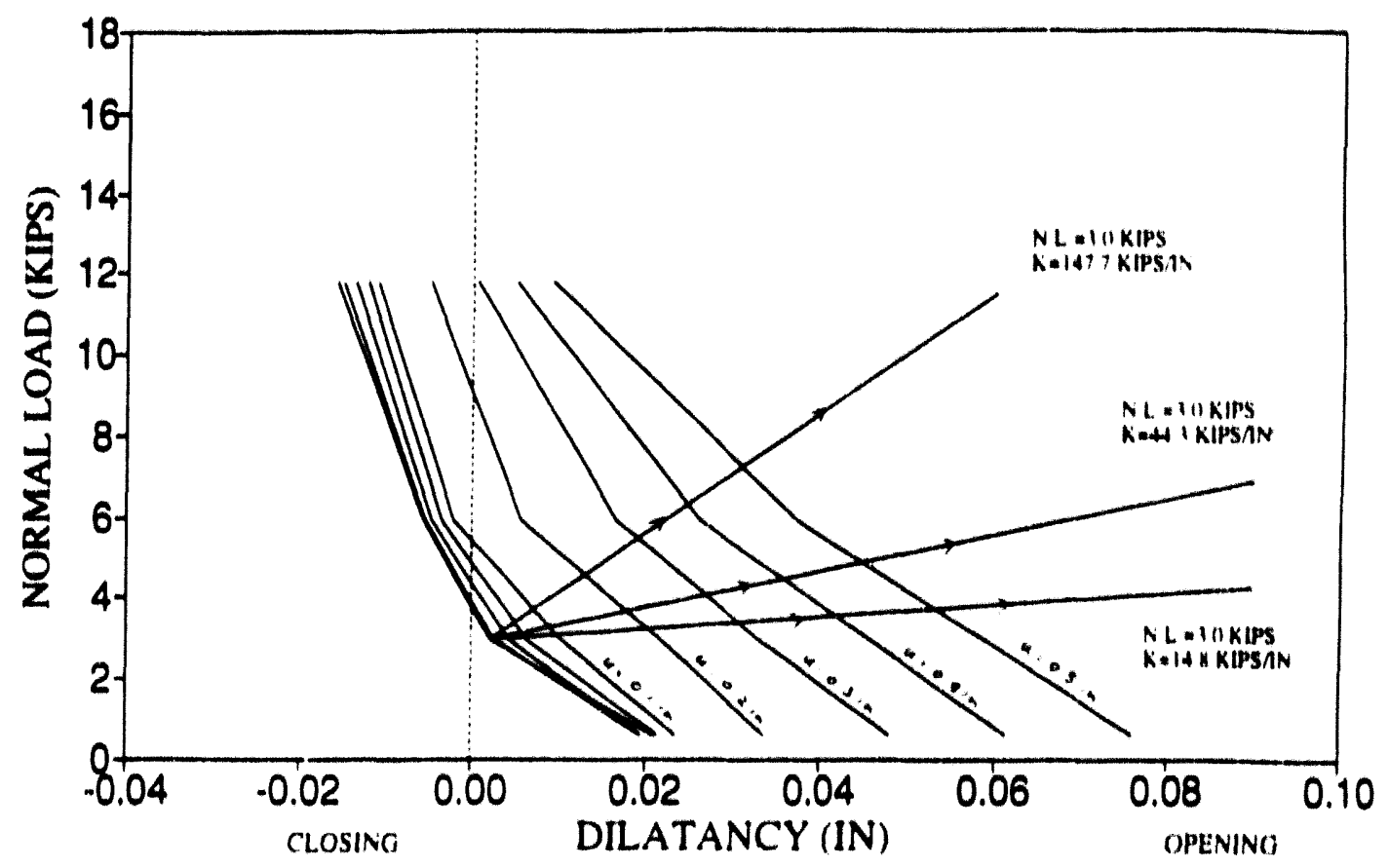

JOINT - DEFORMATION RF2 SPECIMEN - 3RD CYCLE REVERSE

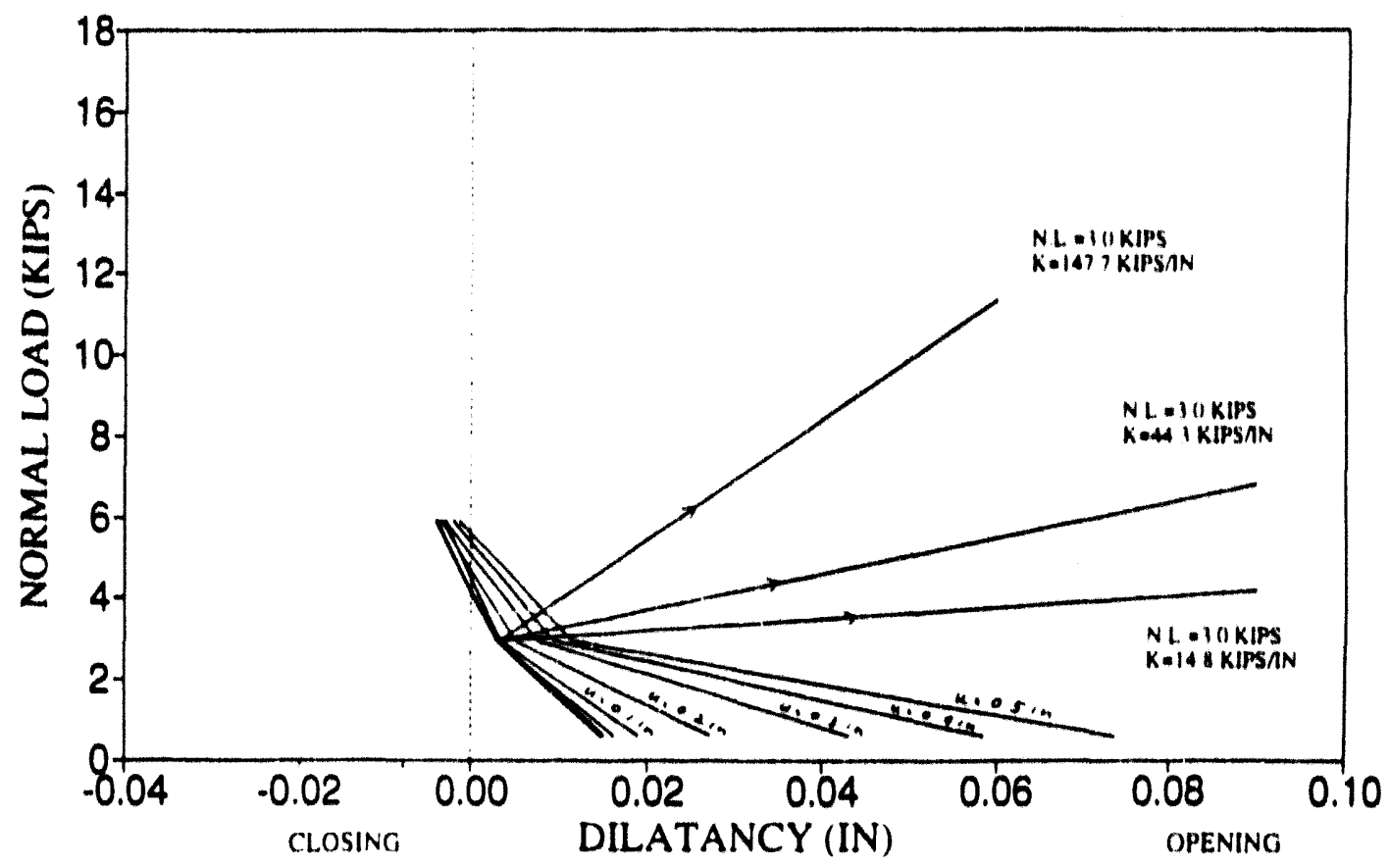



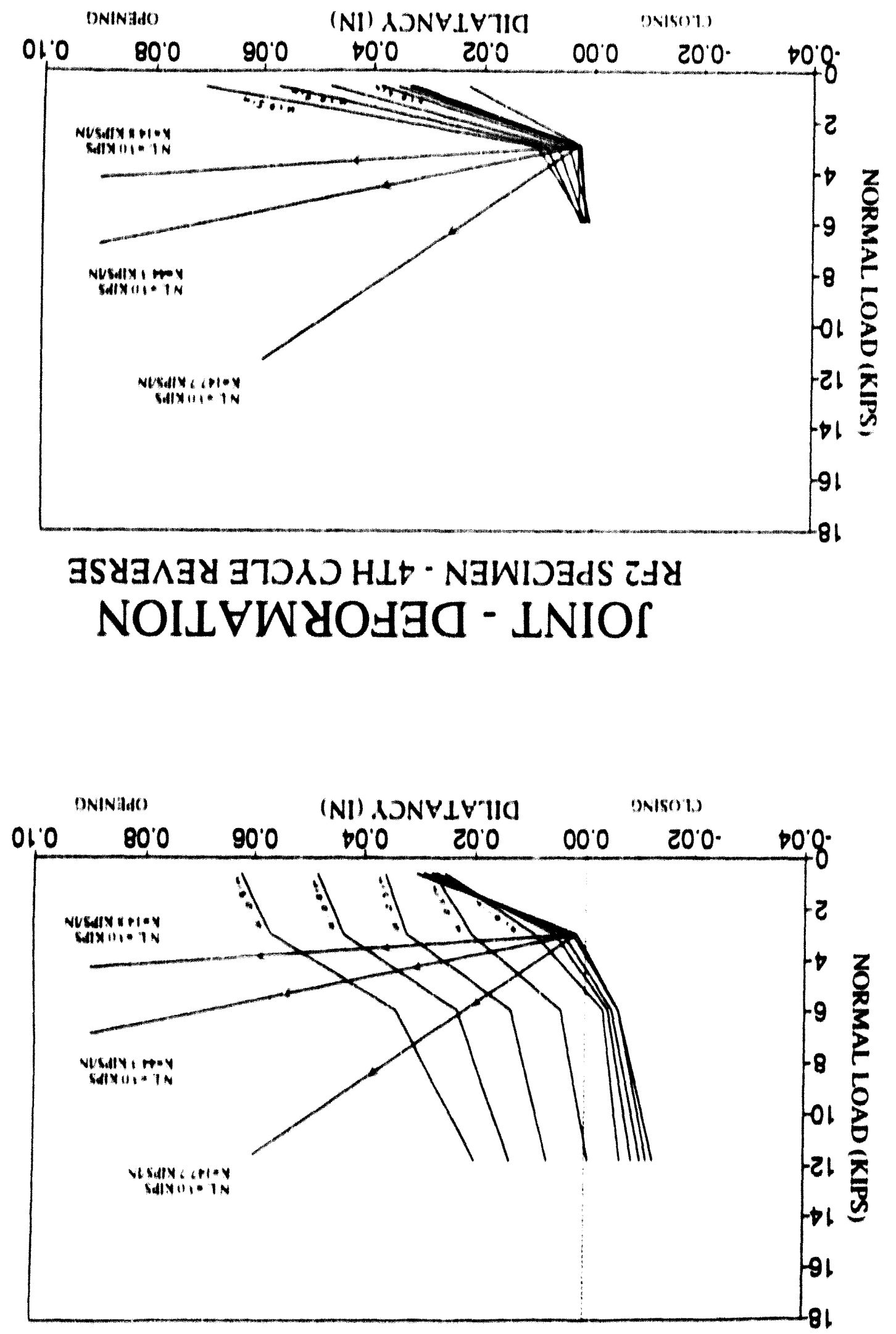

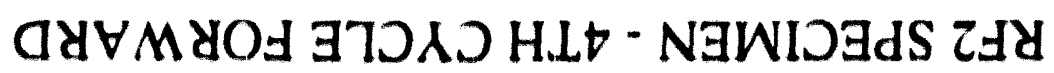
NOIL $\forall$ WYOABO - LNIOS 


\section{JOINT - DEFORMATION RF2 SPECIMEN - 5TH CYCLE FORWARD}

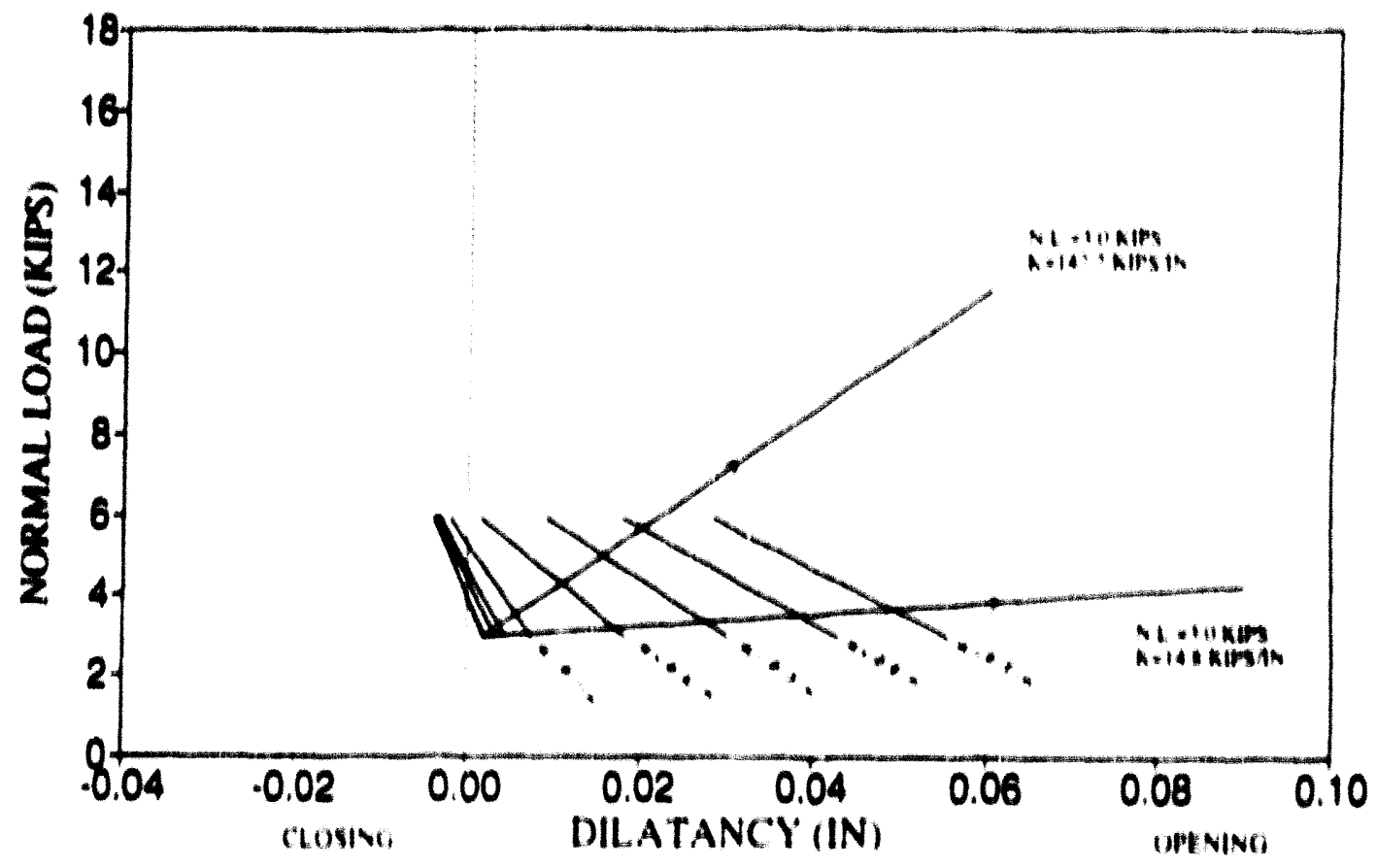

JOINT - DEFORMATION RFI SPECIMEN - 5TH CYCLE REVERSE

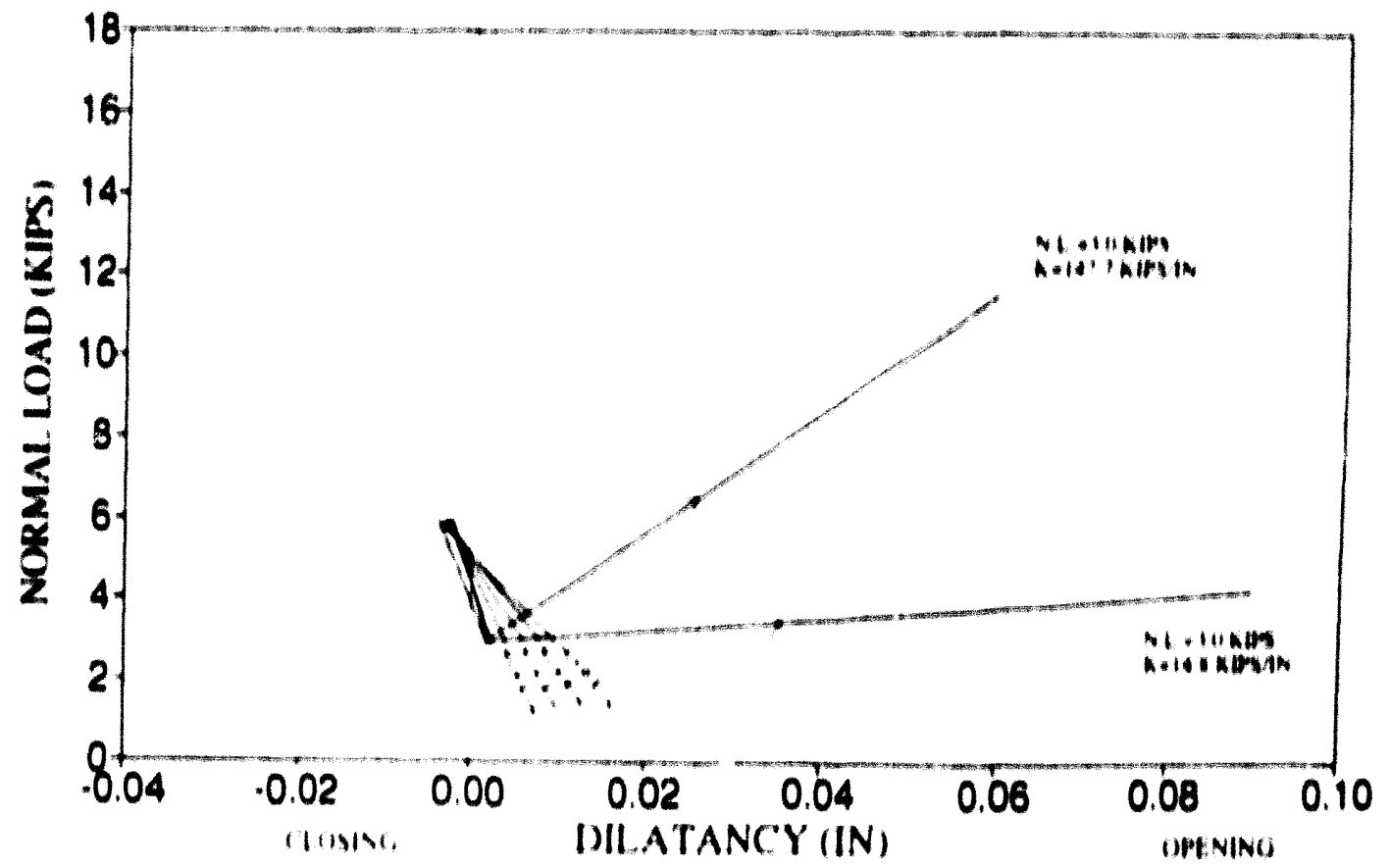




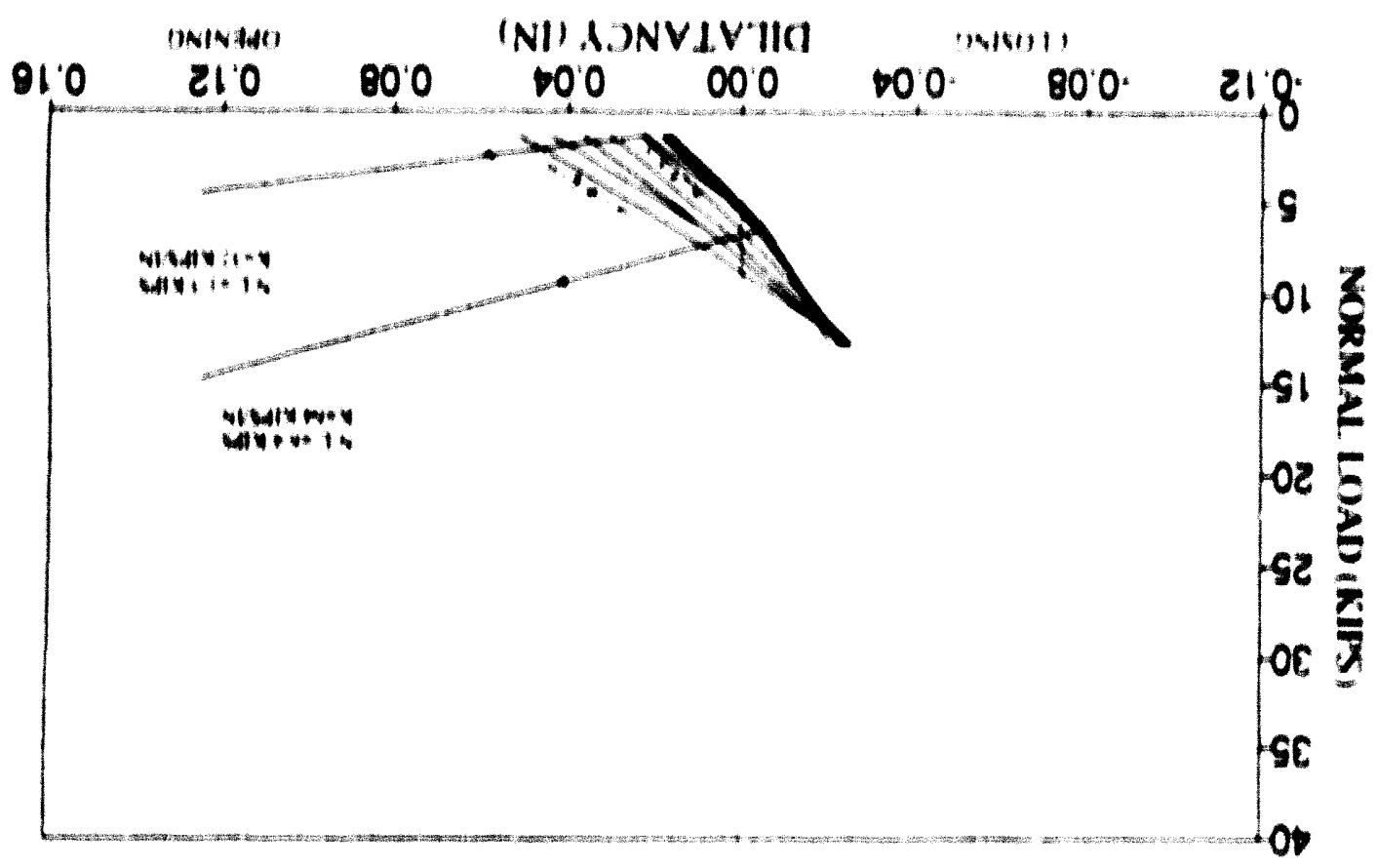

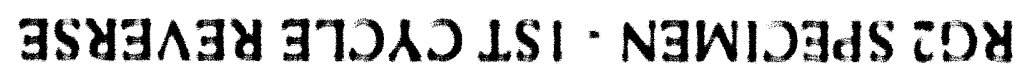
NOIL $\forall W Y O A \exists Q-I N I O S$

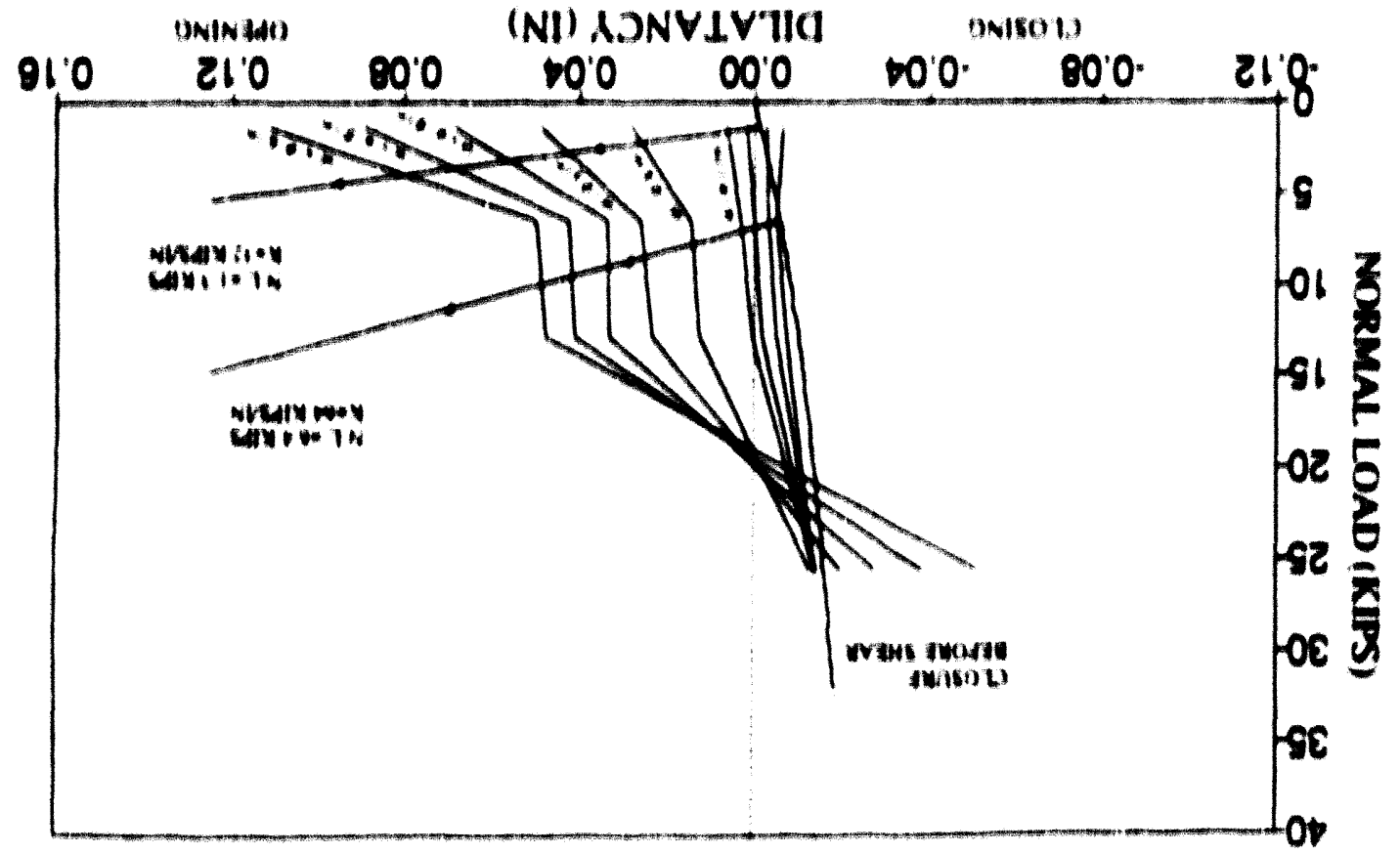

वYVMYOA J7DND LSI - NGWIDGdS ZDY NOIL $\forall W Y O A G Q$ - INIOI 


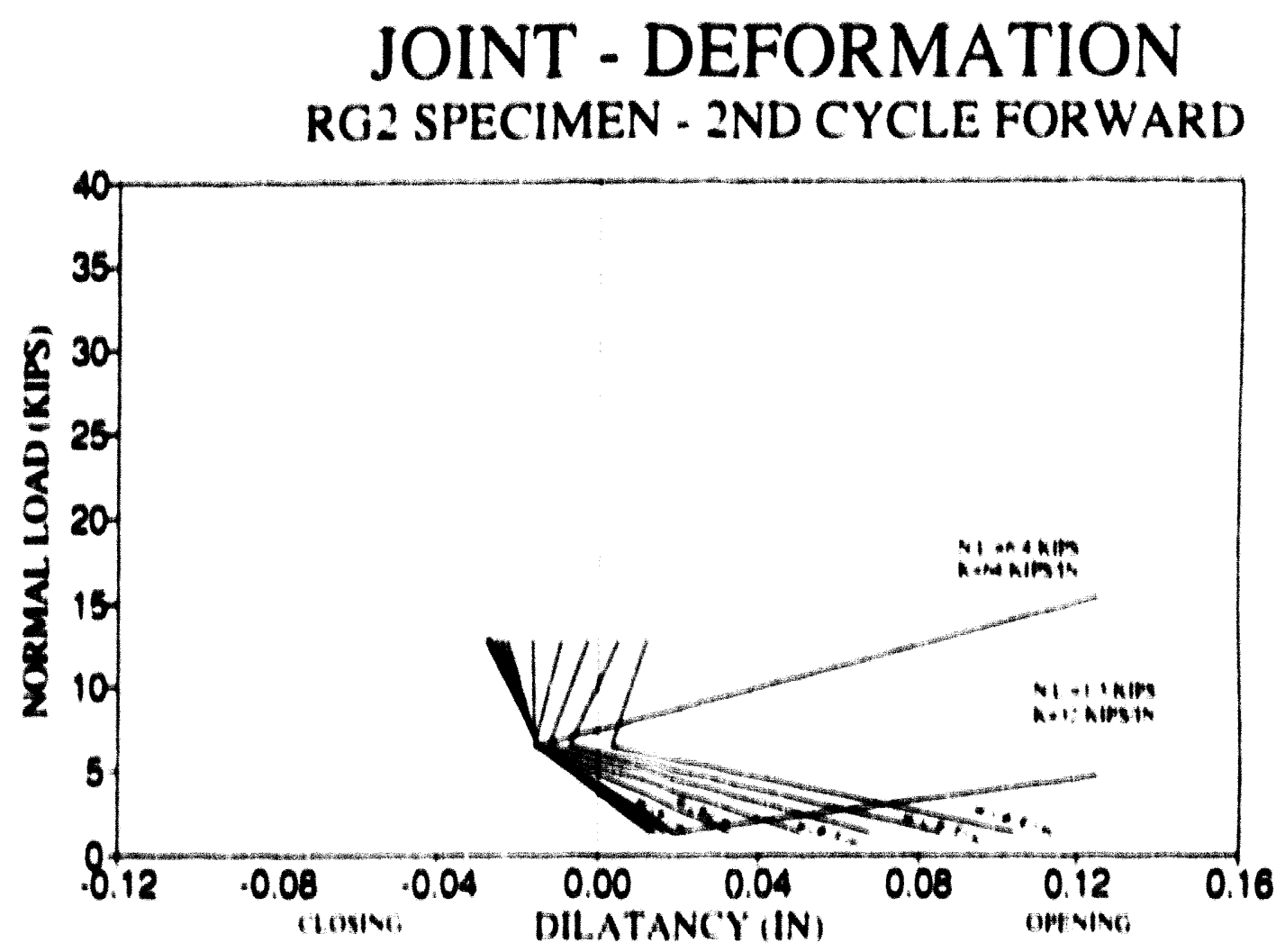

\section{JOINT - DEFORMATION RG2 SPECIMEN - 2ND CYCLE REVERSE}

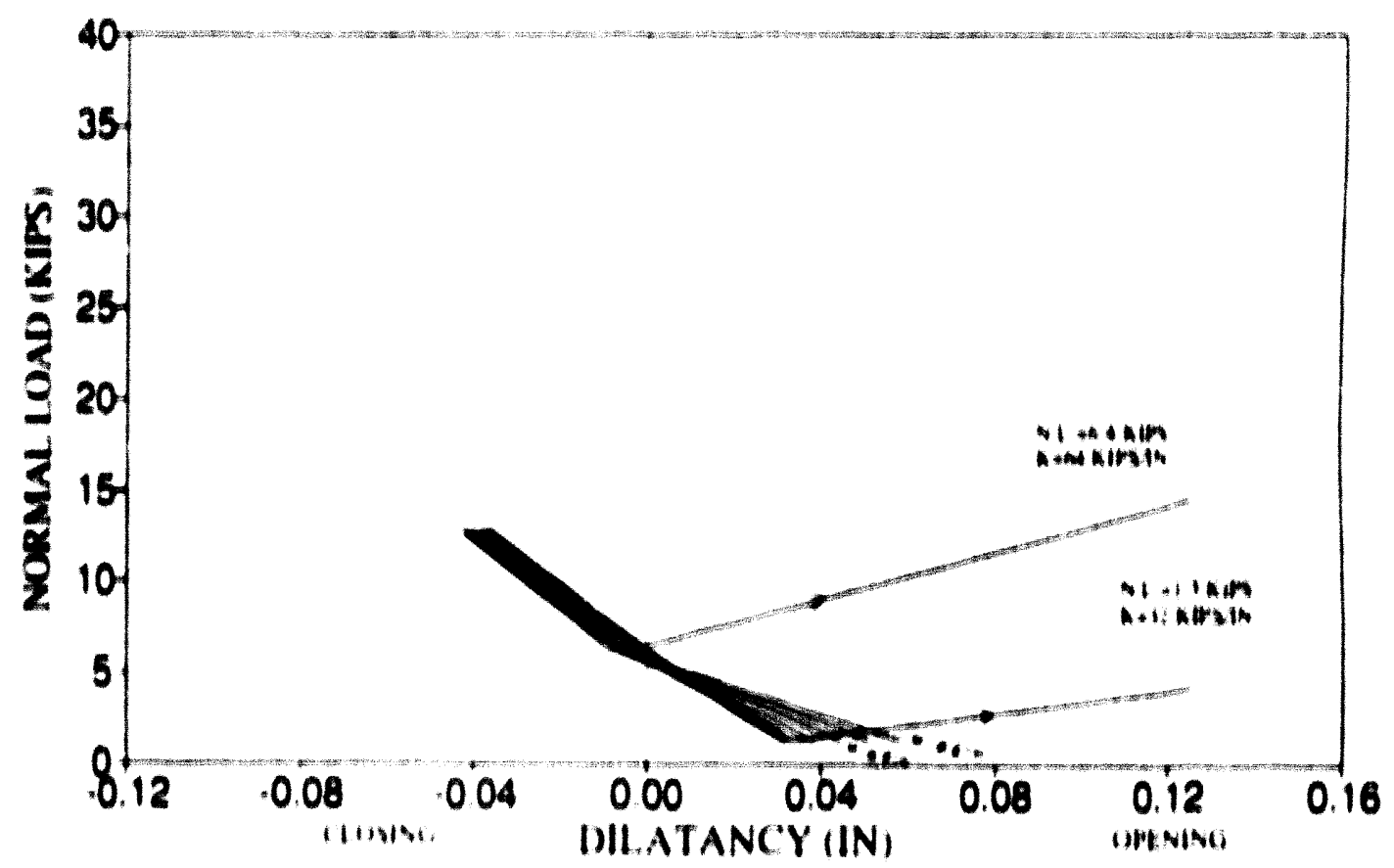




\section{APPENDIX :}

Comparieon Between Prediction and Obeervation of Dllatancy and shear Load

SAMPLE DESCRIDTION

PAGE

KR7F4 Dilatancy compartaon of 1t cycle forward, Notmal Load $=3.6 \mathrm{klps} ; \mathrm{K}=18.0 \mathrm{klps} / \mathrm{in}$

KRTF4

Shear load comparion of 1 et cycle forward, Notmal Load $=3.6 \mathrm{klps} ; \mathrm{K}=18.0 \mathrm{klps} / \mathrm{in}$

KRTFA Dilatancy comparison of lat cycle reverse, Normal Load $=3.6 \mathrm{klpa} ; \mathrm{K}-18.0 \mathrm{klps} / \mathrm{ln}$

KRTFA Shear load compariaon of tot cycle reverae, Normal hoad $-3.6 \mathrm{klpa} K=18.0 \mathrm{klps} / \mathrm{ln}$

KRTF4

Dilatancy compartion of and cycle corward, Normal Load - $3.6 \mathrm{klpl}$; $-18.0 \mathrm{klps} / \mathrm{in}$

KRTHA

sheat load compation of and cycle torward, Normal Load $3.6 \mathrm{klpa} K=18.0 \mathrm{klpa} / \mathrm{in}$

KR7FA DLlatancy compartion of and cycle revarte, Normal load $=3.6 \mathrm{klpa} ; \mathrm{K}=1 \mathrm{0.0} \mathrm{klpa} / \mathrm{in}$

KRTHA

Shear load compartaon of and cycle reverte. Normal Load - $1.6 \mathrm{klps;} K=18.0 \mathrm{klpa} / \mathrm{in}$

KRT1 Dllatancy compartaon of $3 x d$ cycle forward, Normal Load - $1.6 \mathrm{klpw} K=18.0 \mathrm{klp} / \mathrm{in}$

KRTHA Shear load comparion of ird eycle torward. Normal load - $1.6 \mathrm{klpar} K=18.0 \mathrm{klpa} / \mathrm{ln}$

KRTHA Dlatancy compartaon of $3 x d$ cycla reversa, Normal load $=3.6 \mathrm{klpa} ; \mathrm{K}=18.0 \mathrm{k}$ lpo/ $1 \mathrm{n}$

Kkift shear load compatian of srd cycle reverto. Normal hoad - $1.6 \mathrm{klpar} K-18.0 \mathrm{klps} / \mathrm{ln}$

Kkoth Dllatancy compartaon of ath cycle forward, Normal lioad - $1.6 \mathrm{klpH} K-18.0 \mathrm{klpg} / \mathrm{in}$

Kklfa Shear load compartson of 4th eycle forward. Normal hoad - $\$ .6 \mathrm{klpa} ; \quad K=18.0 \mathrm{Klpe} / \mathrm{ln}$

KkTha Dilatancy compartoon of th cycle reverae. Normal hoad - $1.6 \mathrm{k}$ lps; $K=18.0 \mathrm{k} / \mathrm{pe} / \mathrm{in}$ 
KR7F4 Shear load comparloon of 4 th cycle reverse, Normal Load $=3.6 \mathrm{klps} ; K=18.0 \mathrm{kips} / \mathrm{in}$

KR7F4 Dilatancy comparioon of 5th cycle forward, Normal Load $=3.6 \mathrm{kips} K=18.0 \mathrm{kipg} / \mathrm{in}$

KR7F4 Shear load comparison of 5 th cycle forward, Normal Load $=3.6 \mathrm{kips} ; \mathrm{K}=18.0 \mathrm{kipa} / \mathrm{in}$

KR7F4 Dilatancy comparison of 5 th cycle reverse, Normal Load - $3.6 \mathrm{klps} ; \mathrm{K}=18.0 \mathrm{klpg} / \mathrm{in}$

KR7F4 Shear load comparison of 5 th cycle reverse, Normal toad $=3.6 \mathrm{kipg} ;=18.0 \mathrm{klpg} / \mathrm{in}$

KR9F4 Dilatancy comparison of 18t cycle torward, Normal Load $=3.6 \mathrm{kips} ; \mathrm{K}=54.0 \mathrm{kips} / \mathrm{in}$

KR9F4 Shear load comparison of lat cycle forward, Normal Load $=3.6 \mathrm{klpg} ; \mathrm{K}-54.0 \mathrm{klpa} / \mathrm{in}$

KR9F4 Dilatancy comparison of $18 \mathrm{t}$ cycle reverse, Normal Load $=3.6 \mathrm{kips} ; \mathrm{K}=54.0 \mathrm{klps} / \mathrm{in}$

KR9F4 Shear load compartaon of lat cycle reverse, Normal Load $-3.6 \mathrm{klps} ; \mathrm{K}=54.0 \mathrm{klps} / \mathrm{ln}$

KR9F4 Dilatancy comparison of 2nd cycle forward, Normal Load $=3.6 \mathrm{klps} ; \quad K=54.0 \mathrm{klps} / \mathrm{in}$

KR9FA Shear load compartaon of 2nd cycle forward, Normal Load *3.6 klpa; K $=54.0 \mathrm{klpg} / \mathrm{in}$

KR9F4 Dilatancy comparison of and cycle reverse, Normal Load - $3.6 \mathrm{klps} ; \mathrm{K}-54.0 \mathrm{klps} / \mathrm{in}$

KR9F4 Shear load compartson of and cycle reverse. Normal Load $=3.6 \mathrm{klpg} ; K=54.0 \mathrm{klpg} / \mathrm{in}$

KR9F4 Dilatancy comparioon of $3 \mathrm{rd}$ cycle forward, Normal Load * $3.6 \mathrm{kipe;} \mathrm{K}=54.0 \mathrm{klpg} / \mathrm{in}$

KR9F4 Shear load comparison of 3 rd cycle torward, Normal hoad $=3.6 \mathrm{klps} ; \mathrm{K}=54.0 \mathrm{klpg} / \mathrm{ln}$

KR9FA Dllatancy compartson of $3 \mathrm{rd}$ cycle reverse, Normal Load - $3.6 \mathrm{klpg} ; \mathrm{K}=54.0 \mathrm{klpg} / \mathrm{in}$

KRyf4 Shear load comparison of 3 rd cycle reverse. Normal Load $=3.6 \mathrm{klpsi} K=54.0 \mathrm{klps} / \mathrm{in}$ 
KR9F4 Dilatancy comparison of 4 th cycle forward, Normal Load $=3.6 \mathrm{kips} ; \mathrm{K}=54.0 \mathrm{kips} / \mathrm{in}$

KR9F4 Shear load comparison of 4 th cycle forward, Normal Load $=3.6 \mathrm{kips} ; \mathrm{K}=54.0 \mathrm{kips} / \mathrm{in}$

KR9F4 Dilatancy comparison of 4 th cycle reverse, Normal Load $=3.6 \mathrm{kips} ; K=54.0 \mathrm{kips} / \mathrm{in}$

KR9F4 Shear load comparison of $n$th cycle reverse, Normal Load $=3.6 \mathrm{kips} ; \mathrm{K}=54.0 \mathrm{kips} / \mathrm{in}$

KR9F4 Dilatancy comparison of 5 th cycle forward, Normal Load $=3.6 \mathrm{kips} ; \mathrm{K}=54.0 \mathrm{kips} / \mathrm{in}$

KR9F4 Shear load comparison of $5 \mathrm{th}$ cycle forward, Normal Load $=3.6 \mathrm{kips} ; \mathrm{K}=54.0 \mathrm{kips} / \mathrm{in}$

KR9F4 Dilatancy comparison of 5 th cycle reverse, Normal Load $=3.6 \mathrm{kips} ; K=54.0 \mathrm{kips} / \mathrm{hn}$

KR9F4 Shear load comparison of $5 \mathrm{th}$ cycle reverse, Normal Load $=3.6 \mathrm{klps} ; \mathrm{K}=54.0 \mathrm{klps} / \mathrm{in}$

KR1OFA Dilatancy comparison of 1st cycle forward, Normal Load $=3.6 \mathrm{klps}$; K-179.9 kips/1n

KR1OF4 Shear Load comparison of lat cycle forward, Normal Load $=3.6 \mathrm{klps} ; \mathrm{K}=179.9 \mathrm{klps} / \mathrm{in}$

KR10F4 Dilatancy comparison of 1st. cycle reverse, Normal Load $-3.6 \mathrm{klps} ; \mathrm{K}-179.9 \mathrm{klps} / \mathrm{ln}$

KRlOFA Shear load comparison of $1 \mathrm{st}$ cycle reverse, Normal Load $=3.6 \mathrm{kips} ; \mathrm{K}=179.9 \mathrm{kips} / \mathrm{in}$

KRIOFA Dilatancy comparison of 2nd cycle forward, Normal Load $=3.6 \mathrm{kips} ; \mathrm{K}=179.9 \mathrm{kips} / \mathrm{in}$

KR1OF4 Shear load comparison of 2 nd cycle forward, Normal Load $=3.6 \mathrm{kips} ; \mathrm{K}=179.9 \mathrm{kips} / \mathrm{in}$

KRIOFA Dilatancy comparison of 2nd cycle reverse, Normal Load $=3.6 \mathrm{kips} ; \mathrm{K}=179.9 \mathrm{kips} / \mathrm{in}$

KRlOFA Shear load compartson of 2 nd cycle reverse,

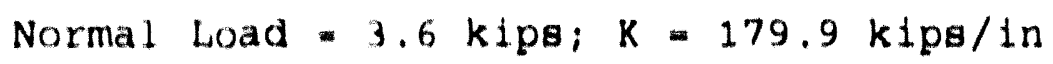

KRiof4 Dilatancy comparteon of 3 rd cycle forward, Normal Load $=3.6 \mathrm{kips;} K=179.9 \mathrm{kips} / \mathrm{in}$ 
KR10F4 Shear load comparison of $3 \mathrm{rd}$ cycle forward, Norma]. Load $=3.6 \mathrm{kips} ; \mathrm{K}=179.9 \mathrm{kjps} / \mathrm{in} \quad \mathrm{B}-25$

KR10F4 Dilatancy comparison of 3 rd cycle reverse, Normal Load $=3.6 \mathrm{kips} ; \mathrm{K}=179.9 \mathrm{kips} / \mathrm{in} \quad \mathrm{B}-26$

KRIOF4 Shear load comparison of 3 rd cycle reverse, Normal Load $=3.6 \mathrm{kips} ; \mathrm{K}=179.9 \mathrm{kips} / \mathrm{in} \quad \mathrm{B}-26$

KR10F4 Dilatancy comparison of 4 th cycle forward, Normal Load $=3.6 \mathrm{kips} ; \mathrm{K}=179.9 \mathrm{klps} / \mathrm{in} \quad \mathrm{B}-27$

KRIOF4 Shear load comparison of $4 \mathrm{th}$ cycle forward, Normal Load $=3.6 \mathrm{kips} ; \mathrm{K}=179.9 \mathrm{kips} / \mathrm{in} \quad$ B-27

KR10F4 Dilatancy comparison of 4 th cycle reverse, Normal Load $=3.6 \mathrm{kips} ; \mathrm{K}=179.9 \mathrm{kips} / \mathrm{in} \quad \mathrm{B}-28$

KRIOF4 Shear load comparison of 4 th cycle reverse, Normal Load $=3.6 \mathrm{kips} ; \mathrm{K}=179.9 \mathrm{kips} / \mathrm{in} \quad \mathrm{B}-28$

KR10F4 Dilatancy comparison of 5 th cycle forward, Normal Load $=3.6 \mathrm{kips} ; \mathrm{K}=179.9 \mathrm{kips} / \mathrm{in} \quad \mathrm{B}-29$

KR10F4 Shear load comparison of $5 \mathrm{th}$ cycle forward, Normal Load $=3.6 \mathrm{klps} ; \mathrm{K}=179.9 \mathrm{kips} / \mathrm{in} \quad$ B -29

KR10F4 Dilatancy comparison of 5 th cycle reverse, Normal Load $=3.6 \mathrm{kips} ; \mathrm{K}=179.9 \mathrm{kips} / \mathrm{in} \quad \mathrm{B}-30$

KR1OF4 Shear load comparison of 5 th cycle reverse, Normal Load $=3.6 \mathrm{kips} ; \mathrm{K}=179.9 \mathrm{kips} / \mathrm{in} \quad \mathrm{B} .30$

KR11F4 Dilatancy comparison of 1 st cycle forward, Normal Load $=7.2 \mathrm{kips} ; \mathrm{K}=54.0 \mathrm{kips} / \mathrm{in} \quad$ B. 31

KRI1F4 Shear load comparison of 1st cycle forward, Normal Load $=7.2 \mathrm{kips} ; \mathrm{K}=54.0 \mathrm{kips} / \mathrm{in} \quad \mathrm{B}-31$

KR11F4 Dilatancy comparison of 1 st cycle reverse, Normal Load $=7.2 \mathrm{kips} ; \mathrm{K}=54.0 \mathrm{kips} / \mathrm{in} \quad$ B. 32

KR11.F4 Shear load comparison of 1 st cycle reverse, Normal Load $=7.2 \mathrm{kips} ; \mathrm{K}=54.0 \mathrm{kips} / \mathrm{in} \quad \mathrm{B}-32$

KR11F4 Dilatancy comparison of 2 nd cycle forward, Normal Load $=7.2 \mathrm{kips} ; K=54.0 \mathrm{kips} / \mathrm{in} \quad B-33$

KR11F4 Shear load comparison of 2nd cycle forward, Normal Load $=7.2 \mathrm{kips} ; K=54.0 \mathrm{kips} / \mathrm{in} \quad \mathrm{B}-33$ 
KR11F4 Dilatancy comparison of 2nd cycle reverse, Normal Load $=7.2 \mathrm{kips} ; K=54.0 \mathrm{kips} / \mathrm{in}$

KR11F4 Shear load comparison of 2 nd cycle reverse, Normal Load $=7.2 \mathrm{kips} ; \mathrm{K}=54.0 \mathrm{kips} / \mathrm{in}$

KR11F4 Dilatancy comparison of 3 rd cycle forward, Normal Load $=7.2 \mathrm{kips} ; \mathrm{K}=54.0 \mathrm{kips} / \mathrm{in}$

KR11F4 Shear load comparison of 3 rd cycle forward, Normal Load $=7.2 \mathrm{kips} ; \mathrm{K}=54.0 \mathrm{kips} / \mathrm{in}$

KR11F4 Dilatancy comparison of 3 rd cycle reverse, Normal Load $=7.2 \mathrm{kips} ; K=54.0 \mathrm{kipg} / \mathrm{in}$

KR11F4 Shear load comparison of 3 rd cycle reverse, Normal Load $=7.2 \mathrm{kips} ; \mathrm{K}=54.0 \mathrm{kips} / \mathrm{in}$

KR11F4 Dilatancy comparison of 4 th cycle forward, Normal Load $=7.2 \mathrm{kips} ; \mathrm{K}=54.0 \mathrm{kips} / \mathrm{in}$

KR11F4 Shear load comparison of 4 th cycle forward, Normal Load $=7.2 \mathrm{kips} ; \mathrm{K}=54.0 \mathrm{kips} / \mathrm{in}$

KR11F4 Dilatancy conparison of 4 th cycle reverse, Normal Load $=7.2 \mathrm{kips} ; \mathrm{K}=54.0 \mathrm{klps} / \mathrm{in}$

KR11F4 Shear load comparison of 4 th cycle reverse, Normal Load $=7.2 \mathrm{kips} ; \mathrm{K}=54.0 \mathrm{kips} / \mathrm{in}$

KR11.F4 Dilatancy comparison of 5 th cycle forward, Normal Load $=7.2 \mathrm{kips} ; K=54.0 \mathrm{kips} / \mathrm{in}$

KR11F4 Shear load comparison of 5 th eycle forward, Normal Load $=7.2 \mathrm{kips} ; \mathrm{K}=54.0 \mathrm{kips} / \mathrm{in}$

KR11F4 Dilatancy comparison of $5 \mathrm{th}$ cycle reverse, Normal Load $=7.2 \mathrm{kips} ; \mathrm{K}=54.0 \mathrm{kips} / \mathrm{in}$

KR11F4 Shear load comparison of 5 th cycle reverse, Normal Load $=7.2 \mathrm{kips} ; \mathrm{K}=54.0 \mathrm{kips} / \mathrm{in}$

KR12F4 Dilatancy comparison of 1 st cycle forward, Normal Load $=7.2 \mathrm{kips} ; K=179.9 \mathrm{kips} / \mathrm{in}$

KR12F4 Shear load comparison of 1st cycle forward, Normal Load $=7.2 \mathrm{kips} ; K=179.9 \mathrm{kips} / \mathrm{in}$

KR12F4 Dilatancy comparison of 1 st cycle reverse, Normal Load $=7.2 \mathrm{kips} ; \mathrm{K}=179.9 \mathrm{kips} / \mathrm{in}$ 
KR12F4 Shear load comparison of 1st cycle reverse, Normal Load $=7.2 \mathrm{kips} ; \mathrm{K}=179.9 \mathrm{kips} / \mathrm{in}$

KR12F4 Dilatancy comparison of 2 nd cycle forward, Normal Load $=7.2 \mathrm{kips} ; \mathrm{K}=179.9 \mathrm{kips} / \mathrm{in}$

KR12F4 Shear load comparison of 2 nd cycle forward, Normal Load $=7.2 \mathrm{kips} ; \mathrm{K}=179.9 \mathrm{kips} / \mathrm{in}$

KR12F4 Dilatancy comparison of 2 nd cycle reverse, Normal Load $=7.2 \mathrm{kips} ; \mathrm{K}=179.9 \mathrm{kips} / \mathrm{in}$

KR12F4 Shear load comparison of 2 nd cycle reverse, Normal Load $=7.2 \mathrm{kips} ; \mathrm{K}=179.9 \mathrm{kips} / \mathrm{in}$

KR12F4 Dilatancy comparison of 3 rd cycle forward, Normal Load $=7.2 \mathrm{kips} ; \mathrm{K}=179.9 \mathrm{kips} / \mathrm{in}$

KR12F4 Shear load comparison of 3 rd cycle forward, Normal Load $=7.2 \mathrm{kips} ; \mathrm{K}=179.9 \mathrm{kips} / \mathrm{in}$

KR12F4 Dilatancy comparison of 3 rd cycle reverse, Normal Load $=7.2 \mathrm{kips} ; \mathrm{K}=179.9 \mathrm{kips} / \mathrm{in}$

KR12F4 Shear load comparison of 3 rd cycle reverse, Normal Load $=7.2 \mathrm{kips} ; \mathrm{K}=179.9 \mathrm{kips} / \mathrm{in}$

KR12F4 Dilatancy comparison of 4 th cycle forward, Normal Load $=7.2 \mathrm{kips} ; \mathrm{K}=179.9 \mathrm{kips} / \mathrm{in}$

KR12F4 Shear load comparison of 4 th cycle forward, Normal Load $=7.2 \mathrm{kips} ; \mathrm{K}=179.9 \mathrm{kips} / \mathrm{in}$

KR12F4 Dilatancy comparison of 4 th cycle reverse, Normal Load $=7.2 \mathrm{kips} ; \mathrm{K}=179.9 \mathrm{kips} / \mathrm{in}$

KR12F4 Shear load comparison of 4 th cycle reverse, Normal Load $=7.2 \mathrm{kips} ; \mathrm{K}=179.9 \mathrm{kips} / \mathrm{in}$

KR7F3 Dilatancy comparison of 1st cycle forward, Normal Load $=3.8 \mathrm{kips} ; \mathrm{K}=18.8 \mathrm{kips} / \mathrm{in}$

KR7F3 Shear load comparison of 1st cycle forward, Normal Load $=3.8 \mathrm{kips} ; \mathrm{K}=18.8 \mathrm{kips} / \mathrm{in}$

KR7F3 Dilatancy comparison of 1st cycle reverse, Normal Load $=3.8 \mathrm{kips} ; \mathrm{K}=18.8 \mathrm{kips} / \mathrm{in}$

KR7F3 Shear load comparison of 1st cycle reverse, Normal Load $=3.8 \mathrm{kips} ; K=18.8 \mathrm{kips} / \mathrm{in}$ 
KR7F3 Dilatancy comparison of 2nd cycle forward, Normal Load $=3.8 \mathrm{kips} ; \mathrm{K}=18.8 \mathrm{kips} / \mathrm{in}$

KR7F3 Shear load comparison of 2nd cycle forward, Normal Load $=3.8 \mathrm{kips} ; \mathrm{K}=18.8 \mathrm{kips} / \mathrm{in}$

KR7F3 Dilatancy comparison of 2 nd cycle reverse, Normal Load $=3.8 \mathrm{kips} ; \mathrm{K}=18.8 \mathrm{kips} / \mathrm{in}$

KR7F3 Shear load comparison of 2 nd cycle reverse, Normal Load $=3.8 \mathrm{kips} ; \mathrm{K}=18.8 \mathrm{kips} / \mathrm{in}$

KR7F3 Dilatancy comparison of 3 rd cycle forward, Normal Load $=3.8 \mathrm{kips} ; \mathrm{K}=18.8 \mathrm{kips} / \mathrm{in}$

KR7F3 Shear load comparison of 3 rd cycle forward, Normal Load $=3.8 \mathrm{kips} ; K=18.8 \mathrm{kips} / \mathrm{in}$

KR7F3 Dilatancy comparison of 3 rd cycle reverse, Normal Load $=3.8 \mathrm{kips} ; \mathrm{K}=18.8 \mathrm{kips} / \mathrm{in}$

KR7F3 Shear load comparison of 3 rd cycle reverse, Normal Load $=3.8 \mathrm{kips} ; \mathrm{K}=18.8 \mathrm{kips} / \mathrm{in}$

KR7F3 Dilatancy comparison of 4 th cycle forward, Normal Load $=3.8 \mathrm{kips} ; \mathrm{K}=18.8 \mathrm{kips} / \mathrm{in}$

KR7F3 Shear load comparison of 4 th cycle forward, Normal Load $=3.8 \mathrm{kips} ; \mathrm{K}=18.8 \mathrm{kips} / \mathrm{in}$

KR7F3 Dilatancy comparison of 4 th cycle reverse, Normal Load $=3.8 \mathrm{kips} ; \mathrm{K}=18.8 \mathrm{kips} / \mathrm{in}$

KR7F3 Shear load comparison of 4 th cycle reverse, Normal Load $=3.8 \mathrm{kips} ; K=18.8 \mathrm{kips} / \mathrm{in}$

KR7F3 Dilatancy comparison of 5 th cycle forward, Normal Load $=3.8 \mathrm{kips} ; \mathrm{K}=18.8 \mathrm{kips} / \mathrm{in}$

KR7F3 Shear load comparison of 5 th cycle forward, Normal Load $=3.8 \mathrm{kips} ; \mathrm{K}=18.8 \mathrm{kips} / \mathrm{in}$

KR7F3 Dilatancy comparison of 5 th cycle reverse, Normal Load $=3.8 \mathrm{kips} ; \mathrm{K}=18.8 \mathrm{kips} / \mathrm{in}$

KR7F3 Shear load comparison of 5 th cycle reverse, Normal Load $=3.8 \mathrm{kips} ; \mathrm{K}=18.8 \mathrm{kips} / \mathrm{in}$

KR8F3 Dilatancy comparison of 1st cycle forward, Normal Load $=3.8 \mathrm{kips} ; \mathrm{K}=56.3 \mathrm{kips} / \mathrm{in}$ 
KR8F3 Shear load comparison of 1st cycle forward, Normal Load $=3.8 \mathrm{kips} ; K=56.3 \mathrm{kips} / \mathrm{in}$

KR8F3 Dilatancy comparison of 1 st cycle reverse, Normal Load $=3.8 \mathrm{kips} ; \mathrm{K}=56.3 \mathrm{kips} / \mathrm{in}$

KR8F3 Shear load comparison of 1st cycle reverse, Normal Load $=3.8 \mathrm{kips} ; \mathrm{K}=56.3 \mathrm{kips} / \mathrm{in}$

KR8F3 Dilatancy comparison of 2 nd cycle forward, Normal Load $=3.8 \mathrm{kips} ; \mathrm{K}=56.3 \mathrm{kips} / \mathrm{in}$

KR8F3 Shear load comparison of 2nd cycle forward, Normal Load $=3.8 \mathrm{kips} ; \mathrm{K}=56.3 \mathrm{kips} / \mathrm{in}$

KR8F3 Dilatancy comparison of 2 nd cycle reverse, Normal Load $=3.8 \mathrm{kips} ; \mathrm{K}=56.3 \mathrm{kips} / \mathrm{in}$

KR8F3 Shear load comparison of and cycle reverse, Normal Load $=3.8 \mathrm{kips} ; \mathrm{K}=56.3 \mathrm{kips} / \mathrm{in}$

KR8F3 Dilatancy comparison of $3 \mathrm{rd}$ cycle forward, Normal Load $=3.8 \mathrm{kips} ; \mathrm{K}=56.3 \mathrm{kips} / \mathrm{in}$

KR8F3 Shear load comparison of 3 rd cycle forward, Normal Load $=3.8 \mathrm{kips} ; \mathrm{K}=56.3 \mathrm{kips} / \mathrm{in}$

KR8F3 Dilatancy comparison of 3 rd cycle reverse, Normal Load $=3.8 \mathrm{kips} ; \mathrm{K}=56.3 \mathrm{kips} / \mathrm{in}$ $B-64$

KR8F3 Shear load comparison of 3 rd cycle reverse, Normal Load $=3.8 \mathrm{kips} ; \mathrm{K}=56.3 \mathrm{kips} / \mathrm{in}$

KR8F3 Dilatancy comparison of 4 th cycle forward, Normal Load $=3.8 \mathrm{kips} ; \mathrm{K}=56.3 \mathrm{kips} / \mathrm{in}$

KR8F3

Shear load comparison of 4 th cycle forward, Normal Load $=3.8 \mathrm{kips} ; \mathrm{K}=56.3 \mathrm{kips} /$ in

KR8F3 Dilatancy comparison of 4 th cycle reverse, Normal Load $=3.8 \mathrm{kips} ; \mathrm{K}=56.3 \mathrm{kips} / \mathrm{in}$

KR8F3 Shear load comparison of 4 th cycle reverse, Normal Load $=3.8 \mathrm{kips} ; \mathrm{K}=56.3 \mathrm{kips} / \mathrm{in}$

KR8F3 Dilatancy comparison of 5 th cycle forward, Normal Load $=3.8 \mathrm{kips} ; K=56.3 \mathrm{kips} / \mathrm{in}$

KR8F3 Shear load comparison of 5 th cycle forward, Normal Load $=3.8 \mathrm{kips} ; \mathrm{K}=56.3 \mathrm{kips} / \mathrm{in}$ 
KR8F3 Dilatancy comparison of 5 th cycle reverse, Normal Load $=3.8 \mathrm{kips} ; \mathrm{K}=56.3 \mathrm{kips} / \mathrm{in}$

KR8F3 Shear load comparison of 5 th cycle reverse, Normal Load $=3.8 \mathrm{kips} ; \mathrm{K}=56.3 \mathrm{kips} / \mathrm{in}$

KR9F3 Dilatancy comparison of 1 st cycle forward, Normal Load $=3.8 \mathrm{kips} ; \mathrm{K}=187.5 \mathrm{kips} / \mathrm{in}$

KR9F3 Shear load comparison of 1st cycle forward, Normal Load $=3.8 \mathrm{kips} ; \mathrm{K}=187.5 \mathrm{kips} / \mathrm{in}$

KR9F3 Dilatancy comparison of 1 st cycle reverse, Normal Load $=3.8 \mathrm{kips} ; \mathrm{K}=187.5 \mathrm{kips} / \mathrm{in}$

KR9F3 Shear load comparison of 1st cycle reverse, Normal Load $=3.8 \mathrm{kips} ; K=187.5 \mathrm{kips} /$ in

KR9F3 Dilatancy comparison of 2 nd cycle forward, Normal Load $=3.8 \mathrm{kips} ; \mathrm{K}=187.5 \mathrm{kips} / \mathrm{in}$

KR9F3 Shear load comparison of 2nd cycle forward, Normal Load $=3.8 \mathrm{kips} ; \mathrm{K}=187.5 \mathrm{kips} / \mathrm{in}$

KR9F3 Dilatancy comparison of 2 nd cycle reverse, Normal Load $=3.8 \mathrm{kips} ; \mathrm{K}=187.5 \mathrm{kips} / \mathrm{in}$

KR9F3 Shear load comparison of 2 nd cycle reverse, Normal Load $=3.8 \mathrm{kips} ; \mathrm{K}=187.5 \mathrm{kips} / \mathrm{in}$

KR9F3 Dilatancy comparison of $3 \mathrm{rd}$ cycle forward, Normal Load $=3.8 \mathrm{kips} ; \mathrm{K}=187.5 \mathrm{kips} / \mathrm{in}$

KR9F3 Shear load comparison of $3 \mathrm{rd}$ cycle forward, Normal Load $=3.8 \mathrm{kips} ; \mathrm{K}=187.5 \mathrm{kips} / \mathrm{in}$

KR9F3 Dilatancy comparison of $3 \mathrm{rd}$ cycle reverse, Normal Load $=3.8 \mathrm{kips} ; \mathrm{K}=187.5 \mathrm{kips} / \mathrm{in}$

KR9F3 Shear load comparison of $3 \mathrm{rd}$ cycle reverse, Normal Load $=3.8 \mathrm{kips} ; \mathrm{K}=187.5 \mathrm{kips} / \mathrm{in}$

KR9F3 Dilatancy comparison of 4 th cycle forward, Normal Load $=3.8 \mathrm{kips} ; \mathrm{K}=187.5 \mathrm{kips} / \mathrm{in}$

KR9F3 Shear load comparison of 4 th cycle forward, Normal Load $=3.8 \mathrm{kips} ; \mathrm{K}=187.5 \mathrm{kips} / \mathrm{in}$

KR9F3 Dilatancy comparison of 4 th cycle reverse, Normal Load $=3.8 \mathrm{kips} ; K=187.5 \mathrm{kips} / \mathrm{in}$ 
KR9F3 Shear load comparison of 4 th cycle reverse, Normal Load $=3.8 \mathrm{kips} ; \mathrm{K}=187.5 \mathrm{kips} / \mathrm{in}$

KR9F 3 Dilatancy comparison of 5 th cycle forward, Normal Load $=3.8 \mathrm{kips} ; \mathrm{K}=187.5 \mathrm{kips} / \mathrm{in}$

KR9F3 Shear load comparison of 5 th cycle forward, Normal Load $=3.8 \mathrm{kips} ; K=187.5 \mathrm{kips} / \mathrm{fn}$

KR9F3 Dilatancy comparison of 5 th cycle reverse, Normal Load $=3.8 \mathrm{kips} ; \mathrm{K}=187.5 \mathrm{kips} / \mathrm{in}$

KR9F3 Shear load comparison of 5 th cycle reverse, Normal Load $=3.8 \mathrm{kips} ; \mathrm{K}=187.5 \mathrm{kIps} / \mathrm{in}$

KR10F3 Dilatancy comparison of 1st cycle forward, Normal Load $=7.5 \mathrm{kips} ; \mathrm{K}=56.3 \mathrm{kips} / \mathrm{in}$

KR10F3 Shear load comparison of 1st cycle forward, Normal Load $=7.5 \mathrm{kips} ; \mathrm{K}=56.3 \mathrm{kips} / \mathrm{in}$

KR1OF3 Dilatancy comparison of 1 st cycle reverse, Normal Load $=7.5 \mathrm{kips} ; \mathrm{K}=56.3 \mathrm{kips} / \mathrm{in}$

KR10F3 Shear load comparison of 1st cycle reverse, Normal Load $=7.5 \mathrm{kips} ; \mathrm{K}=56.3 \mathrm{kips} / \mathrm{in}$

KR10F3 Dilatancy comparison of 2 nd cycle forward, Normal Load $=7.5 \mathrm{kips} ; K=56.3 \mathrm{kips} / \mathrm{in}$

KR1OF3 Shear load comparison of 2 nd cycle forward, Normal Load $=7.5 \mathrm{kips} ; \mathrm{K}=56.3 \mathrm{kips} / \mathrm{in}$

KR10F3 Dilatancy comparison of 2 nd cycle reverse, Normal Load $=7.5 \mathrm{kips} ; \mathrm{K}=56.3 \mathrm{kips} / \mathrm{in}$

KR10F3 Shear load comparison of 2 nd cycle reverse, Normal Load $=7.5 \mathrm{kips} ; \mathrm{K}=56.3 \mathrm{kips} / \mathrm{in}$

KR1OF3 Dilatancy comparison of 3 rd cycle forward, Normal Load $=7.5 \mathrm{kips} ; \mathrm{K}=56.3 \mathrm{kips} / \mathrm{in}$

KR10F3 Shear load comparison of $3 \mathrm{rd}$ cycle forward, Normal Load $=7.5 \mathrm{kips} ; \mathrm{K}=56.3 \mathrm{kips} / \mathrm{in}$

KR10F3 Dilatancy comparison of 3 rd cycle reverse, Normal Load $=7.5 \mathrm{kips} ; \mathrm{K}=56.3 \mathrm{kips} / \mathrm{in}$

KR10F3 Shear load comparison of 3 rd cycle reverse, Normal Load $=7.5 \mathrm{kips} ; \mathrm{K}=56.3 \mathrm{kips} / \mathrm{in}$ 
KR1OF3 Dilatancy comparison of 4 th cycle forward, Normal Load $=7.5 \mathrm{klps} ; \mathrm{K}=56.3 \mathrm{ktps} / \mathrm{in}$

KR1OF3 Shear load comparison of 4 th cycle forward, Normal Load $=7.5 \mathrm{kips} ; \mathrm{K}=56.3 \mathrm{kips} / \mathrm{in}$

KR10F3 Dilatancy comparison of 4 th cycle reverse, Normal Load $=7.5 \mathrm{kips}$; $\mathrm{k}=56.3 \mathrm{klps} / \mathrm{in}$

KR1OF3 Shear load comparison of 4 th cycle reverse, Normal Load $=7.5 \mathrm{kips}$; $K=56.3 \mathrm{kips} / \mathrm{in}$

KR10F3 Dilatancy comparison of 5 th cycle forward, Normal Load $=7.5 \mathrm{klps} ; \mathrm{K}=56.3 \mathrm{kips} / \mathrm{in}$

KR1OF3 Shear load comparison of 5 th cycle forward, Normal Load $=7.5 \mathrm{kips;} K=56.3 \mathrm{kips} / \mathrm{in}$

KR1OF3 Dilatancy comparison of 5 th cycle reverse, Normal Load $=7.5 \mathrm{klps}$; $K=56.3 \mathrm{kips} / \mathrm{in}$

KRIOF3 Shear load comparison of 5 th cycle reverse, Normal Load $=7.5 \mathrm{kips;} K=56.3 \mathrm{kips} / \mathrm{in}$

KR11F3 Dilatancy comparison of 1at cycle forward,

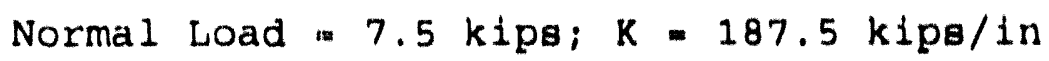

KR11F3 Shear load comparison of 1 st cycle forward, Normal Load $=7.5 \mathrm{klps} ; \mathrm{K}=187.5 \mathrm{klps} / \mathrm{in}$

KR11F3 Dilatancy comparison of lat cycle reverse, Normal Load $=7.5 \mathrm{kips} ; \mathrm{K}=187.5 \mathrm{kips} / \mathrm{in}$

KR11F3 Shear load comparison of 1 st cycle reverse, Normal Load $=7.5 \mathrm{kips} ; \mathrm{K}=187.5 \mathrm{kips} / \mathrm{in}$ Dilatancy comparison of 2 nd cycle forward, Normal Load $=7.5 \mathrm{kips} ; \mathrm{K}=187.5 \mathrm{kips} / \mathrm{in}$ Shear load comparison of 2 nd cycle forward, Normal Load $=7.5 \mathrm{kips} ; \mathrm{K}=187.5 \mathrm{kips} / \mathrm{in}$

KR11F3 Dilatancy comparison of 2 nd cycle reverse, Normal Load $=7.5 \mathrm{kips} ; \mathrm{K}=187.5 \mathrm{kips} / \mathrm{in}$

KR11F3 Shear load comparison of 2 nd cycle reverse, Normal Load $=7.5 \mathrm{kips} ; \mathrm{K}=187.5 \mathrm{kips} / \mathrm{in}$

KR11F3 Dilatancy comparison of 3 rd cycle forward, Normal Load $=7.5 \mathrm{kips} ; K=187.5 \mathrm{kips} / \mathrm{in}$ 
KR1LF3 Shear load compartaon of 3 rd cycle forwatd, Normal Load $=7.5 \mathrm{Klps} ; \mathrm{K} \approx 187.5 \mathrm{k} / \mathrm{pg} / \mathrm{ll}$

KR11F3 Dllatancy compartaon of $3 r d$ cycle reverae, Normal Load $=7.5 \mathrm{~K}$ lpa; $K=187.5 \mathrm{klps} / \mathrm{in}$

KR11F3 Shear load comparison of 3 rd cycle reverse, Normal Load $=7.5 \mathrm{k}$ lpe; $K=187.5 \mathrm{k} / \mathrm{pe} / \mathrm{ln}$

KR11F3 Dilatancy comparison of 4th cycle forward, Normal Load - $7.5 \mathrm{klpg} ; K=187.5 \mathrm{klps} / \mathrm{in}$

KR11F3 Shear load comparison of $4 \mathrm{th}$ cycle torward, Normal Load $=7.5 \mathrm{klpg} ; \mathrm{K}-187.5 \mathrm{klpg} / \mathrm{in}$ B $4 \mathrm{~s}$ KR11F3 Dilatancy comparison of 4 th cycle reverae, Normal Load $=7.5 \mathrm{klpa} ; \mathrm{K}=18 \% .5 \mathrm{kips} / \mathrm{in}$

KR11F3 Shear load comparison of ath cycle reverse, Normal Load $=7.5 \mathrm{Kips} ; \mathrm{K}=187.5 \mathrm{kips} / \mathrm{ll}$

KR11F3 Dilatancy comparison of 5 th cycle forward, Normal Load $=7.5 \mathrm{kips} ; \mathrm{K}=187.5 \mathrm{kips} / \mathrm{ln}$

KR1LF3 Shear load comparison of 5 th cycle totward, Normal Load - $7.5 \mathrm{klps;} K=18 \% .5 \mathrm{klps} / \mathrm{in}$

KR11F3 Dilatancy comparison of 5 th cycle reverge, Normal Load $=7.5 \mathrm{klpg} ; \mathrm{K}=187.5 \mathrm{klpg} / \mathrm{ln}$

KR11F3 Shear load comparison of $5 \mathrm{th}$ cycle reveree, Normal Load $-7.5 \mathrm{klpg} ; k-187.5 \mathrm{klps} / \mathrm{in}$

KR6F2 Dilatancy comparison of lat cycle torward, Normal Load $=3.0 \mathrm{kips} ; \mathrm{K}-14.8 \mathrm{klpg} / \mathrm{ln} \quad$ B.99

KR6F2 Shear load comparison of 1 st cycle forward, Normal Load $=3.0 \mathrm{kips;} \mathrm{K}=14.8 \mathrm{kips} / \mathrm{in}$

KR6F2 Dilatancy comparison of 1at cycle reverse, Normal Load $-3.0 \mathrm{kips} ; \mathrm{K}-14.8 \mathrm{kips} / \mathrm{in}$

KR6F2 Shear load comparison of lot cycle reverse, Normal Load $=3.0 \mathrm{kips} ; K=14.8 \mathrm{klps} / \mathrm{in}$

KREF2 Dilatancy comparison of and cycle forward, Normal Load $=3.0 \mathrm{kips;} K=14.8 \mathrm{kips} / \mathrm{in}$

KR6F2 Shear load comparison of 2nd cycle forward, Normal Load $=3.0 \mathrm{kips} ; K=14.8 \mathrm{kips} / \mathrm{in}$ 
0119

$60 t \cdot a$

$60 t \cdot 9$

$80 t \cdot$

$801=A$

$20 t=9$

1.01

901

$901=$

SOI:日

501:

b01:日

6019

$601 \mathrm{H}$

for

$\cot$

2011

UT/GdFA

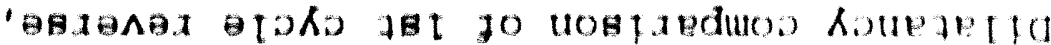

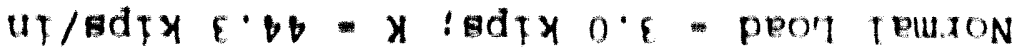

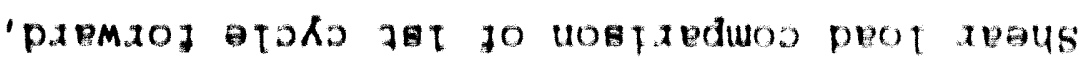

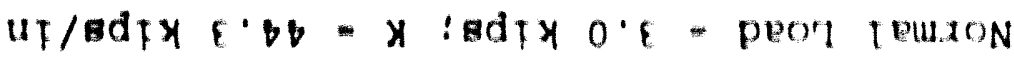

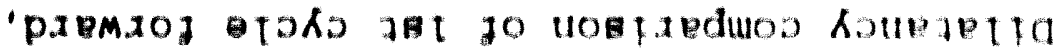

r.dLAX

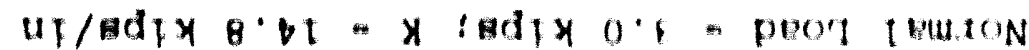

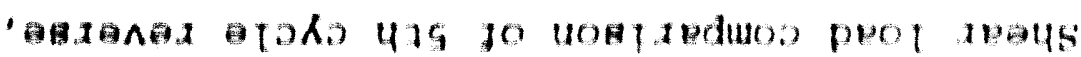
B. $98 \times$

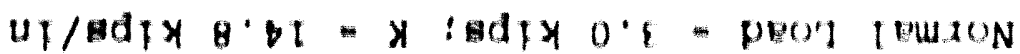

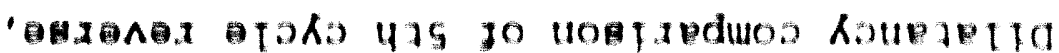
$2.498 \times$ uY/adix 8.

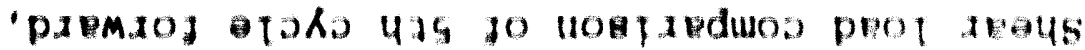
$998 \times$

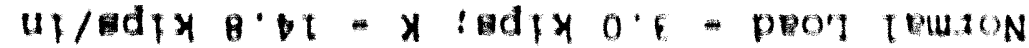

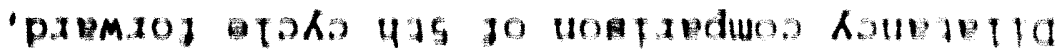
8.948

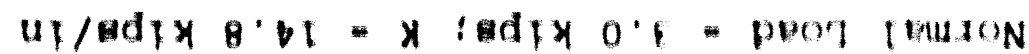

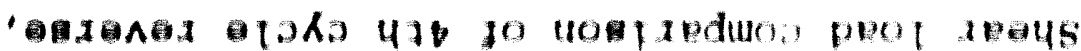

9498 ut/adix B.

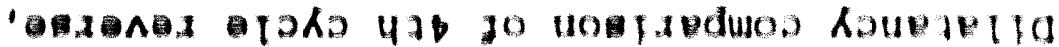
$2498 x$ UY/adix 8.

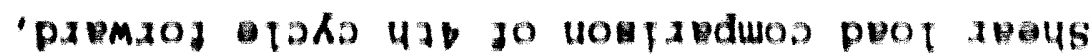
$249 \mathrm{AX}$

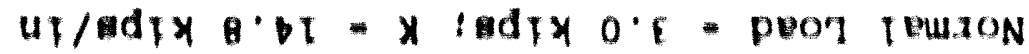

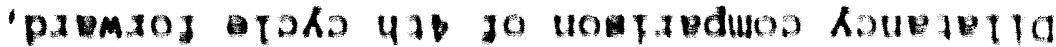
ZA94X

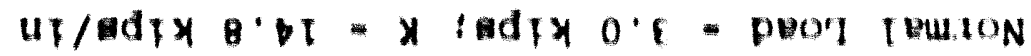

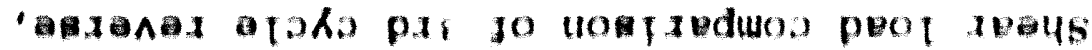

$2498 x$ Ut/ady

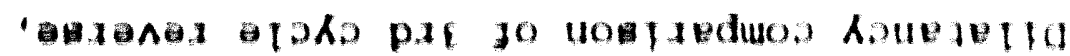
$\operatorname{cad} 9 \mathrm{~A}$

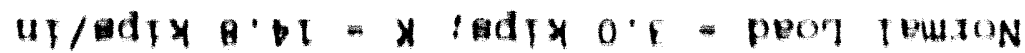

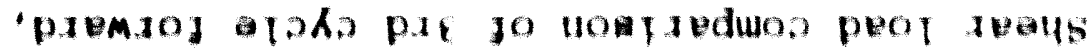
CA9 94

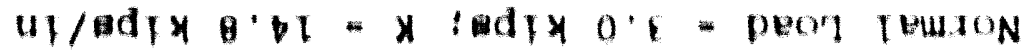

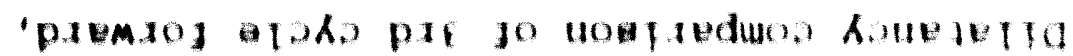
$2448 x$

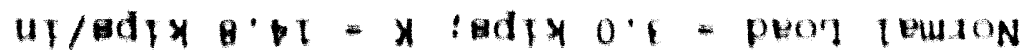

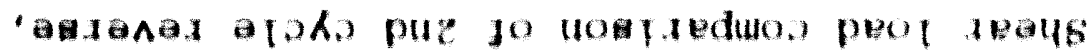
$2 \pi 94 \times$

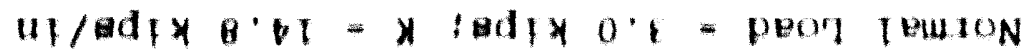
dagranas atoks pur jo nogfaduos hollejello $2494 \times$ 
KR7F2 Shear load compartaon of lat cycle teverea, Nurmal Load $=3.0 \mathrm{Klpa} ; K=44.3 \mathrm{klpa} / \mathrm{In}$

KR7P2 Wlatancy compertaon of znd cycle forward. Notmal Load = 3.0 kipe; $K=44.3 \mathrm{k} / \mathrm{pe} / \mathrm{In}$

KR7F2 Shear load comparison of and rycle forward, Normal Load $=3.0 \mathrm{~K} / \mathrm{pa} ; \mathrm{K}=44.3 \mathrm{klpa} / \mathrm{hn}$

KR7F2 Dilatancy comparioon of and cycle reveree, Normal toad $=3.0 \mathrm{kips} K=44.3 \mathrm{klps} / \mathrm{in}$

KR7F2 Shear load compatison of zind cycle reverae. Normal Load $=3.0 \mathrm{klps} K=44.3 \mathrm{klpa} / \mathrm{ln}$

KR7F2 Dilatancy compariton of 3 rd cycle corward. Normal toad $=3.0 \mathrm{klps} ; \mathrm{K}-44.3 \mathrm{klps} / \mathrm{ln}$

KRTF2 Shear load compartion of ird cycle forward. Normal Load $=3.0 \mathrm{klpa} ; \mathrm{K}=44.3 \mathrm{klpa} / \mathrm{ln}$

KRTP2 Dllataney compartaon of ird cycle raverae. Normal Load $=3.0 \mathrm{k} / \mathrm{pa} ; K=44.3 \mathrm{klpa} / \mathrm{ln}$

KR7F2 Shear load comparteon of Ird cycle revarae. Normal Load $-3.0 \mathrm{klpa} ; \mathrm{K}=44.3 \mathrm{k} 1 \mathrm{pe} / \mathrm{In}$

KRTV2 Dilatancy compartaon of ath cycle forward, Normal Load $=3.0 \mathrm{klpa}$; $\mathrm{K}-44.3 \mathrm{klpa} / \mathrm{ln}$

KR7F2 Shear load compartion of ath cycle forwatd. Nurmal Load $3.0 \mathrm{klps} K=44.3 \mathrm{klps} / \mathrm{ln}$

KRTV2 Dllatancy compartaon of 4th cycle reverae, Normal Load - $3.0 \mathrm{klpa} ; \mathrm{K}-44.3 \mathrm{klpa} / \mathrm{ln}$

KR7F2 Shear load compartaon of Ath cycle reverae. Normal Load $=3.0 \mathrm{klpw} ; \mathrm{K}=44.3 \mathrm{klps} / \mathrm{in}$

KREP2 Dllatancy comparison of lat cycle forward, Normal Load - $3.0 \mathrm{klps}$ K $-147.8 \mathrm{klps} / \mathrm{ln}$

KRAF2 Shear load comparian of iat cycle torward. Normal Load - 3.0 Klpe; K - 147.8 Klps/1n

KRBF2 Dllatancy comparioon of lot cycle reverse, Normal Load $=3.0 \mathrm{klps} ; K=147.8 \mathrm{k} / \mathrm{ps} / \mathrm{ln}$

KR8F2 Shear load compartson of 1at cycle reverse, Normal Load $=3.0 \mathrm{klps} K=147.8 \mathrm{klps} / \mathrm{ln}$ 
KRHFe Dilatancy compariaon of and cycle forward, Normal hoad - $1.0 k$ lpa; $K=147.8$ Klpa/ln

KKAF2 Sheat load comparison of and cycle forward, Notmal load $=3.0 \mathrm{klps} ; \mathrm{K}=14 \% . \mathrm{K} / \mathrm{p}$ / $/ \mathrm{I} \quad$ B. 119

KR\&F. Dilatancy compartaon of znd cycle reverse. Normal boad $=1.0 \mathrm{Klpa}$; $K=147.044 .3 \mathrm{Klp} / \mathrm{In} \quad$ B. 120

KKHF2 Shear load compartaon of and cycle reverse, Notmal Load * $1.0 \mathrm{k} / \mathrm{pa} ; \mathrm{K}=147.8 \mathrm{klpa} / \mathrm{in}$

KRHF2 Dilatancy compatian of Ird cycle forward, Normal Load - $3.0 \mathrm{klps} K=147.8 \mathrm{Klpa} / \mathrm{ln}$

KRAF2 Sheat load compation of ird cycle forward, Normal Load $=3.0 \mathrm{klp} ; \mathrm{K}=147.0 \mathrm{klps} / \mathrm{In}$

KRBF2 Dllatancy compartion of $3 \mathrm{rd}$ cycle raverae, Normal Load = $3.0 \mathrm{klpa}$; K $=147.8 \mathrm{klpe} / \mathrm{In}$

KREF? Shear load compariaon of $3 \mathrm{rd}$ cycle reverse, Normal Load - $3.0 \mathrm{klpa}$; $=147.8 \mathrm{klpu} / \mathrm{in}$

KKAF: Dlatancy compartion of $4 t h$ cycle forward, Normal load $=3.0 \mathrm{klpa}$ : K $=147.8 \mathrm{klpa} / \mathrm{In}$

KRAFe Shear load comparlaon of th cycle forward. Normal load $-3.0 \mathrm{klpg} K=147.8 \mathrm{Klpg} / \mathrm{ln}$

KkBF: Dllatanty compartaon of ath cycle reverse, Normal load $-1.0 \mathrm{klpa} K=147.8 \mathrm{k} / \mathrm{pa} / \mathrm{In}$

KKatz shear luad comparteon of ath cycle reverse. Normal Load - $3.0 \mathrm{Klps}$ K $-147.8 \mathrm{Klps} / \mathrm{ln}$

KkbFz Dllatancy compartson of sth cycle forward, Nommal Load - $3.0 \mathrm{klps;} K=147.8 \mathrm{klpg} / \mathrm{In}$

KkHFe shear load compartwon of 5 th cycle torward, Normal load - $1.0 \mathrm{klps} ; \mathrm{K}=147.8 \mathrm{kipa/in}$

KKHFz Dilatancy compation of 5 th cycle reverse, Normal load - $1.0 \mathrm{klps}$; $-147.8 \mathrm{klps} / \mathrm{ln}$

KRAFz Shear load compartaon of $5 t h$ cycle reverae. Normal hoad $-3.0 \mathrm{klps} ; \mathrm{K}-147.8 \mathrm{klpg} / \mathrm{in}$

Kk5G2 Ditatancy compartson of 1 st cycle torward, Notmal hoad $-1.3 \mathrm{klps} ; \mathrm{K}=32 \mathrm{klps} / \mathrm{ln}$ B. 127 
SAMPLE DESCRTETION

KR502 Shear load comparison of 1 at cycle forward, Normal Load $=1.3 \mathrm{klps} ; \mathrm{K}=32 \mathrm{klpH} / \mathrm{in}$ H 12\%

KR502 Dilatancy compartaon of 1 tot cycle reverue. Normal Load $=1.3 \mathrm{klps} ; k=32 \mathrm{klps} / \mathrm{ln} \quad \mathrm{H}-128$

KR5G2 Shear load comparison of 1 at cycle reveras, Normal Load $=1.3 \mathrm{Klpa} ; K=32 \mathrm{klps} / \mathrm{in} \quad$ B. 128

KR5G2 Dllatancy compariaon of and cycle forward. Normal load $=1.3 \mathrm{kipa;} K-32 \mathrm{klps} / \mathrm{in}$ B. 129

KR5G2 Shear load comparison of 2 nd cycle forward, Normal Load - $1.3 \mathrm{kipa;} K=32 \mathrm{kips} / \mathrm{in} \quad$ B-129

KR502 Dilatancy compartion of and cycle reverue, Normal Load * $1.3 \mathrm{kipa} ; \mathrm{K}=32 \mathrm{klps} / \mathrm{in} \quad \mathrm{B} \cdot 130$

KR5G2 shear loal comparion of 2 nd cycle reverse. Normal Load $=1.3 \mathrm{kips} ; \mathrm{K}=32 \mathrm{k} / \mathrm{p}$ / $/ \mathrm{n} \quad \mathrm{B}+130$

KR602 Dilatancy comparison of lot cycle forward, Normal Load $=6.4 \mathrm{kips} K=64 \mathrm{klpu} / \mathrm{in} \quad \mathrm{H} / 11$

KR602 Shear load comparioon of 1 tot cycle forward, Normal Load $=6.4 \mathrm{k} / \mathrm{pa} ; \mathrm{K}-64 \mathrm{klp} / \mathrm{in} \quad \mathrm{H}-131$

KR662 Dllatancy comparison of lat cycle reverse. Normal Load - $6.4 \mathrm{kips} K=64 \mathrm{klps} / \mathrm{ln} \quad \mathrm{B} 132$

KR602 Shat load compartion of 1 st cycle reverse, Normal Load - $6.4 \mathrm{klpg} ; \mathrm{K}=64 \mathrm{k} 1 \mathrm{pg} / \mathrm{in} \quad \mathrm{B}-132$

KR6G2 Dilatancy compartion of 2nd cycle forward, Normal Load - $6.4 \mathrm{klpg} ; \mathrm{K}-64 \mathrm{klps} / \mathrm{in} \quad \mathrm{B} 1 \mathrm{il}$

KR6G2 Shat load comparison of 2nd cycle forward, Normal Load - $6.4 \mathrm{klpsi} K=64 \mathrm{klpe} / \mathrm{ln} \quad \mathrm{B}=133$

KR6G2 Dilatancy comparison of and cycle reverse, Normal Load - 6.4 klps; K $-64 \mathrm{klps} / \mathrm{in}$ B 134

KRGG2 Shear load comparion of 2nd cycle reveres, Normal Load $=6.4 \mathrm{klpg}$; $=64 \mathrm{kips} / \mathrm{in} \quad \mathrm{b} .134$ 


\section{DILATANCY PREDICTION F4IF $K=18.0 \mathrm{KIPS} / \mathrm{IN}$, NORMAL LOAD=3.6 KIPS}
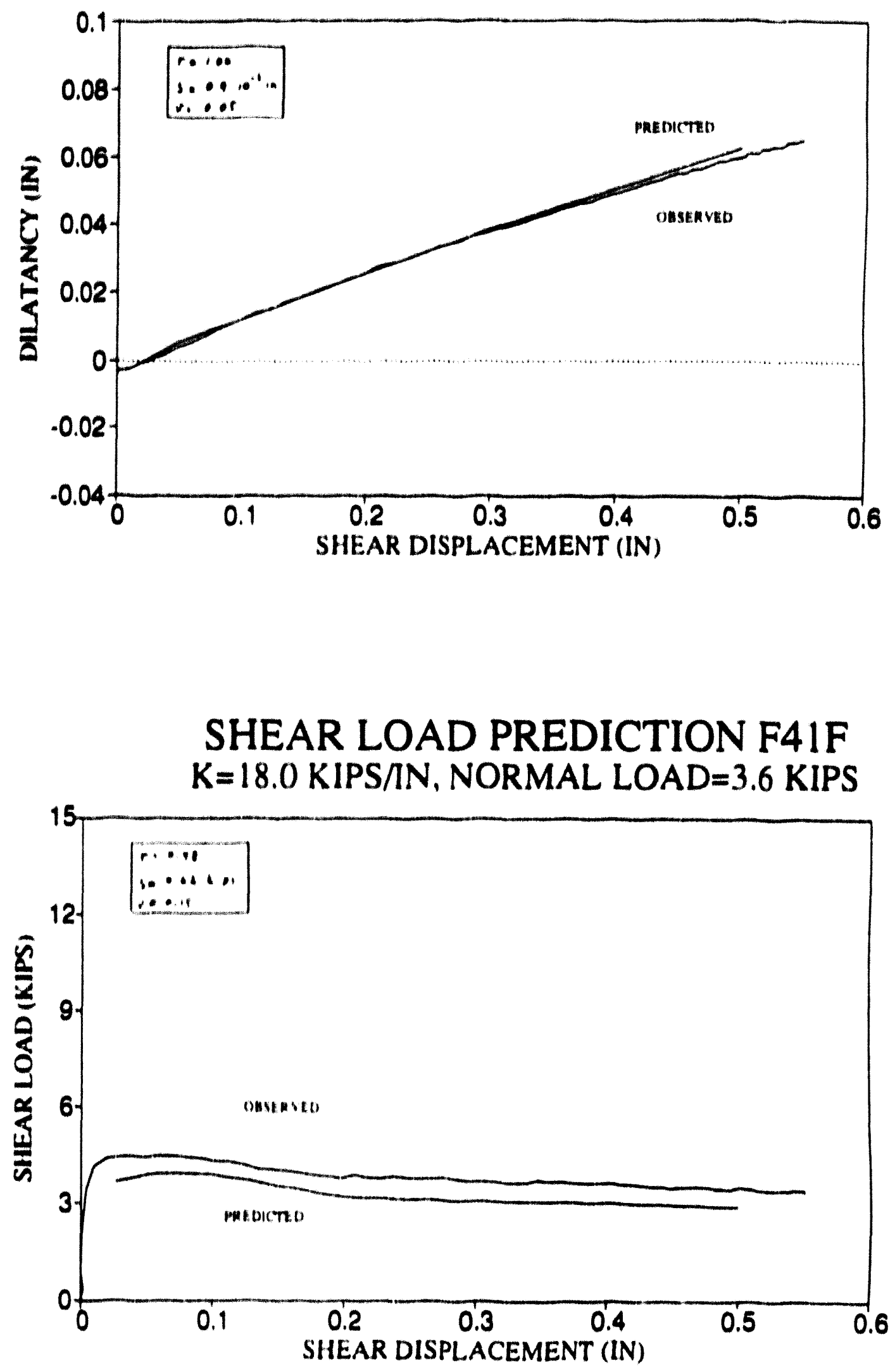

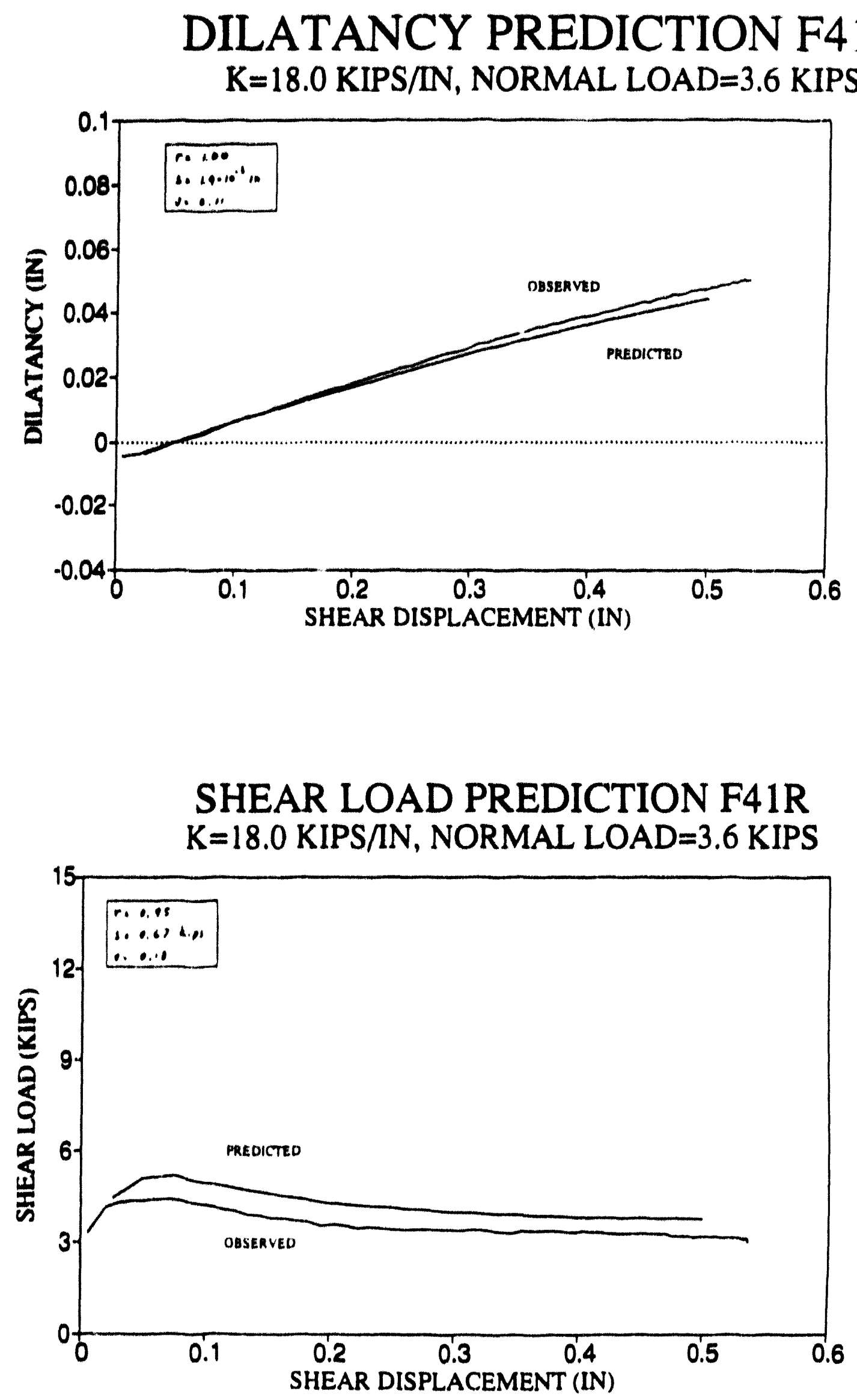


$$
\varepsilon-8
$$

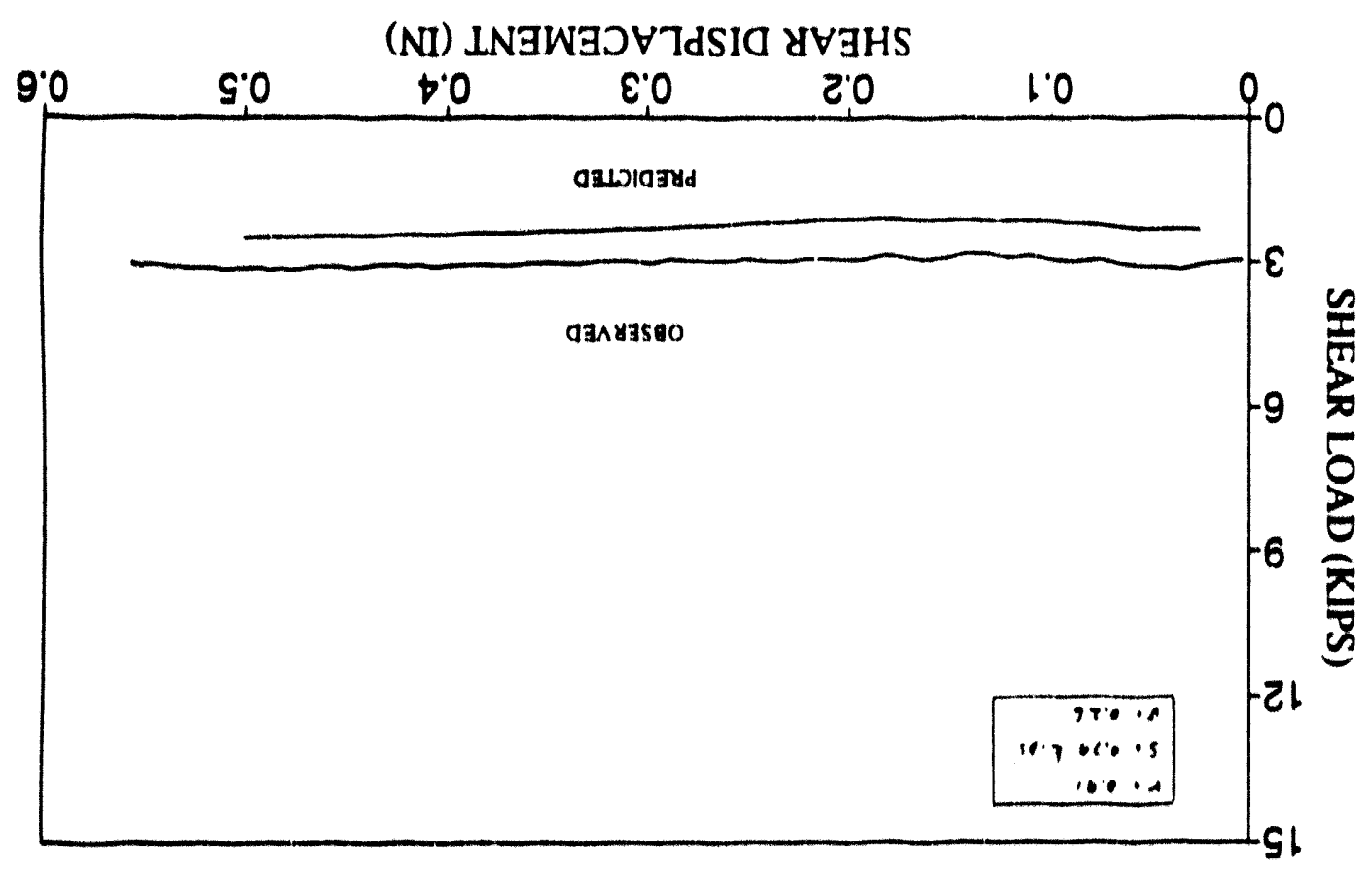

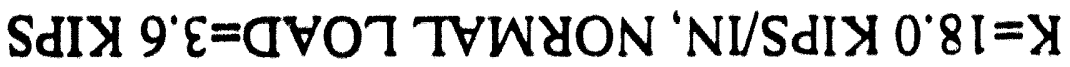

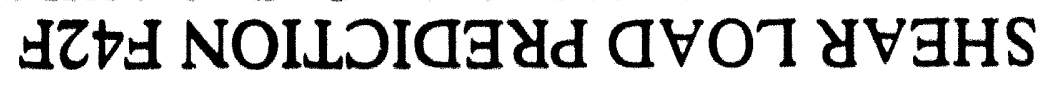

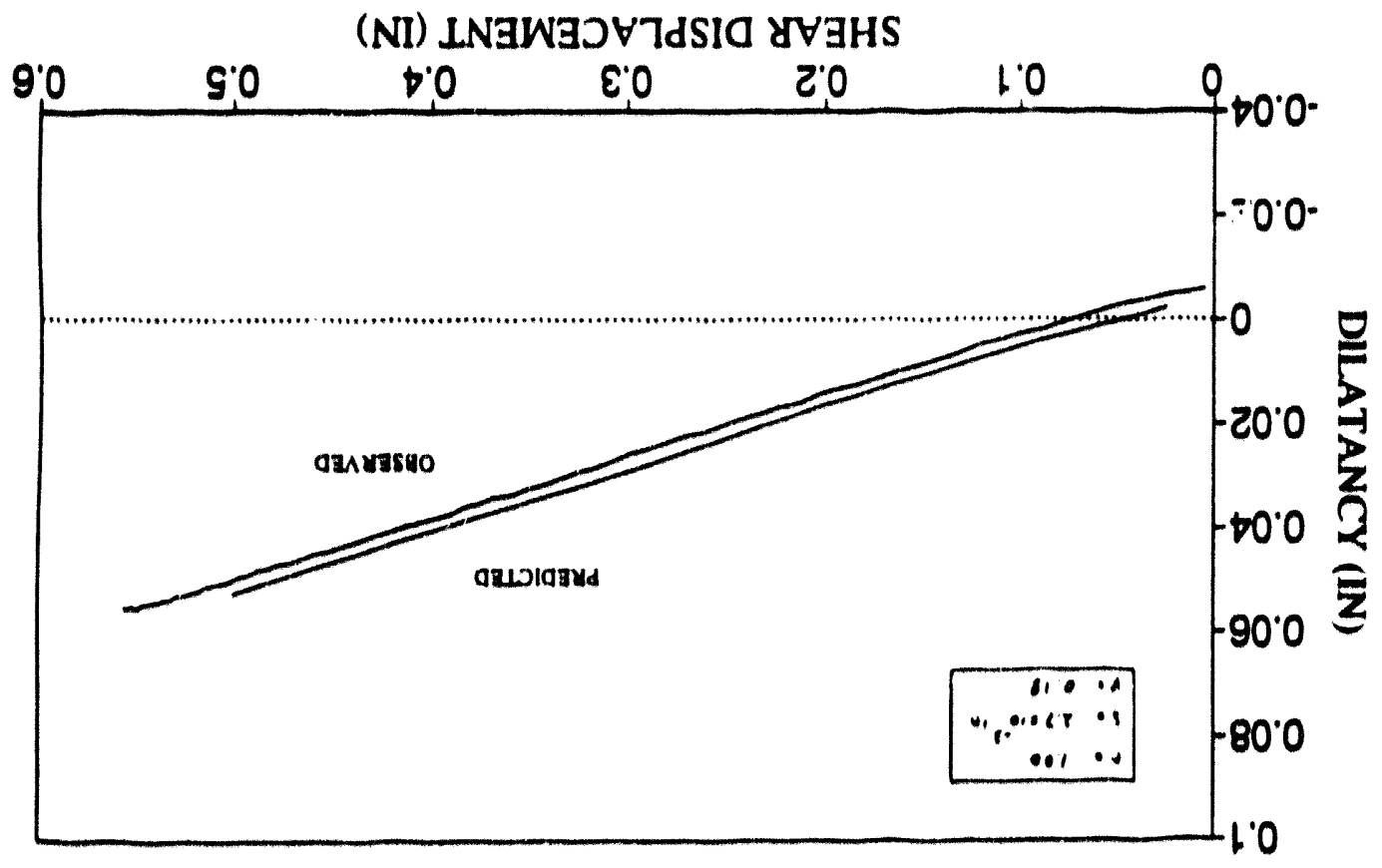

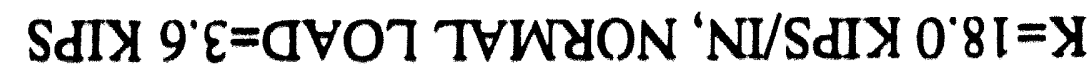
GZ† NOILOIG 


\section{DILATANCY PREDICTION F42R $\mathrm{K}=18.0 \mathrm{KIPS} / \mathrm{IN}$, NORMAL LOAD $=3.6 \mathrm{KIPS}$}

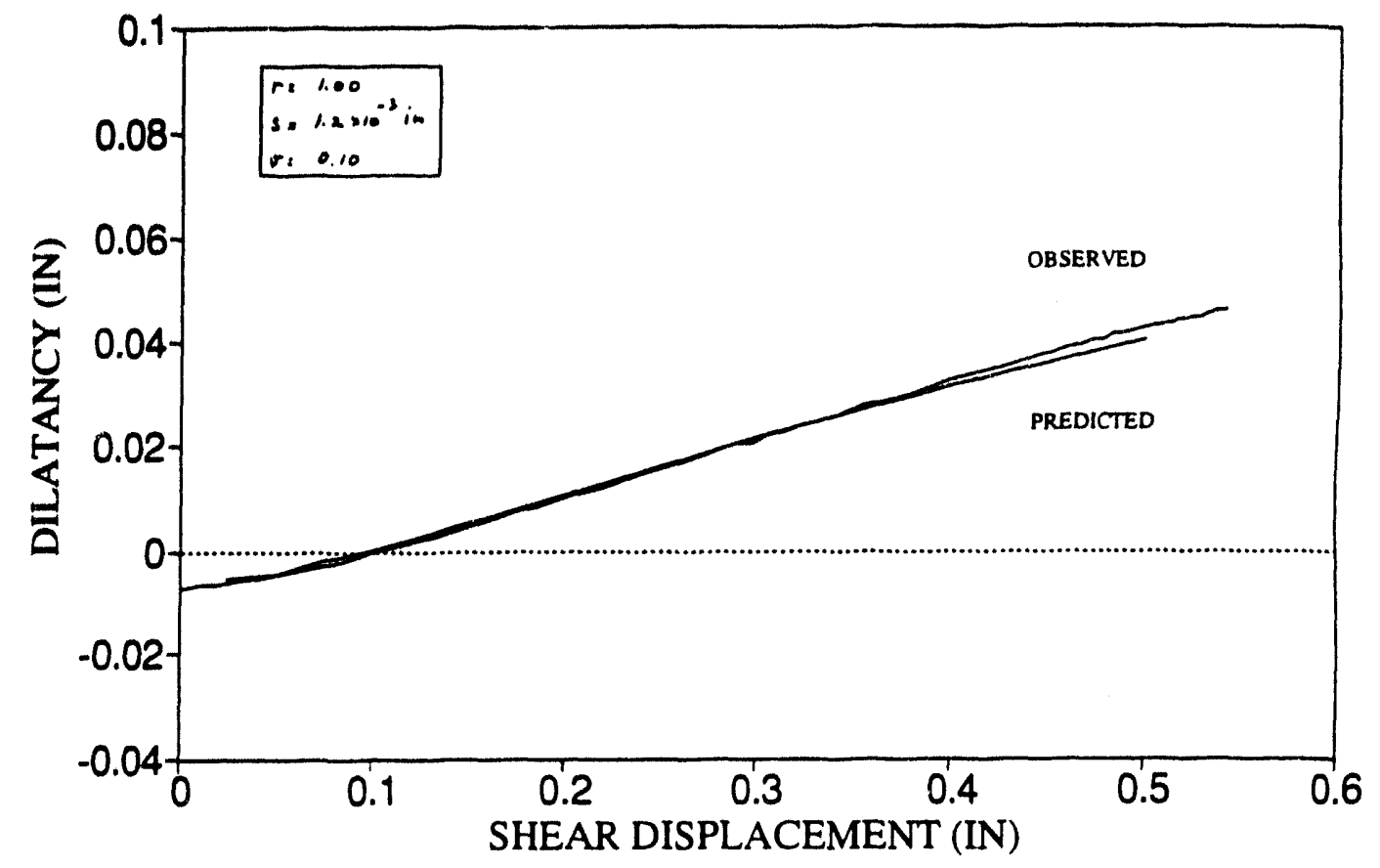

SHEAR LOAD PREDICTION F42R

$\mathrm{K}=18.0 \mathrm{KIPS} / \mathrm{IN}, \mathrm{NORMAL}$ LOAD=3.6 KIPS

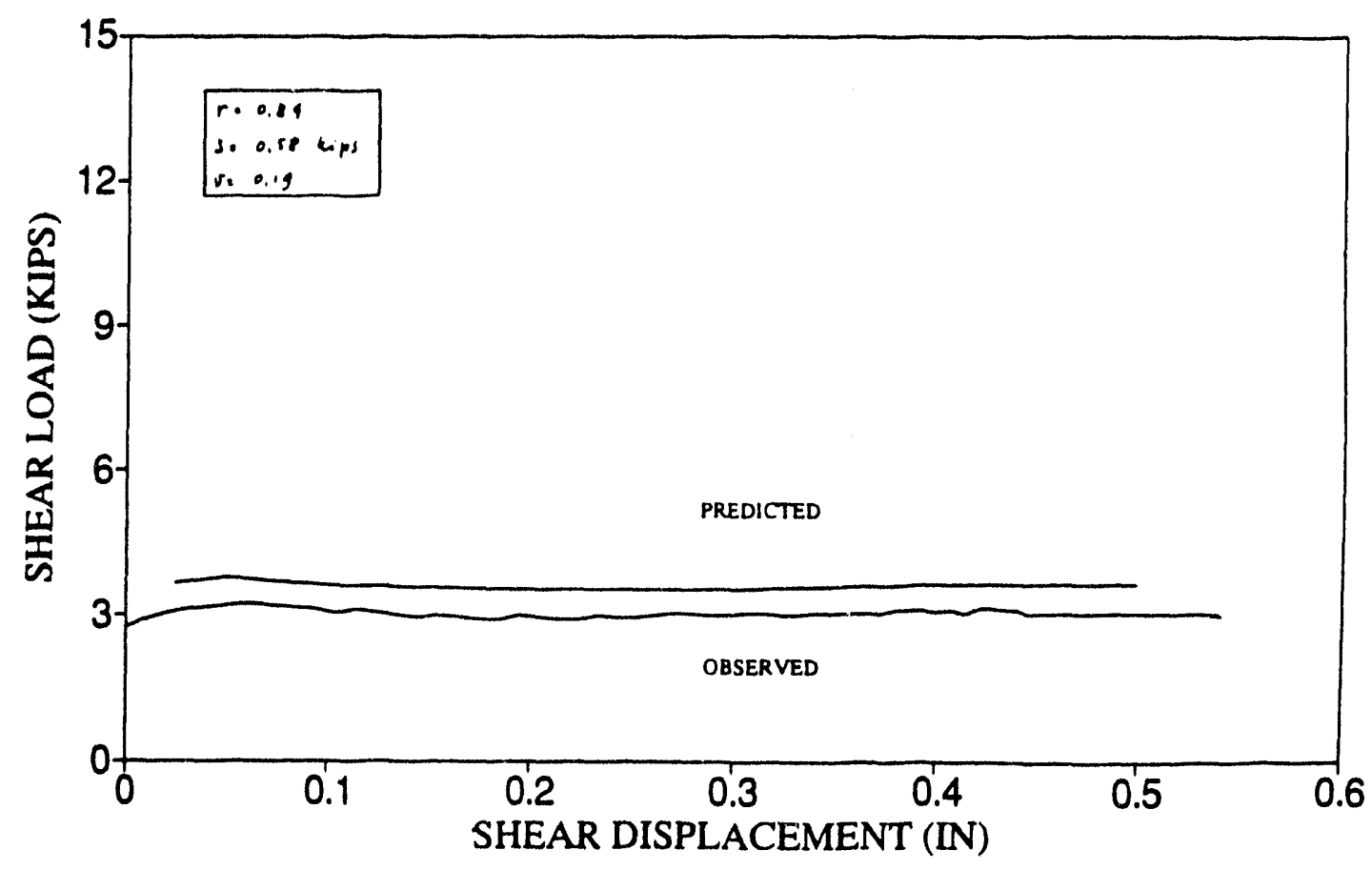

B-4 


\section{DILATANCY PREDICTION F43F $\mathrm{K}=18.0 \mathrm{KIPS} / \mathrm{IN}$, NORMAL LOAD=3.6 KIPS}

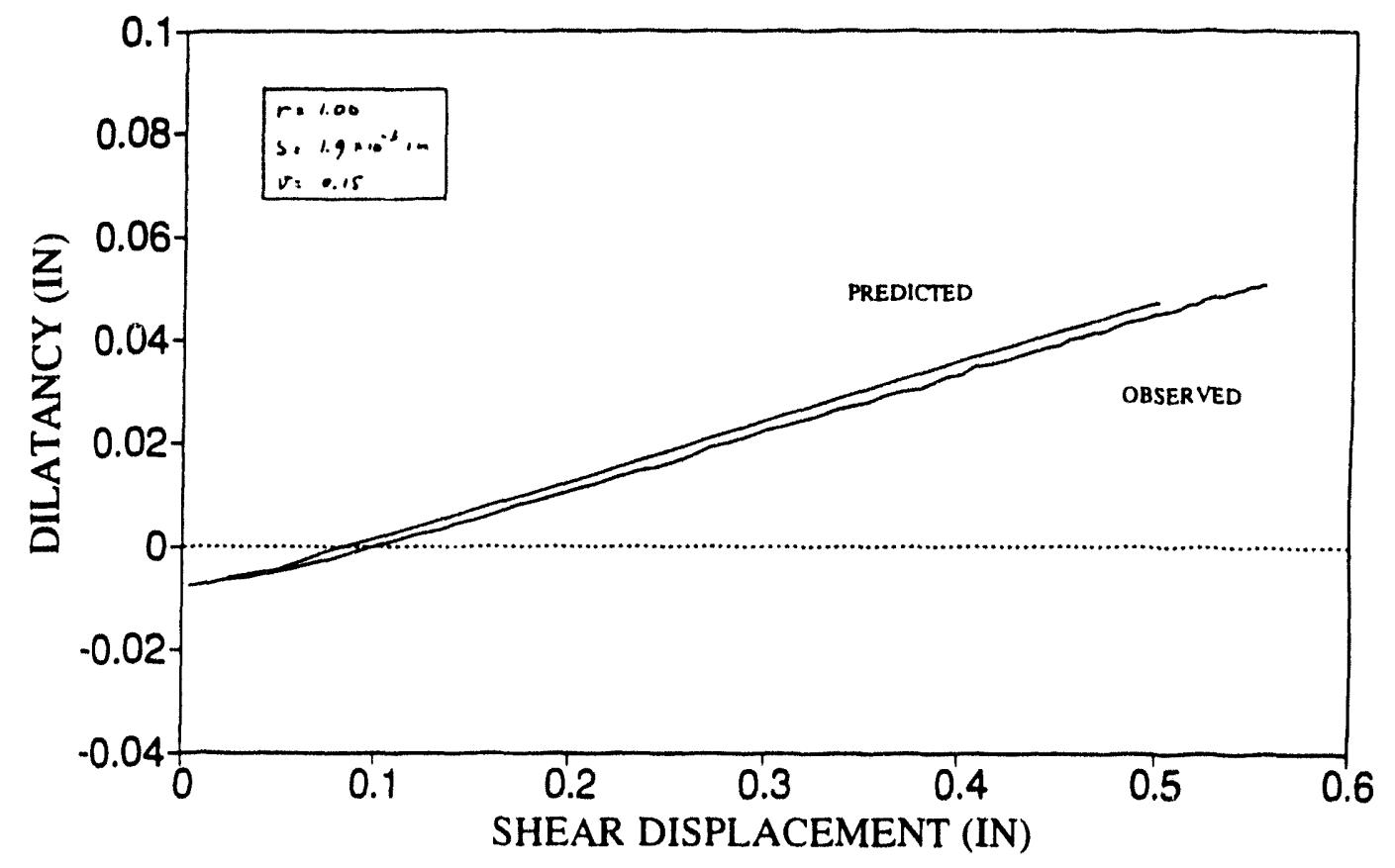

SHEAR LOAD PREDICTION F43F $\mathrm{K}=18.0 \mathrm{KIPS} / \mathrm{IN}$, NORMAL LOAD=3.6 KIPS

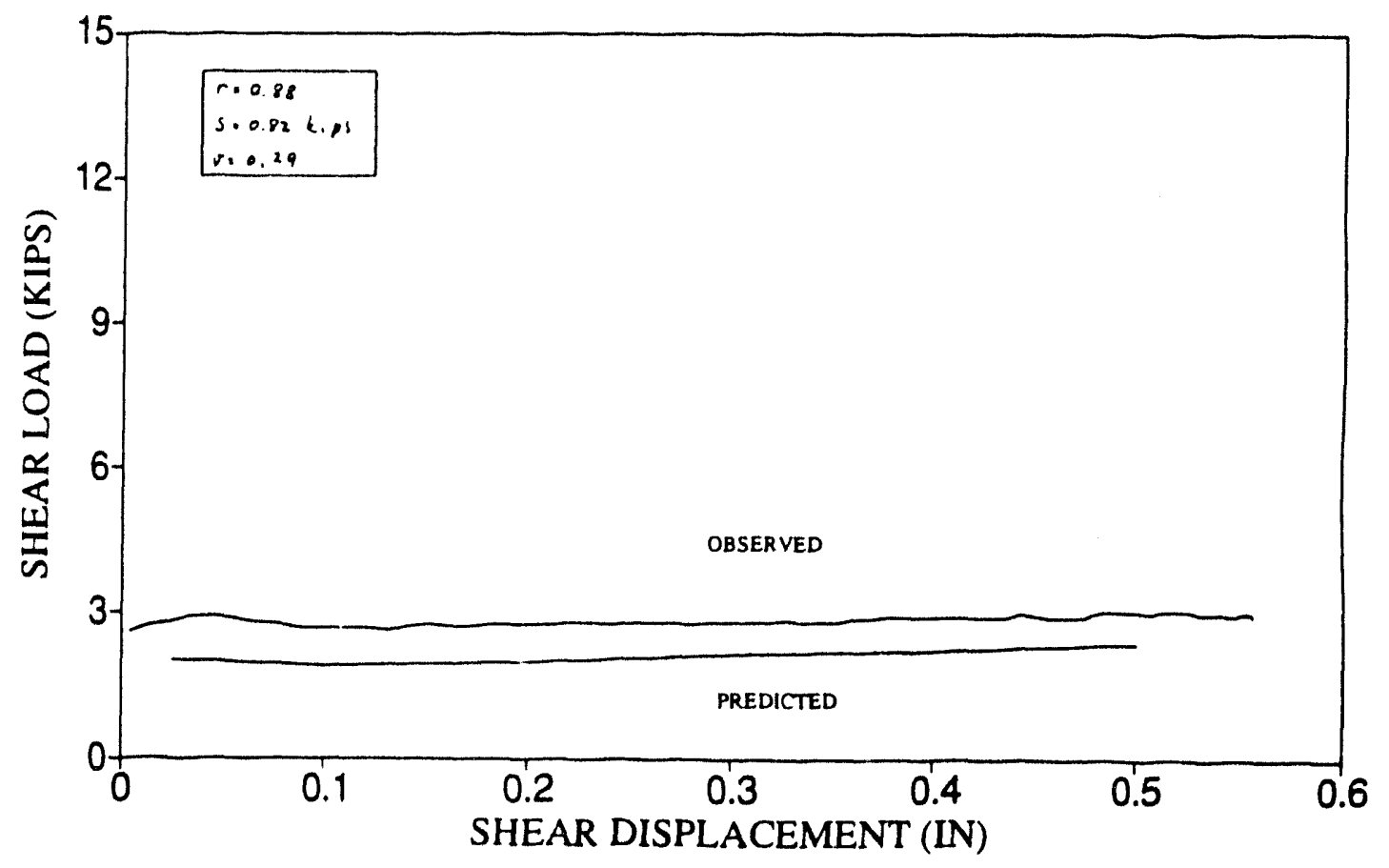




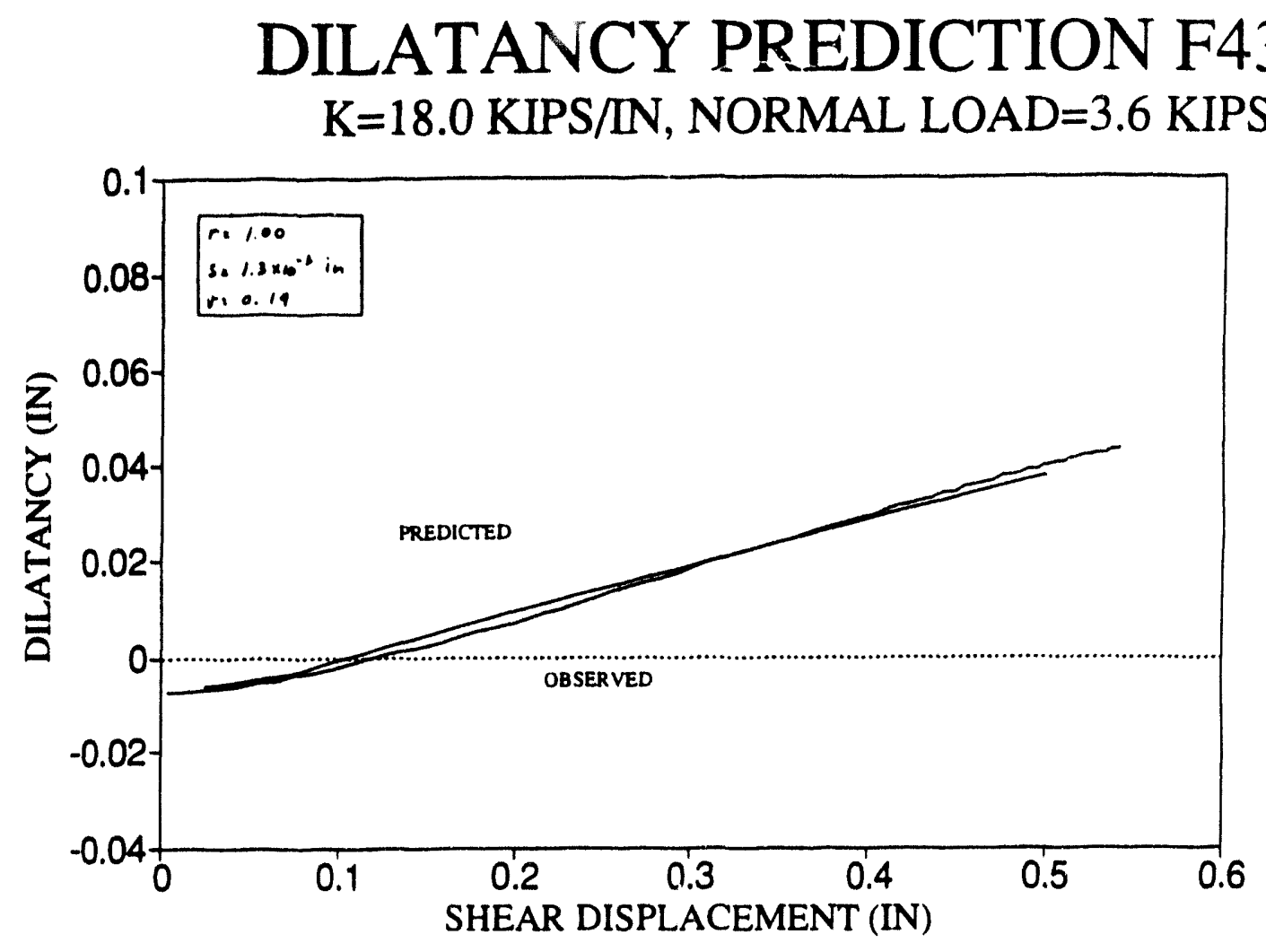

SHEAR LOAD PREDICTION F43R

$\mathrm{K}=18.0 \mathrm{KIPS} / \mathrm{IN}$, NORMAL LOAD=3.6 KIPS

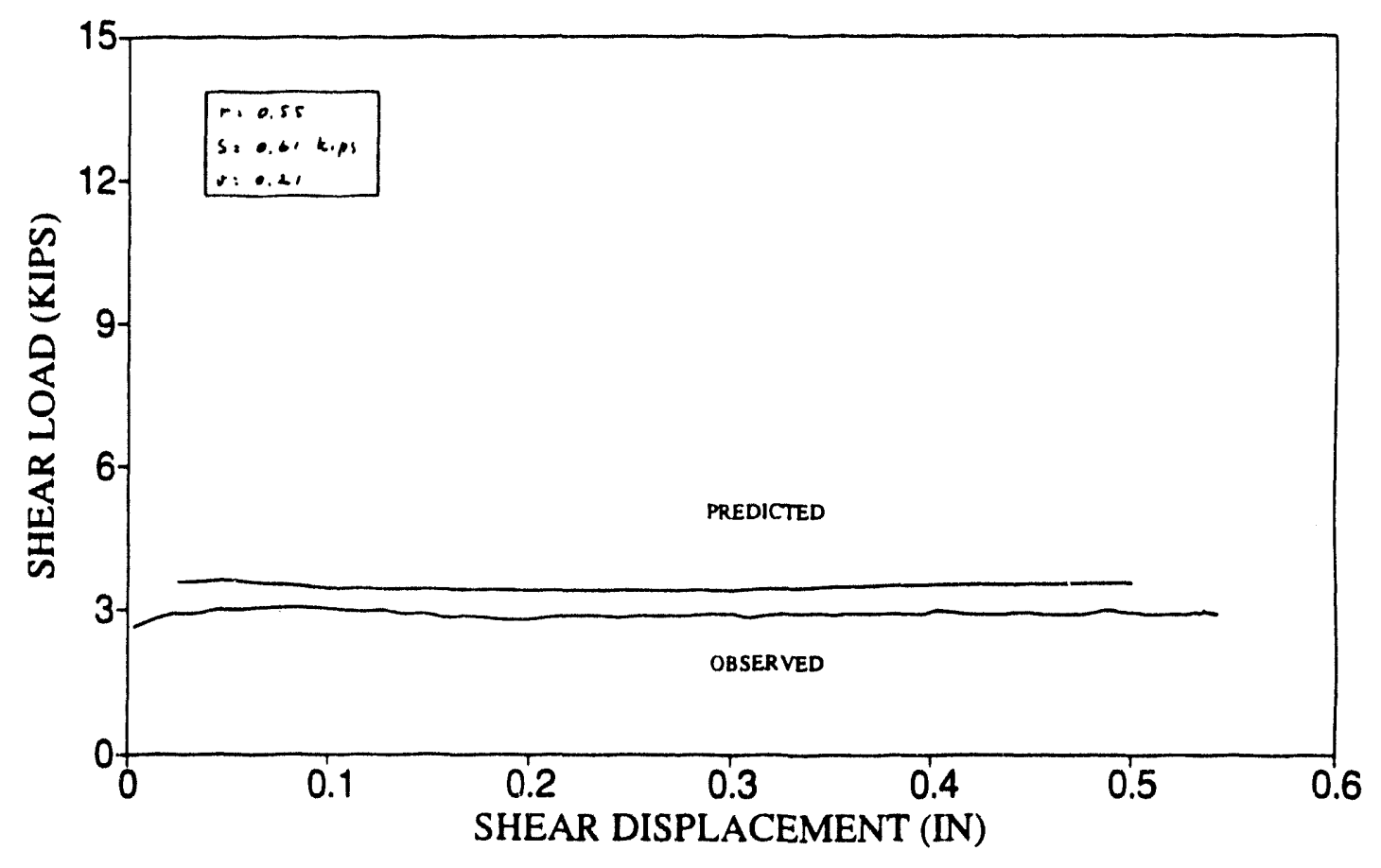




$$
L-g
$$

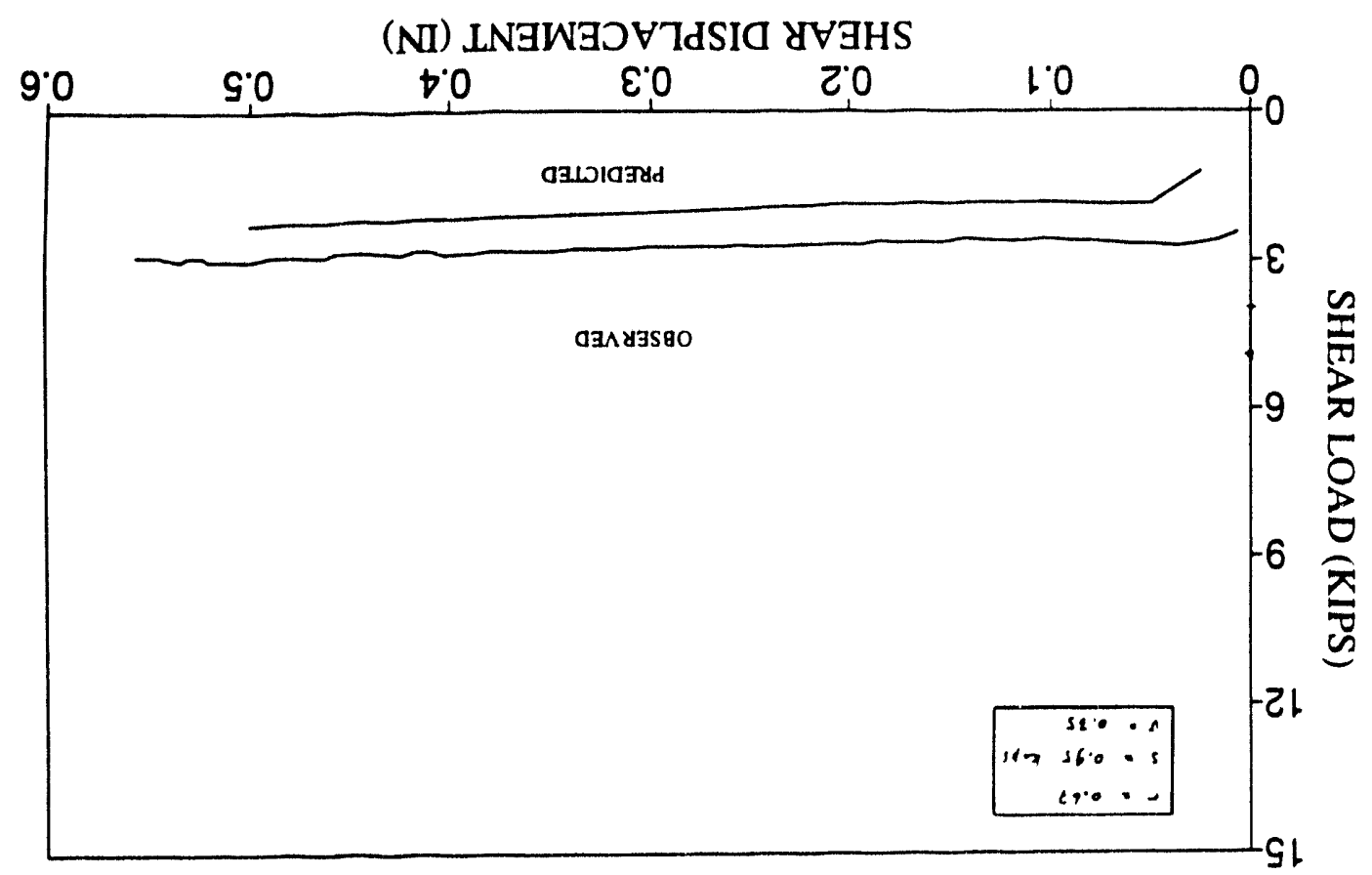

SdIY $9^{\circ} \varepsilon=$ व $\forall O^{\prime} T$ THWON 'NI/SdIY 0.8I =X

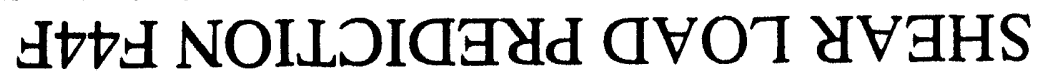

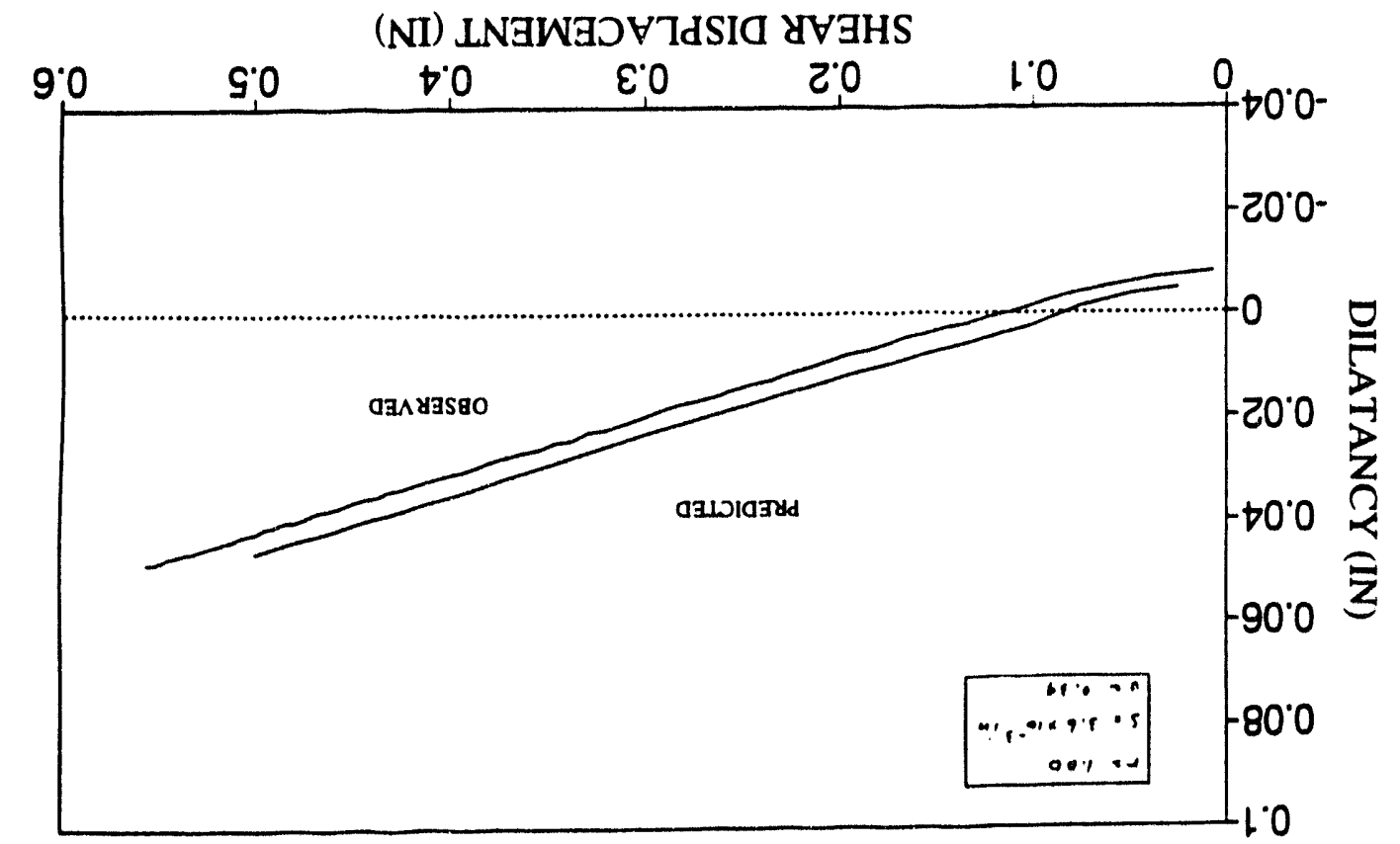

SdIY $9^{\circ} \varepsilon=$ वVOT TVWYON 'NI/SdIY 0 ० $8 \mathrm{I}=\mathrm{X}$

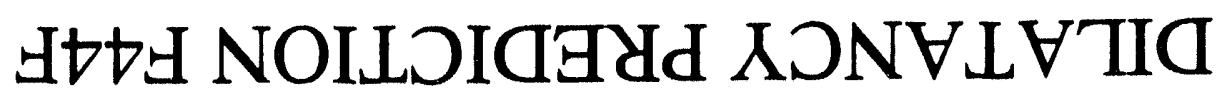




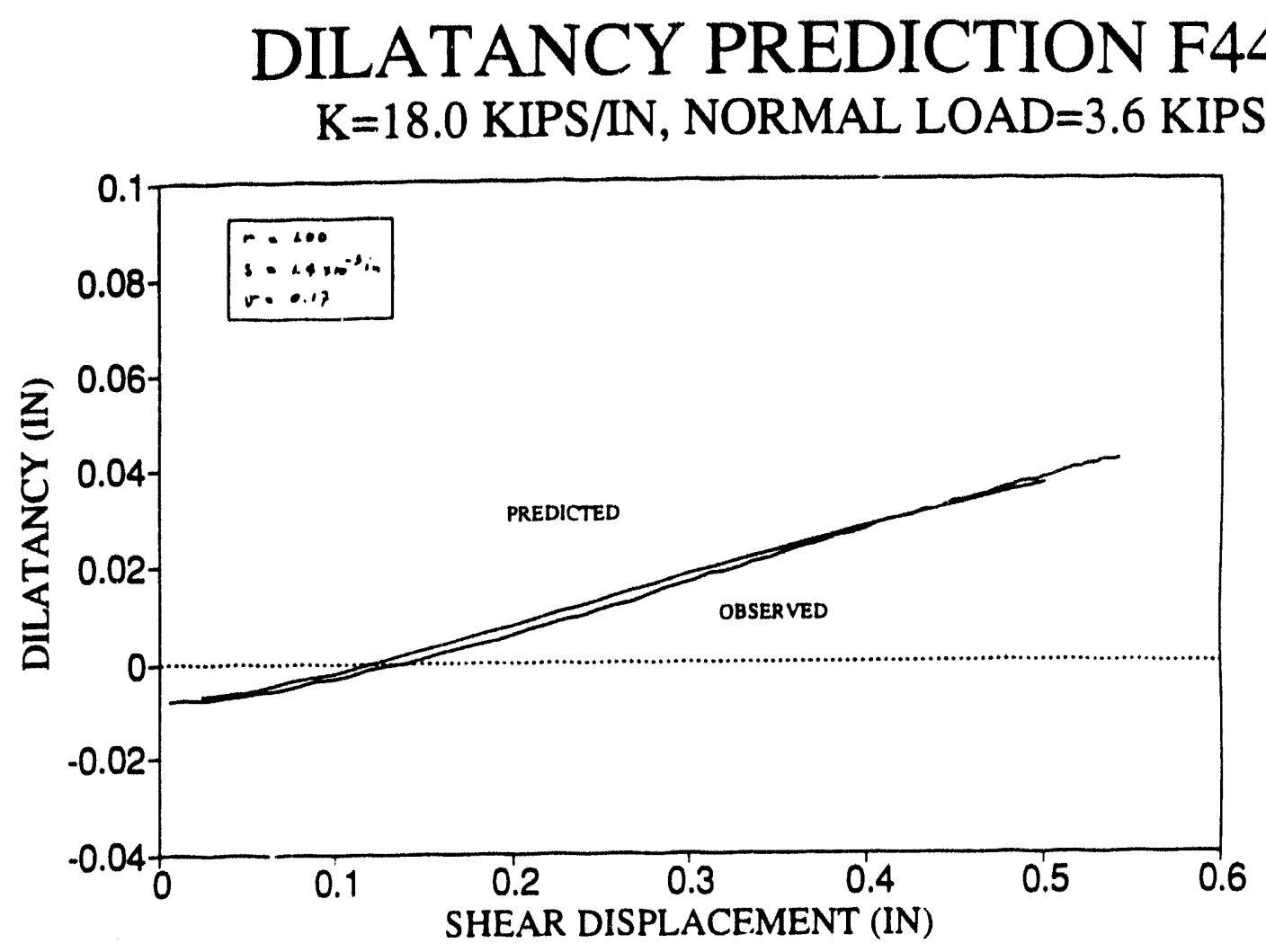

SHEAR LOAD PREDICTION F44R $\mathrm{K}=18.0 \mathrm{KIPS} / \mathrm{IN}$, NORMAL LOAD=3.6 KIPS

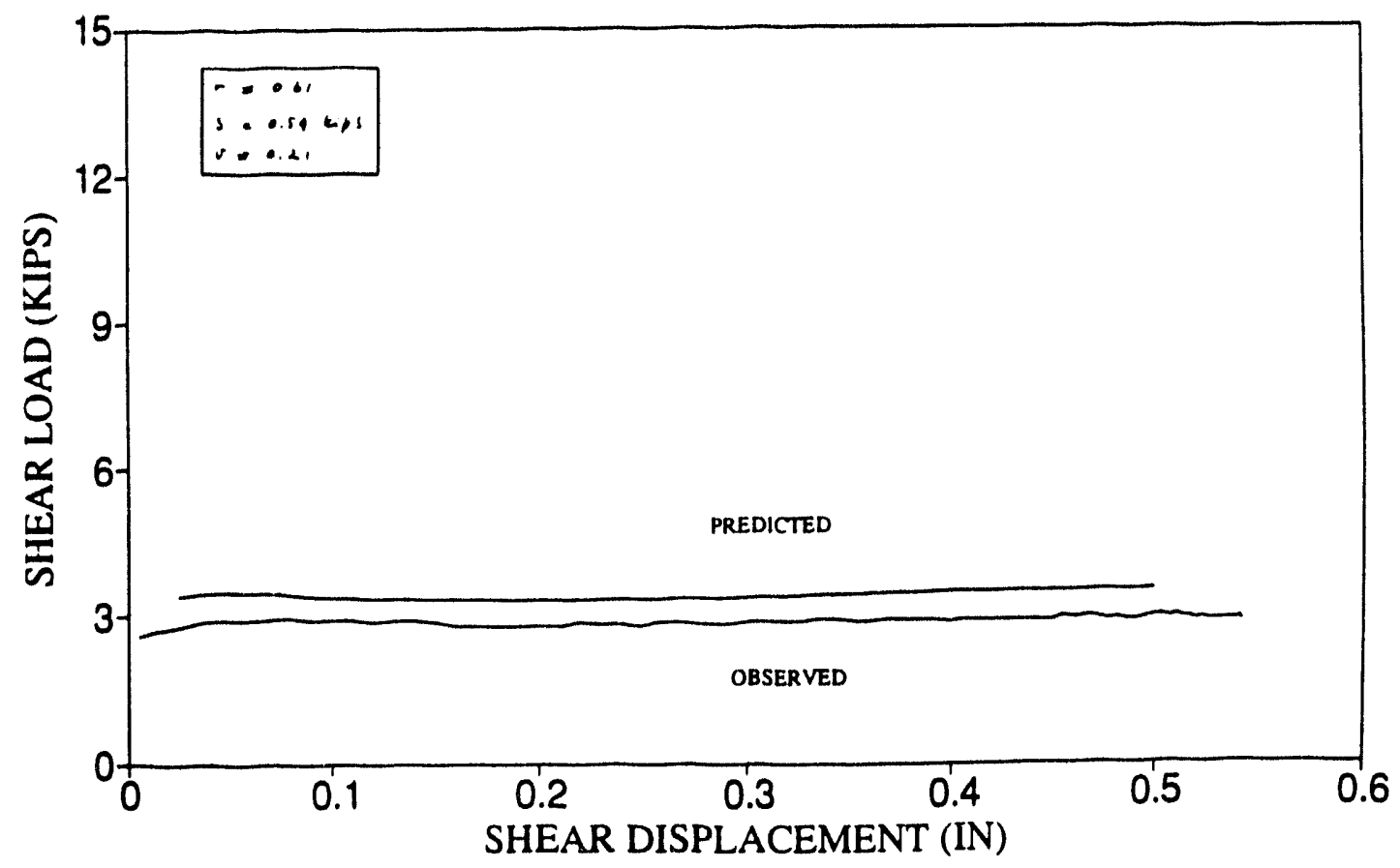



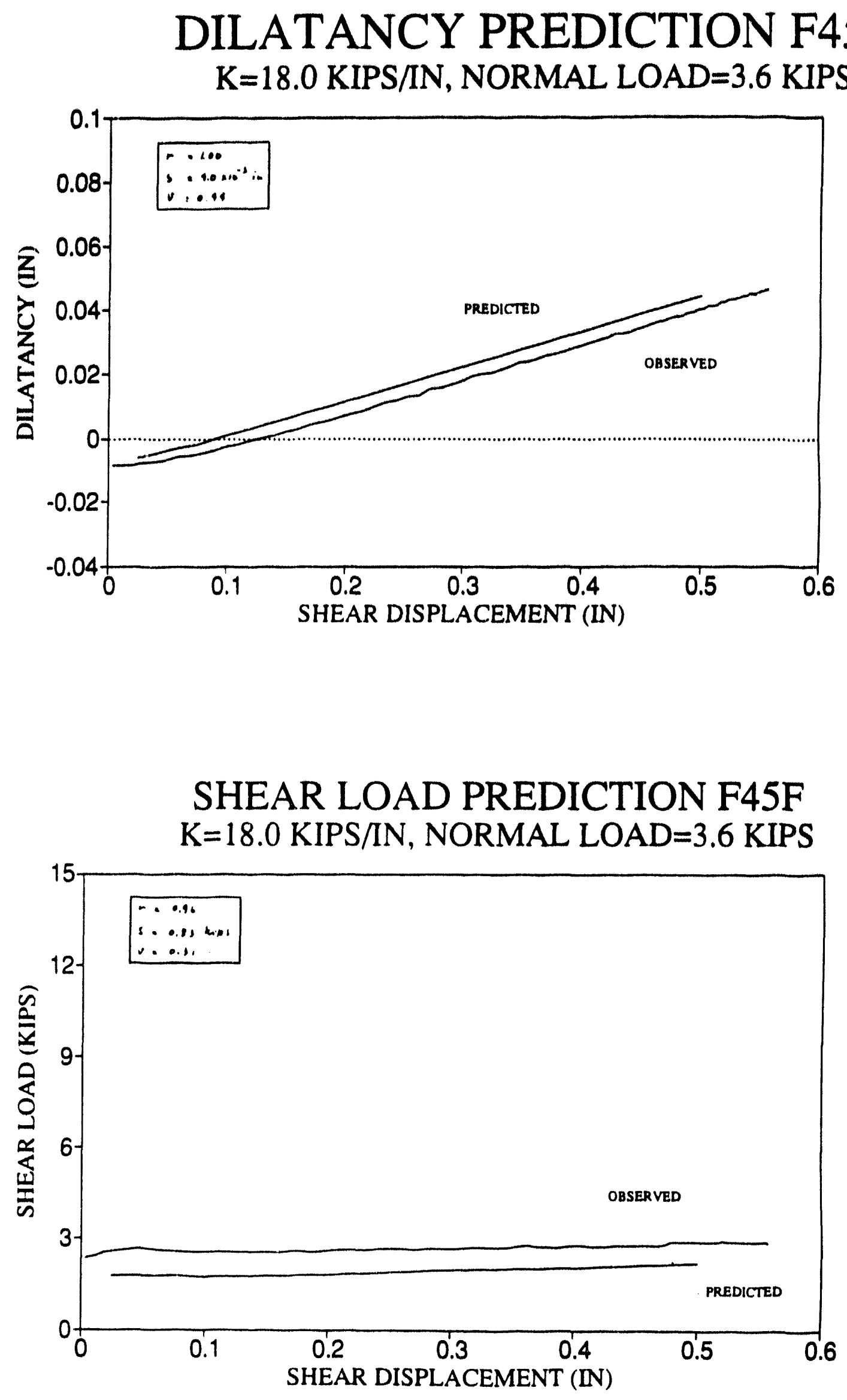

B-9 

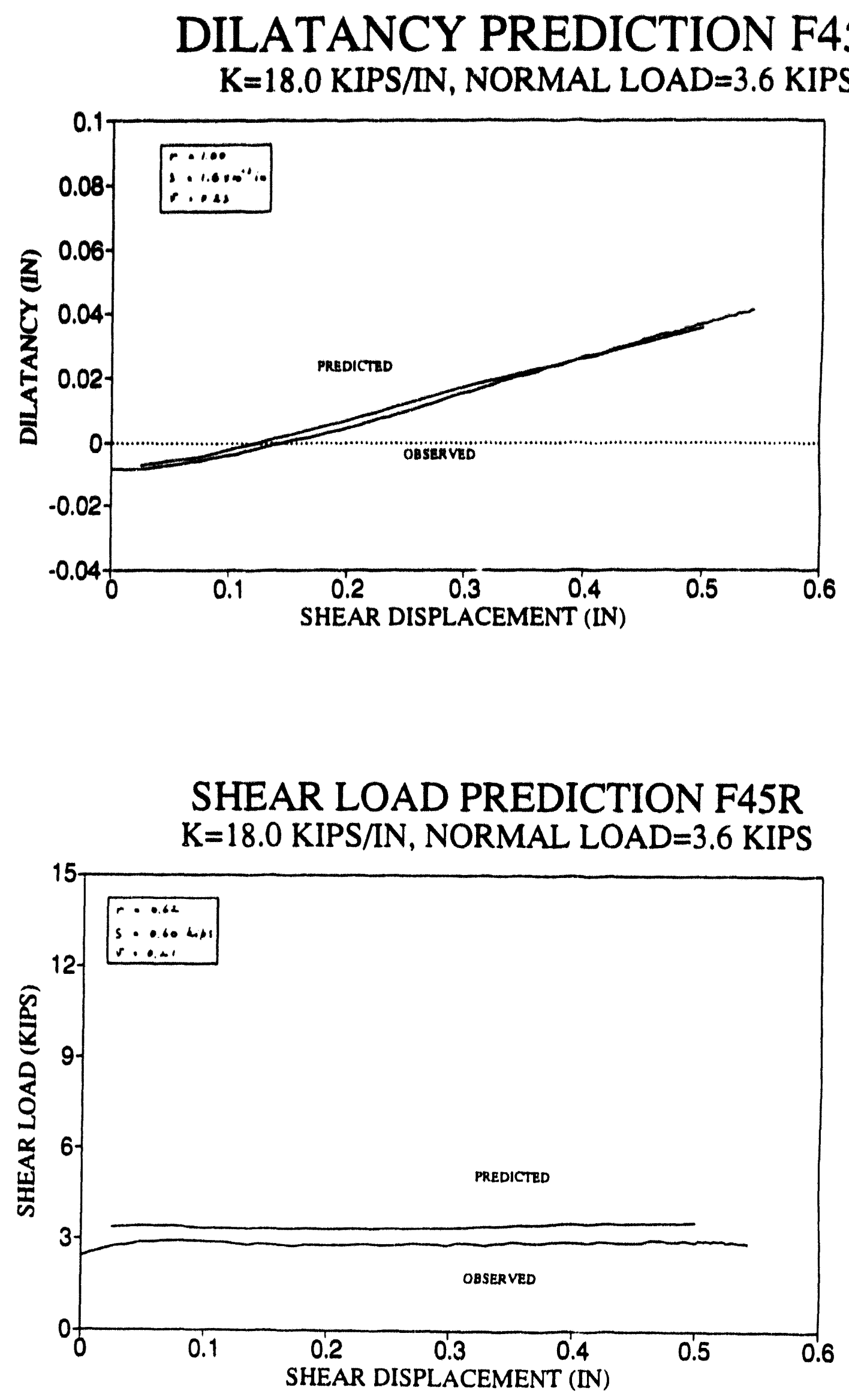


\section{DILATANCY PREDICTION F41F $\mathrm{K}=54.0 \mathrm{KIPS} / \mathrm{IN}$, NORMAL LOAD=3.6 KIPS}

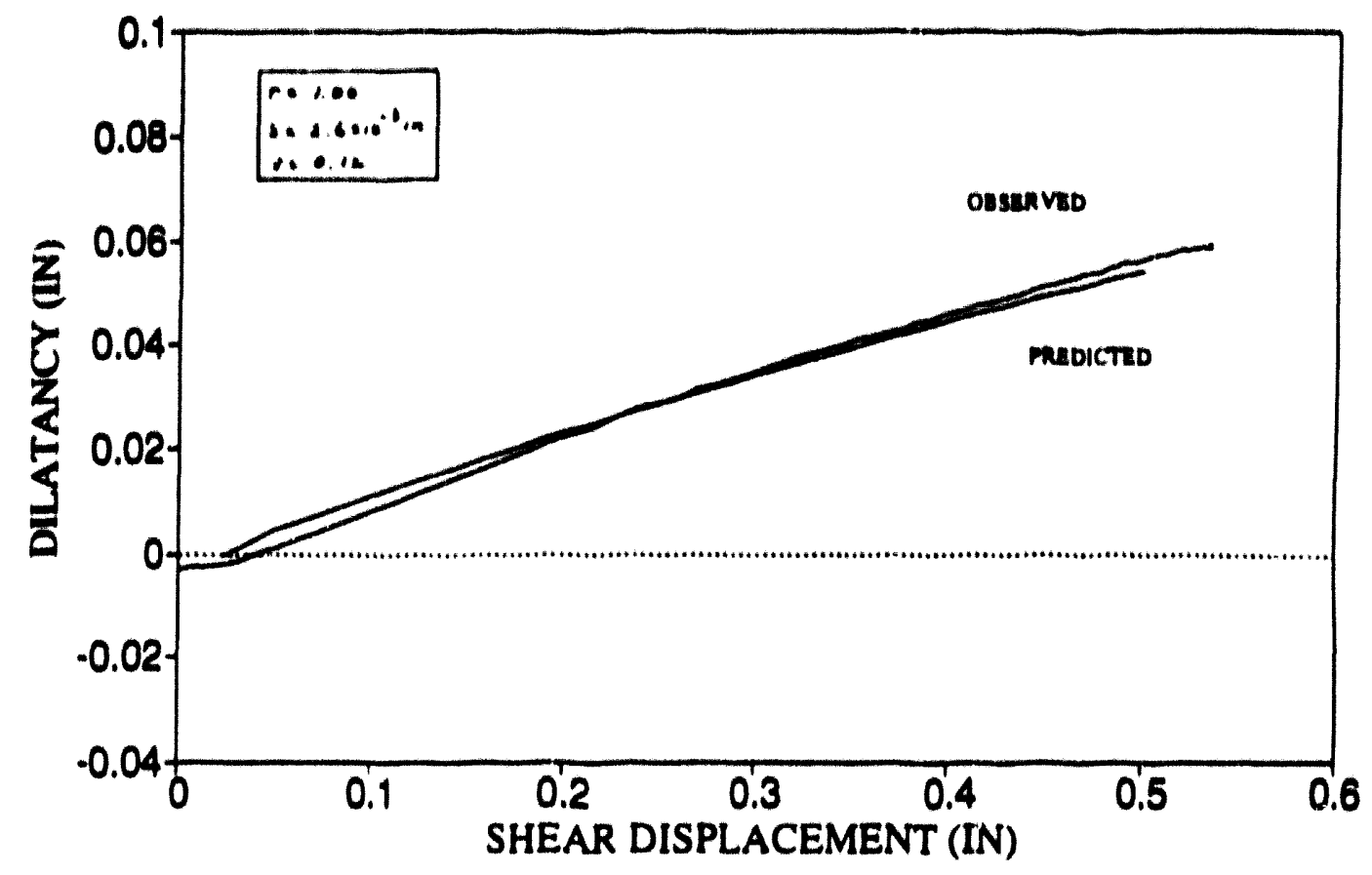

SHEAR LOAD PREDICTION F41F $\mathrm{K}=54.0 \mathrm{KIPS} / \mathrm{IN}$, NORMAL LOAD=3.6 KIPS

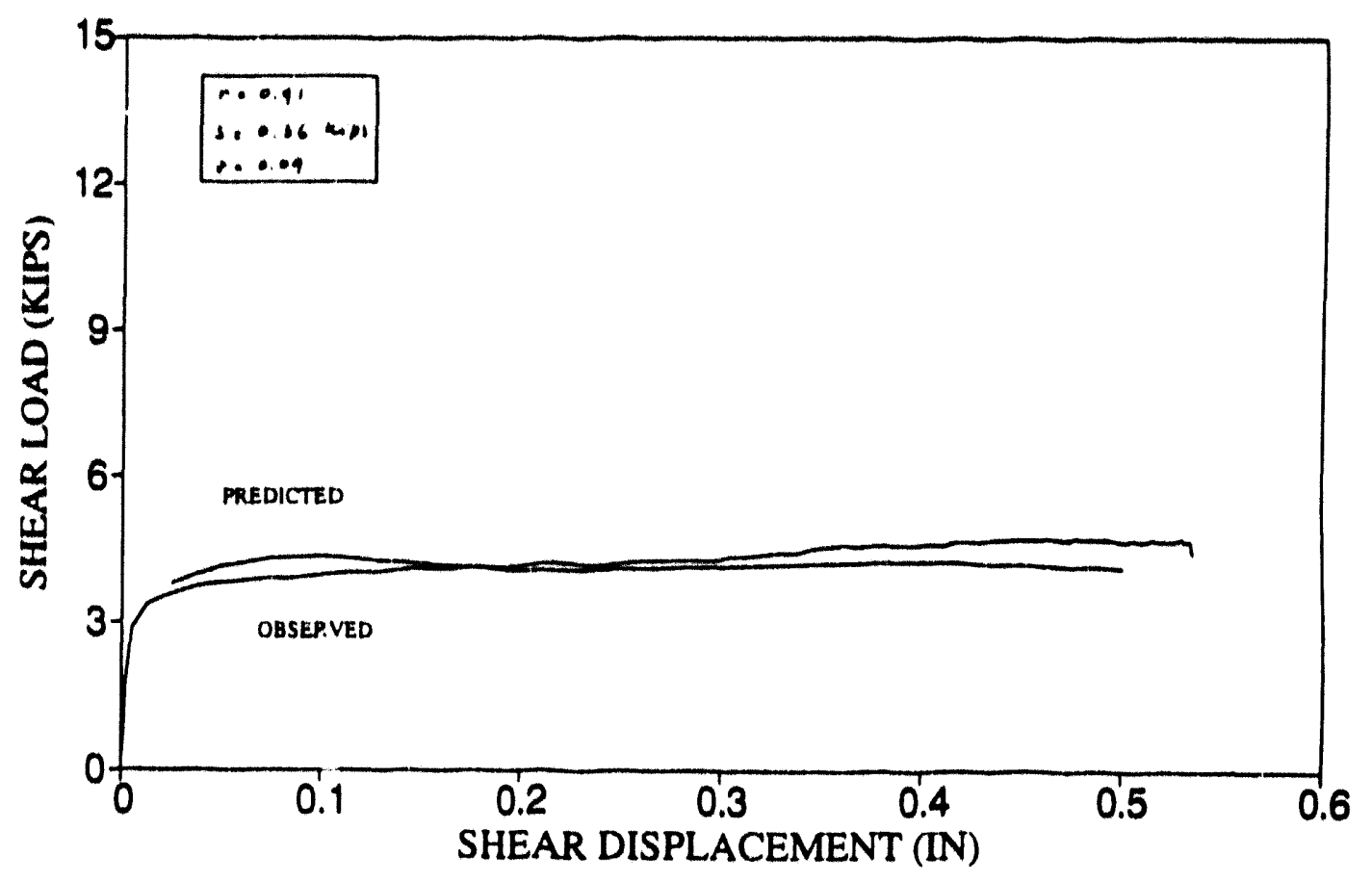




\section{DILATANCY PREDICTION F41R $\mathrm{K}=54.0 \mathrm{KIPS} / \mathrm{IN}$, NORMAL LOAD=3.6 KIPS}

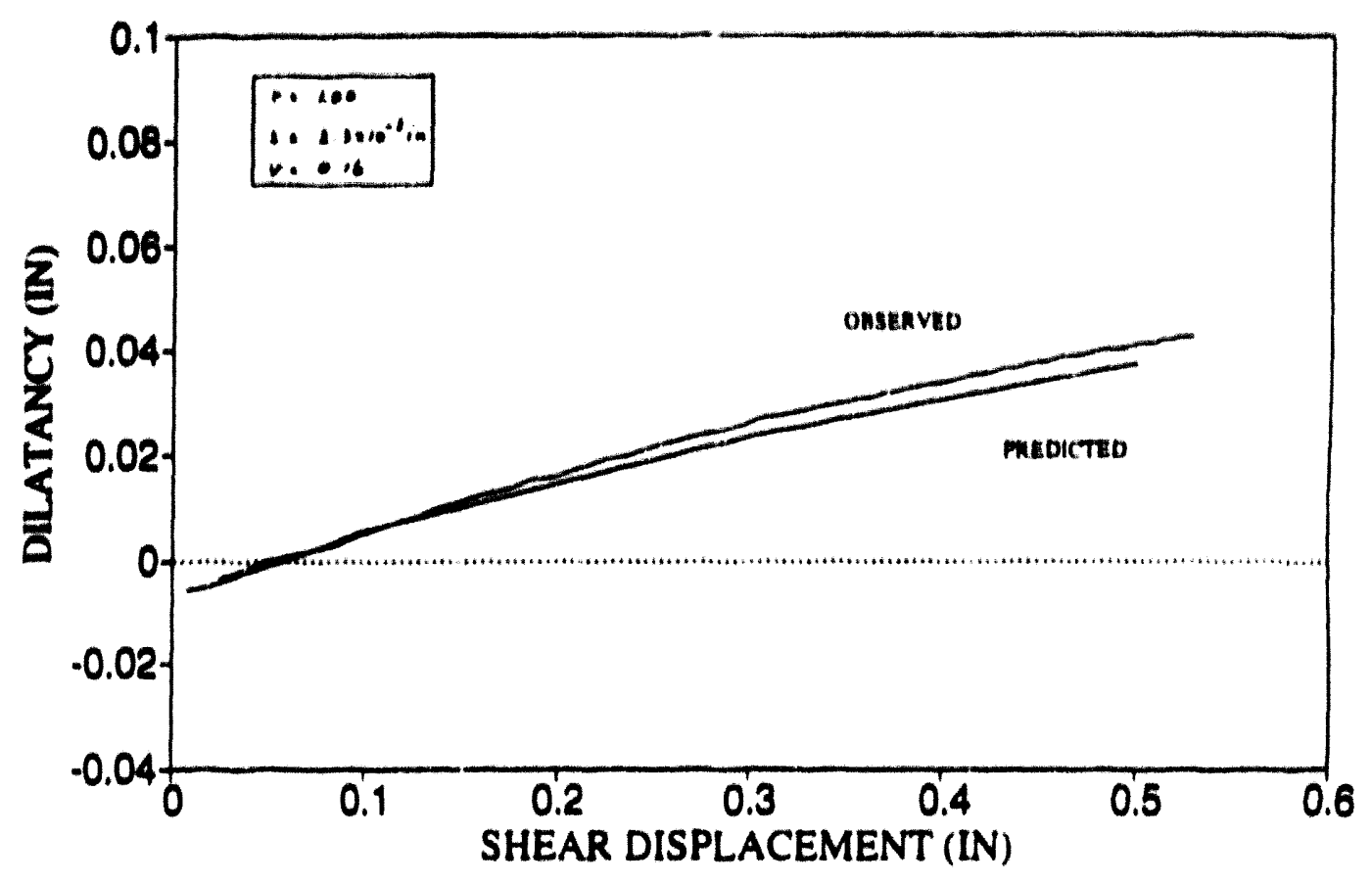

SHEAR LOAD PREDICTION F41R $\mathrm{K}=54.0 \mathrm{KIPS} / \mathrm{IN}$, NORMAL LOAD $=3.6 \mathrm{KIPS}$

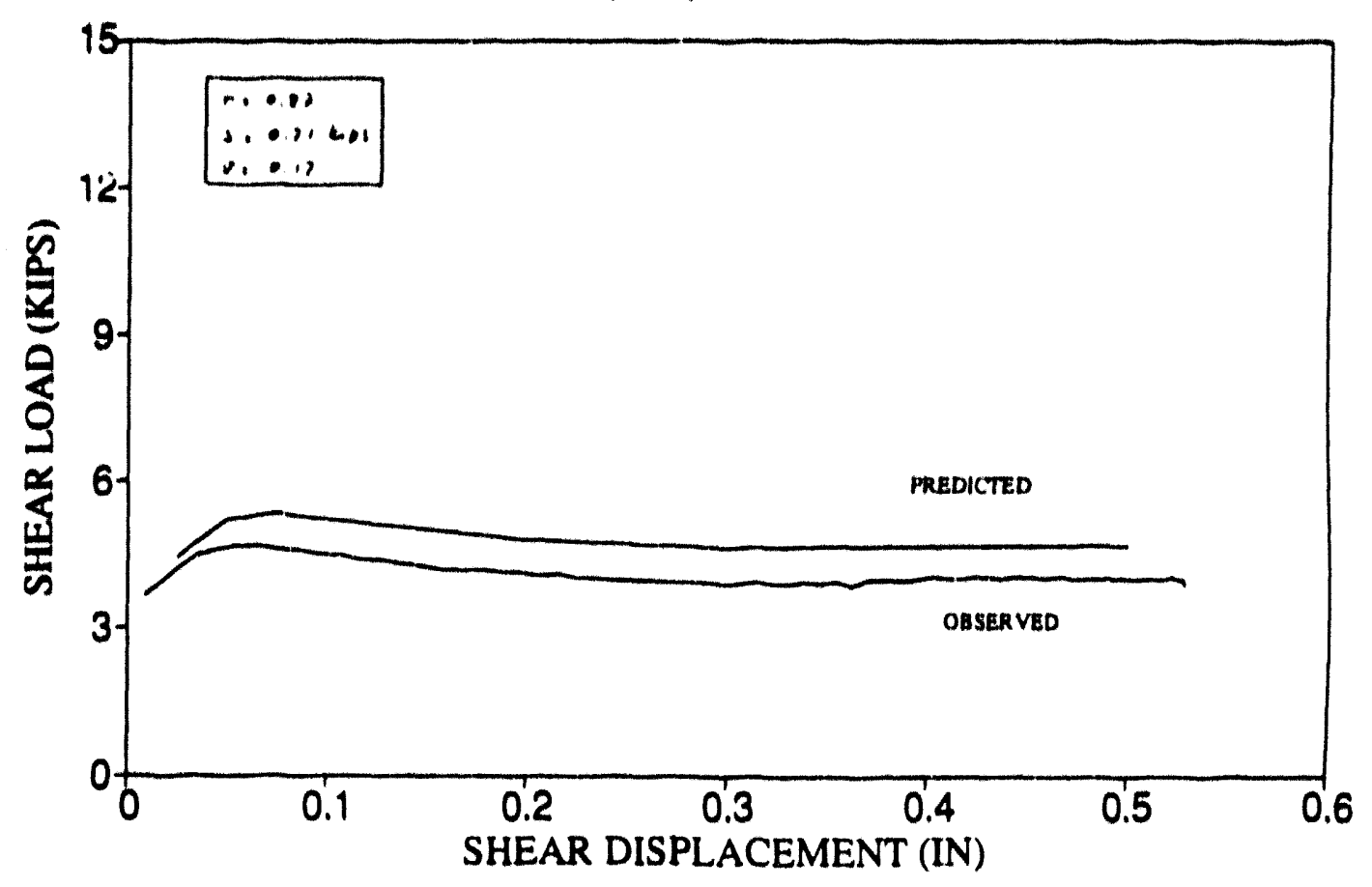




\section{DILATANCY PREDICTION F42F $\mathrm{K}=54.0 \mathrm{KIPS} / \mathrm{IN}$, NORMAL LOAD $=3.6 \mathrm{KIPS}$}

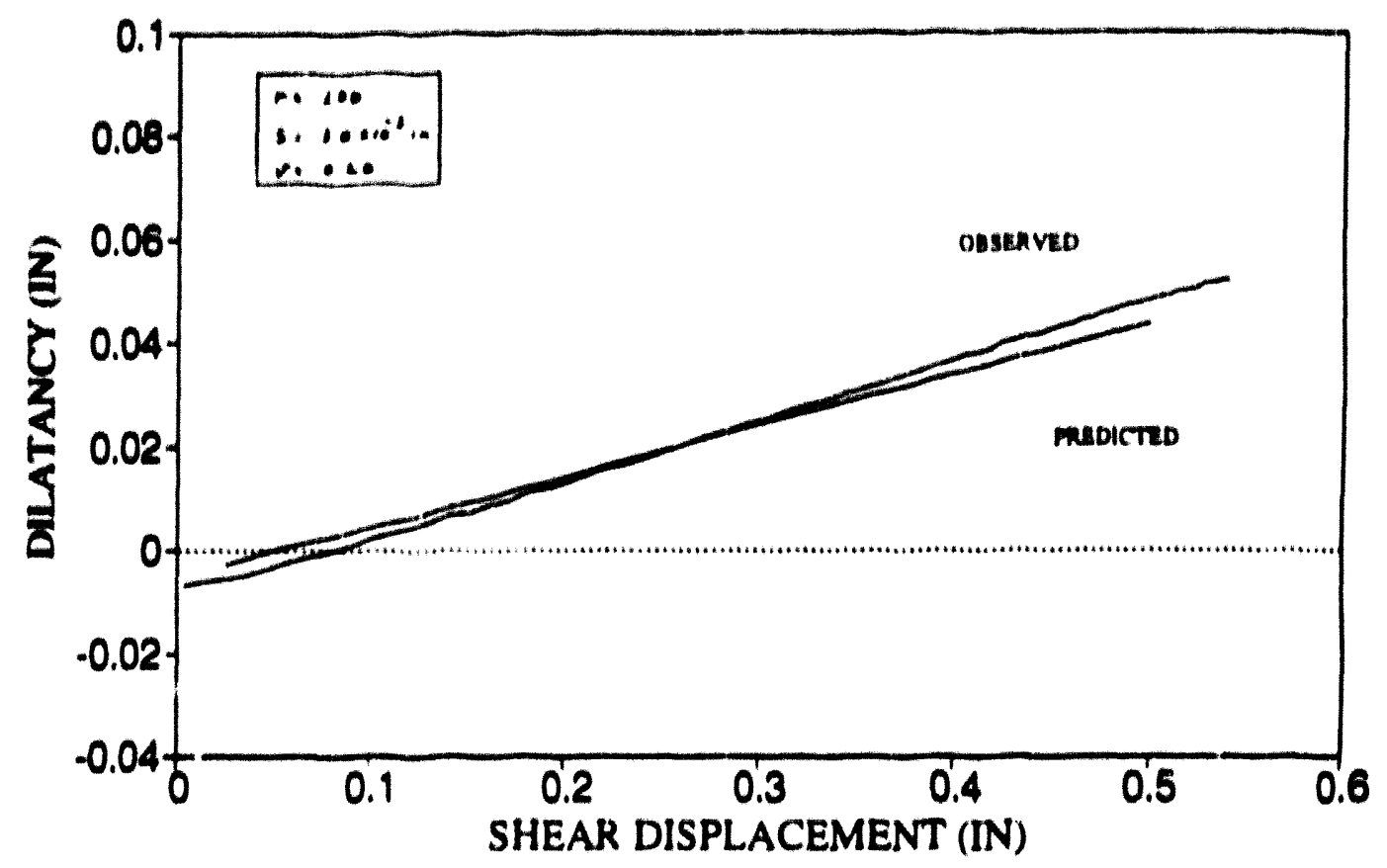

SHEAR LOAD PREDICTION F42F $K=54.0 \mathrm{KIPS} / \mathrm{IN}$, NORMAL LOAD $=3.6 \mathrm{KIPS}$

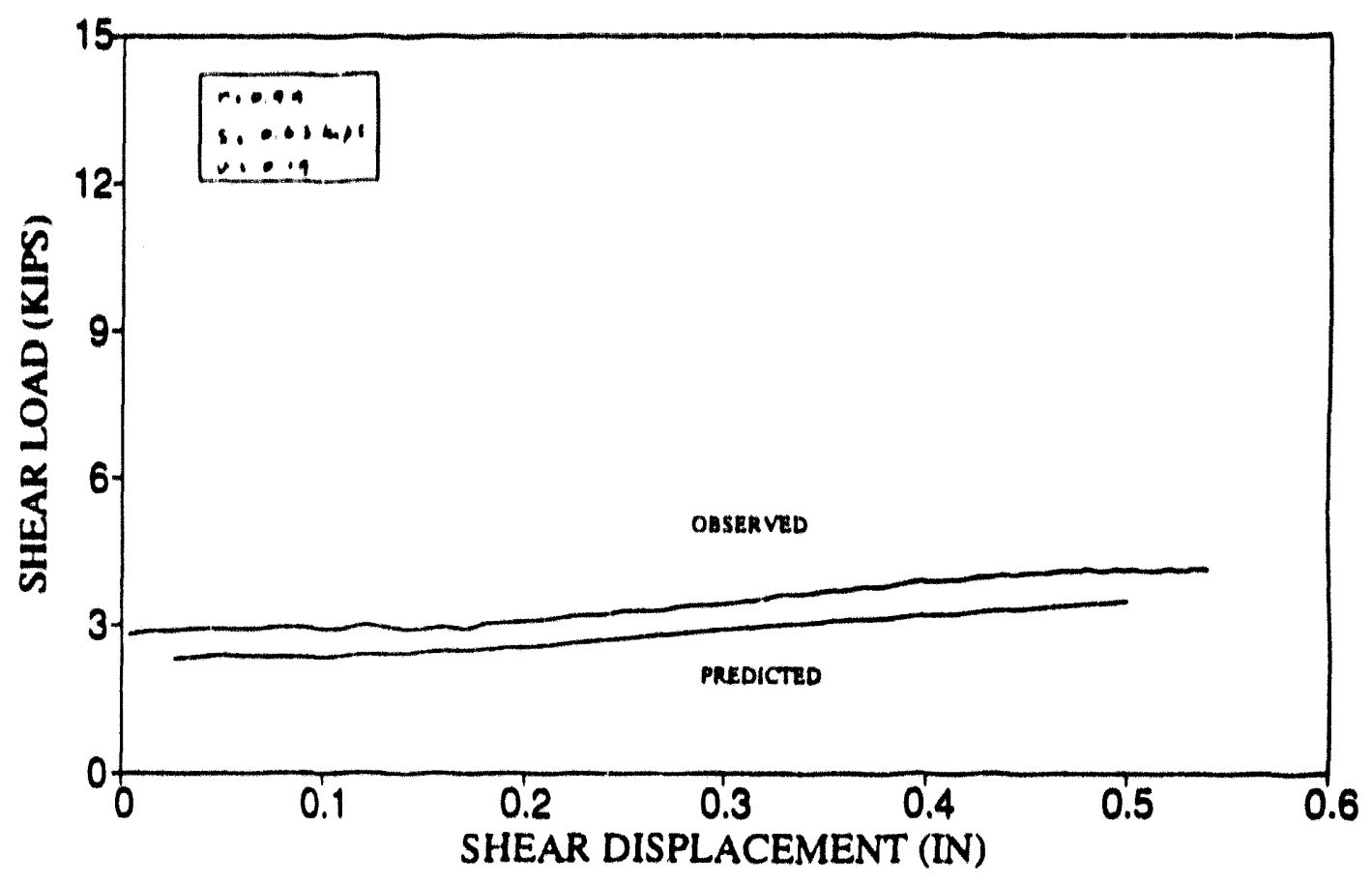



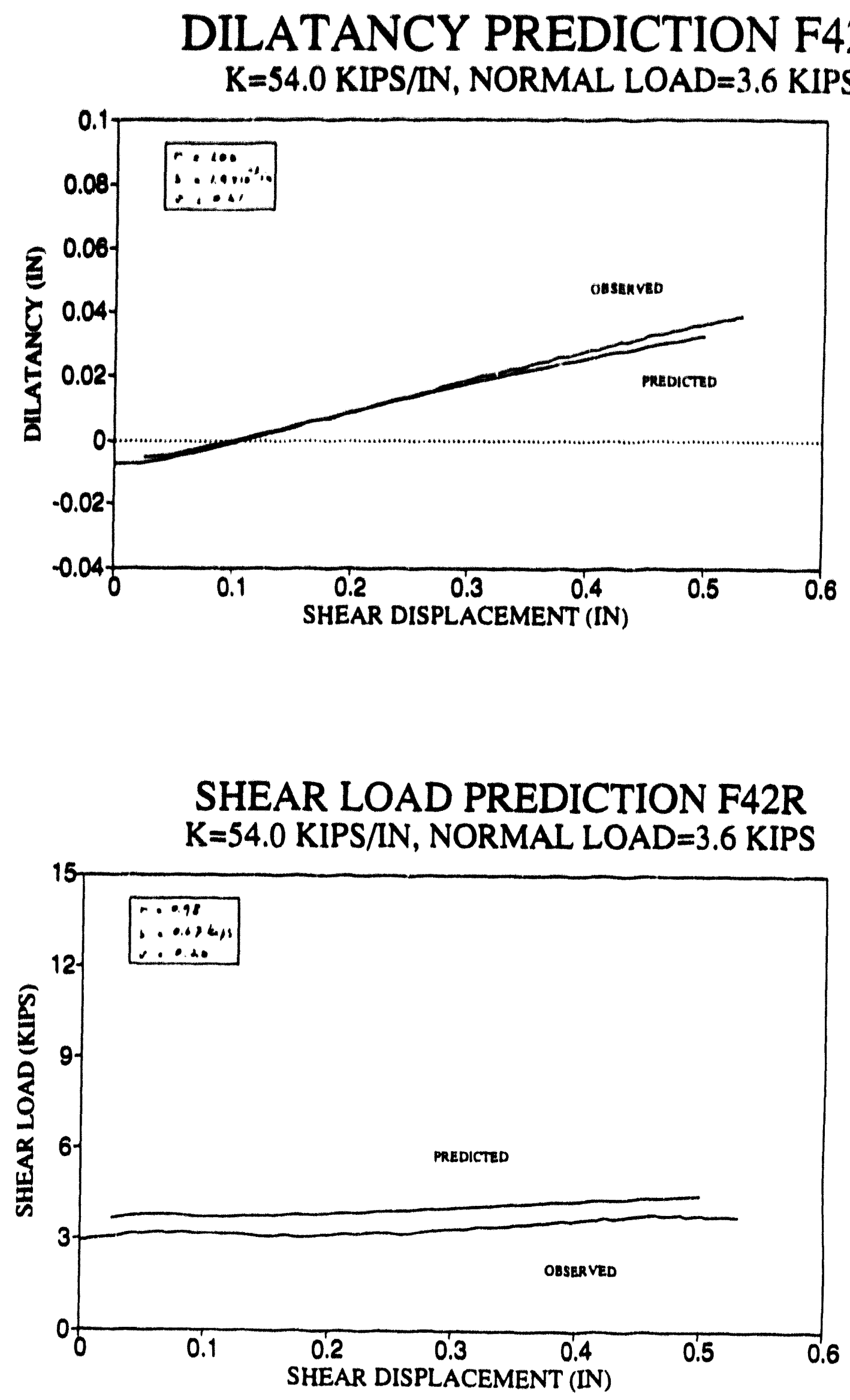

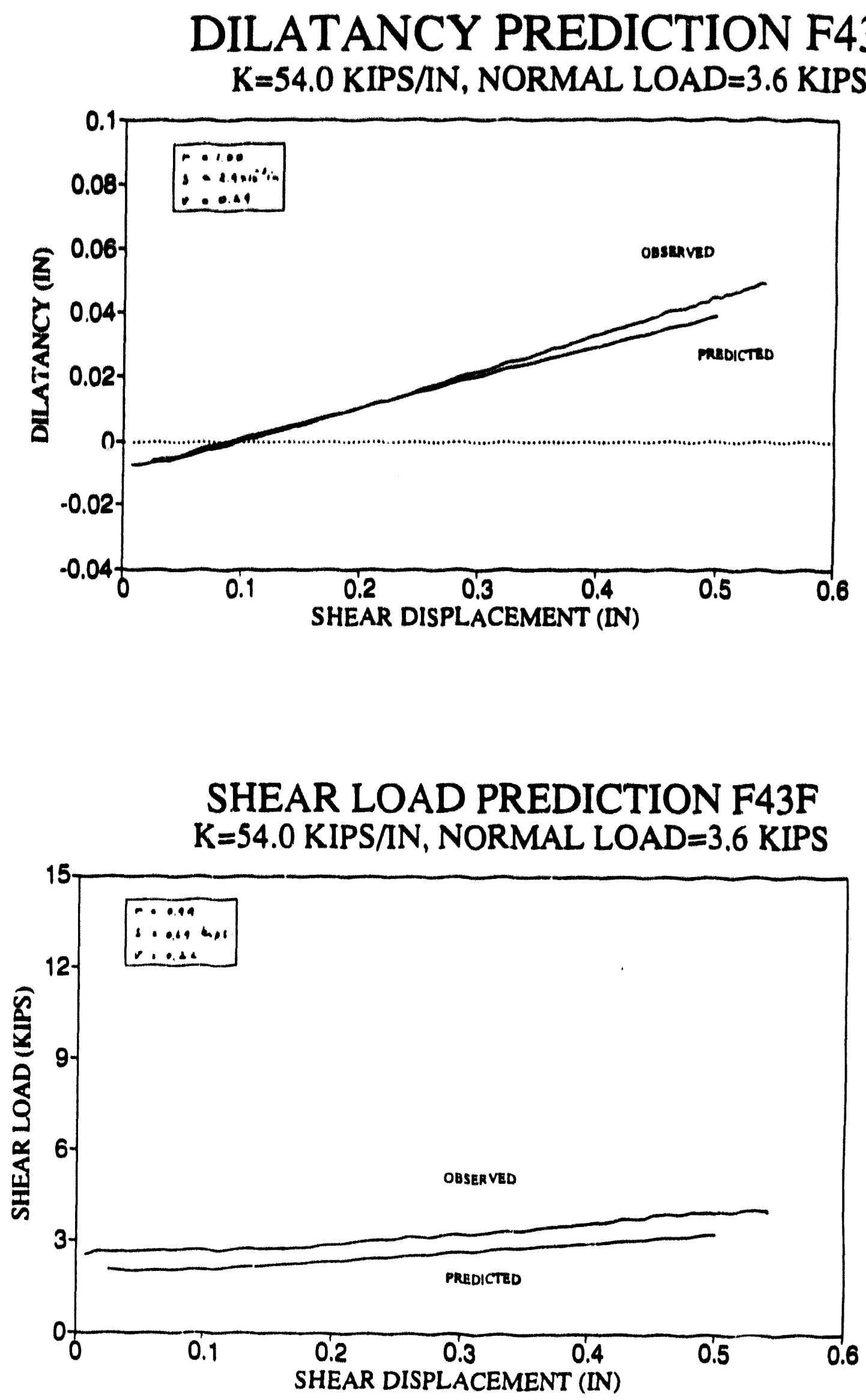

B-15 


\section{DILATANCY PREDICTION F43R $\mathrm{K}=54.0 \mathrm{KIPS} / \mathrm{IN}$, NORMAL LOAD=3.6 KIPS}

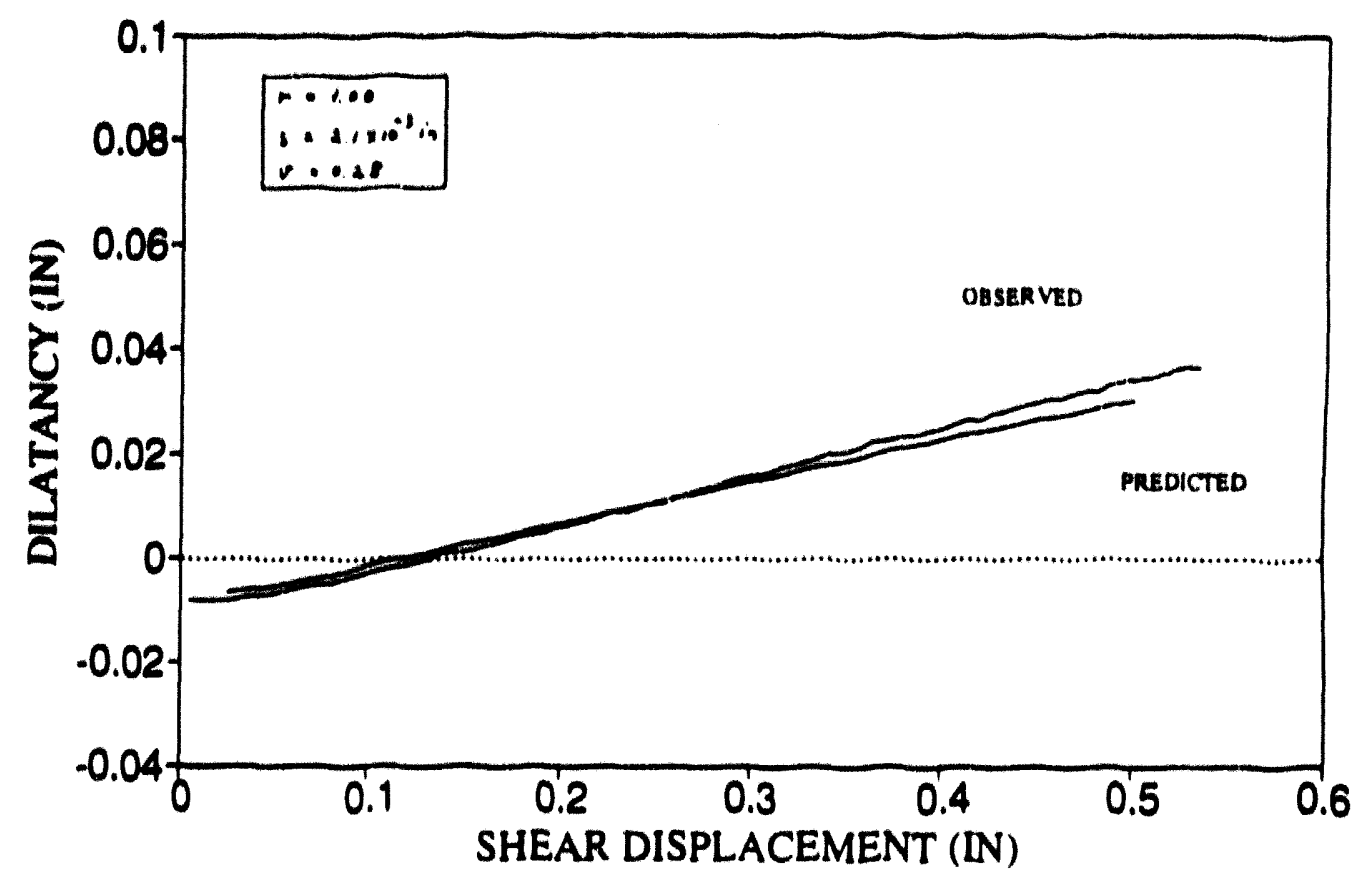

SHEAR LOAD PREDICTION F43R $\mathrm{K}=54.0 \mathrm{KIPS} / \mathrm{IN}$, NORMAL LOAD $=3.6 \mathrm{KIPS}$

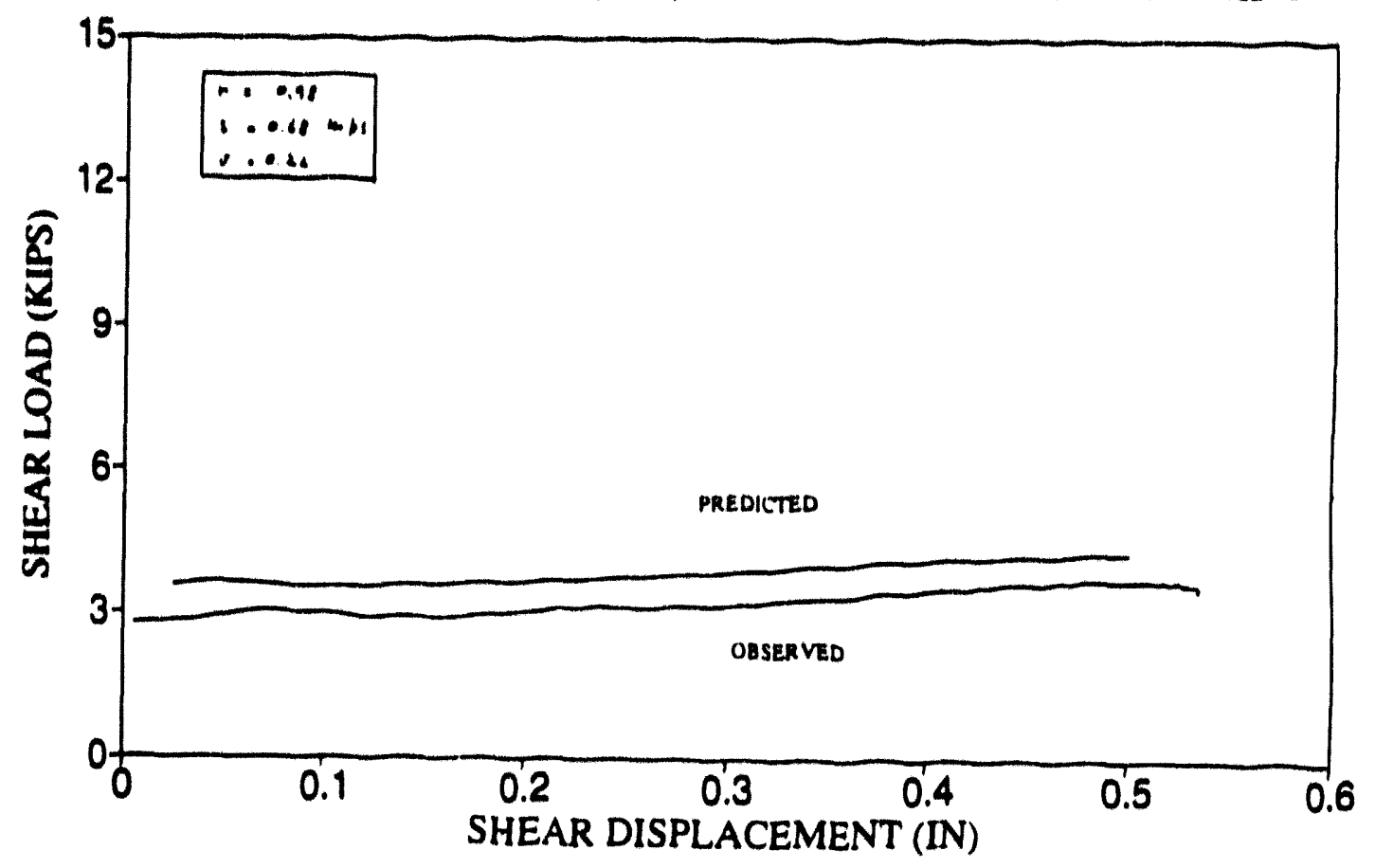



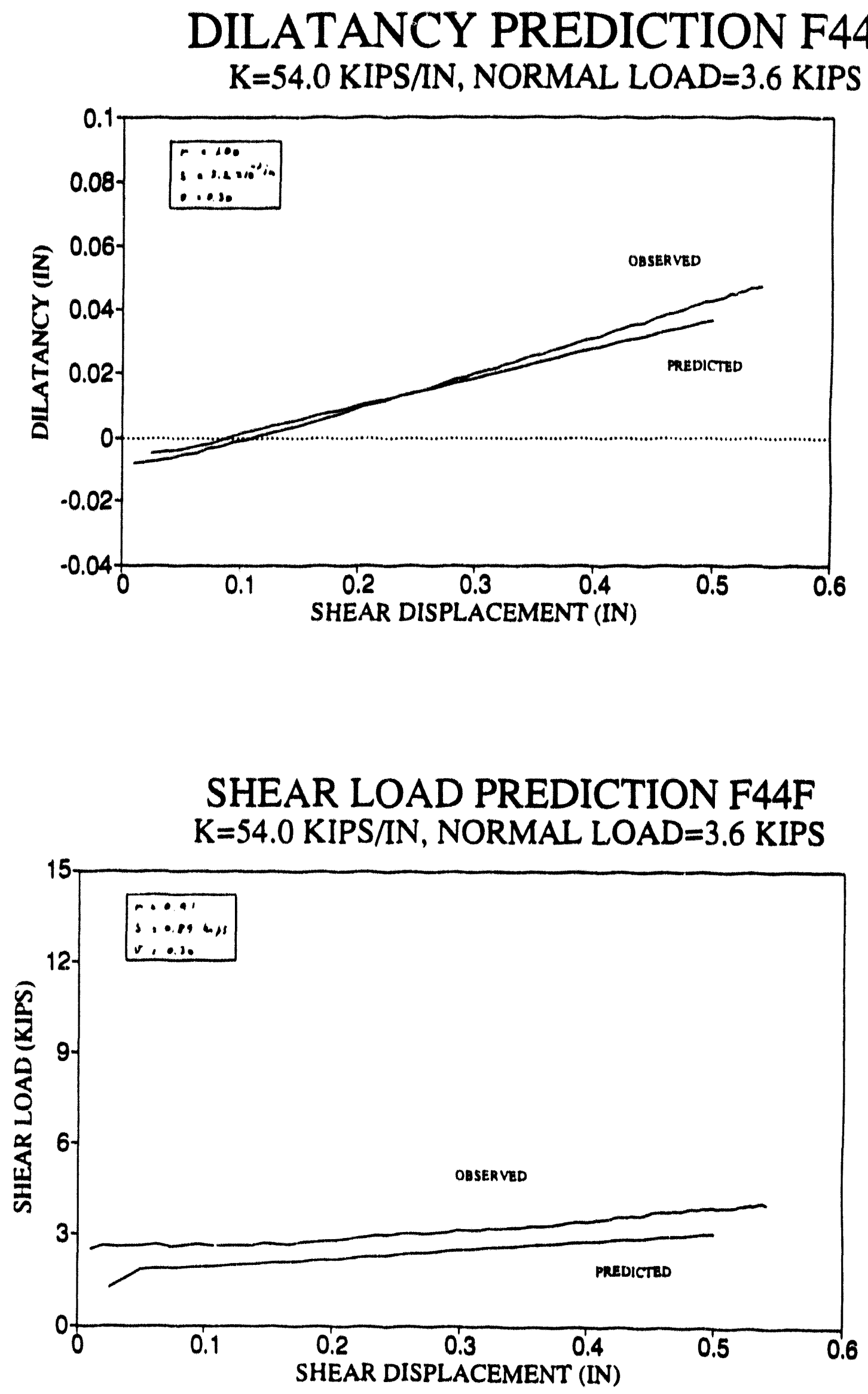
DILATANCY PREDICTION F44R $\mathrm{K}=54.0 \mathrm{KIPS} / \mathrm{IN}$, NORMAL LOAD=3.6 KIPS

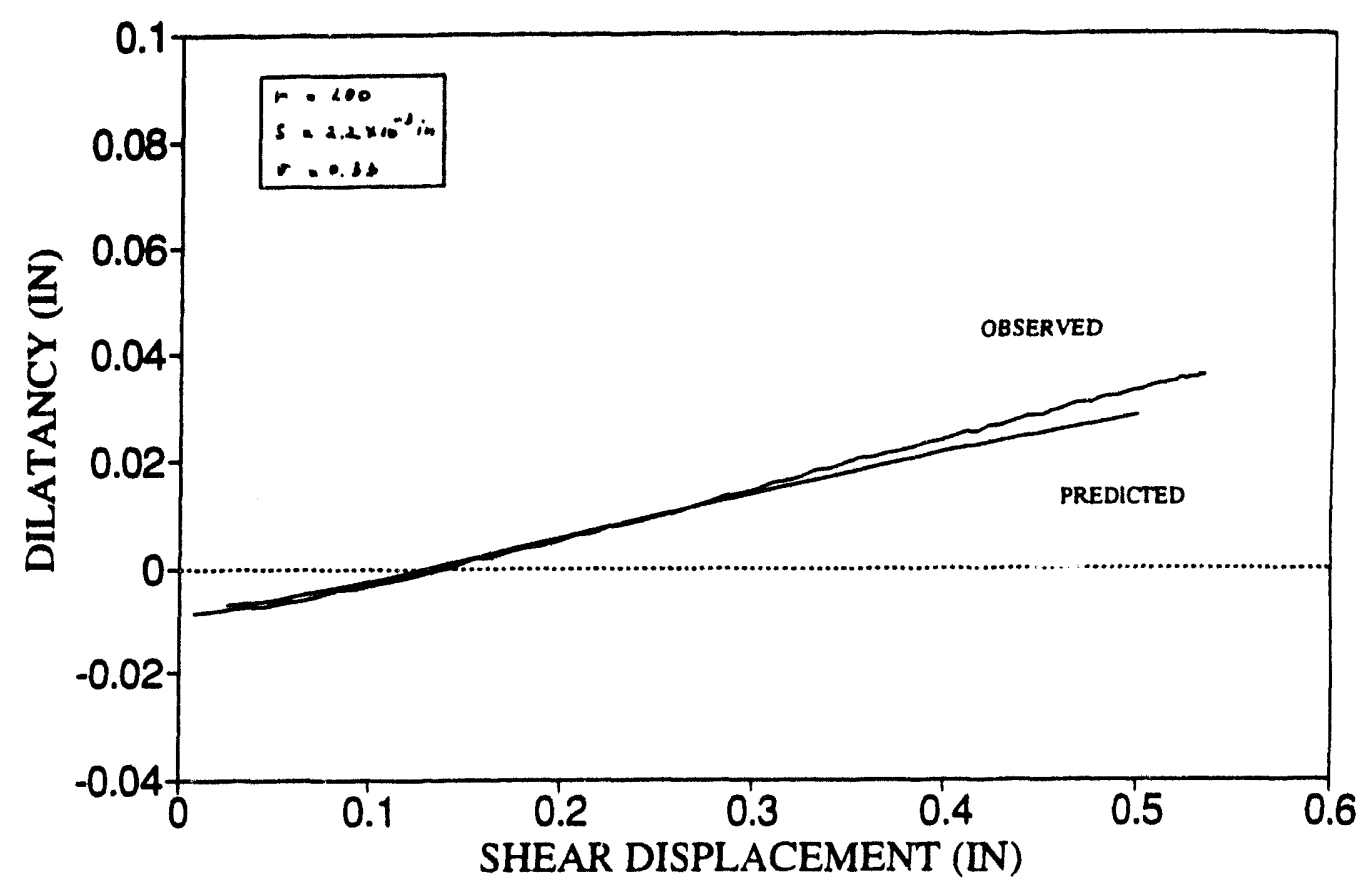

SHEAR LOAD PREDICTION F44R $\mathrm{K}=54.0 \mathrm{KIPS} / \mathrm{IN}$, NORMAL LOAD=3.6 KIPS

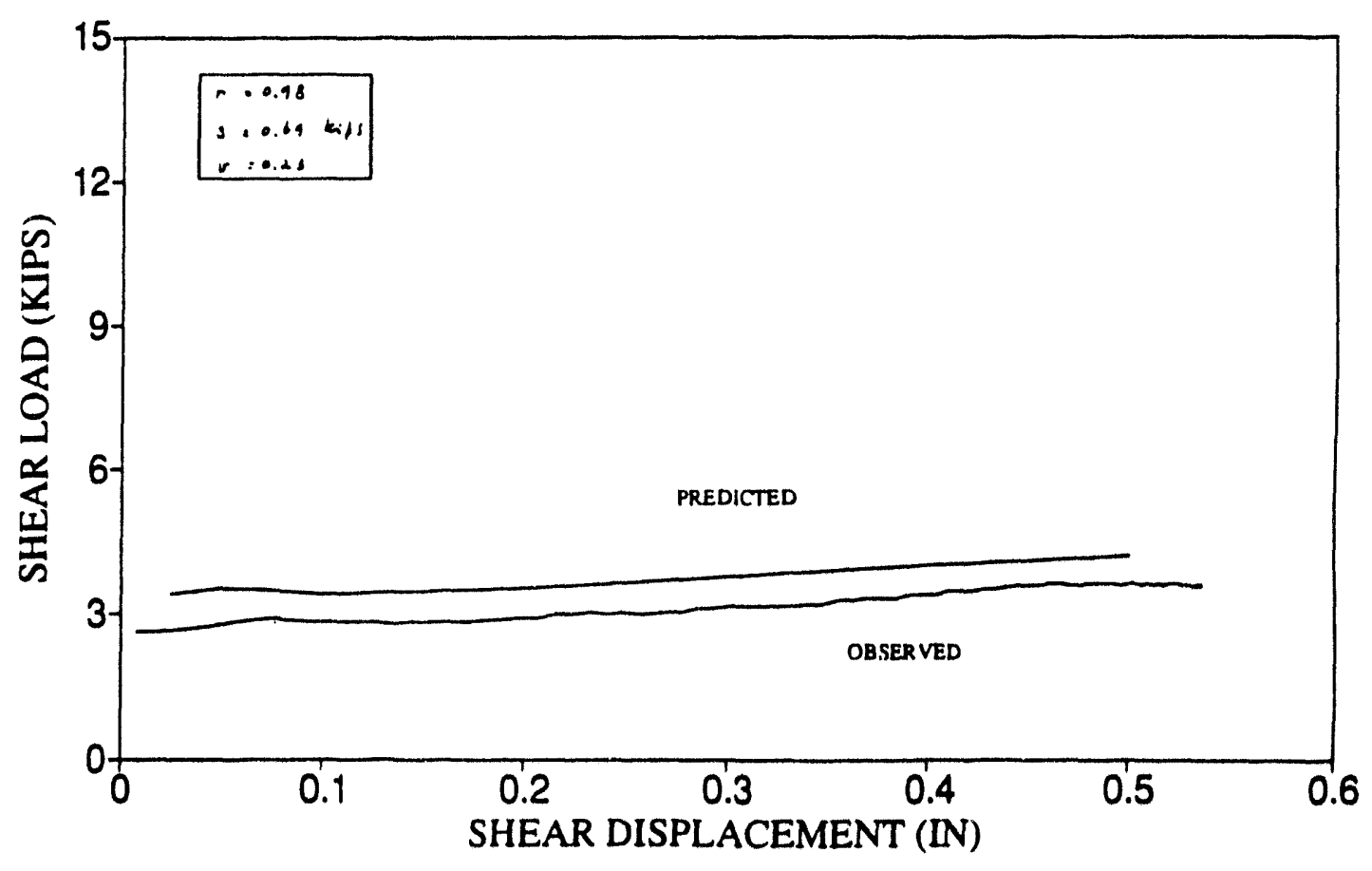


DILATANCY PREDICTION F45F $\mathrm{K}=54.0 \mathrm{KIPS} / \mathrm{IN}$, NORMAL LOAD=3.6 KIPS

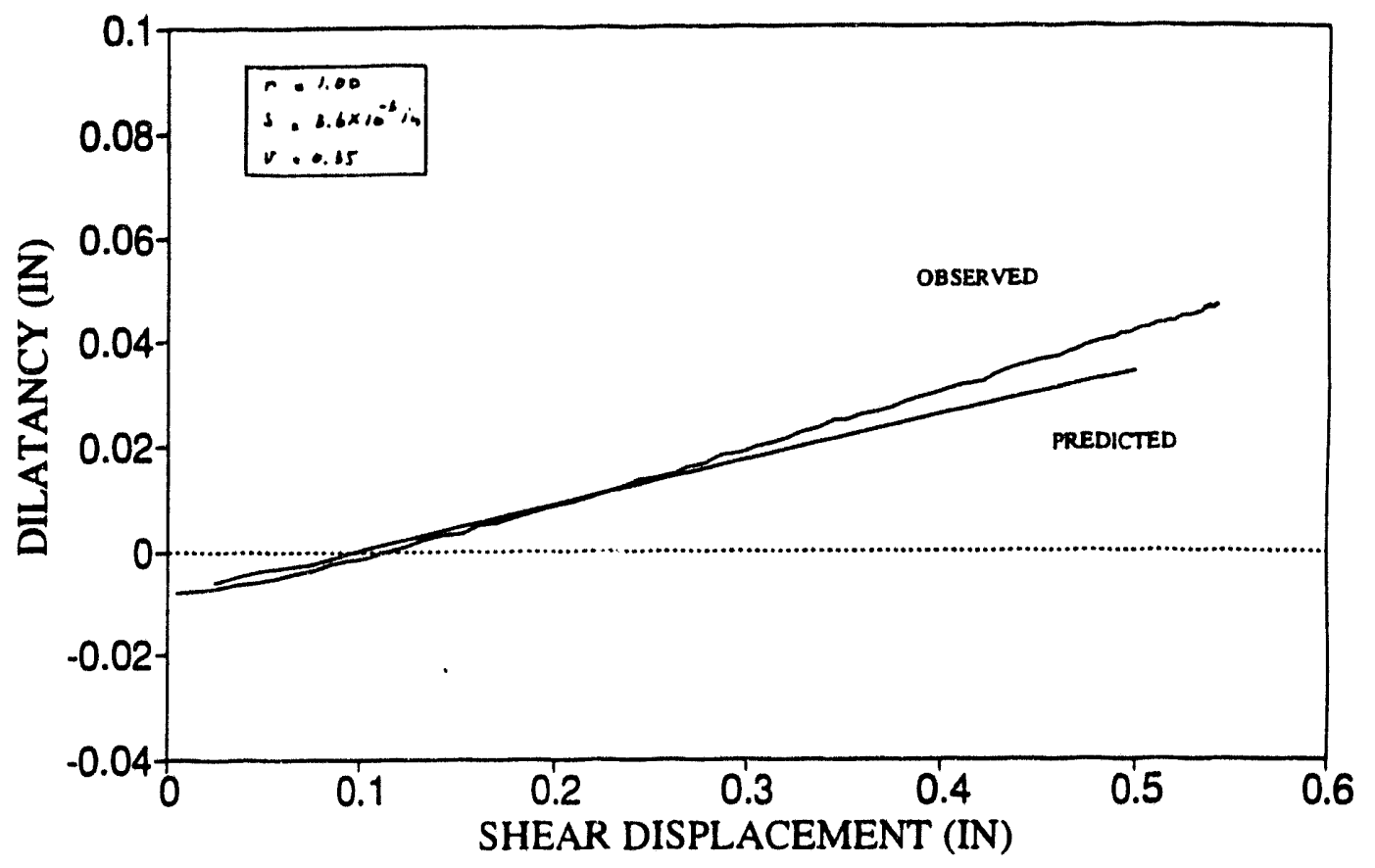

SHEAR LOAD PREDICTION F45F $\mathrm{K}=54.0 \mathrm{KIPS} / \mathrm{IN}$, NORMAL LOAD=3.6 KIPS

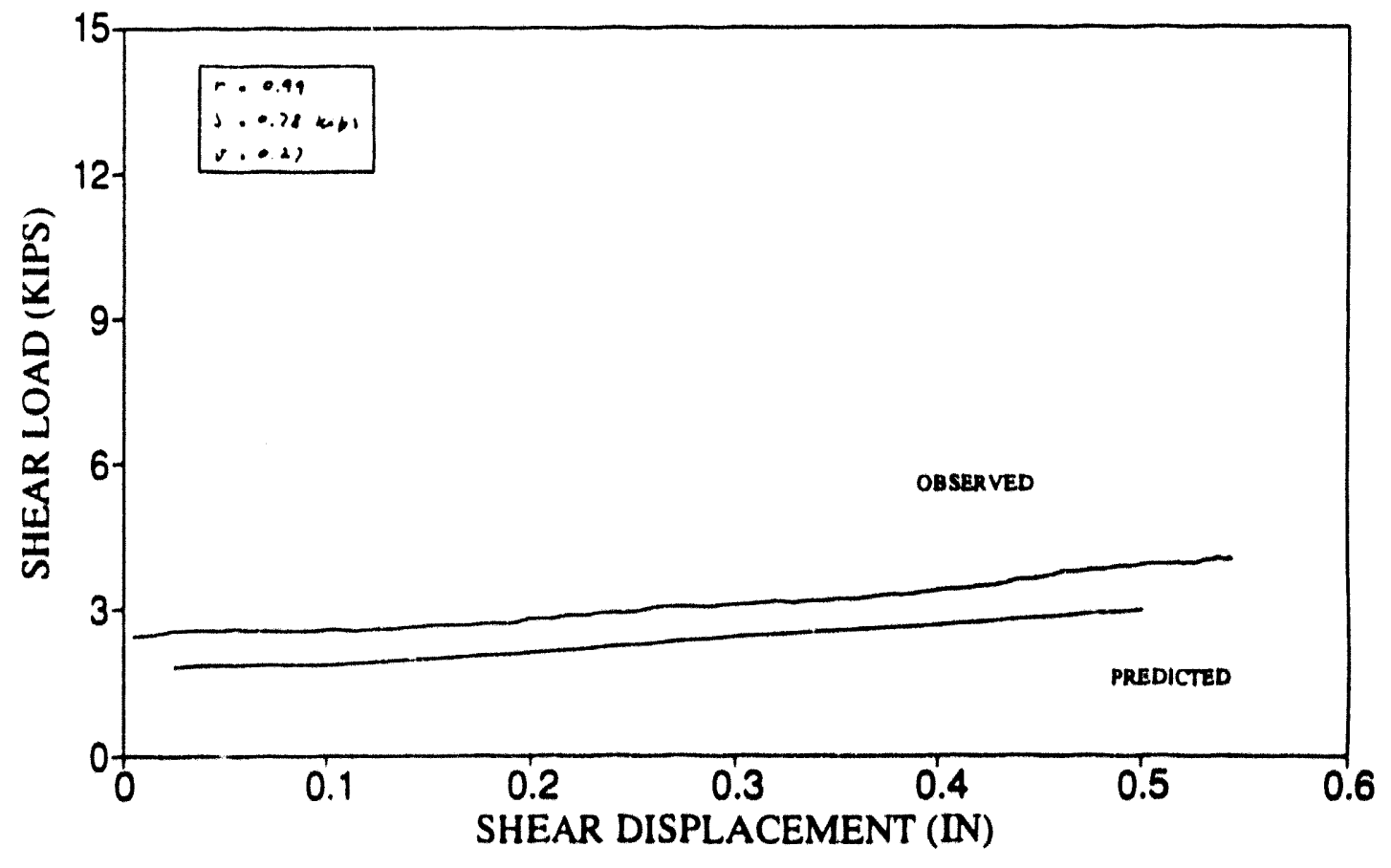



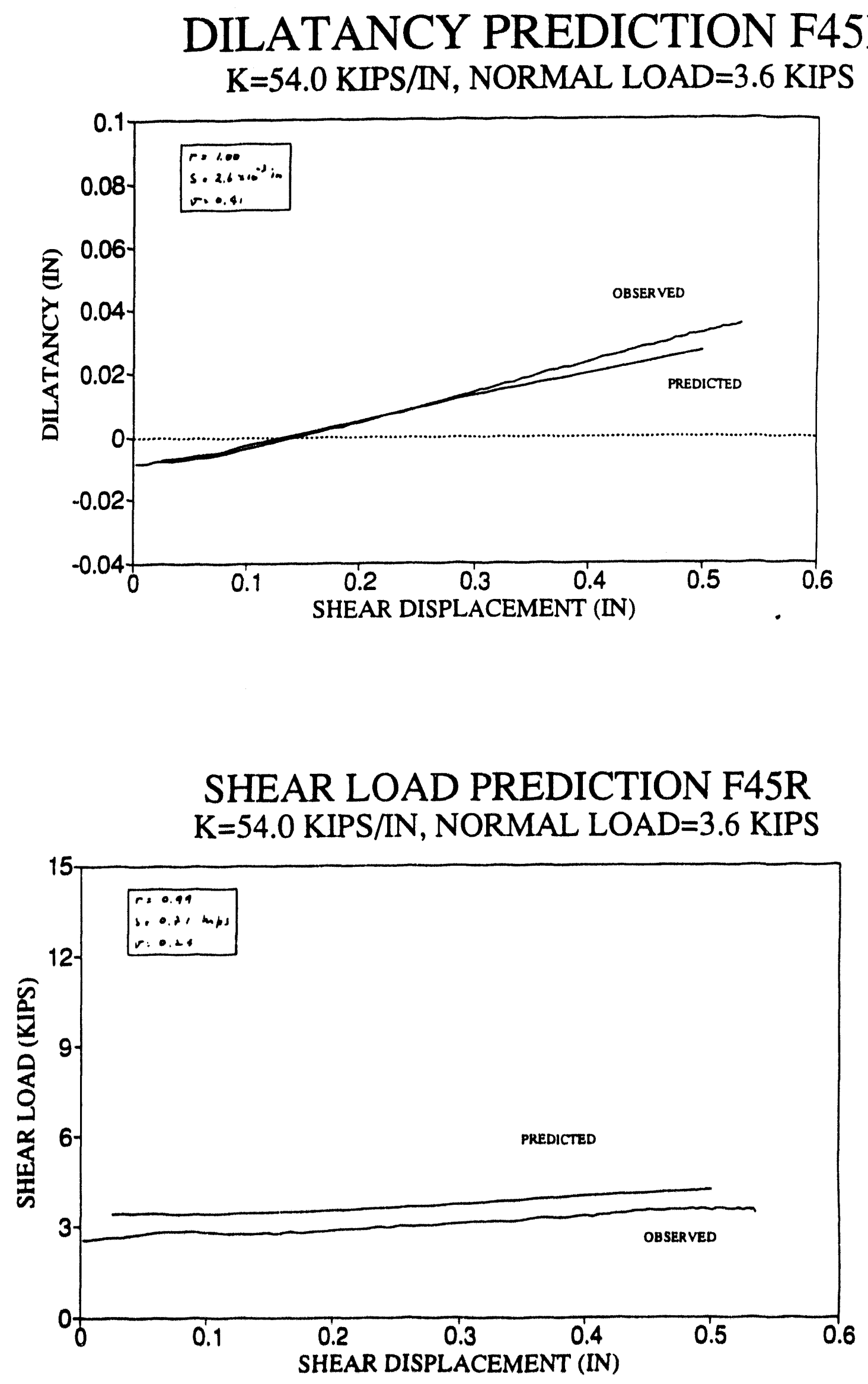


\section{DILATANCY PREDICTION F41F $\mathrm{K}=179.9 \mathrm{KIPS} / \mathrm{IN}$, NORMAL LOAD=3.6 KIPS}

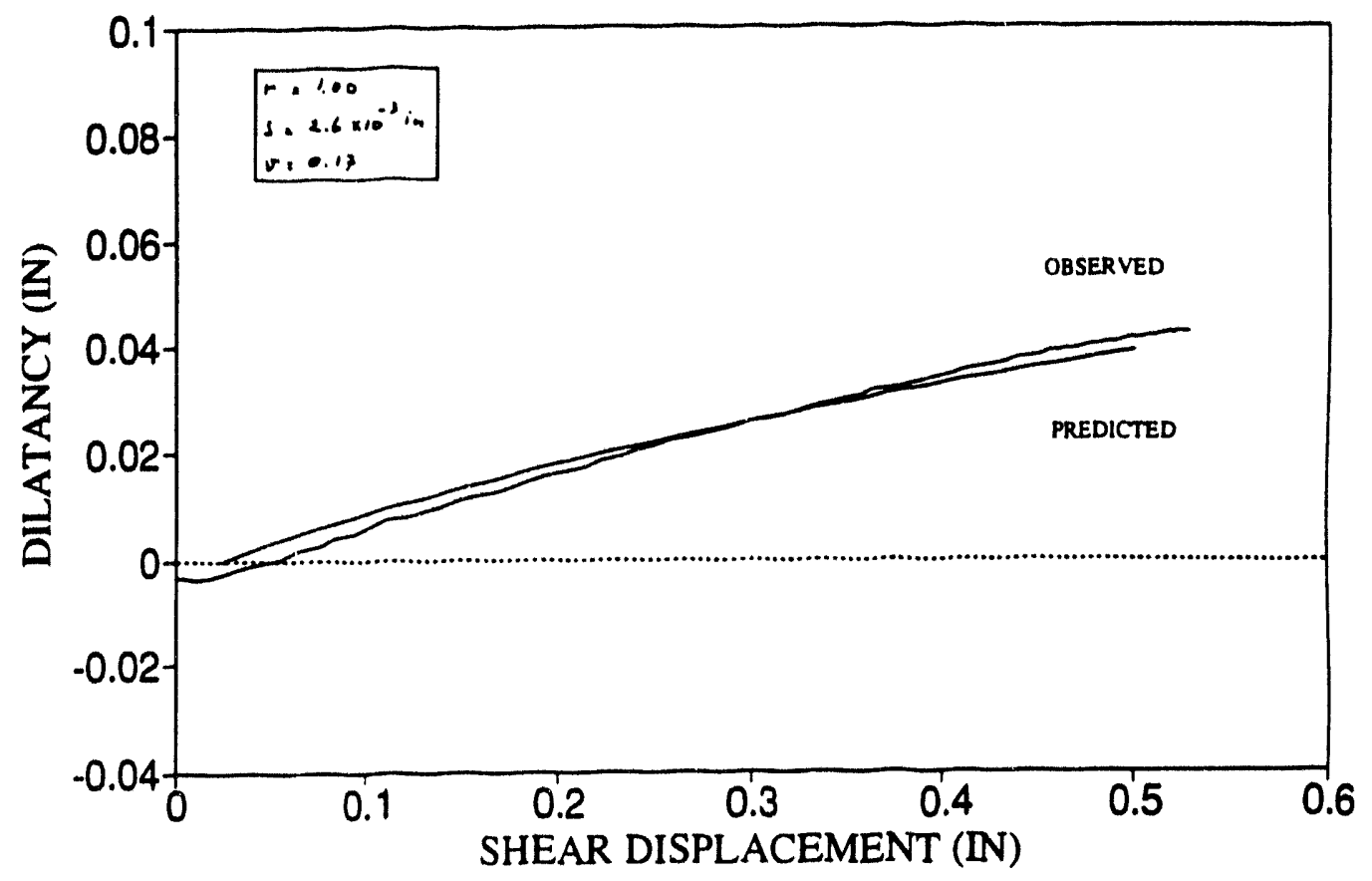

SHEAR LOAD PREDICTION F41F $\mathrm{K}=179.9 \mathrm{KIPS} / \mathrm{IN}$, NORMAL LOAD=3.6 KIPS

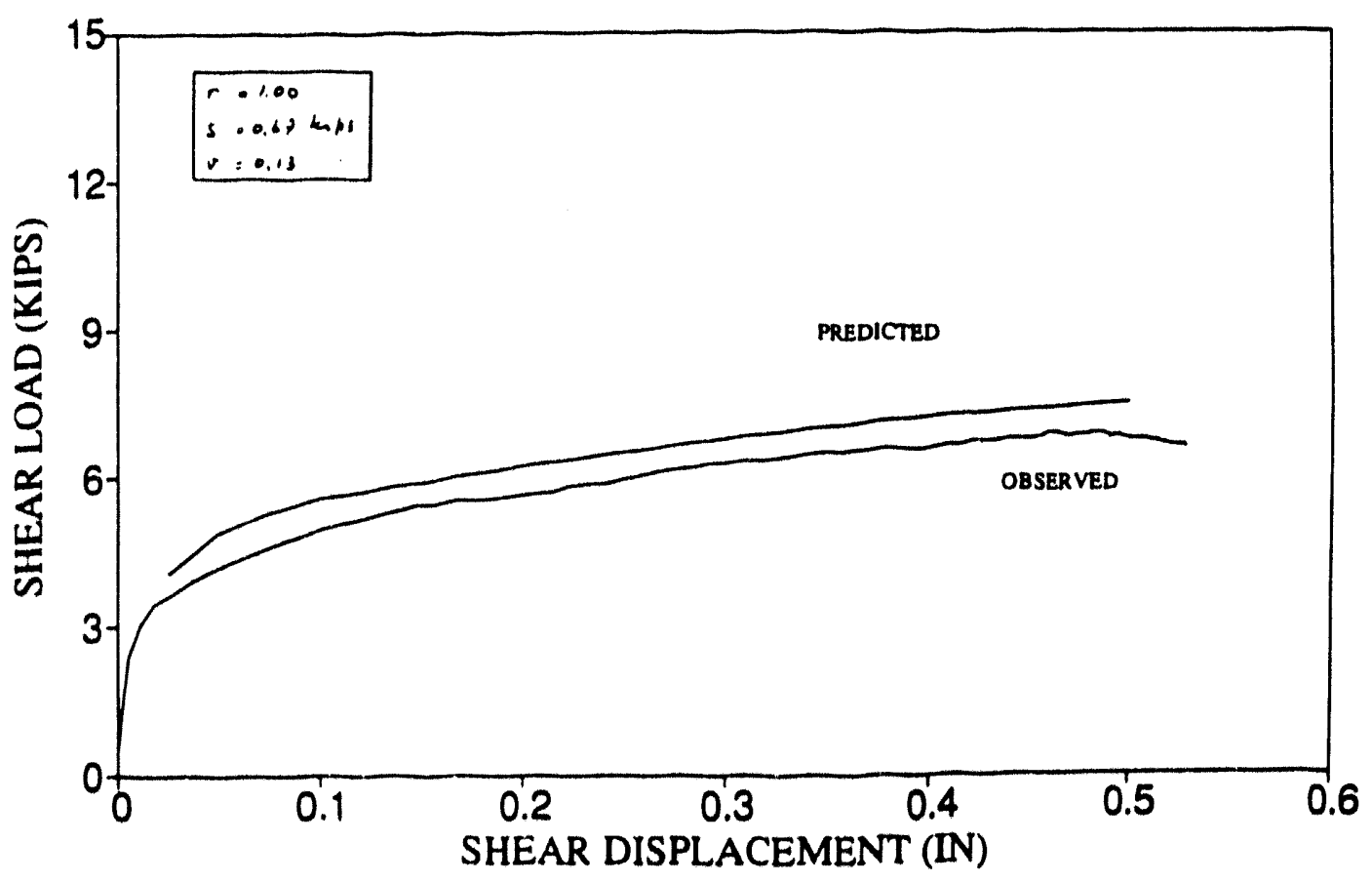


DILATANCY PREDICTION F41R $\mathrm{K}=179.9 \mathrm{KIPS} / \mathrm{IN}$, NORMAL LOAD=3.6 KIPS
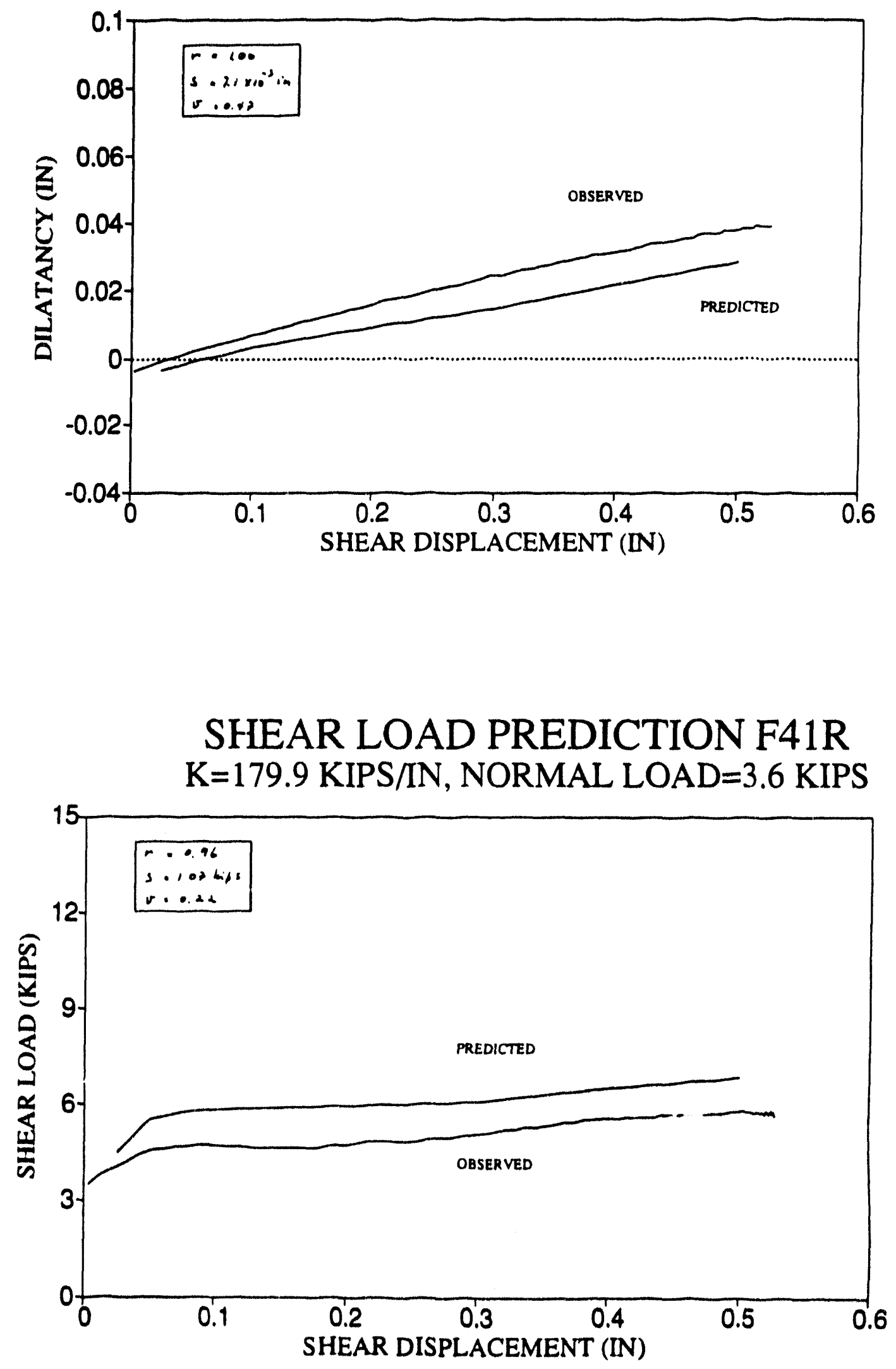

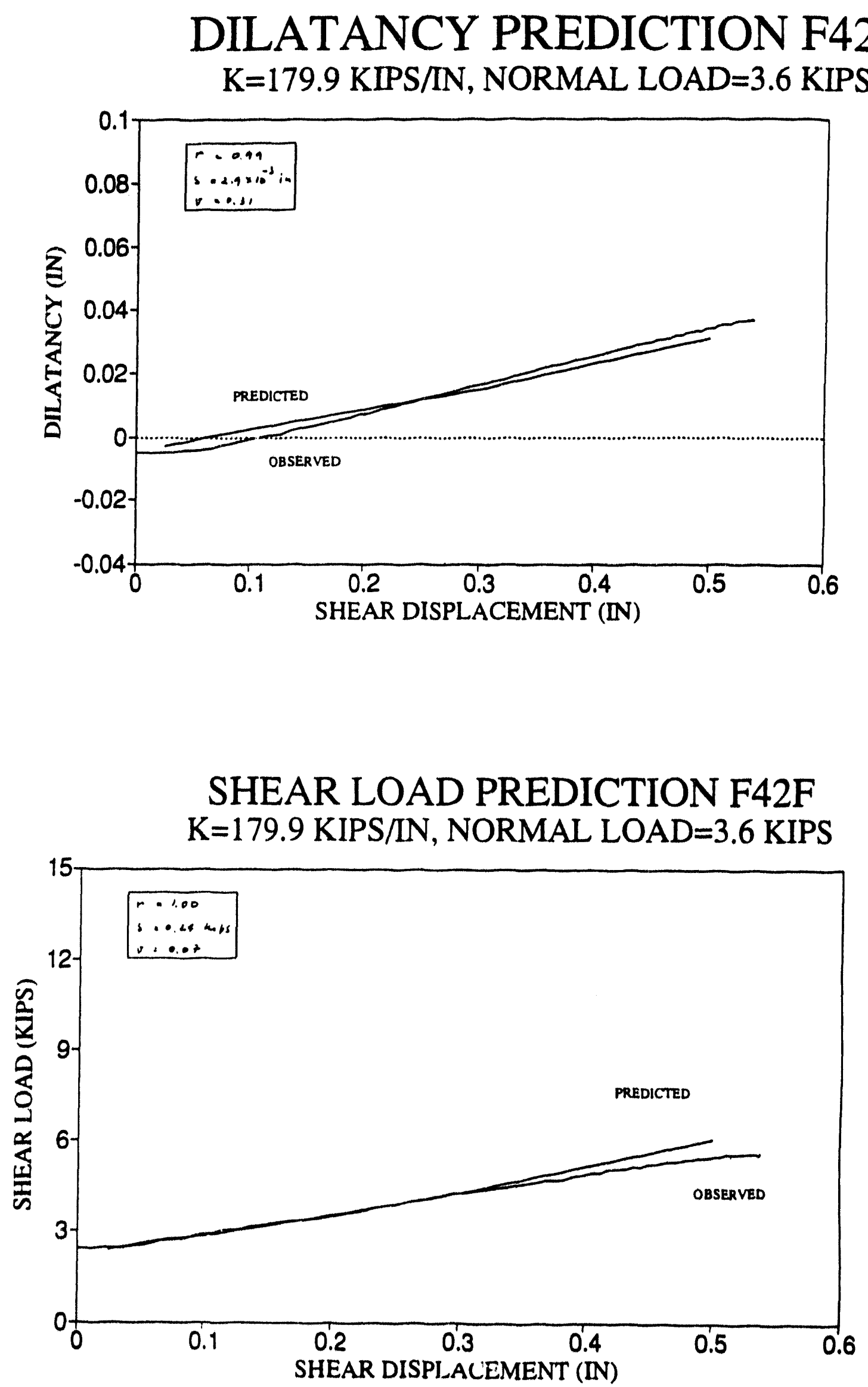

B -23 

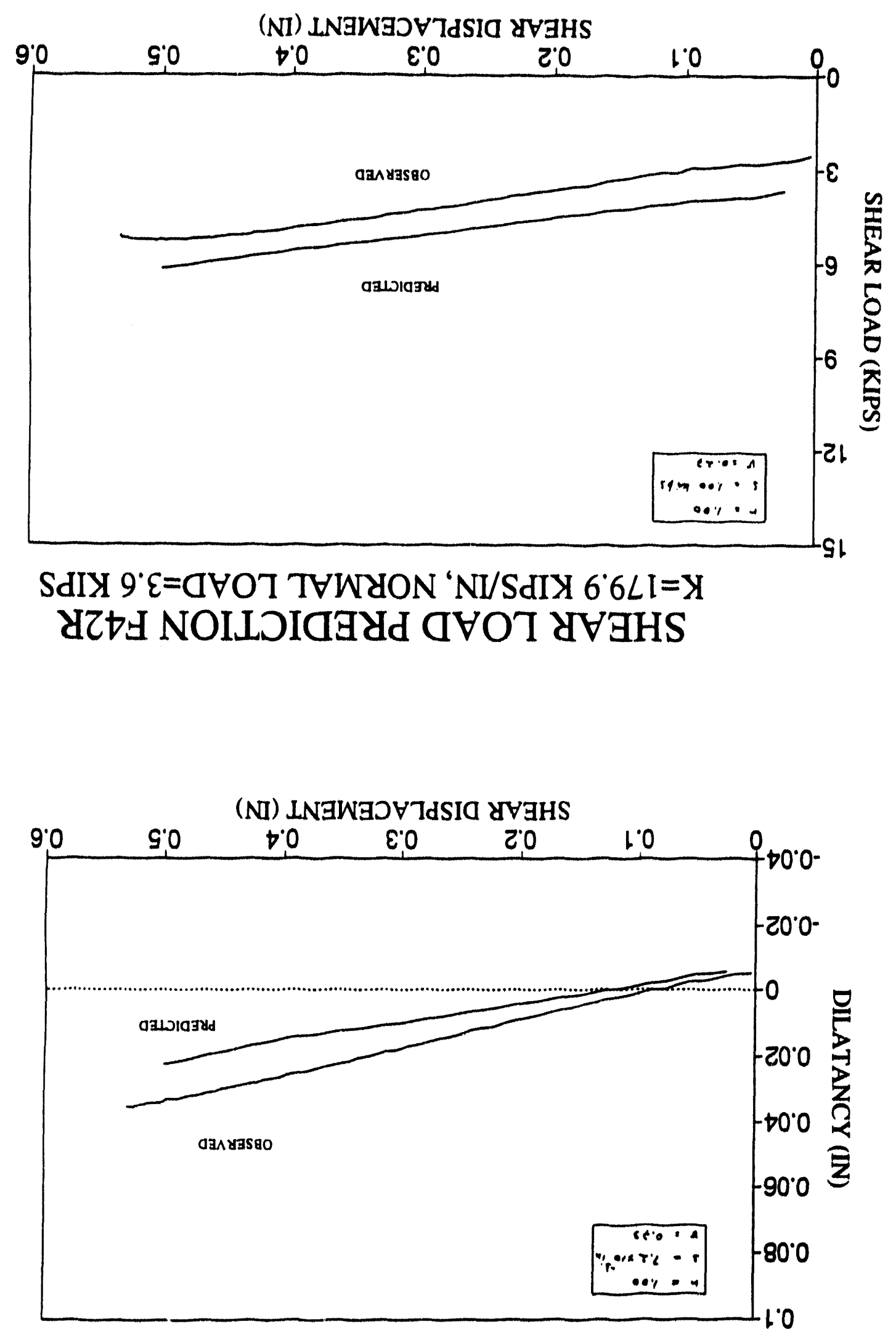

SdIY $9^{\circ} \varepsilon={ }^{\circ}$ THOT THWYON 'NI/SdIX $66^{\circ} 6 \mathrm{LI}=\mathrm{X}$ ¿2tA NOILOIG 

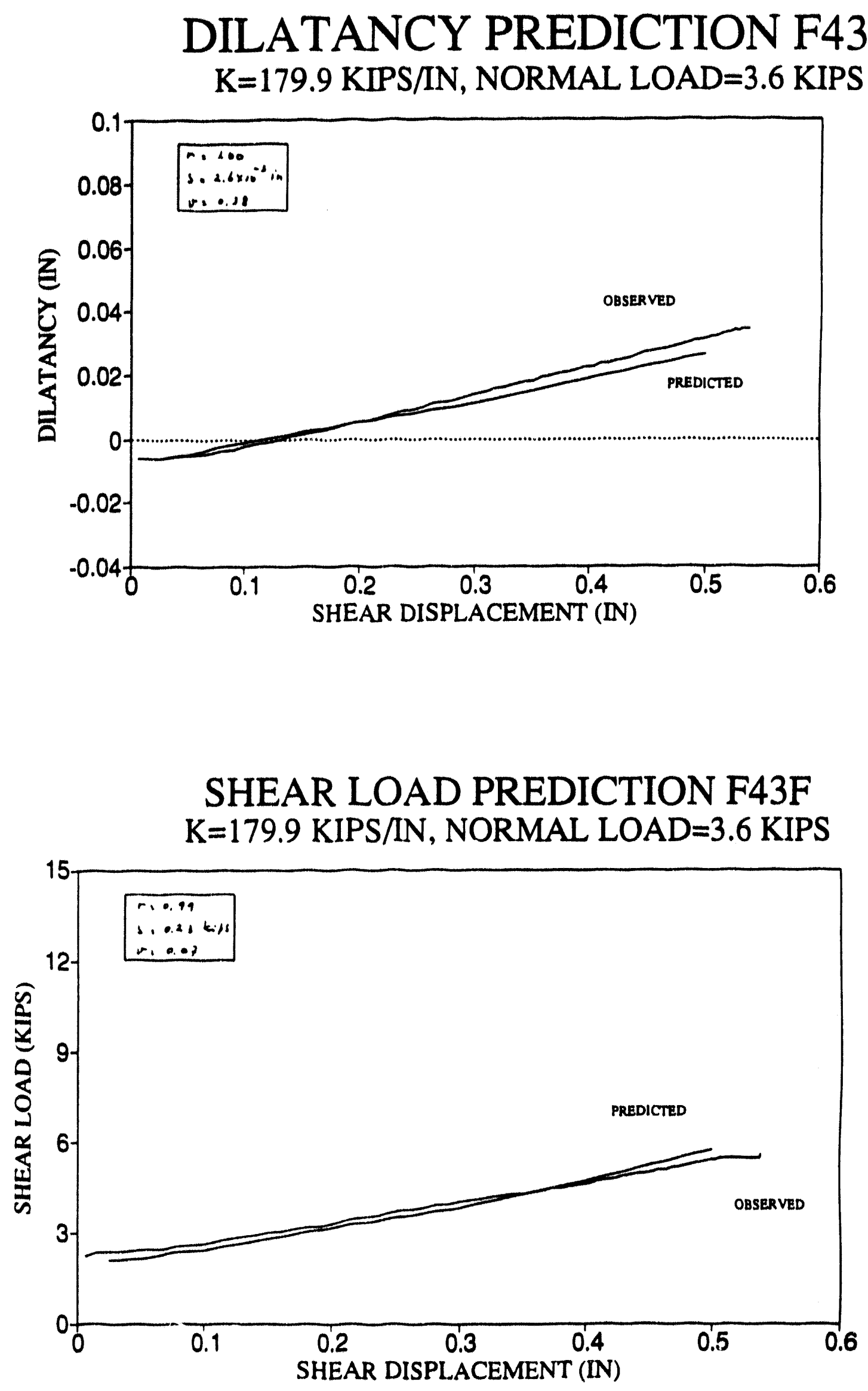

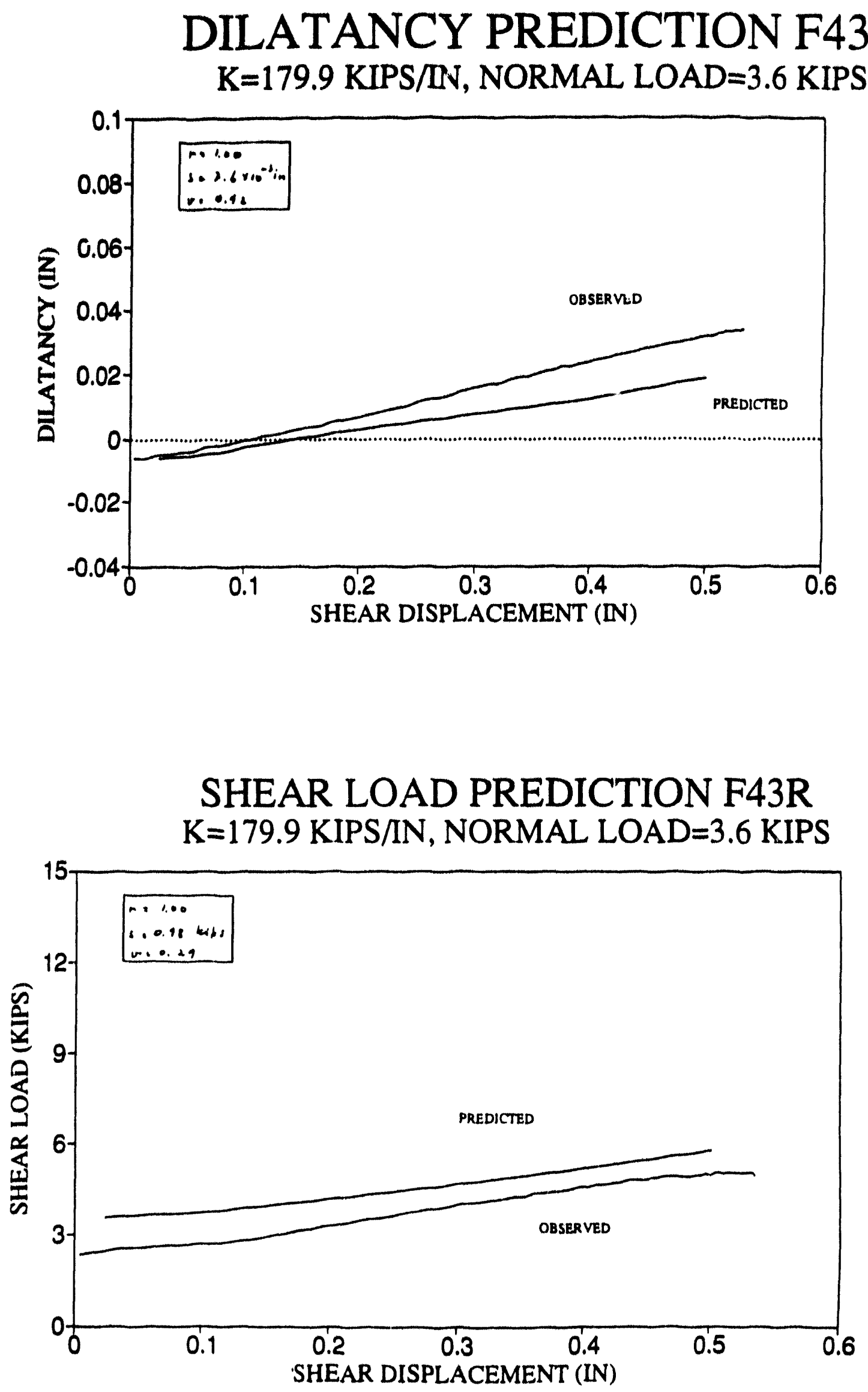

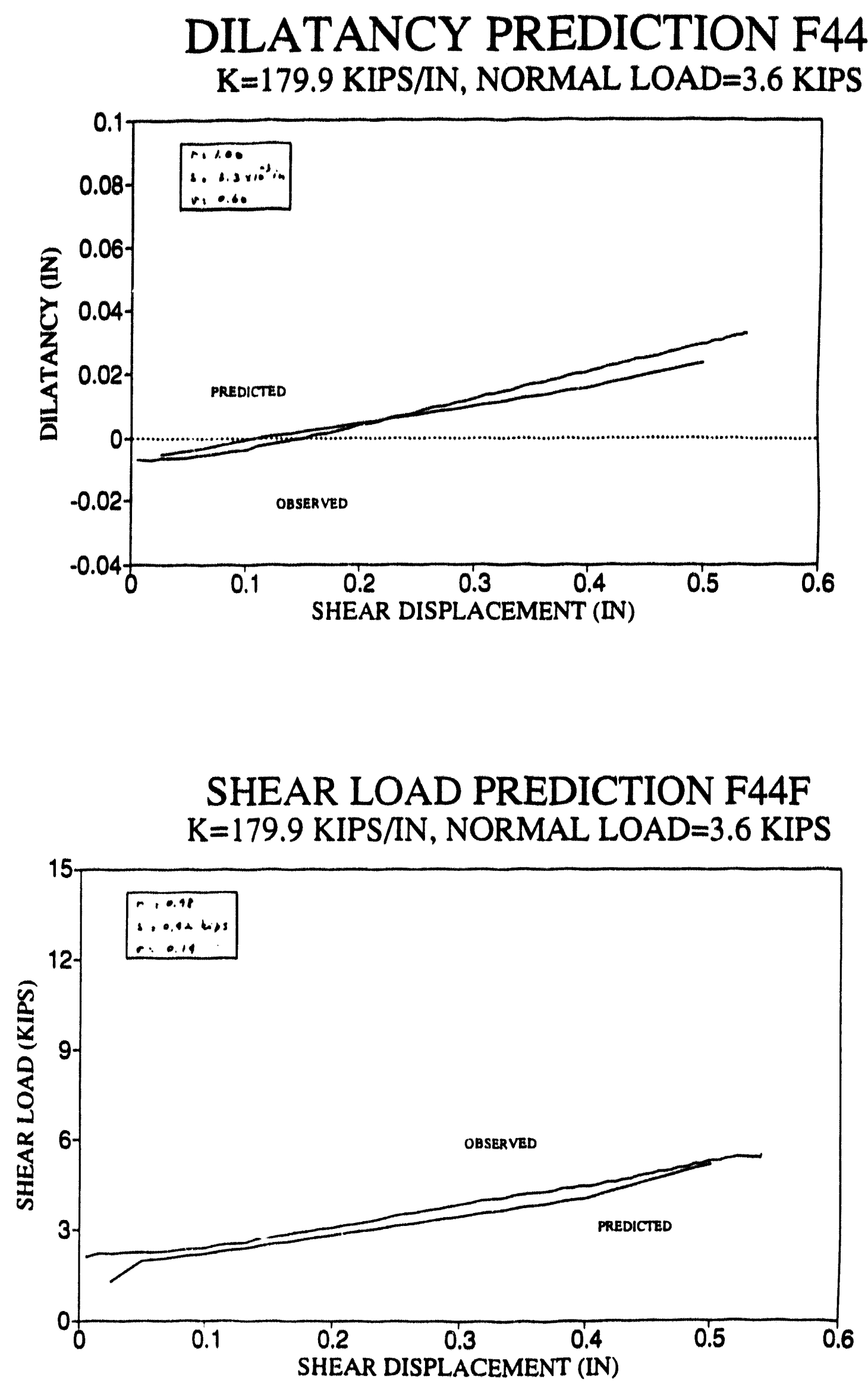


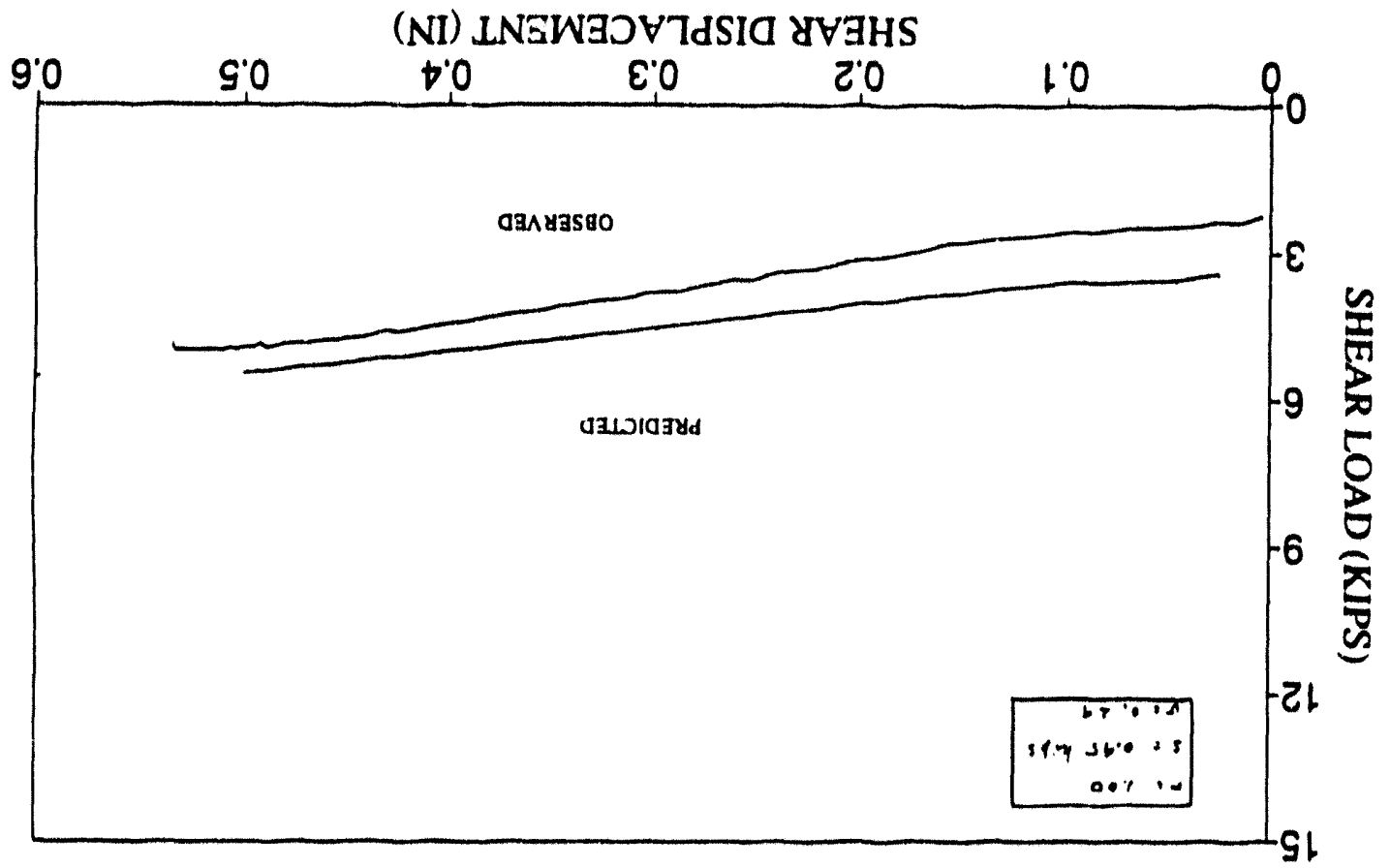

SdIY 9. $\varepsilon=$ व $\forall O T$ THWYON 'NI/SdIX 6.6LI=X

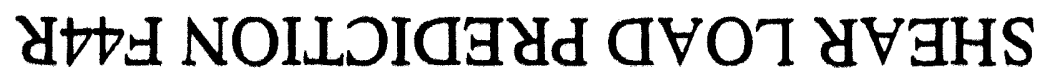

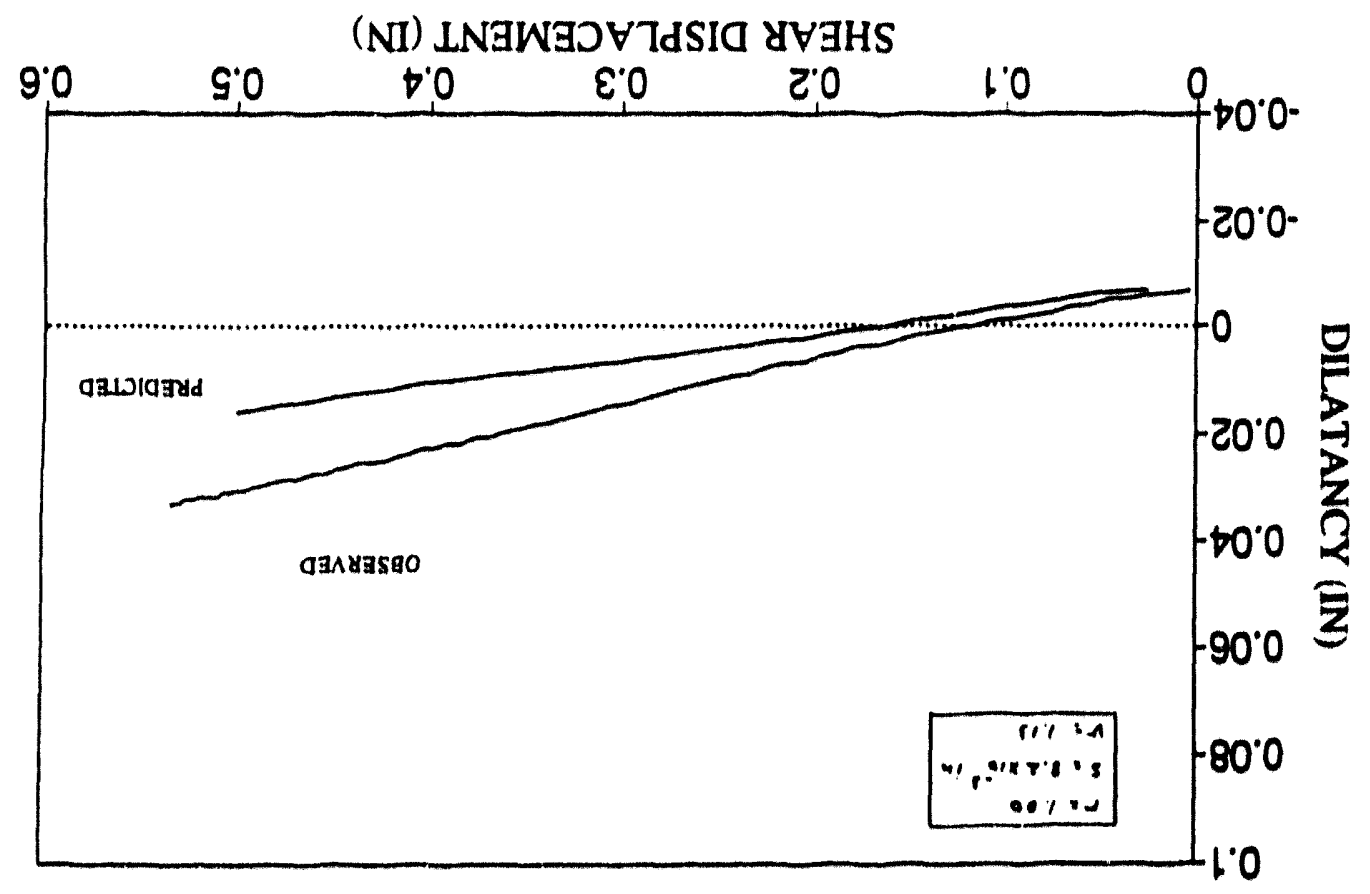

SdIX $9^{\circ} \varepsilon=$ वVOT TVWYON 'NI/SdIX $6^{\circ} 6 \mathrm{LI}=\mathrm{X}$ ¿†tA NOILOIG 


\section{DILATANCY PREDICTION F45F $\mathrm{K}=179.9 \mathrm{KIPS} / \mathrm{IN}$, NORMAL LOAD=3.6 KIPS}

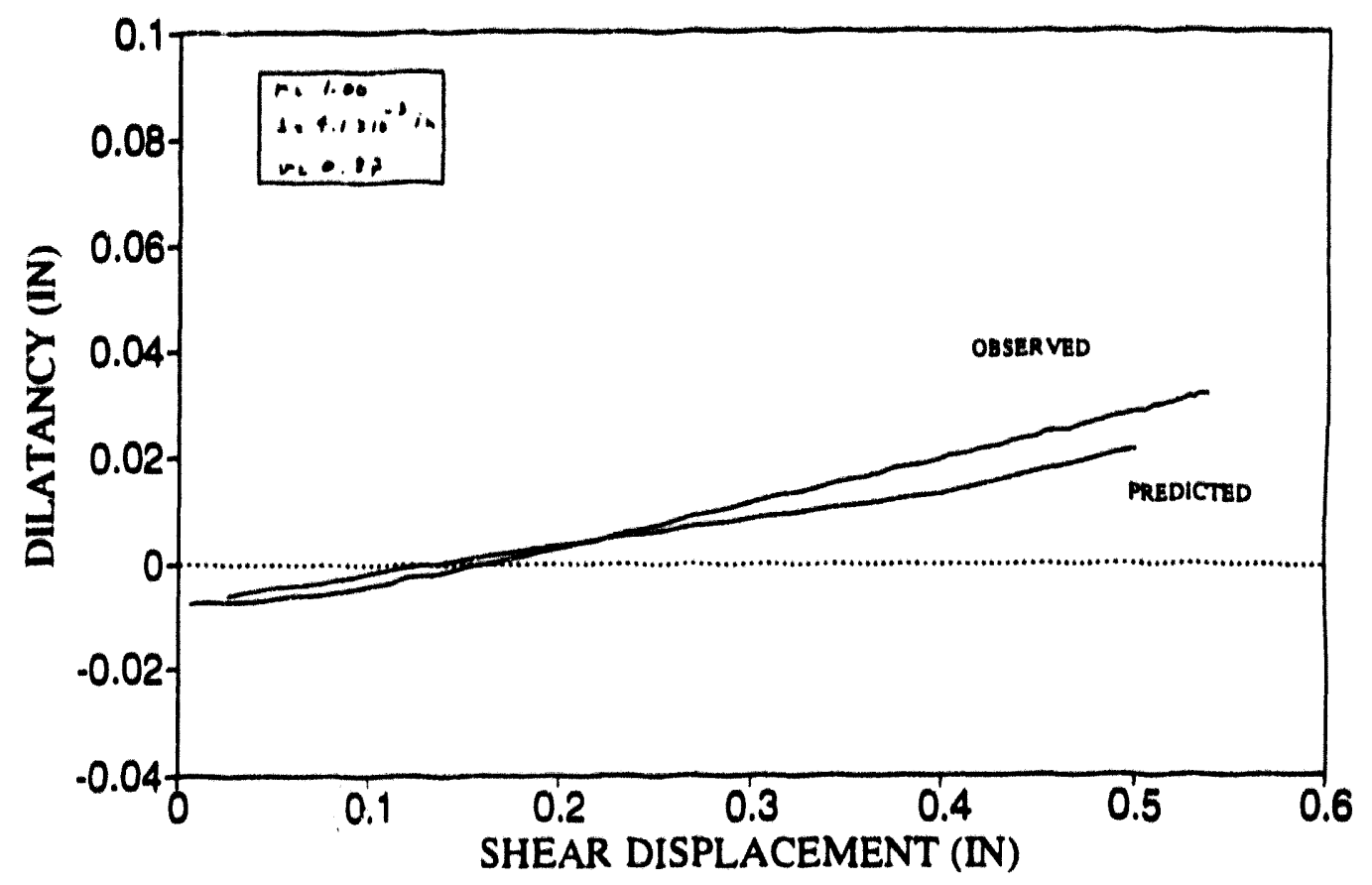

SHEAR LOAD PREDICTION F45F $\mathrm{K}=179.9 \mathrm{KIPS} / \mathrm{IN}$, NORMAL LOAD $=3.6 \mathrm{KIPS}$

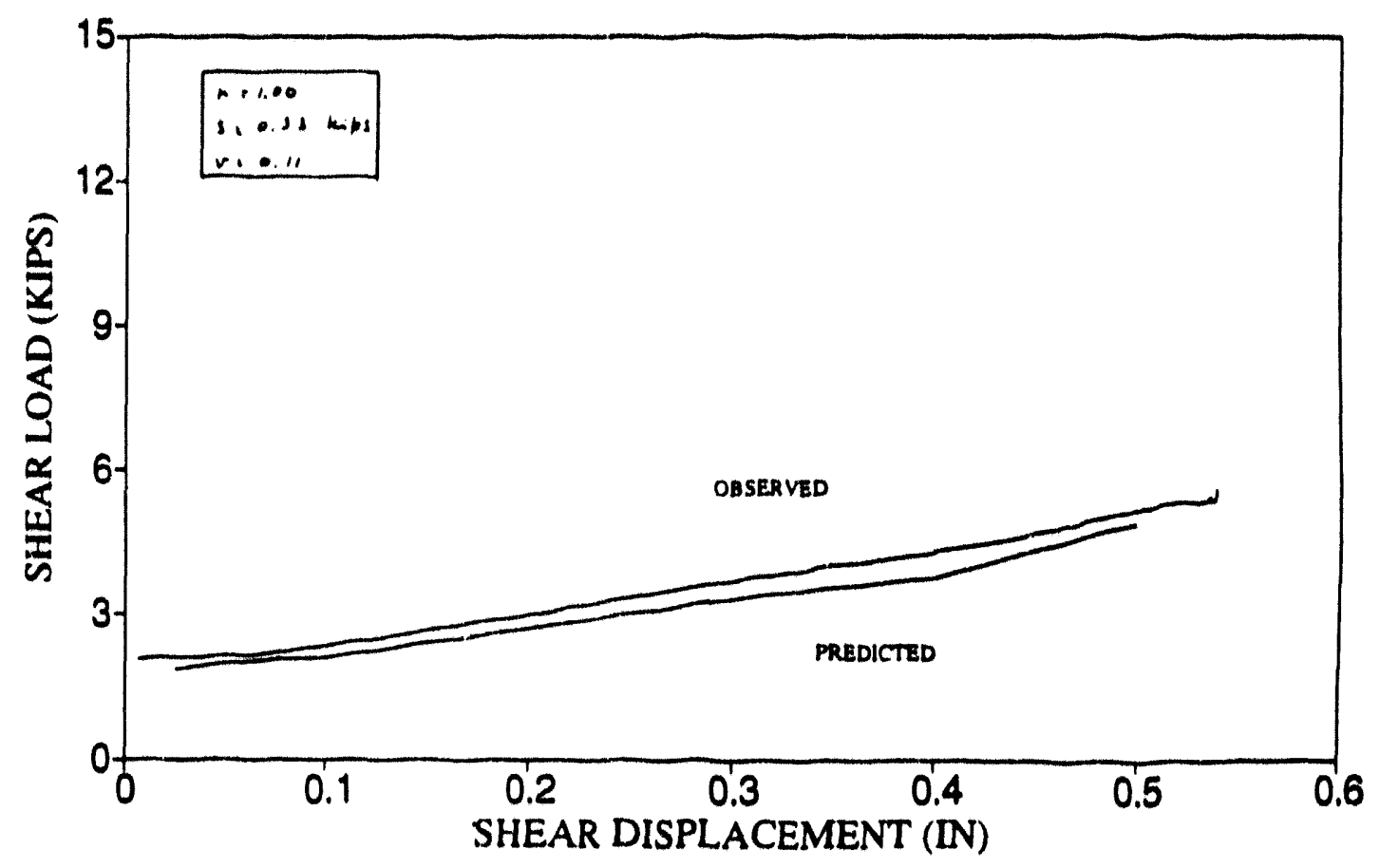



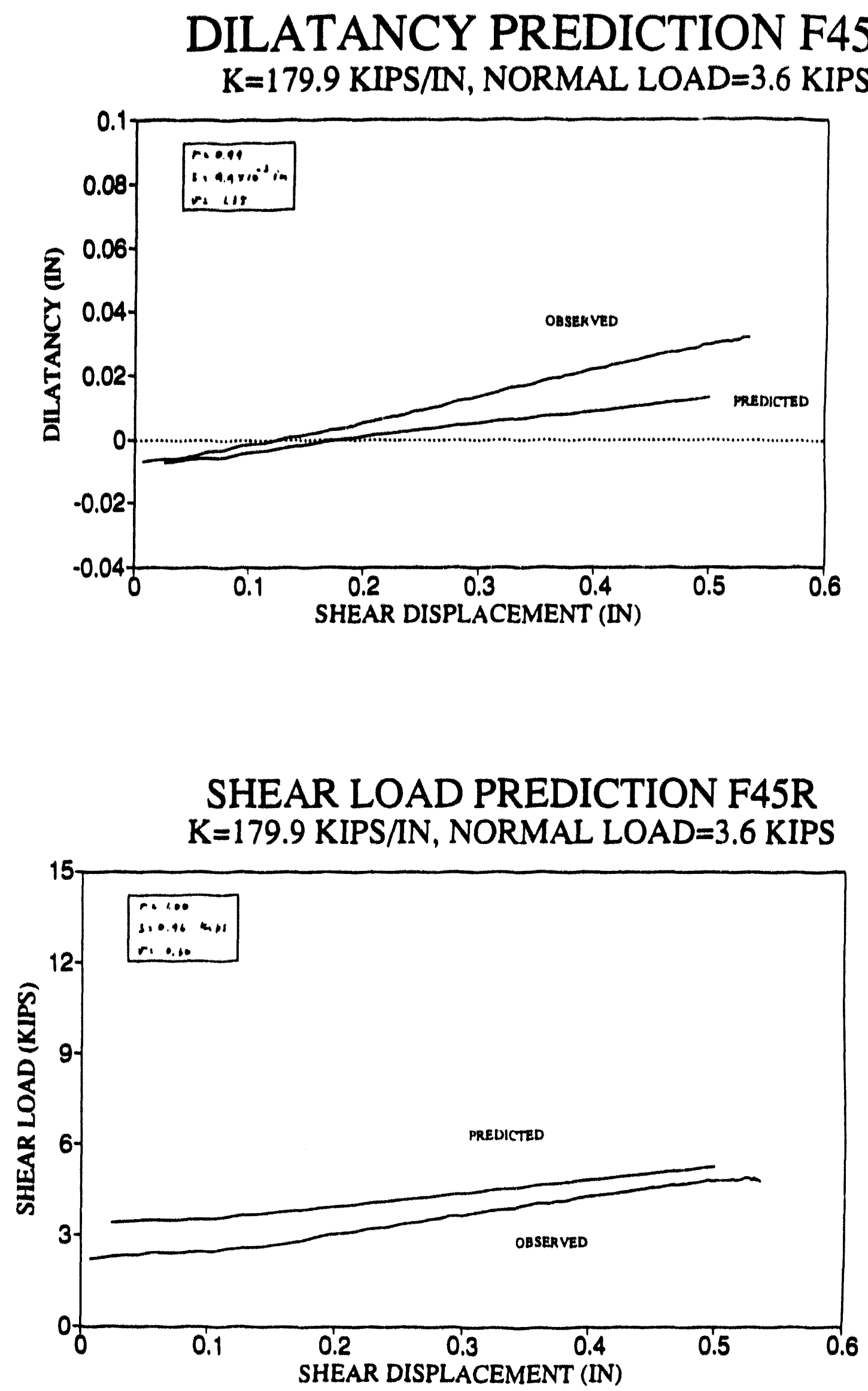

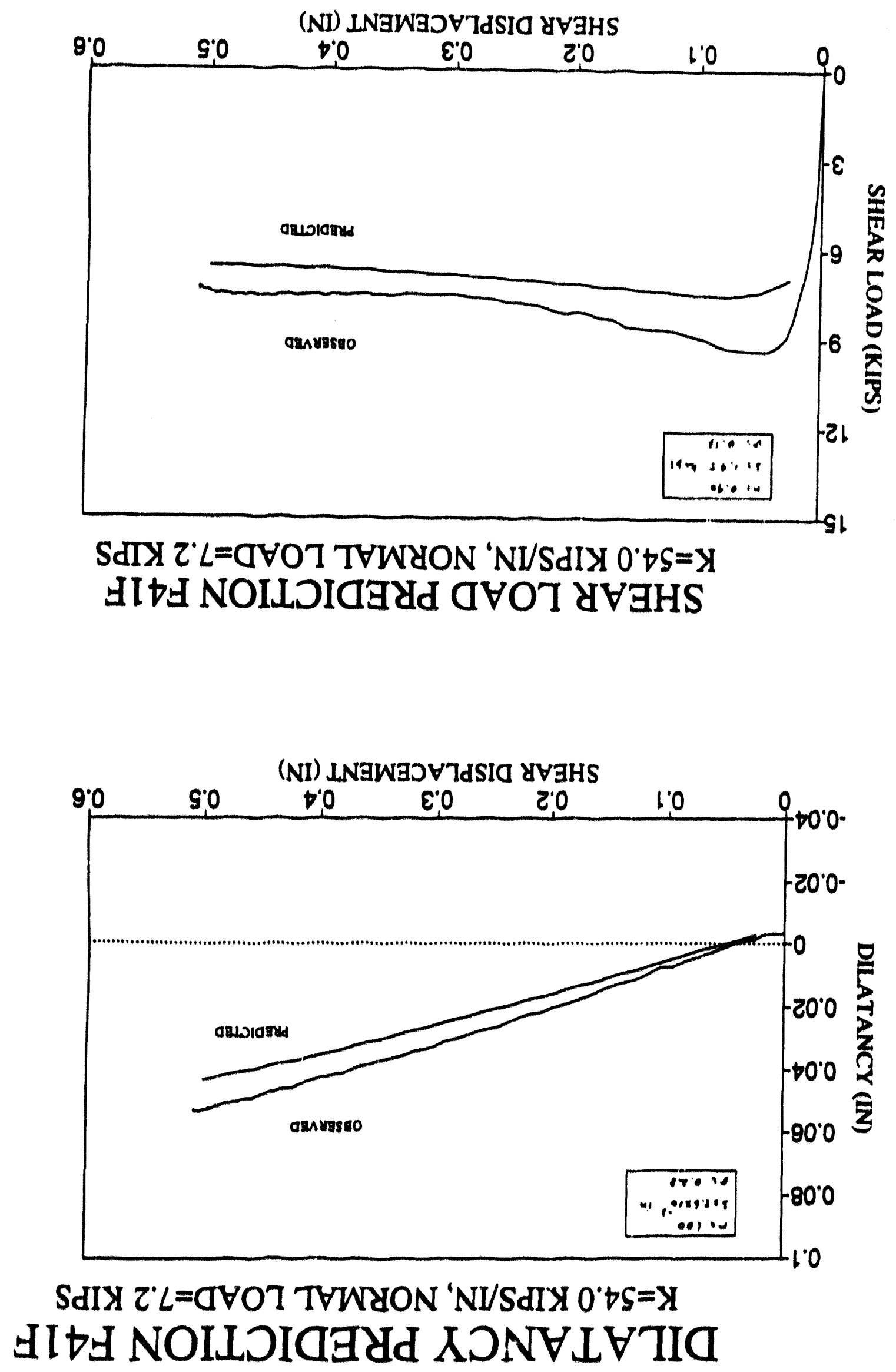

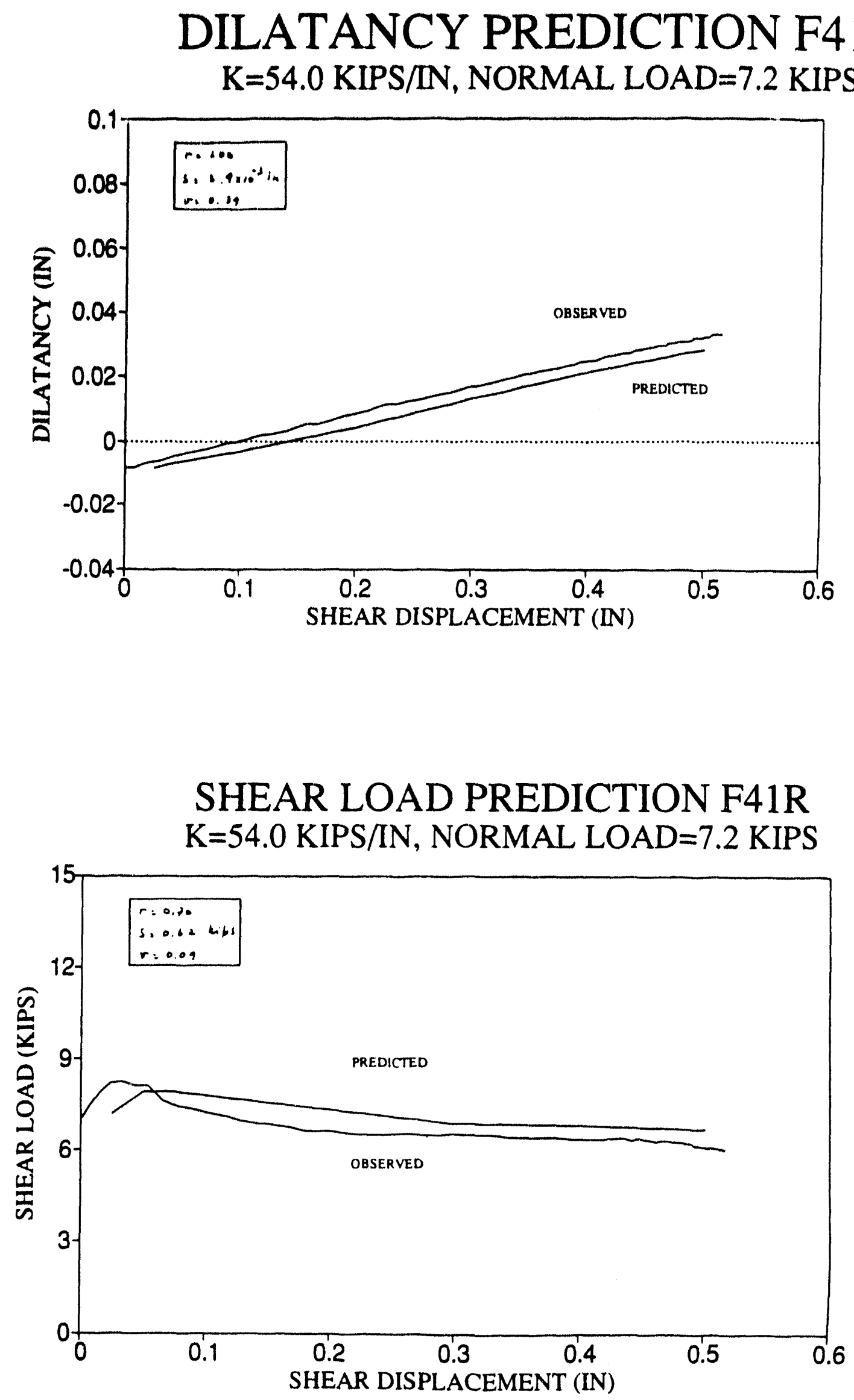

B -32 


\section{DILATANCY PREDICTION F42F $\mathrm{K}=54.0 \mathrm{KIPS} / \mathrm{IN}$, NORMAL LOAD=7.2 KIPS}
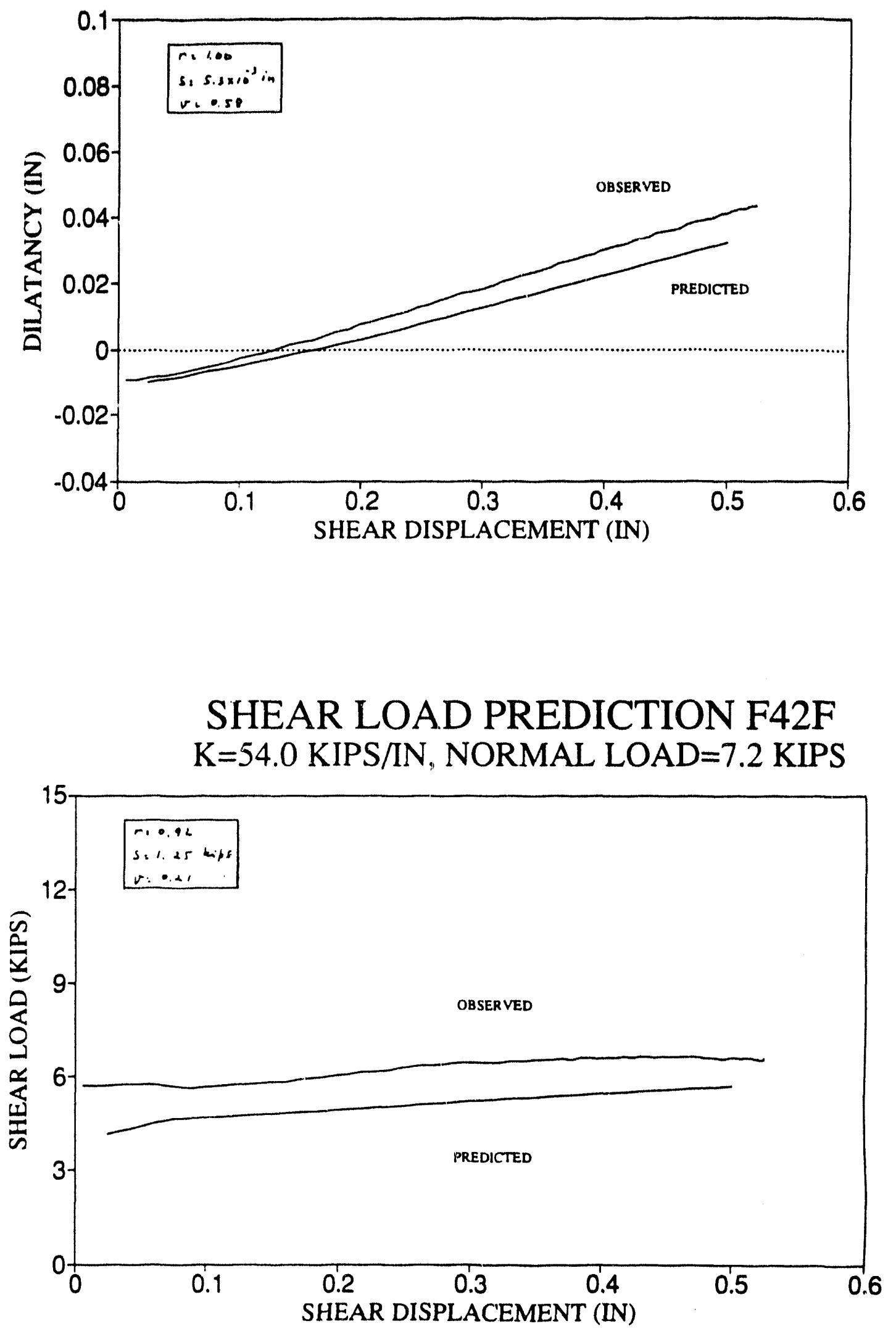

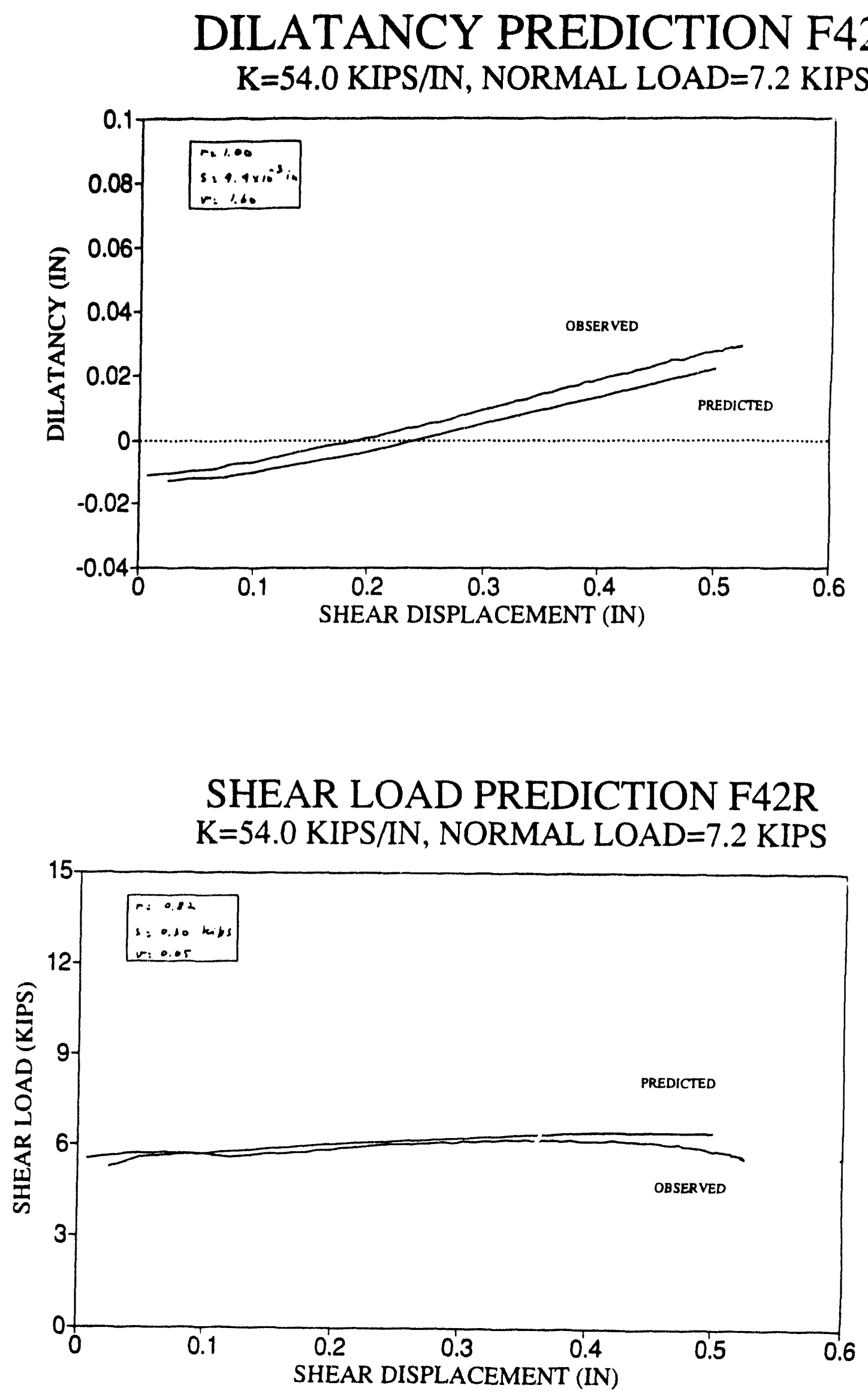


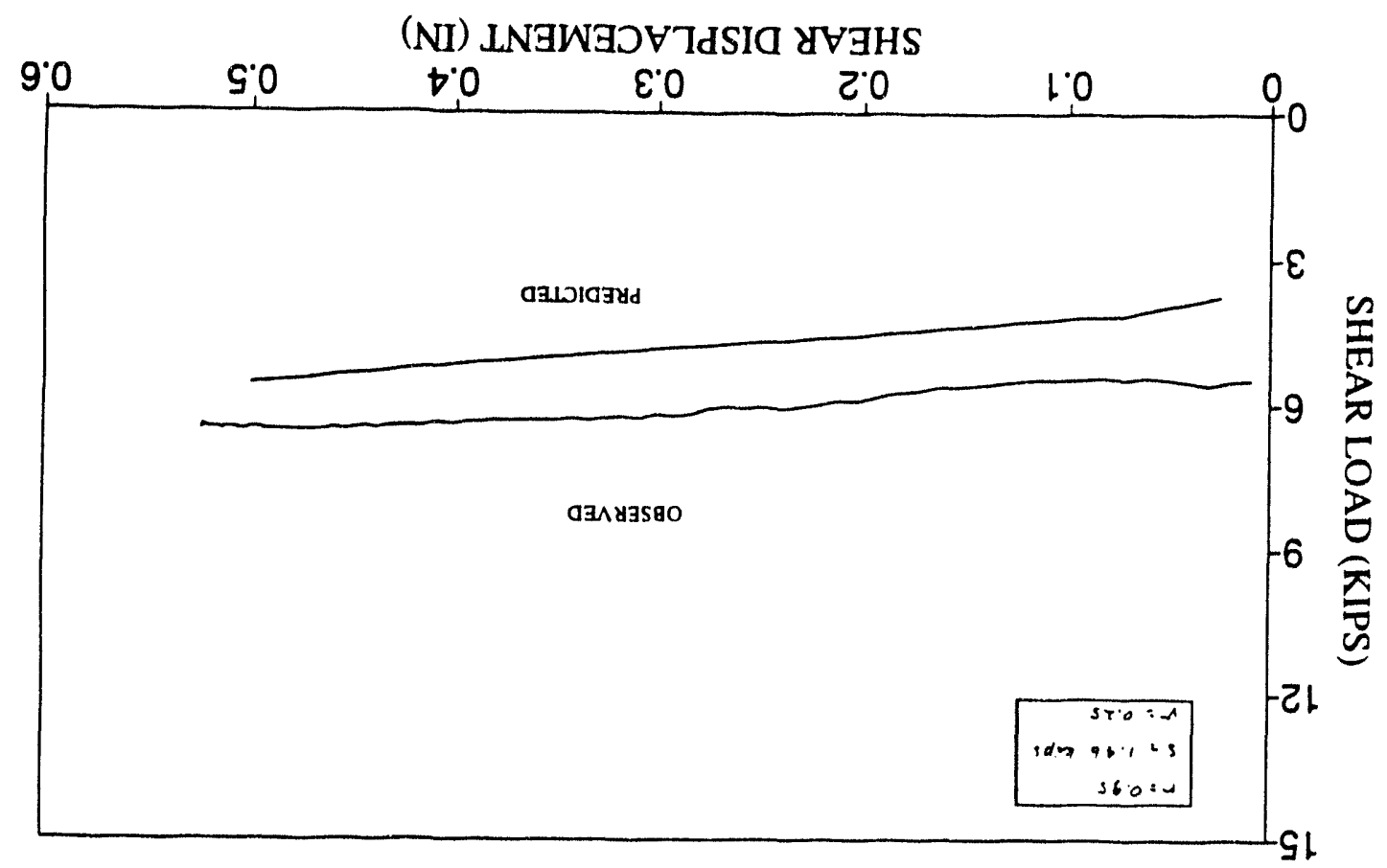

SdIY $\tau$ ' $L=$ G $\forall O T$ THWYON 'NI/SdIX $00^{\circ} \varsigma=$ X

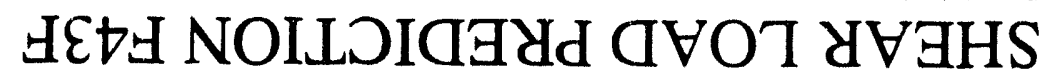

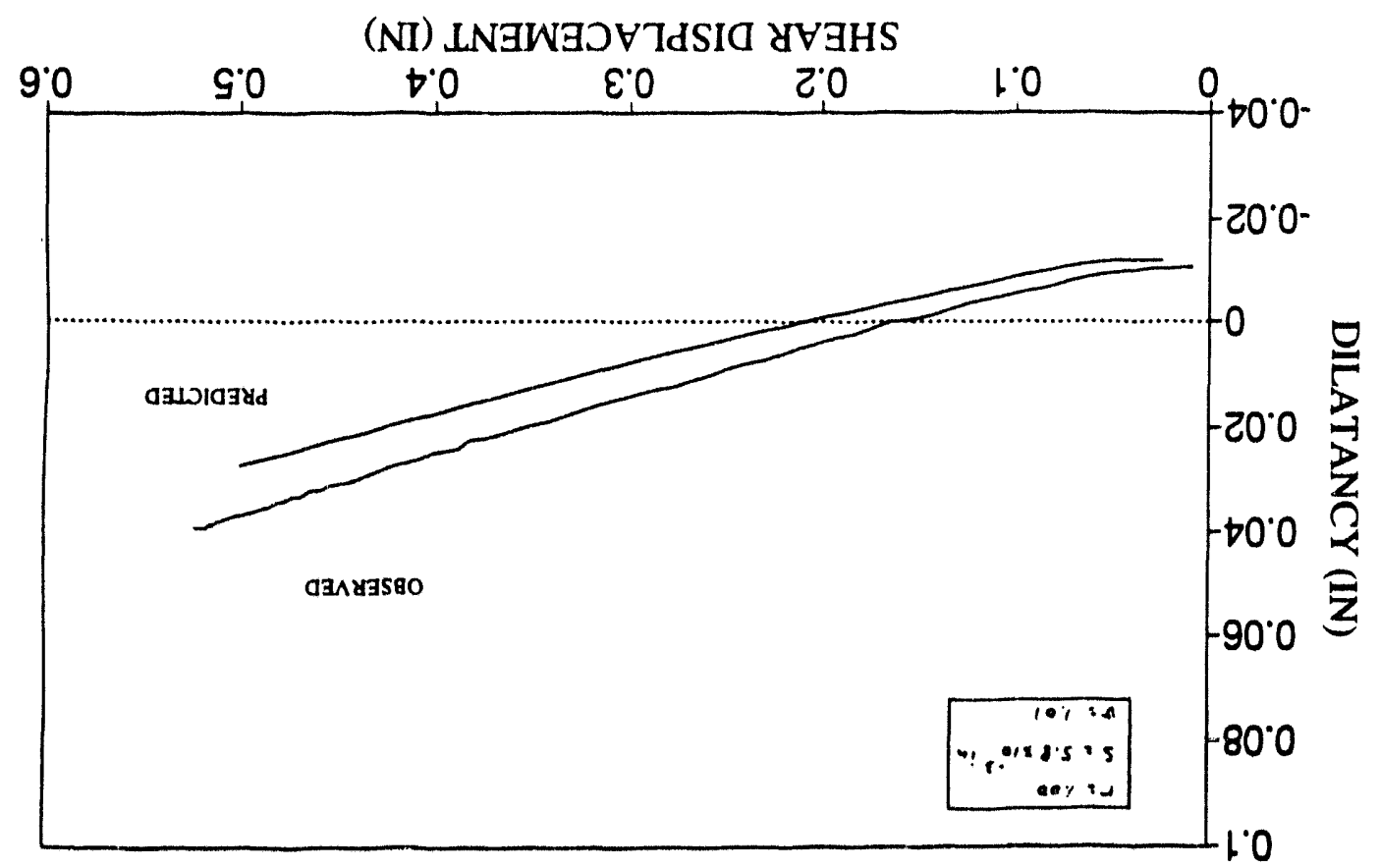

SdIY $\tau^{\circ} L=$ वVO 7 THWYON 'NI/SdTY $0^{\circ} \sqcup S=$ X AEtH NOILOIG 

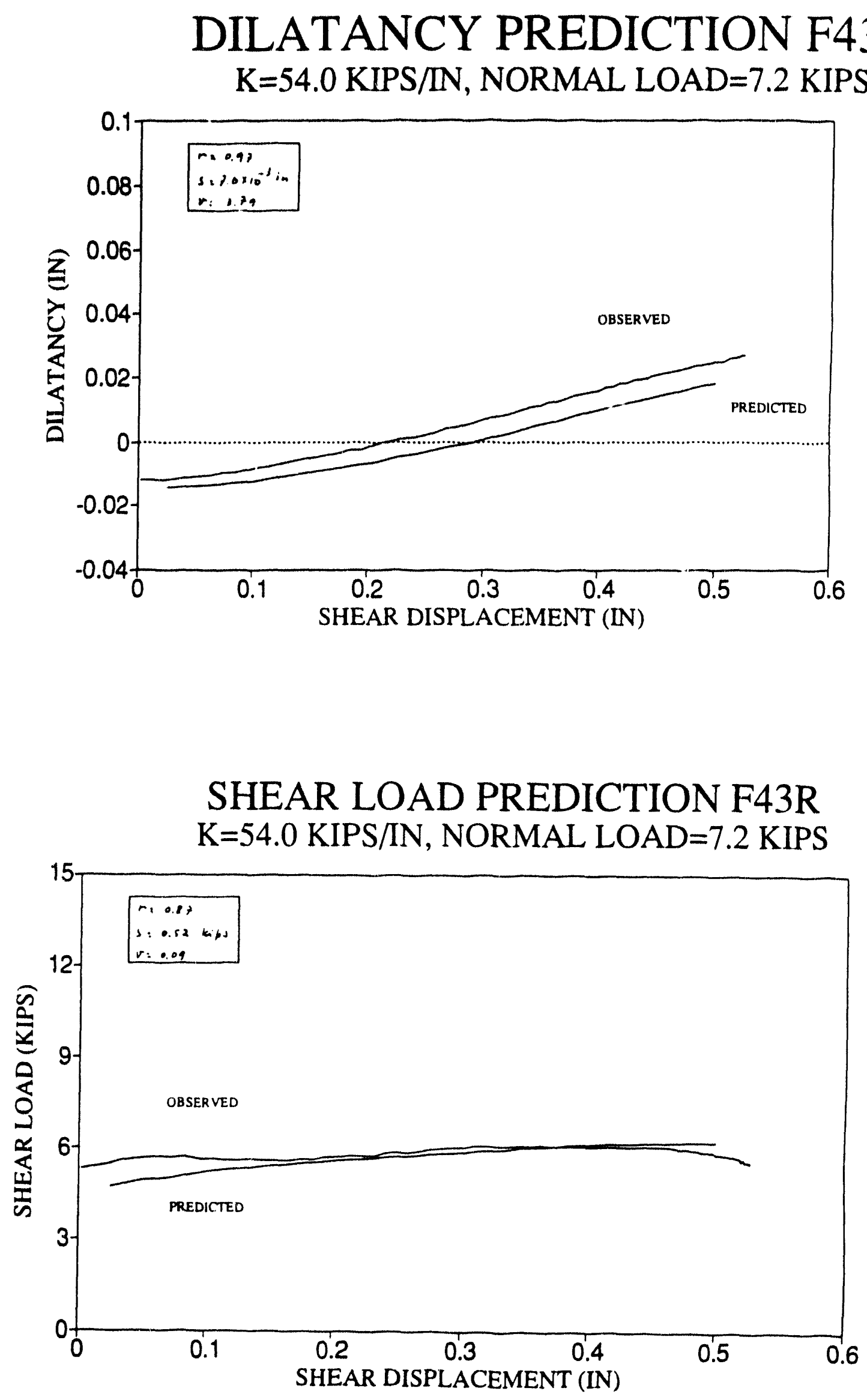


\section{DILATANCY PREDICTION F44F $\mathrm{K}=54.0 \mathrm{KIPS} / \mathrm{IN}$, NORMAL LOAD=7.2 KIPS}

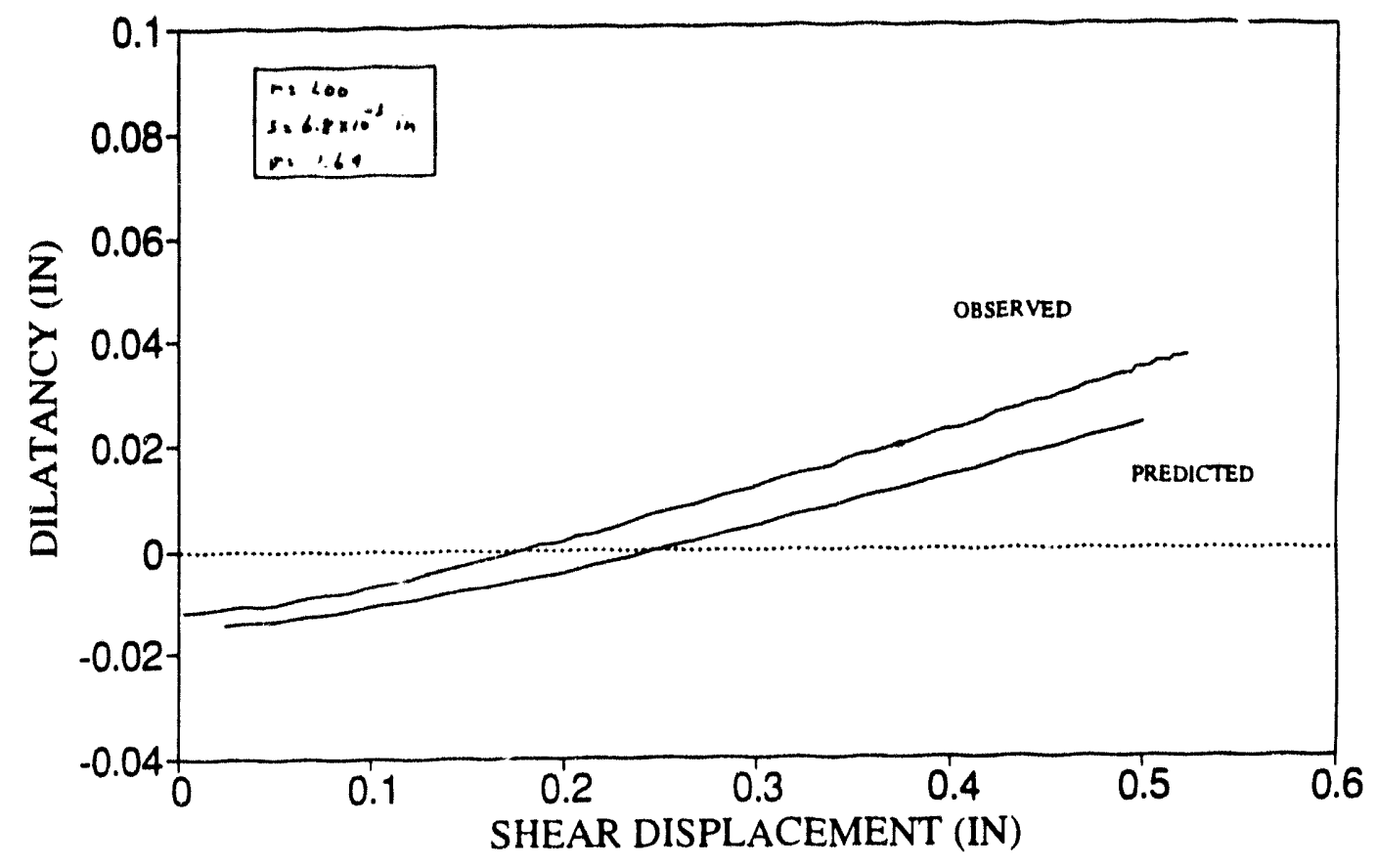

SHEAR LOAD PREDICTION F44F $\mathrm{K}=54.0 \mathrm{KIPS} / \mathrm{IN}$, NORMAL LOAD=7.2 KIPS

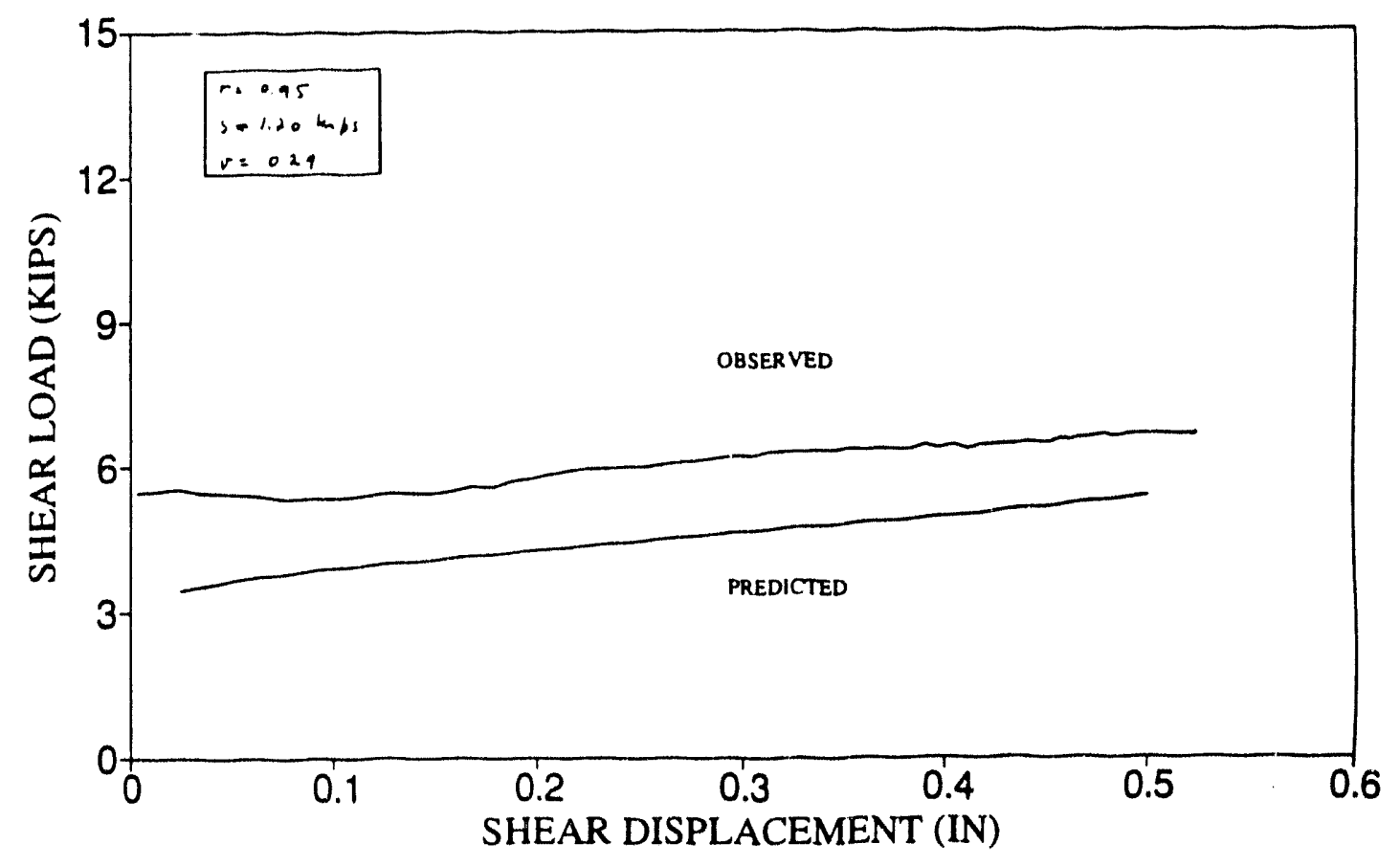



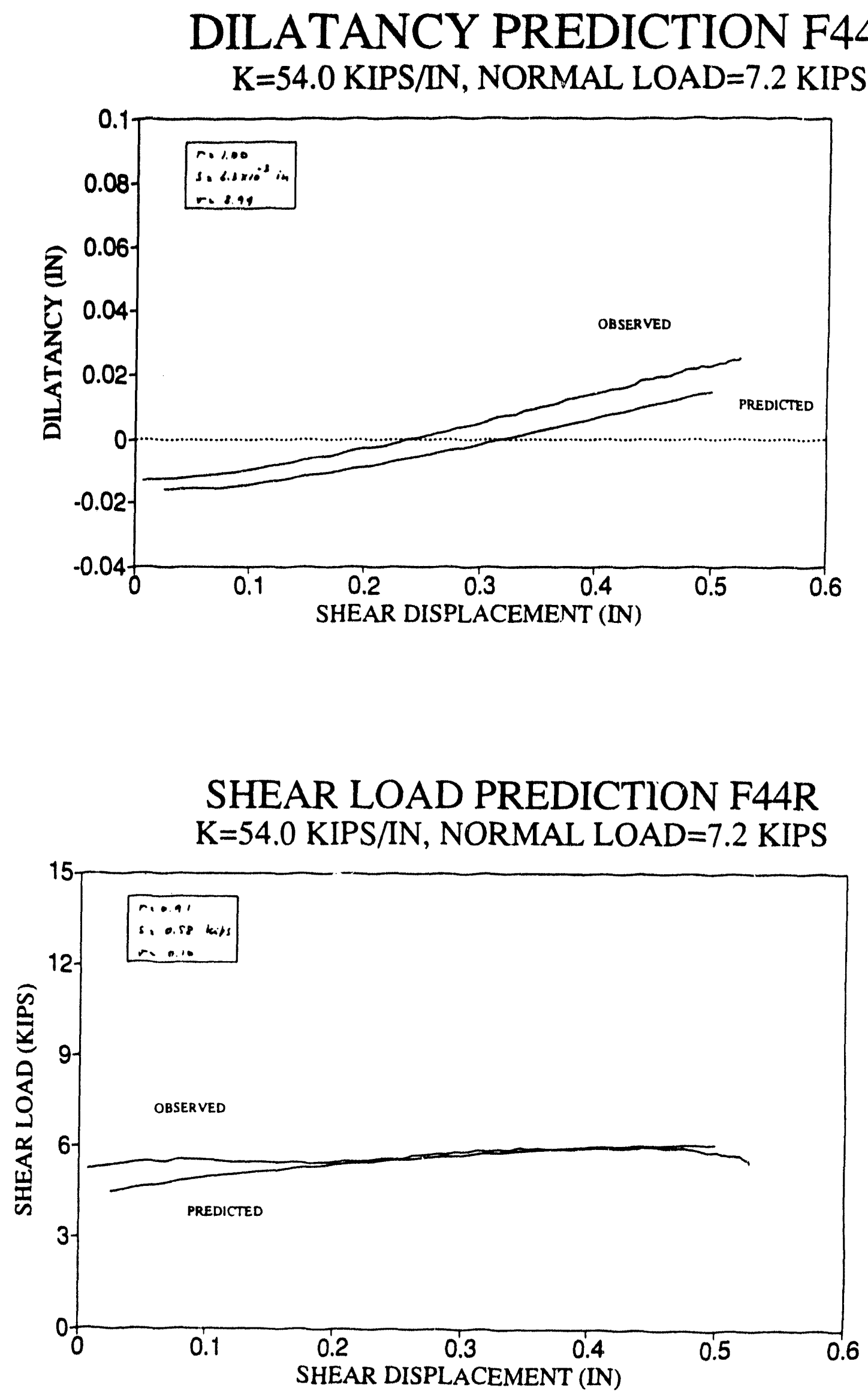

B -38 


\section{DILATANCY PREDICTION F45F $\mathrm{K}=54.0 \mathrm{KIPS} / \mathrm{IN}$, NORMAL LOAD=7.2 KIPS}

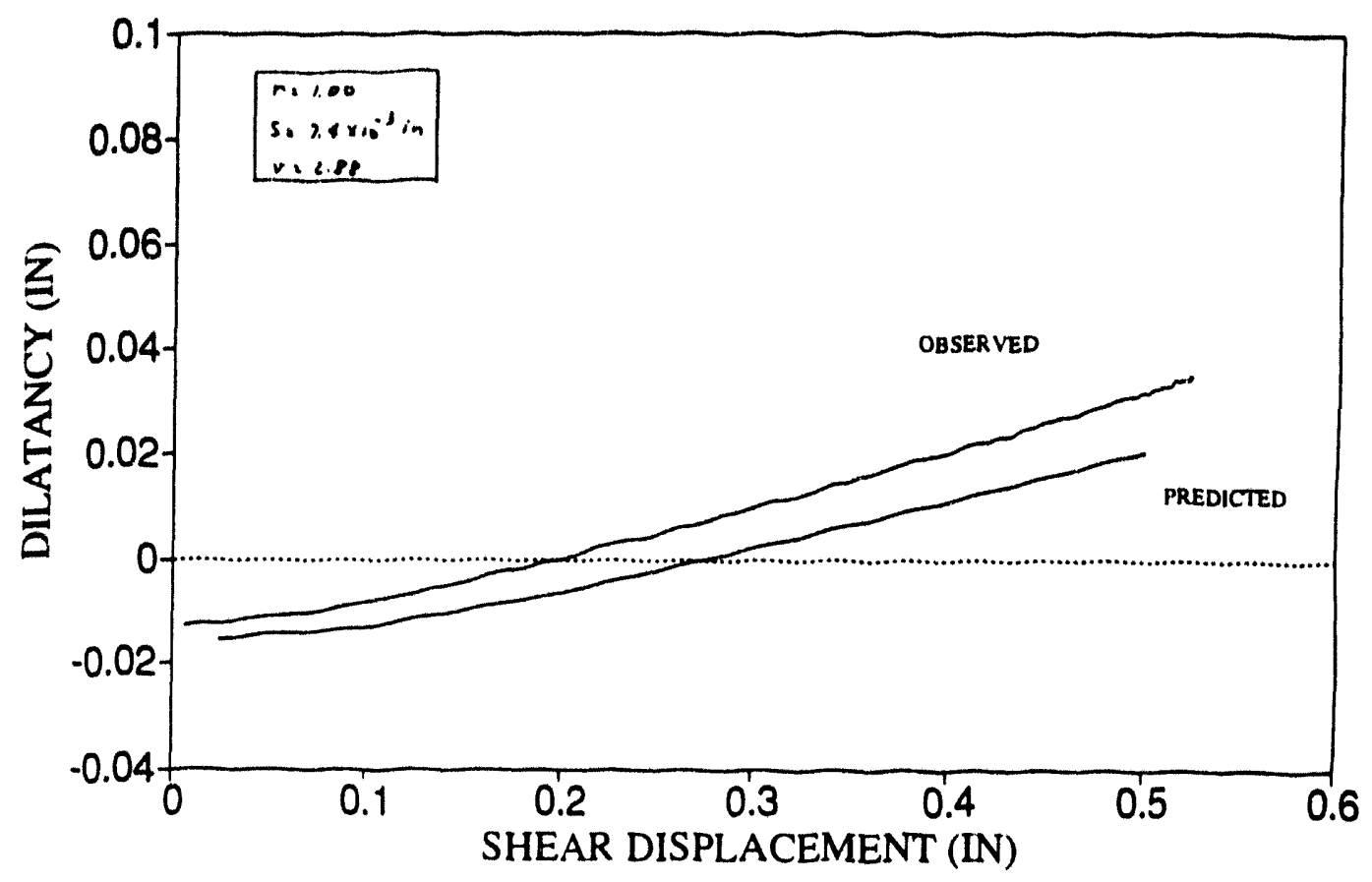

SHEAR LOAD PREDICTION F45F $\mathrm{K}=54.0 \mathrm{KIPS} / \mathrm{IN}$, NORMAL LOAD $=7.2 \mathrm{KIPS}$

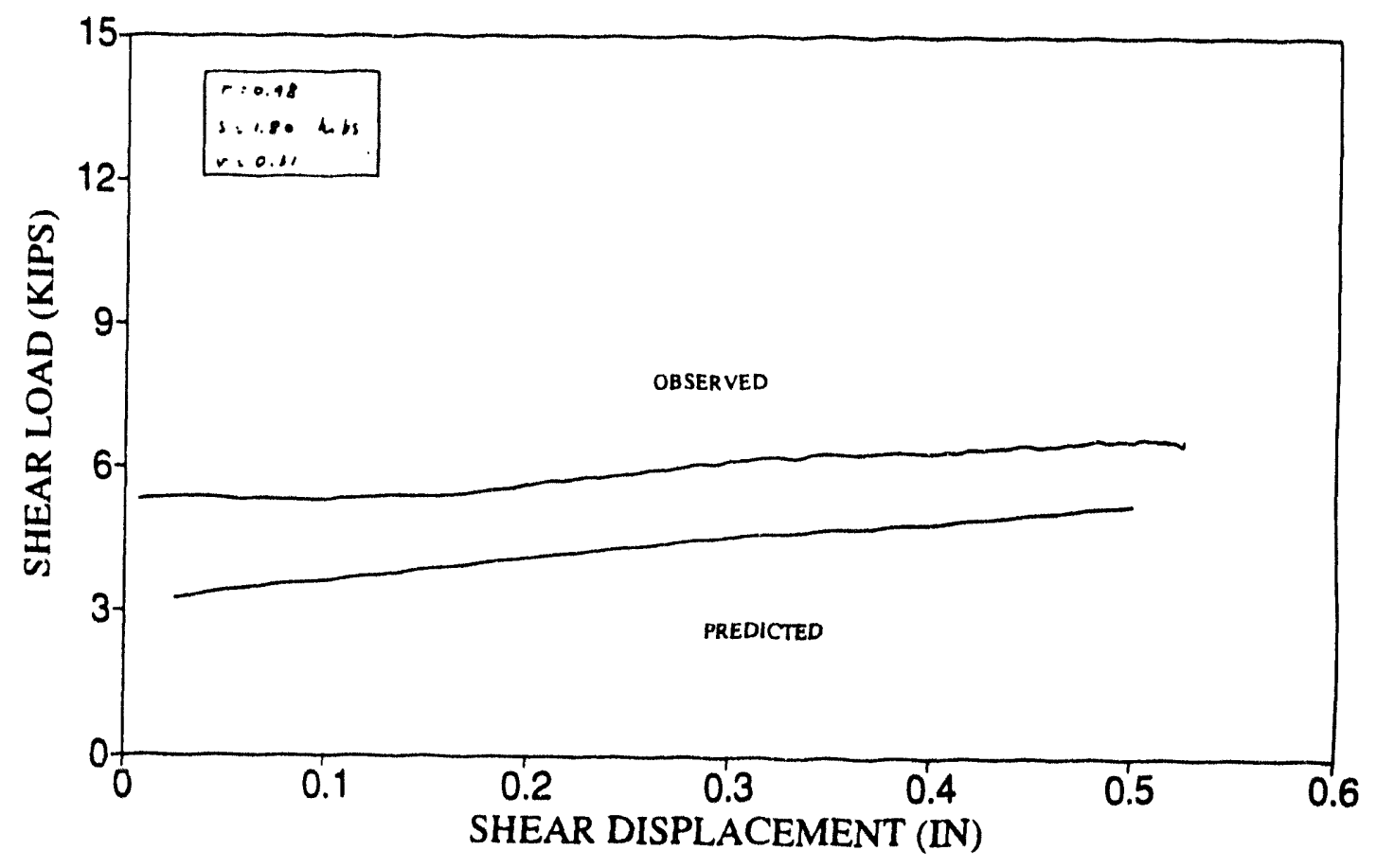




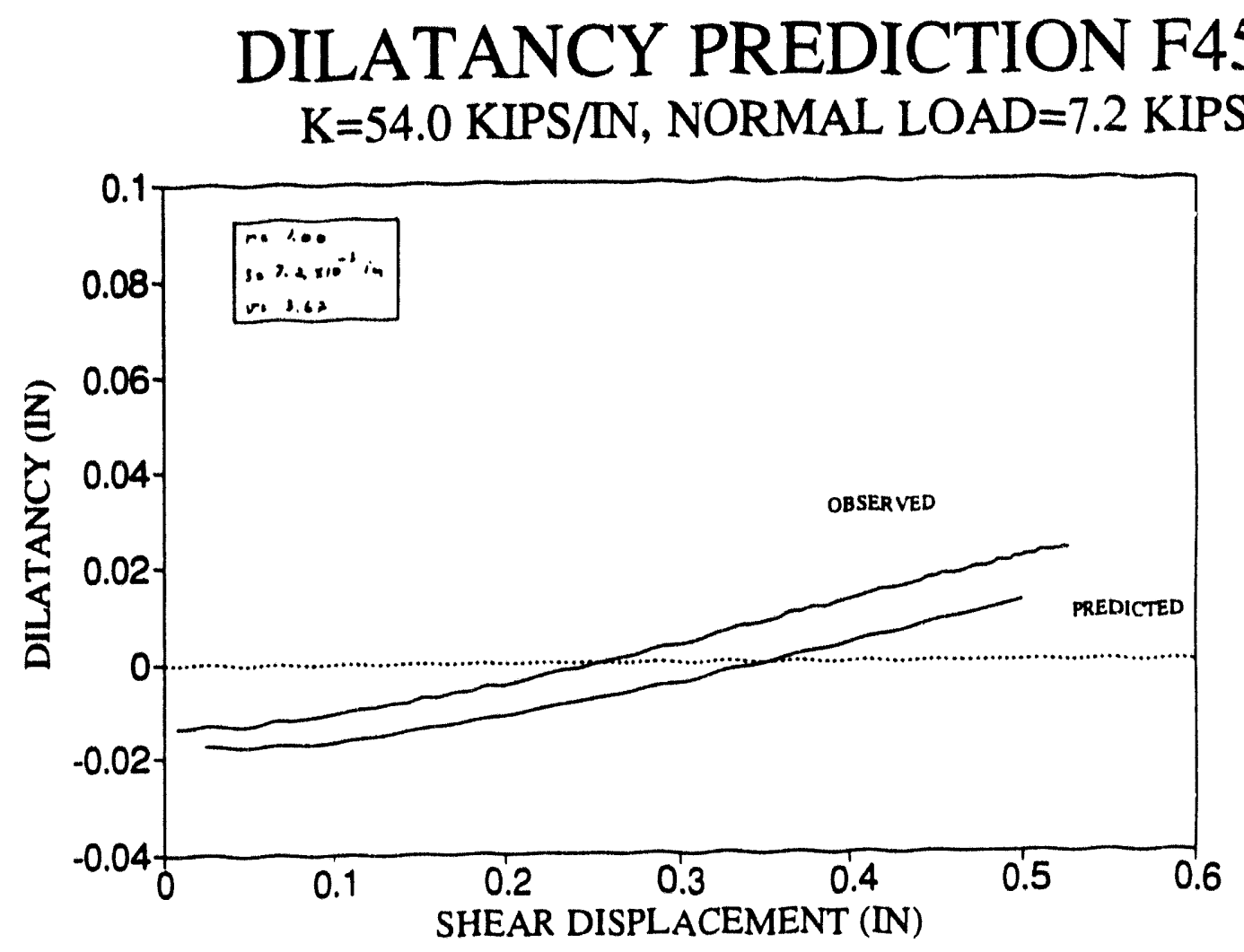

SHEAR LOAD PREDICTION F45R $\mathrm{K}=54.0 \mathrm{KIPS} / \mathrm{IN}$, NORMAL LOAD=7.2 KIPS

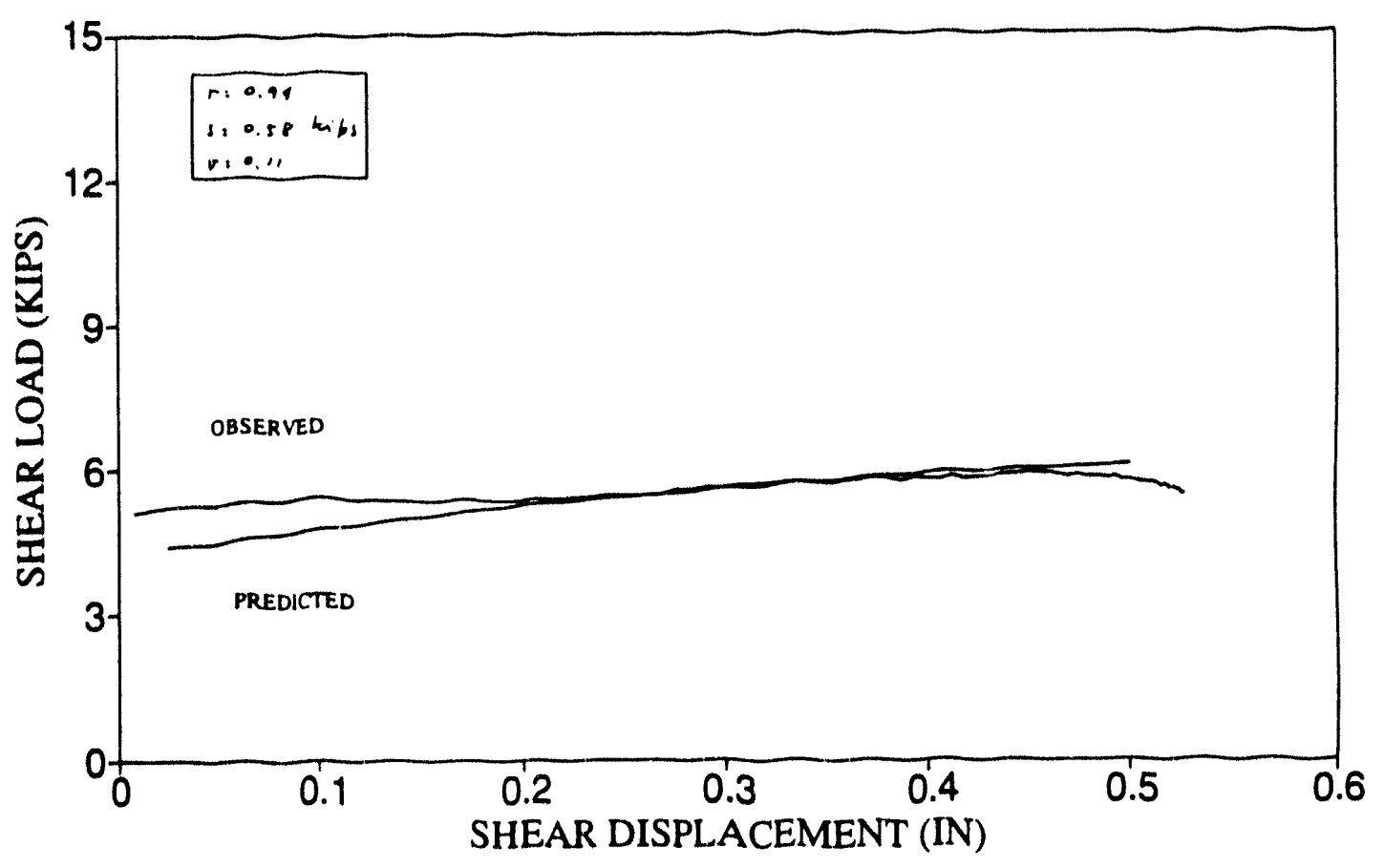




\section{DILATANCY PREDICTION F41F $\mathrm{K}=179.9 \mathrm{KIPS} / \mathrm{IN}$, NORMAL LOAD=7.2 KIPS}

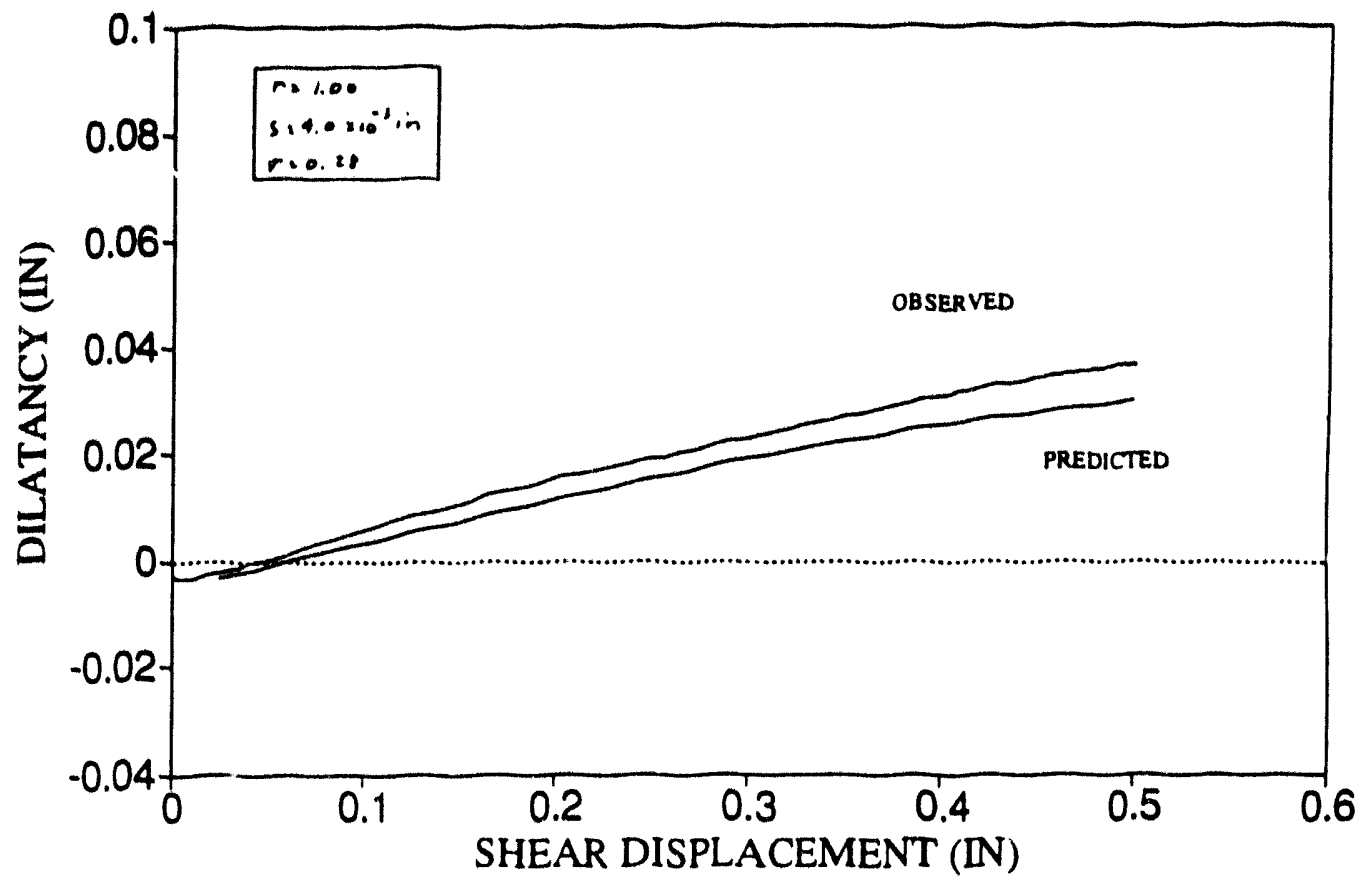

SHEAR LOAD PREDICTION F41F $\mathrm{K}=179.9 \mathrm{KIPS} / \mathrm{N}$, NORMAL LOAD $=7.2 \mathrm{KIPS}$

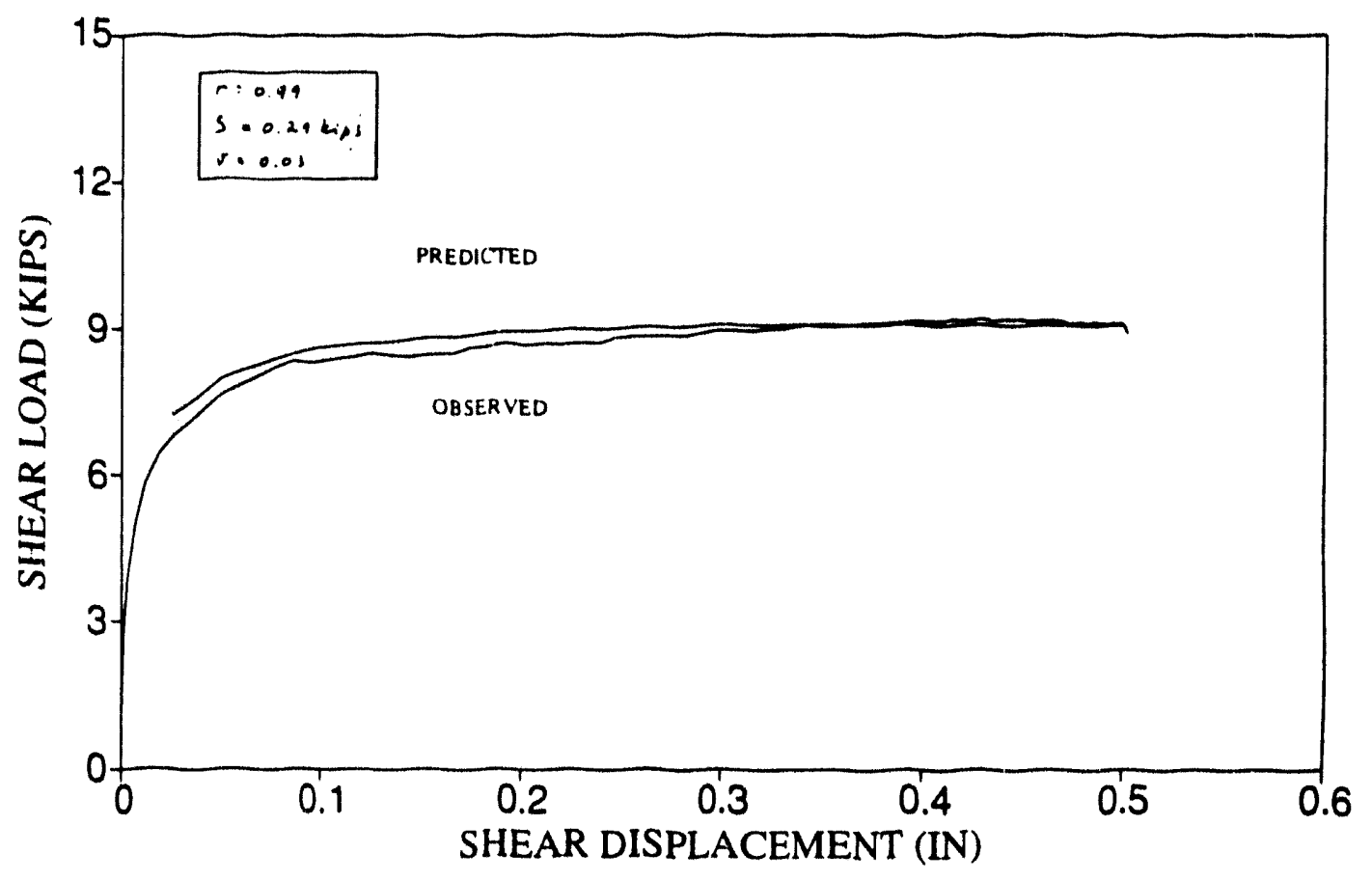




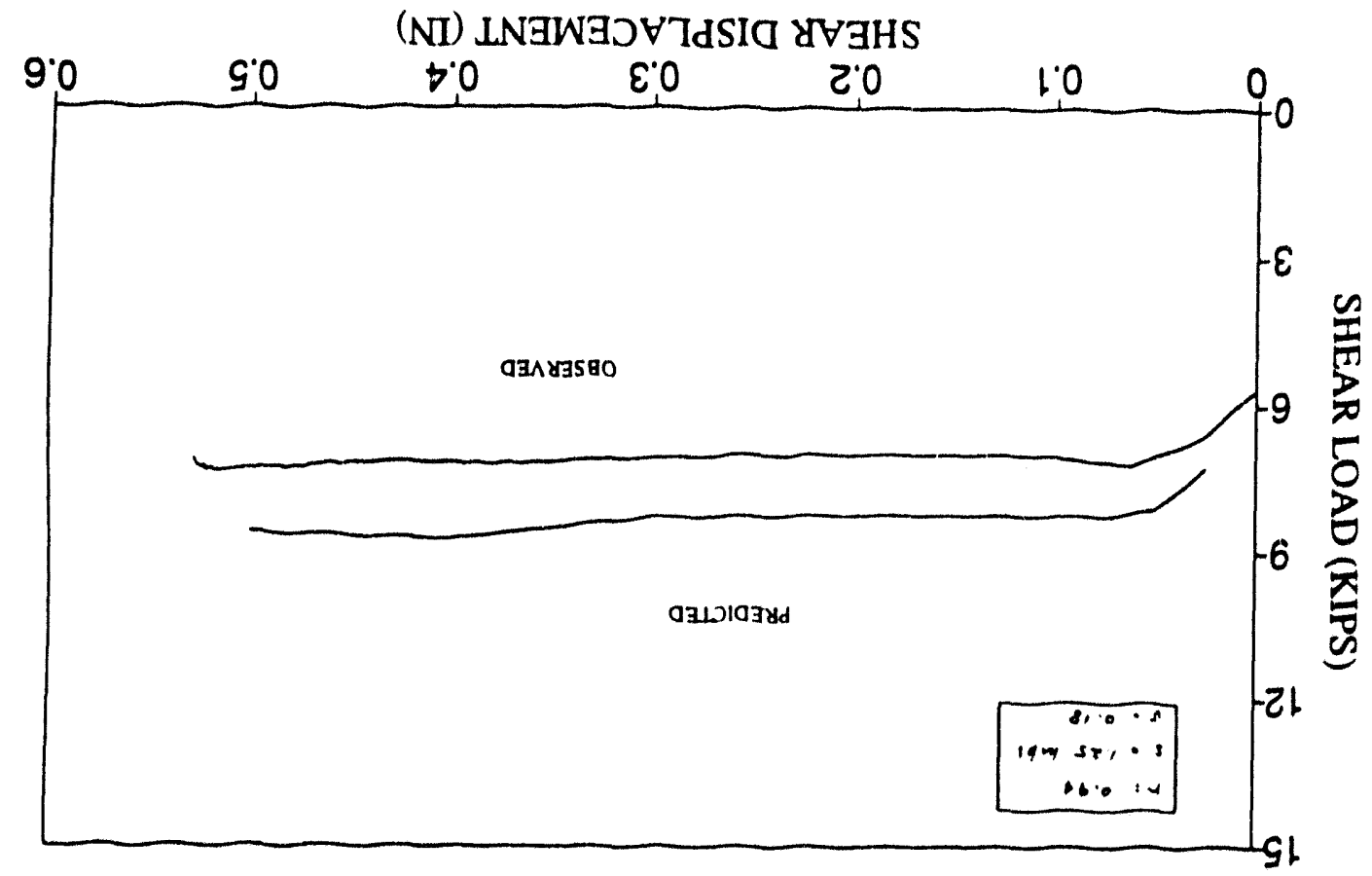

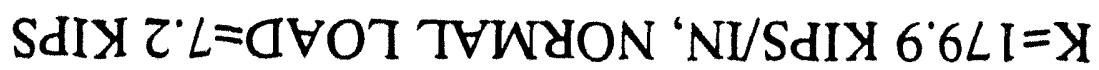

YItH NOILDIGGYd GVOT Y Y

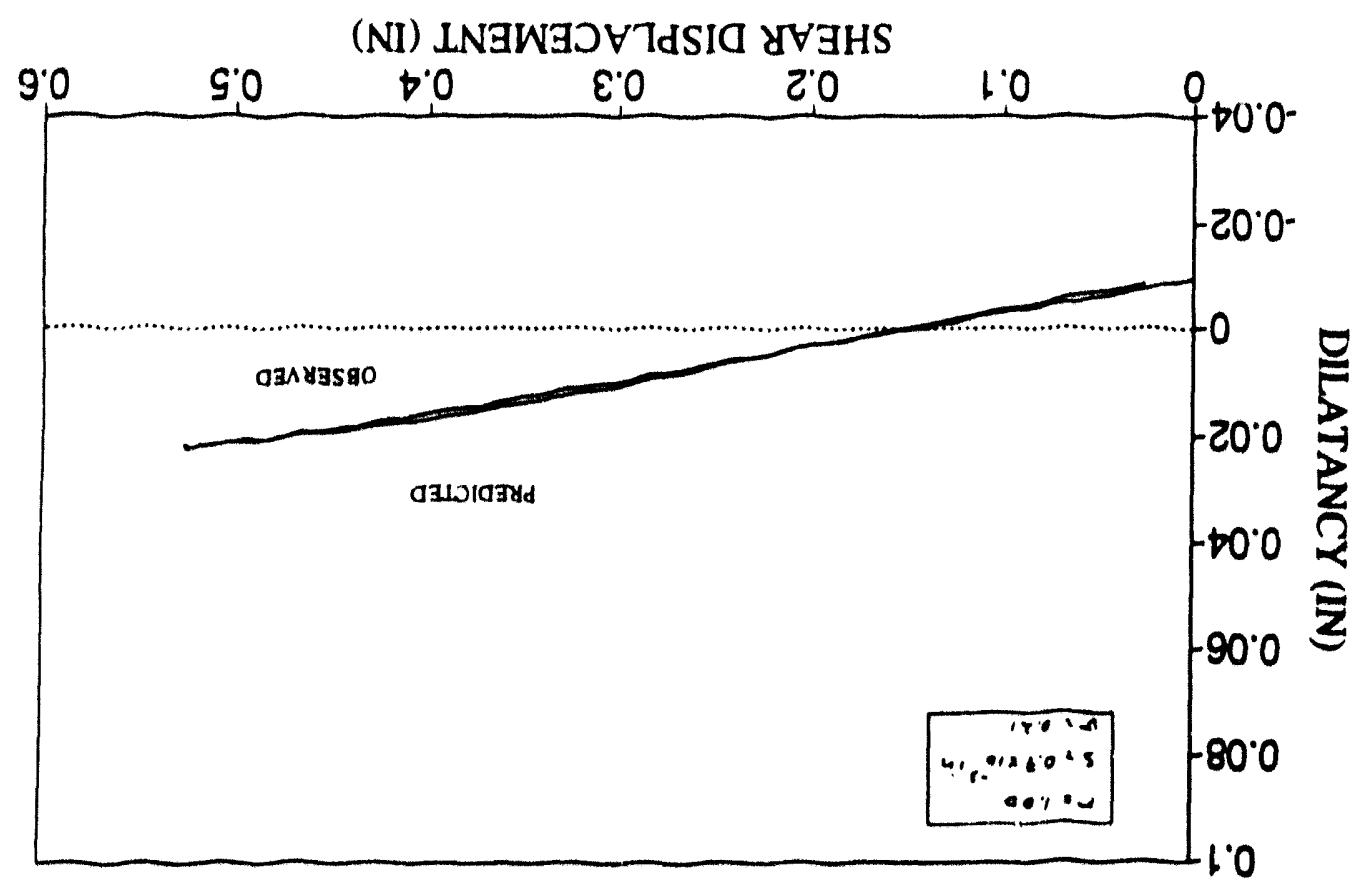

SdIX $Z^{\circ} L=$ QVHOT TVWYON 'NI/SdIX $66^{\circ} 6 L$ I =X УItA NOILDIG Jעd XONVLVTIC 
DILATANCY PREDICTION F42F $\mathrm{K}=179.9 \mathrm{KIPS} / \mathrm{IN}$, NORMAL LOAD $=7.2 \mathrm{KIPS}$

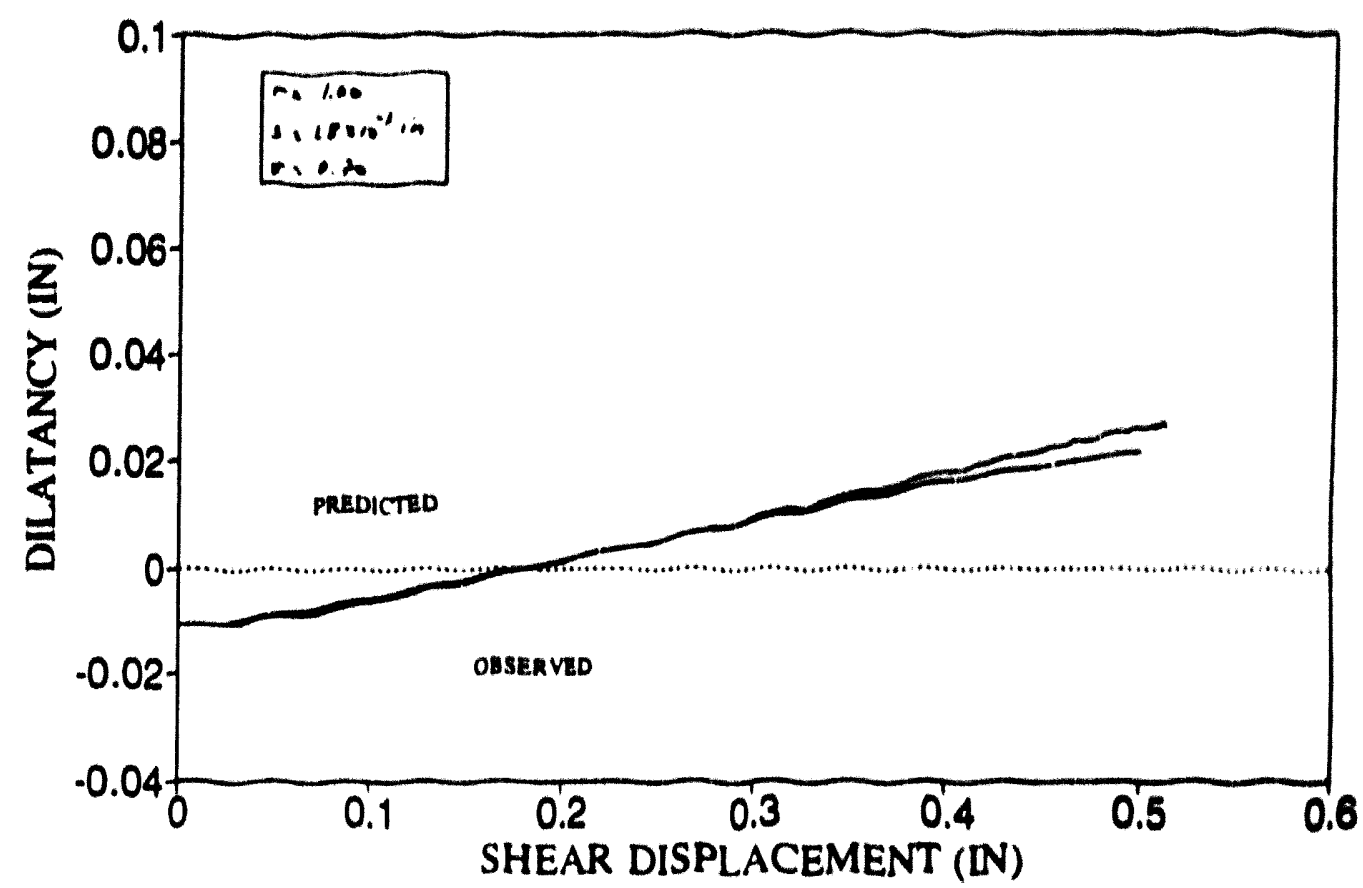

SHEAR LOAD PREDICTION F42F $\mathrm{K}=179.9 \mathrm{KIPS} / \mathrm{IN}$, NORMAL LOAD $=7.2 \mathrm{KIPS}$

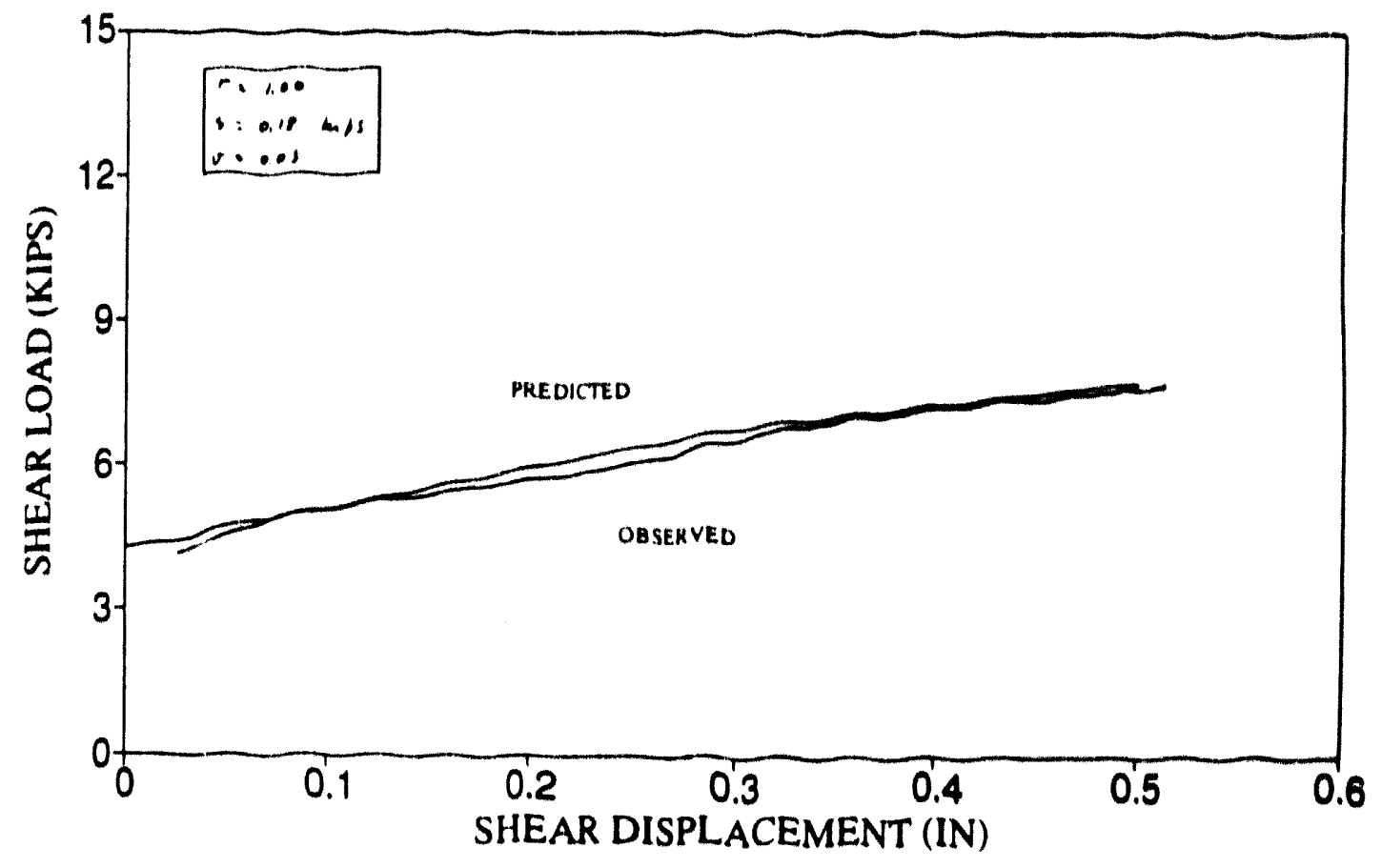


DILATANCY PREDICTION F42R $\mathrm{K}=179.9 \mathrm{KIPS} / \mathrm{IN}$, NORMAL LOAD=7.2 KIPS

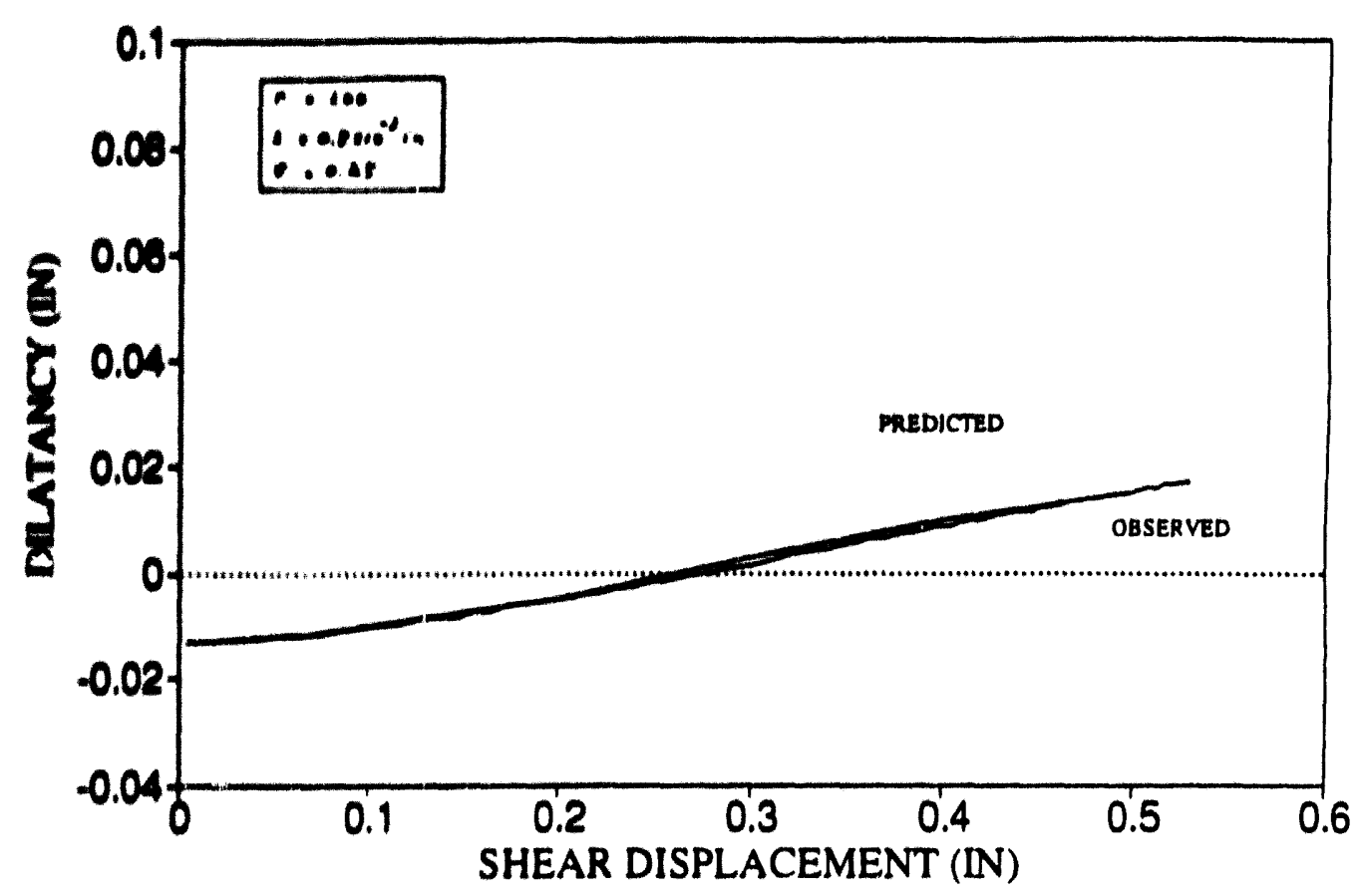

SHEAR LOAD PREDICTION F42R $\mathrm{K}=179.9 \mathrm{KIPS} / \mathrm{IN}$, NORMAL LOAD $=7.2 \mathrm{KIPS}$

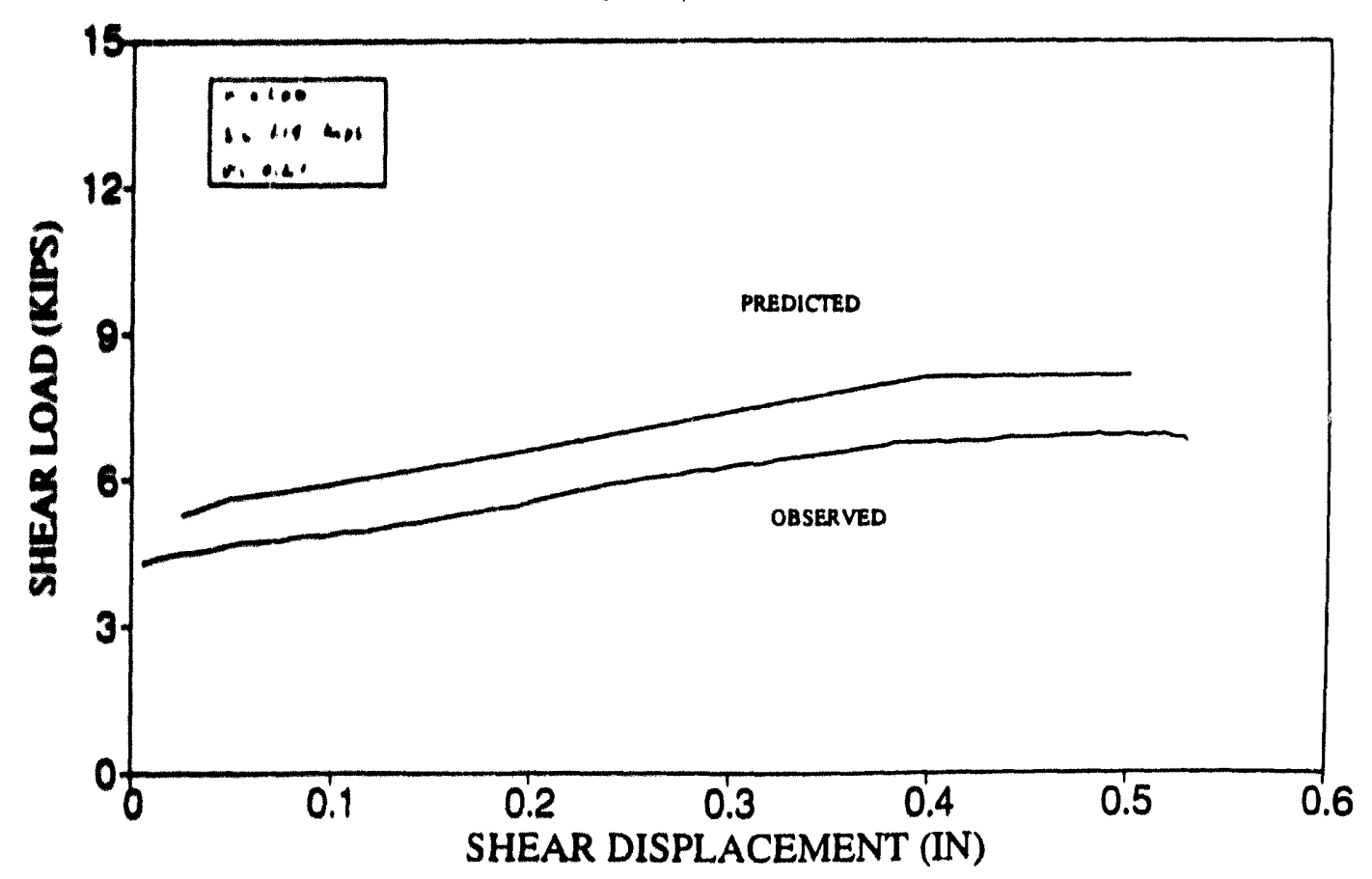




$$
5 \overline{-g}
$$

(NI) LNGW

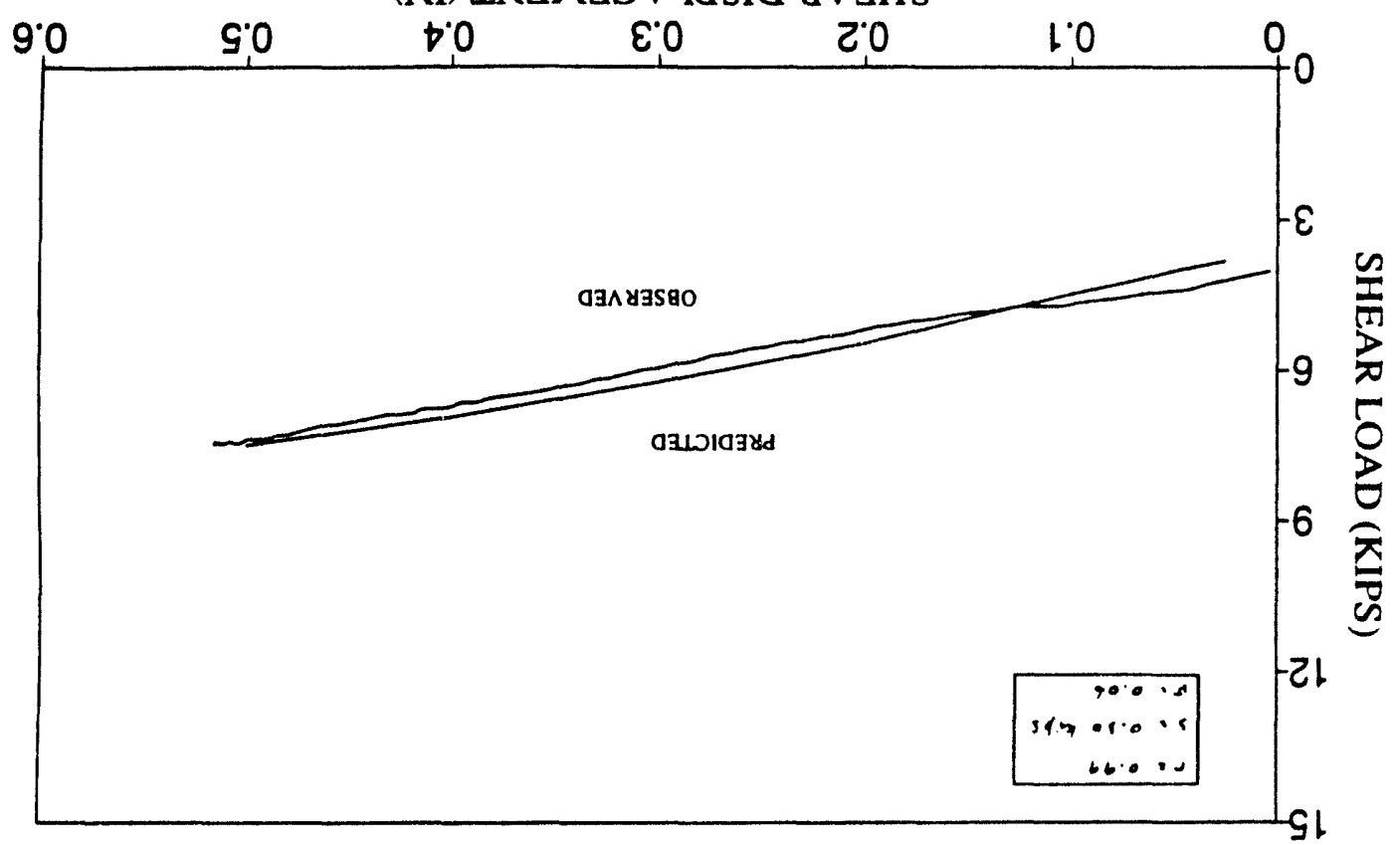

SdIY $\tau^{\circ} L=$ QVVOT TVWYON 'NI/SdIX $6.6 \mathrm{LI}=\mathrm{X}$ HEt

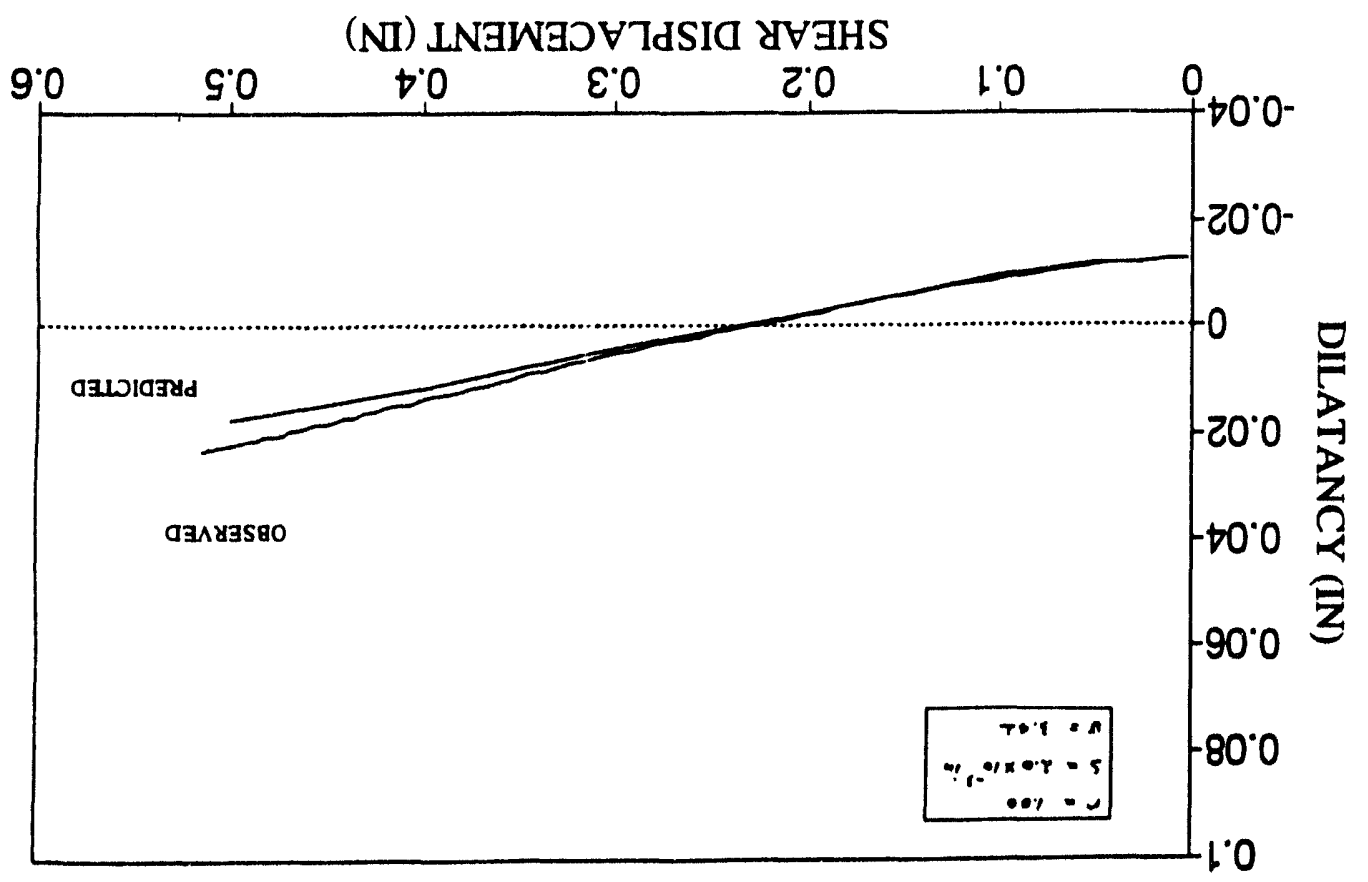

SdIY $Z^{\prime} L=$ बIVOT TVWYON 'NI/SdIY $6{ }^{\circ} 6 L I=X$ ㅂtت NOILOIGAYd XDNFIVTIC 

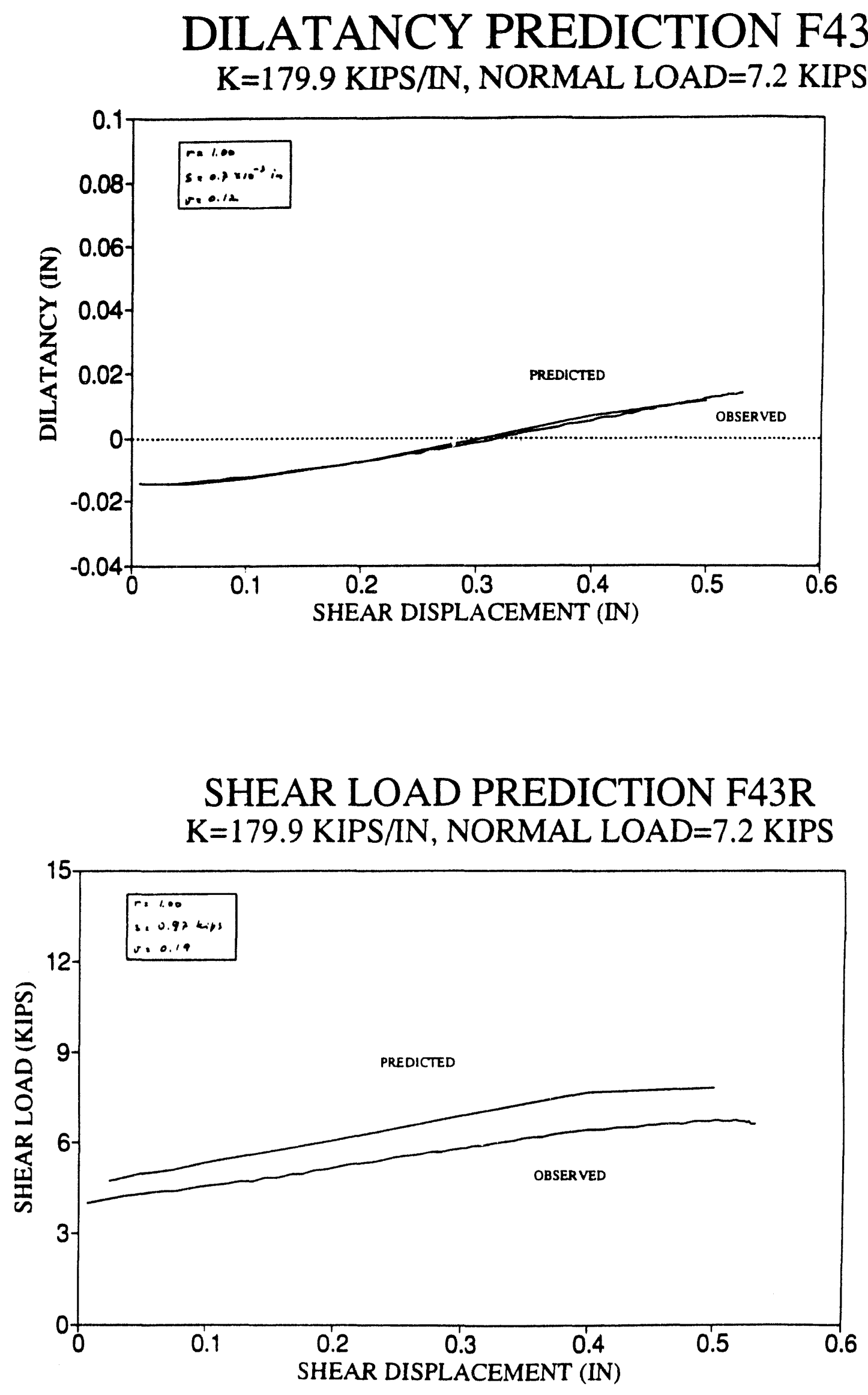

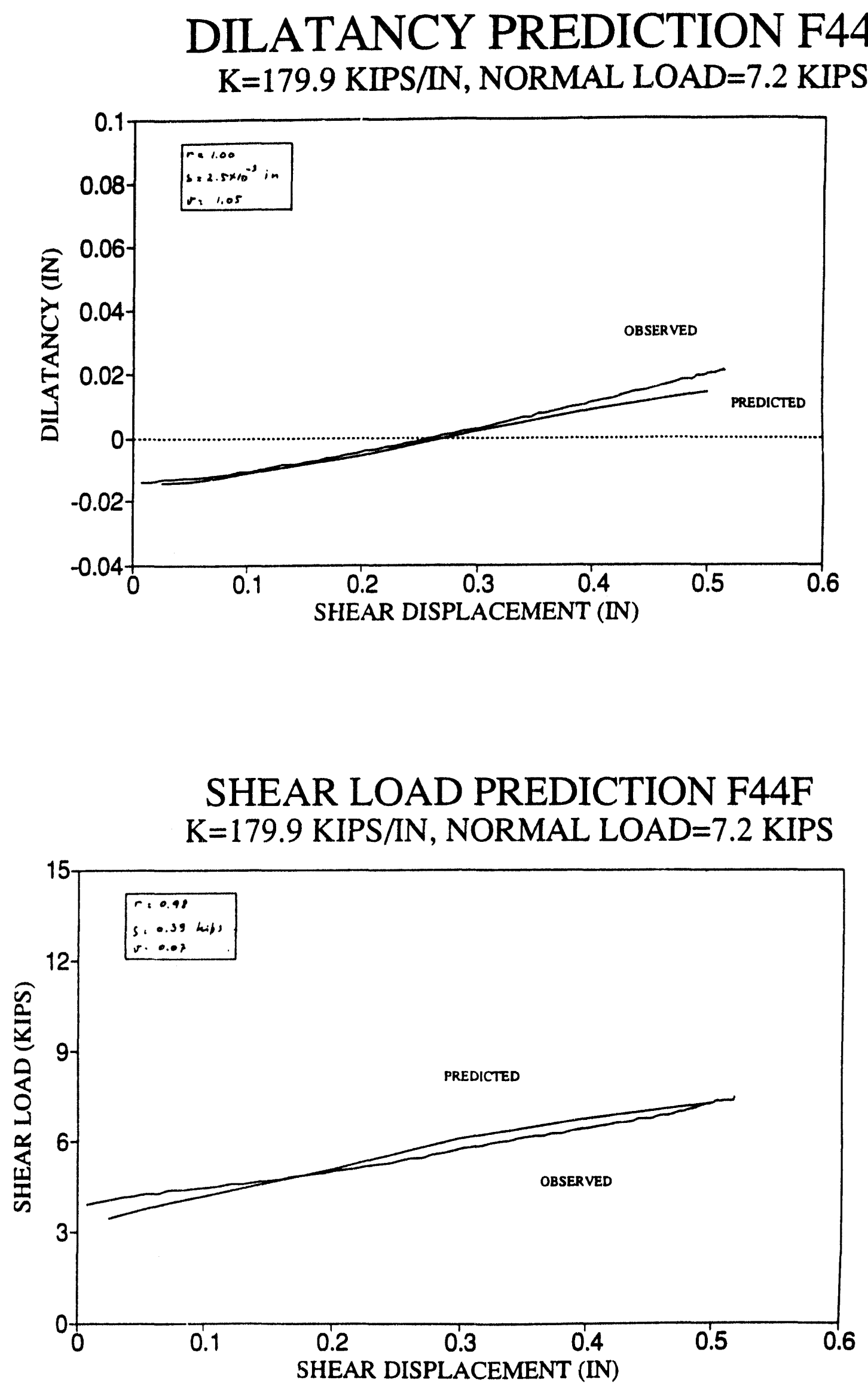


\section{DILATANCY PREDICTION F44R $\mathrm{K}=179.9 \mathrm{KIPS} / \mathrm{IN}$, NORMAL LOAD=7.2 KIPS}

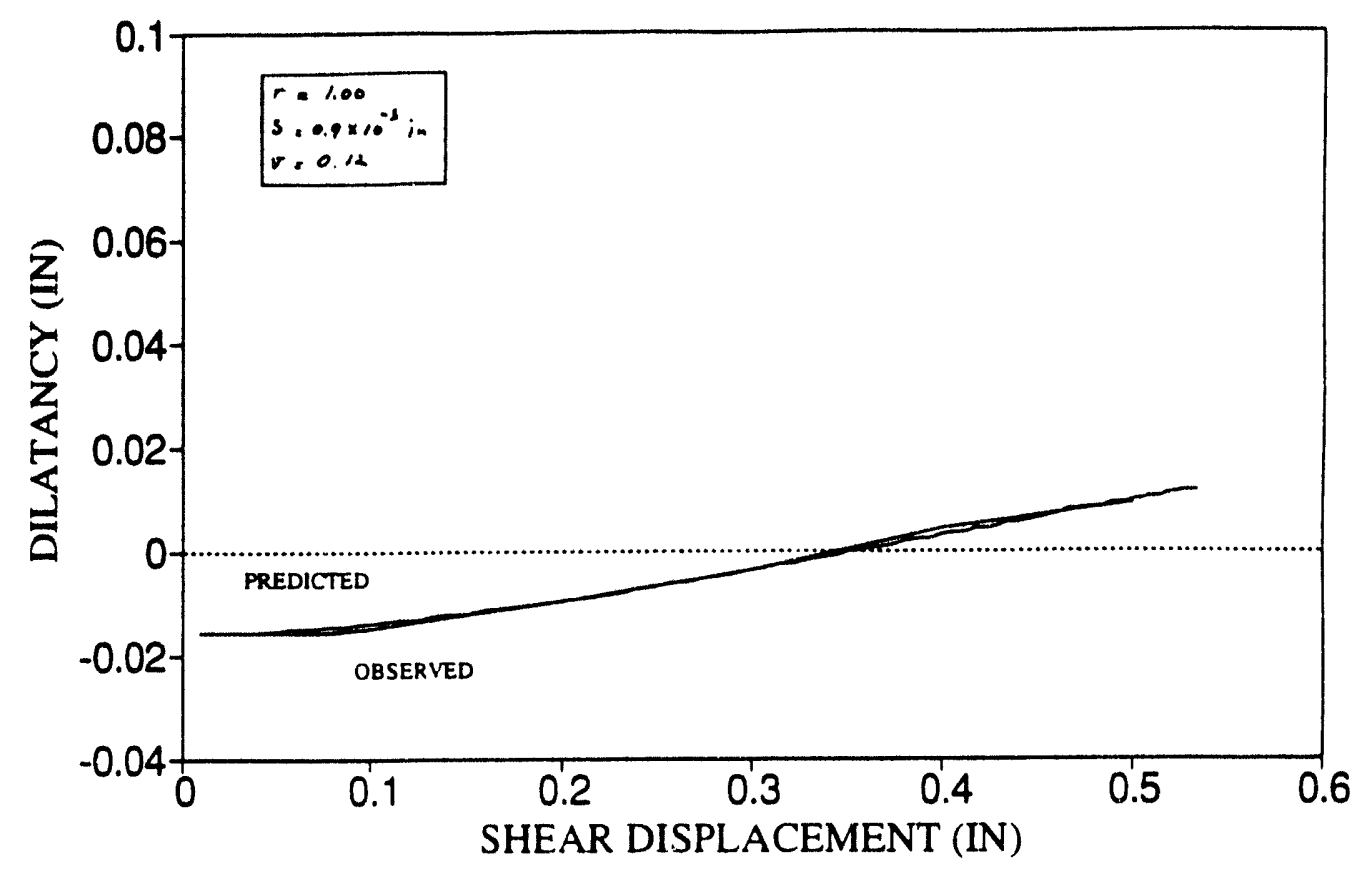

SHEAR LOAD PREDICTION F44R $\mathrm{K}=179.9 \mathrm{KIPS} / \mathrm{IN}$, NORMAL LOAD $=7.2 \mathrm{KIPS}$

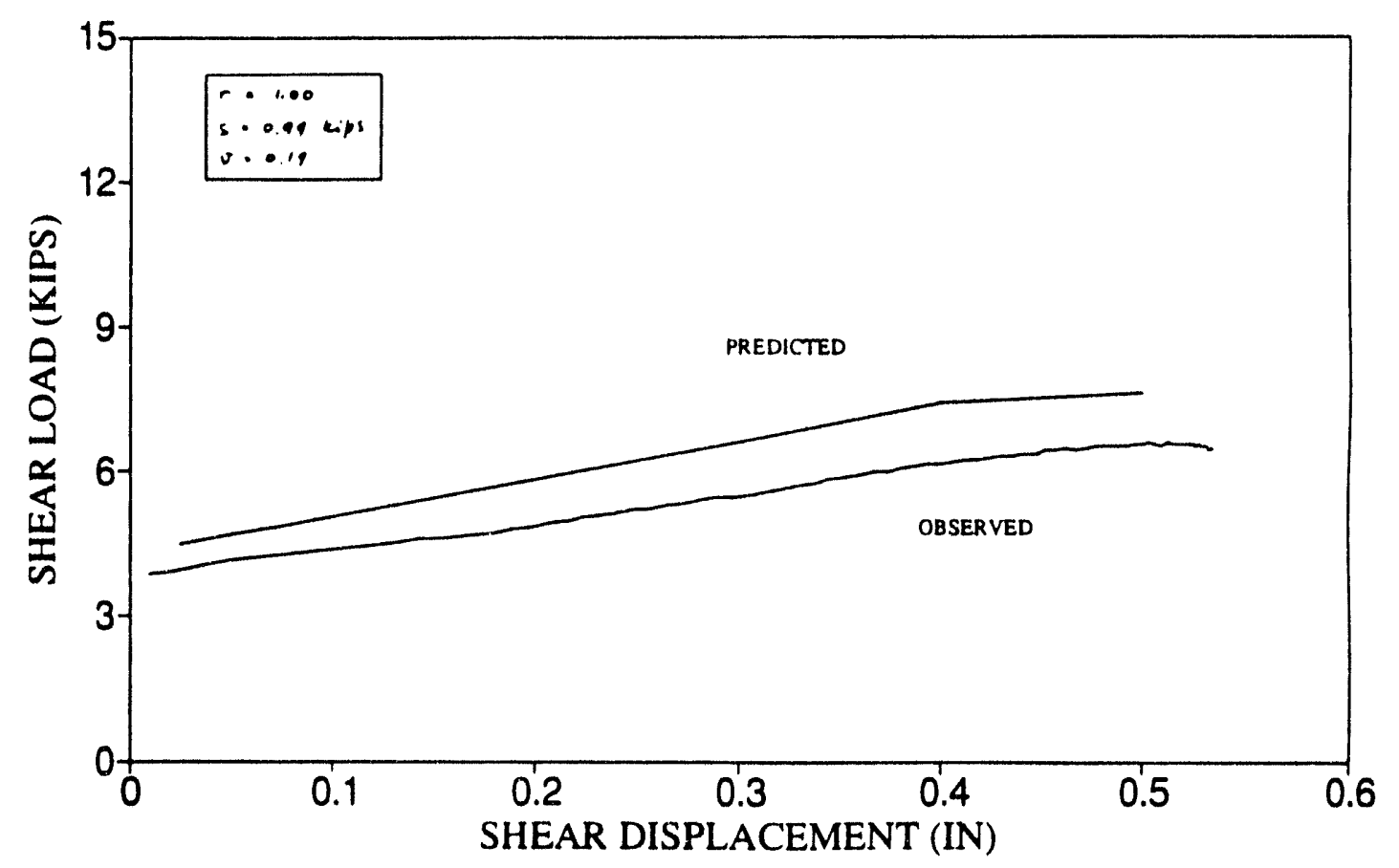




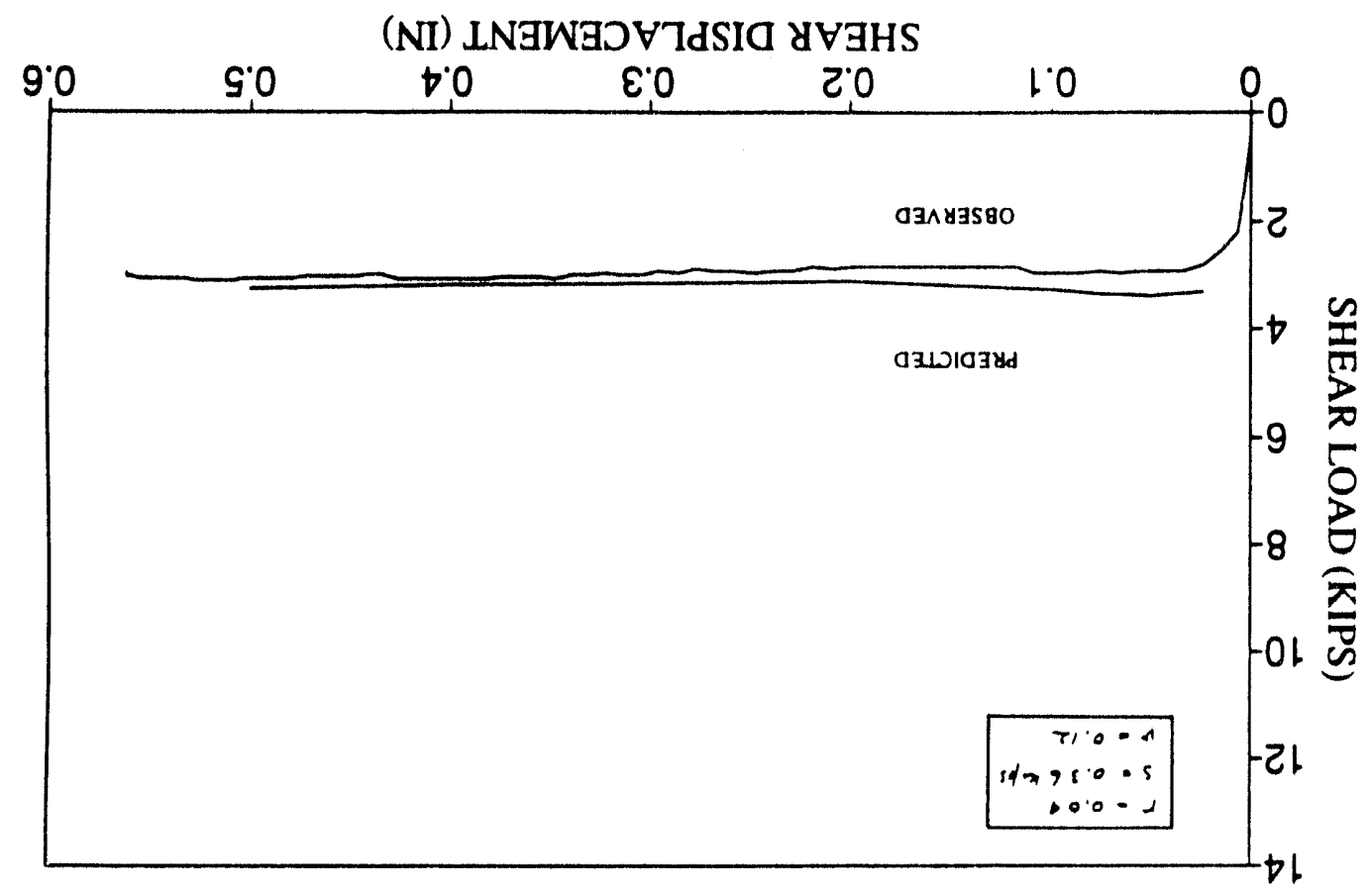

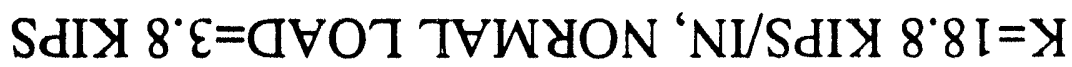

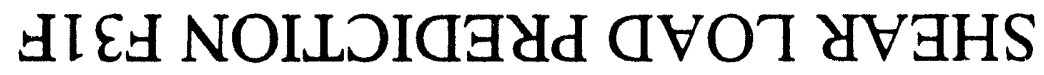

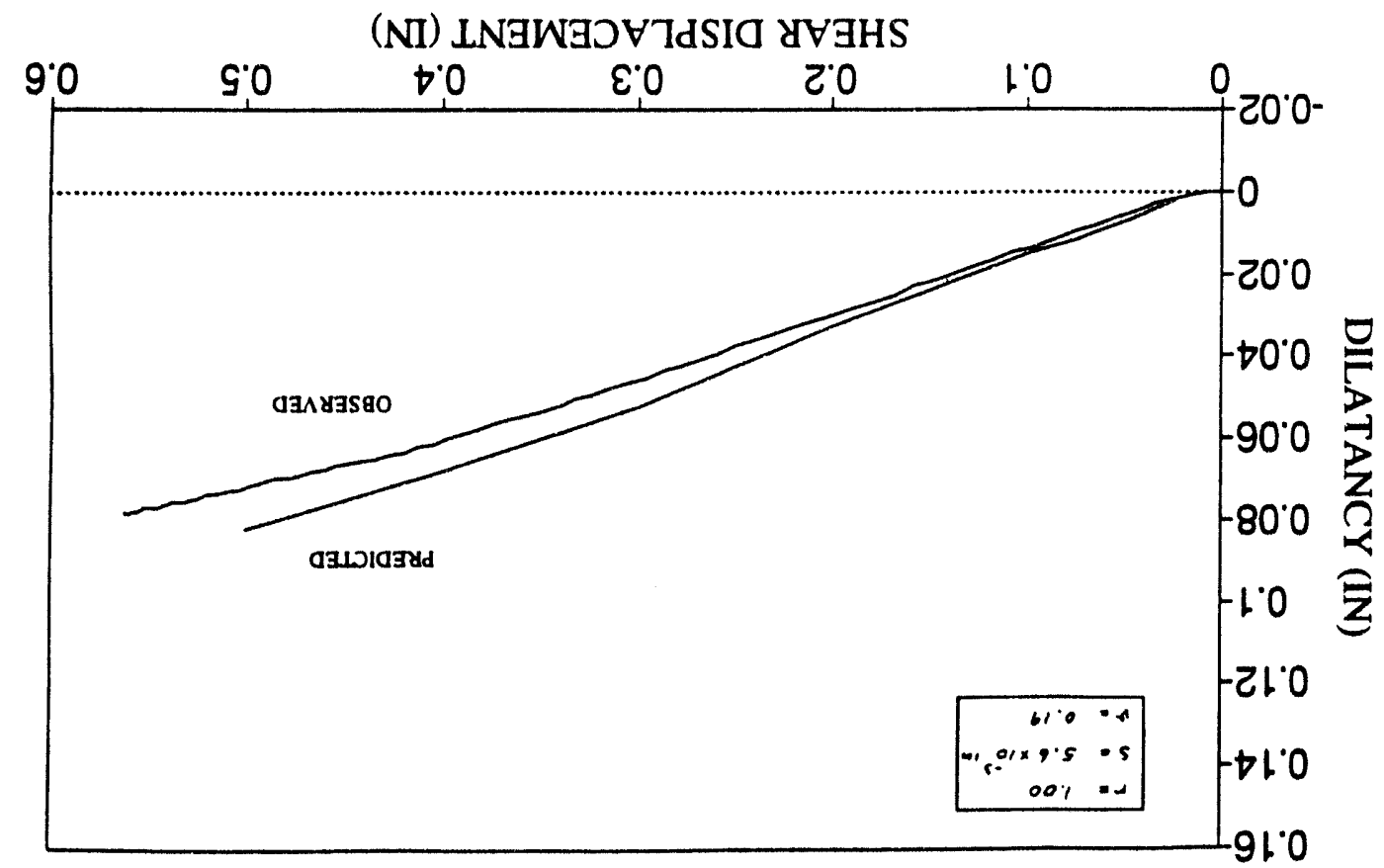

SdIX $8^{\circ} \varepsilon=$ बVOT THWYON 'NI/SdIX $8^{\circ} 8 \mathrm{I}=\mathrm{X}$ GIEヨ NOILOIG 


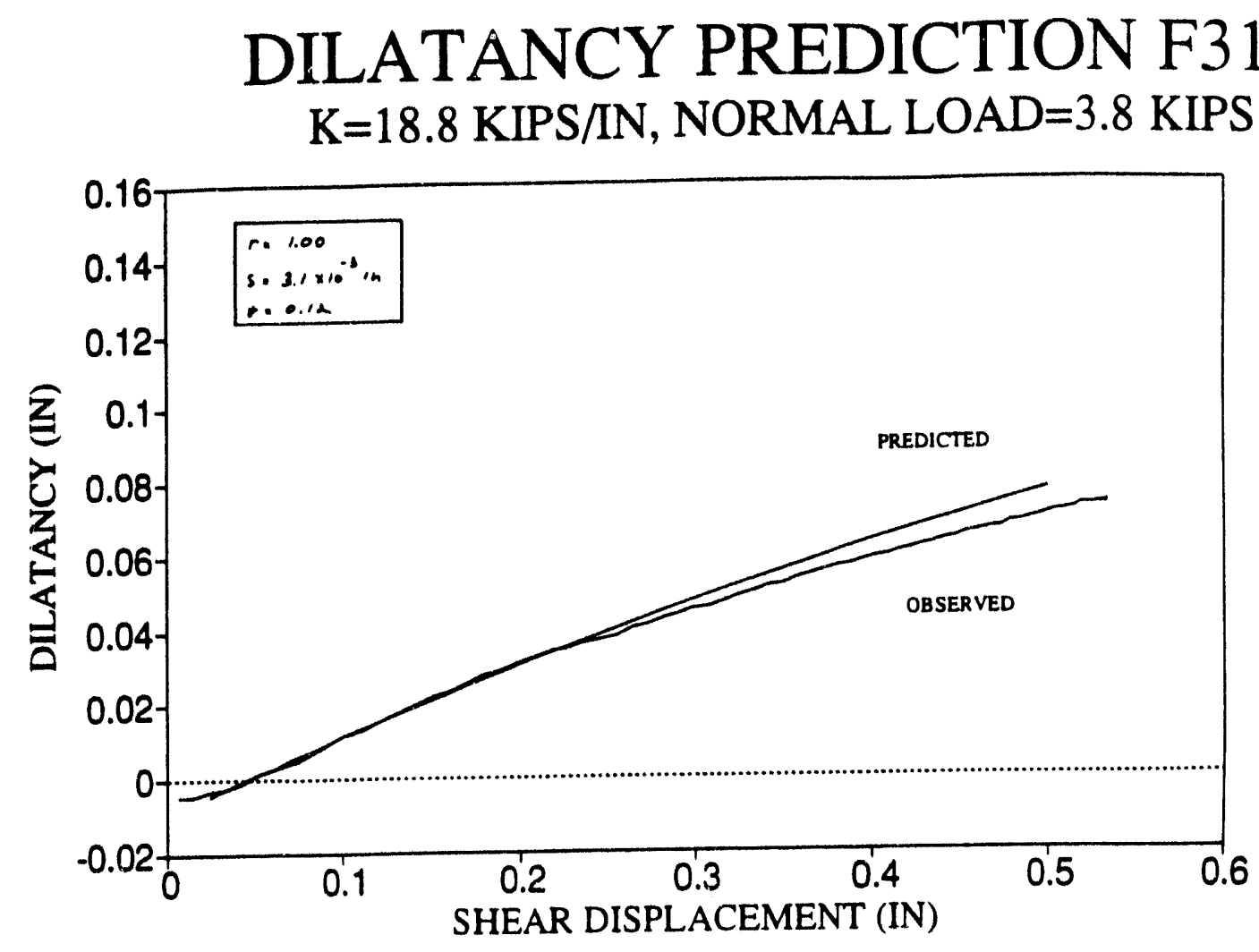

SHEAR LOAD PREDICTION F31R $\mathrm{K}=18.8 \mathrm{KIPS} / \mathrm{IN}$, NORMAL LOAD=3.8 KIPS

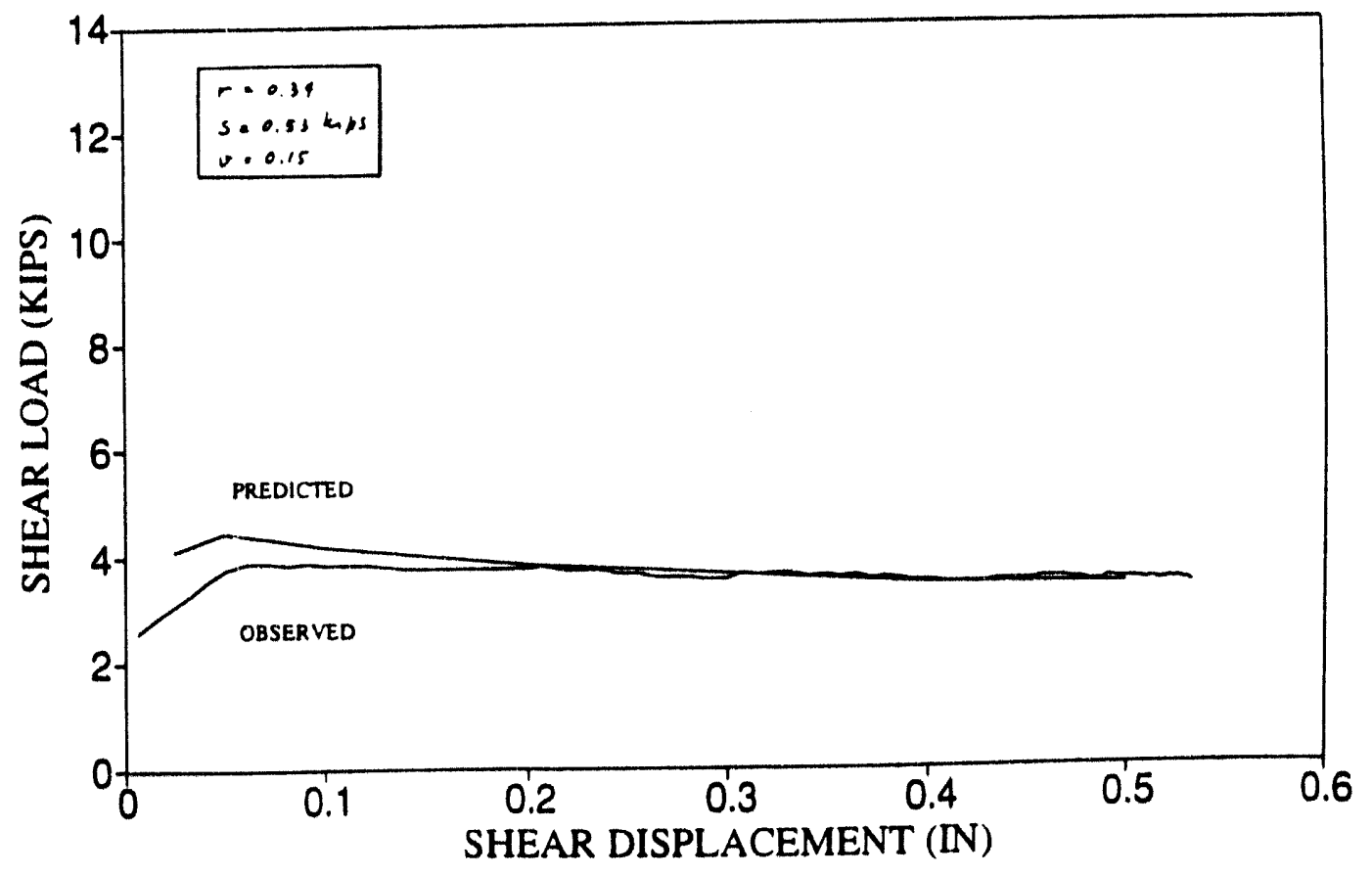


DILATANCY PREDICTION F32F $\mathrm{K}=18.8 \mathrm{KIPS} / \mathrm{IN}$, NORMAL LOAD=3.8 KIPS

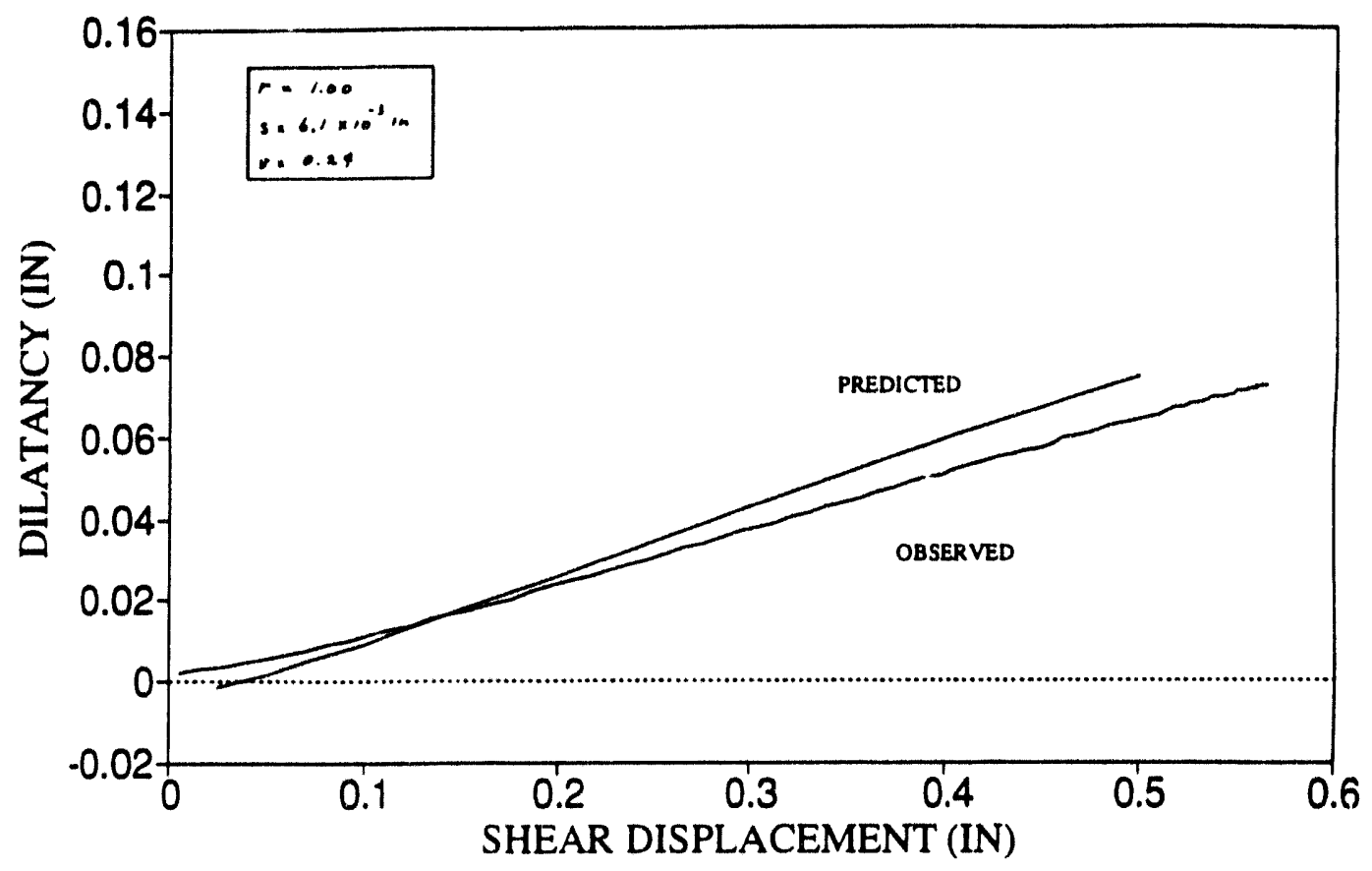

SHEAR LOAD PREDICTION F32F $\mathrm{K}=18.8 \mathrm{KIPS} / \mathrm{IN}$, NORMAL LOAD=3.8 KIPS

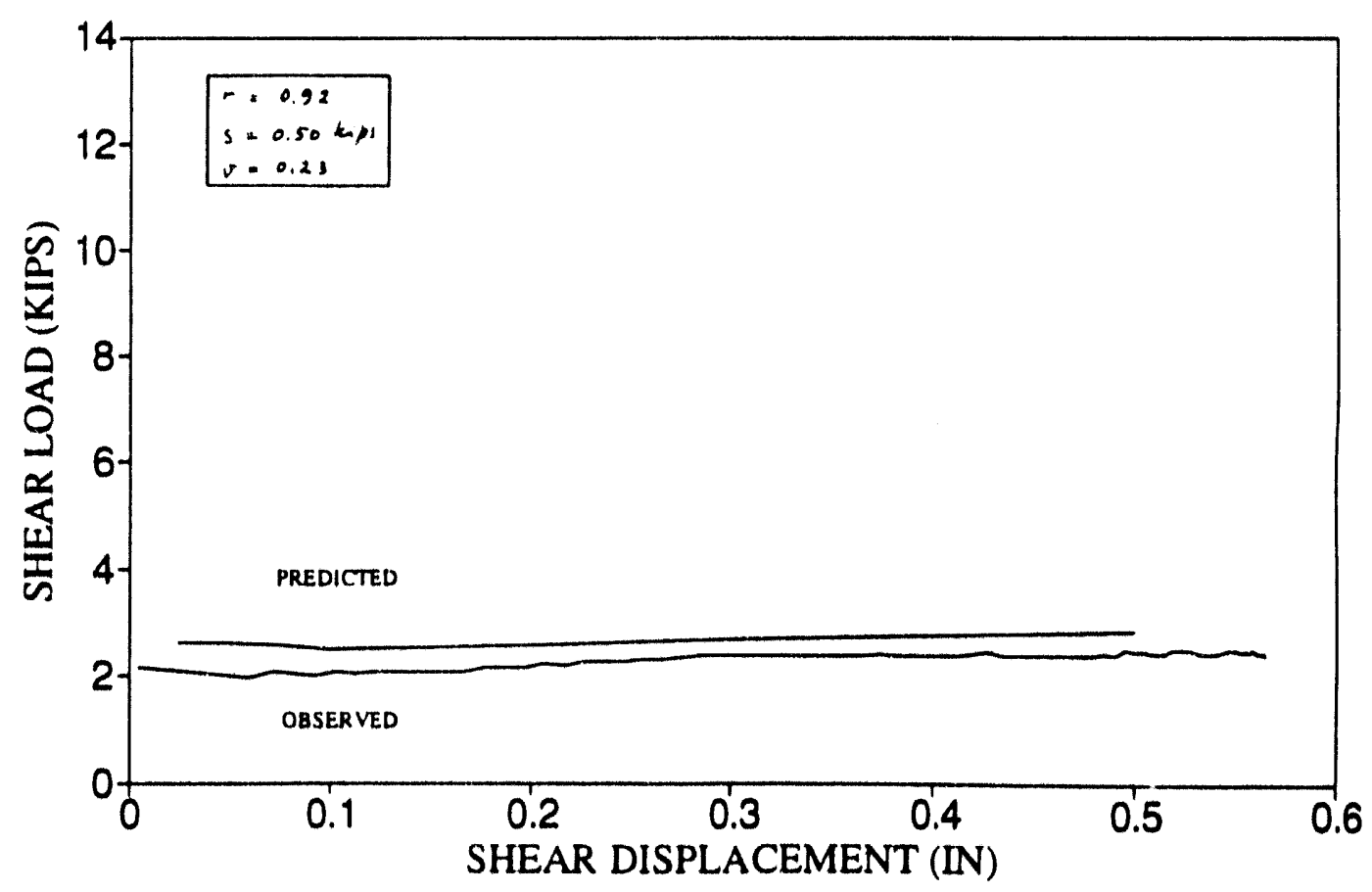



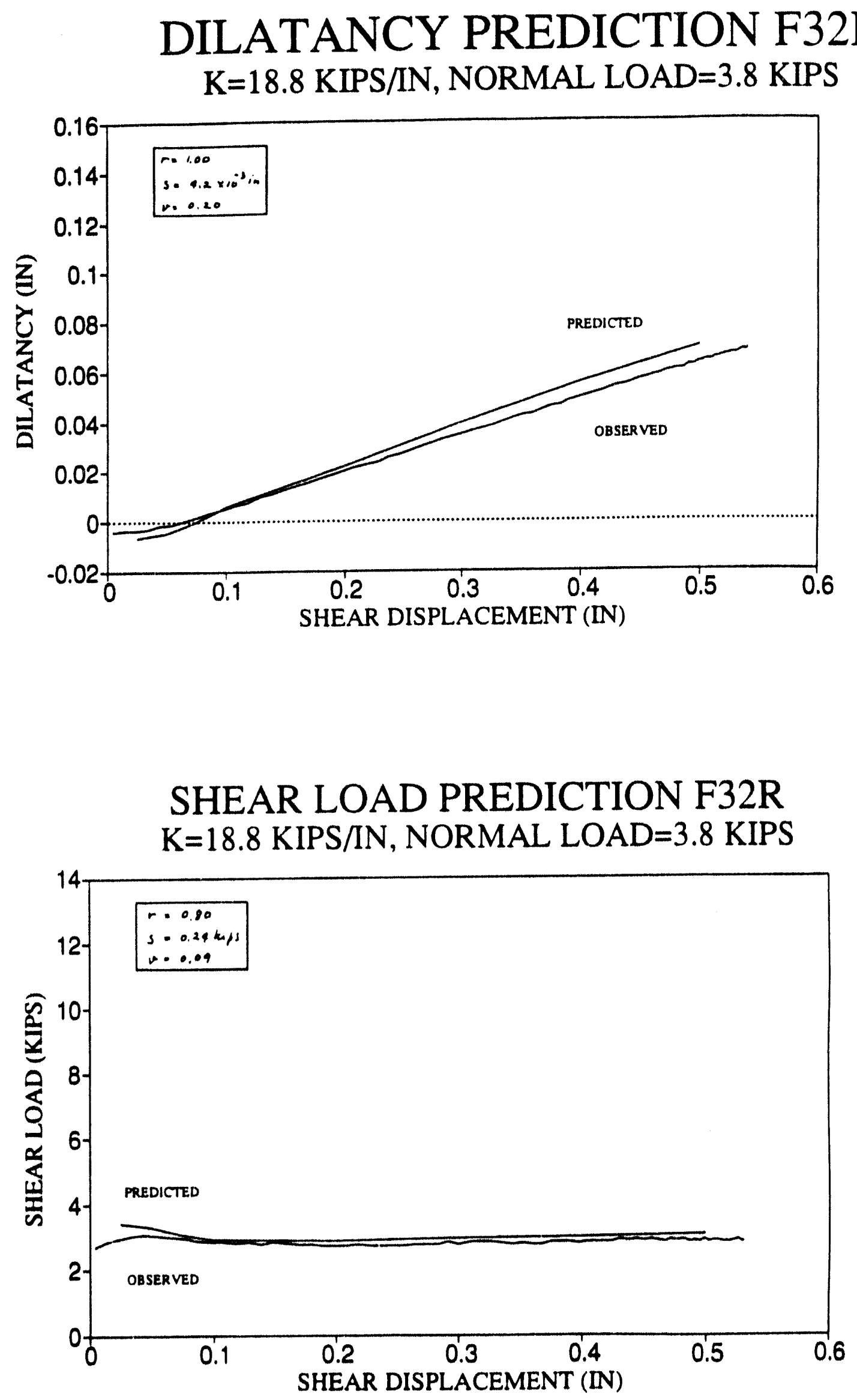

B -52 


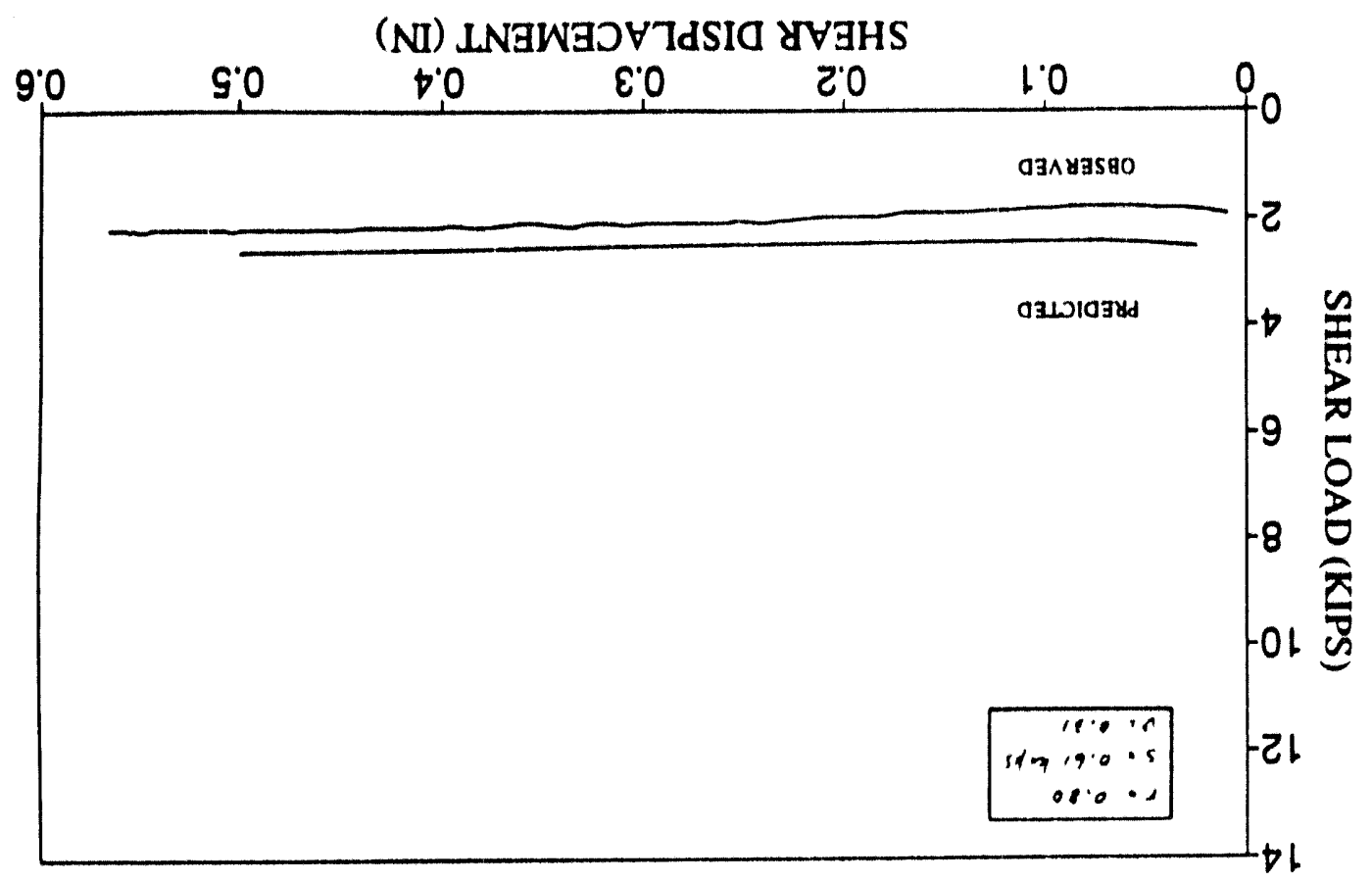

SdIY $8^{\circ} \varepsilon=$ G $\forall 07$ T TWYON 'NI/SdIX 8.8I=X

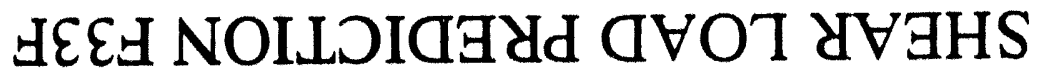

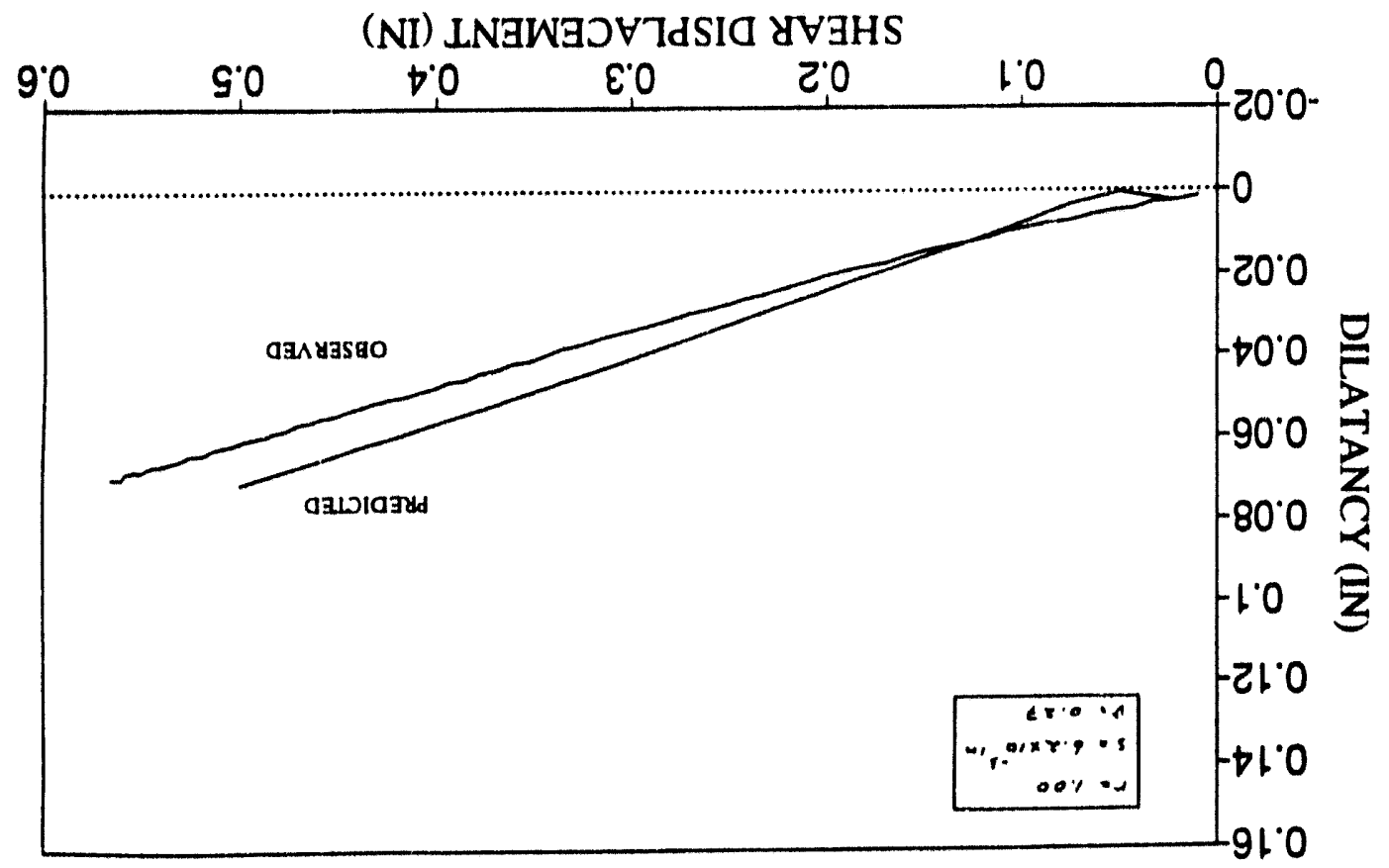

SdIY $8^{\circ} \varepsilon=$ व

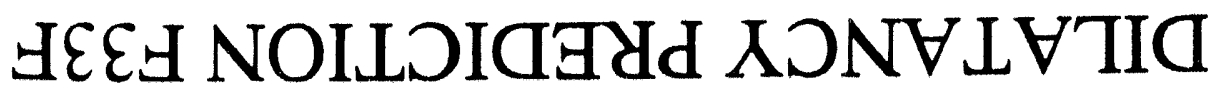



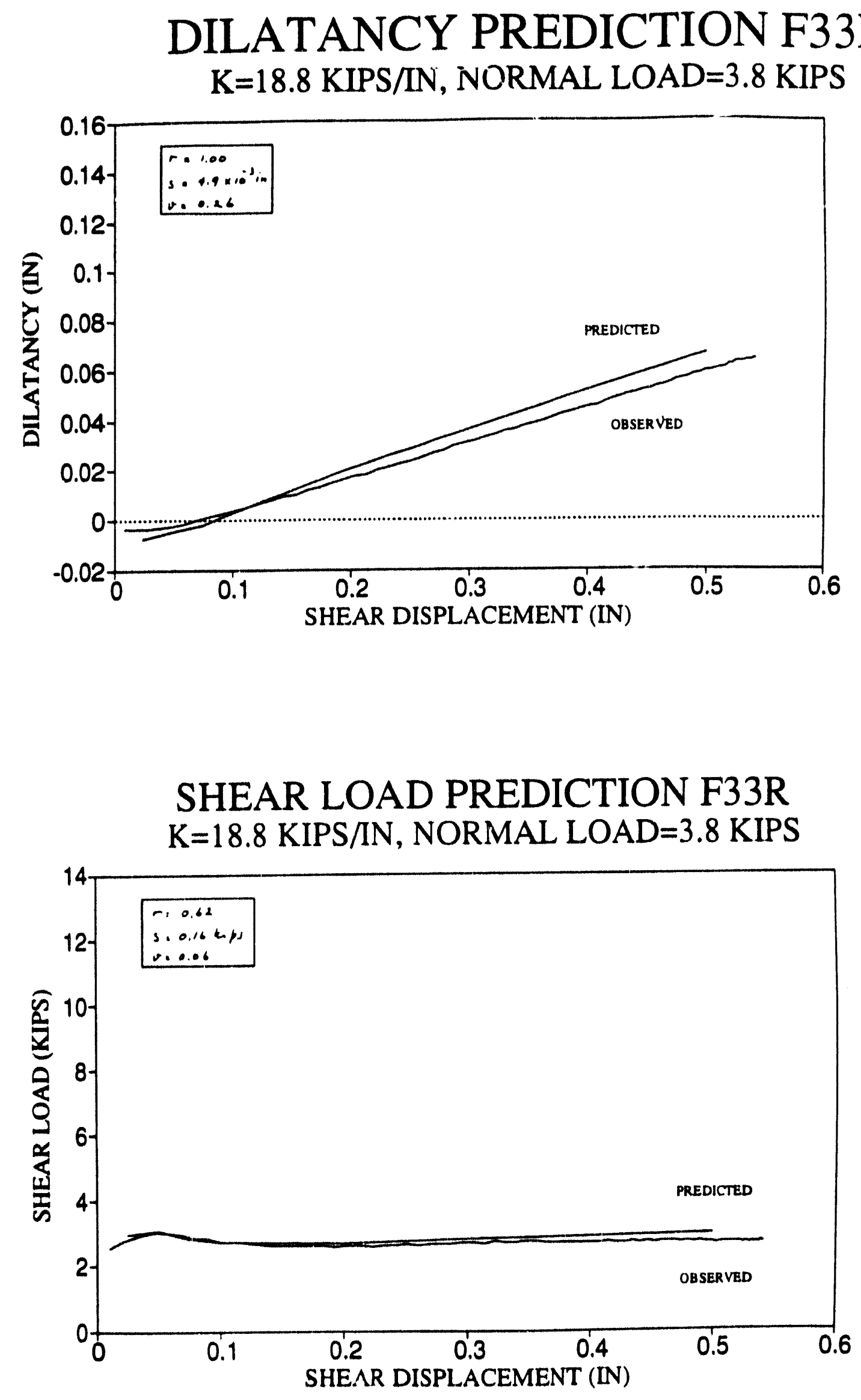

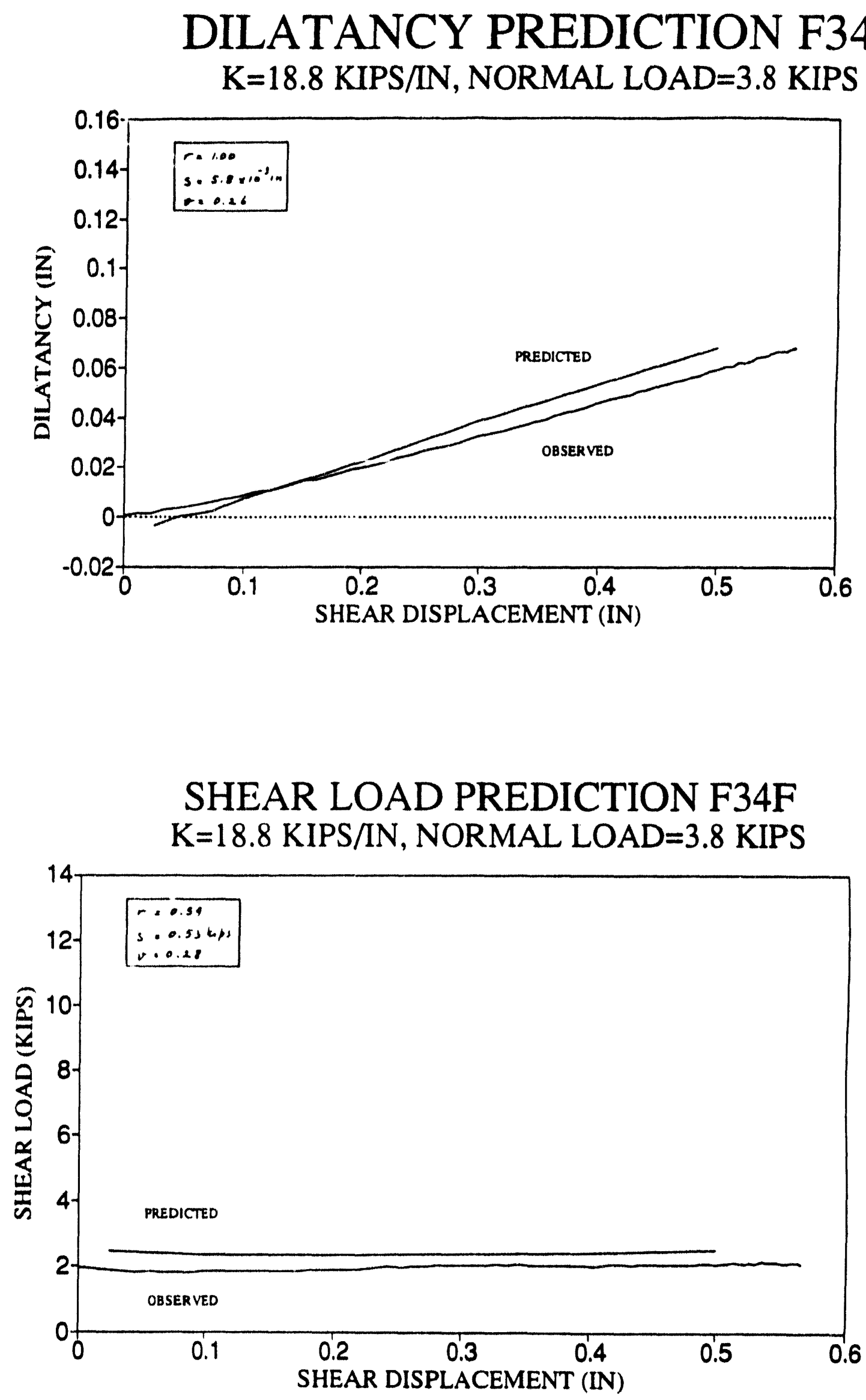

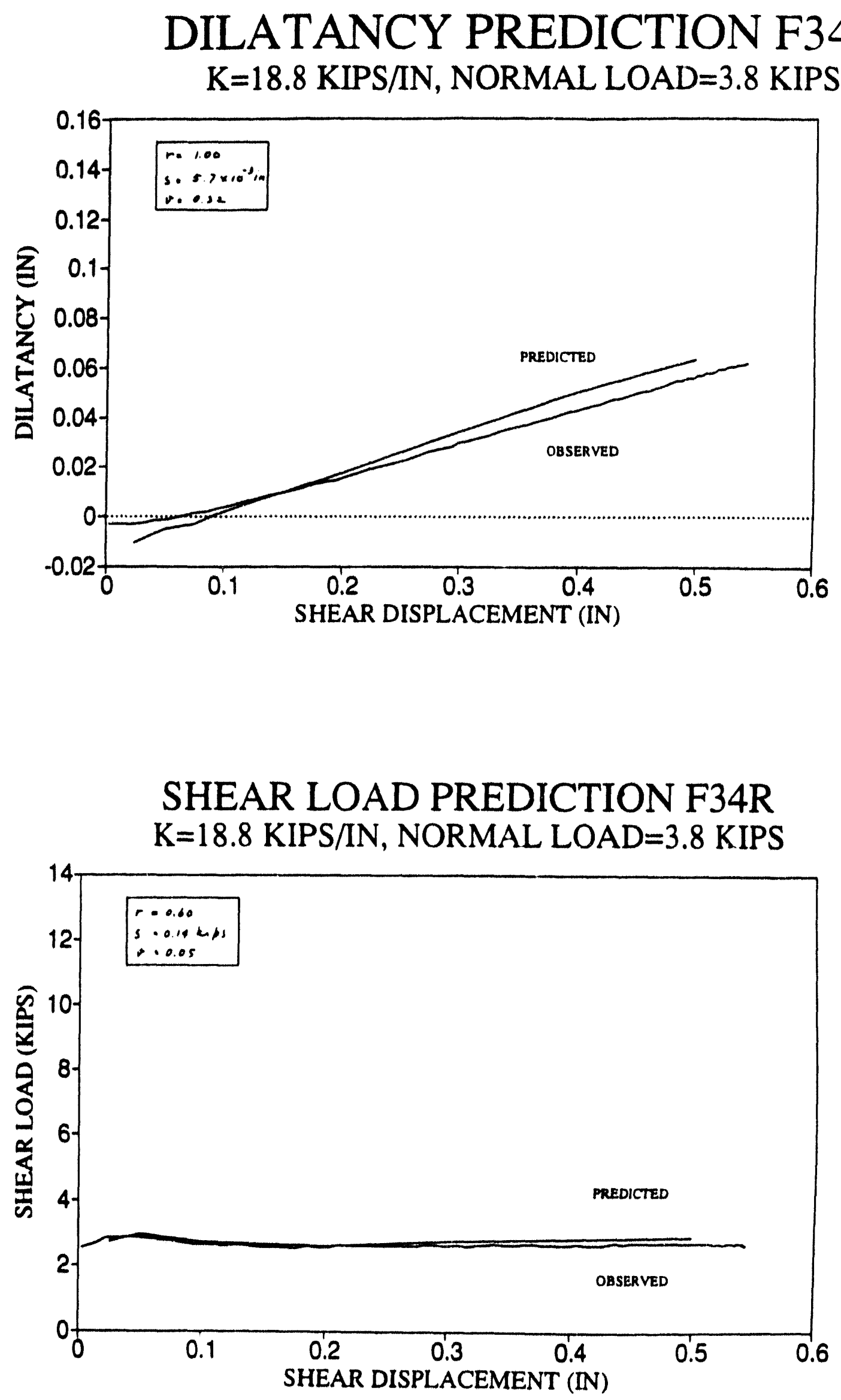

B-56 


\section{DILATANCY PREDICTION F35F $\mathrm{K}=18.8 \mathrm{KIPS} / \mathrm{IN}$, NORMAL LOAD $=3.8 \mathrm{KIPS}$}

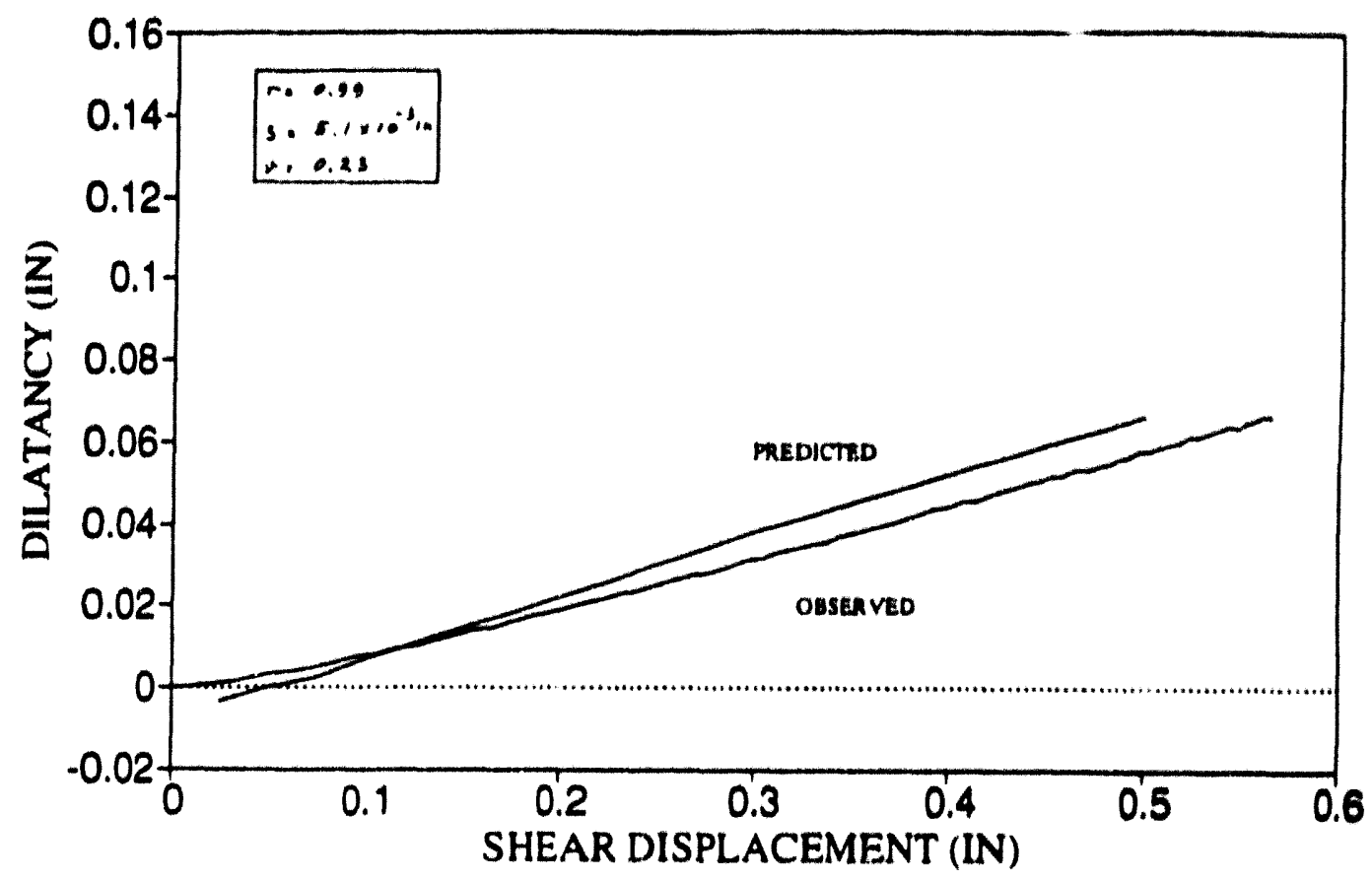

SHEAR LOAD PREDICTION F35F $\mathrm{K}=18.8 \mathrm{KIPS} / \mathrm{IN}$, NORMAL LOAD $=3.8 \mathrm{KIPS}$

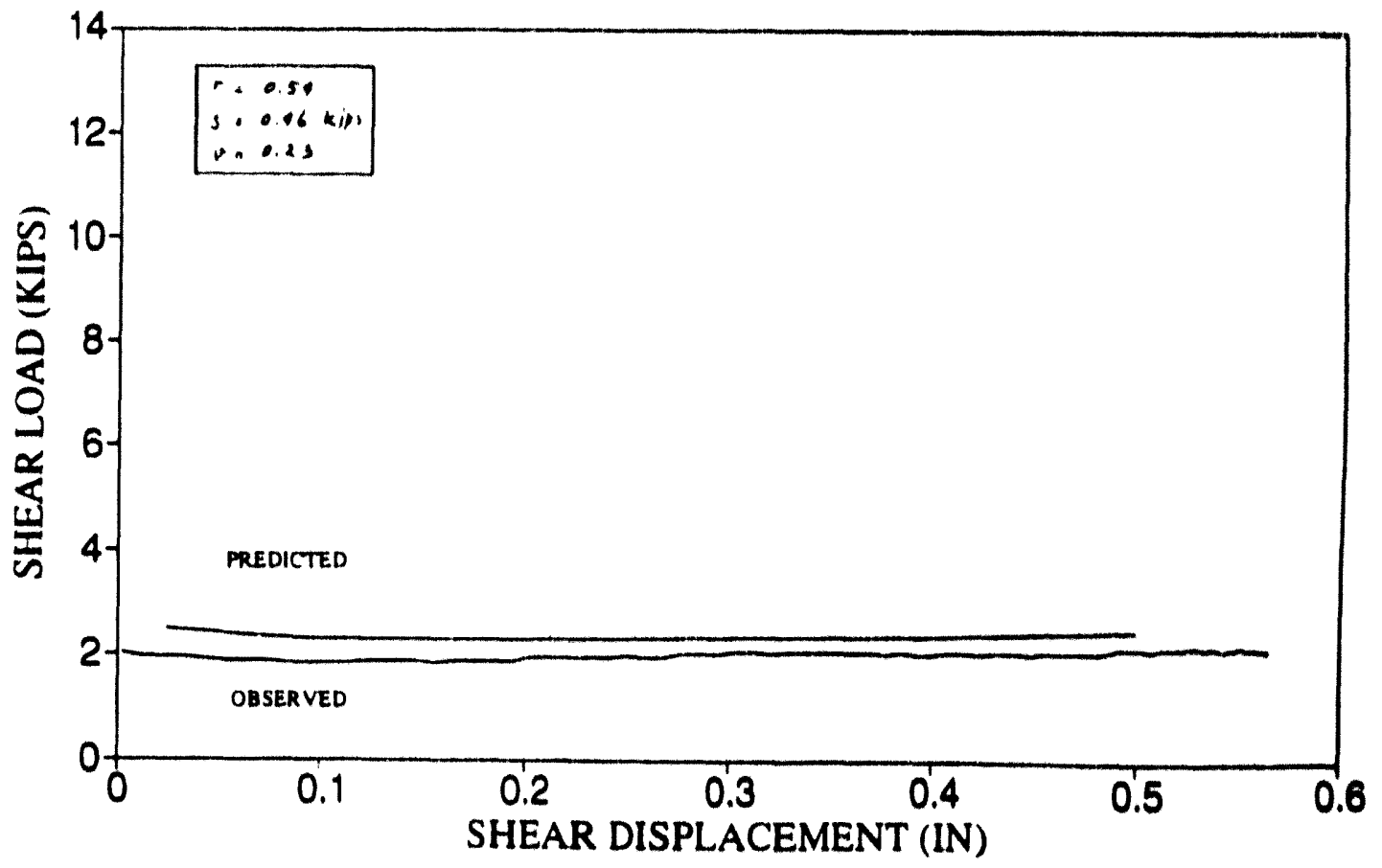



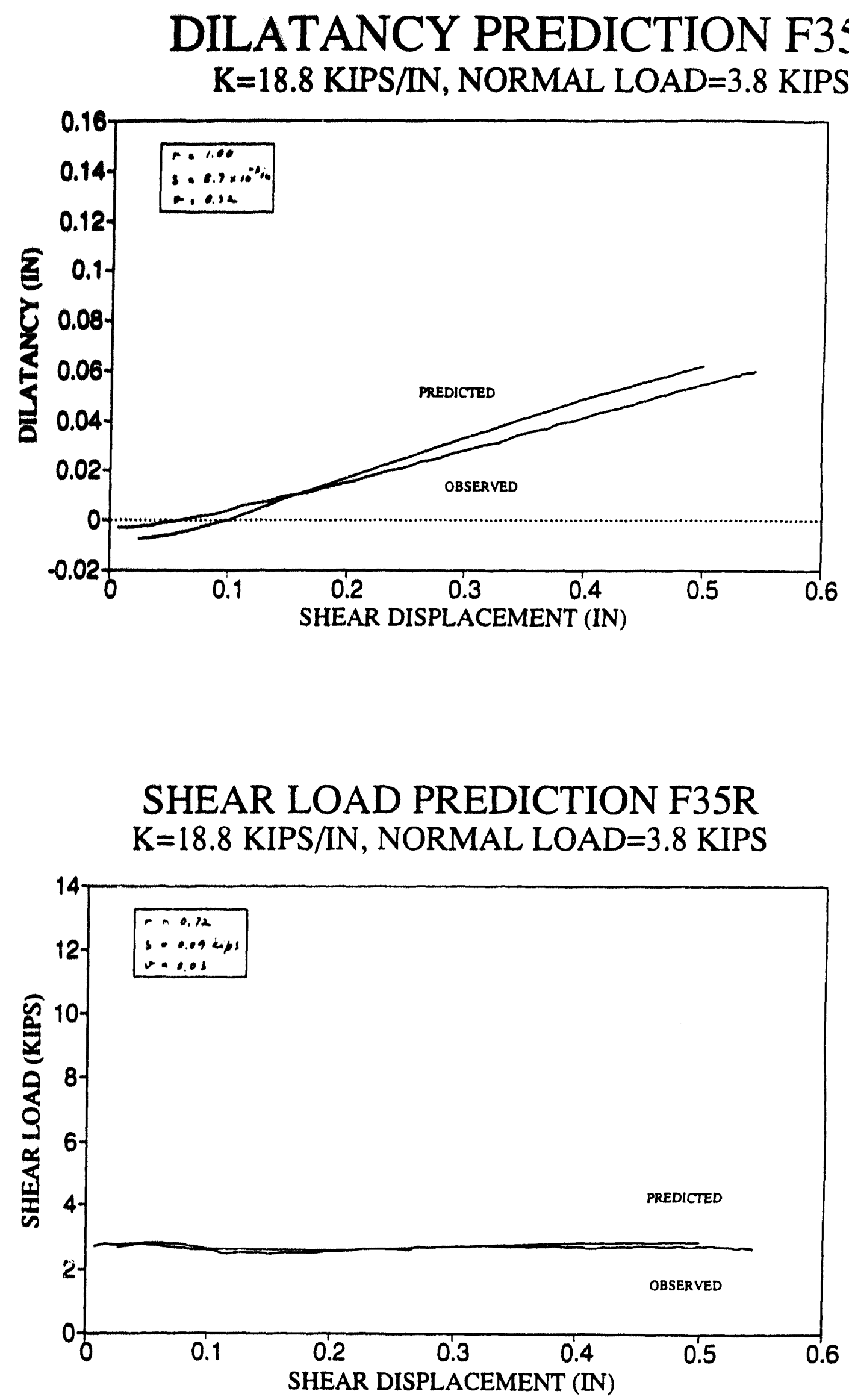


\section{DILATANCY PREDICTION F31F $\mathrm{K}=56.3 \mathrm{KIPS} / \mathrm{IN}$, NORMAL LOAD=3.8 KIPS}

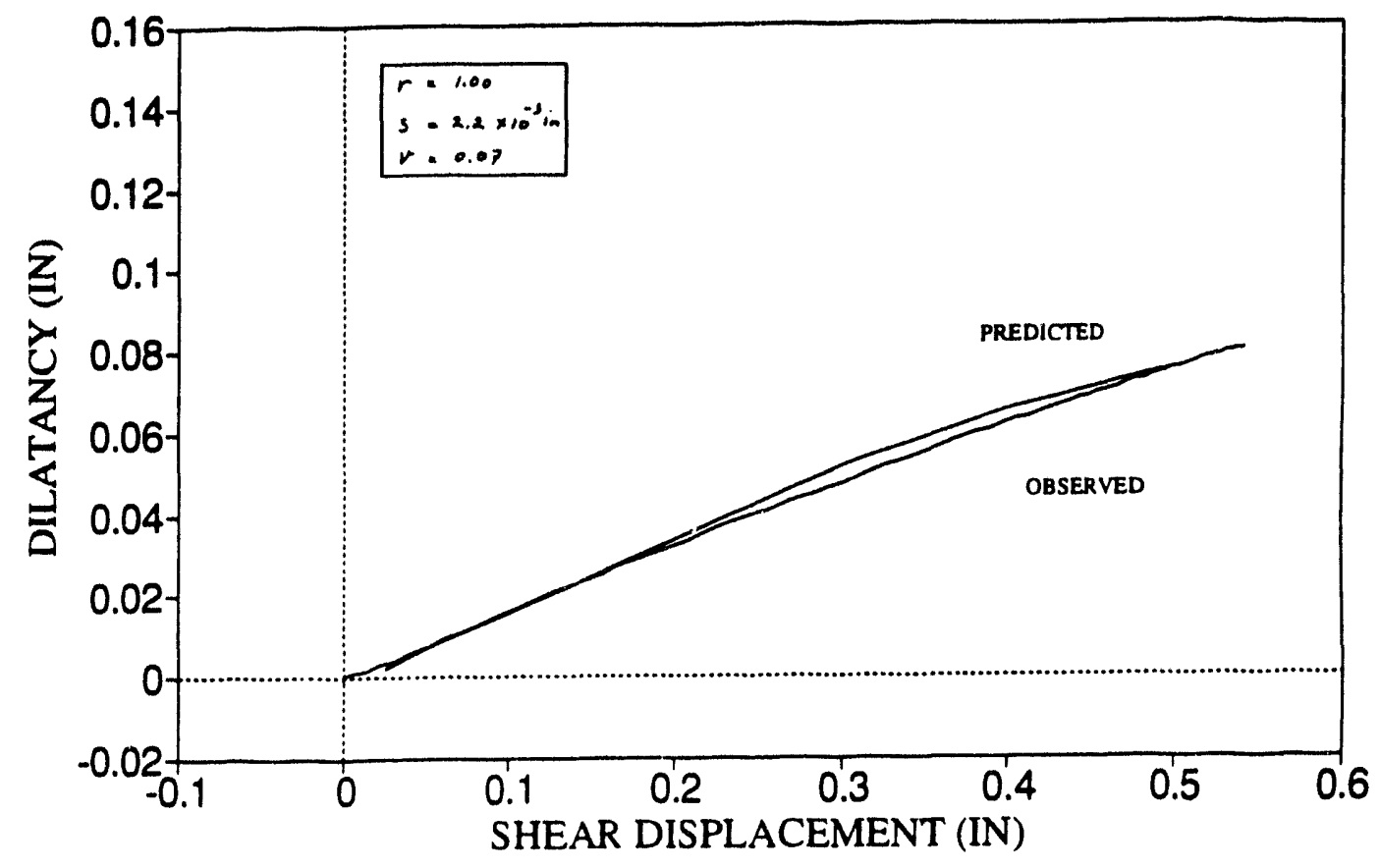

SHEAR LOAD PREDICTION F31F $\mathrm{K}=56.3 \mathrm{KIPS} / \mathrm{IN}$, NORMAL LOAD=3.8 KIPS

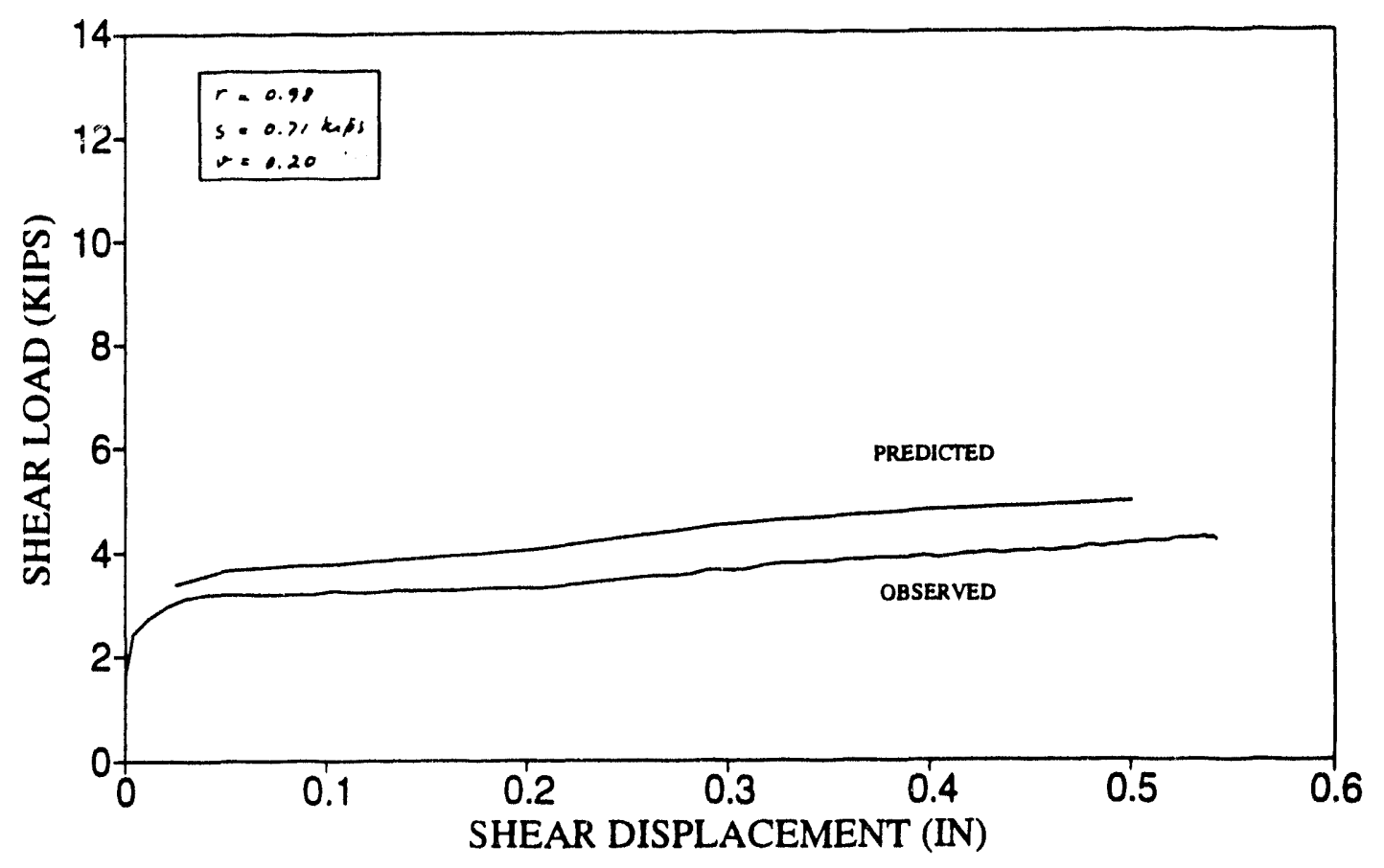




\section{DILATANCY PREDICTION F31R}

$\mathrm{K}=56.3 \mathrm{KIPS} / \mathrm{IN}$, NORMAL LOAD=3.8 KIPS

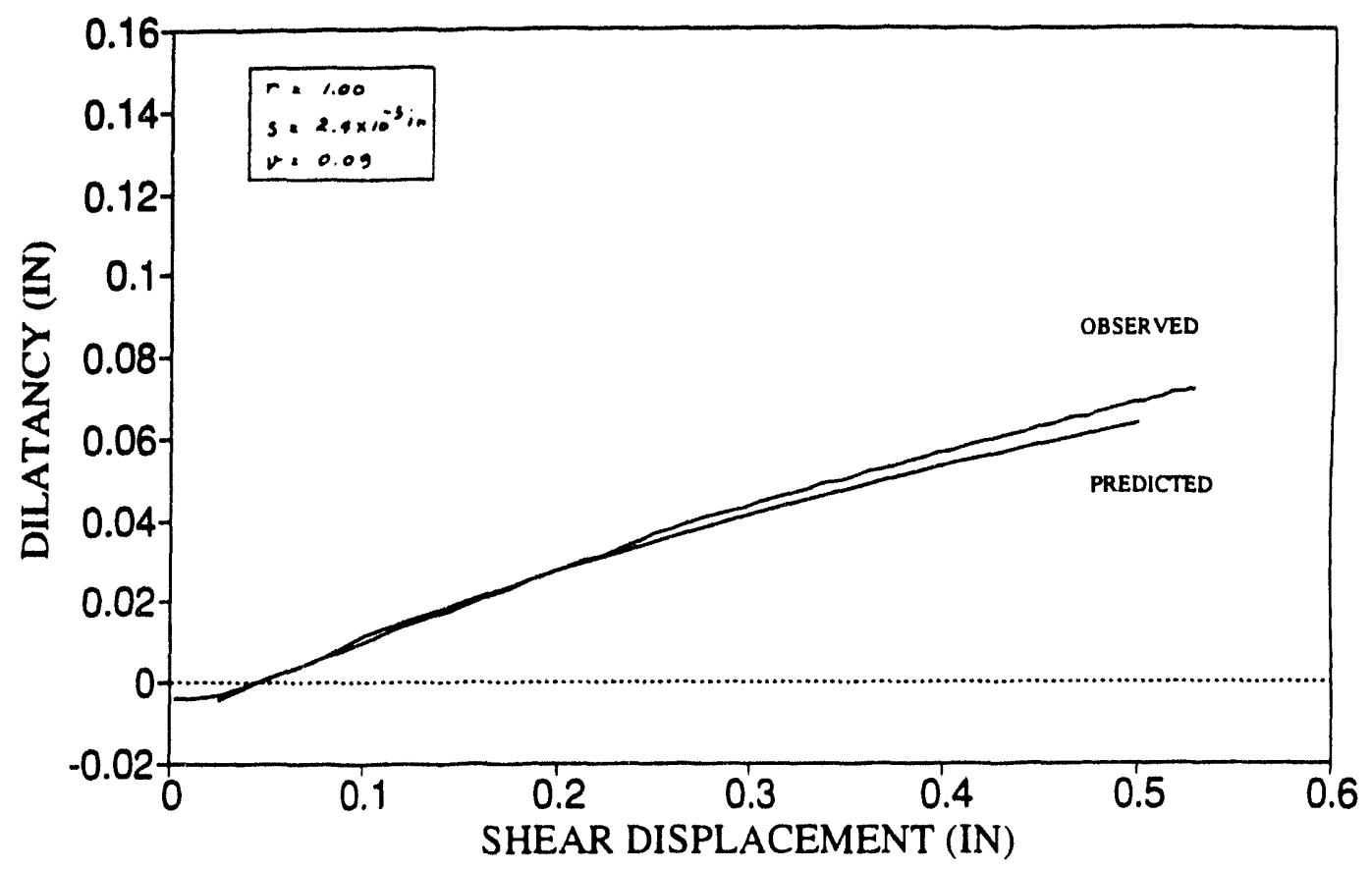

SHEAR LOAD PREDICTION F31R $\mathrm{K}=56.3 \mathrm{KIPS} / \mathrm{IN}$, NORMAL LOAD=3.8 KIPS

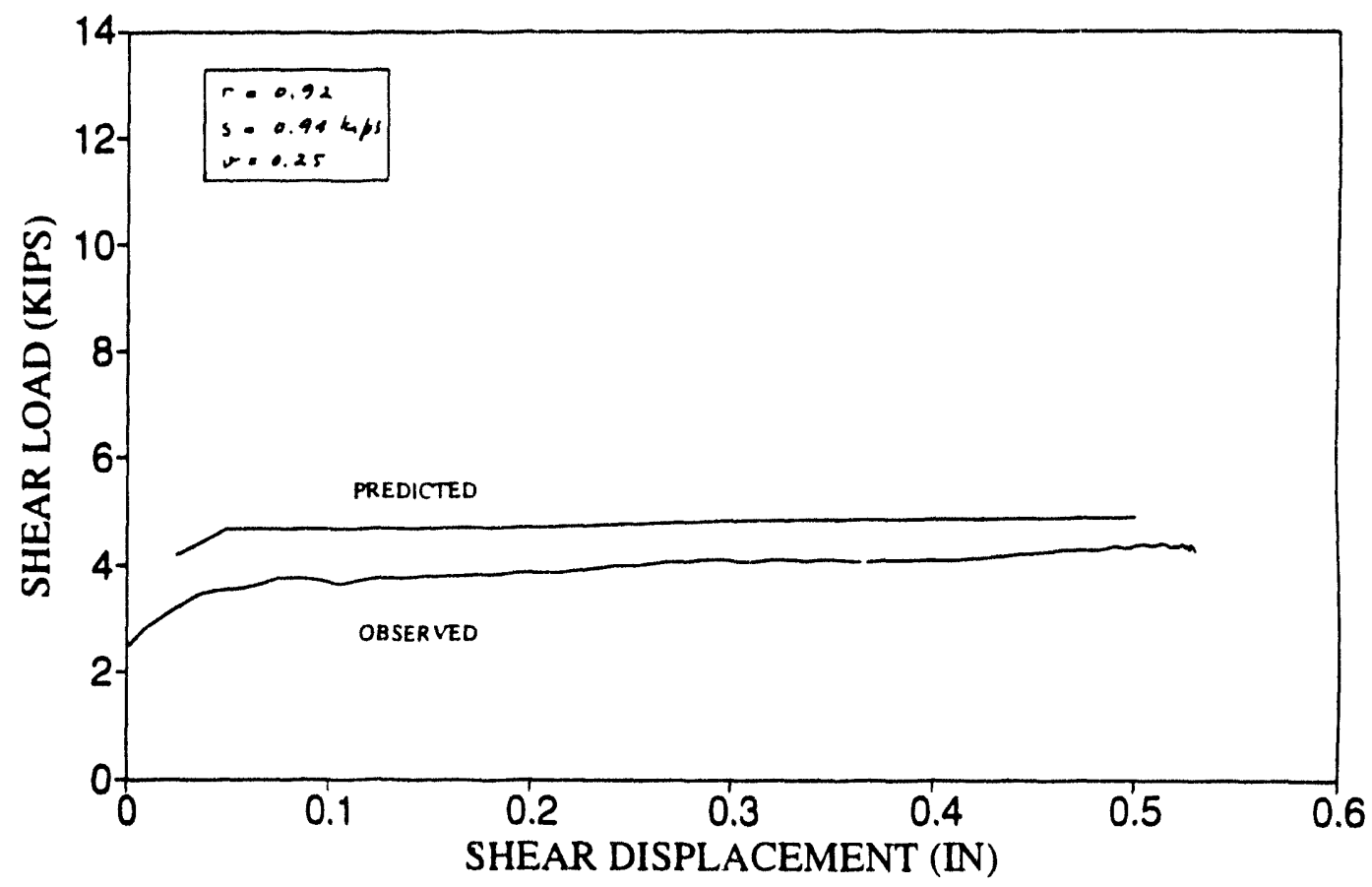



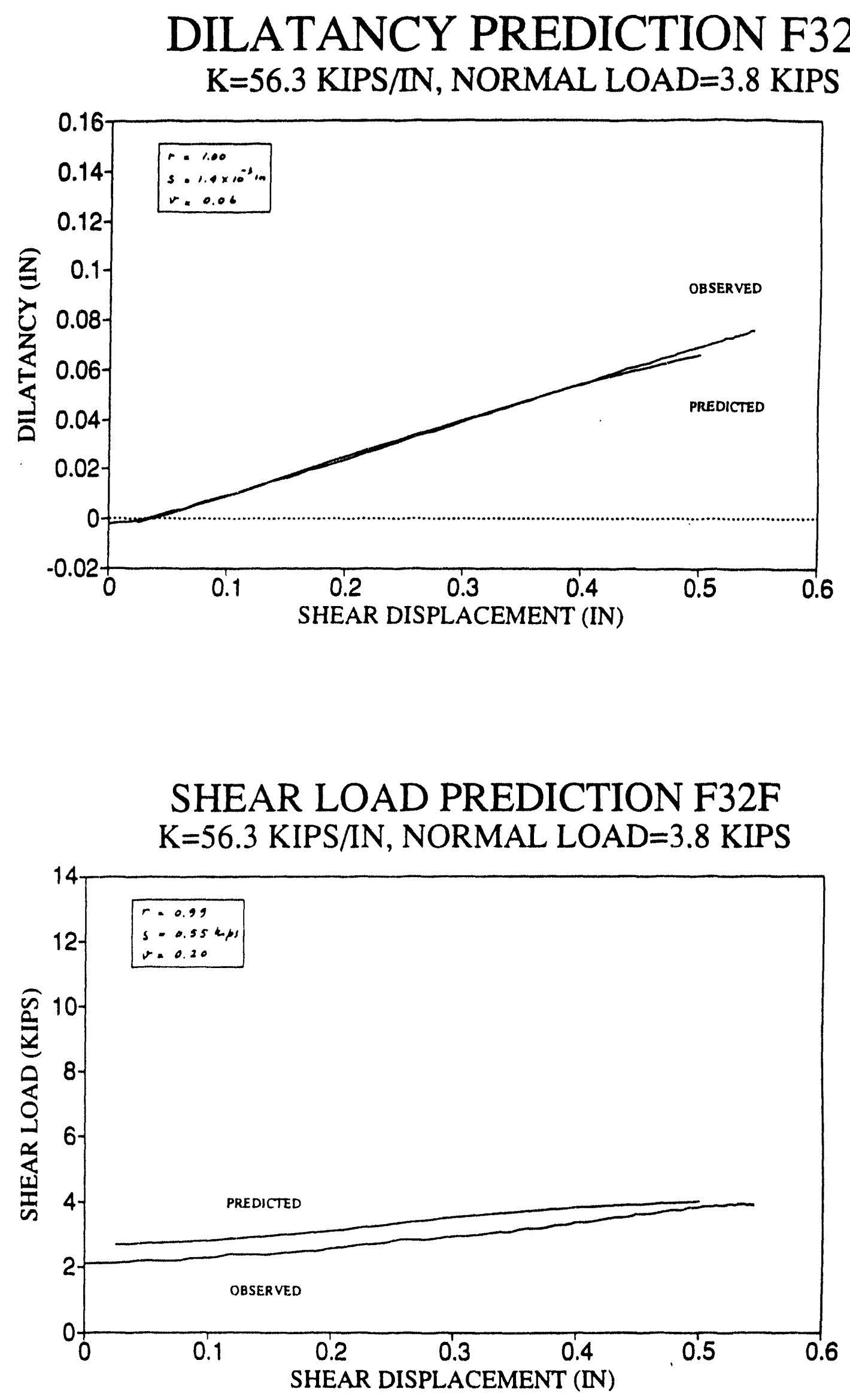

B -61 


\section{DILATANCY PREDICTION F32R $\mathrm{K}=56.3 \mathrm{KIPS} / \mathrm{IN}$, NORMAL LOAD=3.8 KIPS}

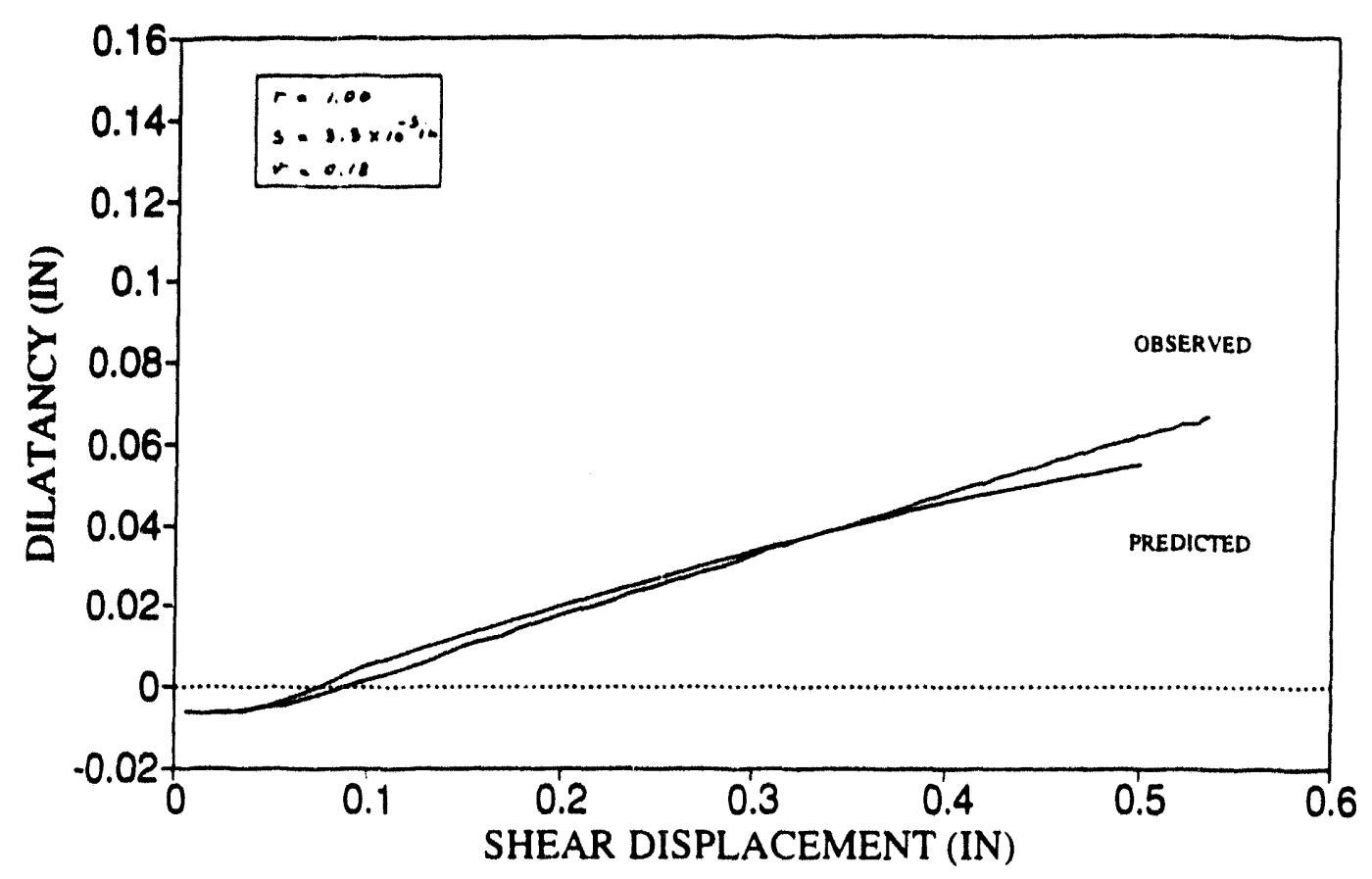

SHEAR LOAD PREDICTION F32R $\mathrm{K}=56.3 \mathrm{KIPS} / \mathrm{IN}$, NORMAL LOAD=3.8 KIPS

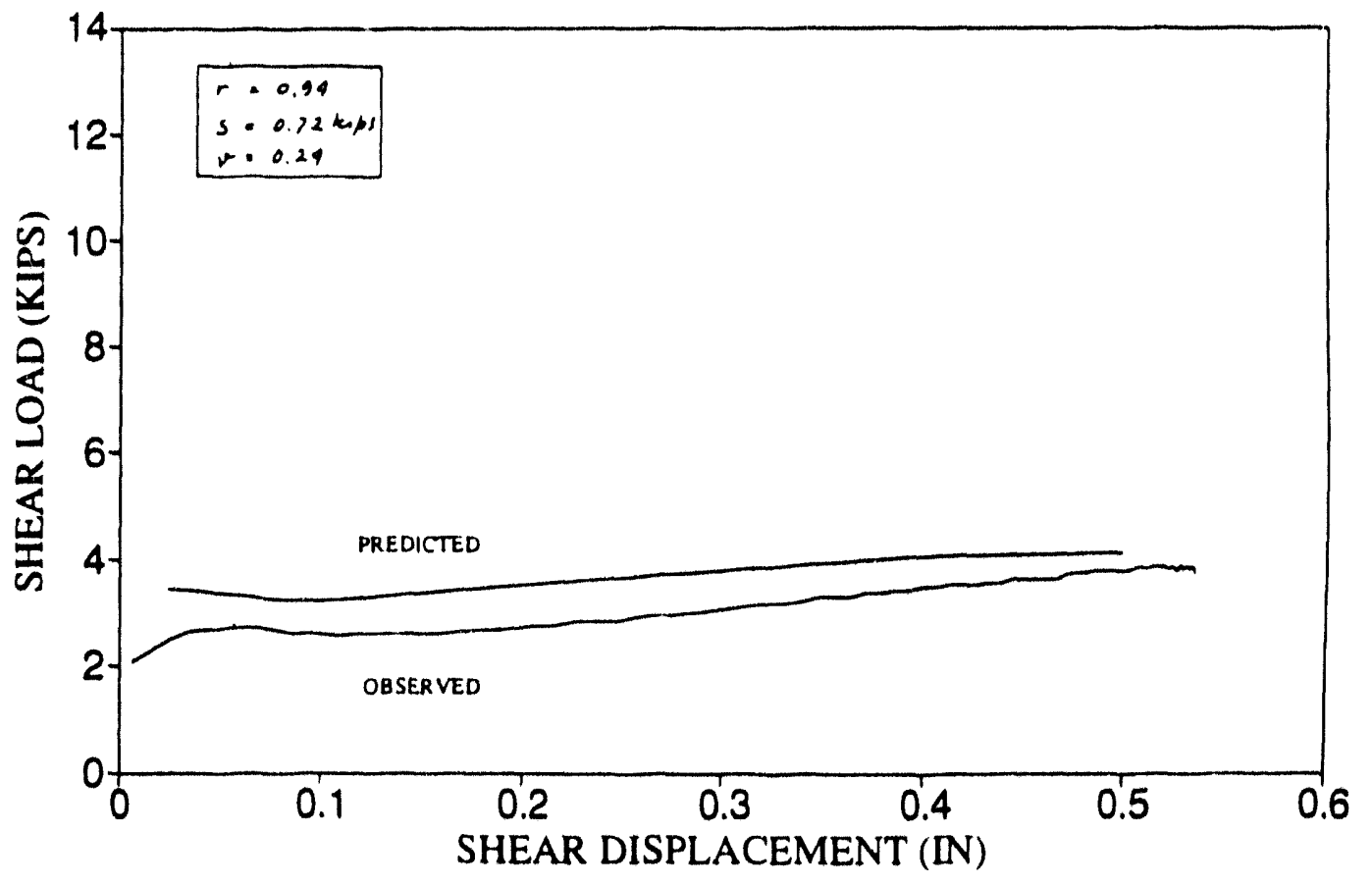




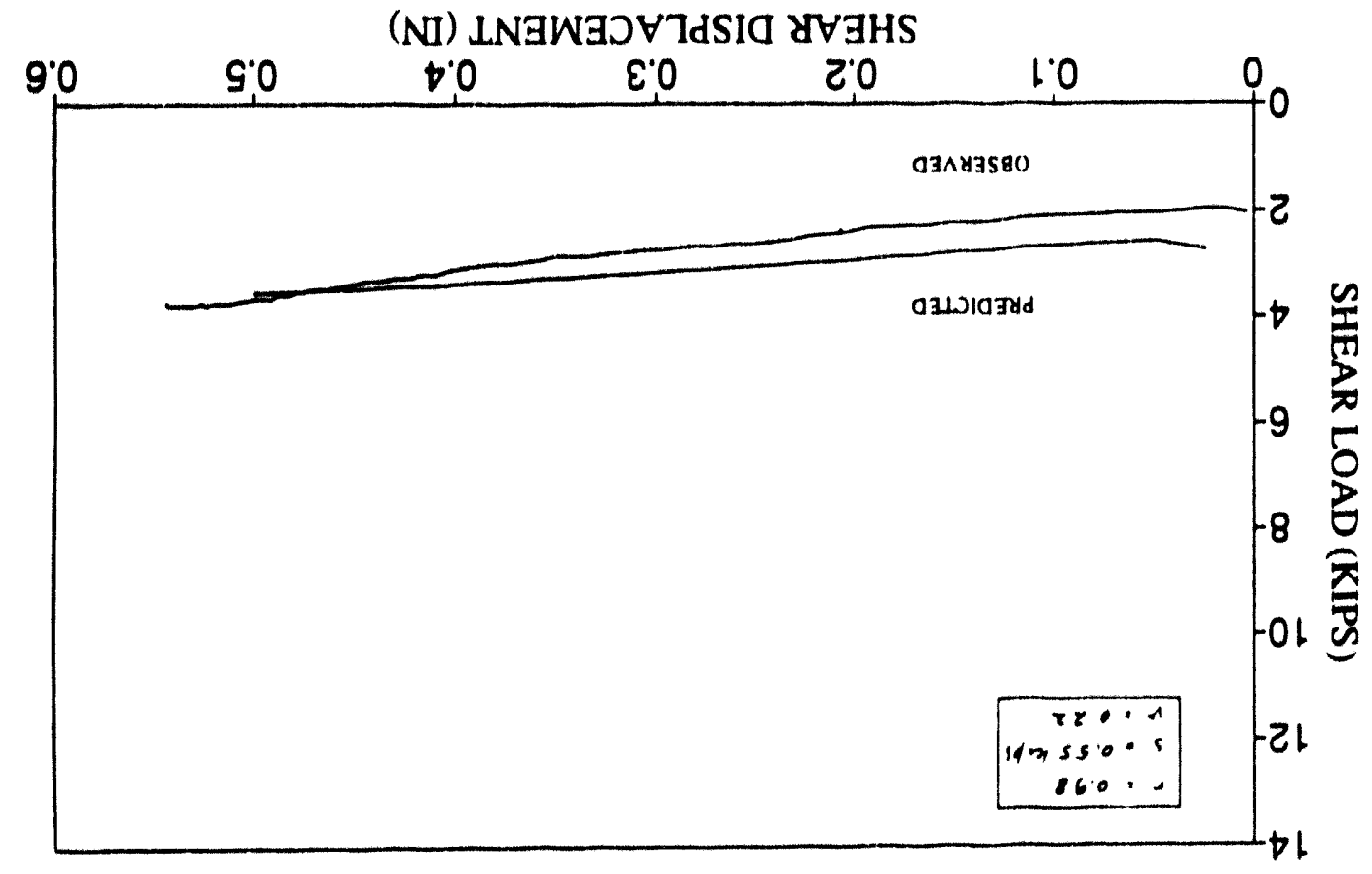

SdIX $8^{\circ} \varepsilon=$ a

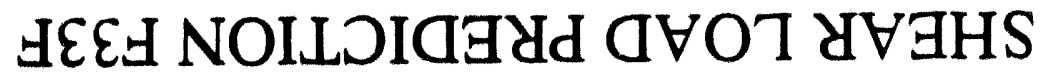

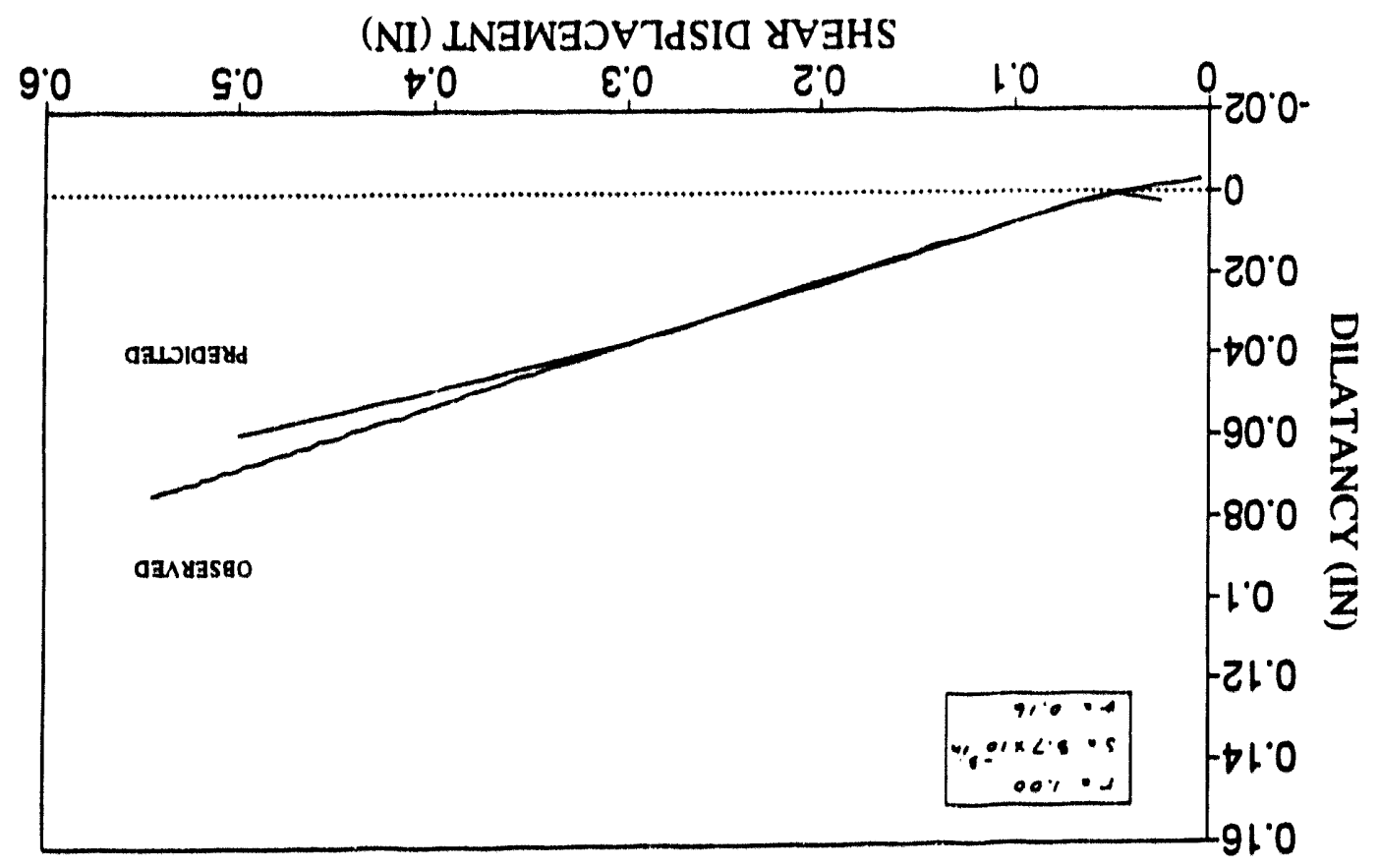

SdIX $8^{\circ} \varepsilon=$ बVOT THWYON 'NI/SdIX $\varepsilon^{\prime} 9 \varsigma=$ X

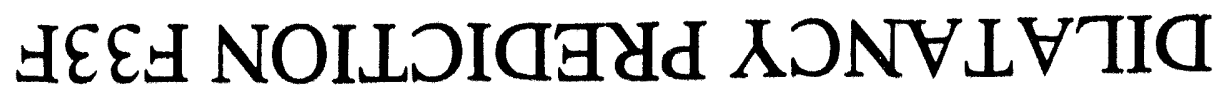



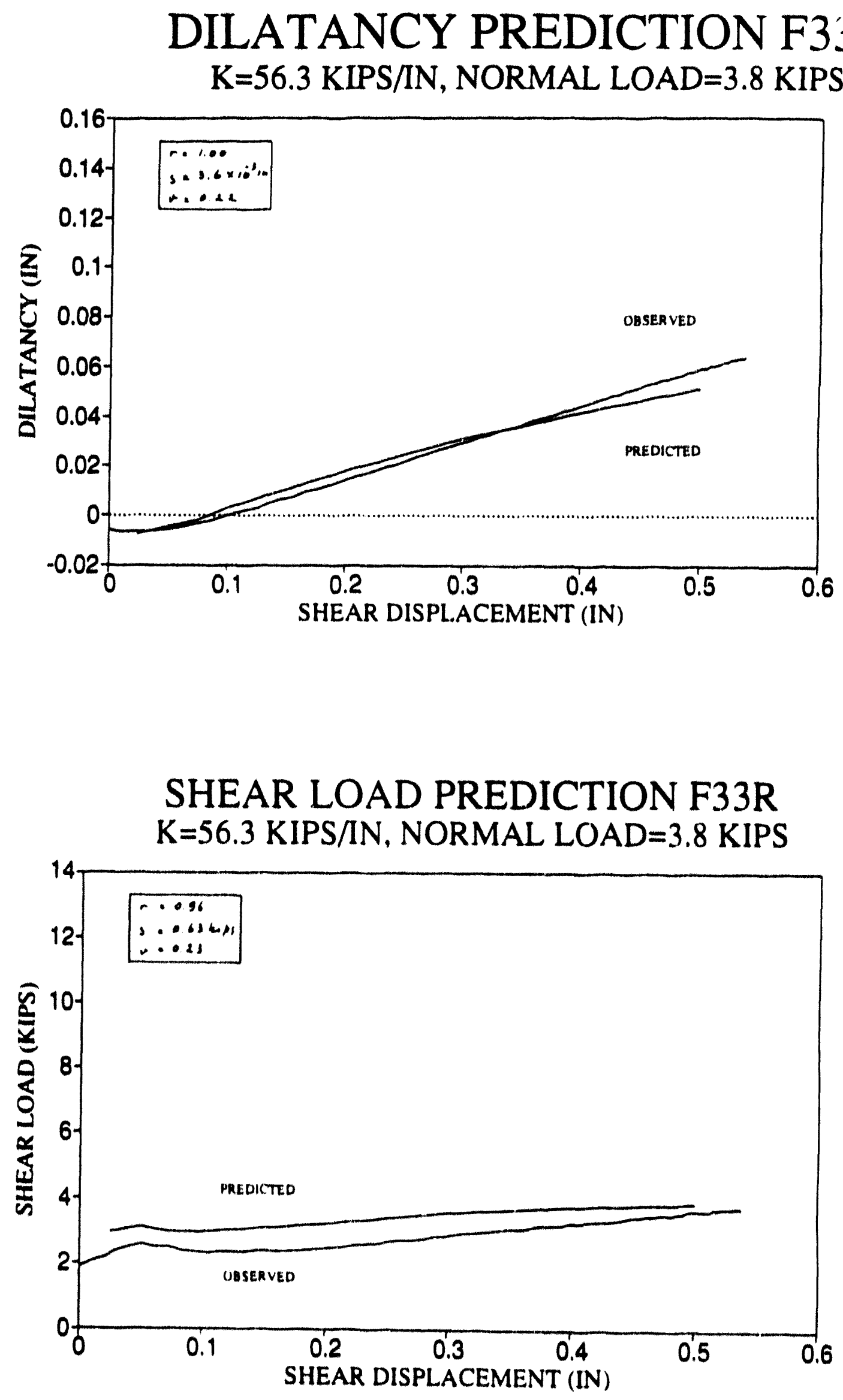

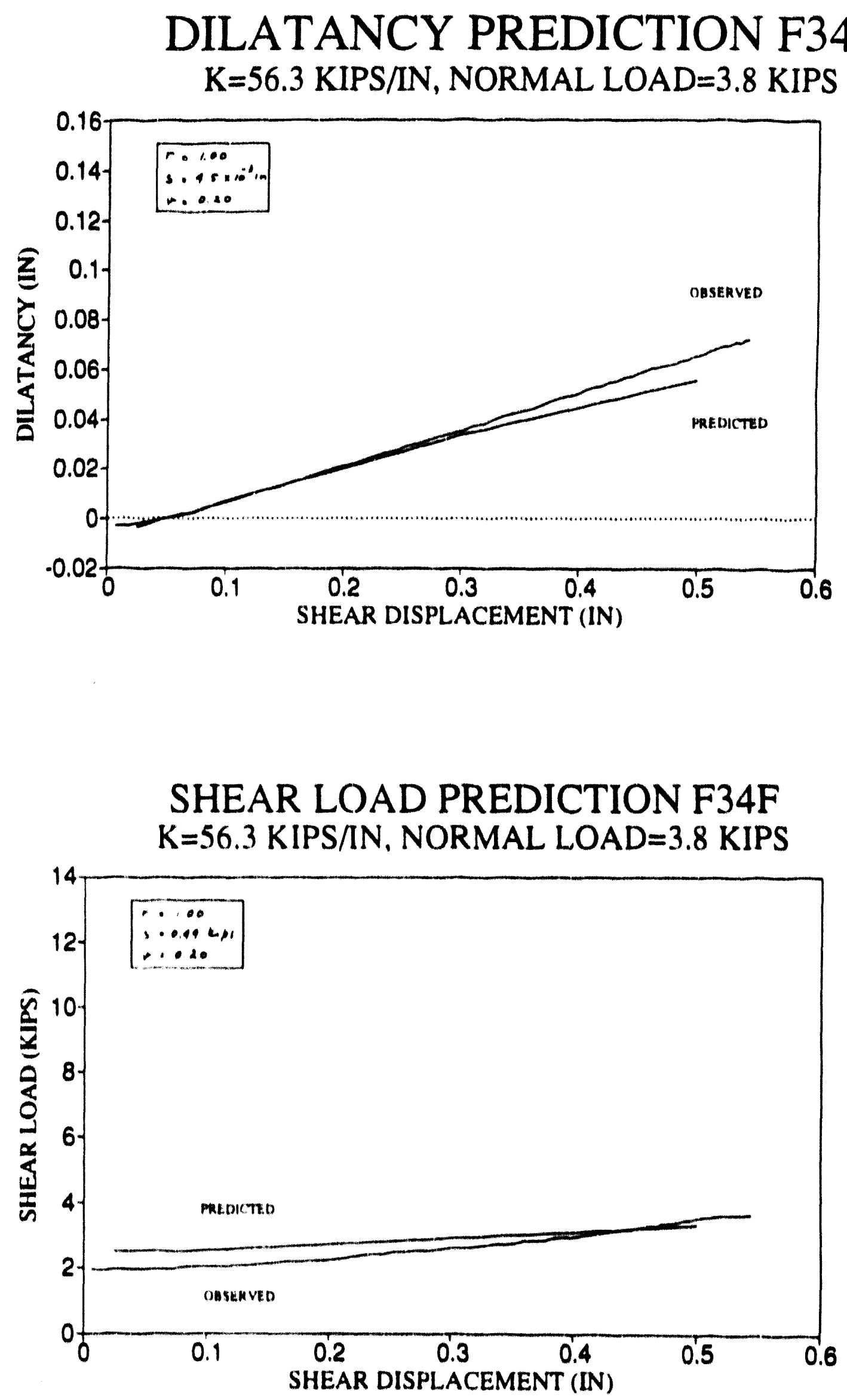
DILATANCY PREDICTION F34R $\mathrm{K}=56.3 \mathrm{KIPS} / \mathrm{IN}$, NORMAL LOAD=3.8 KIPS

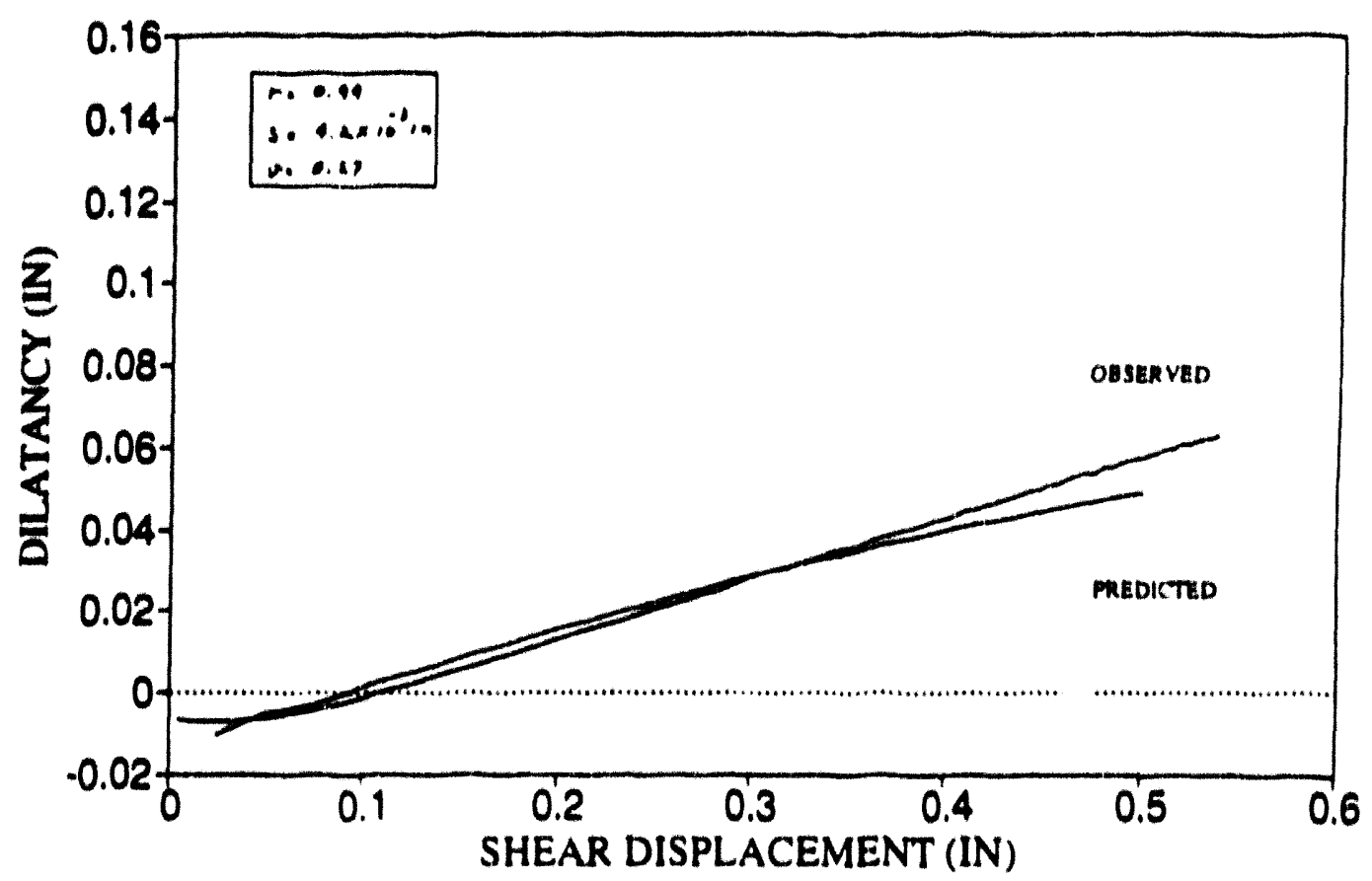

SHEAR LOAD PREDICTION F34R $\mathrm{K}=56.3 \mathrm{KIPS} / \mathrm{IN}$, NORMAL LOAD $=3.8 \mathrm{KIPS}$

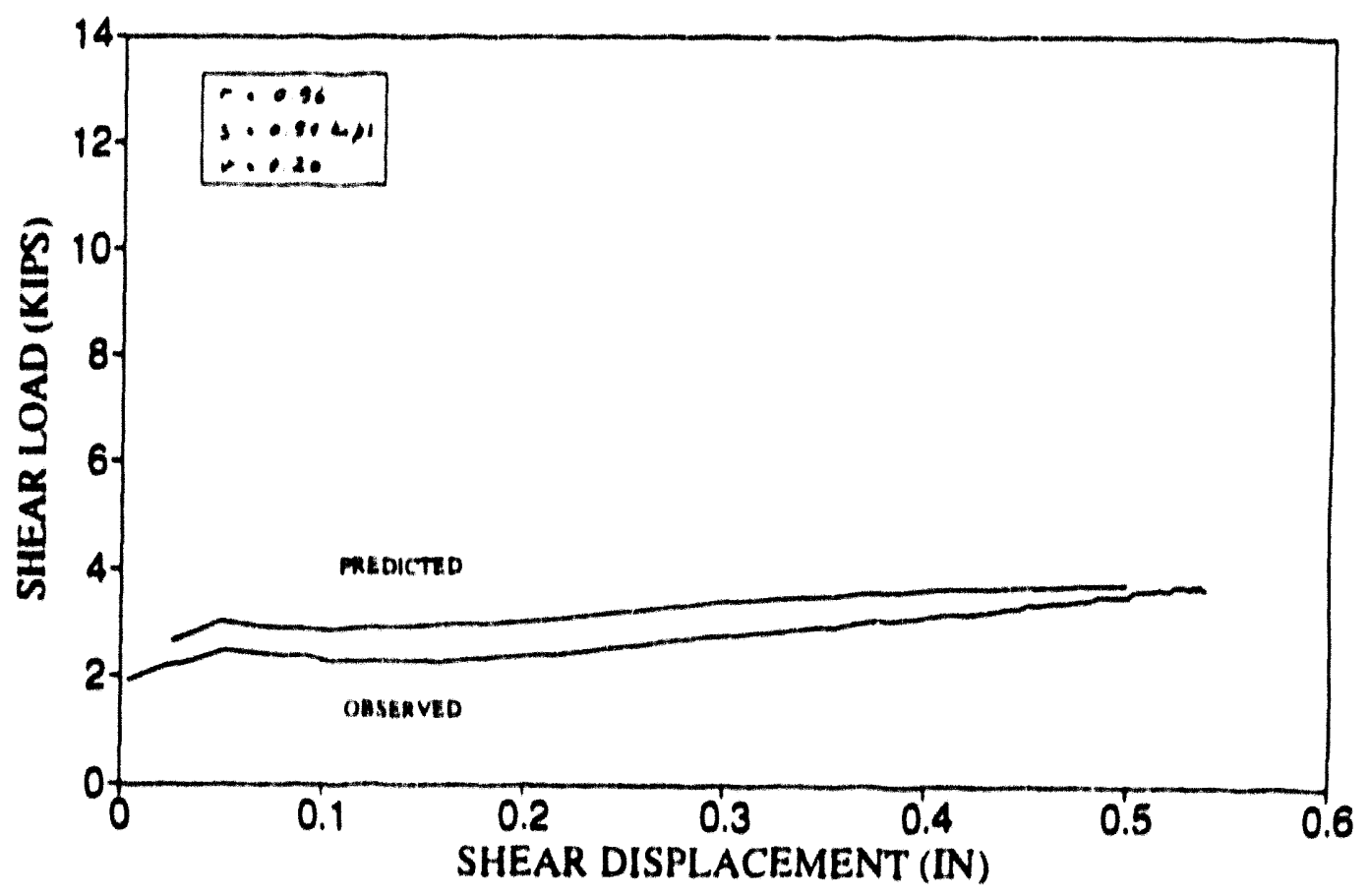



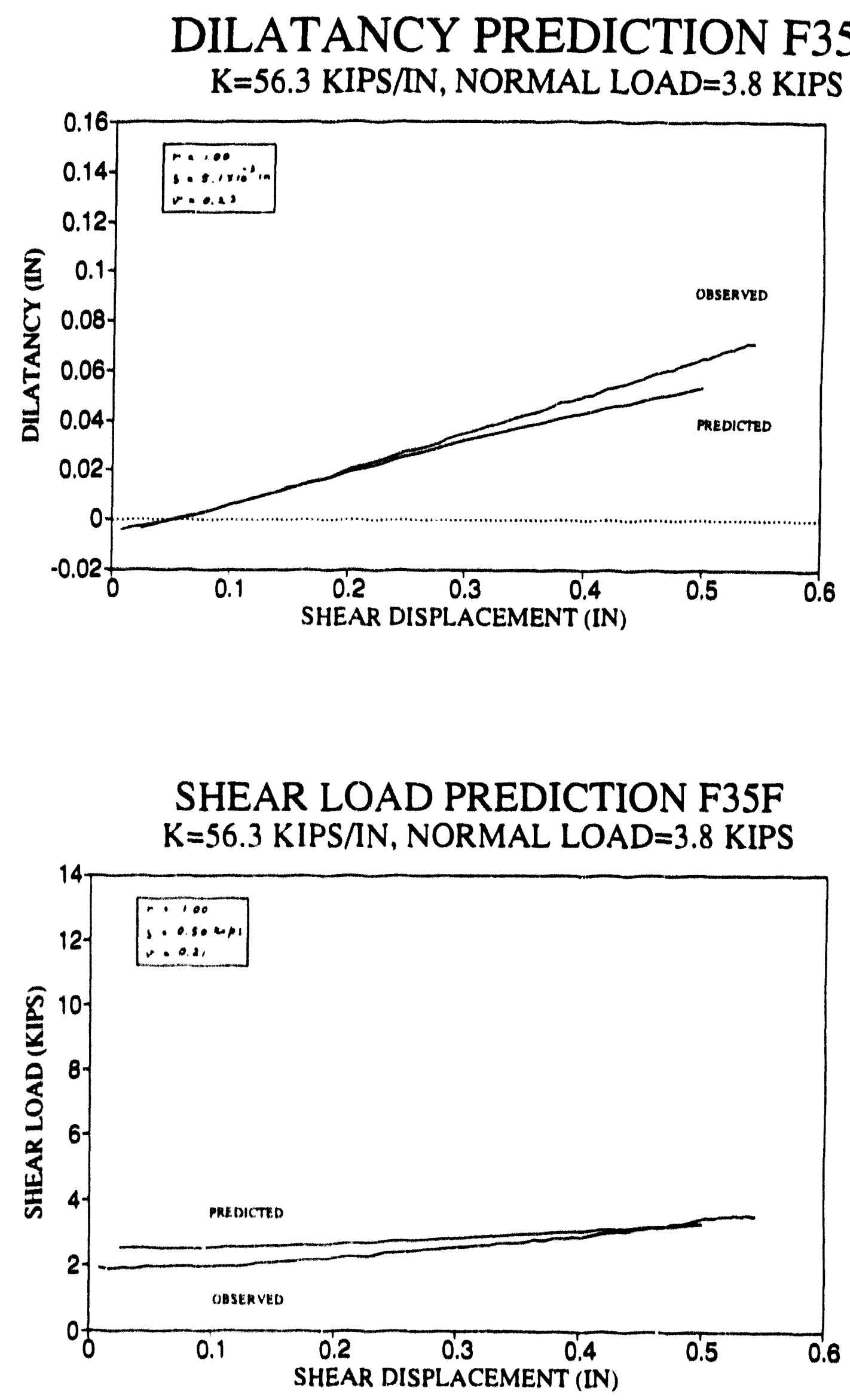
DILATANCY PREDICTION F35R $\mathrm{K}=56.3 \mathrm{KIPS} / \mathrm{IN}$, NORMAL LOAD $=3.8 \mathrm{KIPS}$

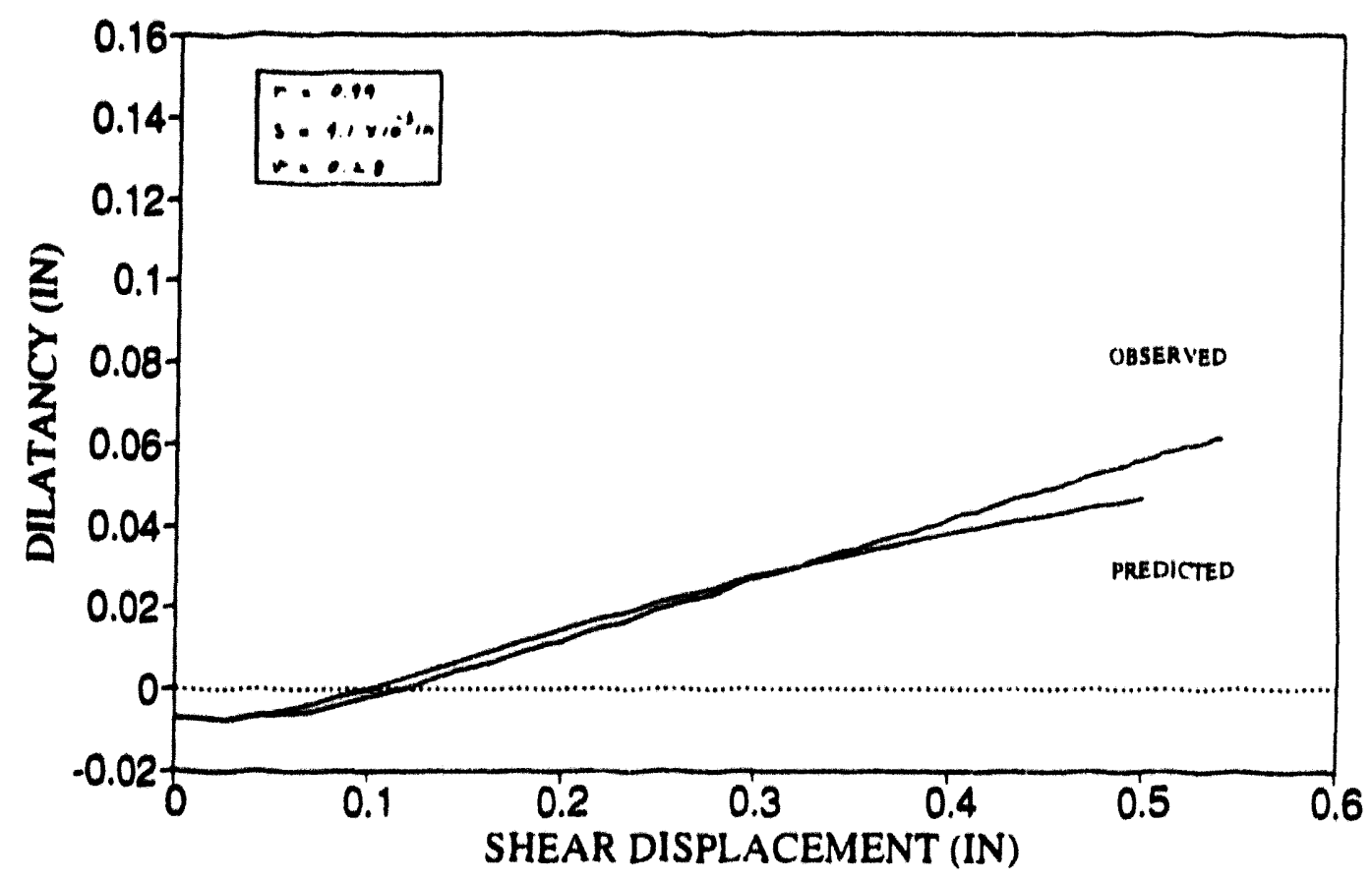

SHEAR LOAD PREDICTION F35R $\mathrm{K}=56.3 \mathrm{KIPS} / \mathrm{IN}$, NORMAL LOAD $=3.8 \mathrm{KIPS}$

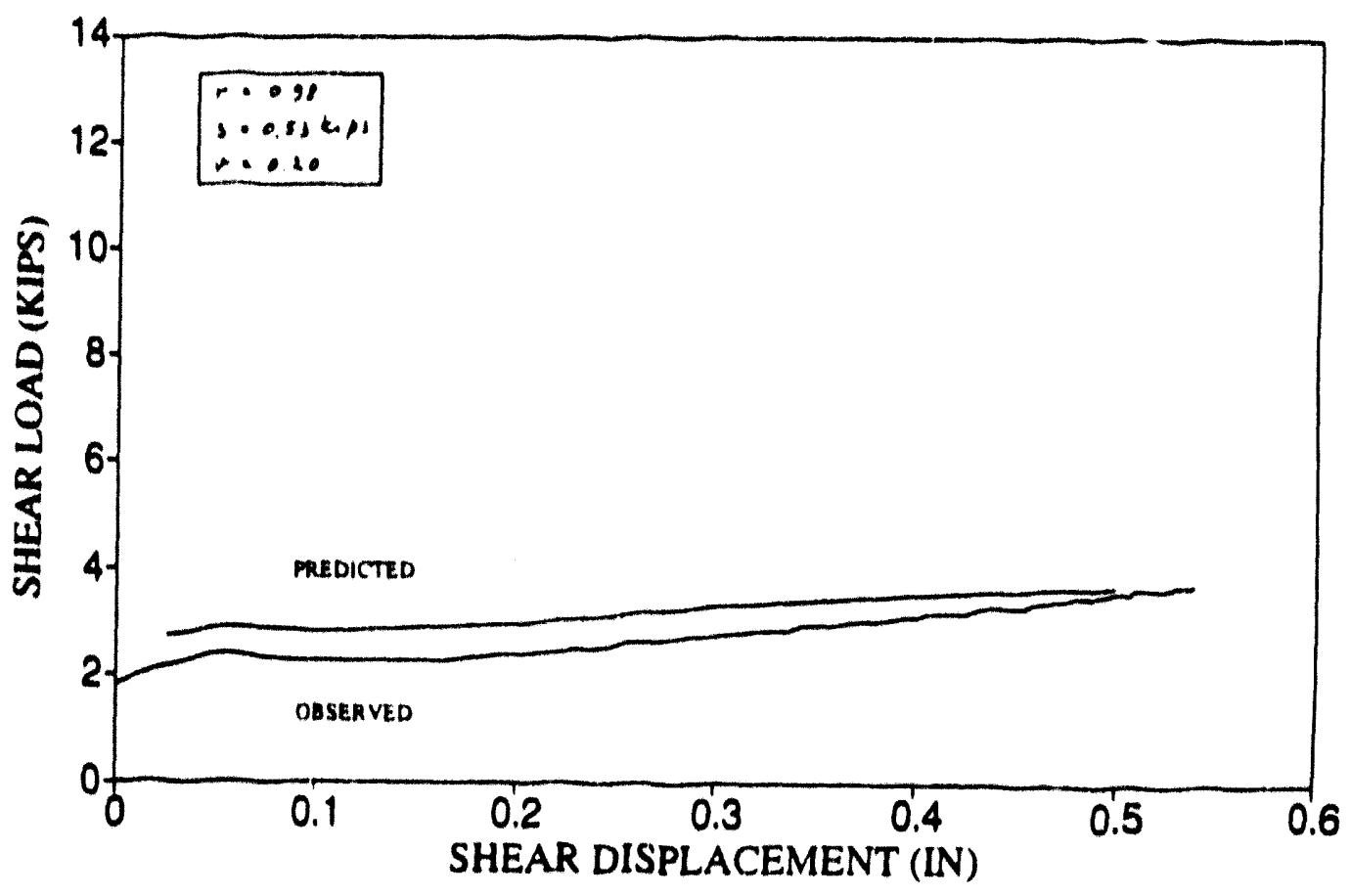



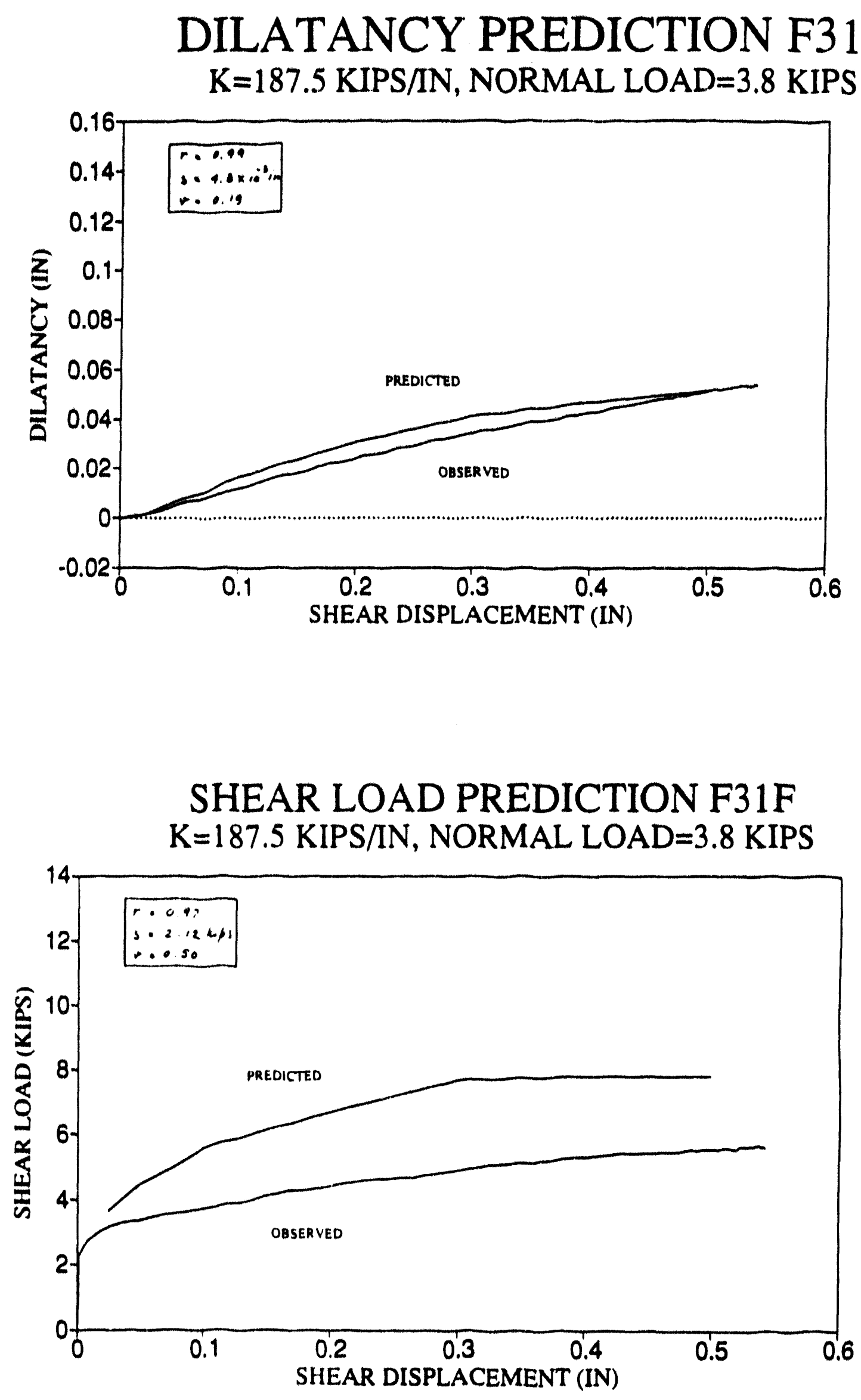

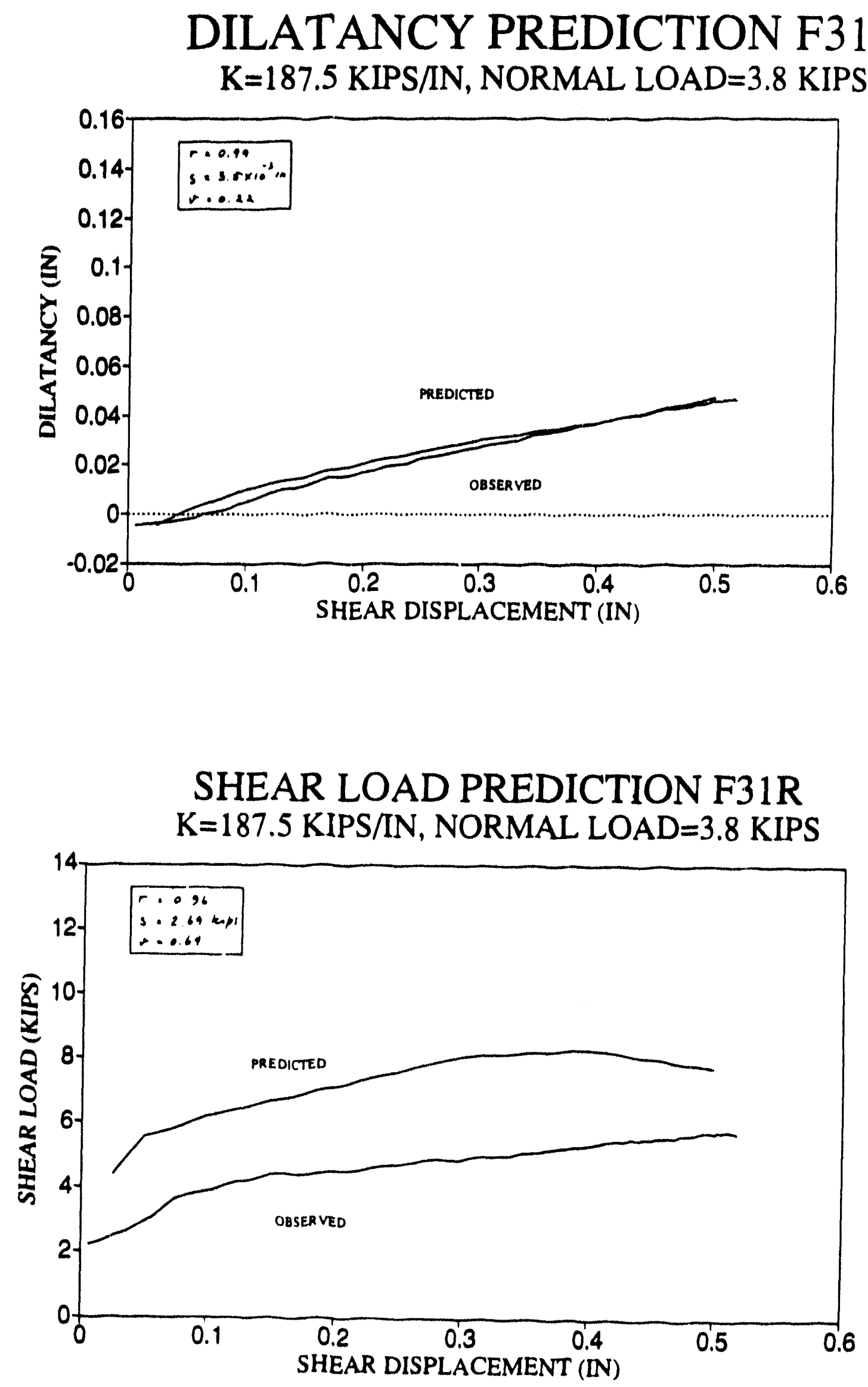

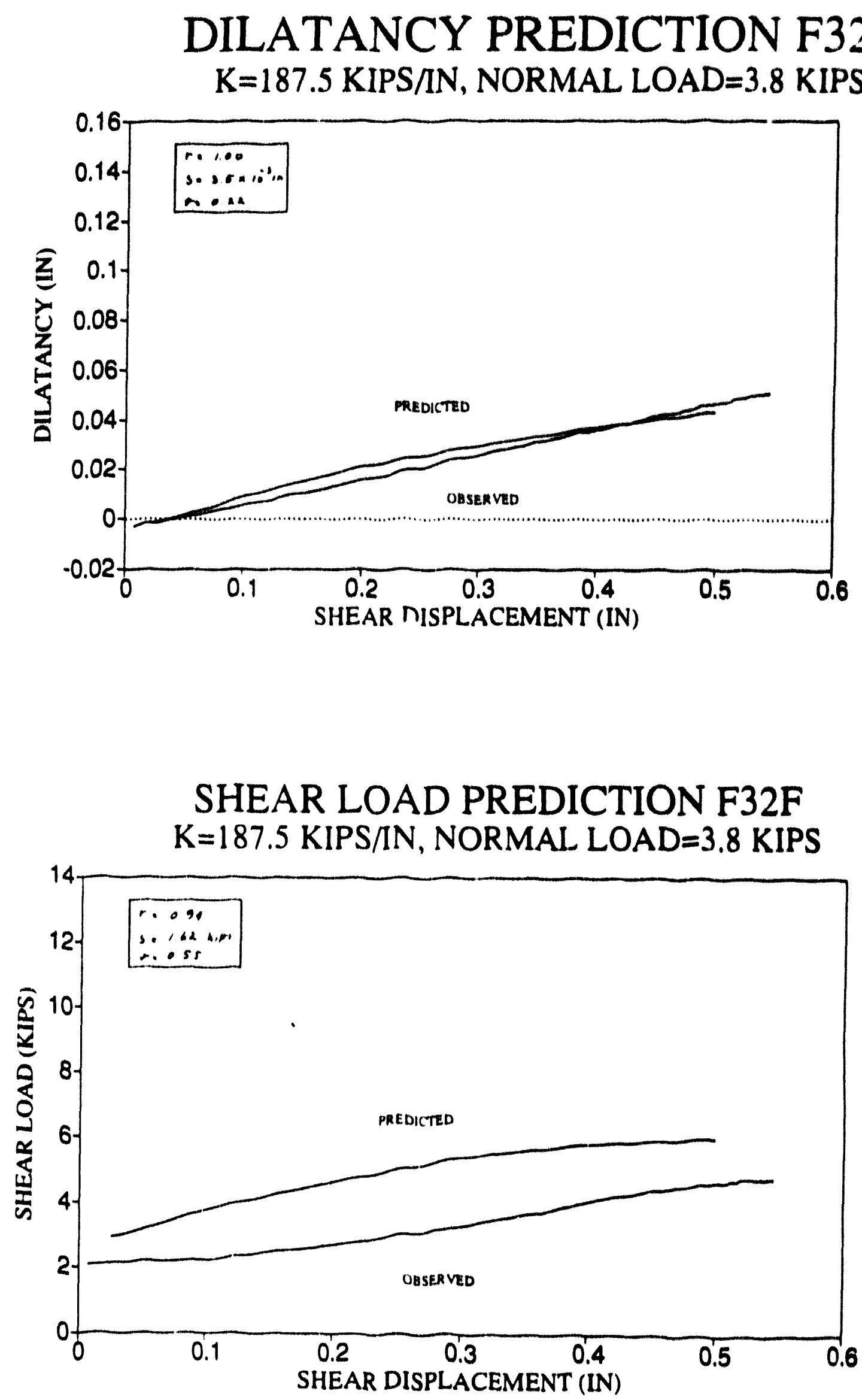
DILATANCY PREDICTION F32R $\mathrm{K}=187.5 \mathrm{KIPS} / \mathrm{IN}$, NORMAL LOAD=3.8 KIPS

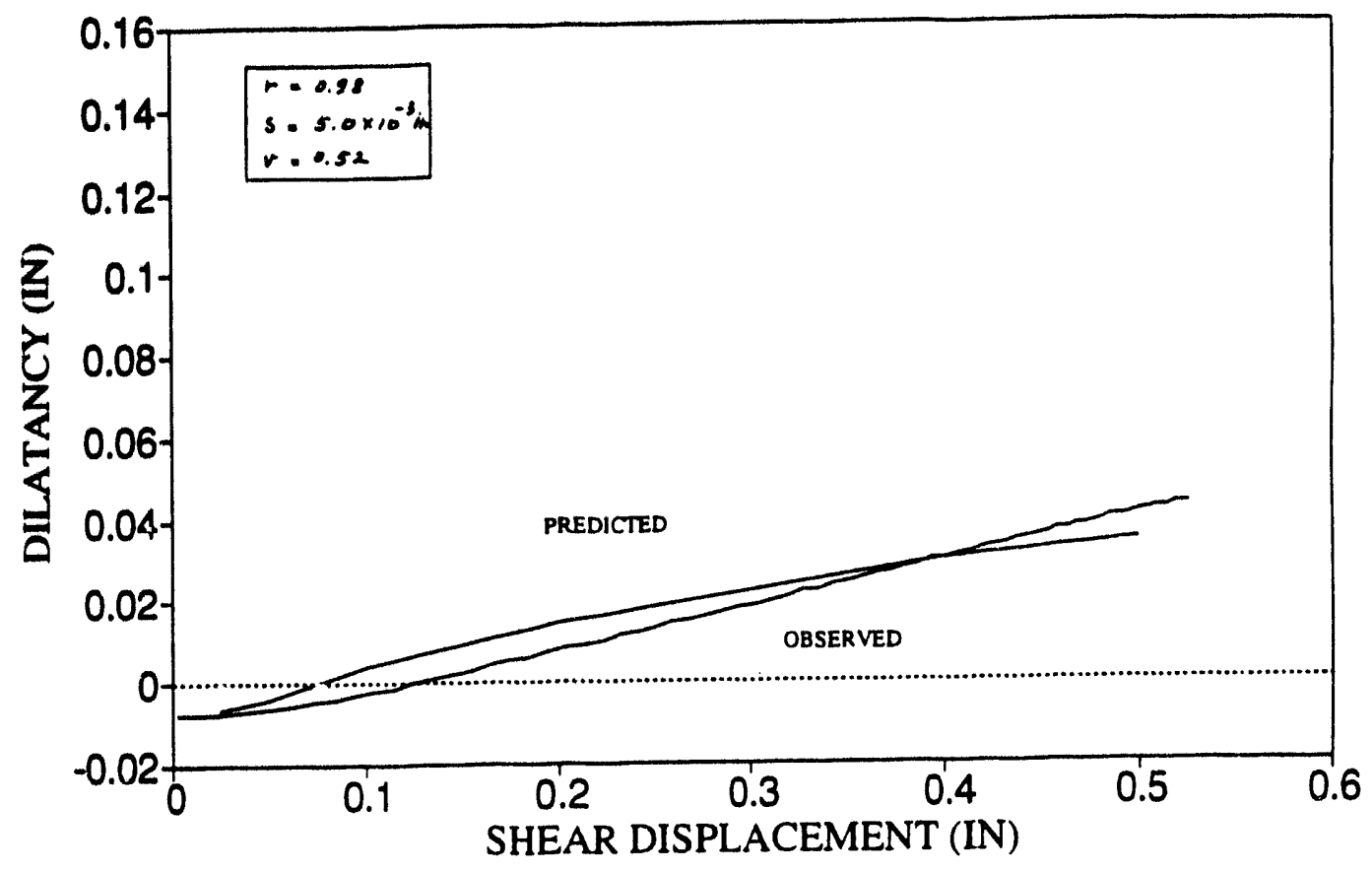

SHEAR LOAD PREDICTION F32R $\mathrm{K}=187.5 \mathrm{KIPS} / \mathrm{IN}$, NORMAL LOAD $=3.8 \mathrm{KIPS}$

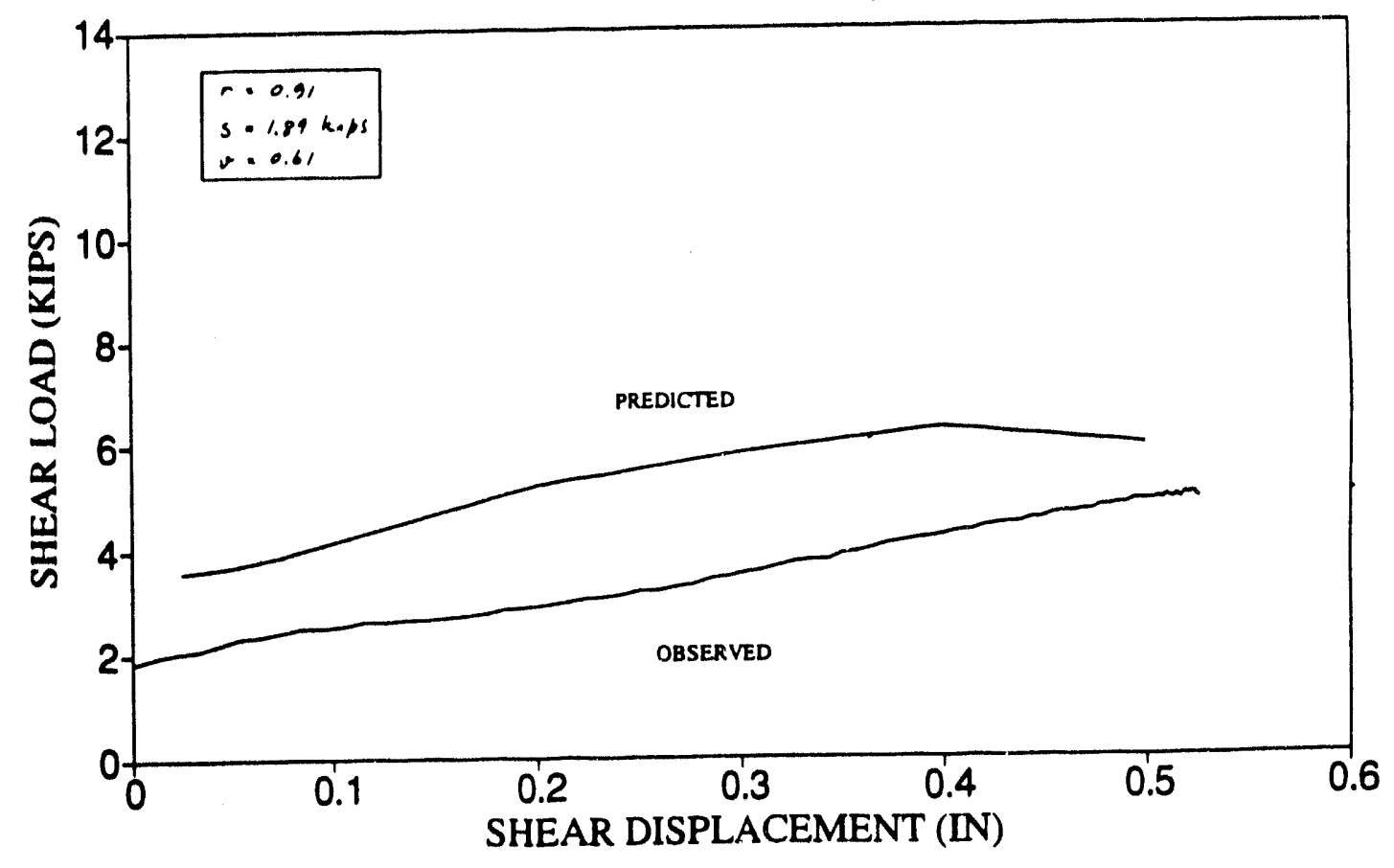




\section{DILATANCY PREDIC IION F33F}

$\mathrm{K}=187.5 \mathrm{KIPS} / \mathrm{IN}$, NORMAL LOAD=3.8 KIPS

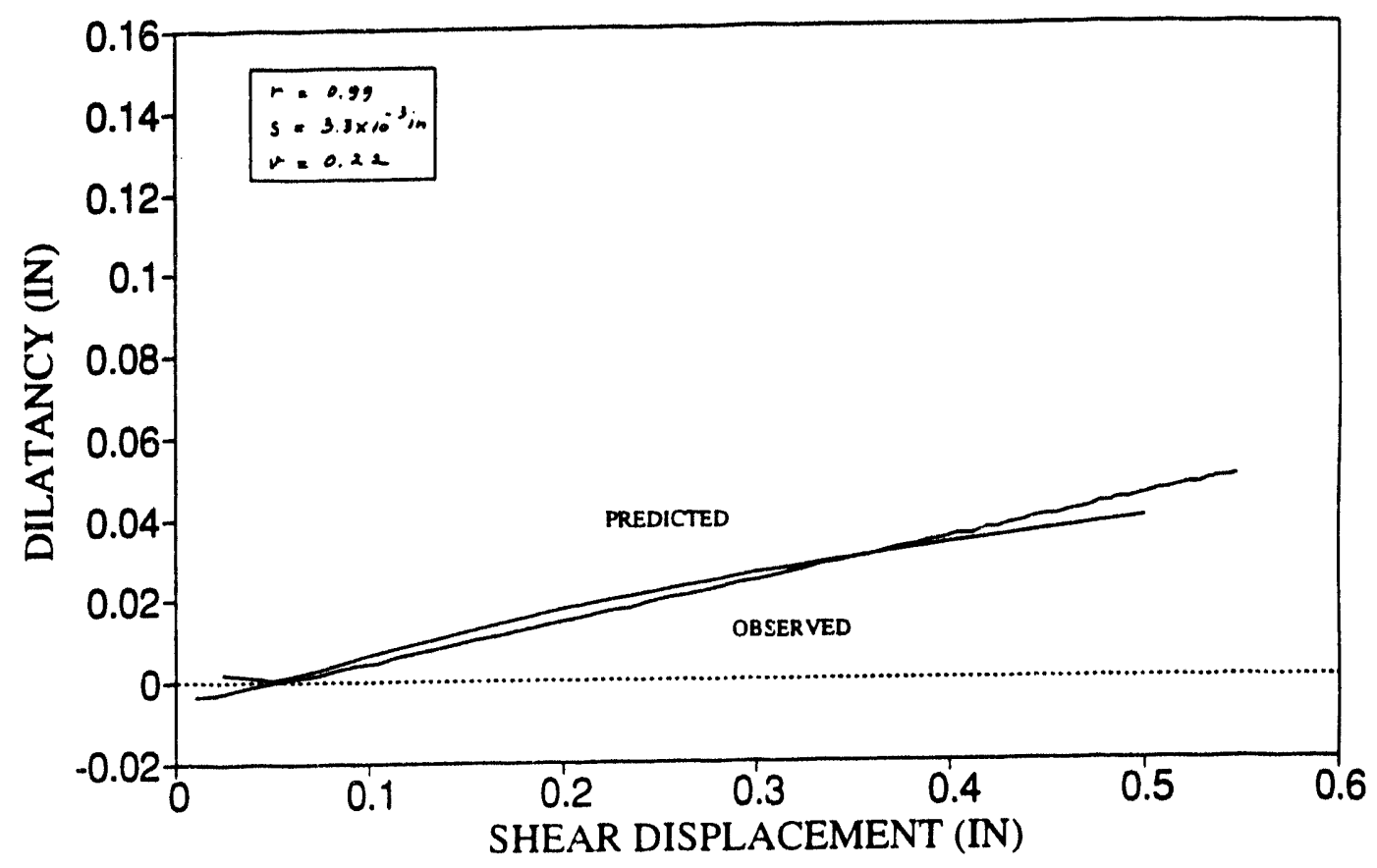

SHEAR LOAD PREDICTION F33F $\mathrm{K}=187.5 \mathrm{KIPS} / \mathrm{IN}$, NORMAL LOAD $=3.8 \mathrm{KIPS}$

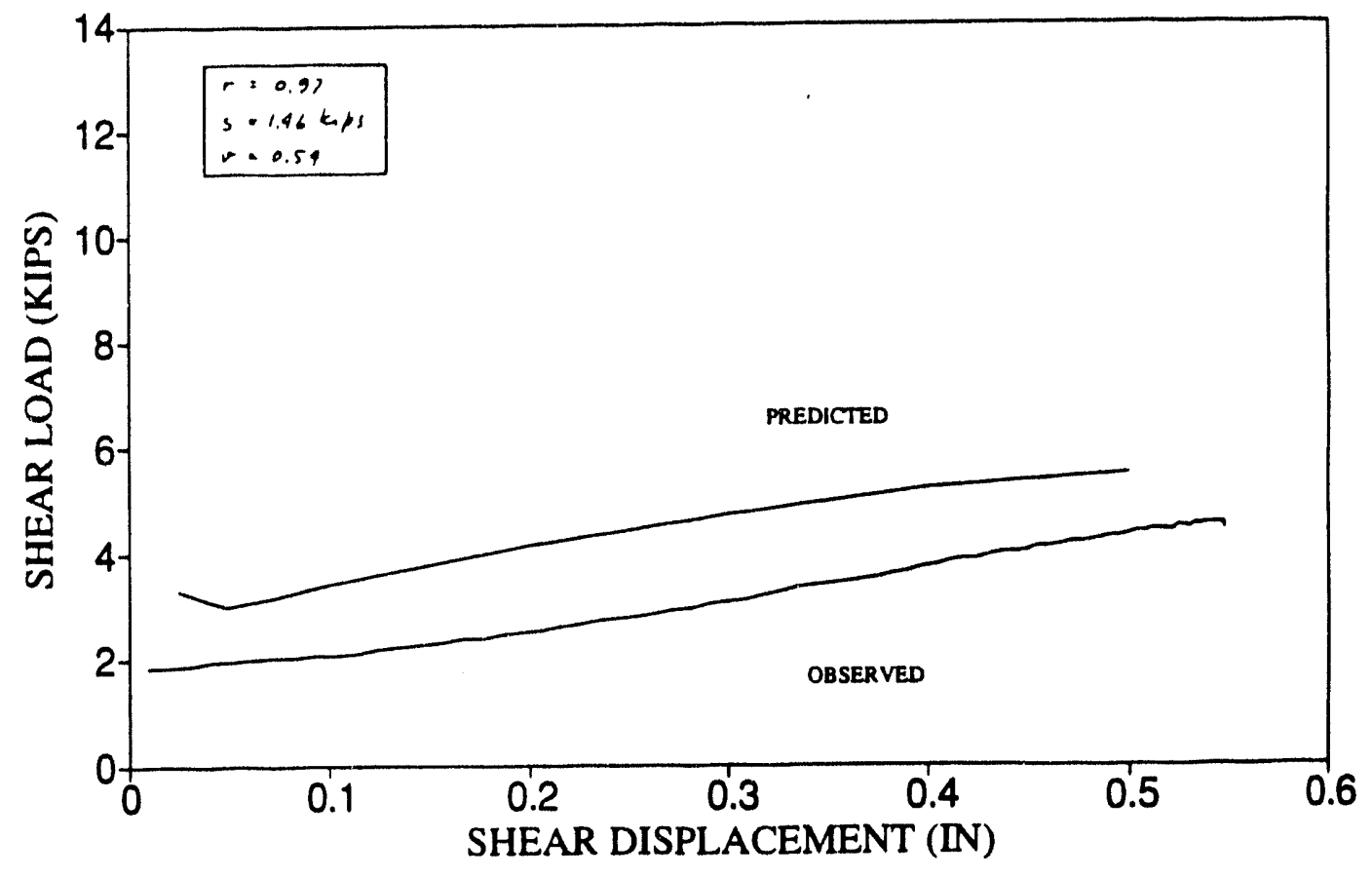



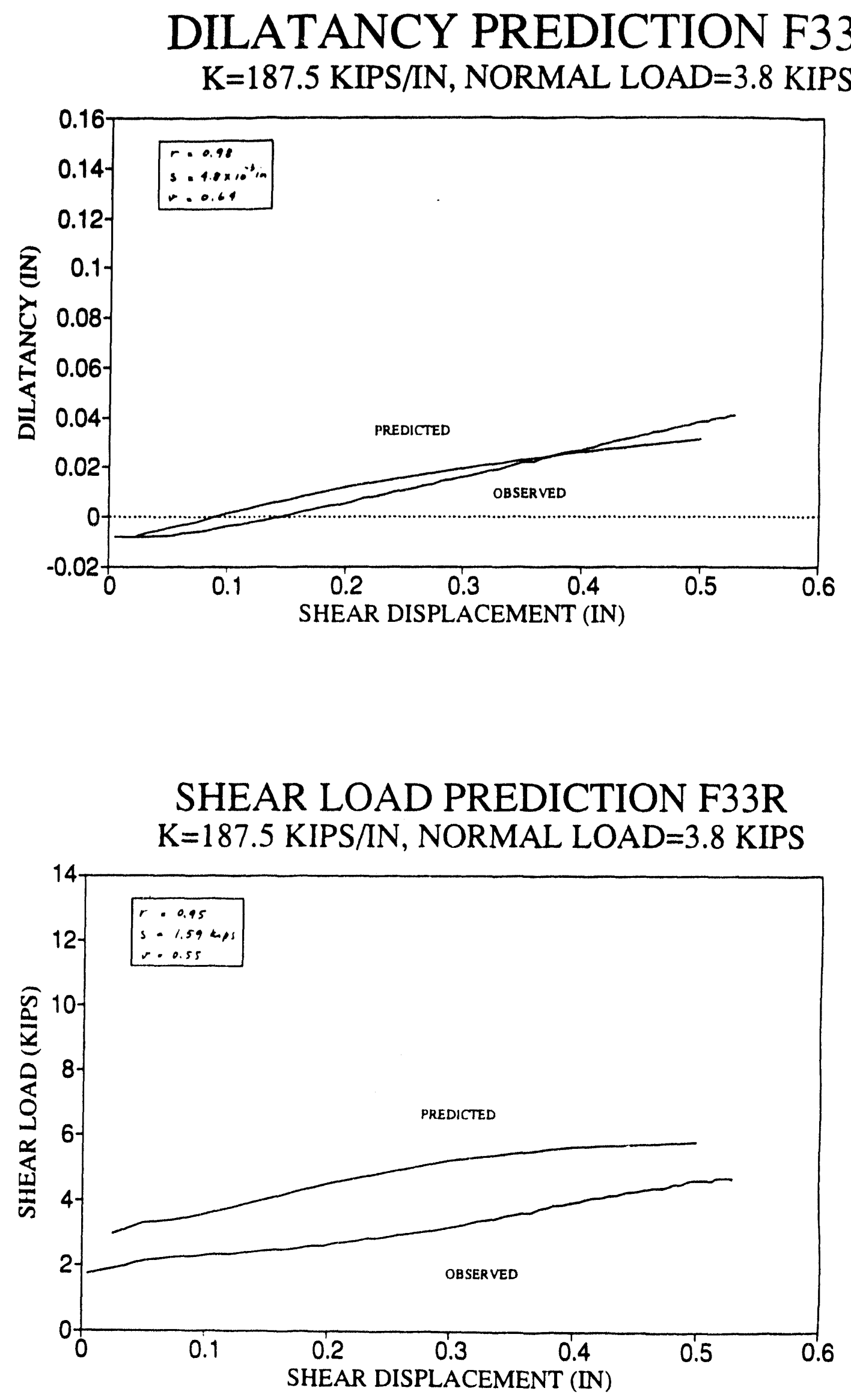

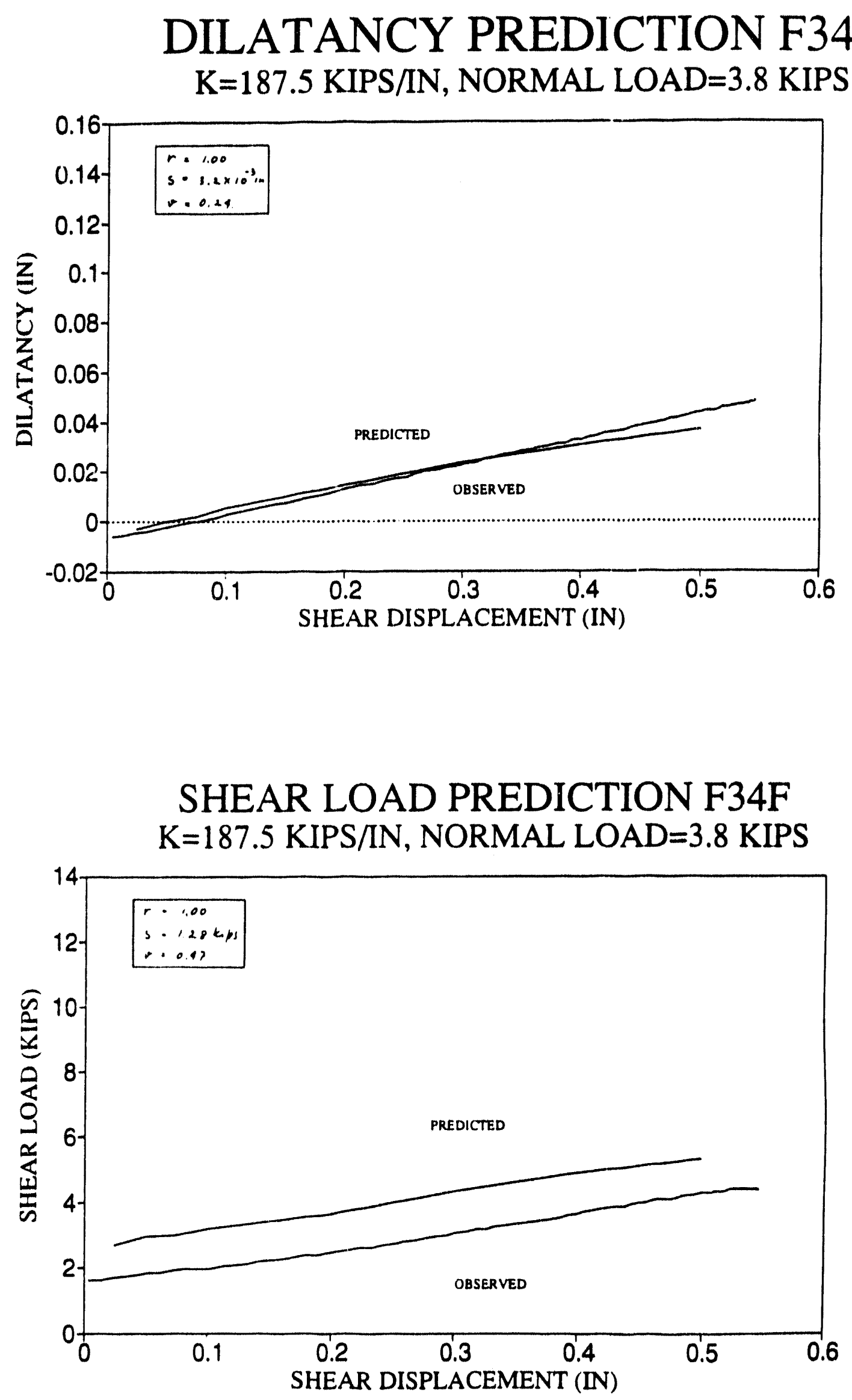


$$
9 L-8
$$
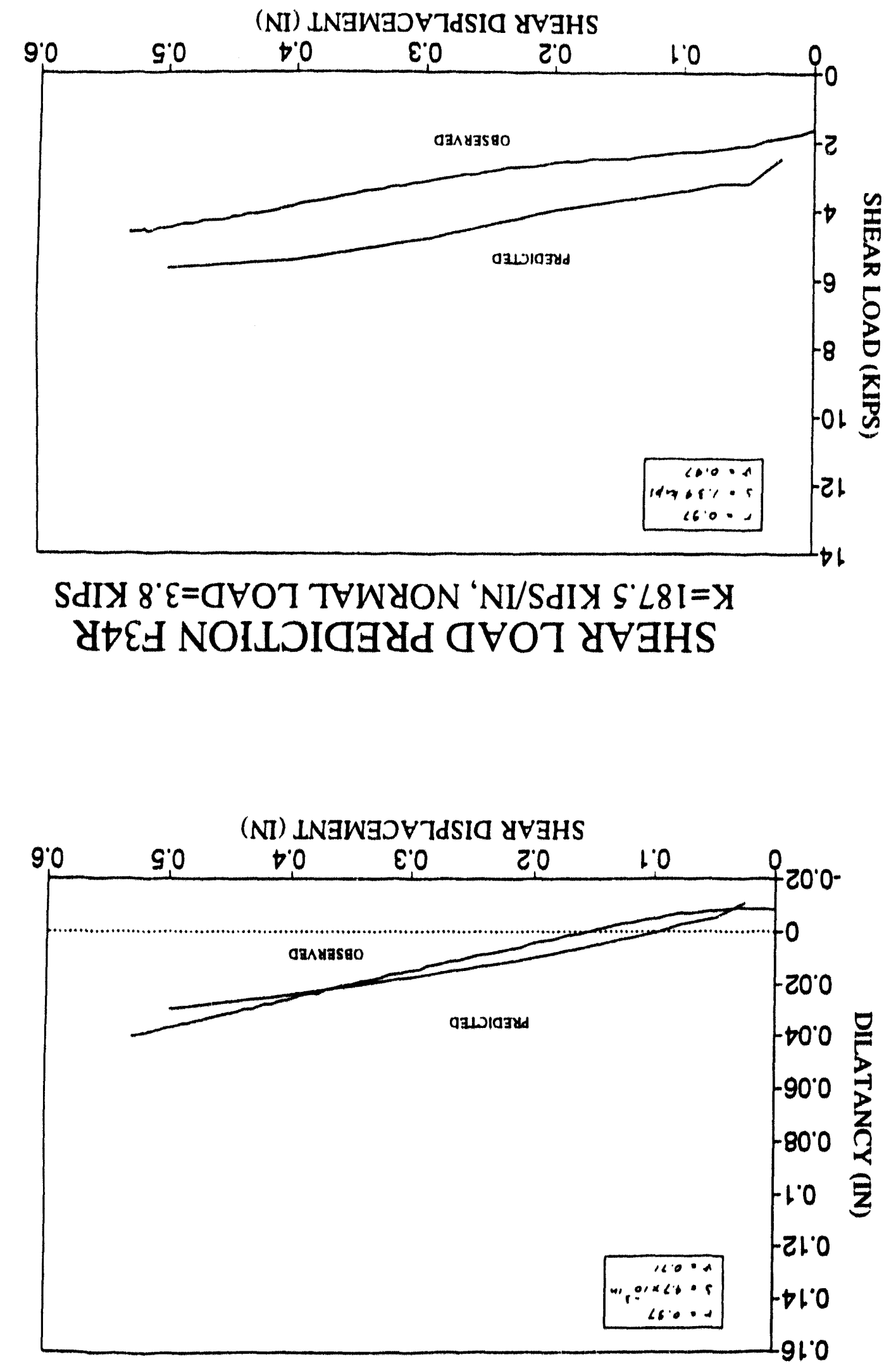

SdIX $8^{\circ} \varepsilon=$ वVOT THWYON 'NI/SdIY $\varsigma^{\prime} \angle 8 I=$ X У†Ë NOILOIG 

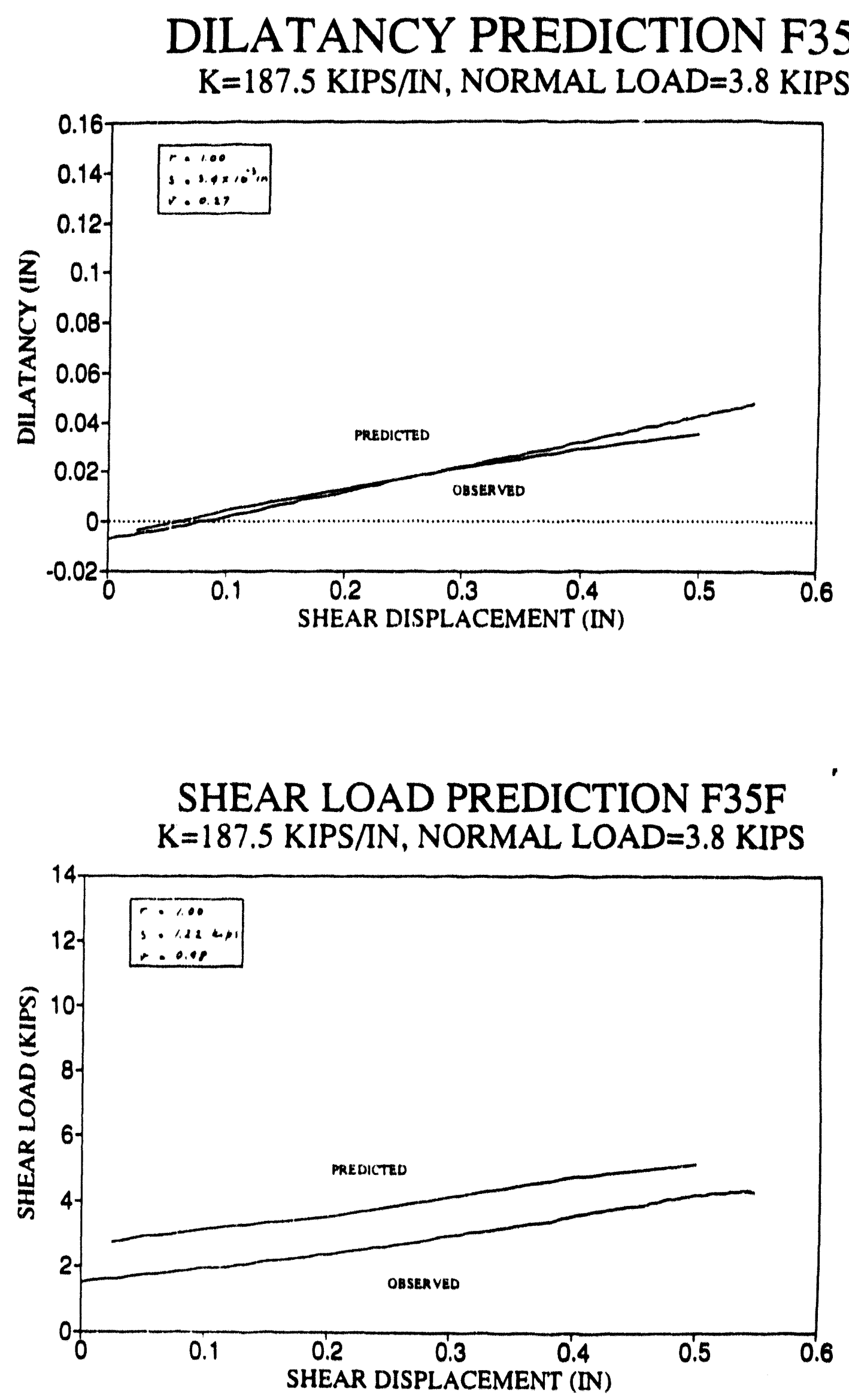

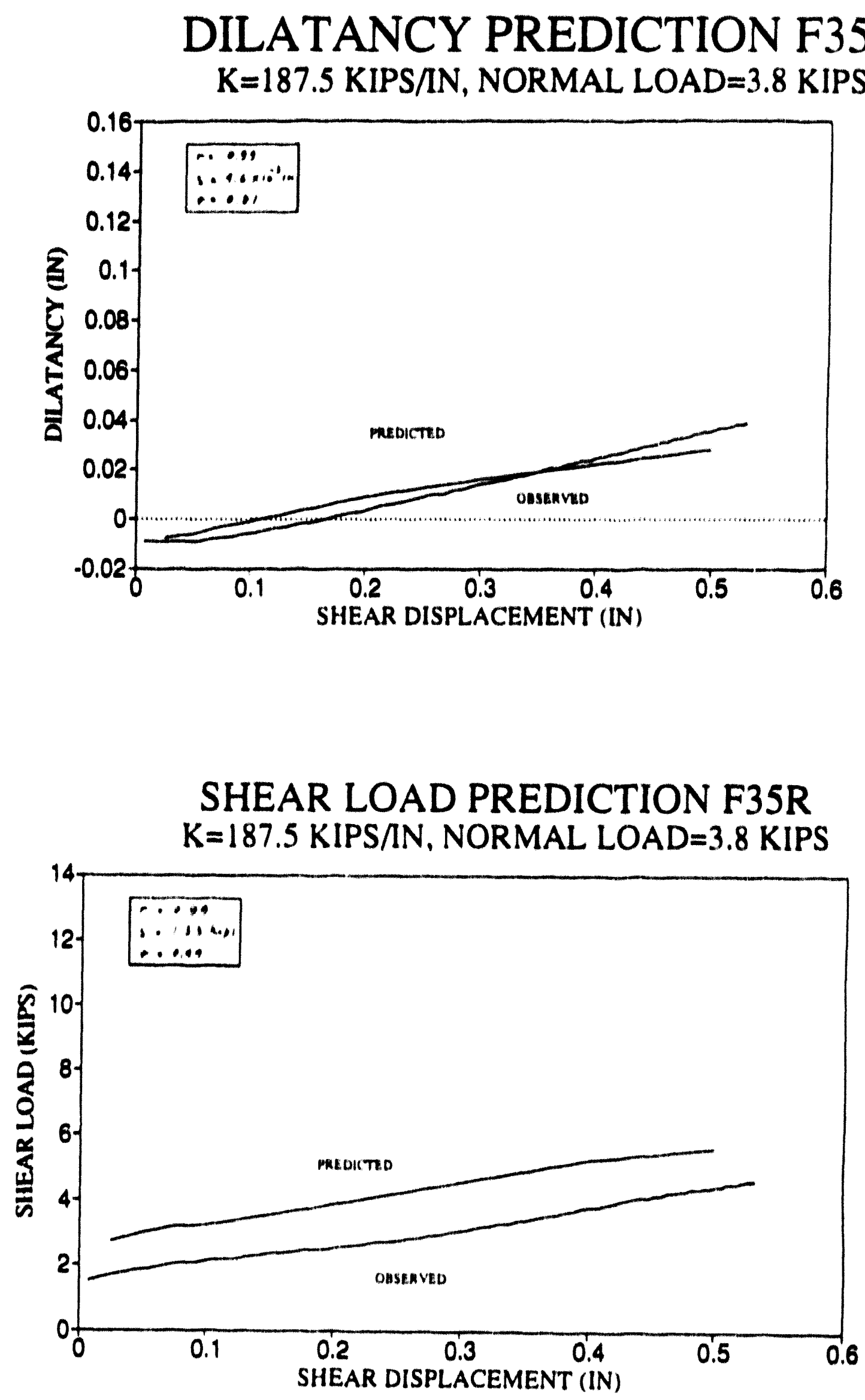

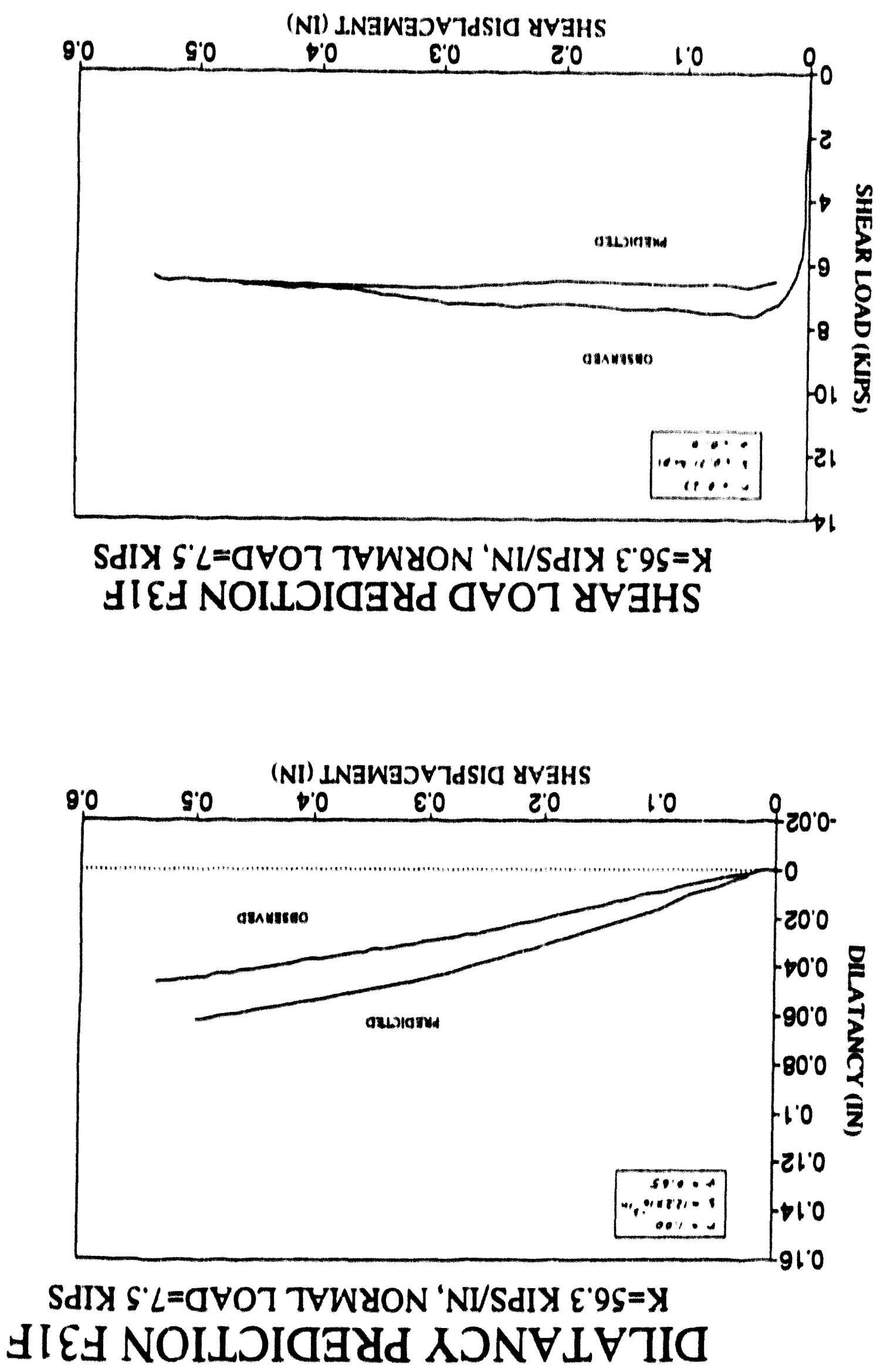

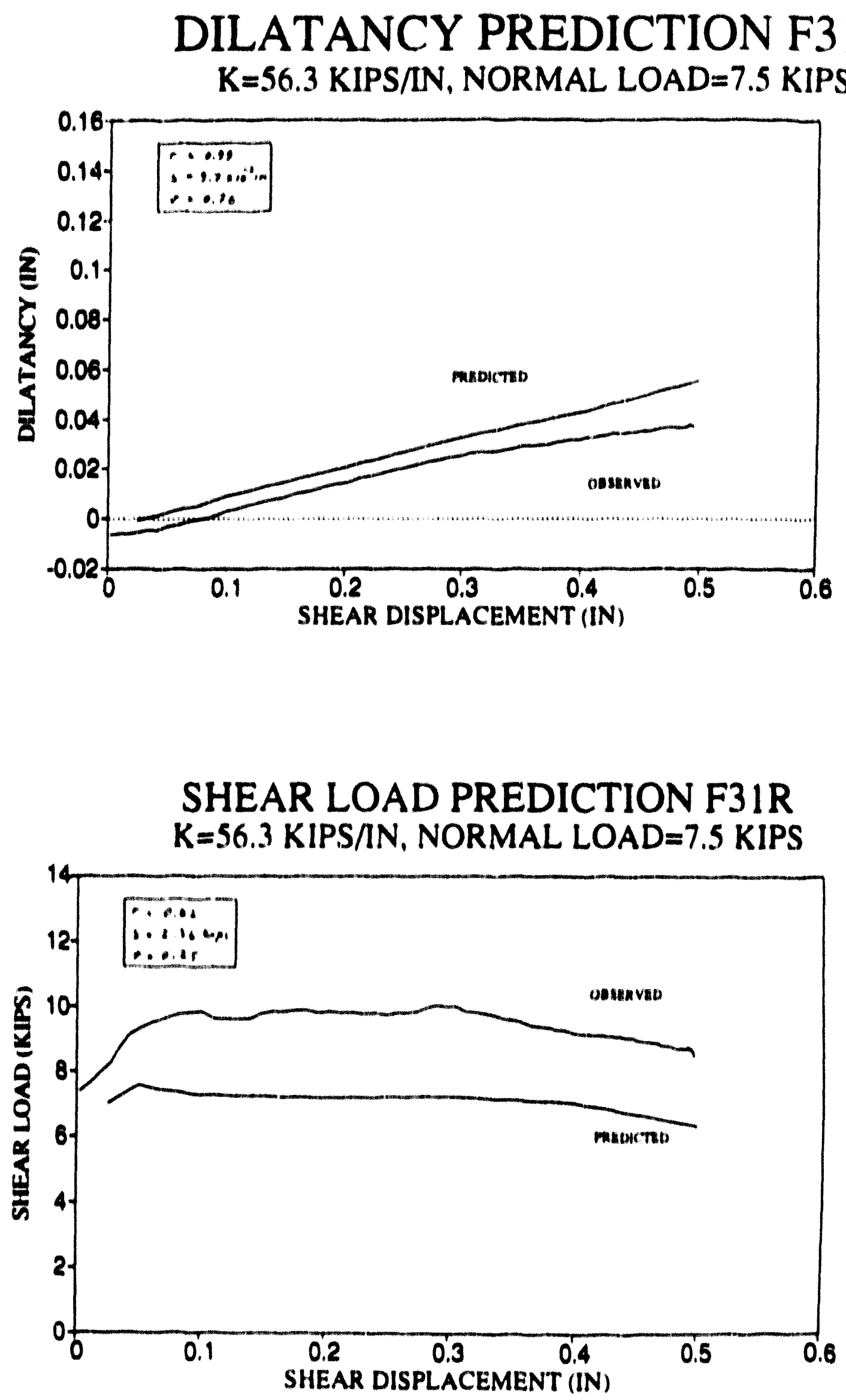

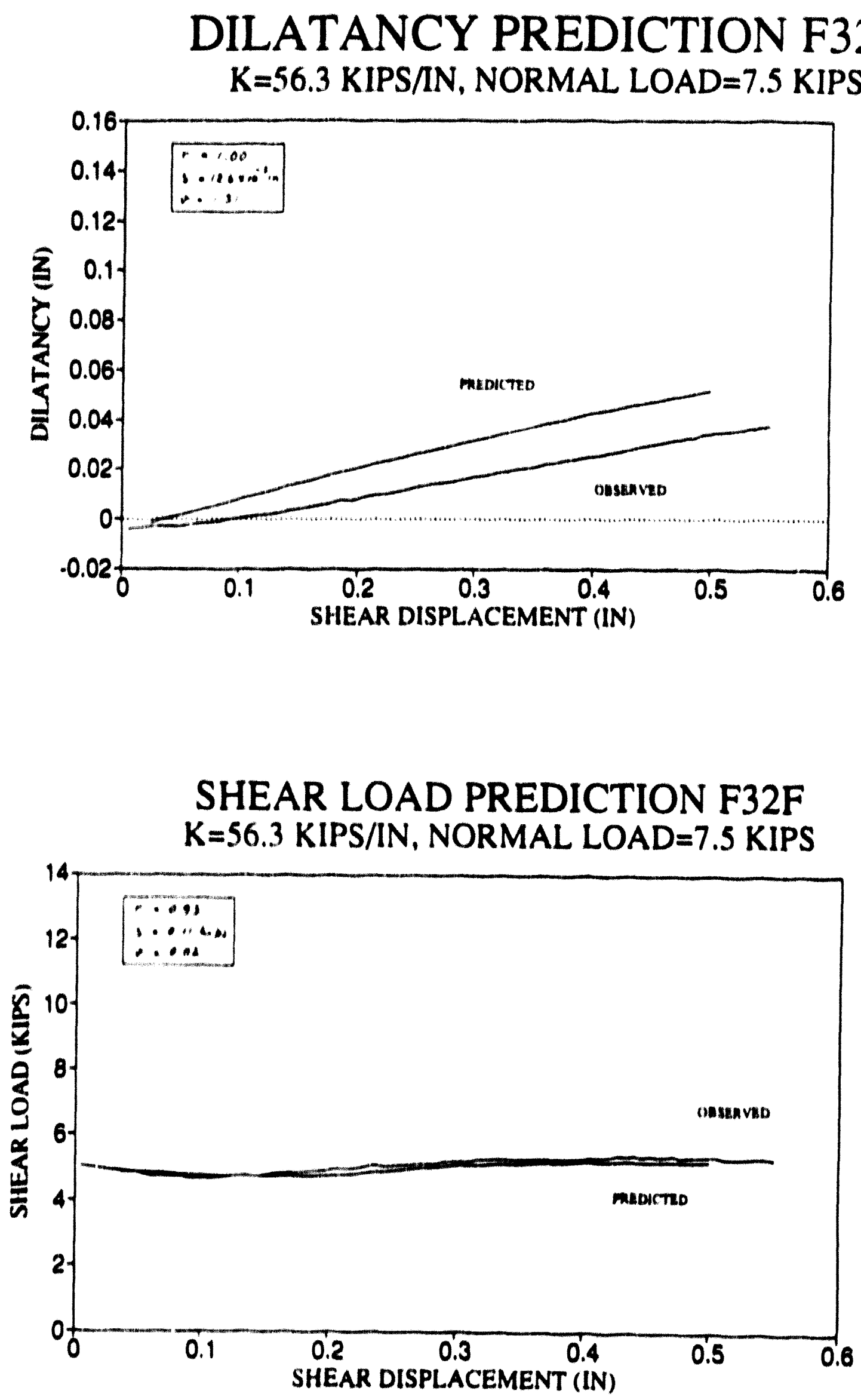


\section{DILATANCY PREDICTION F32R $\mathrm{K}=56.3 \mathrm{KIPS} / \mathrm{IN}$, NORMAL LOAD=7.5 KIPS}
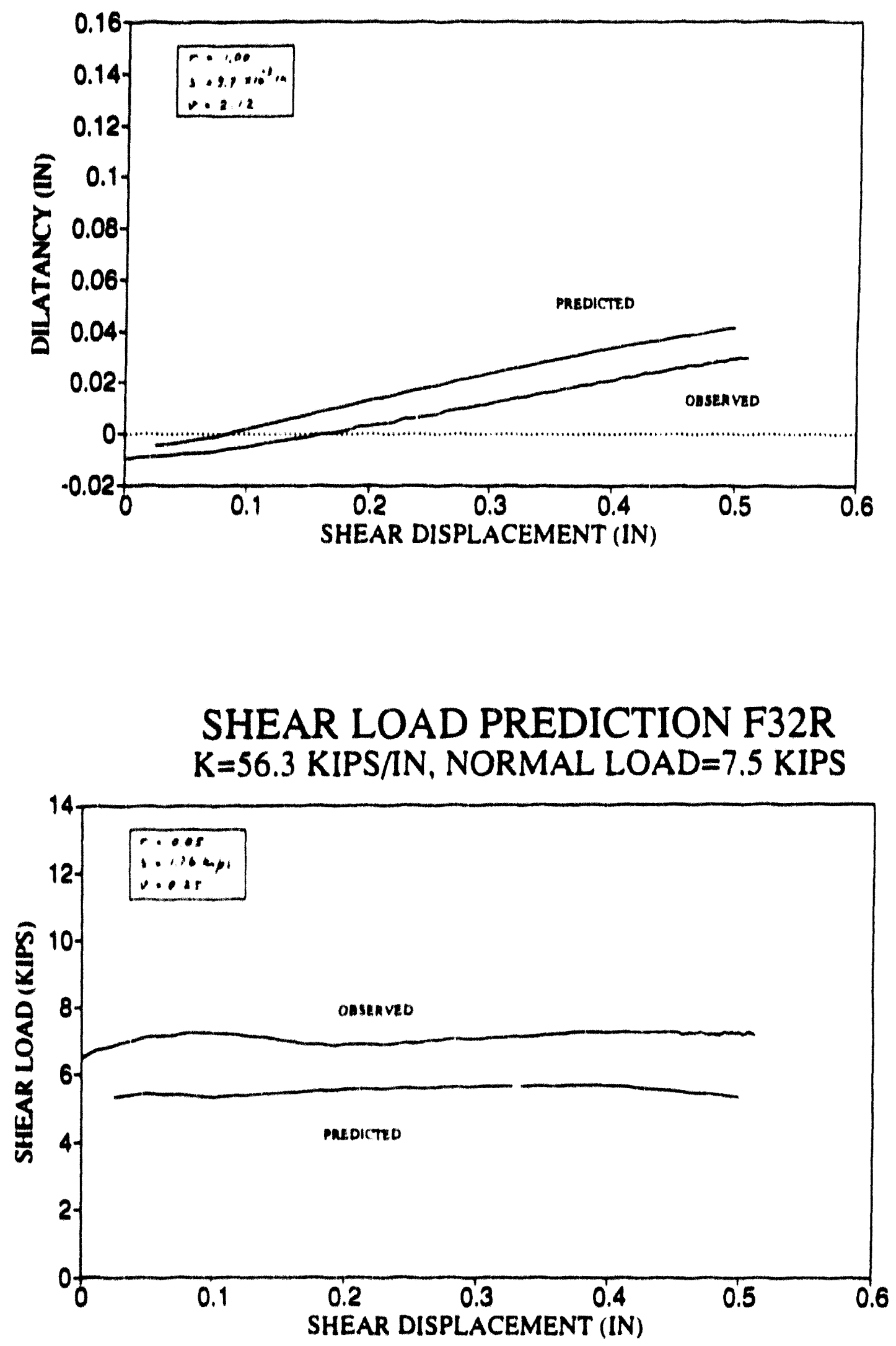

$B-82$ 


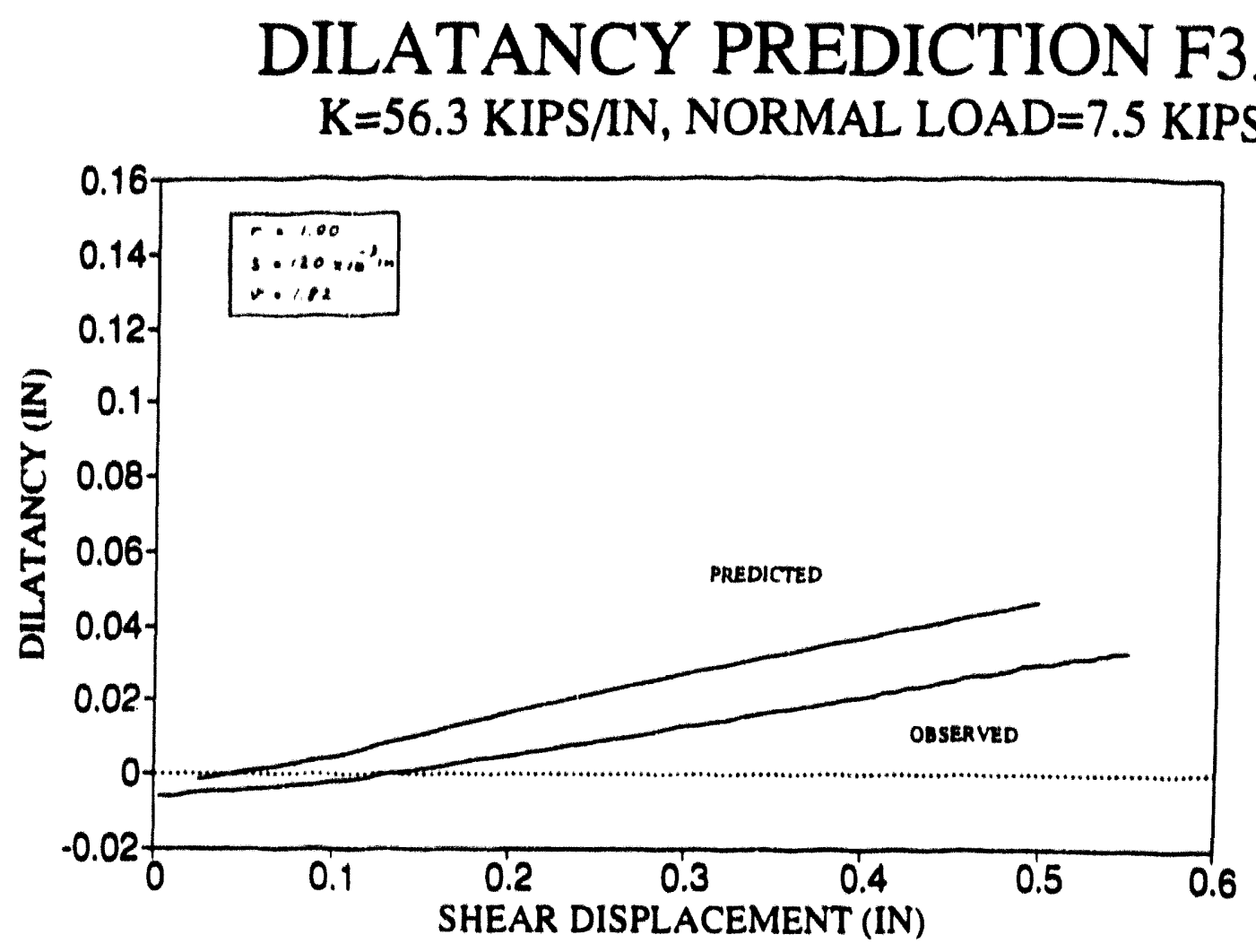

SHEAR LOAD PREDICTION F33F

$\mathrm{K}=56.3 \mathrm{KIPS} / \mathrm{IN}$, NORMAL LOAD $=7.5 \mathrm{KIPS}$

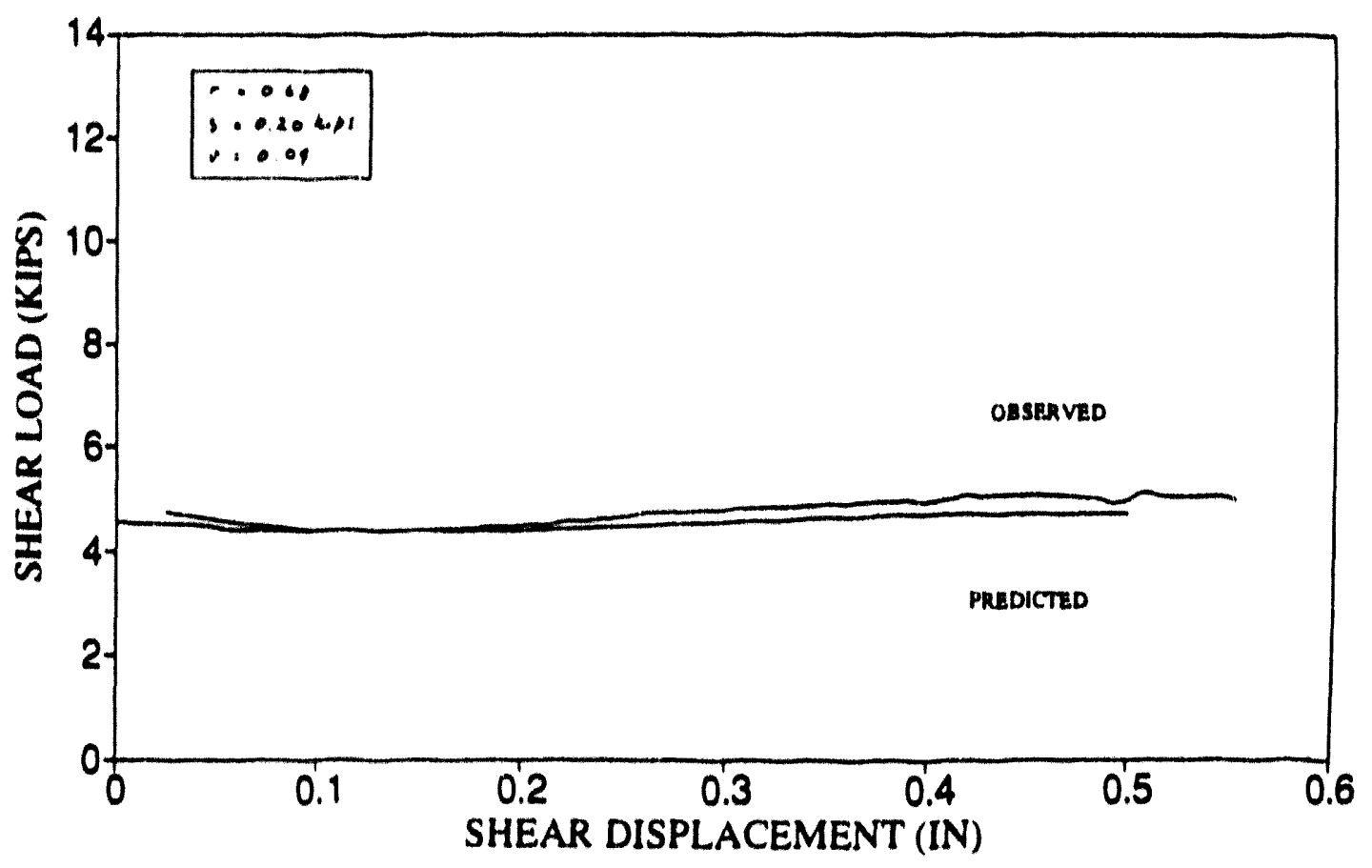



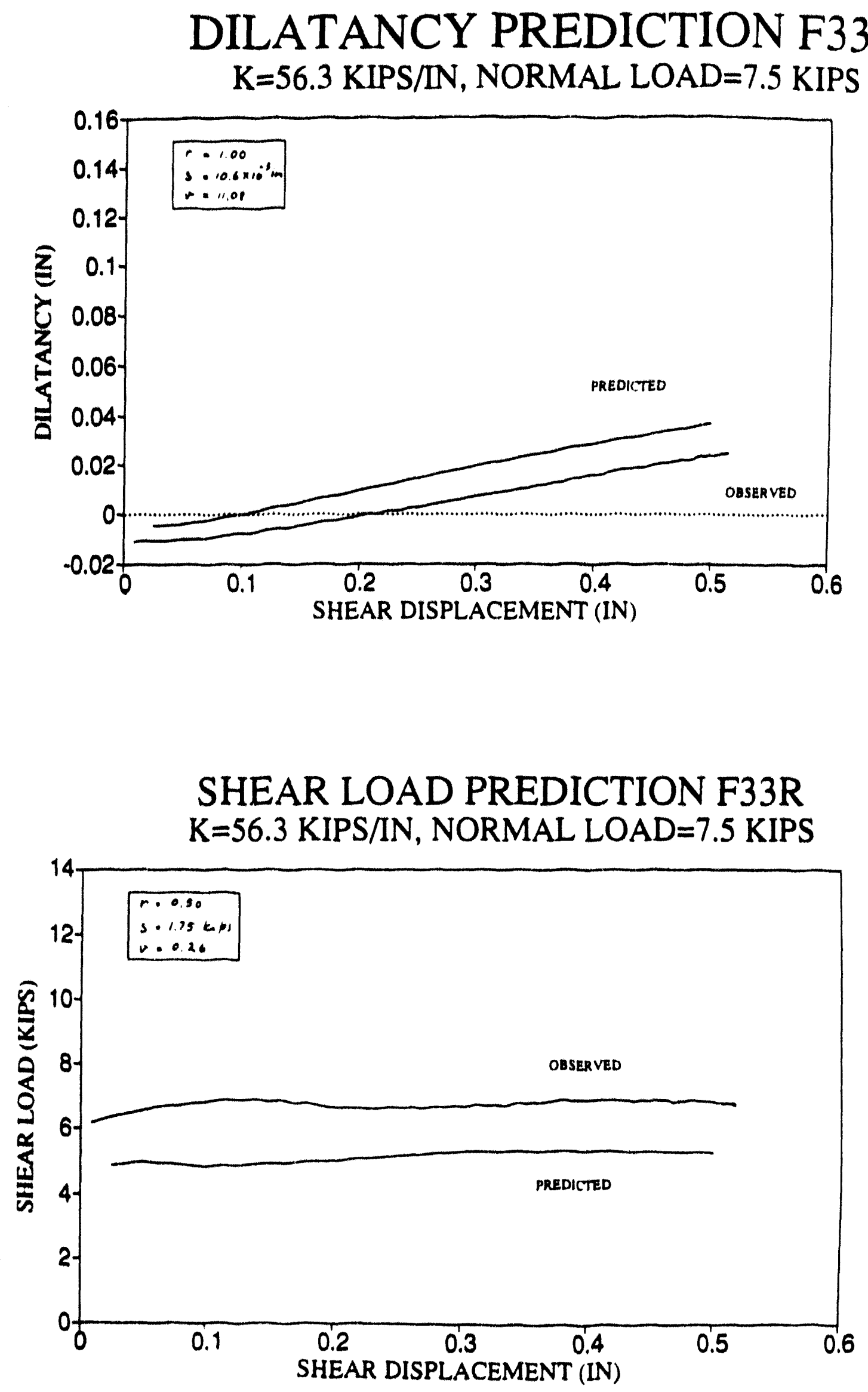
DILATANCY PREDICTION F34F $\mathrm{K}=: 5.3 \mathrm{KIPS} / \mathrm{IN}$, NORMAL LOAD=7.5 KIPS

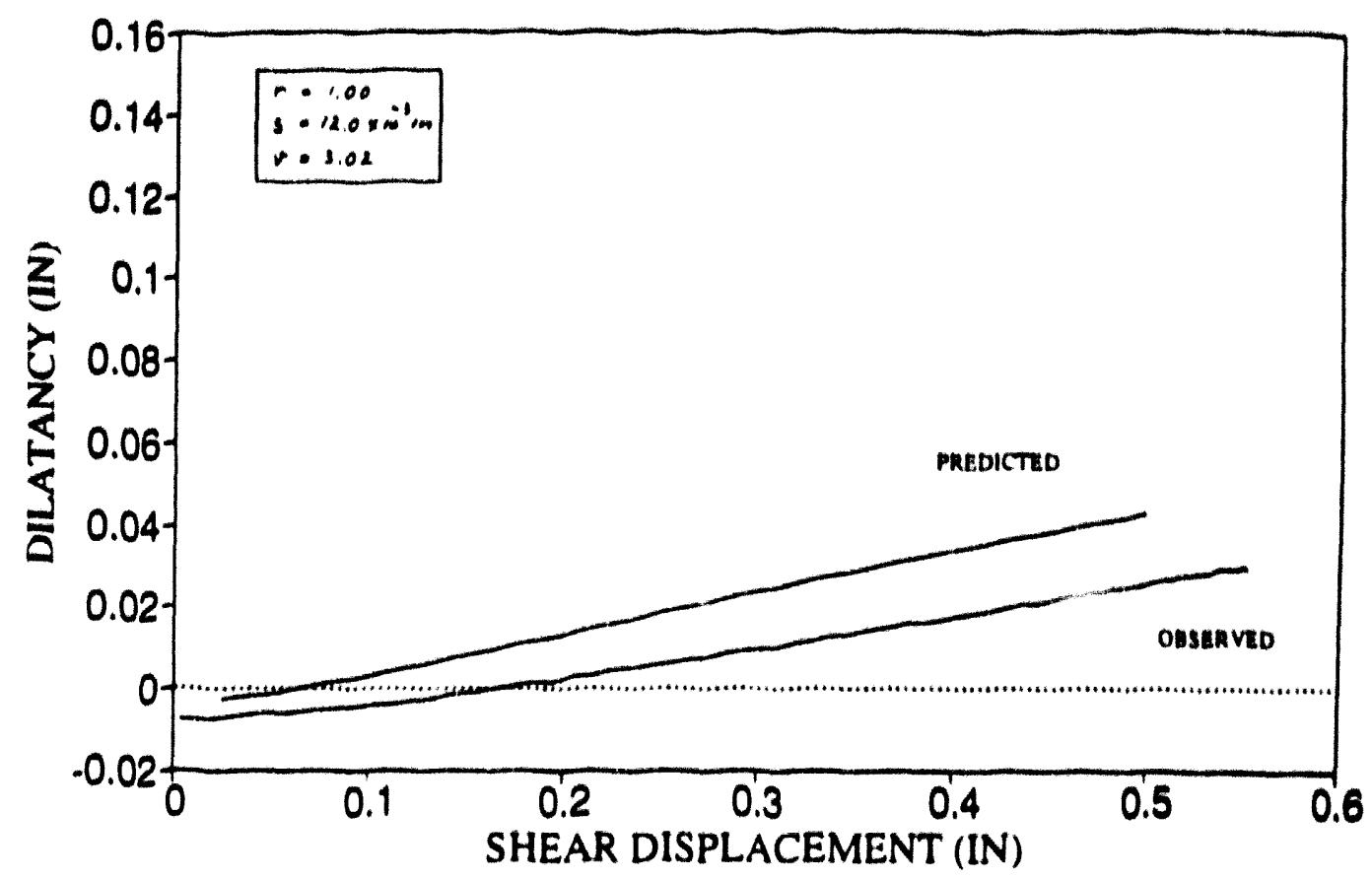

SHEAR LOAD PREDICTION F34F $\mathrm{K}=56.3 \mathrm{KIPS} / \mathrm{NN}$, NORMAL LOAD=7.5 KIPS

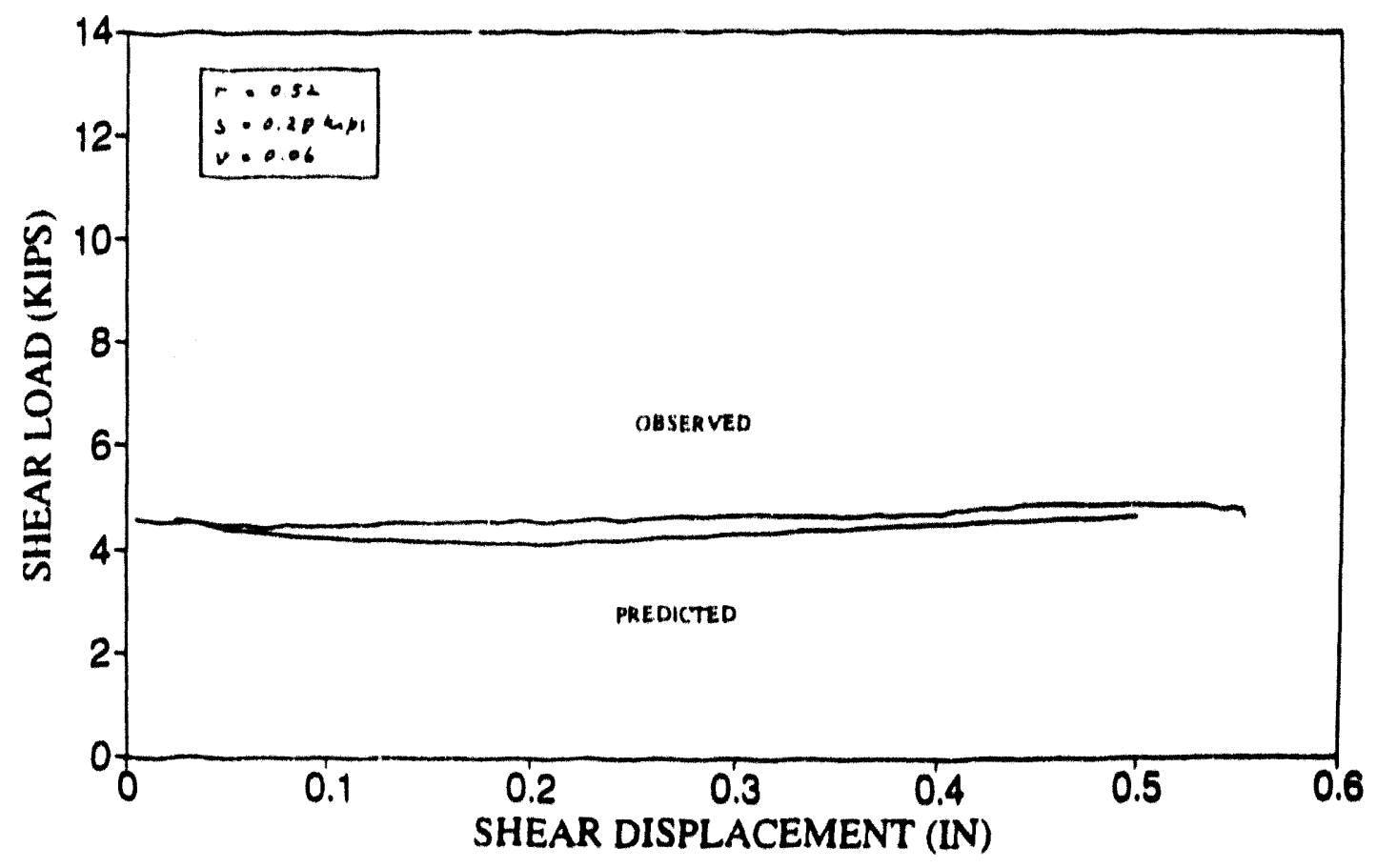




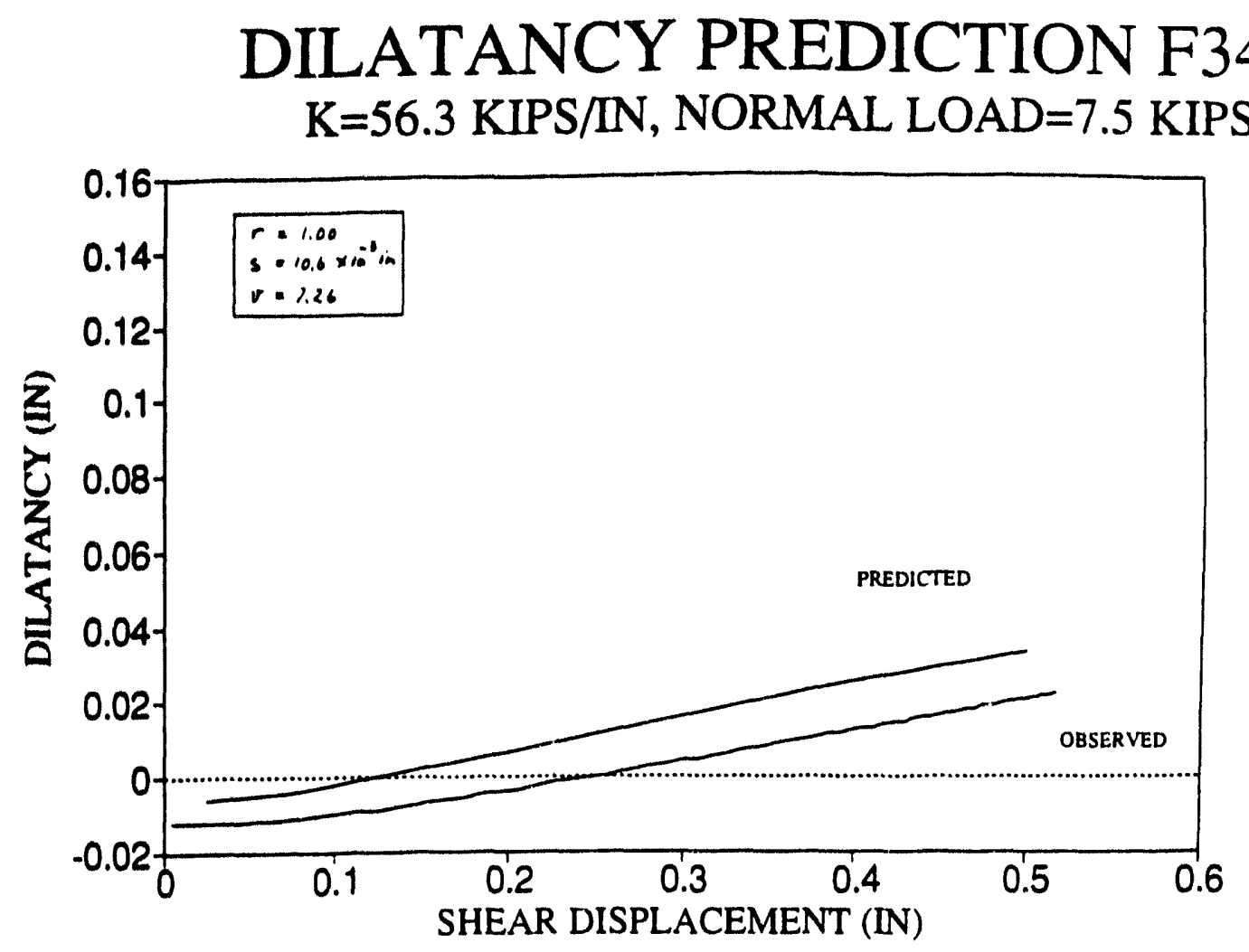

SHEAR LOAD PREDICTION F34R $\mathrm{K}=56.3 \mathrm{KIPS} / \mathrm{IN}$, NORMAL LOAD=7.5 KIPS

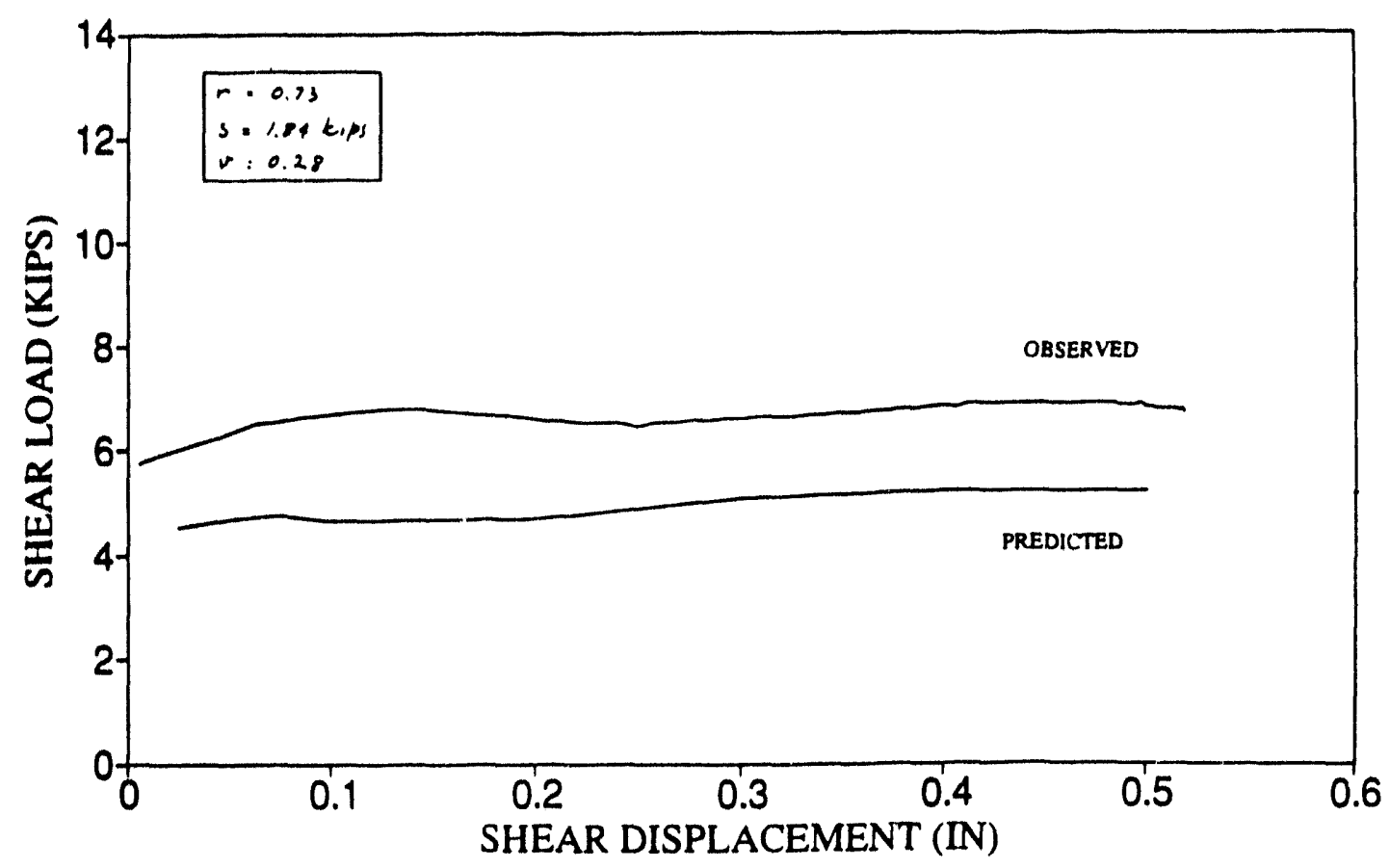




\section{DILATANCY PREDICTION F35F}

$\mathrm{K}=56.3 \mathrm{KIPS} / \mathrm{IN}$, NORMAL LOAD=7.5 KIPS

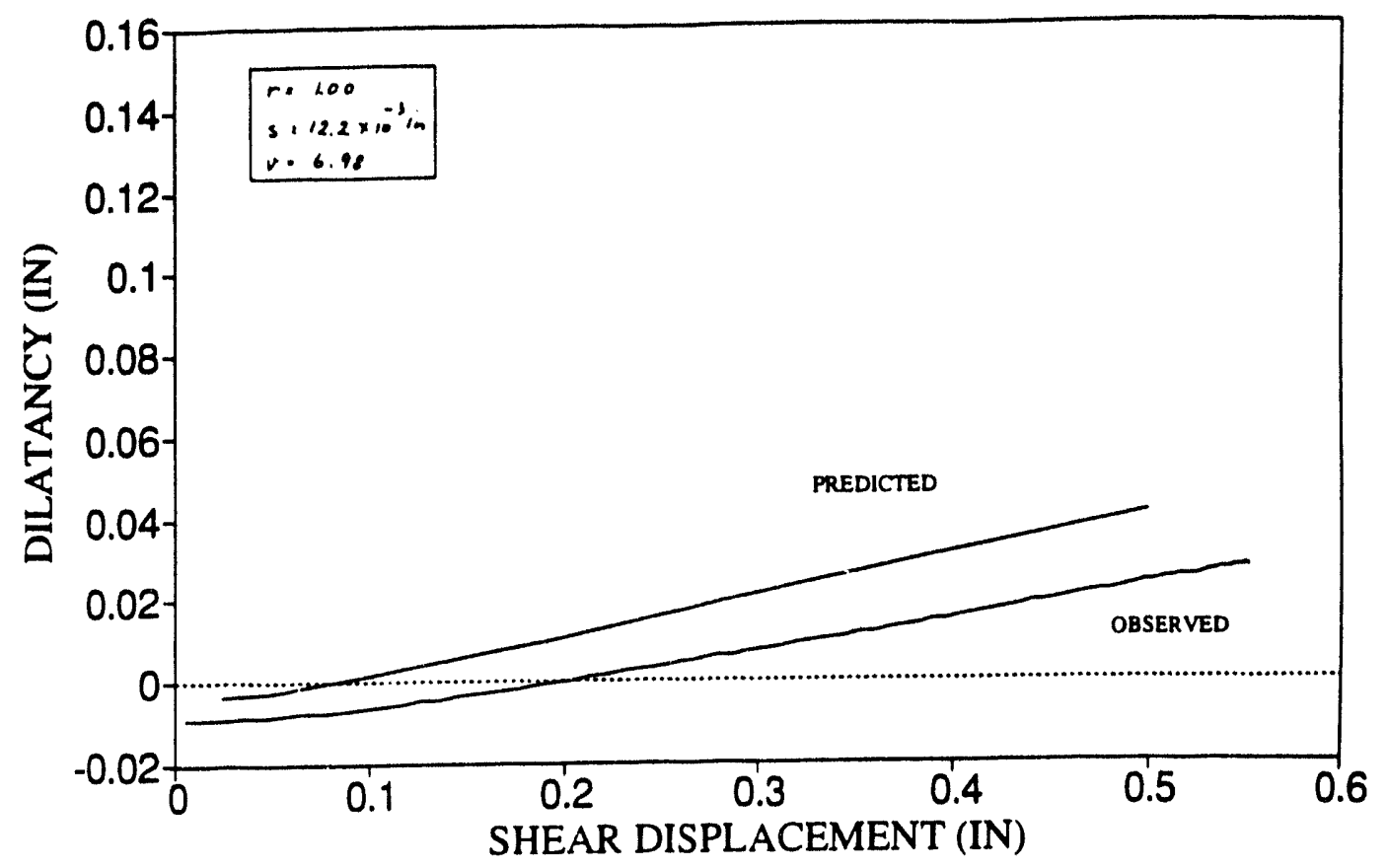

SHEAR LOAD PREDICTION F35F $\mathrm{K}=56.3 \mathrm{KIPS} / \mathrm{IN}$, NORMAL LOAD=7.5 KIPS

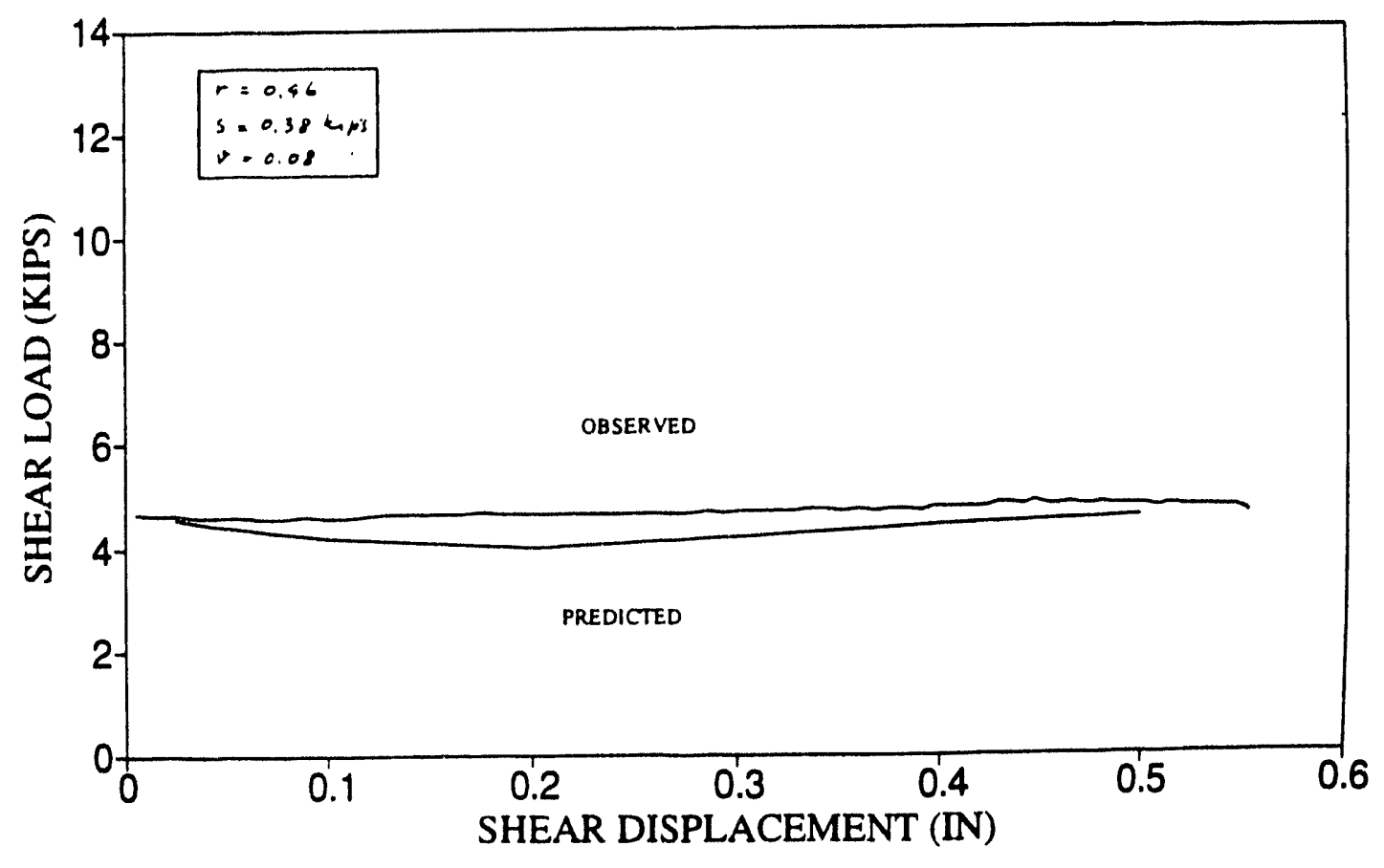




\section{DILATANCY PREDICTION F35R $\mathrm{K}=56.3 \mathrm{KIPS} / \mathrm{IN}$, NORMAL LOAD=7.5 KIPS}

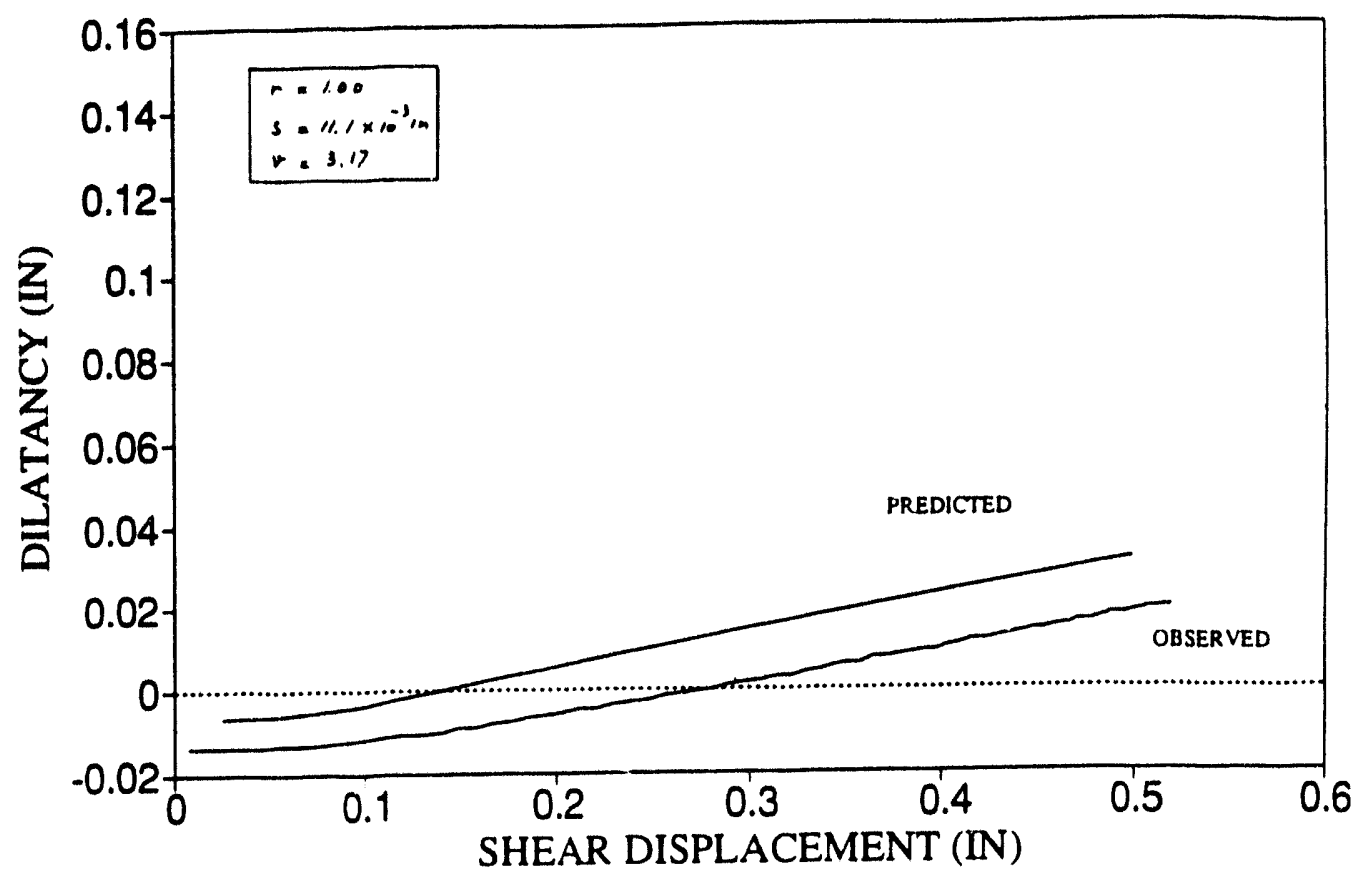

SHEAR LOAD PREDICTION F35R $\mathrm{K}=56.3 \mathrm{KIPS} / \mathrm{IN}$, NORMAL LOAD=7.5 KIPS

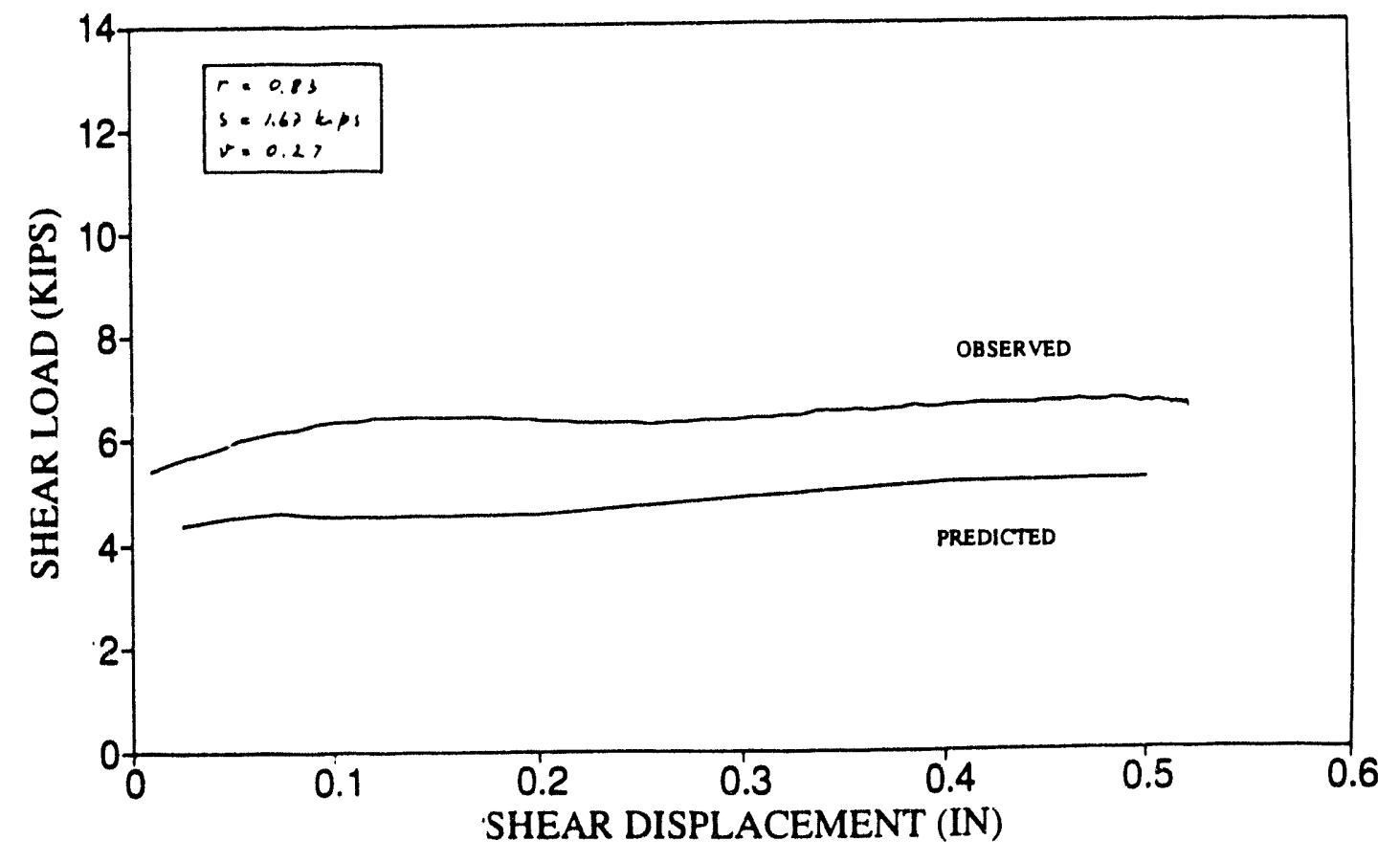


DILATANCY PREDICTION F31F $\mathrm{K}=187.5 \mathrm{KIPS} / \mathrm{IN}$, NORMAL LOAD=7.5 KIPS

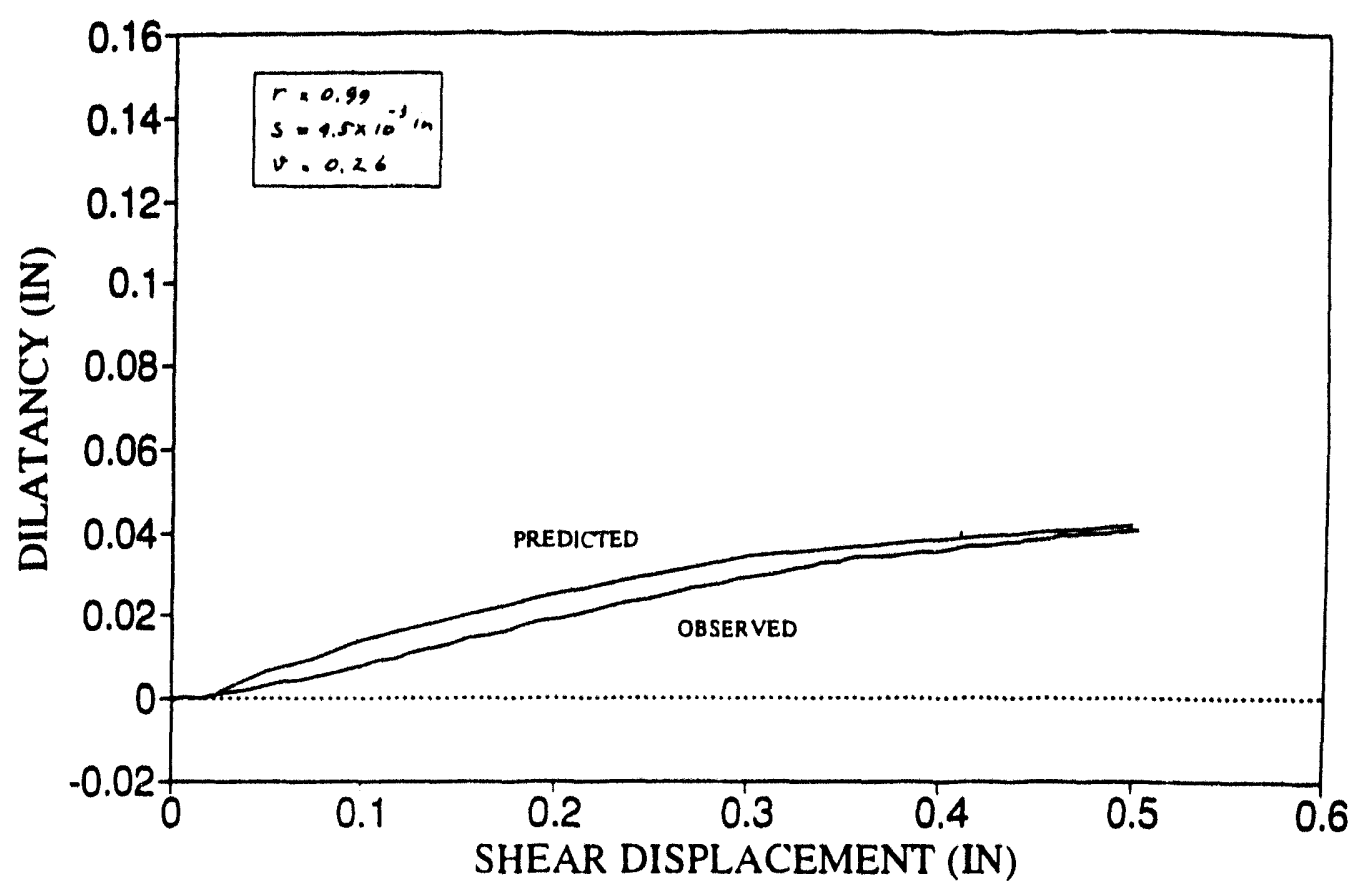

SHEAR LOAD PREDICTION F31F $\mathrm{K}=187.5 \mathrm{KIPS} / \mathrm{IN}$, NORMAL LOAD $=7.5 \mathrm{KIPS}$

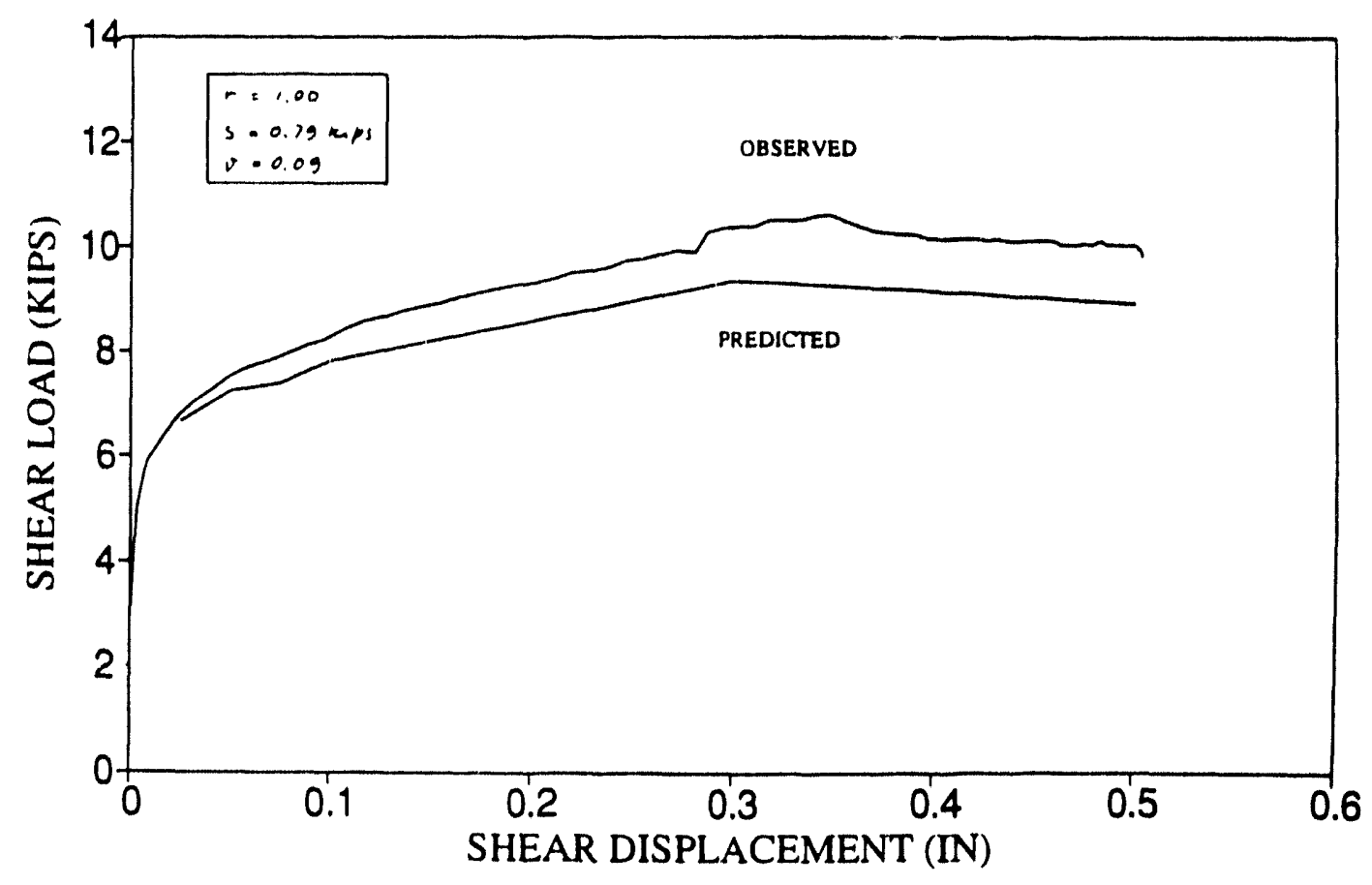



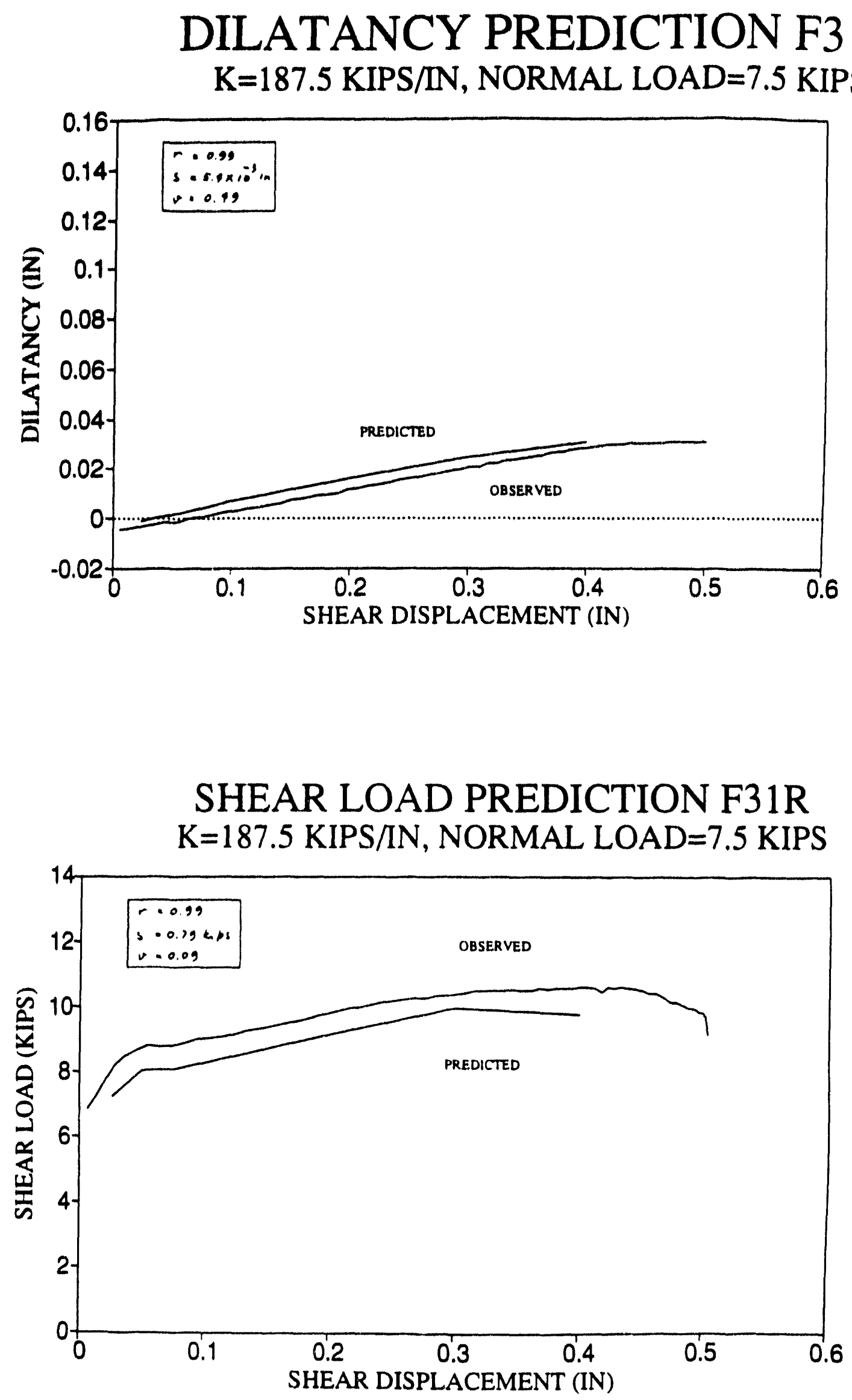
DILATANCY PREDICTION F32F $\mathrm{K}=187.5 \mathrm{KIPS} / \mathrm{IN}$, NORMAL LOAD=7.5 KIPS

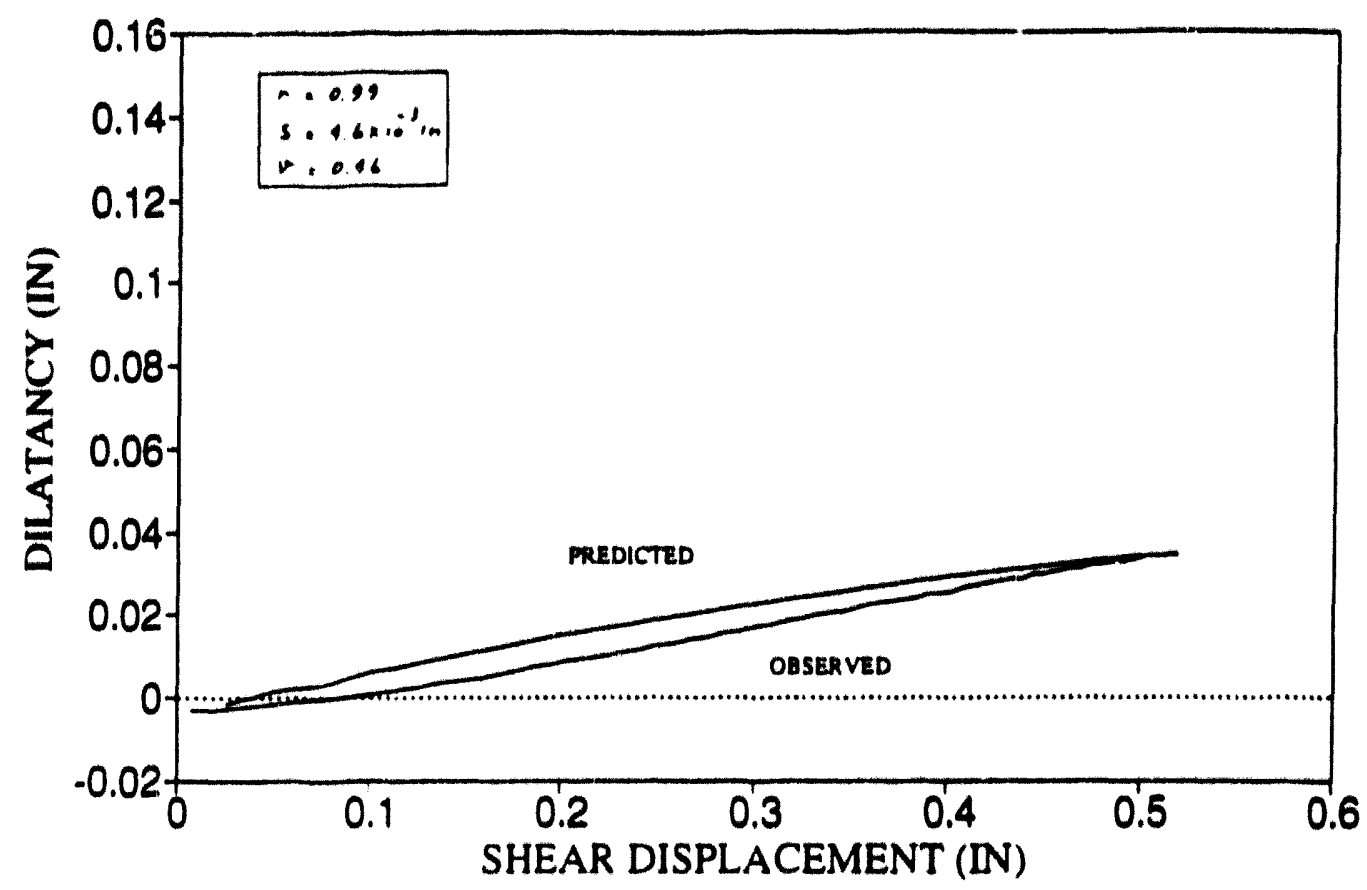

SHEAR LOAD PREDICTION F32F $K=187.5 \mathrm{KIPS} / \mathrm{IN}$, NORMAL LOAD $=7.5 \mathrm{KIPS}$

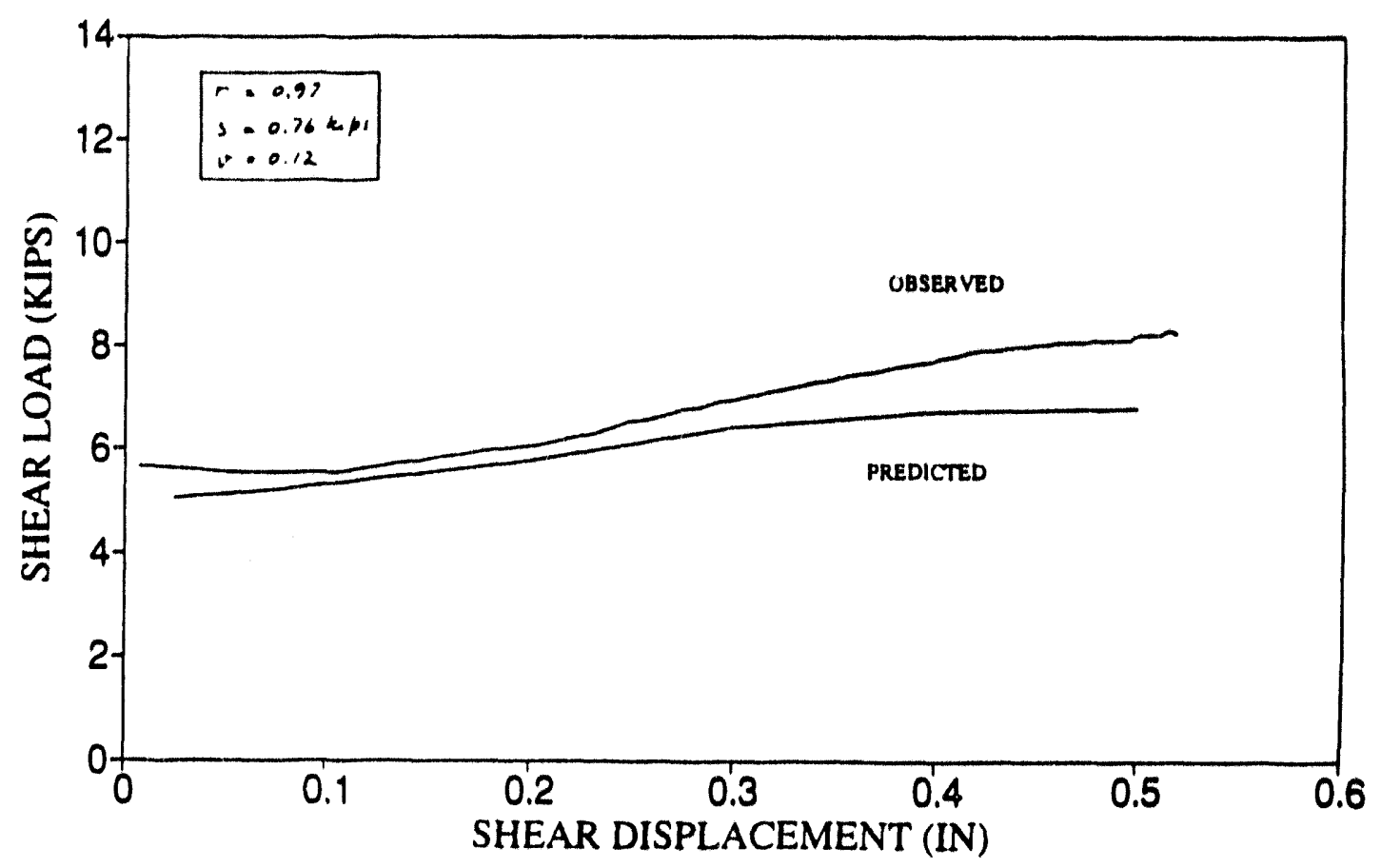



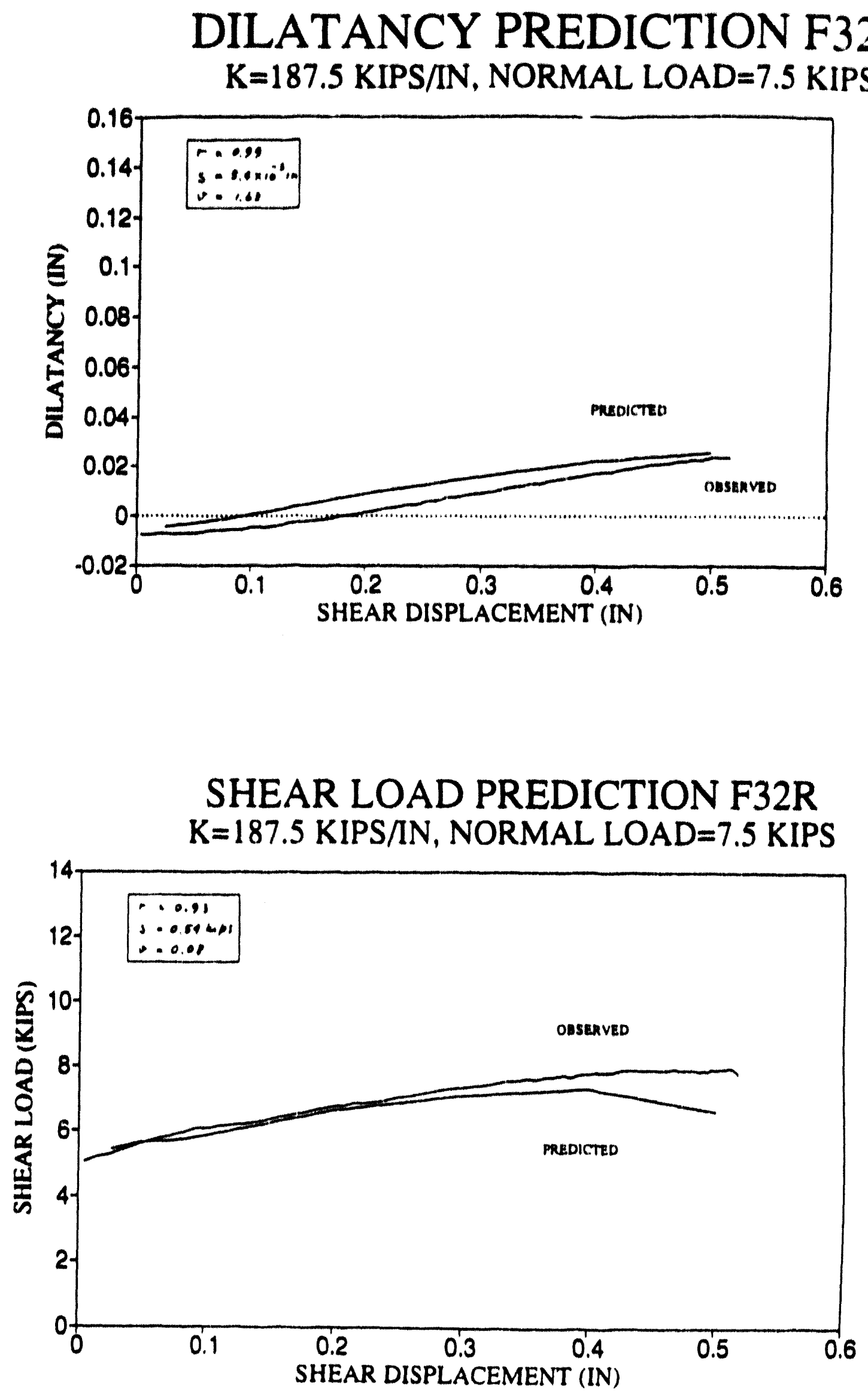

B-92 

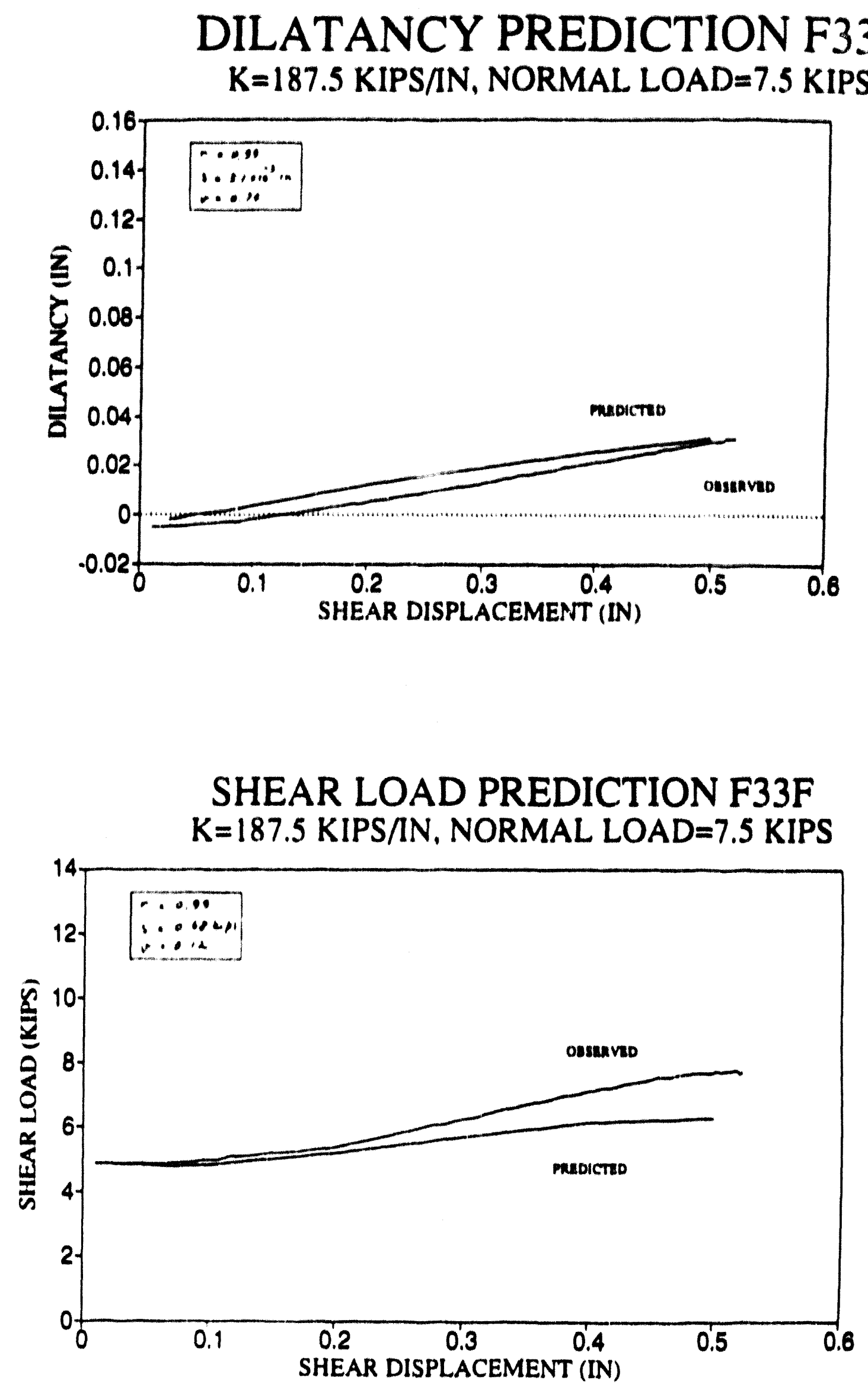

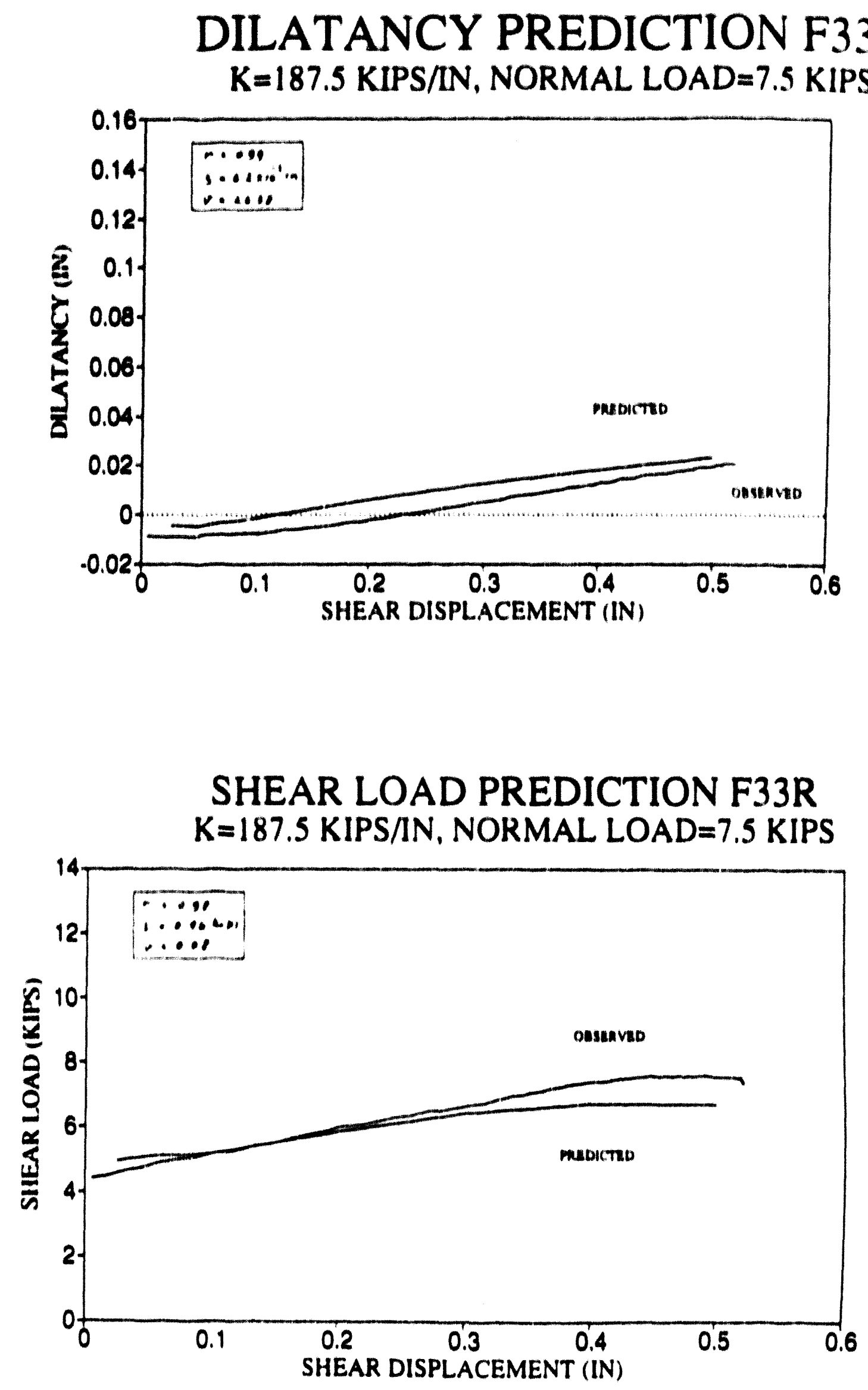

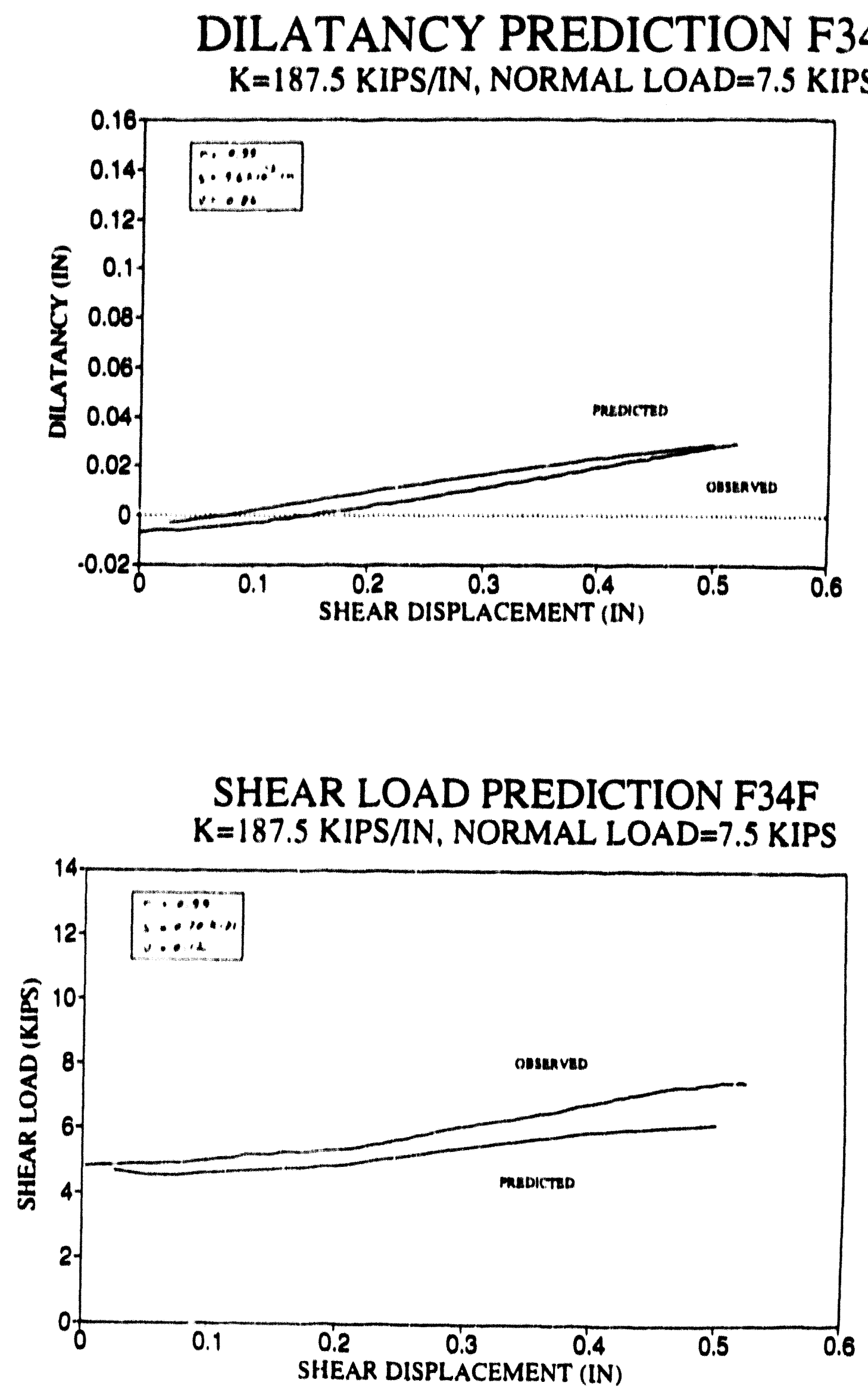
DILATANCY PREDICTION F34R $\mathrm{K}=187.5 \mathrm{KIPS} / \mathrm{IN}$, NORMAL LOAD $=7.5 \mathrm{KIPS}$

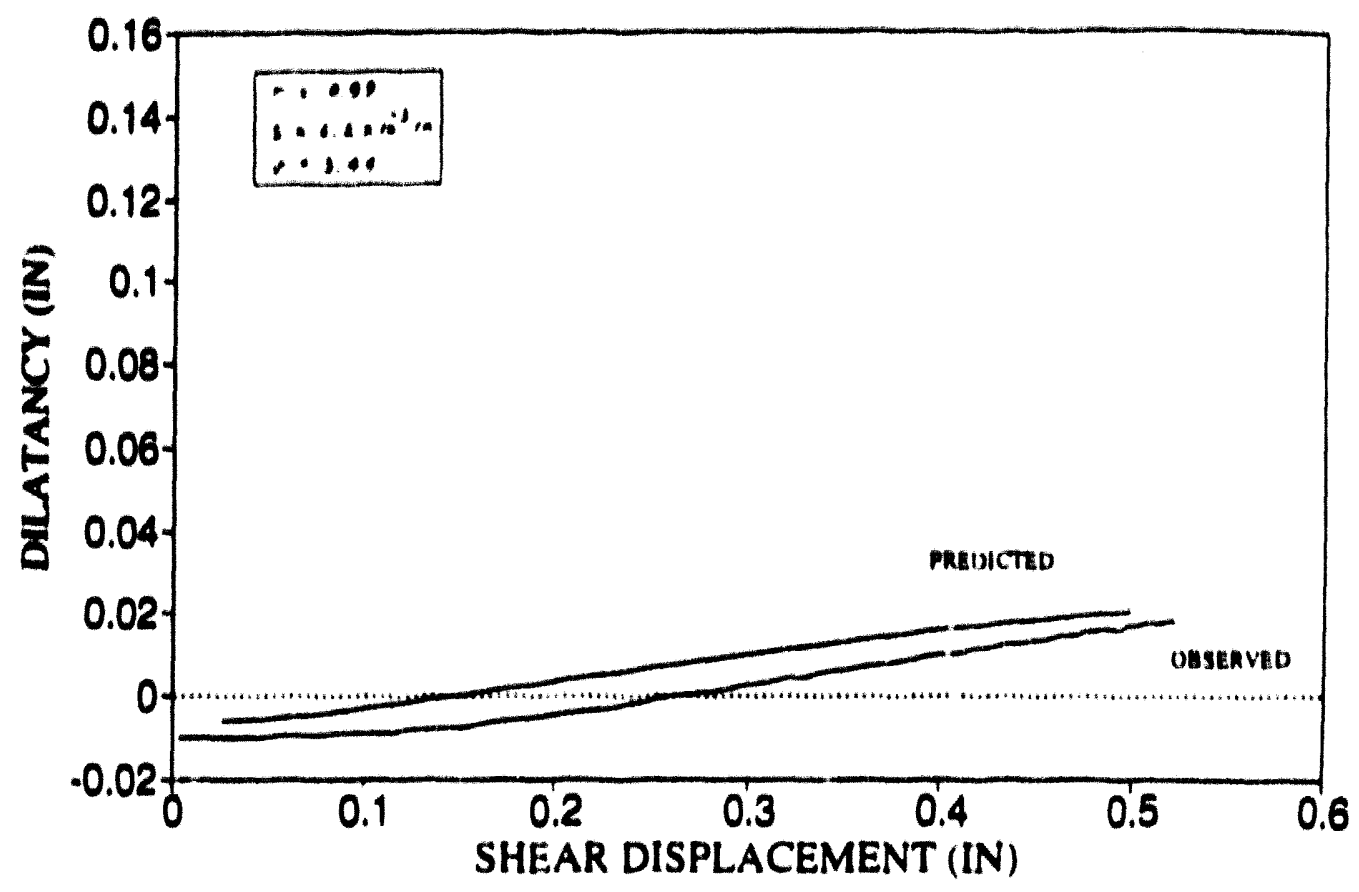

SHEAR LOAD PREDICTION F34R $K=187.5 \mathrm{KIPS} / \mathrm{IN}$, NORMAL LOAD $=7.5 \mathrm{KIPS}$

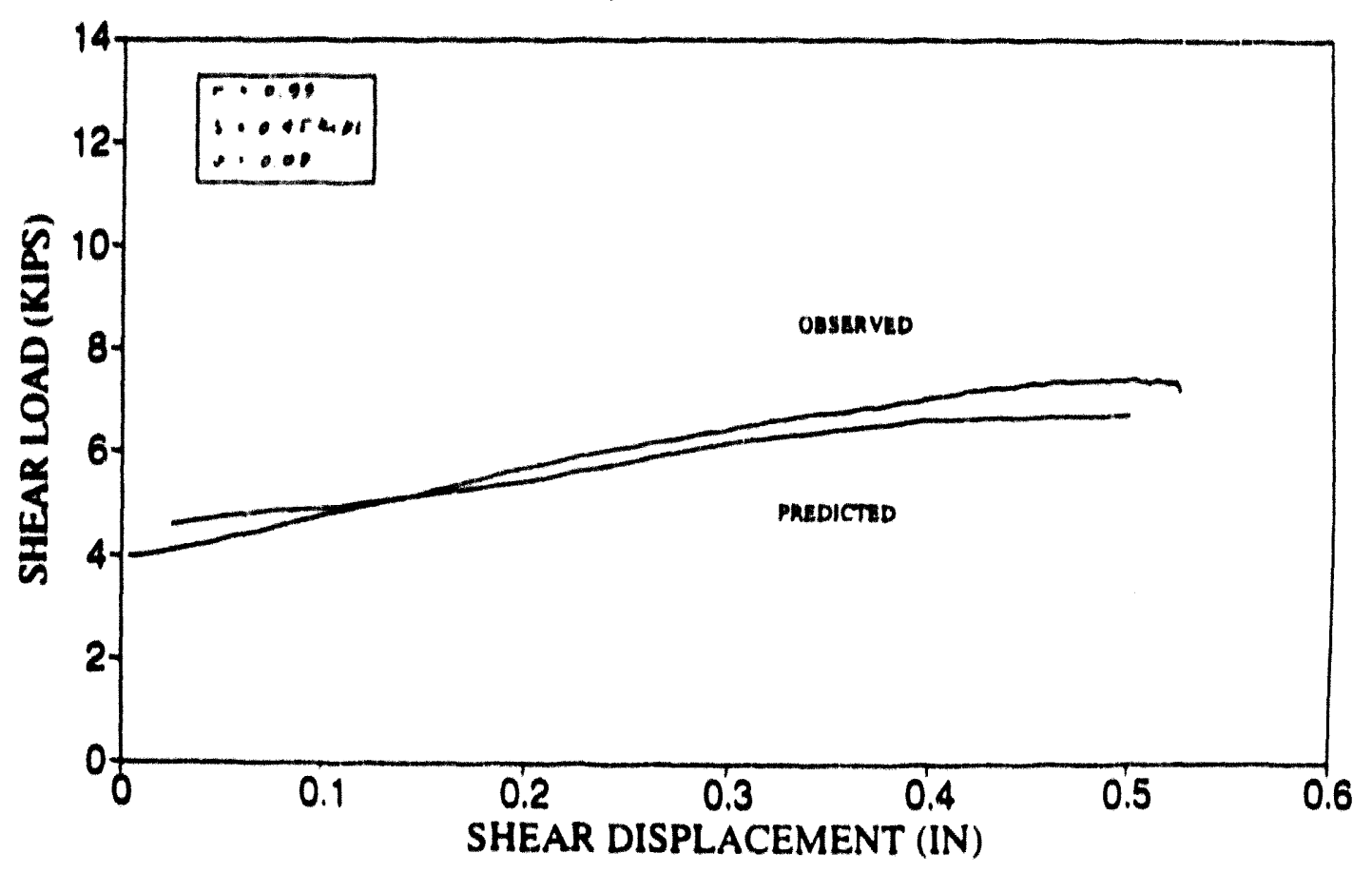




$$
\text { L6-8 }
$$
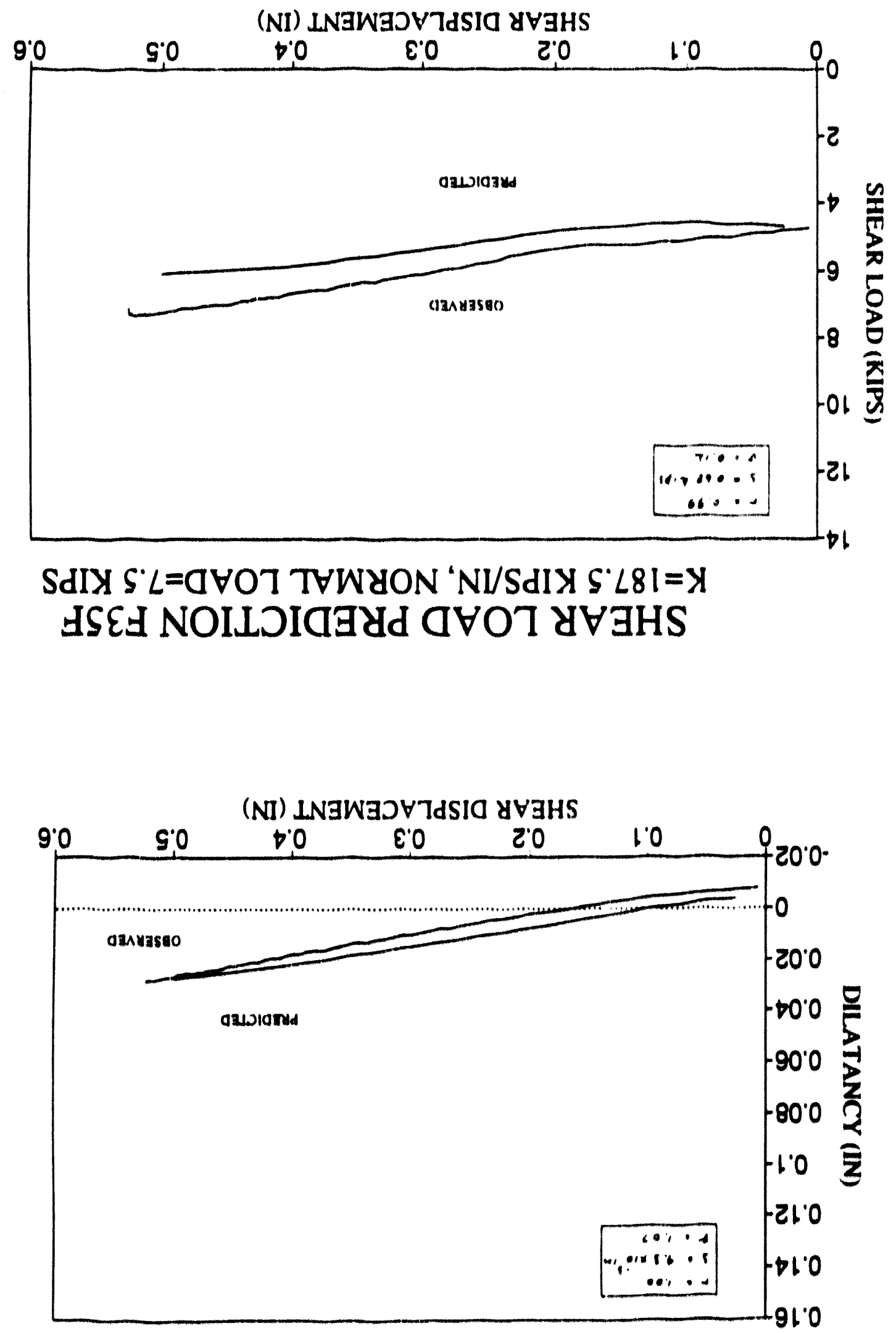

SdIX $\varsigma^{\circ} \angle=$ CIVOT TVWYON 'NI/SdIX $\varsigma^{\prime} \angle 8 I=X$ ${ }^{\prime} S \varepsilon_{\exists}$ NOILDIG 
DILATANCY PREDICTION F35R $\mathrm{K}=187.5 \mathrm{KIPS} / \mathrm{IN}$, NORMAL LOAD $=7.5 \mathrm{KIPS}$

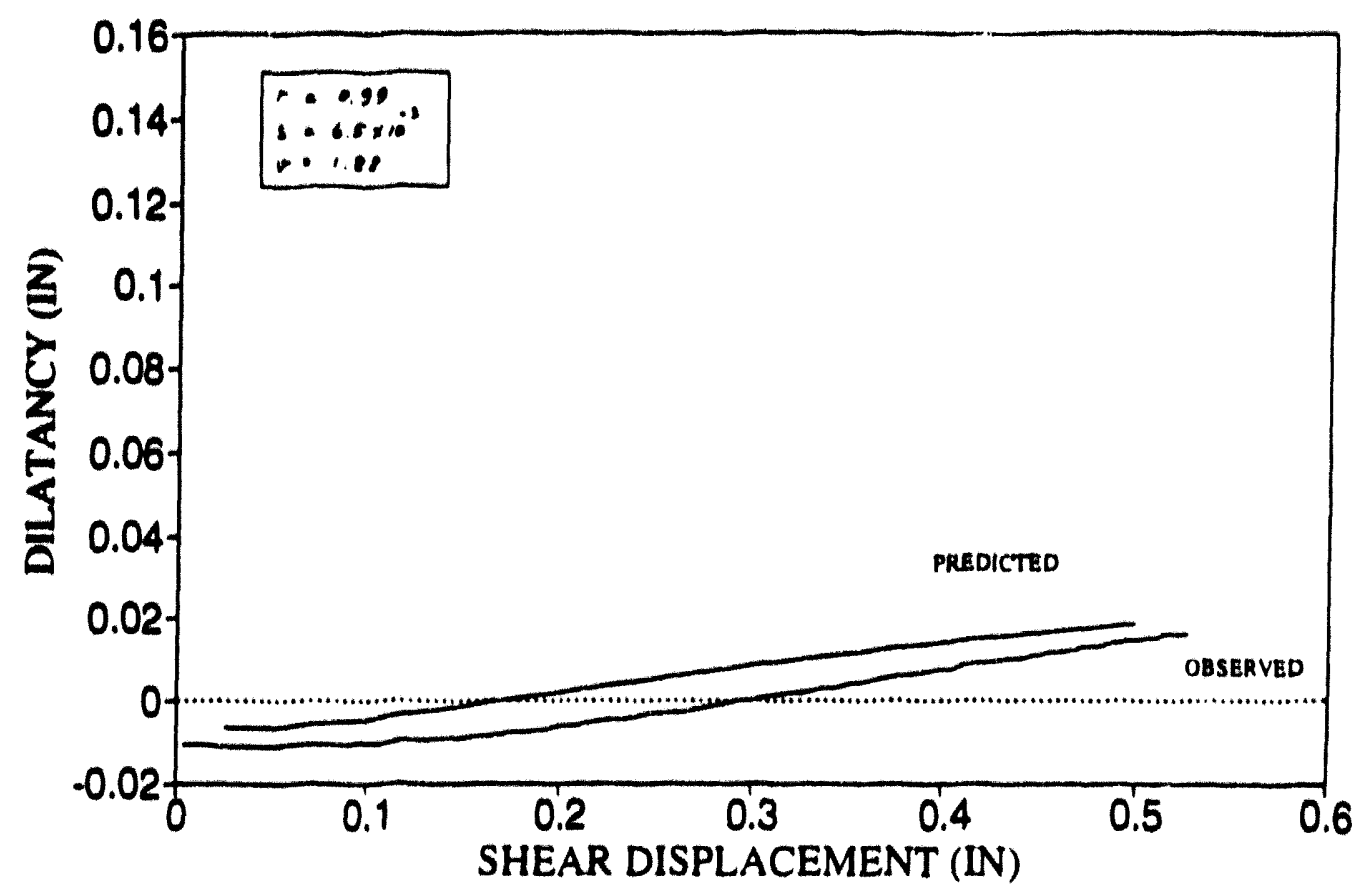

SHEAR LOAD PREDICTION F35R $\mathrm{K}=187.5 \mathrm{KIPS} / \mathrm{IN}$, NORMAL LOAD $=7.5 \mathrm{KIPS}$

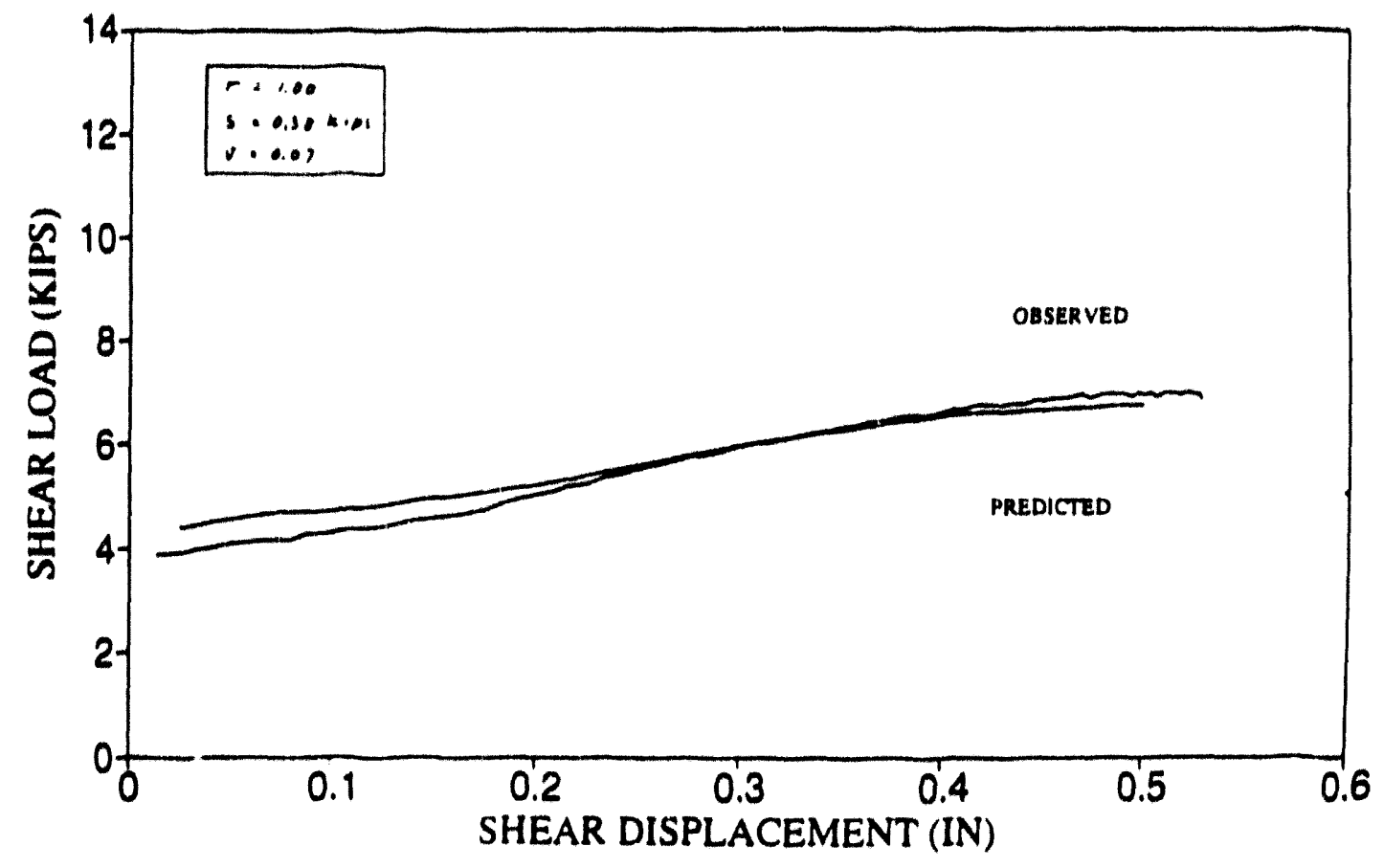




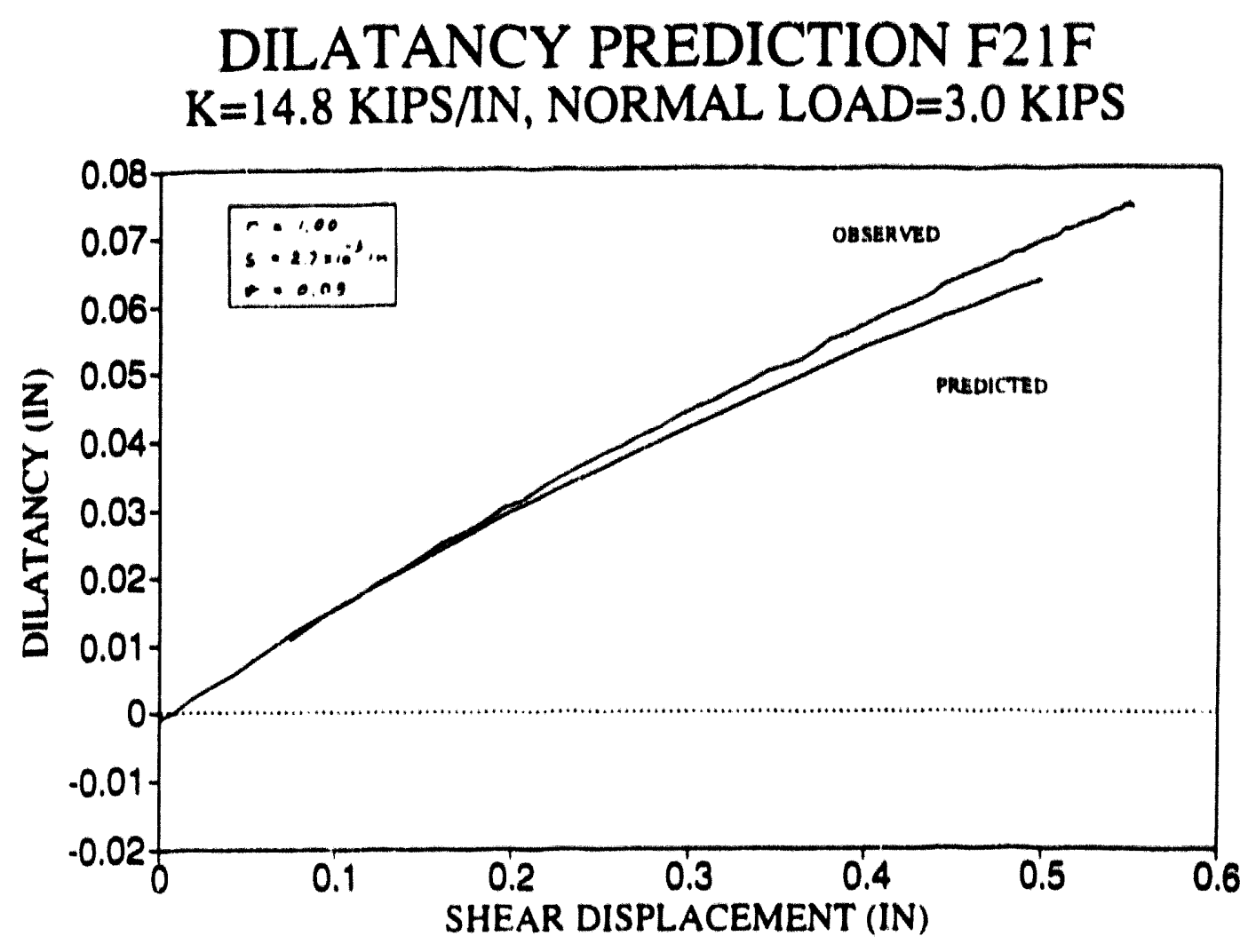

SHEAR LOAD PREDICTION F21F $\mathrm{K}=14.8 \mathrm{KIPS} / \mathrm{IN}$, NORMAL LOAD=3.0 KIPS

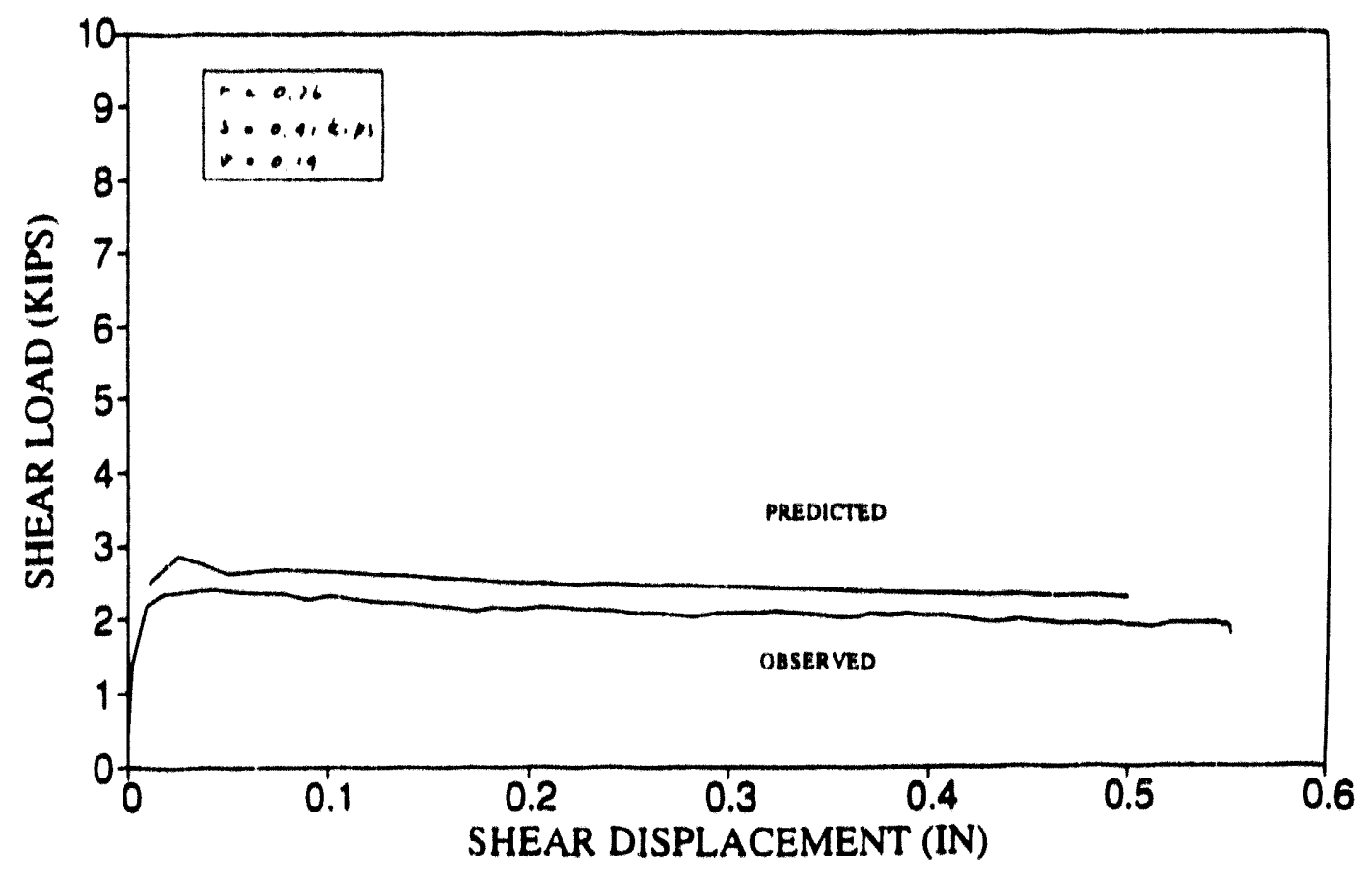




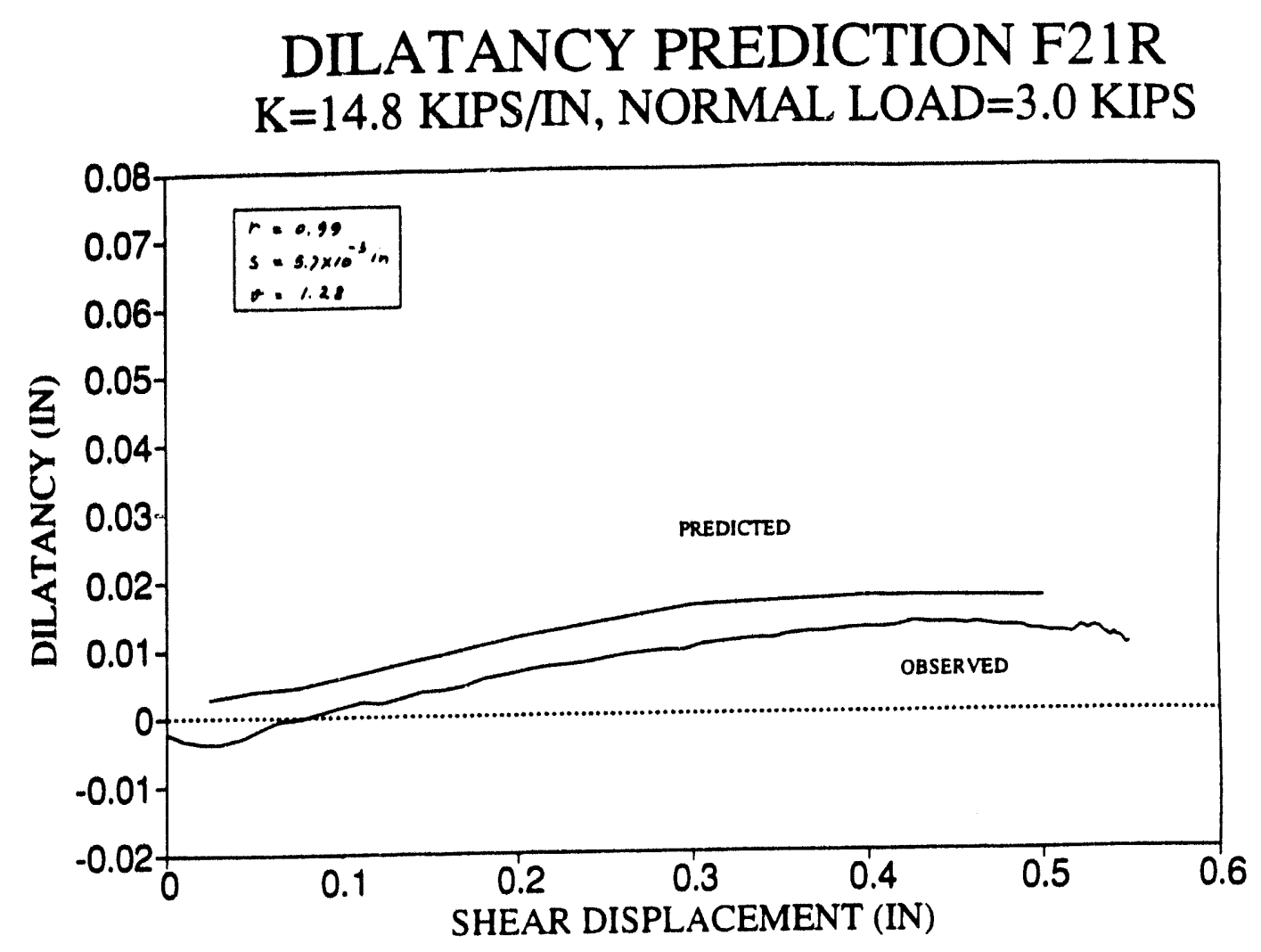

SHEAR LOAD PREDICTION F21R $\mathrm{K}=14.8 \mathrm{KIPS} / \mathrm{IN}$, NORMAL LOAD=3.0 KIPS

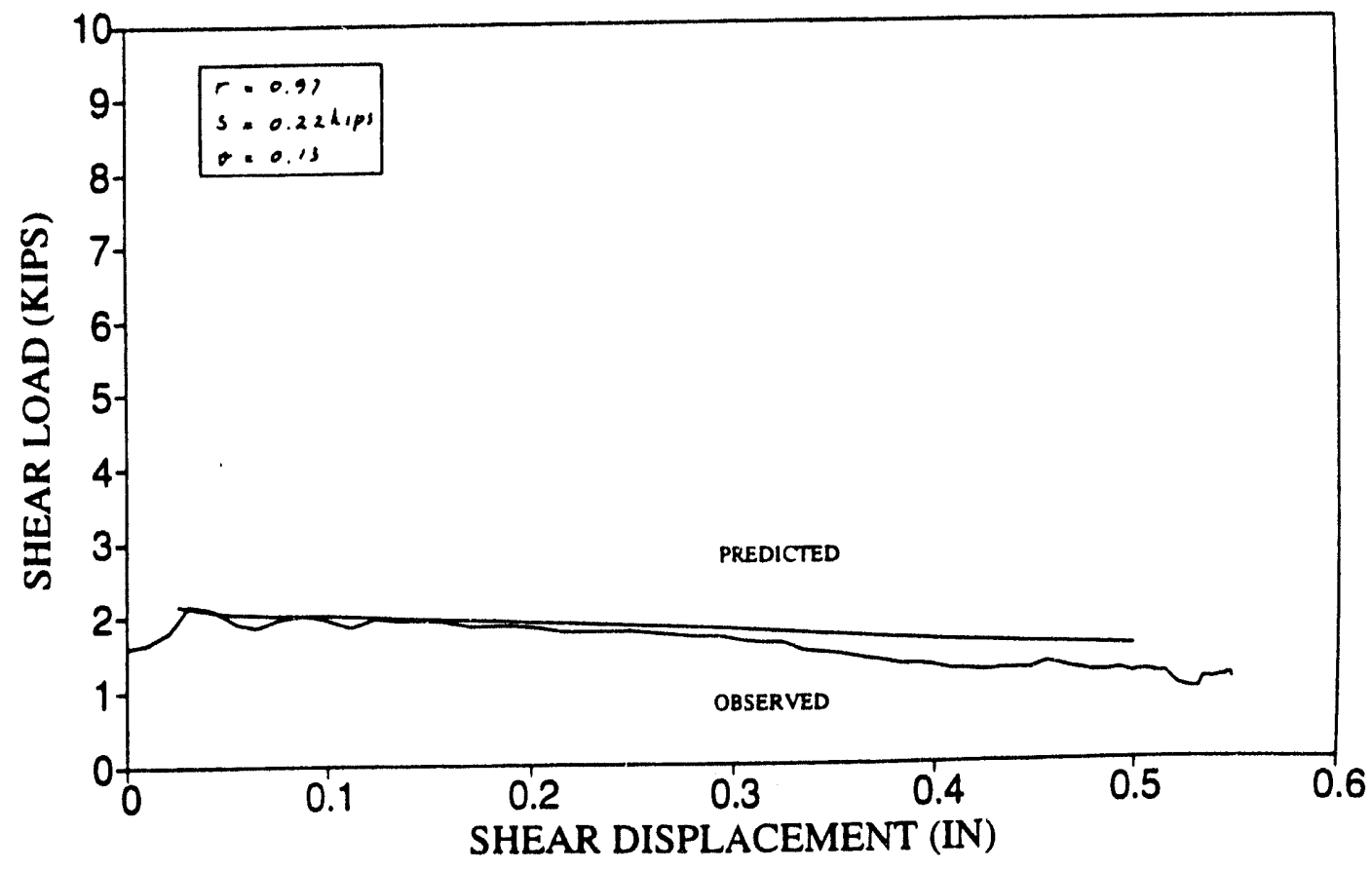




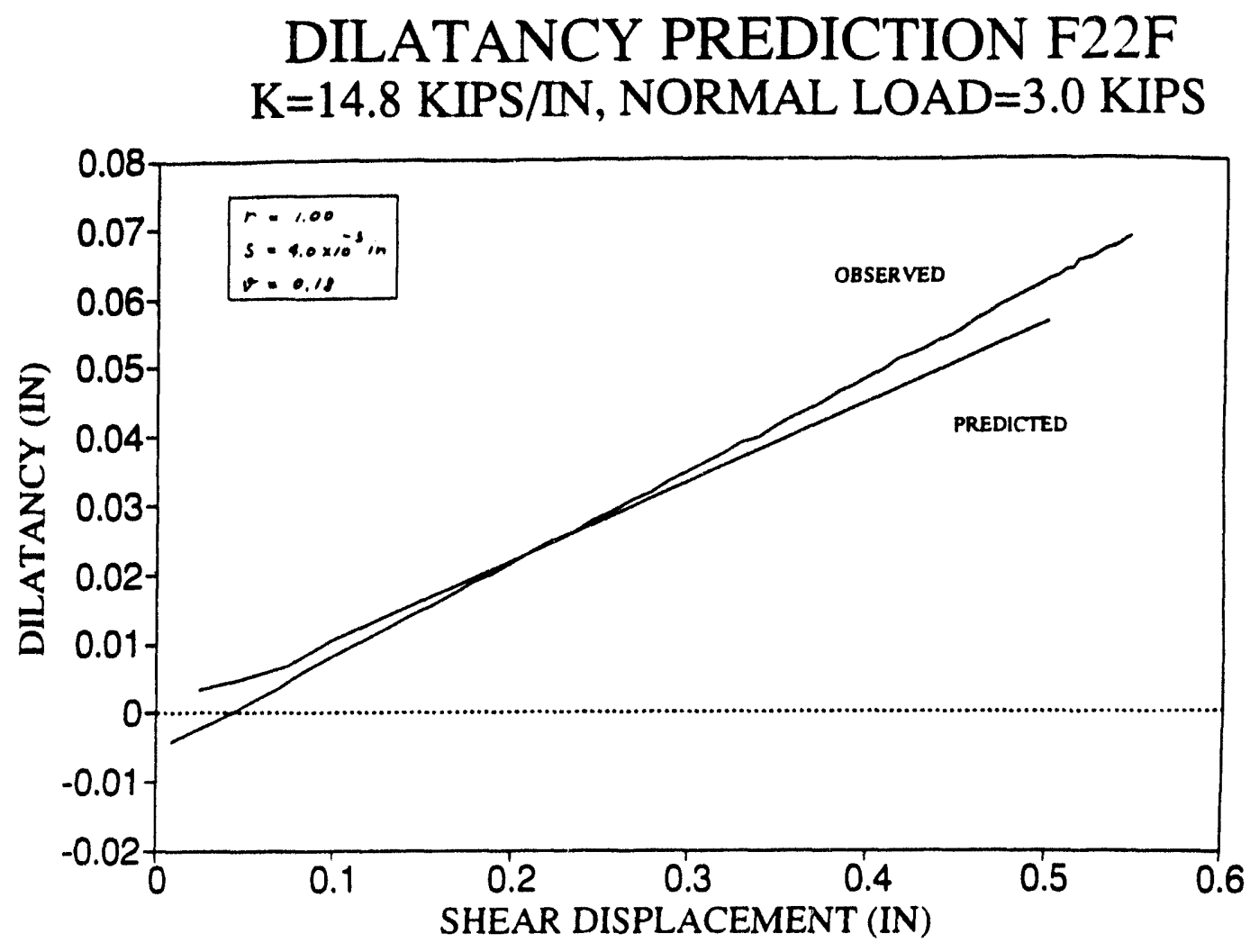

SHEAR LOAD PREDICTION F22F

$\mathrm{K}=14.8 \mathrm{KIPS} / \mathrm{IN}$, NORMAL LOAD $=3.0 \mathrm{KIPS}$

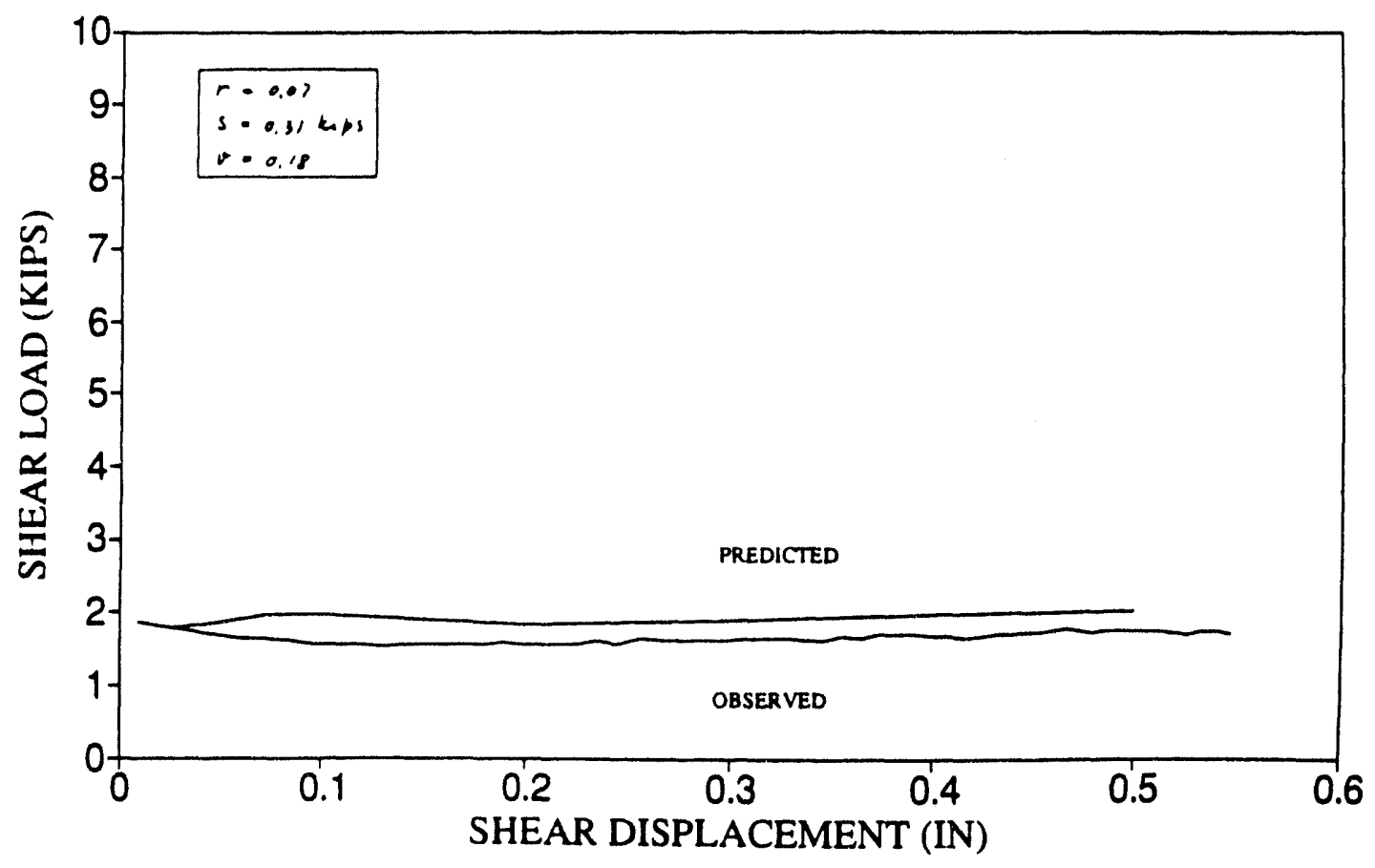




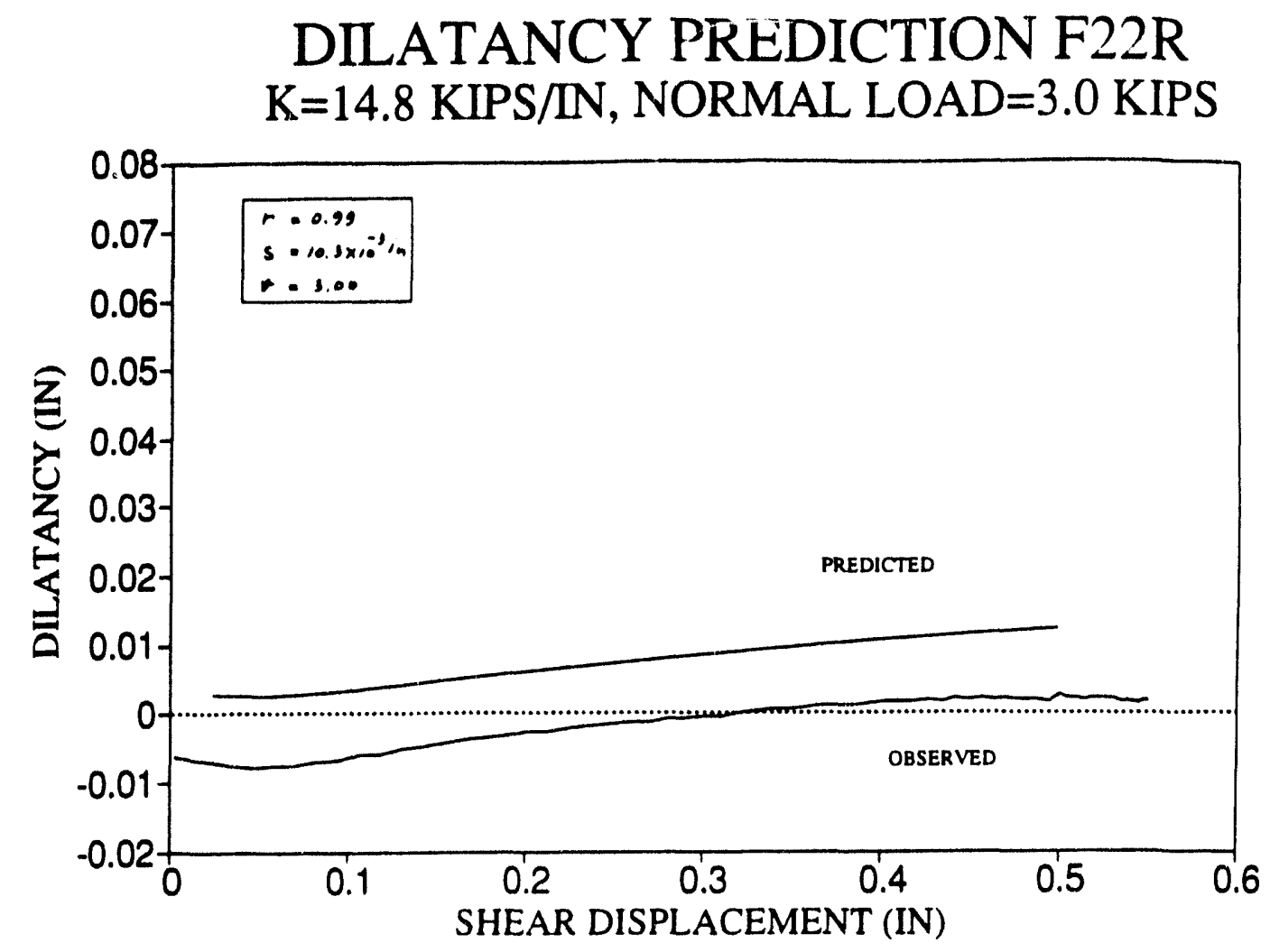

SHEAR LOAD PREDICTION F22R $\mathrm{K}=14.8 \mathrm{KIPS} / \mathrm{IN}$, NORMAL LOAD=3.0 KIPS

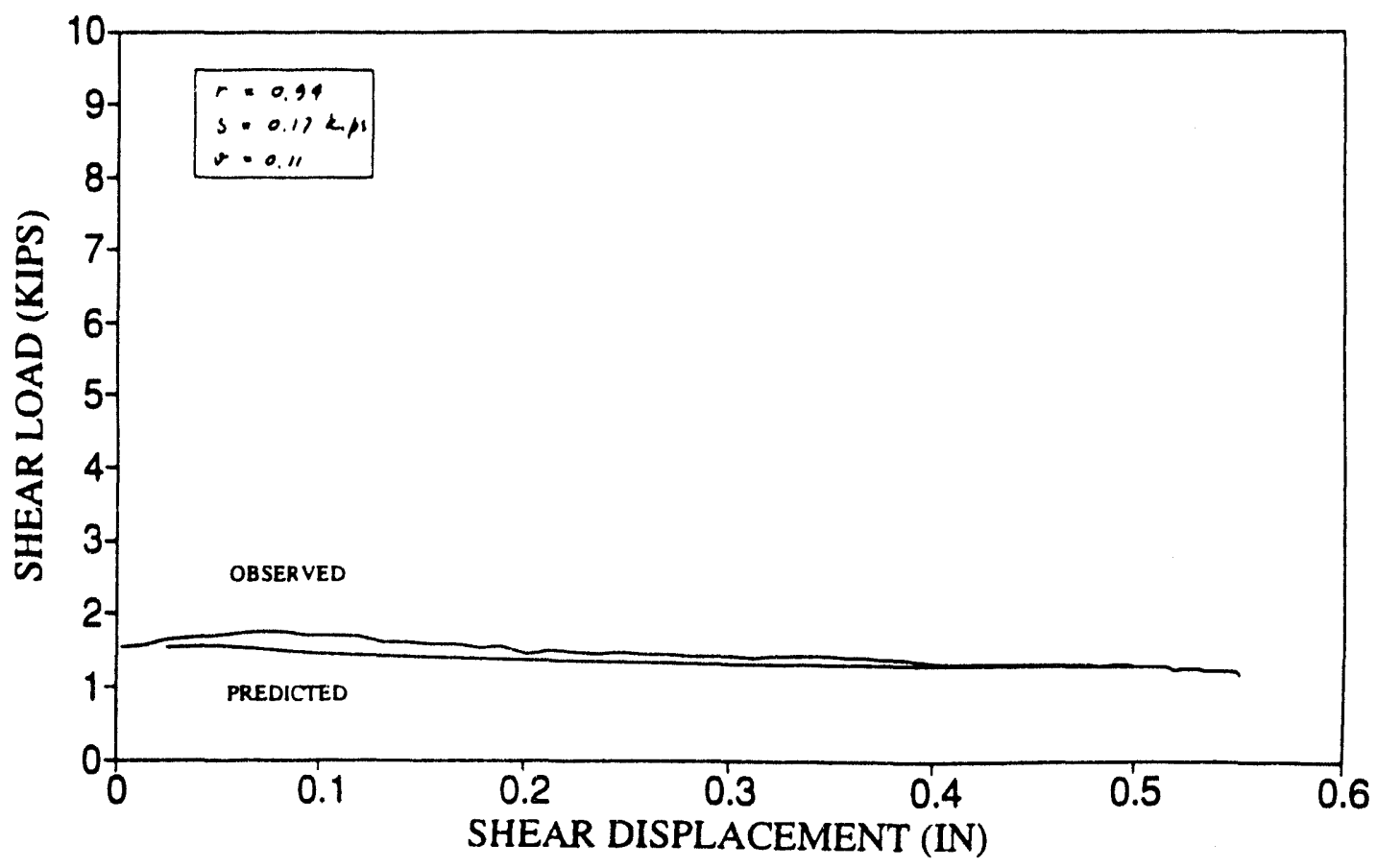



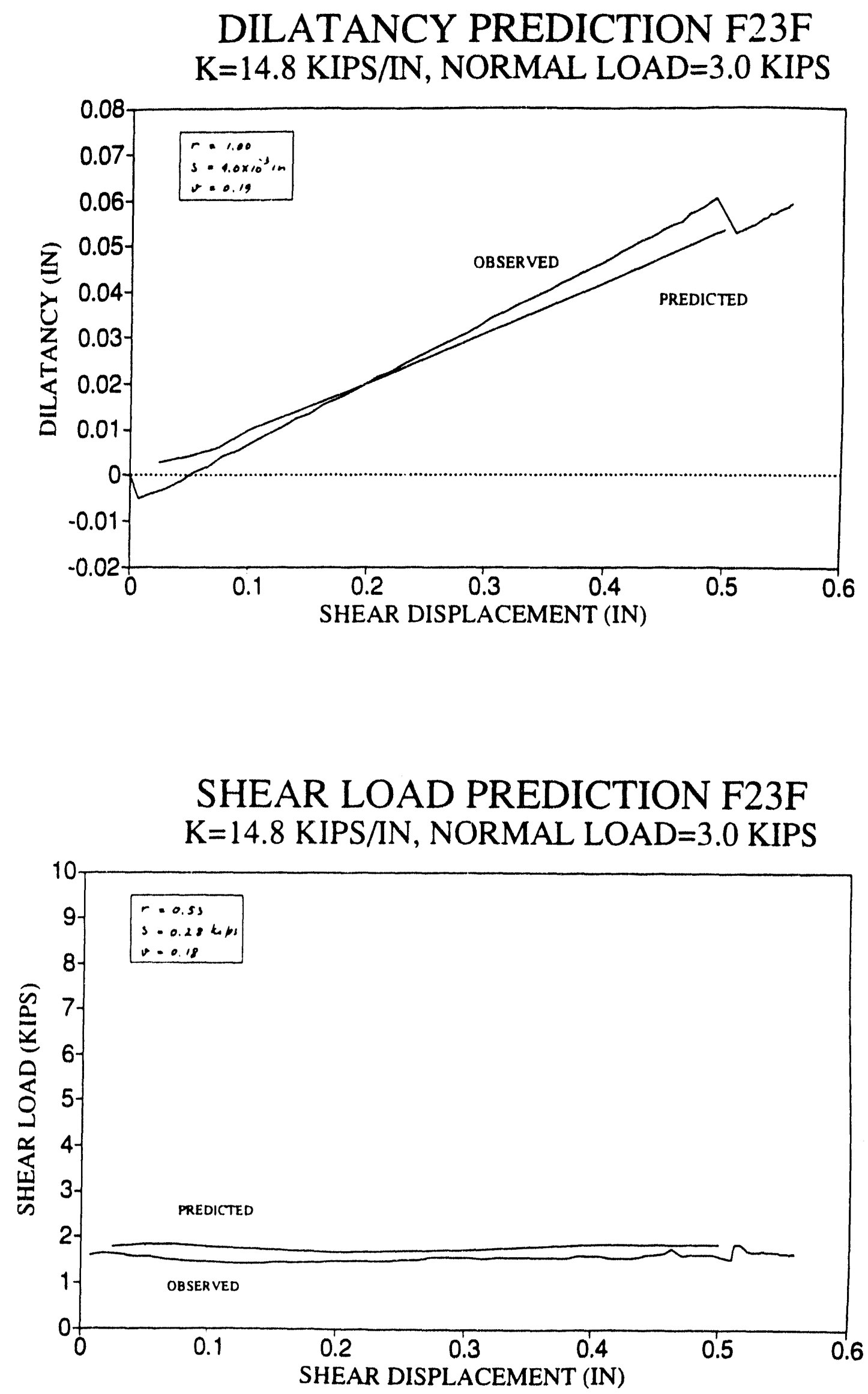

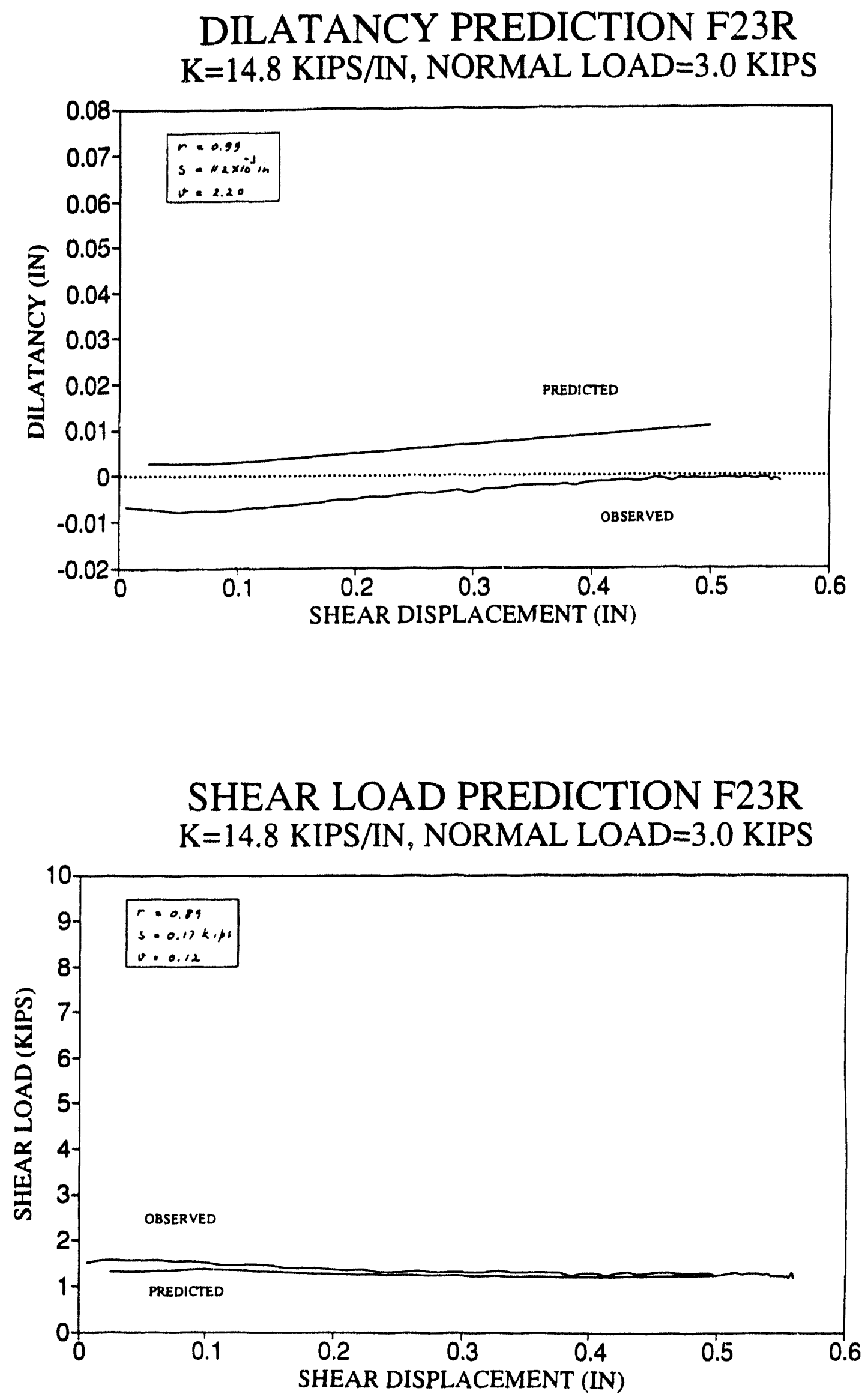

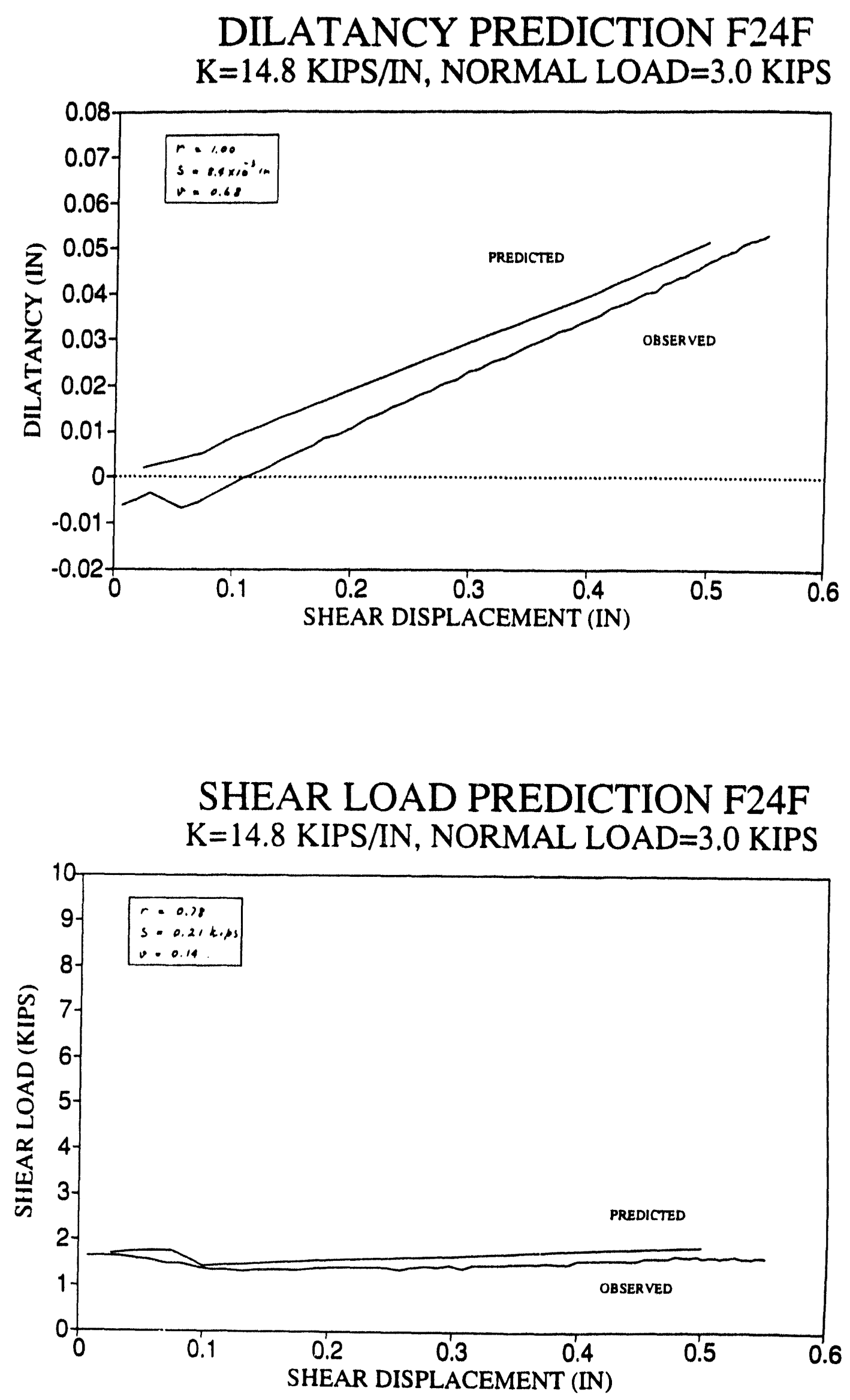

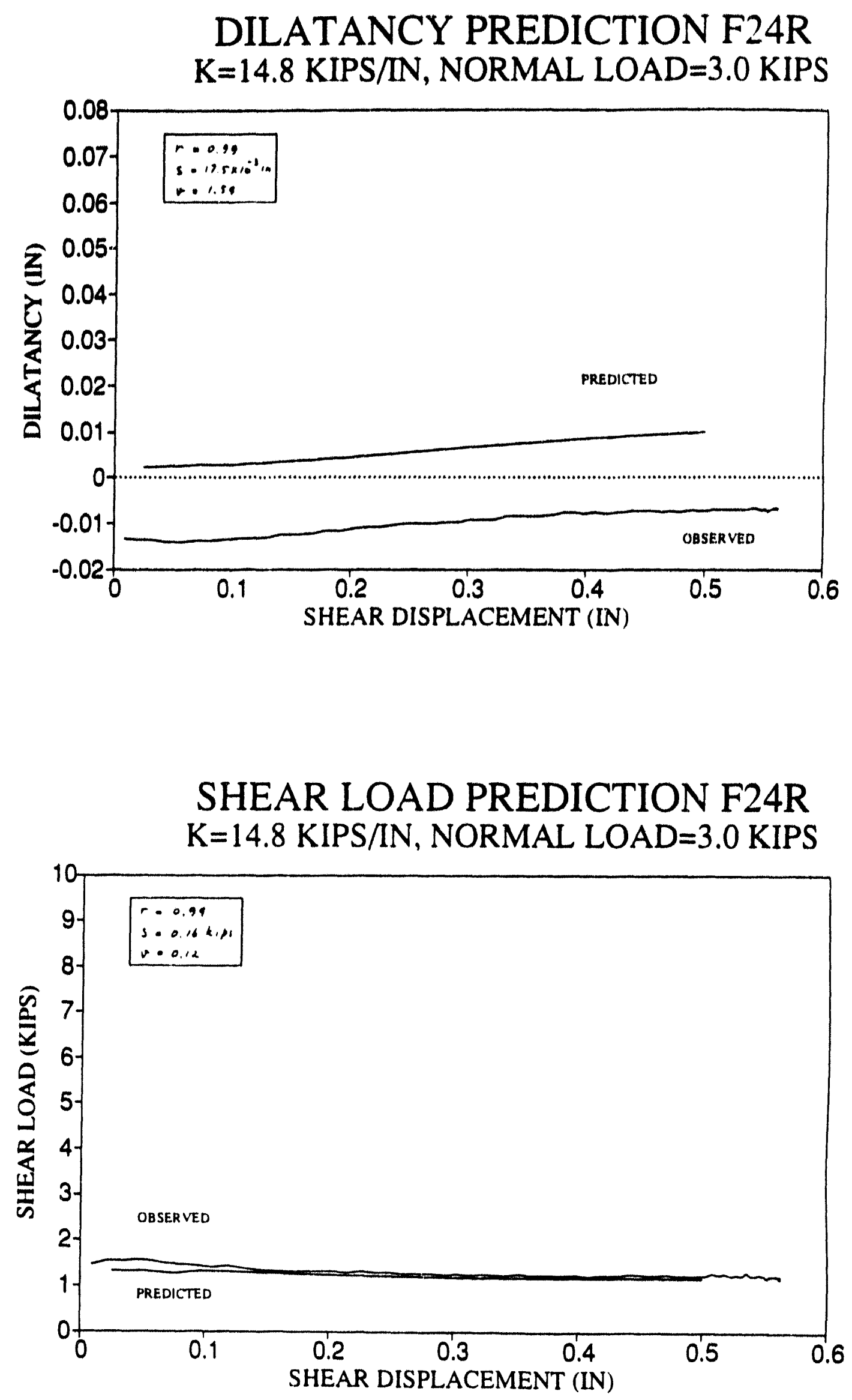

B-106 

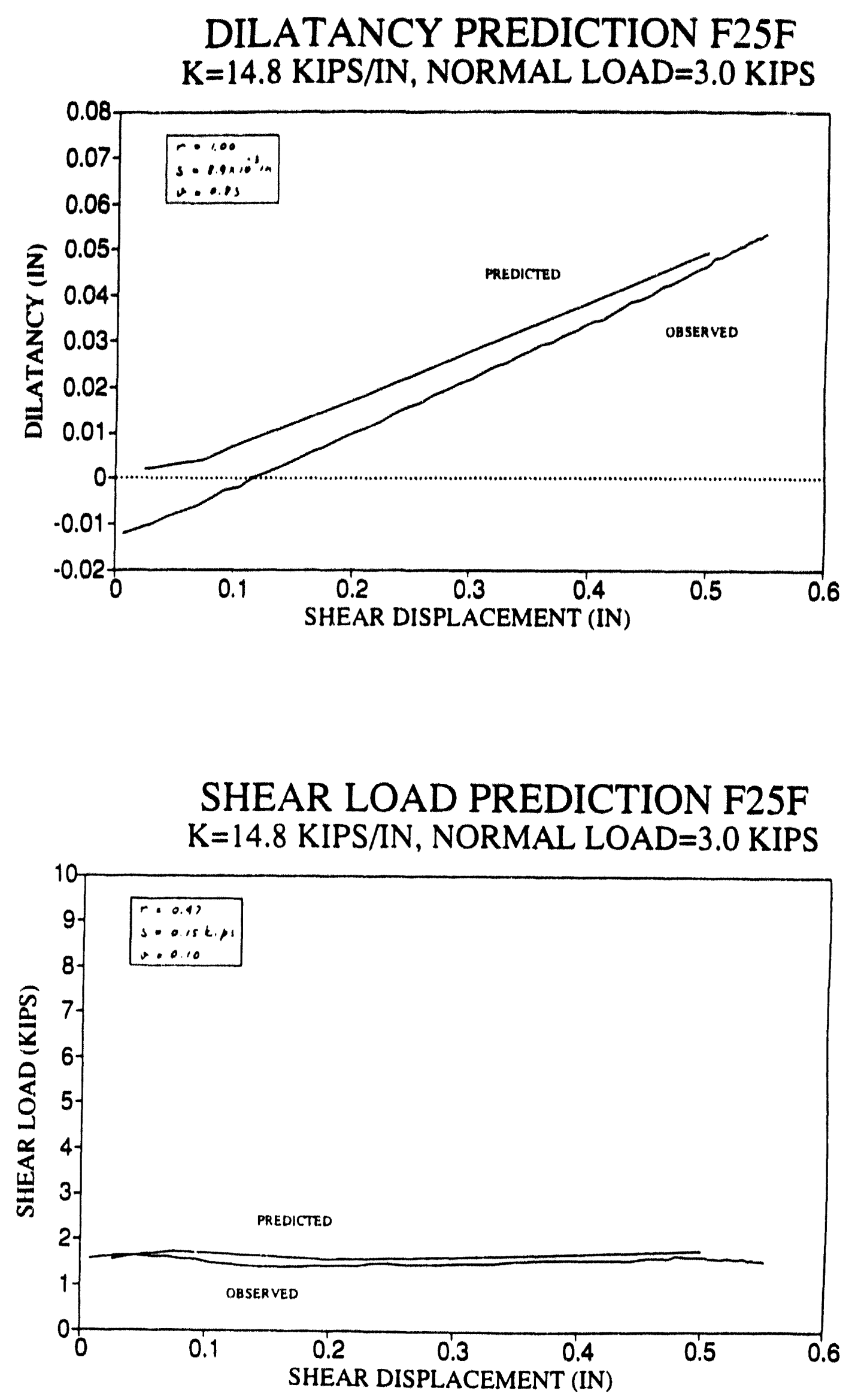


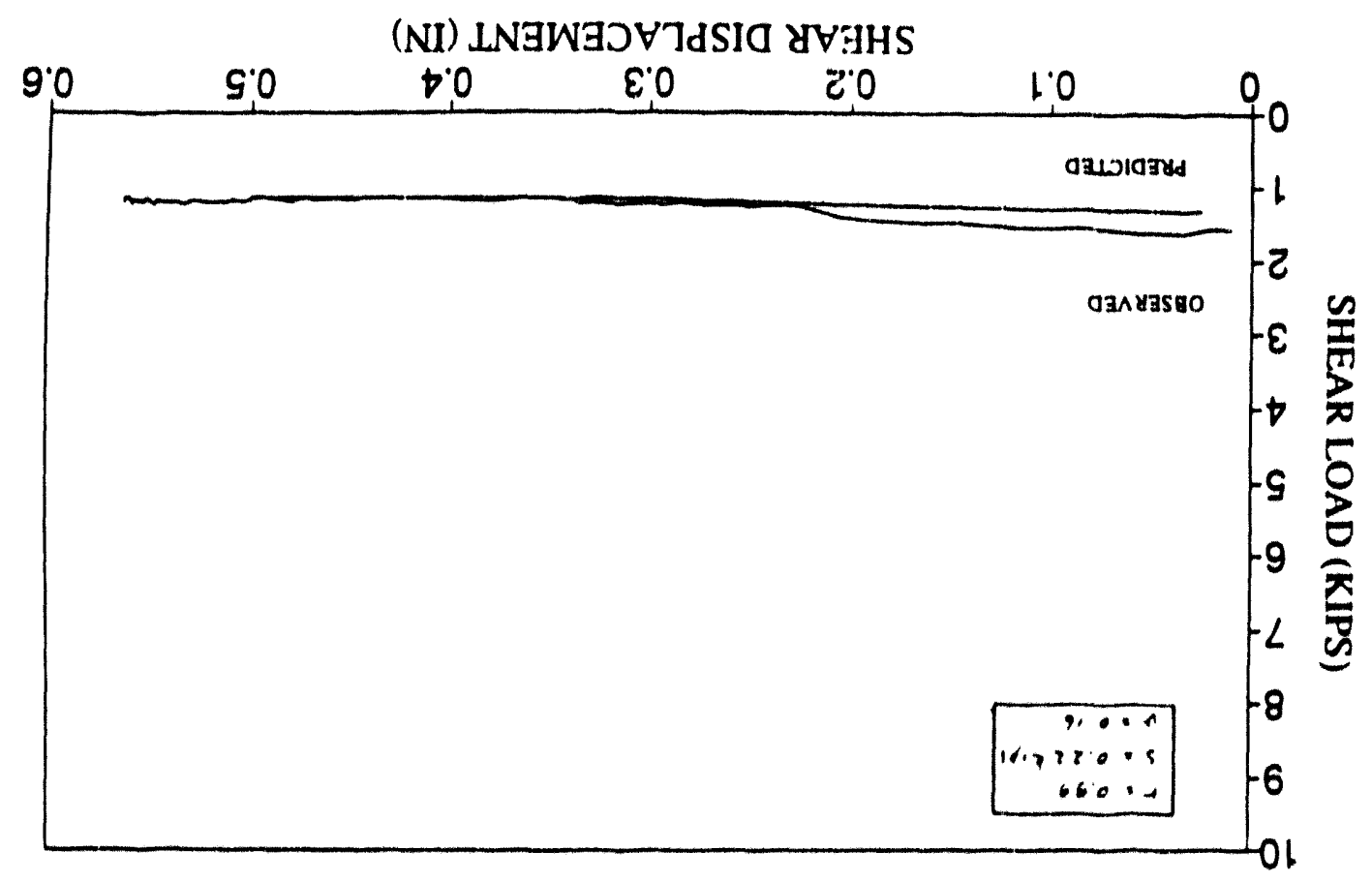

SdIX $0^{\circ} \varepsilon=व \forall O 7$ THWYON 'NI/SdIY 8.

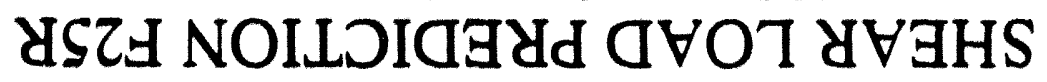

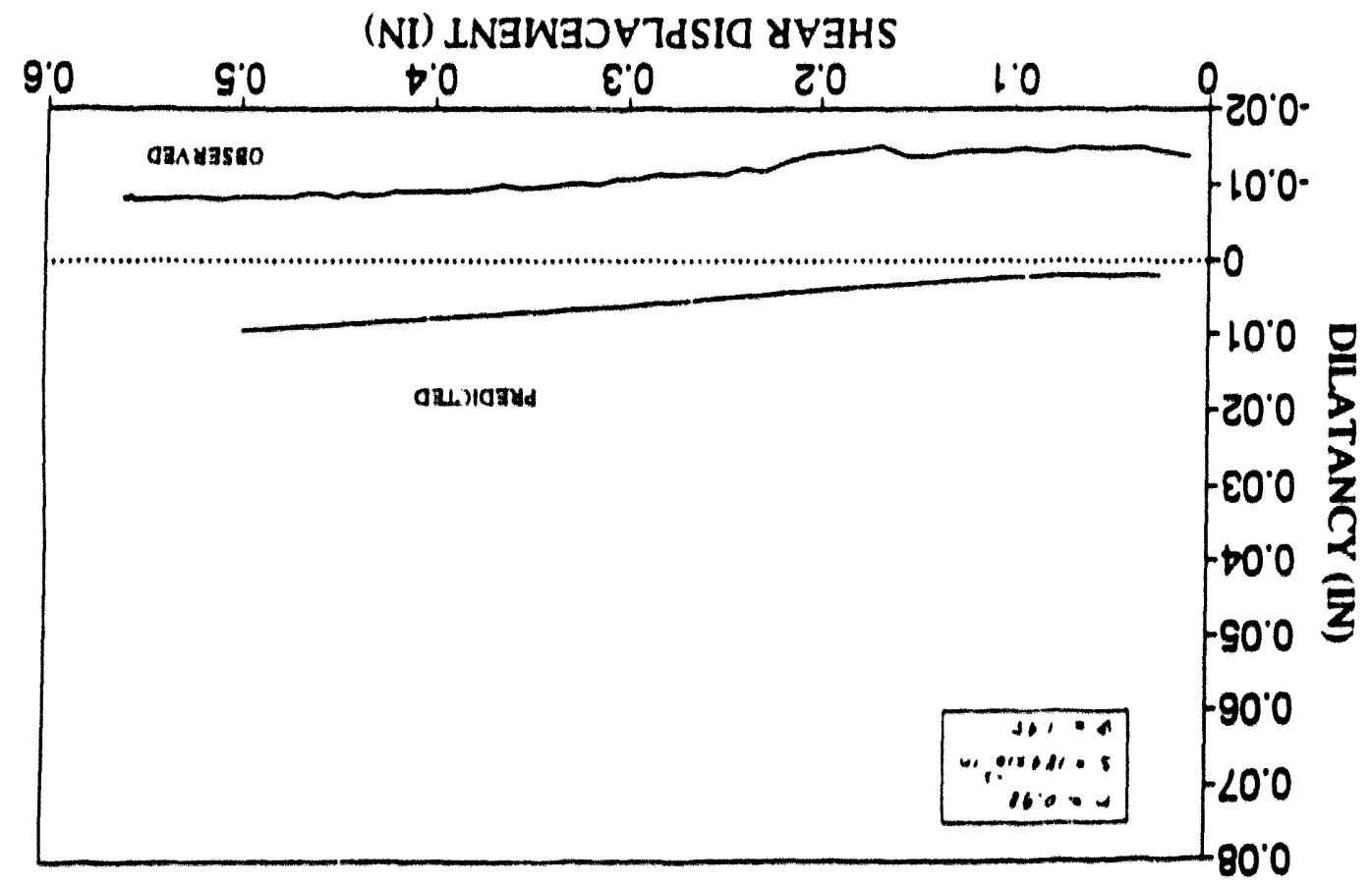

SdIX $0^{\prime} \varepsilon=$ वVOT TVWYON 'NI/SdIX $8^{\circ} \not 1=$ X

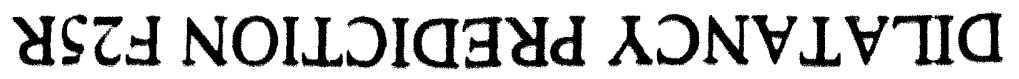




\section{$60 \tau-8$}
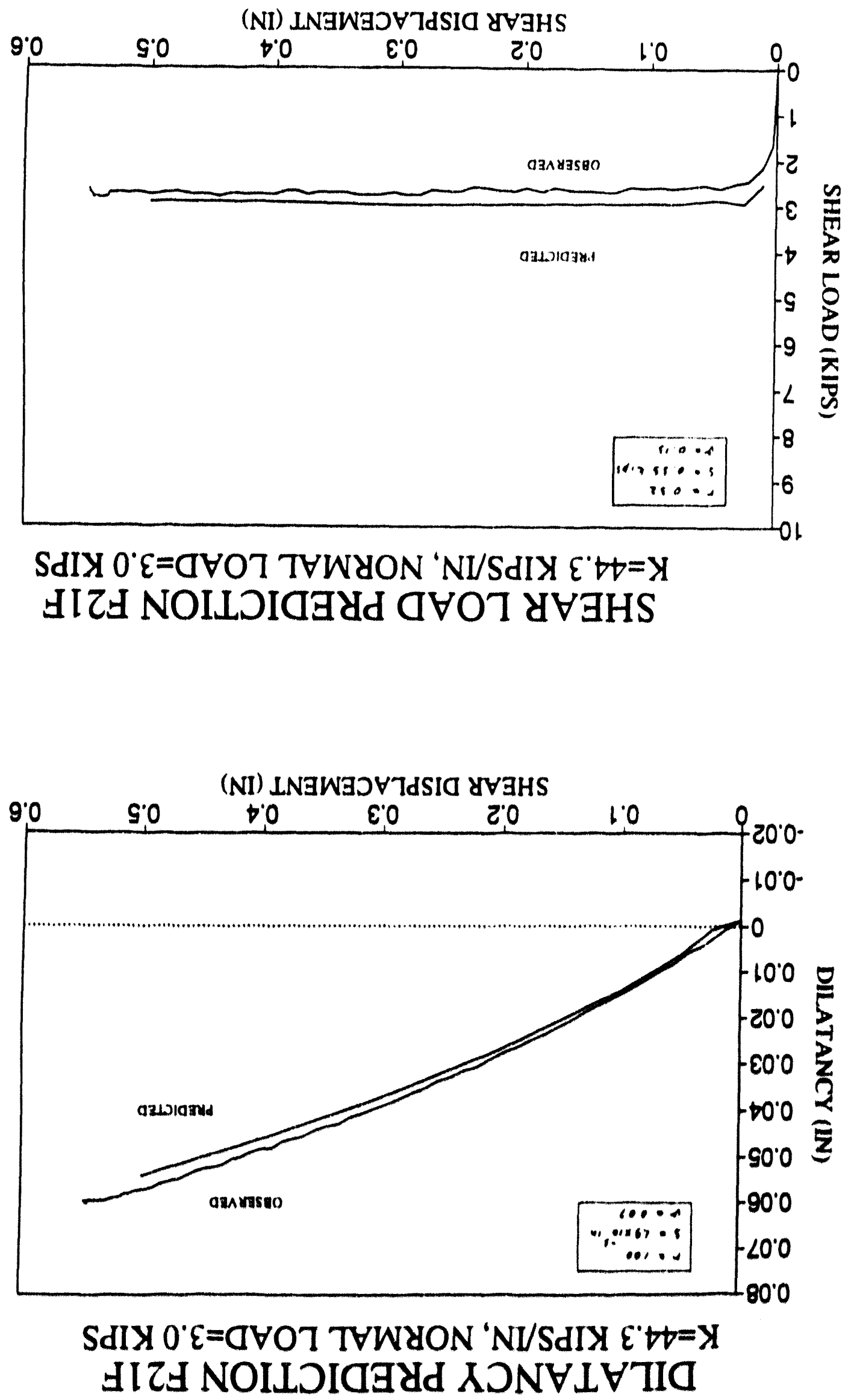


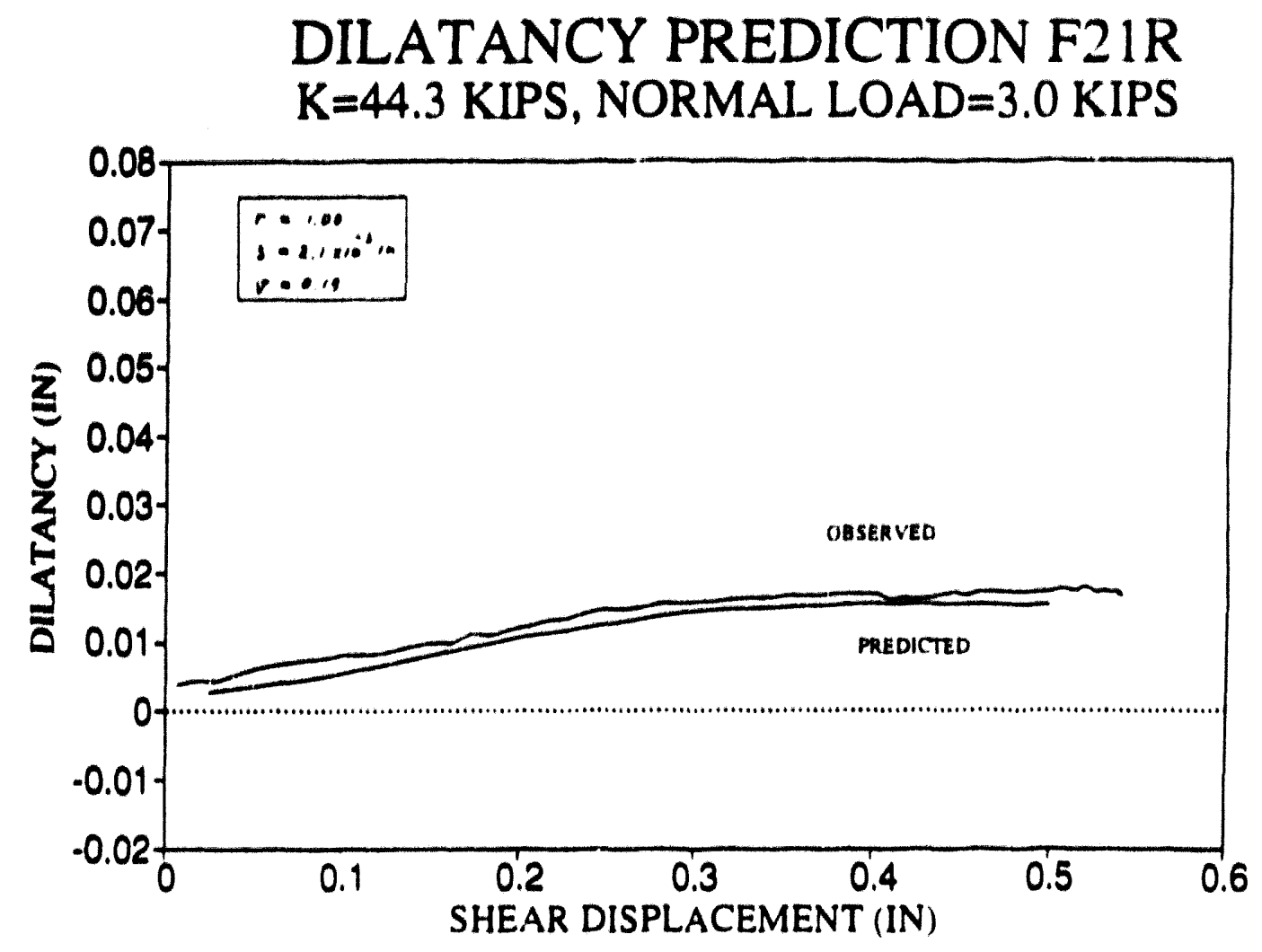

SHEAR LOAD PREDICTION F21R $\mathrm{K}=44.3 \mathrm{KIPS} / \mathrm{IN}$, NORMAL LOAD $=3.0 \mathrm{KIPS}$

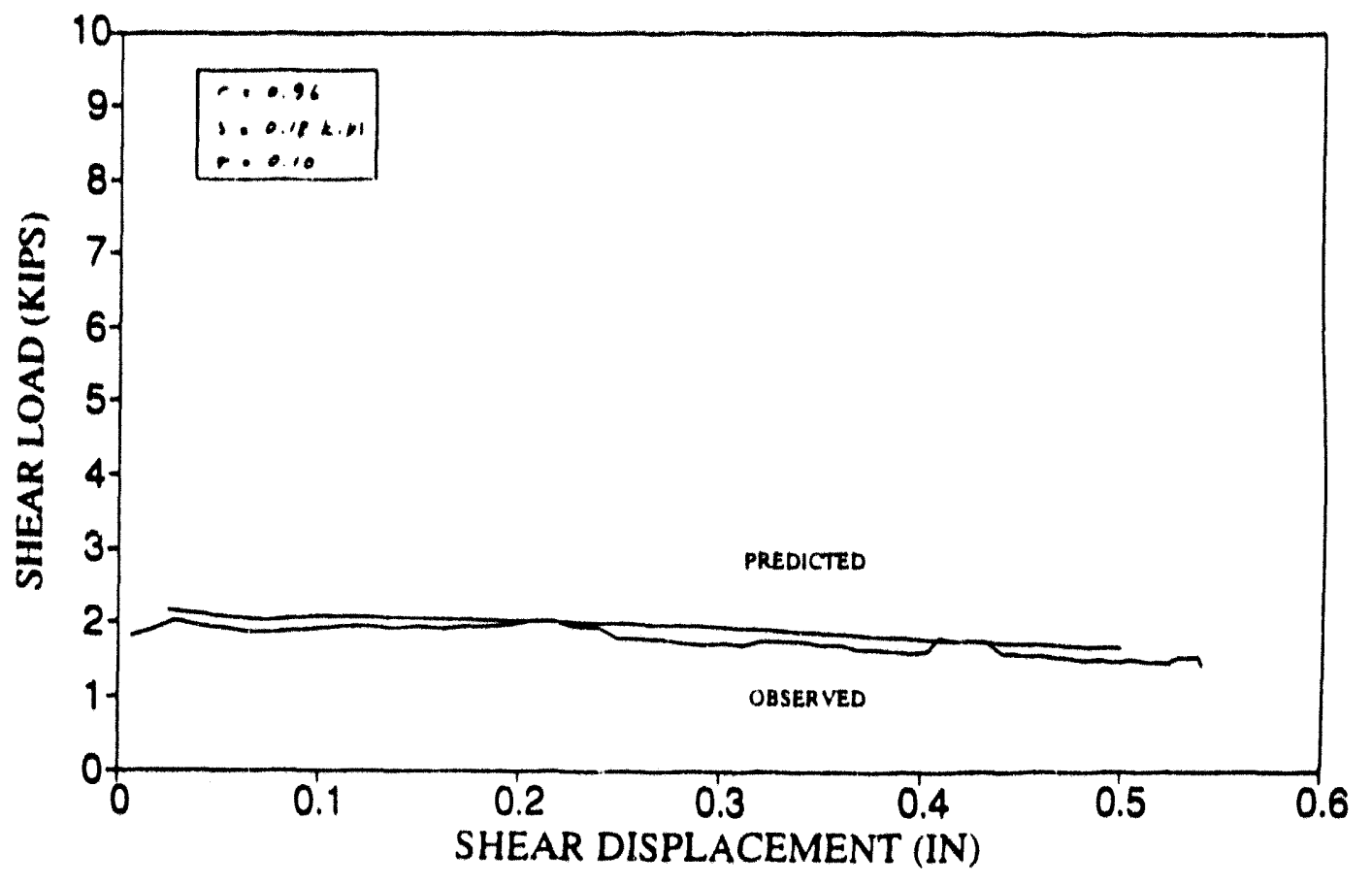



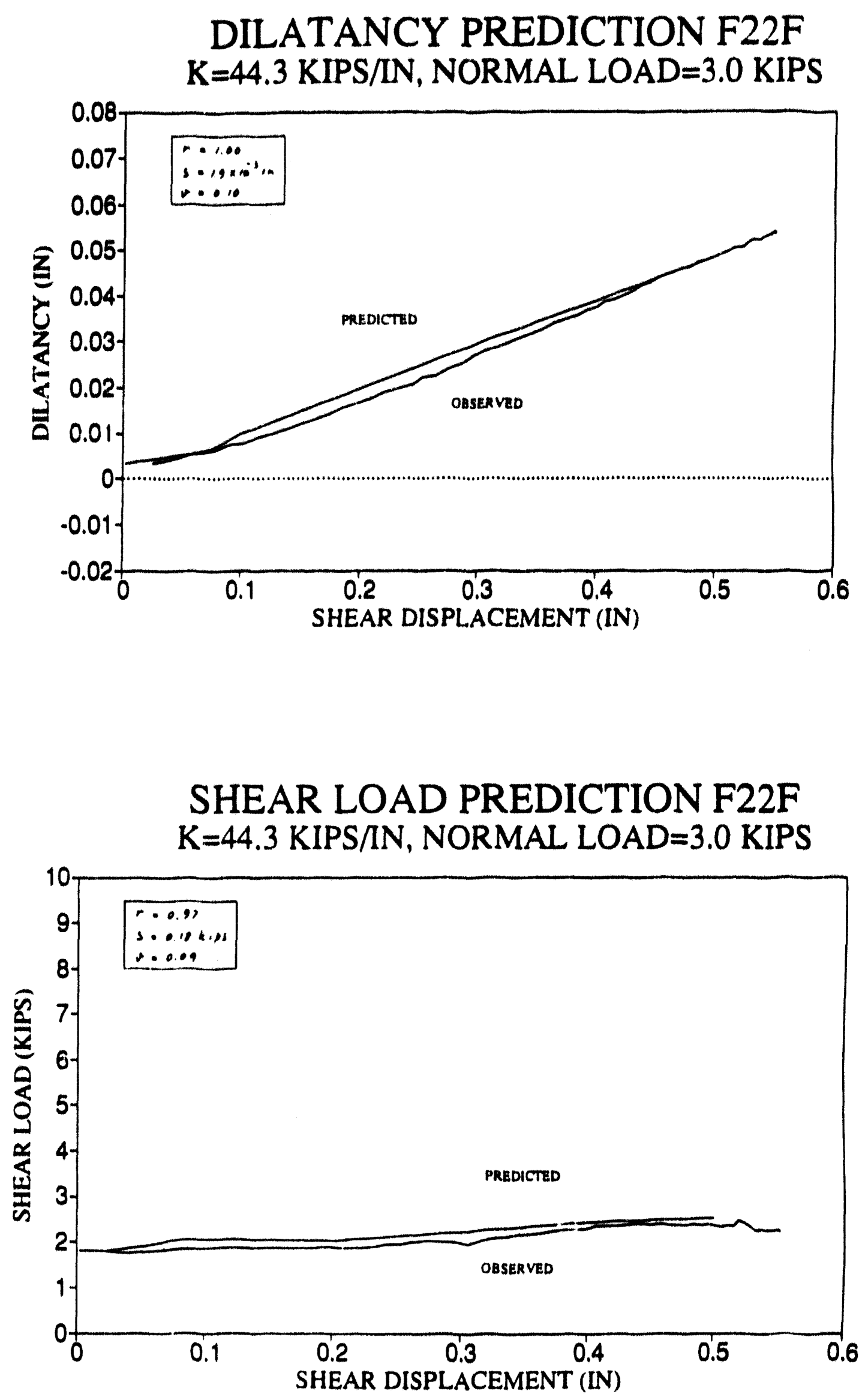

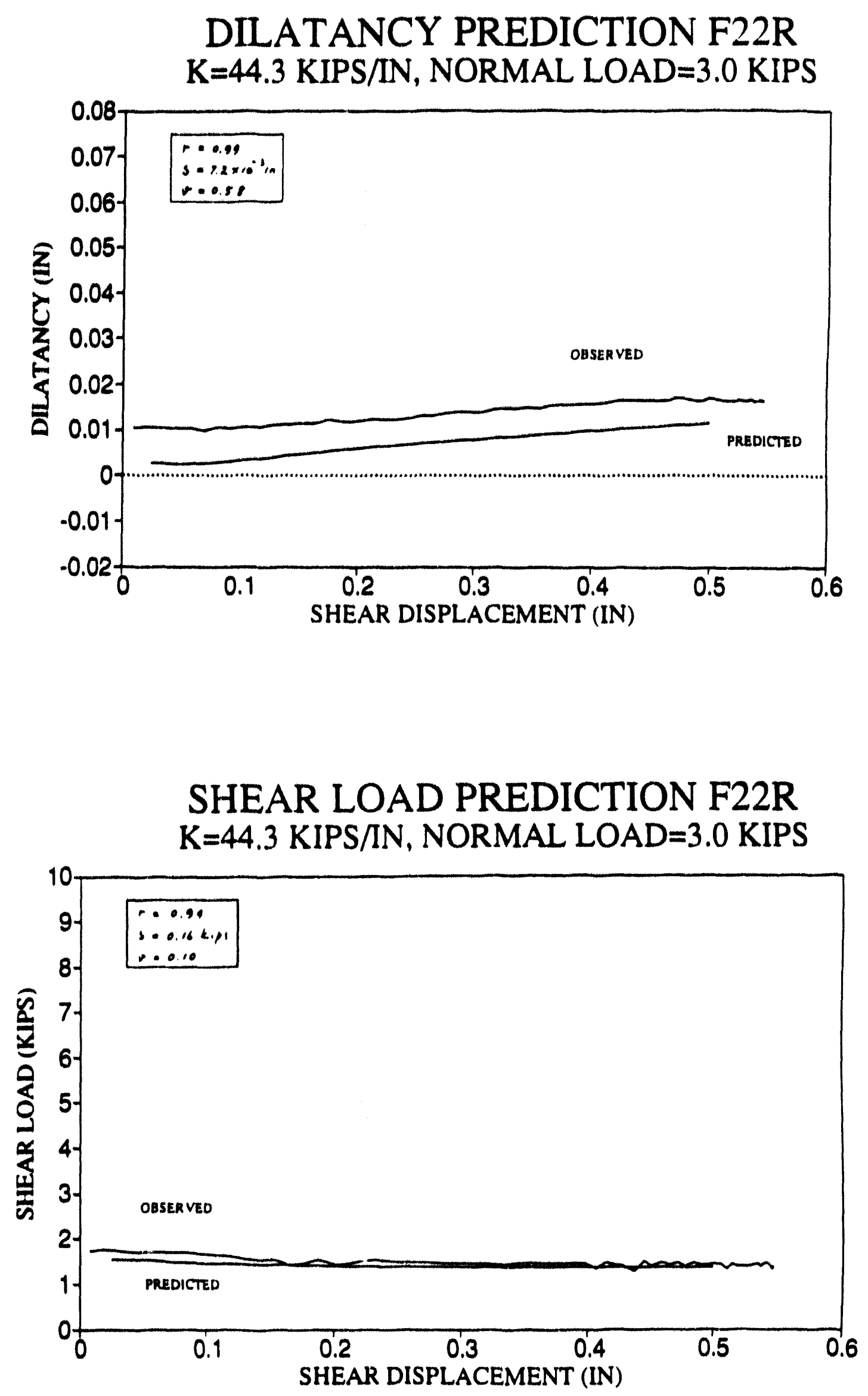

B- 112 

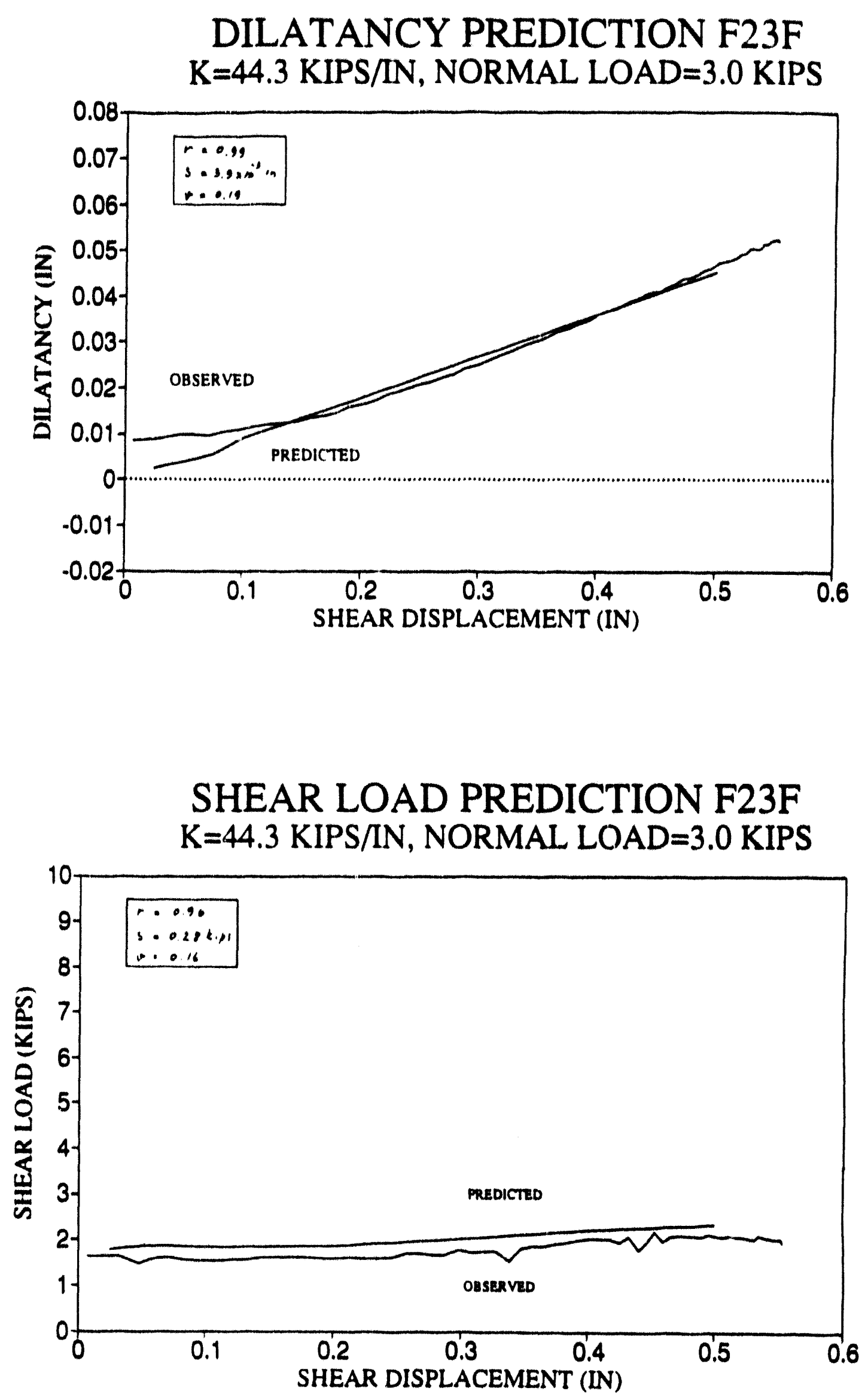


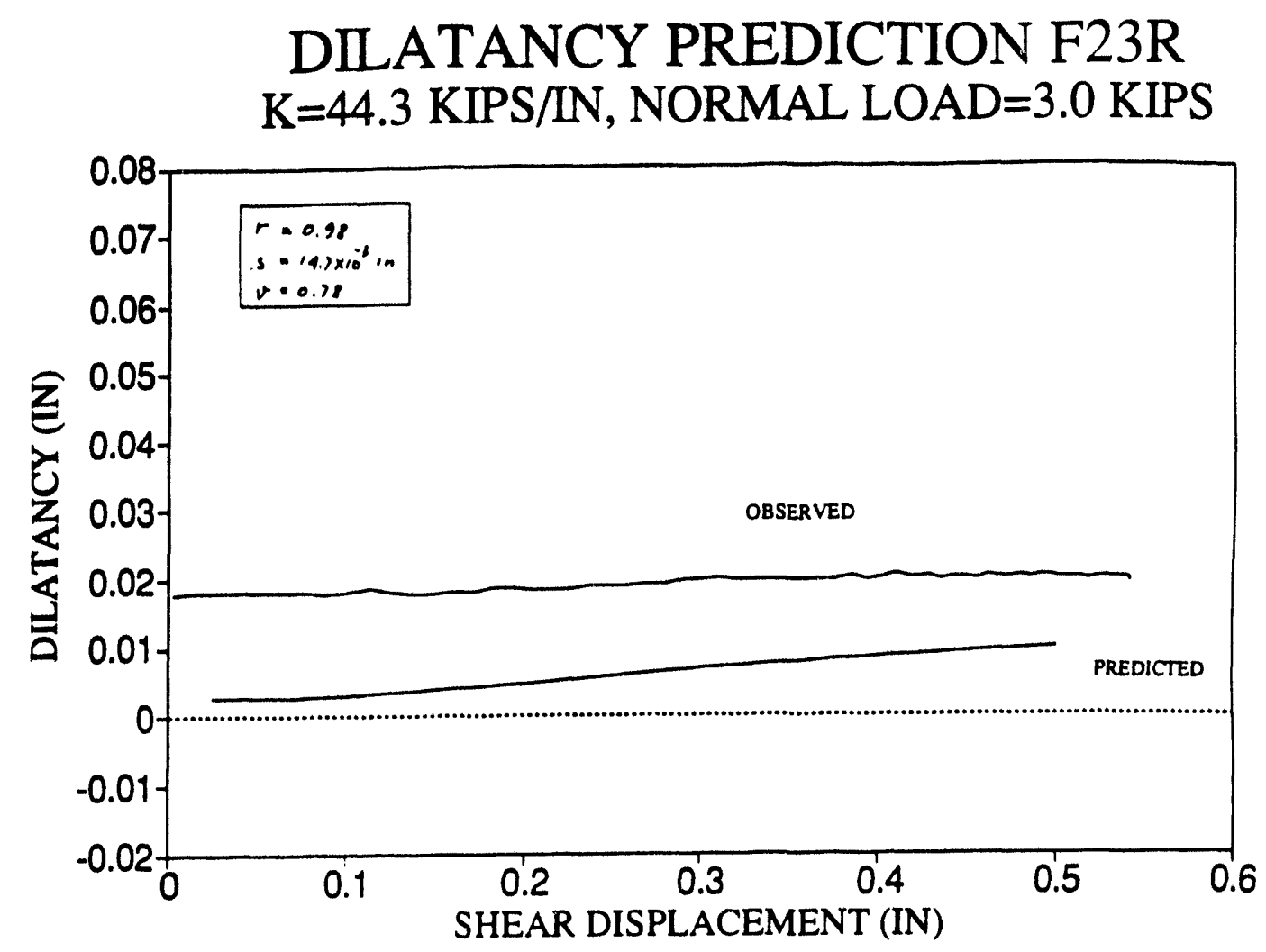

SHEAR LOAD PREDICTION F23R $\mathrm{K}=44.3 \mathrm{KIPS} / \mathrm{IN}$, NORMAL LOAD=3.0 KIPS

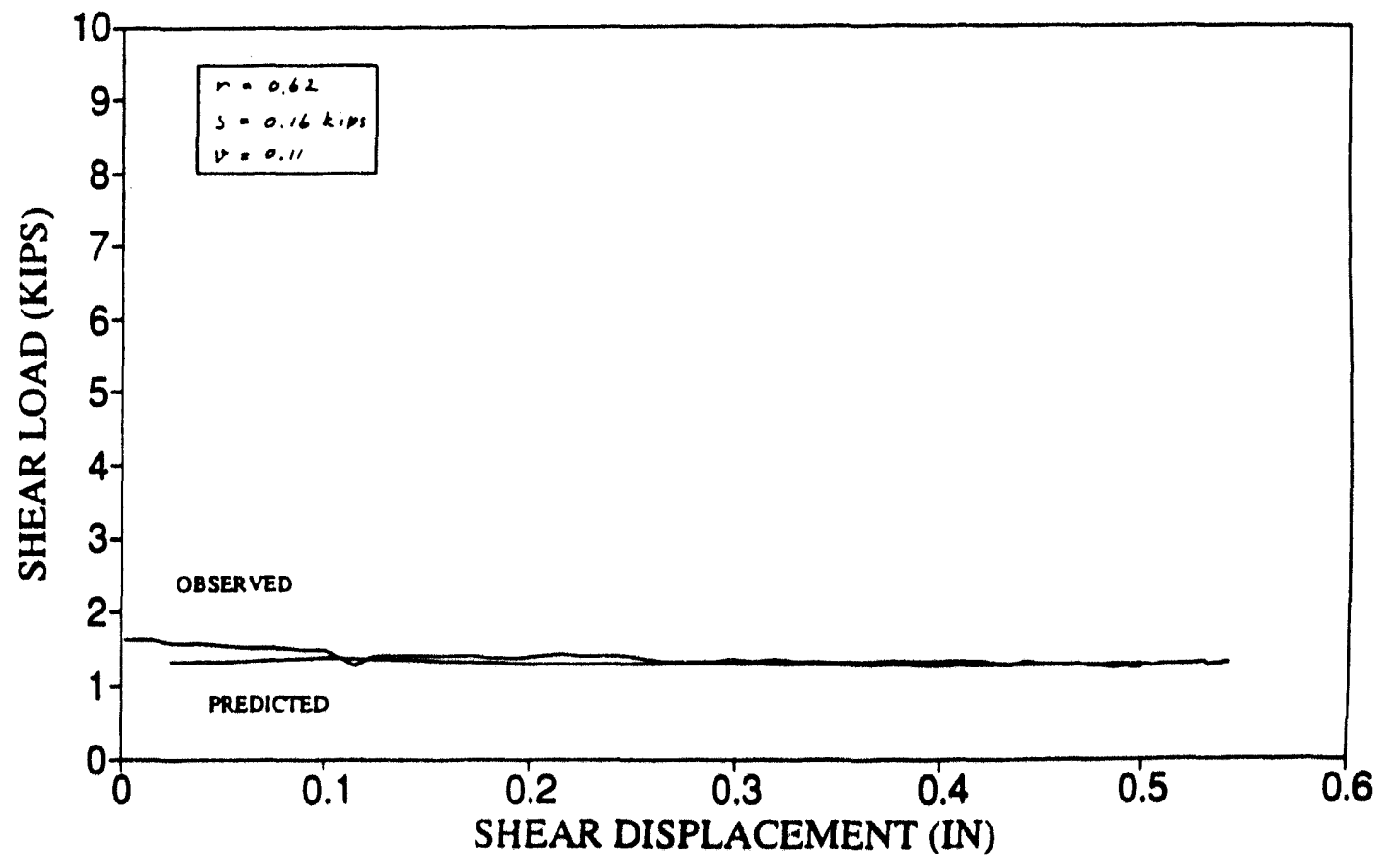




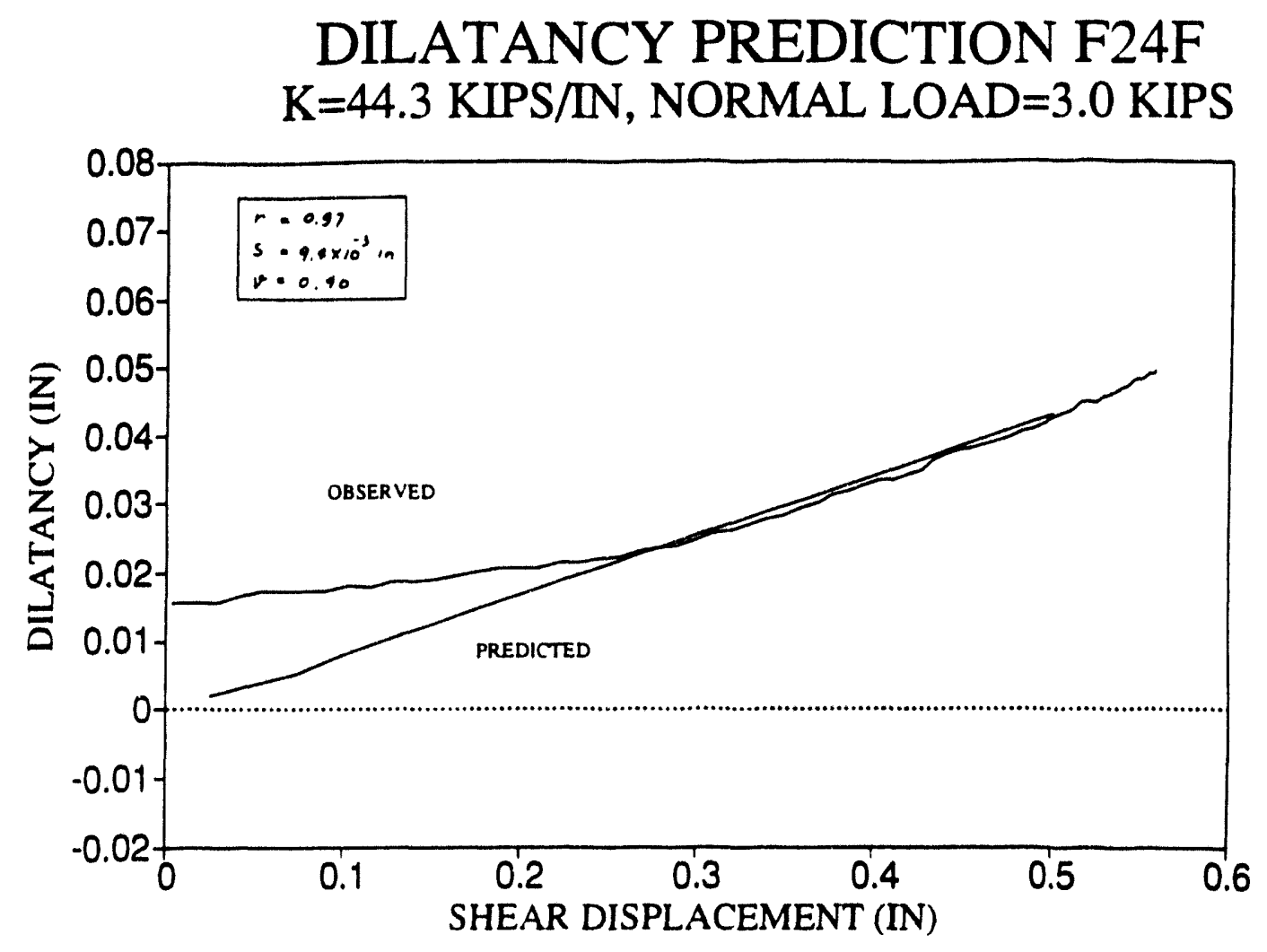

SHEAR LOAD PREDICTION F24F $\mathrm{K}=44.3 \mathrm{KIPS} / \mathrm{IN}$, NORMAL LOAD=3.0 KIPS

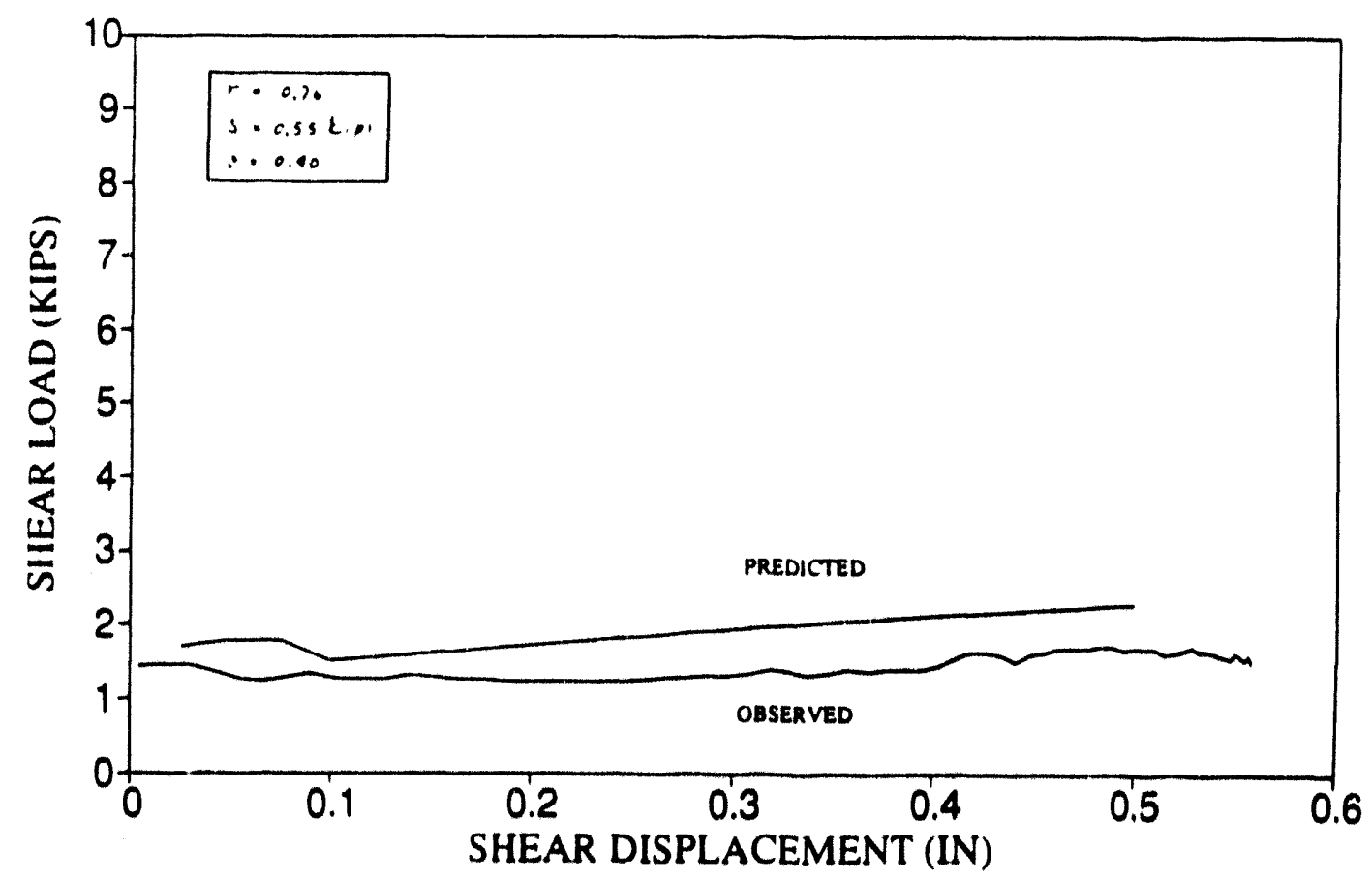



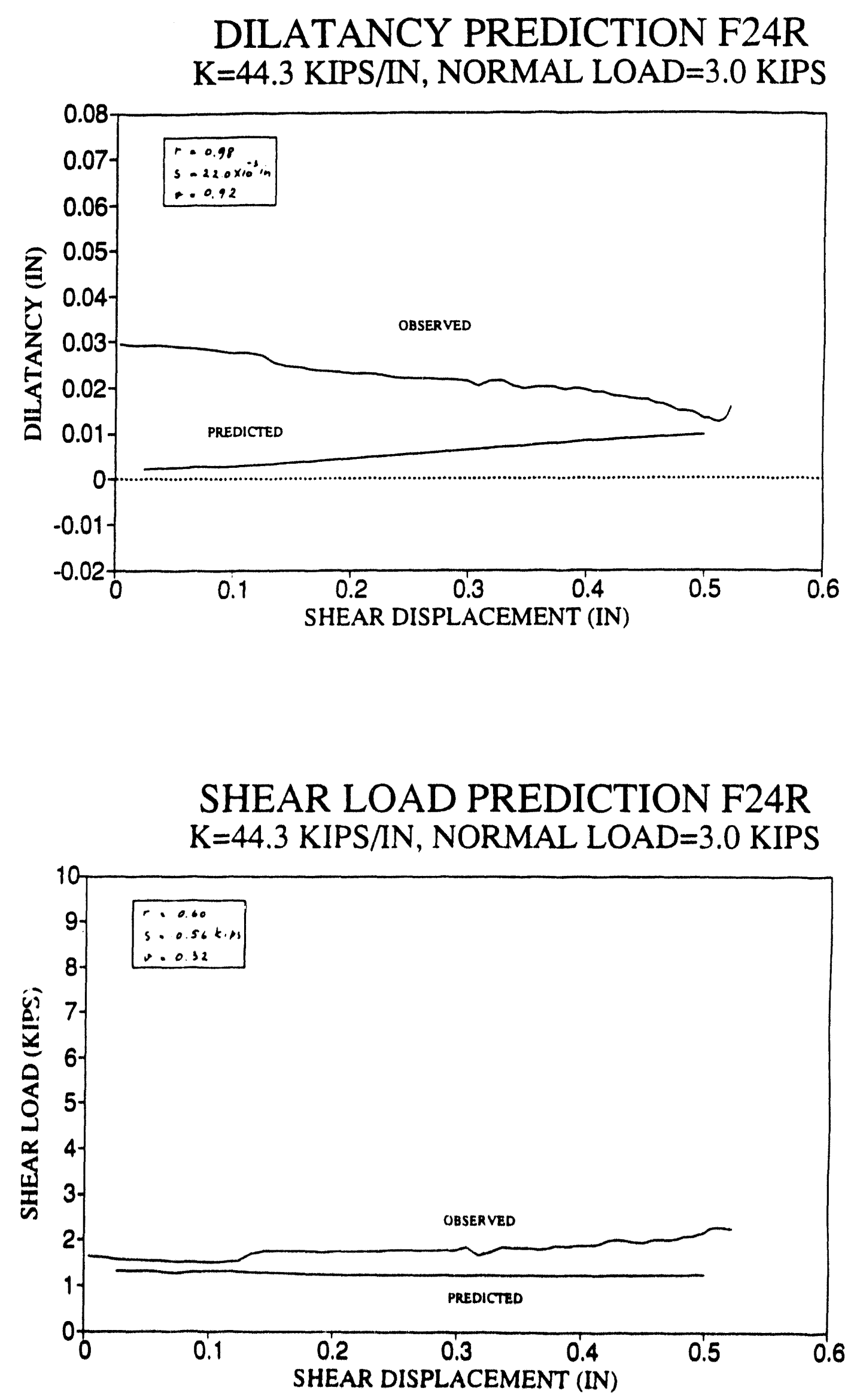

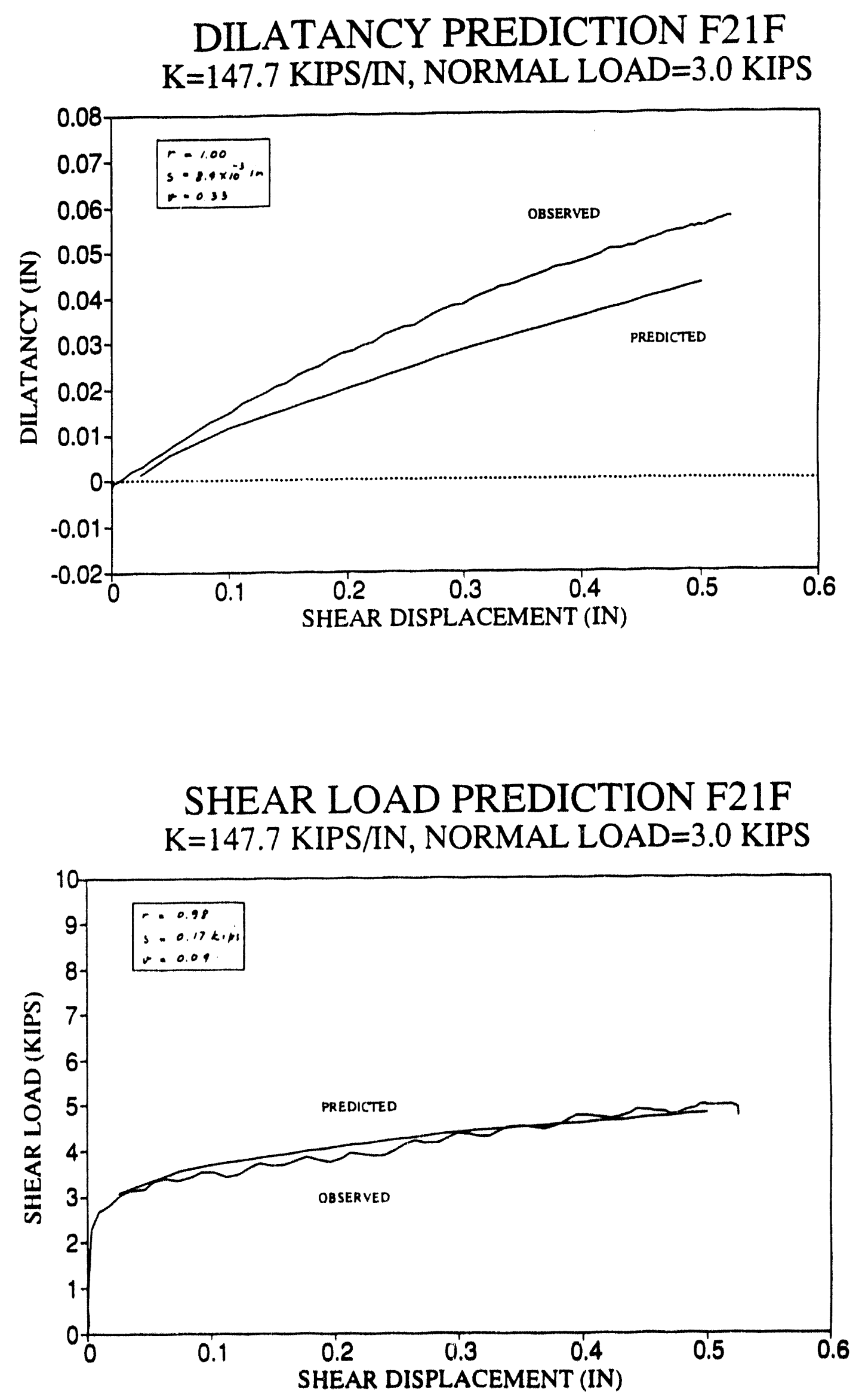

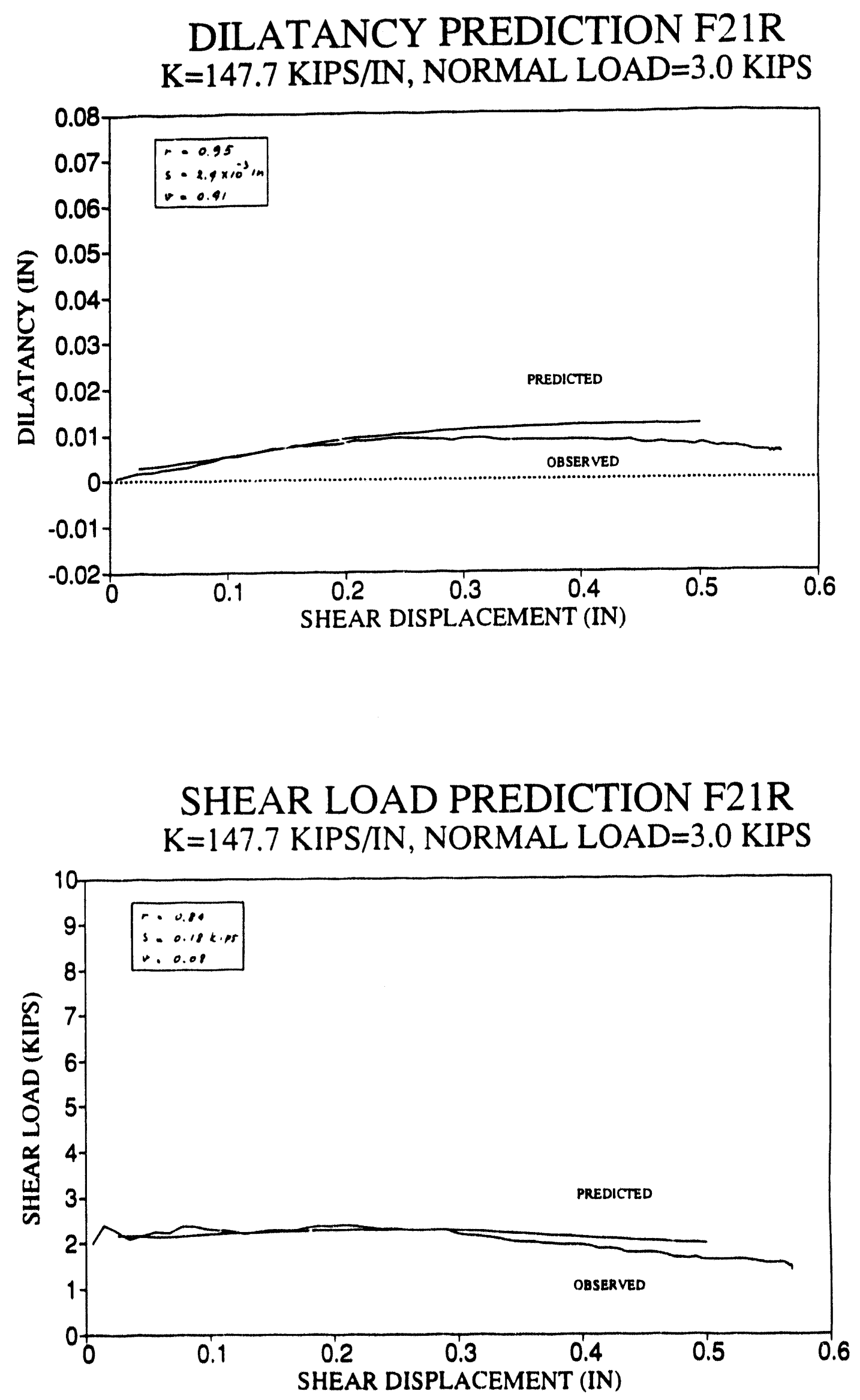


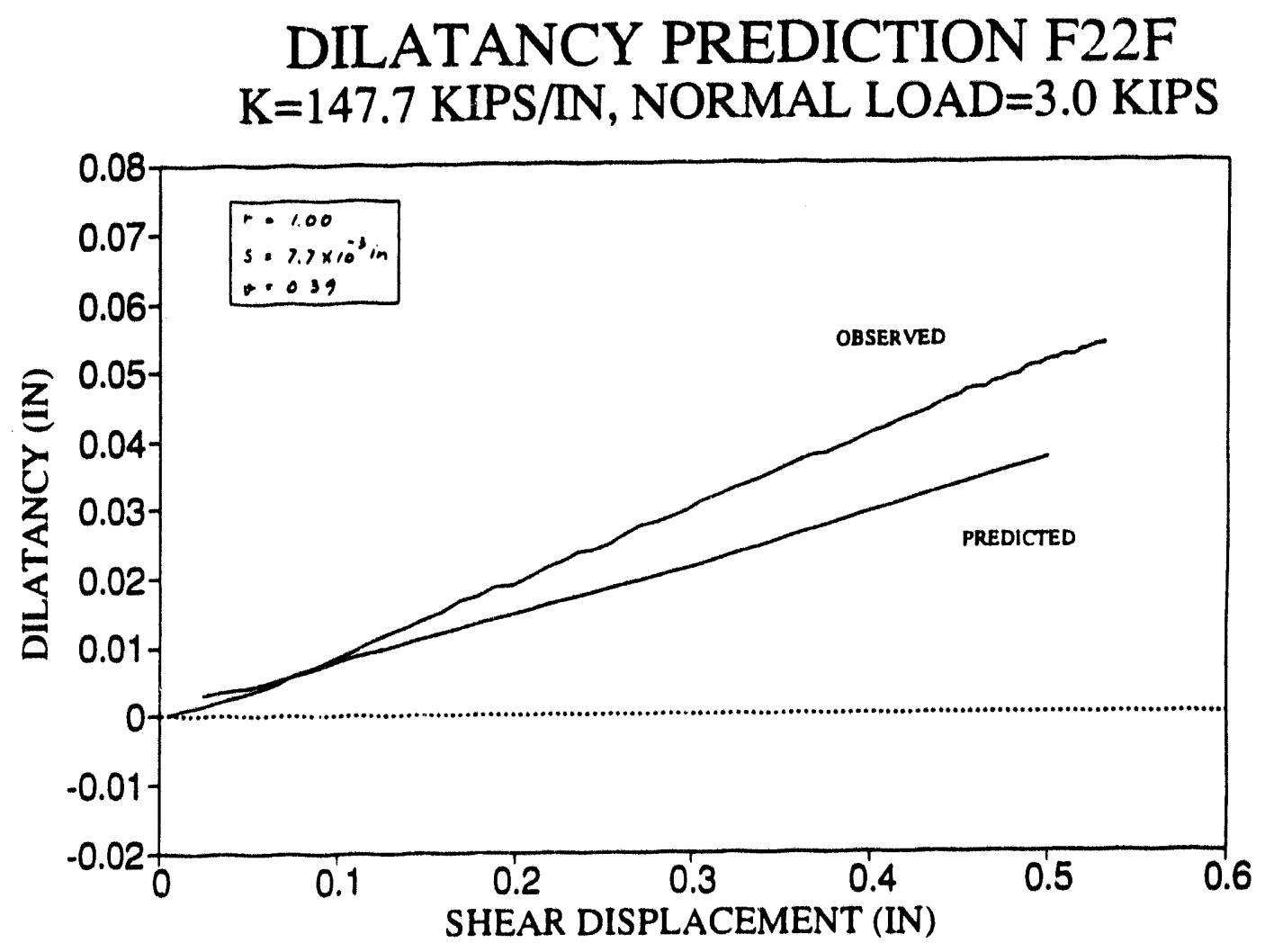

SHEAR LOAD PREDICTION F22F

$\mathrm{K}=147.7 \mathrm{KIPS} / \mathrm{IN}$, NORMAL LOAD $=3.0 \mathrm{KIPS}$

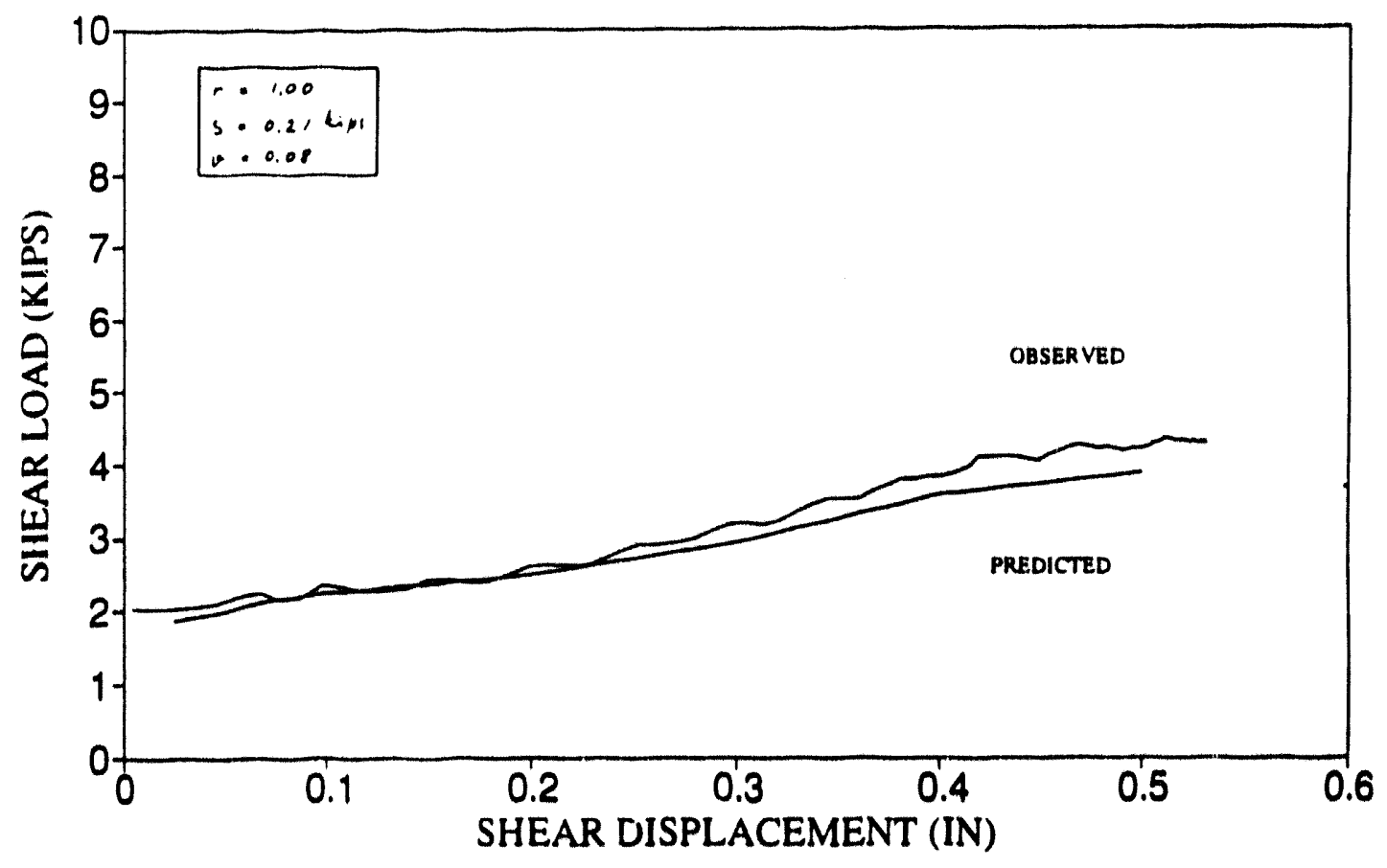



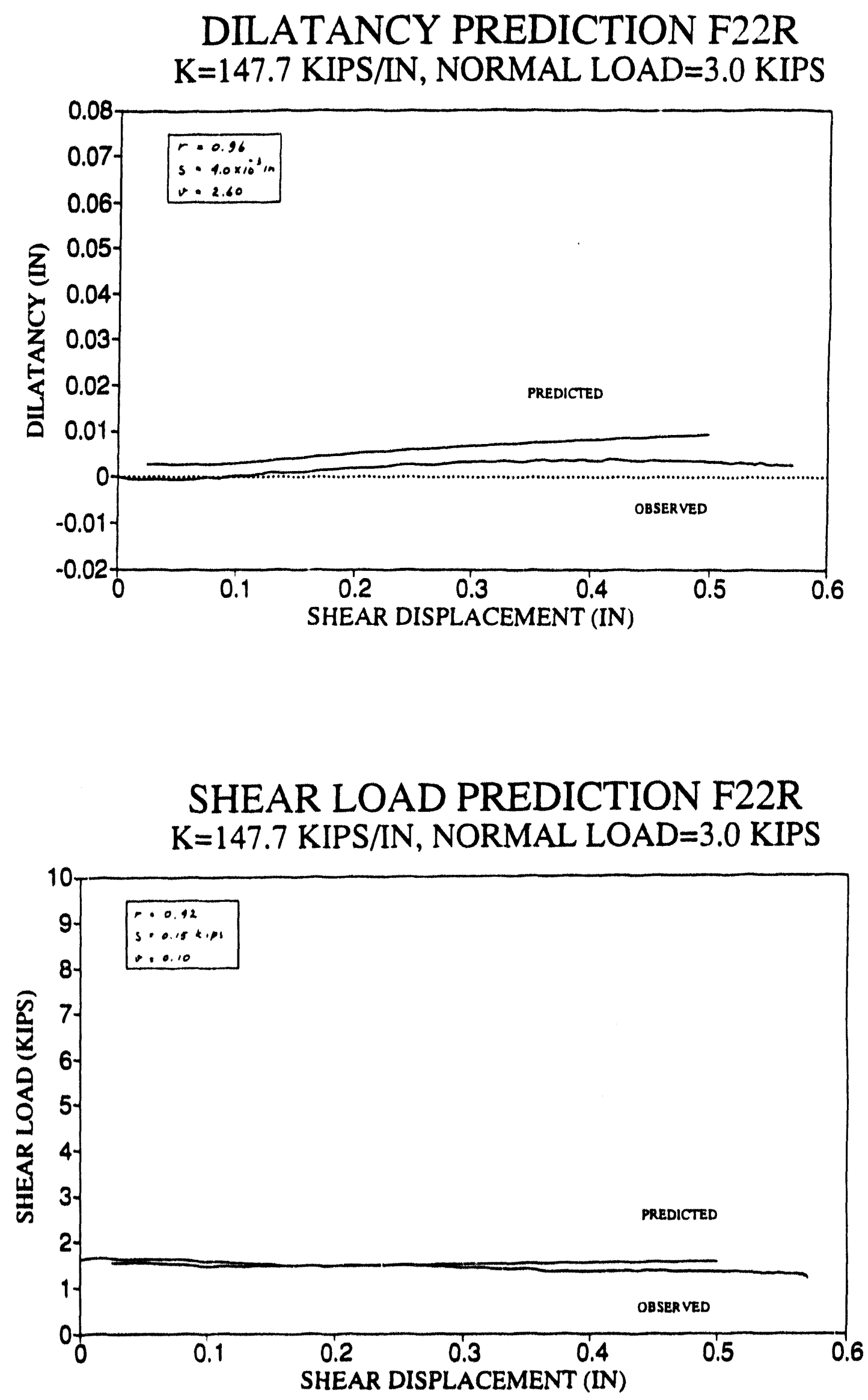

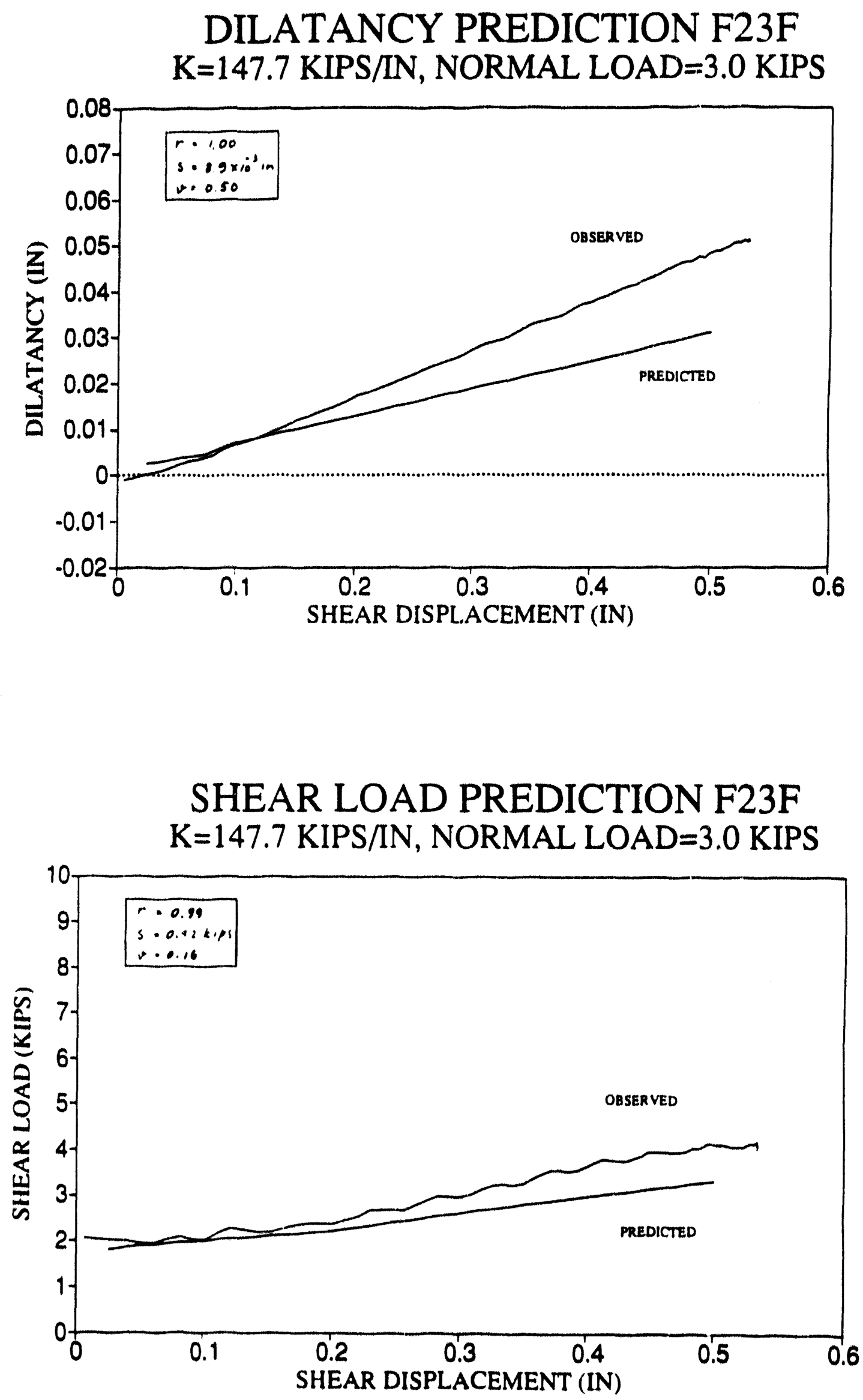

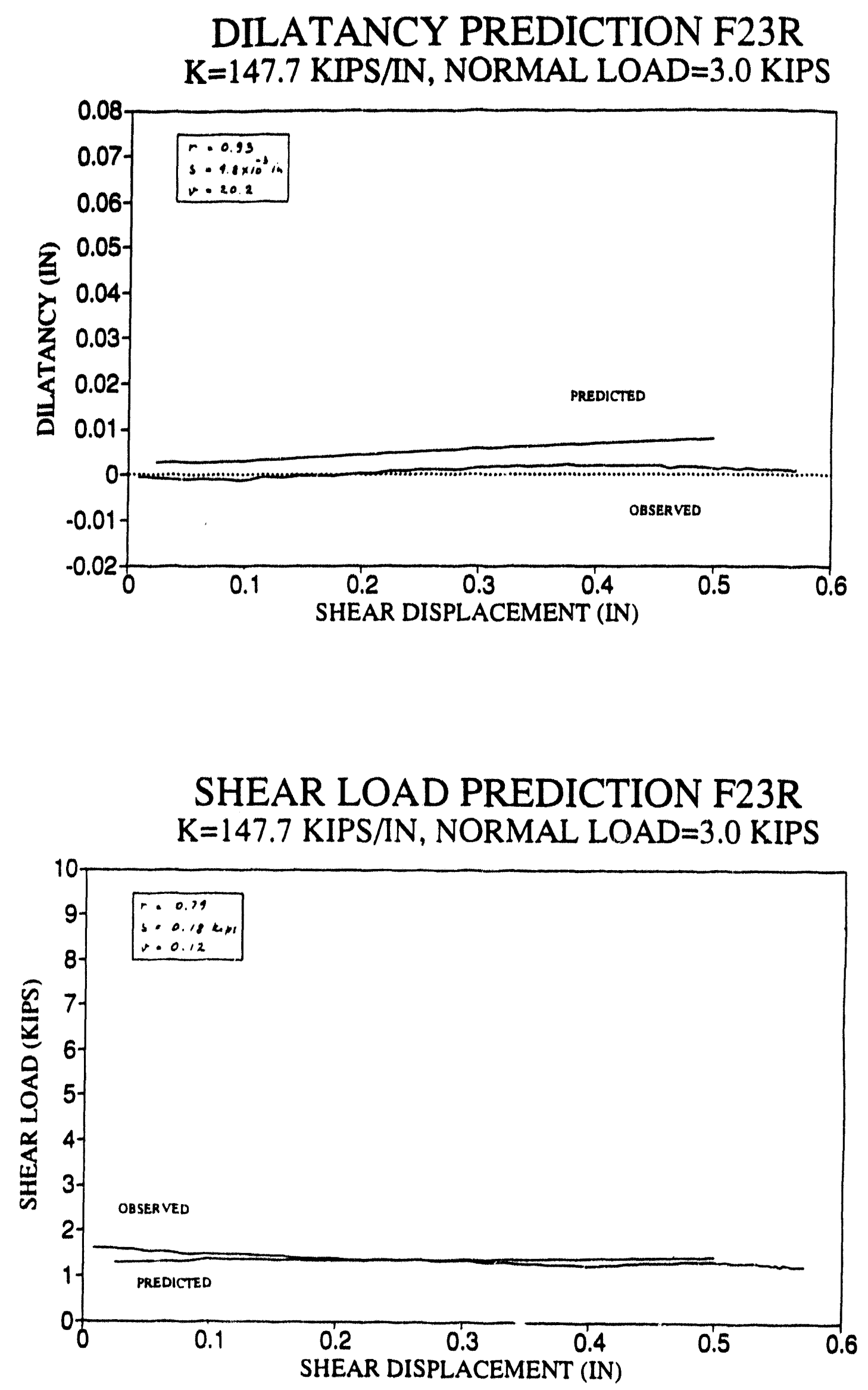

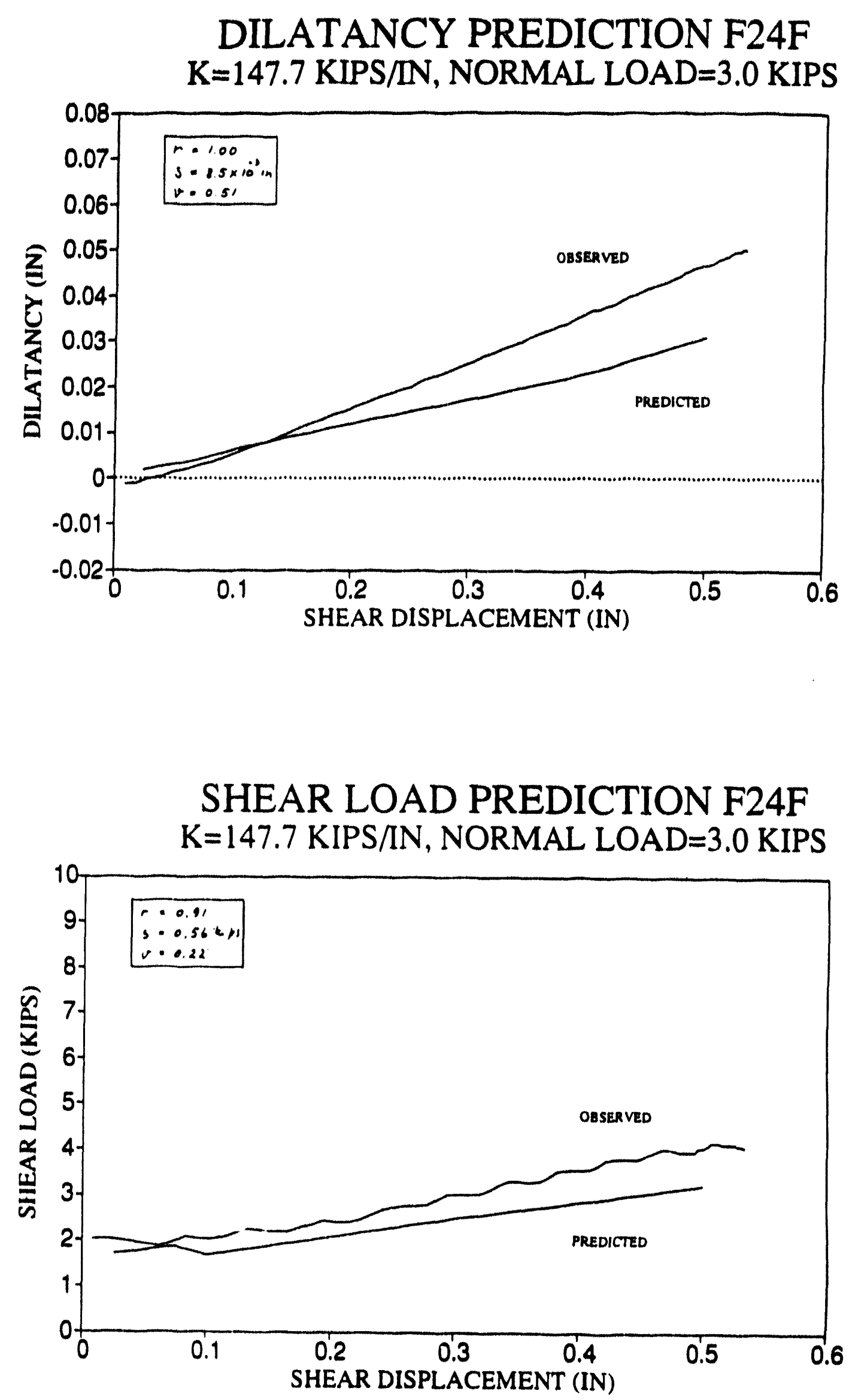

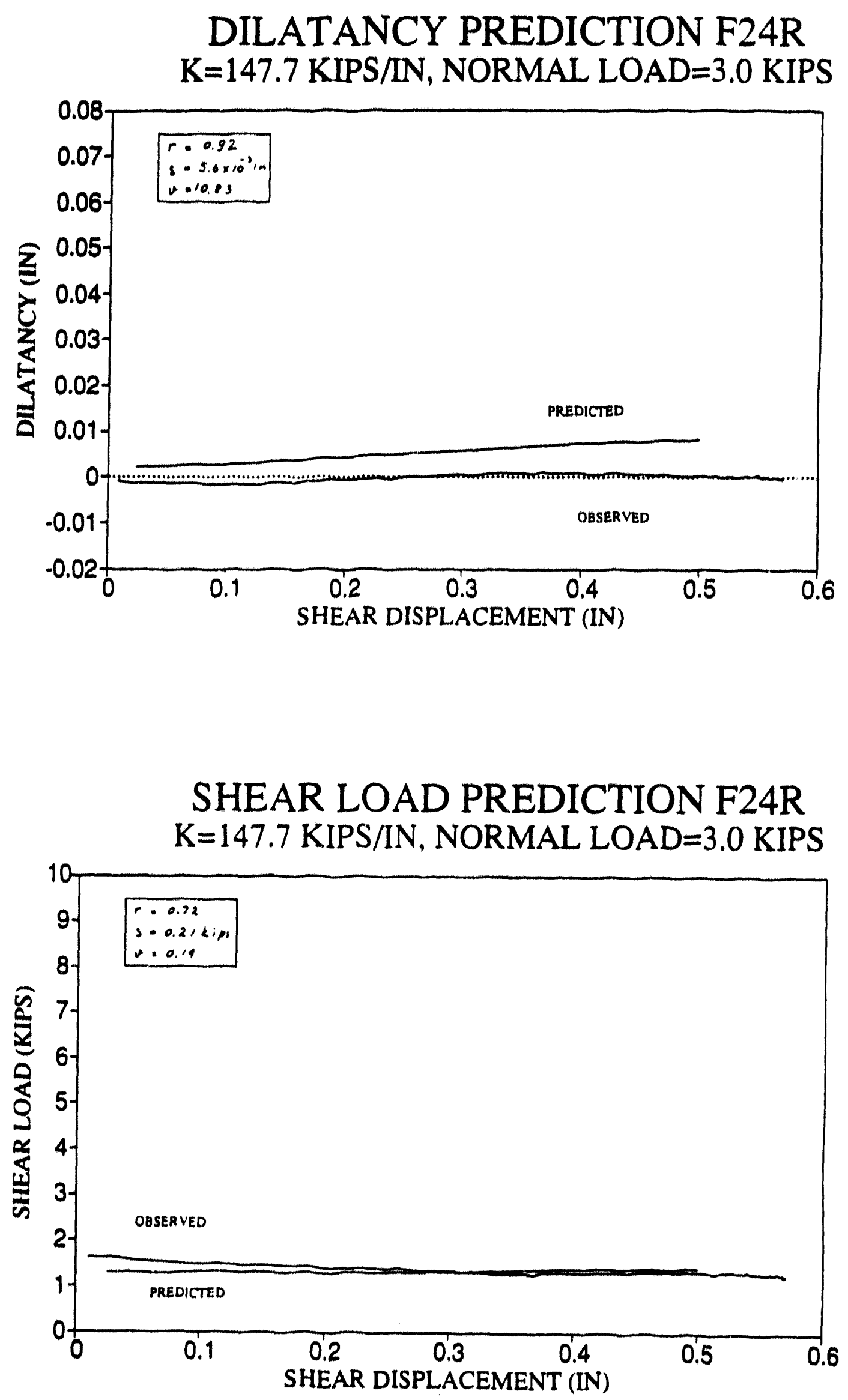

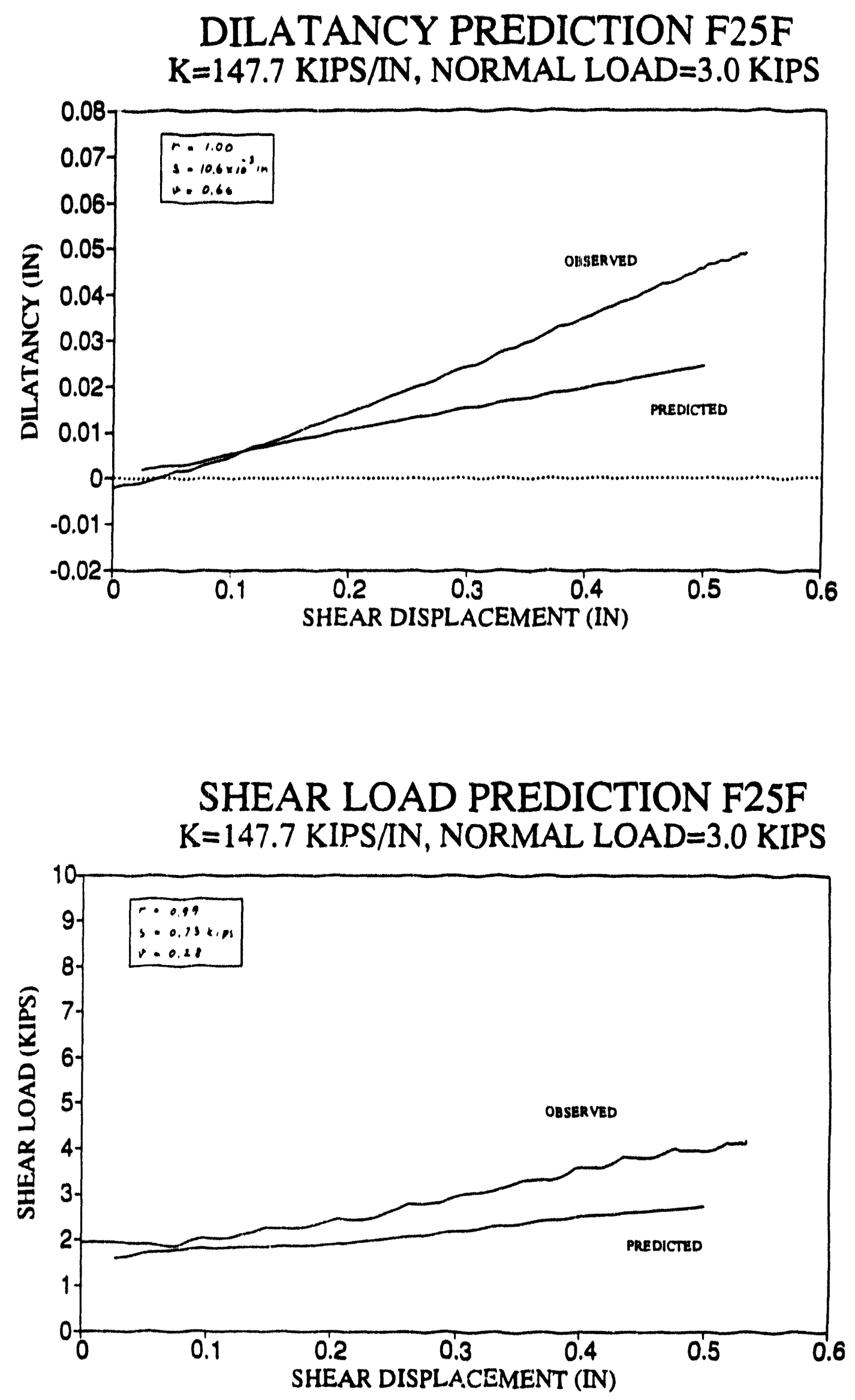


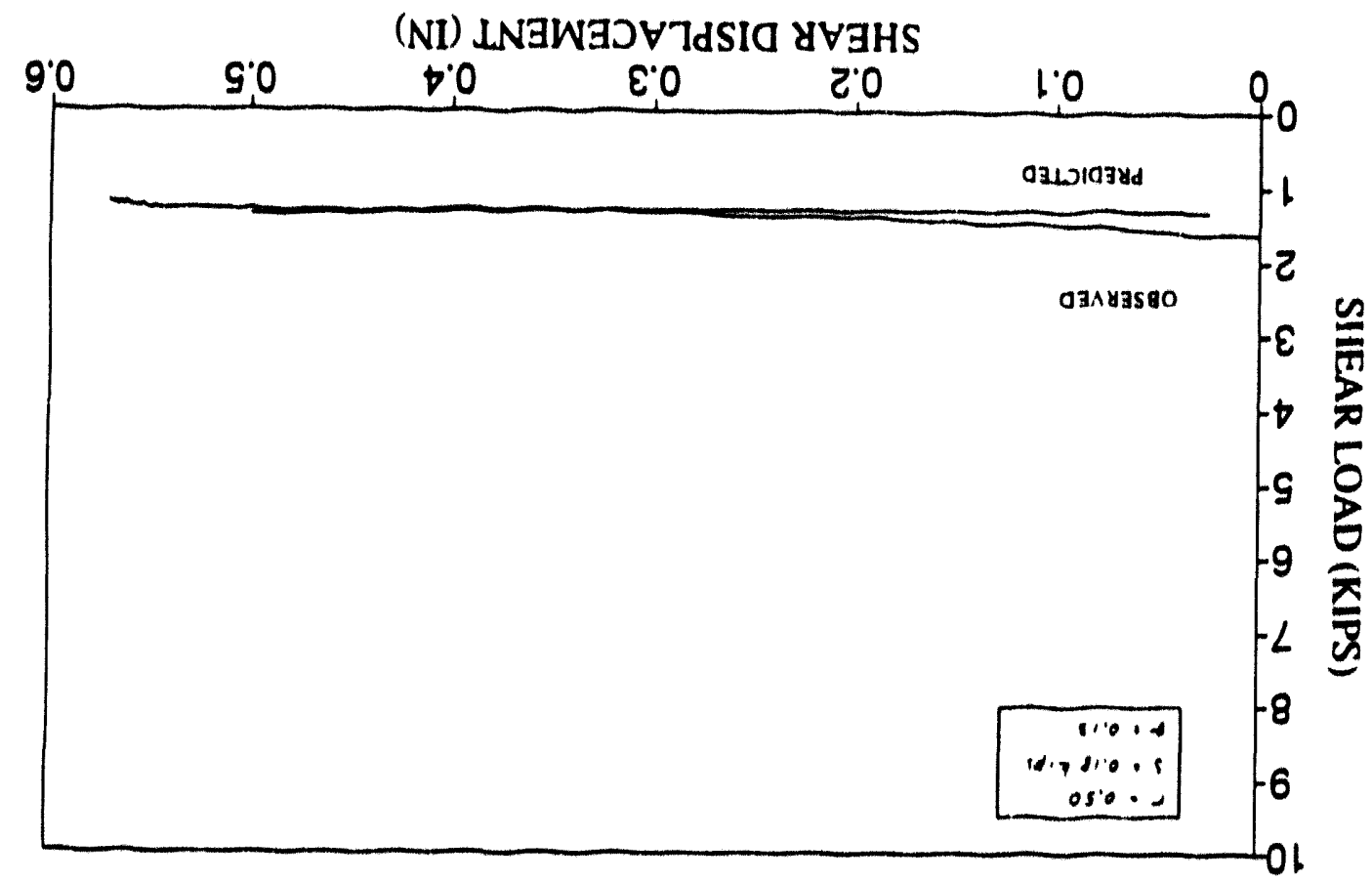

SdIX 0 ' $\varepsilon=\square \forall O T$ TVWYON 'NI/SdIX $\angle$ ' $\angle D I=$ X

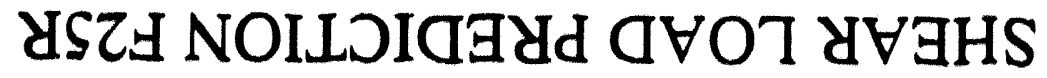

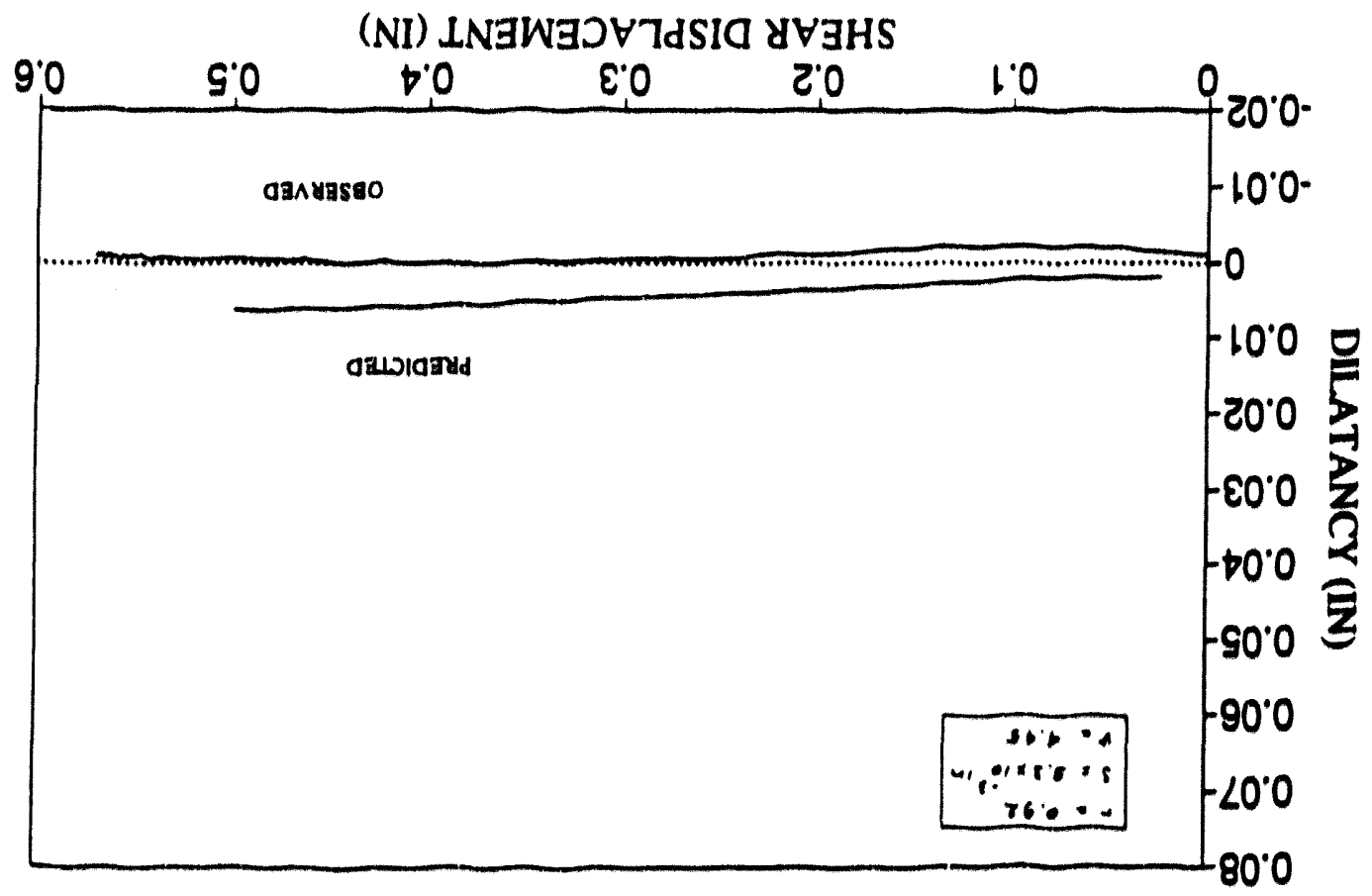

SdIX $0^{\circ} \varepsilon=$ वVOT TVWYON 'NI/SdIX $L ' \angle \downarrow I=X$ ¿ৎZష NOILOIG 


\section{DILATANCY PREDICTION G21F}

$\mathrm{K}=32 \mathrm{KIPS} / \mathrm{IN}$, NORMAL LOAD $=1.3 \mathrm{KIPS}$

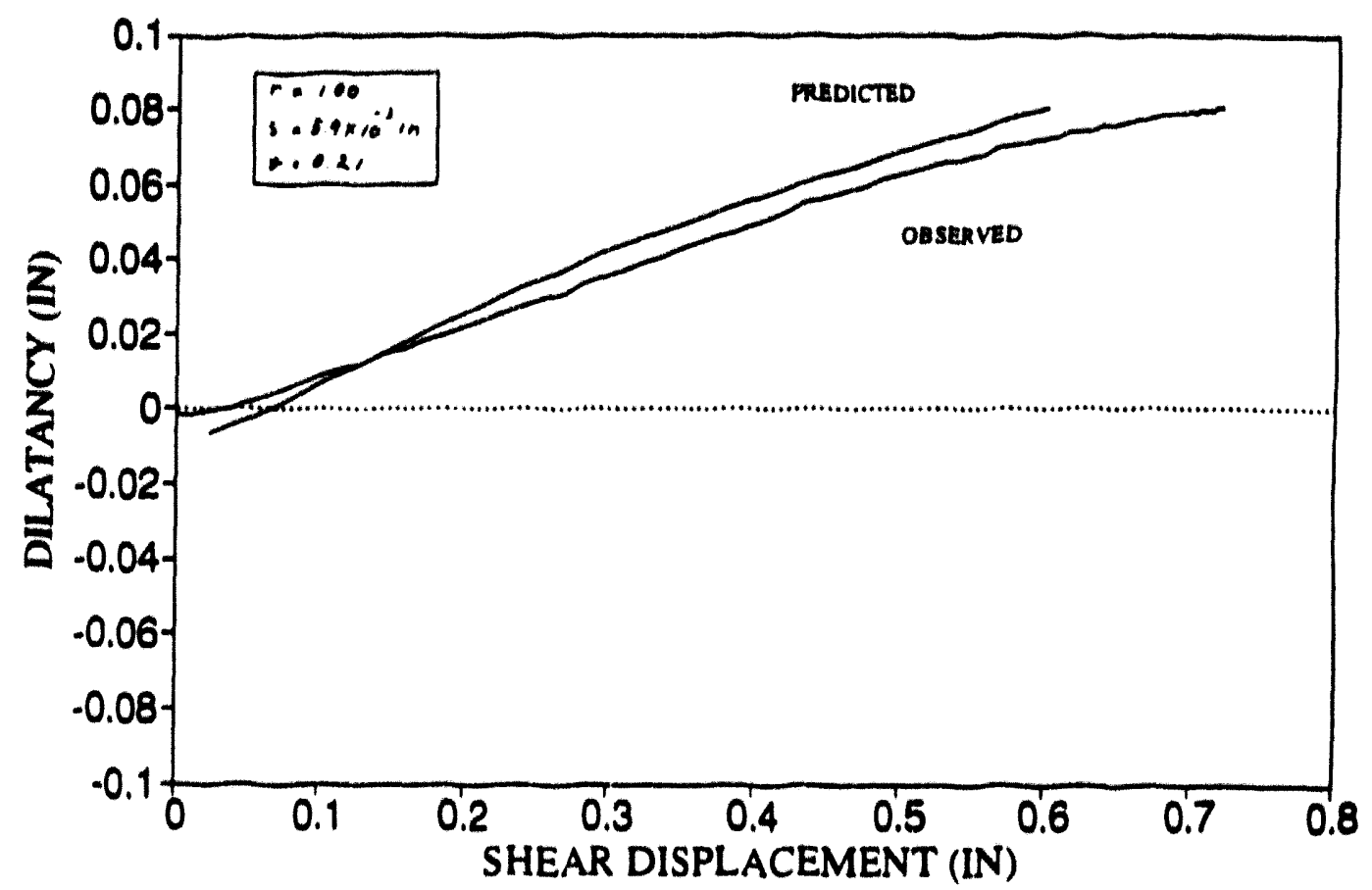

SHEAR LOAD PREDICTION G21F

$\mathrm{K}=32 \mathrm{KIPS} / \mathrm{IN}$, NORMAL LOAD=1.3 KIPS

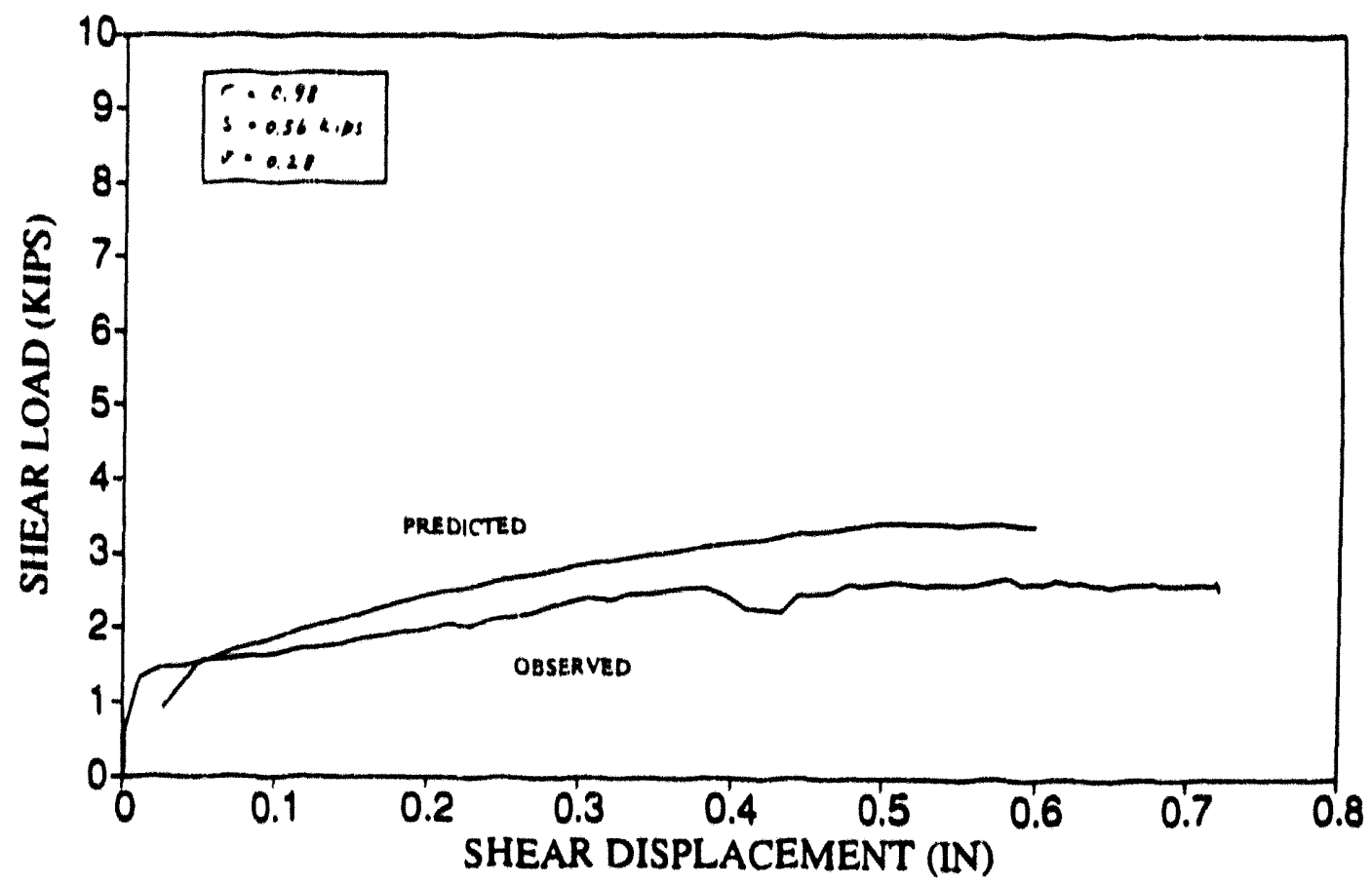




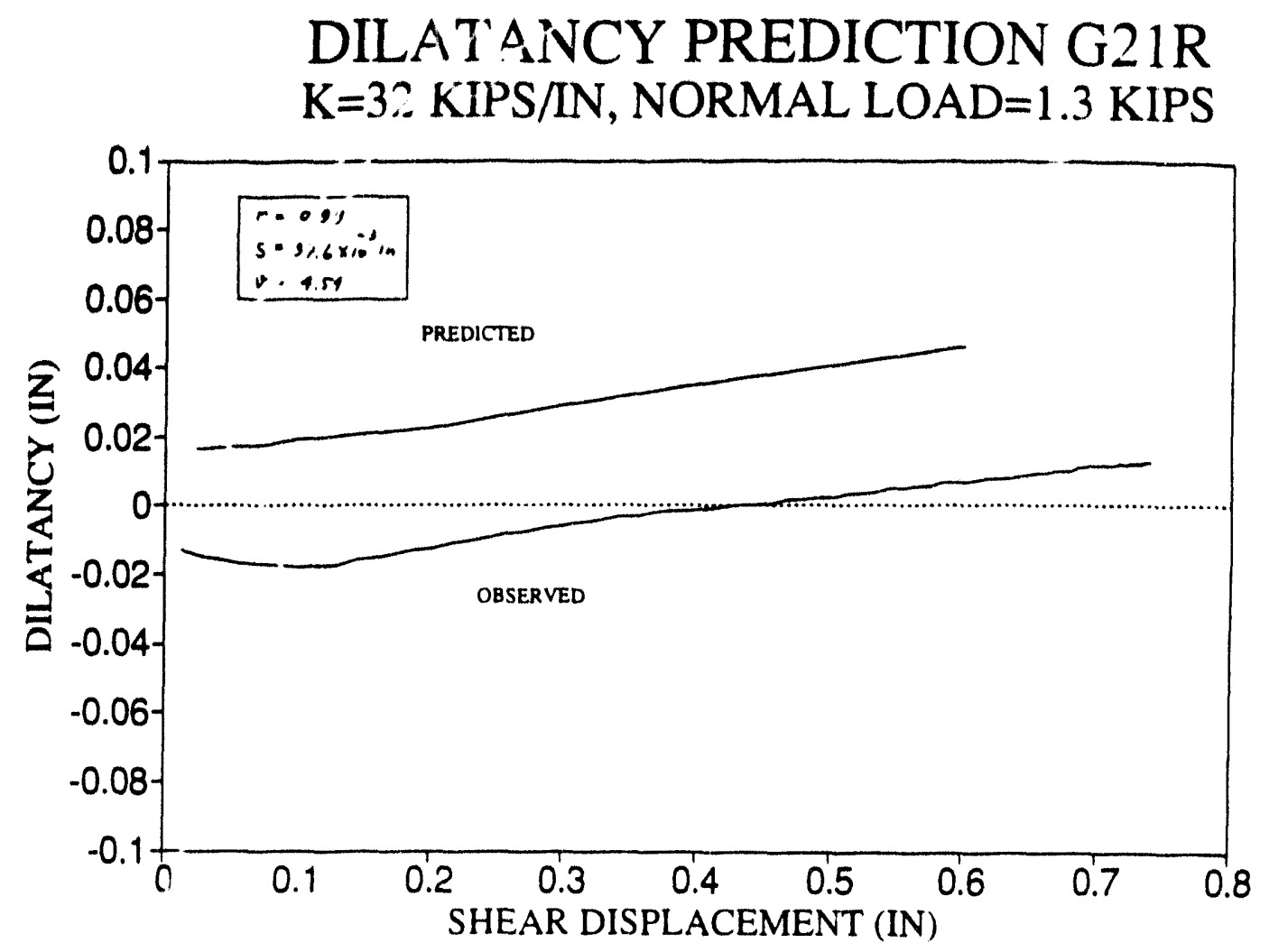

SHEAR LOAD PREDICTION G21R $\mathrm{K}=32 \mathrm{KIPS} / \mathrm{IN}$, NORMAL LOAD=1.3 KIPS

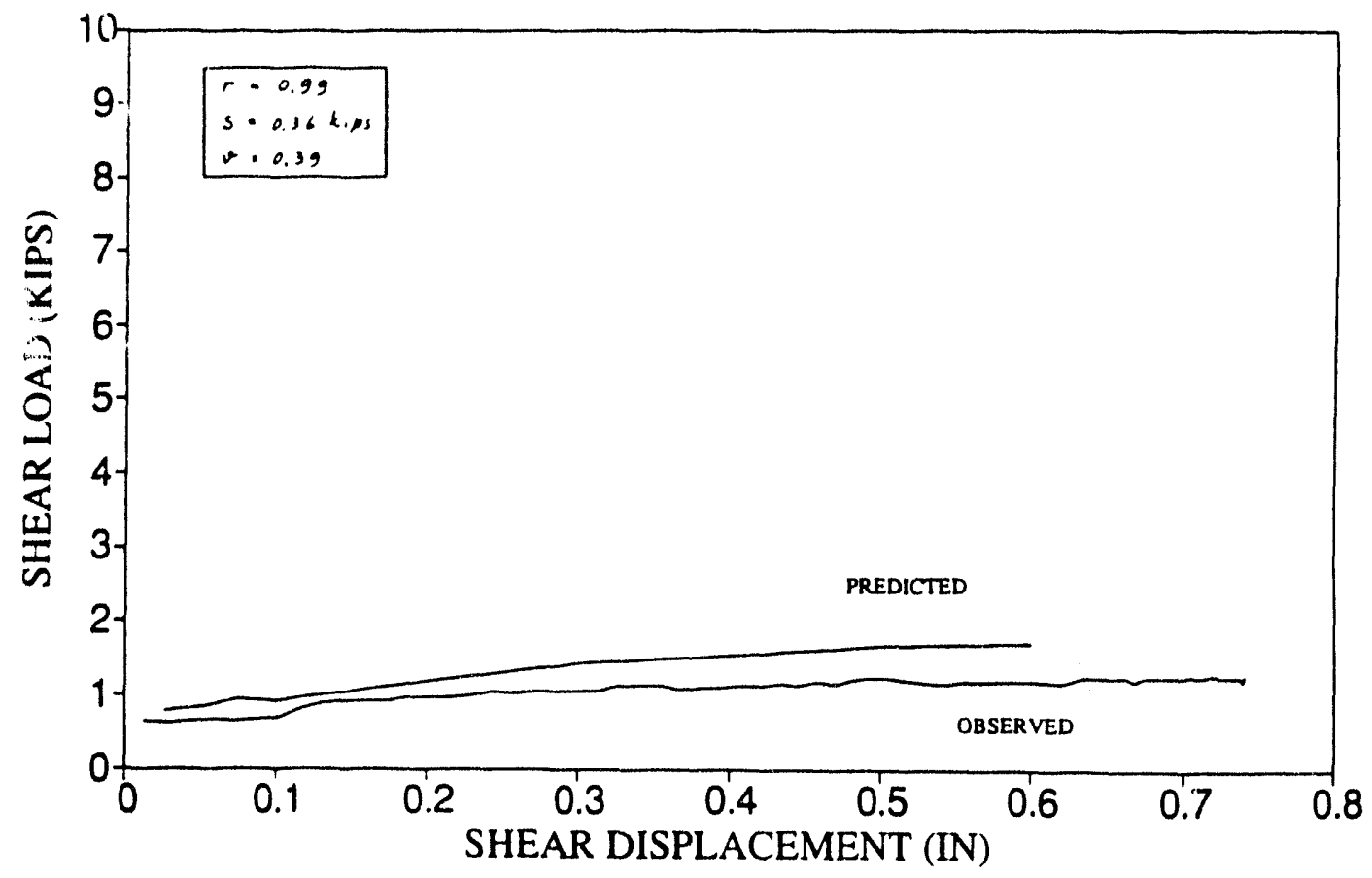




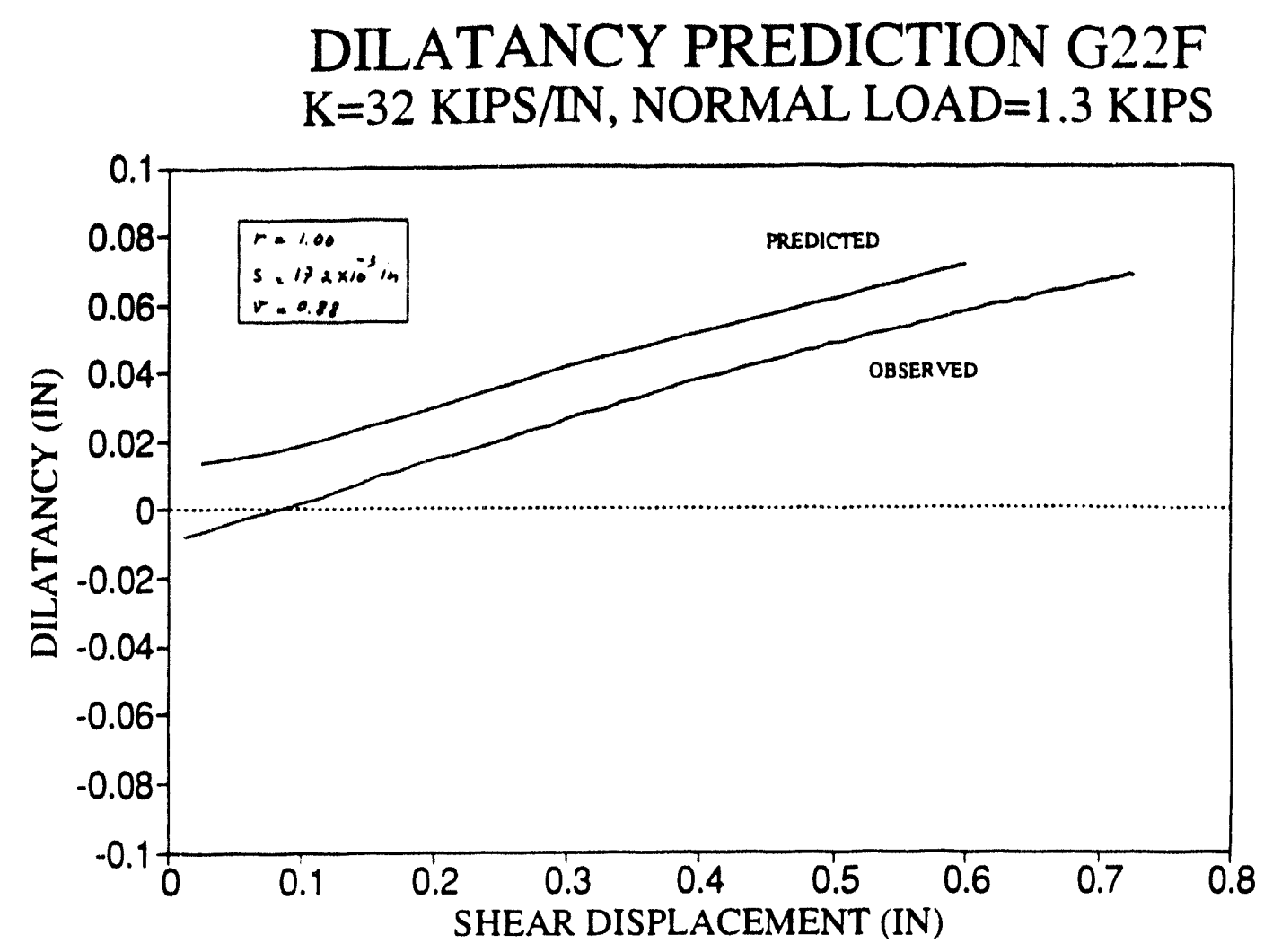

SHEAR LOAD PREDICTION G22F

$\mathrm{K}=32 \mathrm{KIPS} / \mathrm{IN}$, NORMAL LOAD $=1.3 \mathrm{KIPS}$

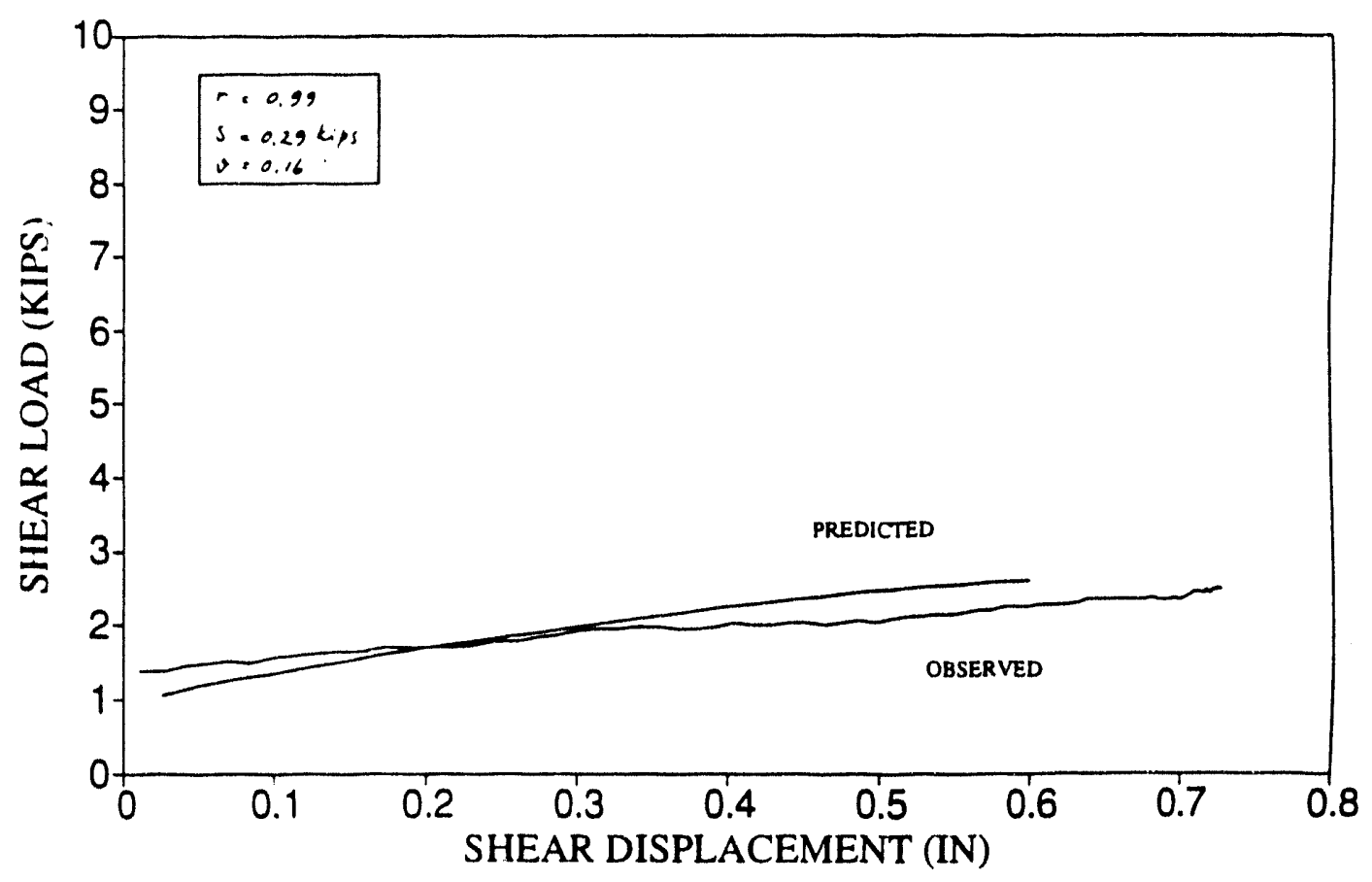




\section{DILATANCY PREDICTION G22R $\mathrm{K}=32 \mathrm{KIPS} / \mathrm{IN}$, NORMAL LOAD $=1.3 \mathrm{KIPS}$}

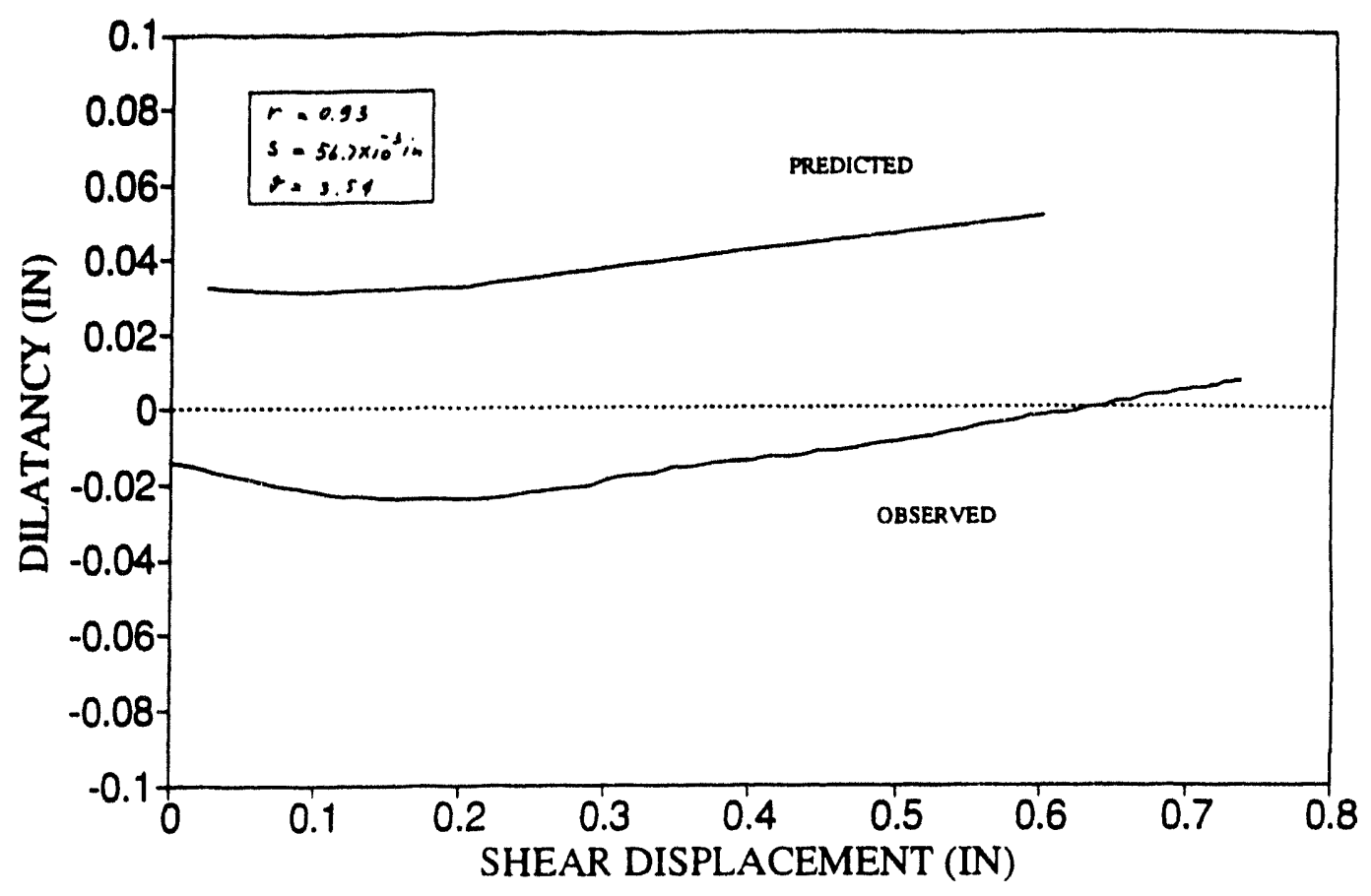

SHEAR LOAD PREDICTION G22R

$\mathrm{K}=32 \mathrm{KIPS} / \mathrm{IN}$, NORMAL LOAD $=1.3 \mathrm{KIPS}$

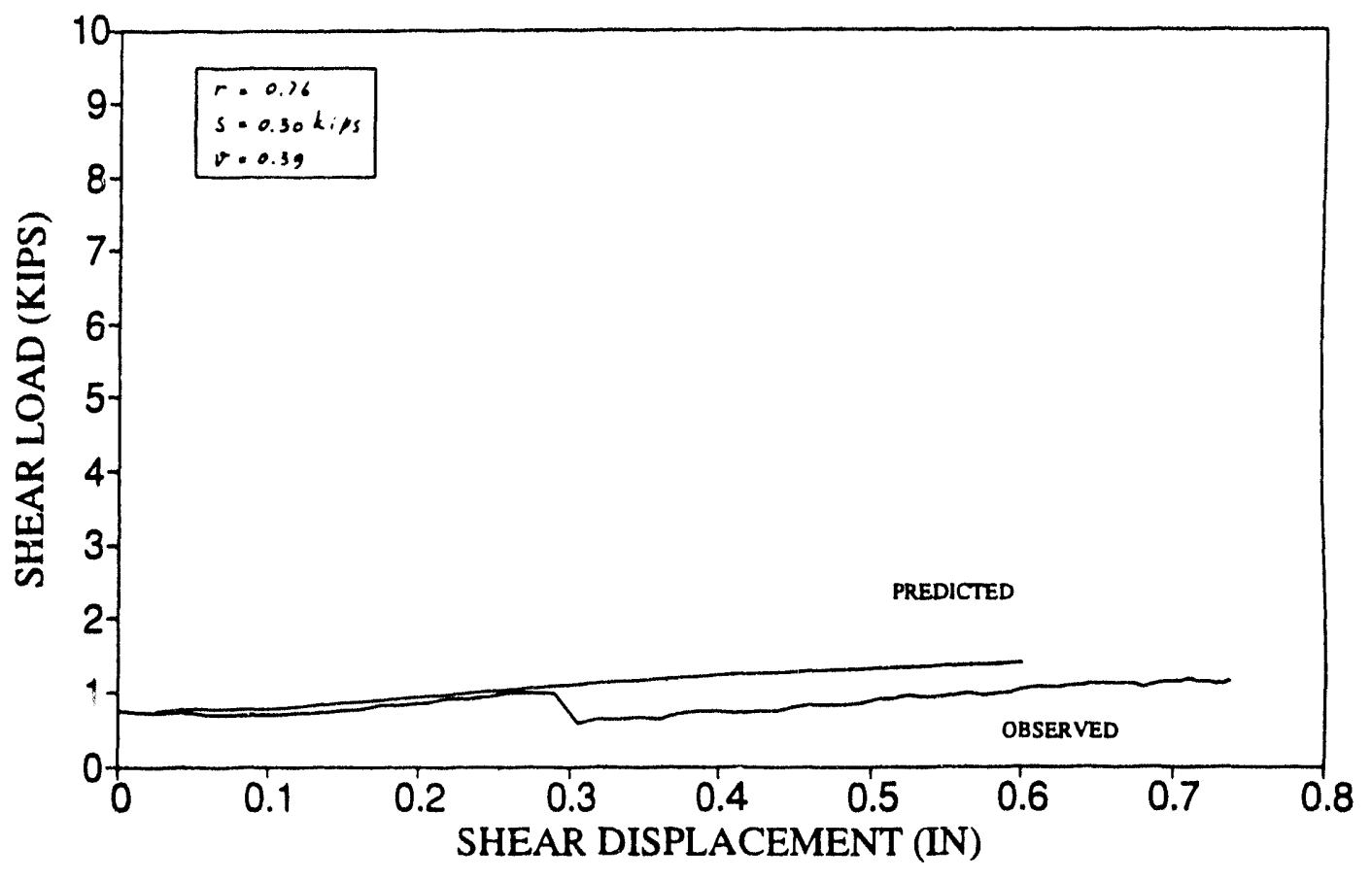




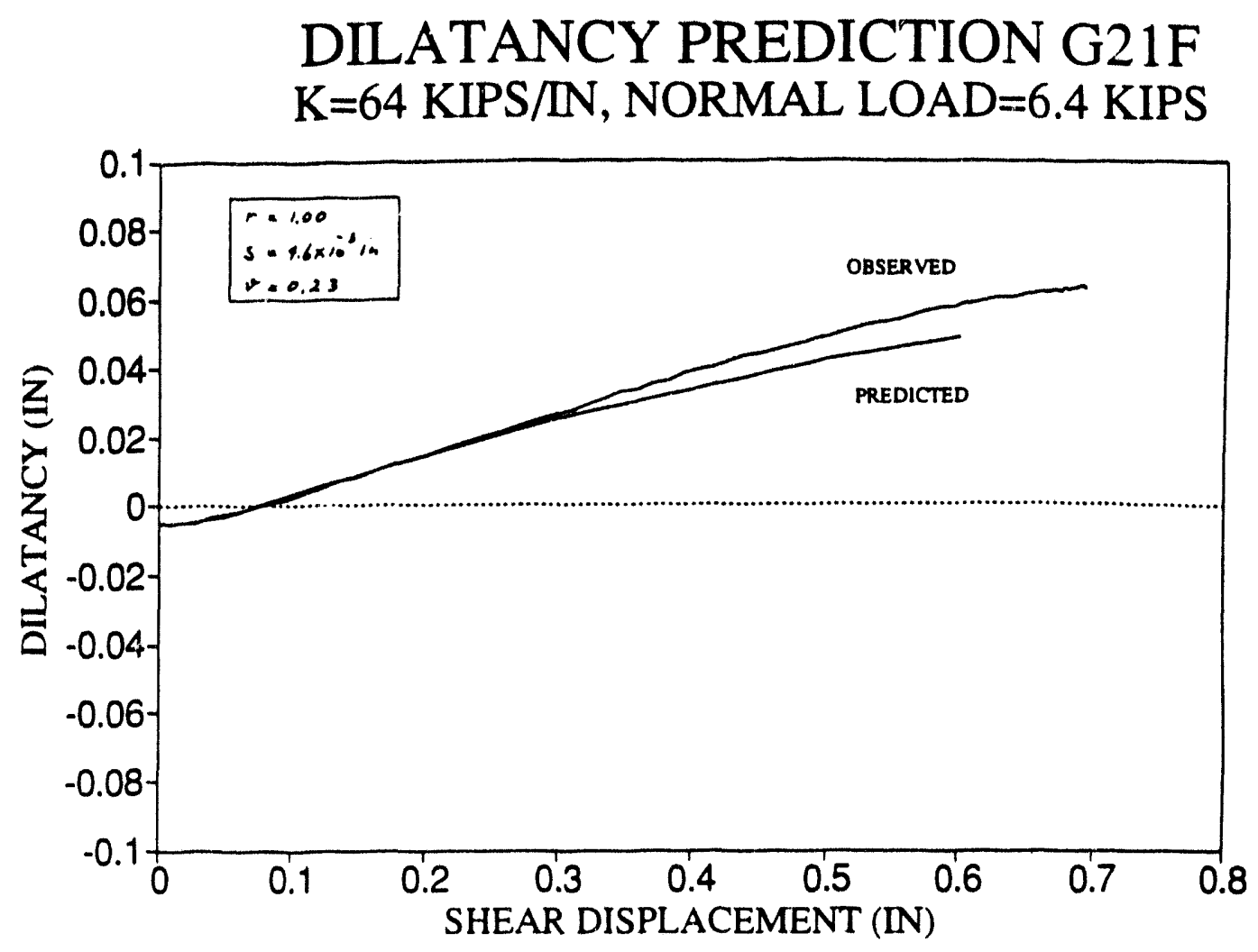

SHEAR LOAD PREDICTION G21F

$\mathrm{K}=64 \mathrm{KIPS} / \mathrm{IN}$, NORMAL LOAD=6.4 KIPS

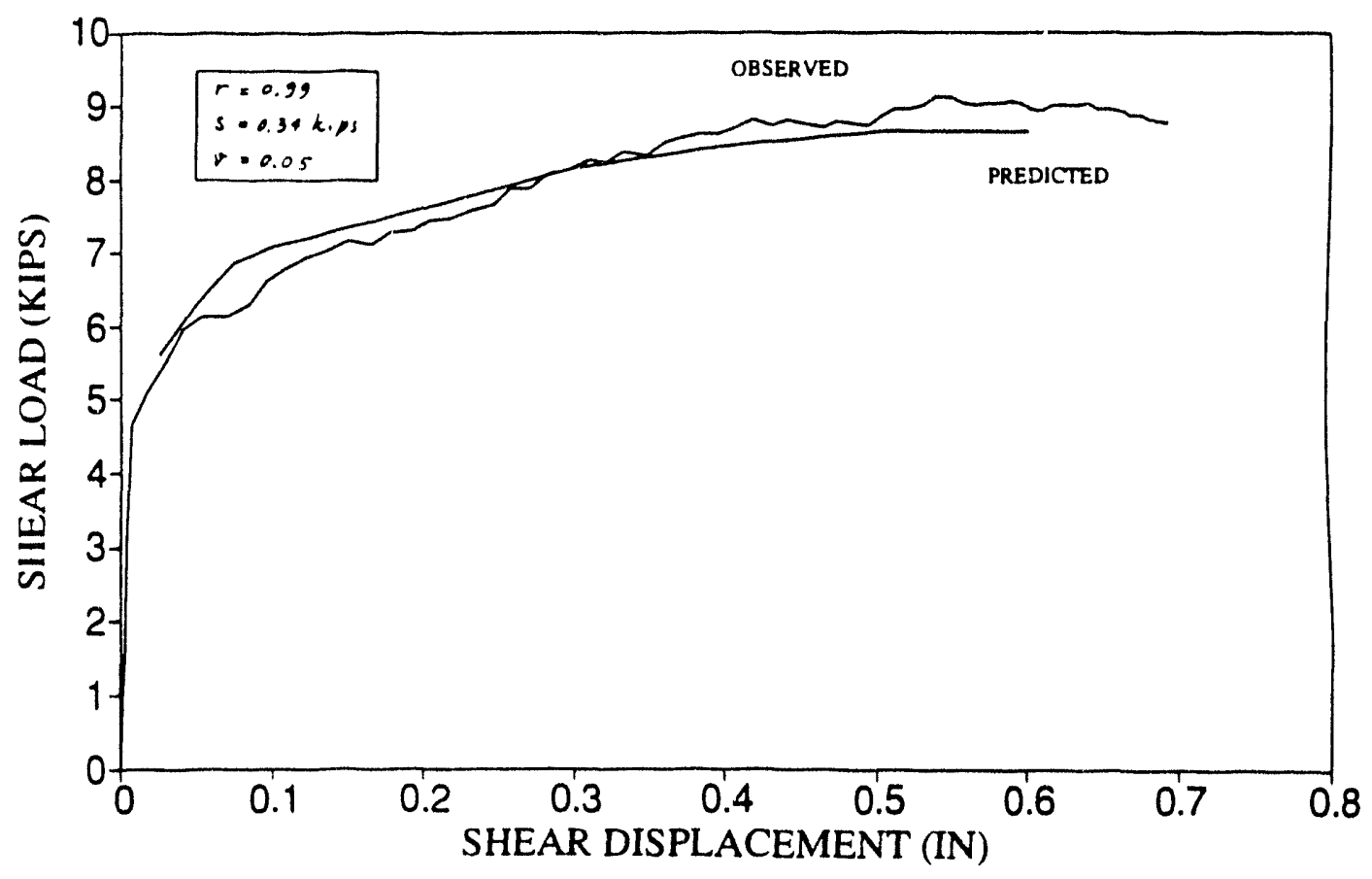


DILATANCY PREDICTION G21R $\mathrm{K}=64 \mathrm{KIPS} / \mathrm{IN}, \mathrm{NORMAL}$ LOAD=6.4 KIPS

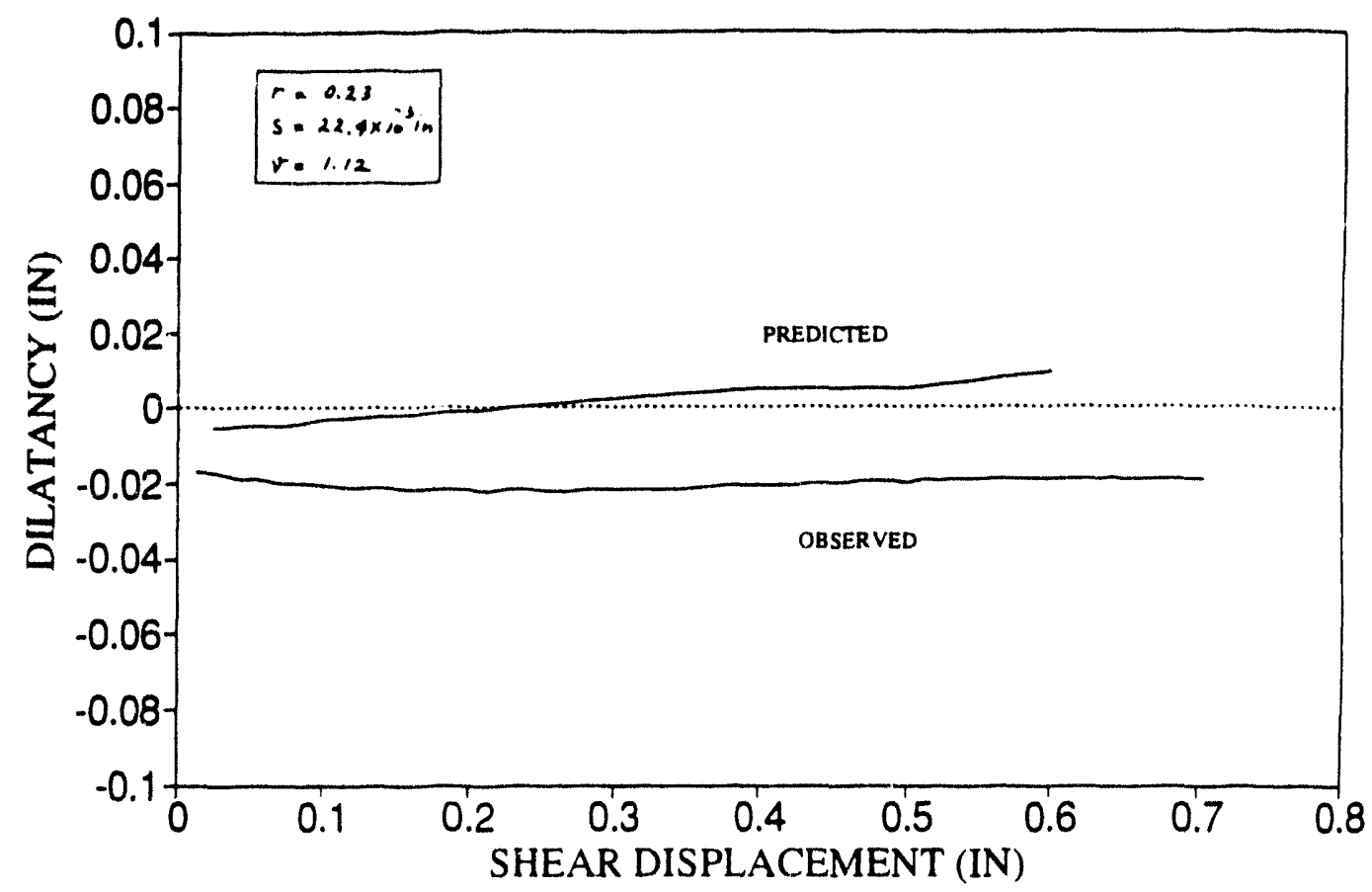

SHEAR LOAD PREDICTION G21R $\mathrm{K}=64 \mathrm{KIPS} / \mathrm{IN}$, NORMAL LOAD=6.4 KIPS

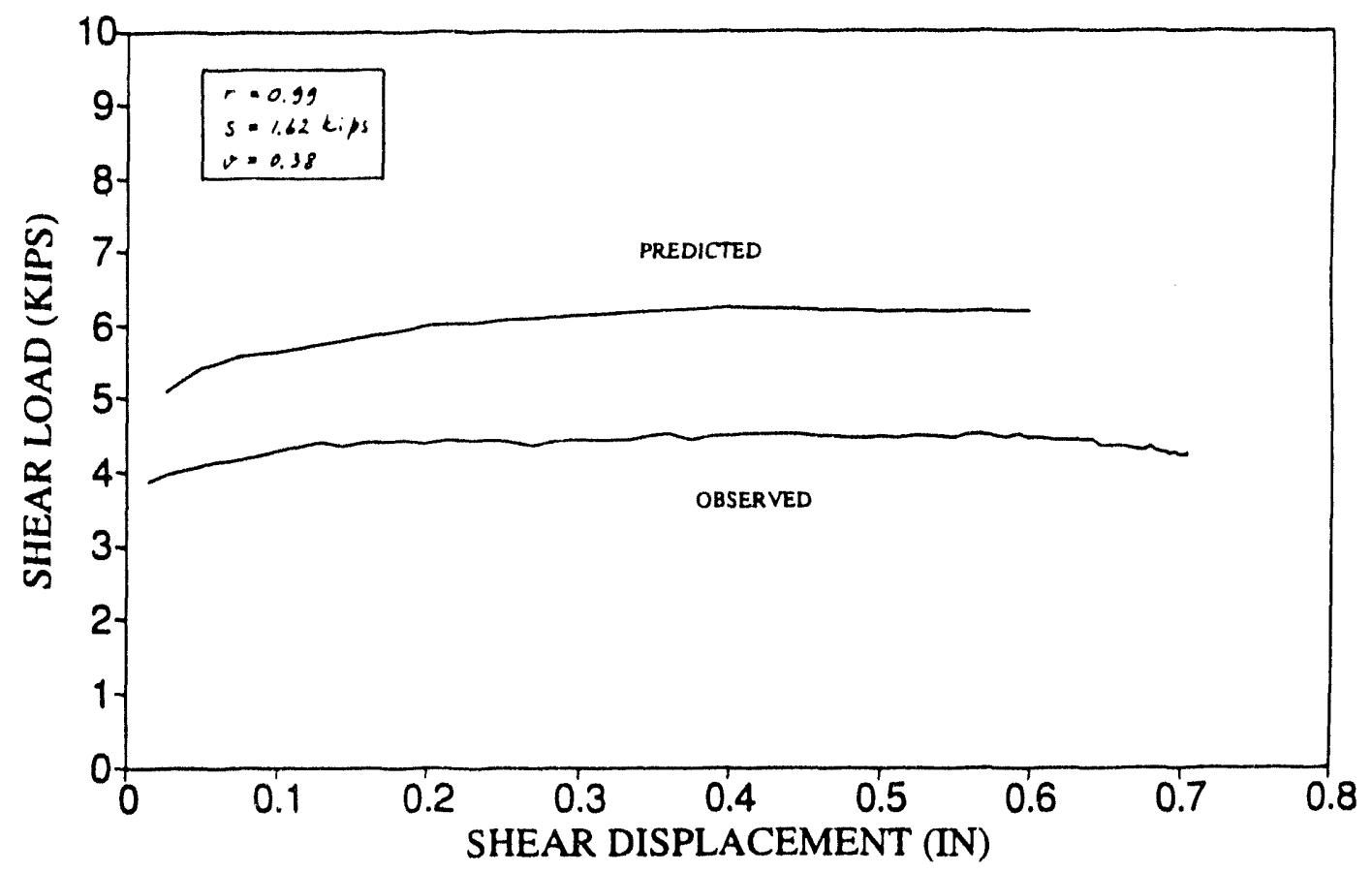


DILATANCY PREDICTION G22F $\mathrm{K}=64 \mathrm{KIPS} / \mathrm{IN}$, NORMAL LOAD $=6.4 \mathrm{KIPS}$

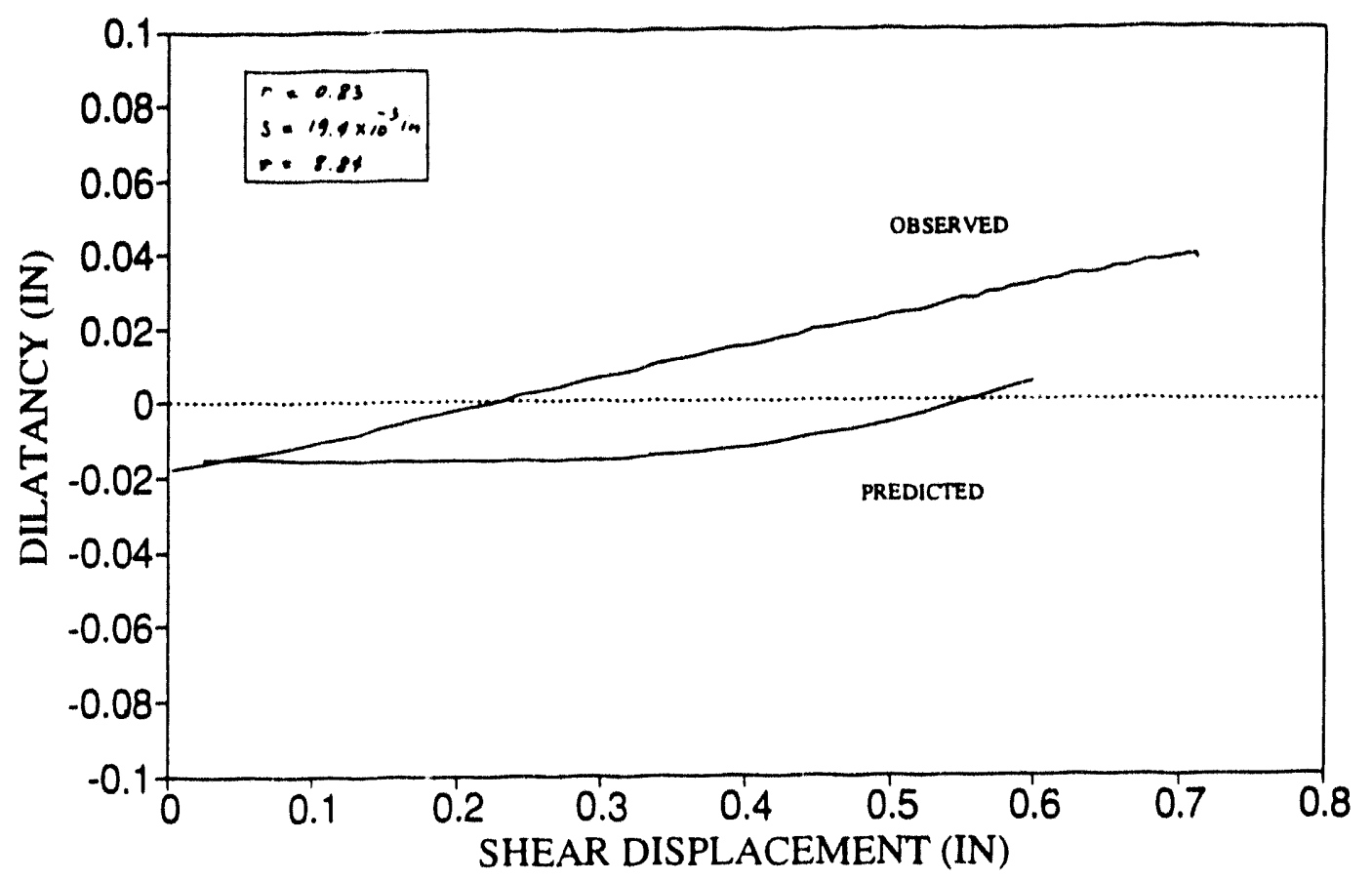

SHEAR LOAD PREDICTION G22F $\mathrm{K}=64 \mathrm{KIPS} / \mathrm{IN}$, NORMAL LOAD=6.4 KIPS

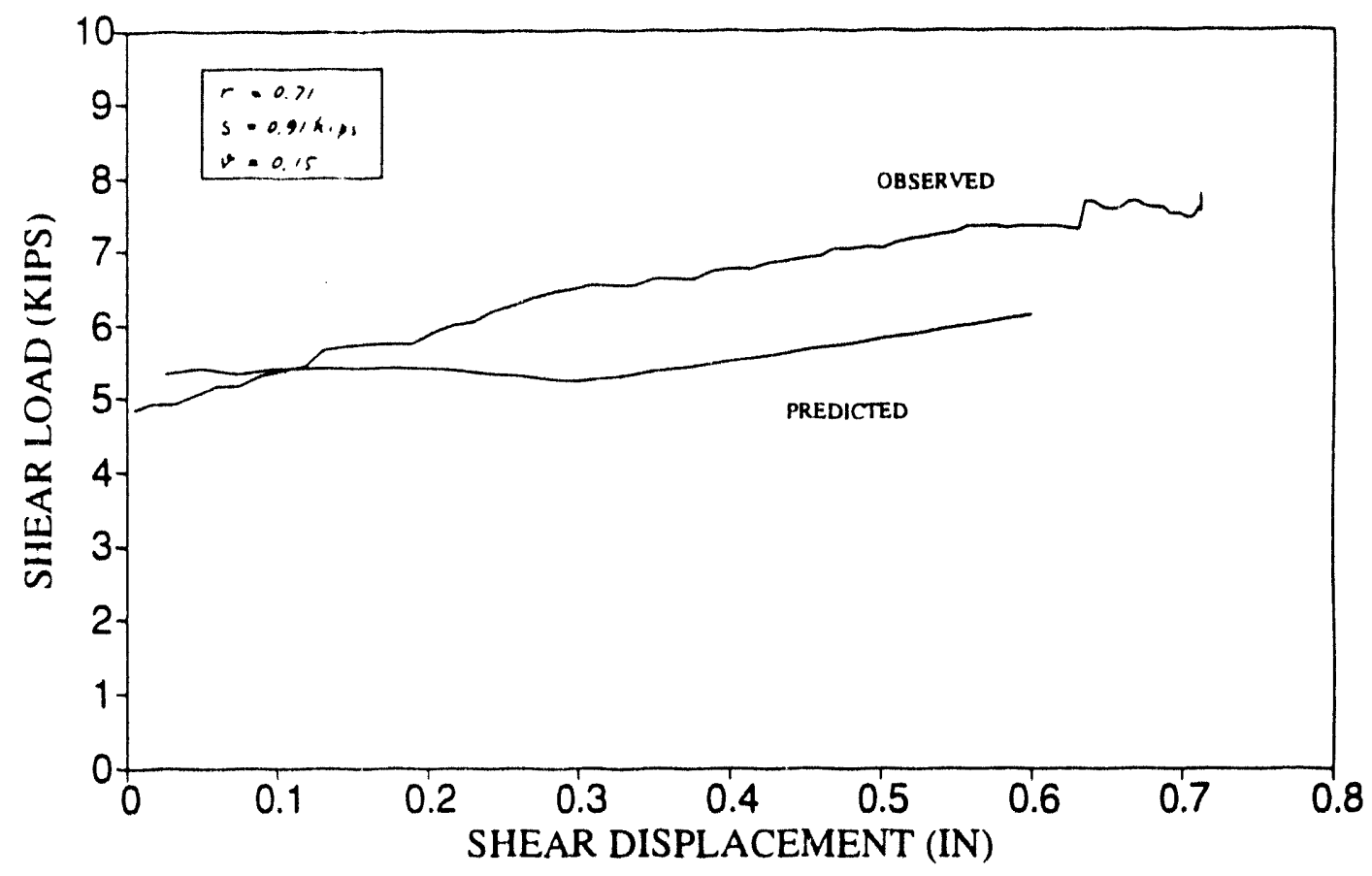


DILATANCY PREDICTION G22R $\mathrm{K}=64 \mathrm{KIPS} / \mathrm{IN}$, NORMAL LOAD=6.4 KIPS

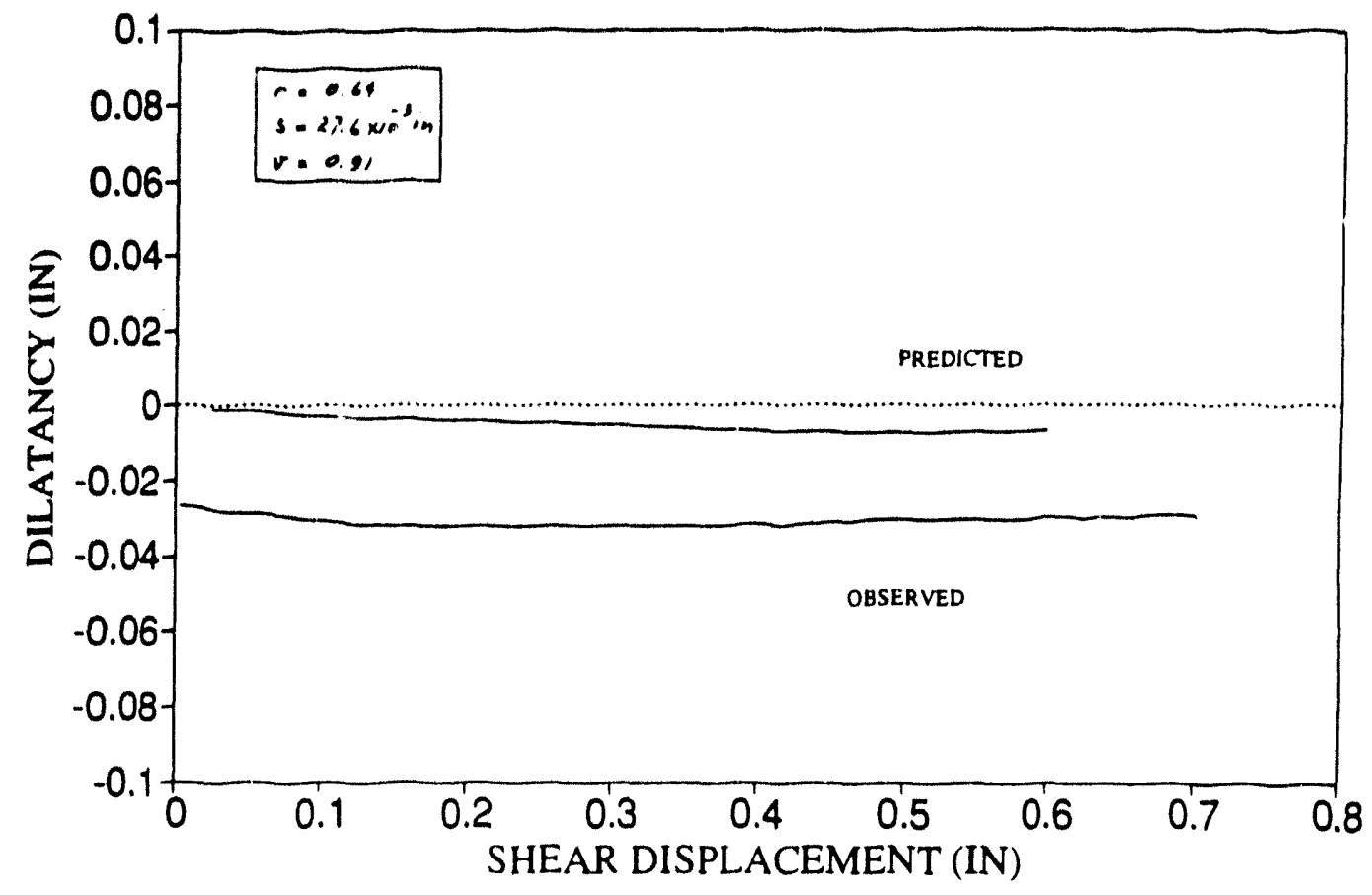

SHEAR LOAD PREDICTION G22R $\mathrm{K}=64 \mathrm{KIPS} / \mathrm{IN}$, NORMAL LOAD=6.4 KIPS

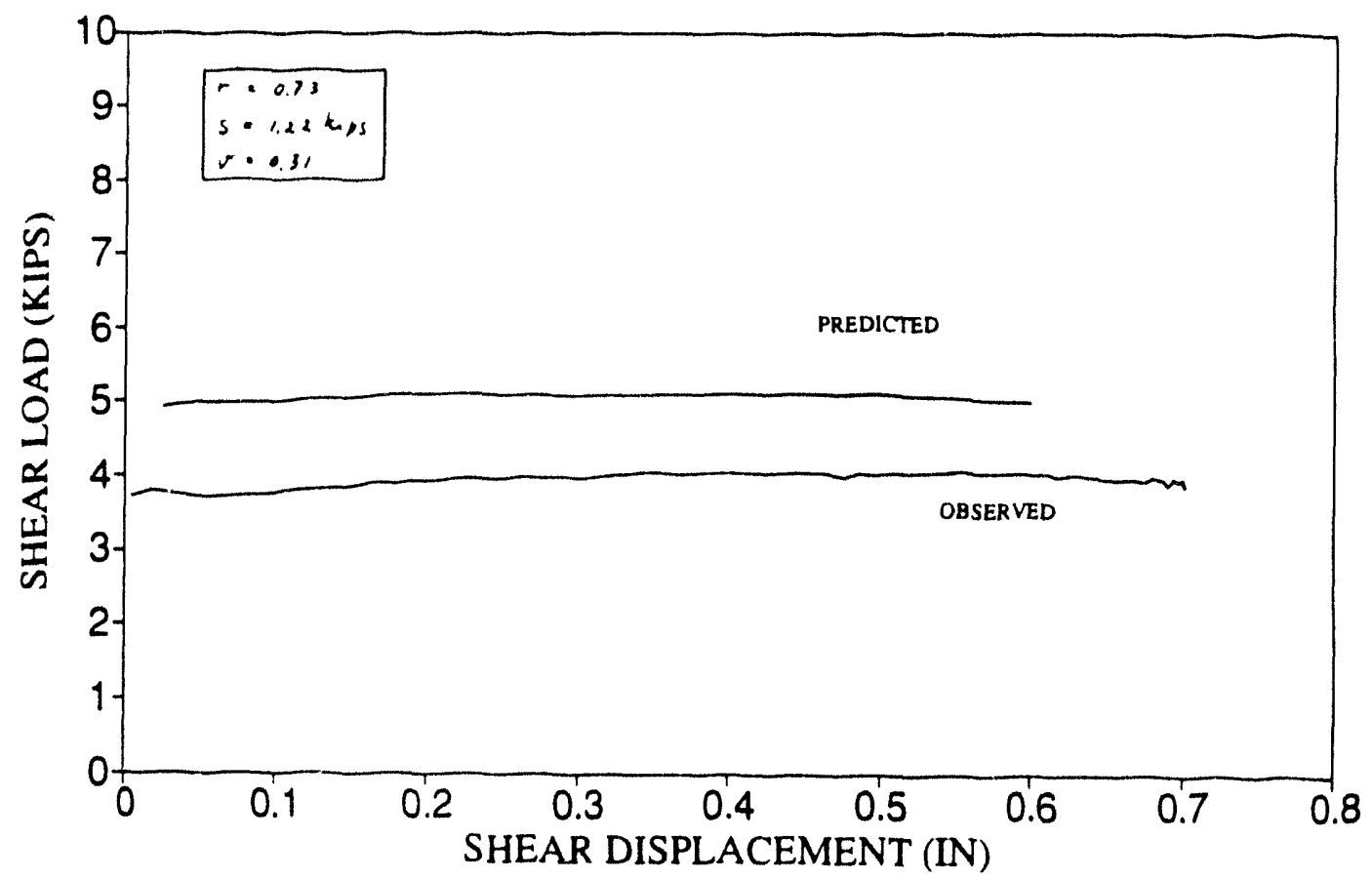




\section{APPENDIX C}

Coefficient of correlation, standard error, and coefficient of variation load

KR7F4 Dilatancy comparison, Normal Load $=3.6 \mathrm{kips}$;

$\mathrm{K}=18.0 \mathrm{kips} / \mathrm{in}$

C -1

KR7F4 Shear load comparison, Normal Load $=3.6 \mathrm{kips}$;

$\mathrm{K}=18.0 \mathrm{kips} / \mathrm{in}$

KR9F4 Dilatancy comparison, Normal Load $=3.6 \mathrm{kips}$;

$\mathrm{K}=54.0 \mathrm{kips} / \mathrm{in}$

KR9F4 Shear load comparison, Normal Load $=3.6 \mathrm{kips}$;

$\mathrm{K}=54.0 \mathrm{kips} / \mathrm{in}$

KR10F4 Dilatancy comparison, Normal Load $=3.6 \mathrm{kips}$;

$\mathrm{K}=179.9 \mathrm{kips} / \mathrm{in}$

KR10F4 Shear load comparison, Normal Load $=3.6 \mathrm{kips}$;

$\mathrm{K}=179.9 \mathrm{kips} / \mathrm{in}$

KR11F4 Dilatancy comparison, Normal Load $=7.2 \mathrm{kips}$;

$\mathrm{K}=54.0 \mathrm{kips} / \mathrm{in}$

KR11F4 Shear load comparison, Normal Load $=7.2 \mathrm{kips}$;

$\mathrm{K}=54.0 \mathrm{kips} / \mathrm{in}$

KR12F4 Dilatancy comparison, Normal Load $=7.2 \mathrm{kips}$;

$\mathrm{K}=179.9 \mathrm{kips} / \mathrm{in}$

KR12F4 Shear load comparison, Normal Load $=7.2 \mathrm{kips}$;

$\mathrm{K}=179.9 \mathrm{kips} / \mathrm{in}$

KR7F3 Dilatancy comparison, Normal Load $=3.8 \mathrm{kips}$;

$\mathrm{K}=18.8 \mathrm{kips} / \mathrm{in}$

KR7F3 Shear load comparison, Normal Load $=3.8 \mathrm{kips}$;

$\mathrm{K}=18.8 \mathrm{kips} / \mathrm{in}$

KR8F3 Dilatancy Comparison, Normal Load $=3.8 \mathrm{kips}$;

$\mathrm{K}=56.3 \mathrm{kips} / \mathrm{in}$

KR8F3 Shear load comparison, Normal Load $=3.8 \mathrm{kips}$;

$\mathrm{K}=56.3 \mathrm{kips} / \mathrm{in}$

KR9F3 Dilatancy Comparison, Normal Load $=3.8 \mathrm{kips}$;

$\mathrm{K}=187.5 \mathrm{kips} / \mathrm{in}$ 
KR9F3 Shear load comparison, Normal Load $=3.8 \mathrm{kips}$; $\mathrm{K}=187.5 \mathrm{kips} / \mathrm{in}$

KR10F3 Dilatancy comparison, Normal Load $=7.5 \mathrm{kips}$; $\mathrm{K}=56.3 \mathrm{kips} / \mathrm{in}$

KR10F3 Shear load comparison, Normal Load $=7.5 \mathrm{kips}$;

$\mathrm{K}=56.3 \mathrm{kips} / \mathrm{in}$

KR11F3 Dilatancy comparison, Normal Load $=7.5 \mathrm{kips}$; $\mathrm{K}=187.5 \mathrm{kips} / \mathrm{in}$

KR11F3 Shear load comparison, Normal Load $=7.5 \mathrm{kips}$; $\mathrm{K}=187.5 \mathrm{kips} / \mathrm{in}$

KR6F2 Dilatancy comparison, Normal Load $=3.0 \mathrm{kips}$;

$\mathrm{K}=14.8 \mathrm{kips} / \mathrm{in}$

KR6F2 Shear load comparison, Normal Load $=3.0 \mathrm{kips}$; $\mathrm{K}=14.8 \mathrm{kips} / \mathrm{in}$

KR7F2 Dilatancy comparison, Normal Load $=3.0 \mathrm{kips}$;

$\mathrm{K}=44.3 \mathrm{kips} / \mathrm{in}$

KR7F2 Shear load comparison, Normal Load $=3.0 \mathrm{kips}$; $\mathrm{K}=44.3 \mathrm{kips} / \mathrm{in}$

KR8F2 Dilatancy comparison, Normal Load $=3.0 \mathrm{kips}$; $\mathrm{K}=147.8 \mathrm{kips} / \mathrm{in}$

KR8F2 Shear load comparison, Normal Load $=3.0 \mathrm{kips}$; $\mathrm{K}=147.8 \mathrm{kips} / \mathrm{in}$

KR5G2 Dilatancy comparison, Normal Load $=1.3 \mathrm{kips}$; $\mathrm{K}=32 \mathrm{kips} / \mathrm{in}$

KR5G2 Shear load comparison, Normal Load $=1.3 \mathrm{kips}$; $\mathrm{K}=32 \mathrm{kips} / \mathrm{in}$

KR6G2 Dilatancy Comparison, Normal Load $=6.4 \mathrm{kips}$; $\mathrm{K}=64 \mathrm{kips} / \mathrm{in}$

KR6G2 Shear load comparison, Normal ' 'oad $=6.4 \mathrm{kips}$; $\mathrm{K}=64 \mathrm{kips} / \mathrm{in}$ 
Coefficient of Correlation, Standard Error, and Coefficient of Variation for Dilatancy. Sample KR7F4 Tested under initial normal load $3.6 \mathrm{kips}$ and applied stiffness $18.0 \mathrm{kips} / \mathrm{in}$.

\begin{tabular}{|c|c|c|c|}
\hline Sample & $\begin{array}{c}\text { Coefficient of } \\
\text { Correlation } \\
\text { KR7F4 }\end{array}$ & $\begin{array}{c}\text { Standard } \\
\text { Error } \\
(\text { s })\end{array}$ & $\begin{array}{c}\text { Coefficient of } \\
\text { Variation } \\
\left(10^{3} \text { in. }\right)\end{array}$ \\
\hline Forward & 1.00 & 0.9 & 0.05 \\
1st cycle & 1.00 & 2.7 & 0.18 \\
2nd cycle & 1.00 & 1.9 & 0.15 \\
3rd cycle & 1.00 & 3.6 & 0.34 \\
4th cycle & 1.00 & 4.0 & 0.44 \\
5th cycle & & & \\
\hline Reverse & 1.00 & 1.9 & 0.11 \\
1st cycle & 1.00 & 1.2 & 0.10 \\
2nd cycle & 1.00 & 1.3 & 0.14 \\
3rd cycle & 1.00 & 1.4 & 0.23 \\
4th cycle & 1.00 & 1.6 & \\
5th cycle &
\end{tabular}

Coefficient of Correlation, Standard Error, and Coefficient of

Variation for Shear Load. Sample KR7F4 tested under initial normal load $3.6 \mathrm{kips}$ and applied stiffness $18.0 \mathrm{kips} / \mathrm{in}$.

\begin{tabular}{|c|c|c|c|}
\hline $\begin{array}{l}\text { Sample } \\
\text { KR7F4 }\end{array}$ & $\begin{array}{c}\text { Coefficient of } \\
\text { Correlation } \\
(r)\end{array}$ & $\begin{array}{c}\text { Standard } \\
\text { Error } \\
(\mathrm{s}) \\
\text { (kips) }\end{array}$ & $\begin{array}{c}\text { Coefficient of } \\
\text { Variation } \\
(v)\end{array}$ \\
\hline $\begin{array}{l}\text { Forward } \\
\text { 1st cycle } \\
\text { 2nd cycle } \\
3 \text { rd cylle } \\
4 \text { th cycle } \\
5 \text { th cycle }\end{array}$ & $\begin{array}{l}0.98 \\
0.91 \\
0.88 \\
0.67 \\
0.96 \\
\end{array}$ & $\begin{array}{l}0.62 \\
0.79 \\
0.82 \\
0.95 \\
0.83 \\
\end{array}$ & $\begin{array}{l}0.15 \\
0.26 \\
0.29 \\
0.35 \\
0.31 \\
\end{array}$ \\
\hline $\begin{array}{l}\text { Reverse } \\
\text { 1st cycle } \\
\text { 2nd cycle } \\
3 \text { rd cycle } \\
4 \text { th cycle } \\
5 \text { th cycle }\end{array}$ & $\begin{array}{l}0.95 \\
0.84 \\
0.55 \\
0.61 \\
0.62\end{array}$ & $\begin{array}{l}0.67 \\
0.58 \\
0.61 \\
0.59 \\
0.60\end{array}$ & $\begin{array}{l}0.18 \\
0.19 \\
0.21 \\
0.21 \\
0.21\end{array}$ \\
\hline
\end{tabular}


Coefficient of Correlation, Standart Error, and Coe'ficient of Variation for Dilatancy. Sample KR9F4 tested under initial normal load $3.6 \mathrm{kips}$ and applied stiffness $54.0 \mathrm{kips} / \mathrm{in}$.

\begin{tabular}{|c|c|c|c|}
\hline Sample & $\begin{array}{c}\text { Coefficient of } \\
\text { Correlation } \\
\text { KR9F4 }\end{array}$ & $\begin{array}{c}\text { Standard } \\
\text { Error } \\
(\text { s })\end{array}$ & $\begin{array}{c}\text { Coefficient of } \\
\text { Variation } \\
\left(10^{-3} \text { in. }\right)\end{array}$ \\
\hline Forward & 1.00 & & 0.12 \\
1st cycle & 1.00 & 2.6 & 0.20 \\
2nd cycle & 1.00 & 3.0 & 0.24 \\
3rd cycle & 1.00 & 3.9 & 0.30 \\
4th cycle & 1.00 & 3.6 & 0.35 \\
5th cycle & & & \\
Reverse & 1.00 & 2.3 & 0.16 \\
1st cycle & 1.00 & 1.9 & 0.21 \\
2nd cycle & 1.00 & 2.1 & 0.28 \\
3rd cycle & 1.00 & 2.2 & 0.33 \\
4th cycle & 1.00 & 2.6 & 0.41 \\
5th cycle & & & \\
\hline
\end{tabular}

Coefficient of Correlation, standard Error, and Coefficient of

Variation for Shear Load. Sample KR9F4 tested under initial normal load $3.6 \mathrm{kips}$ and applied stiffness $51.0 \mathrm{kips} / \mathrm{in}$.

\begin{tabular}{|c|c|c|c|}
\hline $\begin{array}{l}\text { Sample } \\
\text { KR9F4 }\end{array}$ & $\begin{array}{c}\text { Coefficient of } \\
\text { Correlation } \\
\left(\begin{array}{c}r \\
(\end{array}\right.\end{array}$ & $\begin{array}{c}\text { Standard } \\
\text { Error } \\
(\text { s ) } \\
\text { (kips) }\end{array}$ & $\begin{array}{c}\text { Coefficient of } \\
\text { Variation } \\
(\mathrm{v})\end{array}$ \\
\hline $\begin{array}{l}\text { Forward } \\
\text { 1st cycle } \\
\text { 2nd cycle } \\
3 \text { rd cycle } \\
4 \text { th cycle } \\
5 \text { th cycle }\end{array}$ & $\begin{array}{l}0.41 \\
0.99 \\
0.99 \\
0.91 \\
0.99 \\
\end{array}$ & $\begin{array}{l}0.36 \\
0.63 \\
0.68 \\
0.89 \\
0.78 \\
\end{array}$ & $\begin{array}{l}0.09 \\
0.19 \\
0.22 \\
0.30 \\
0.27 \\
\end{array}$ \\
\hline $\begin{array}{l}\text { Reverse } \\
\text { 1st cycle } \\
2 \mathrm{nd} \text { cycle } \\
3 \mathrm{rd} \text { cycle } \\
4 \mathrm{th} \text { cycle } \\
5 \mathrm{th} \text { cycle }\end{array}$ & $\begin{array}{l}0.87 \\
0.98 \\
0.98 \\
0.98 \\
0.99\end{array}$ & $\begin{array}{l}0.71 \\
0.67 \\
0.68 \\
0.89 \\
0.78\end{array}$ & $\begin{array}{l}0.17 \\
0.20 \\
0.22 \\
0.23 \\
0.24\end{array}$ \\
\hline
\end{tabular}


Coefficient of Correlation, Standard Error, and Coefficient of Variation for Dilatancy. Sample KR1OF4 tested under inftial normal load $3.6 \mathrm{kips}$ and applied stifness $179.9 \mathrm{klps} / \mathrm{in}$.

\begin{tabular}{|c|c|c|c|}
\hline $\begin{array}{l}\text { Sample } \\
\text { KR1OF4 }\end{array}$ & $\begin{array}{c}\text { Coefficient of } \\
\text { Correlation } \\
(r)\end{array}$ & $\begin{array}{c}\text { Standard } \\
\text { Error } \\
\left(10^{1}\right) \\
\text { 1n. })\end{array}$ & $\begin{array}{c}\text { Coefflctent of } \\
\text { Vartation } \\
(v)\end{array}$ \\
\hline $\begin{array}{l}\text { Forward } \\
1 \mathrm{st} \text { cycle } \\
2 \mathrm{nd} \text { cycle } \\
3 \mathrm{rd} \text { cycle } \\
4 \mathrm{th} \text { cycle } \\
5 \mathrm{th} \text { cycle }\end{array}$ & $\begin{array}{l}1.00 \\
1.00 \\
1.00 \\
1.00 \\
1.00 \\
\end{array}$ & $\begin{array}{l}2.6 \\
2.9 \\
2.6 \\
3.3 \\
4.1 \\
\end{array}$ & $\begin{array}{l}0.17 \\
0.31 \\
0.38 \\
0.60 \\
0.87 \\
\end{array}$ \\
\hline $\begin{array}{l}\text { Reverse } \\
\text { 1st cycle } \\
\text { 2nd cycle } \\
3 \mathrm{rd} \text { cycle } \\
4 \mathrm{th} \text { cycle } \\
5 \mathrm{th} \text { cycle }\end{array}$ & $\begin{array}{l}1.00 \\
1.00 \\
1.00 \\
1.00 \\
0.99\end{array}$ & $\begin{array}{l}7.1 \\
7.2 \\
7.6 \\
8.2 \\
9.9\end{array}$ & $\begin{array}{l}0.47 \\
0.73 \\
0.92 \\
1.13 \\
1.35\end{array}$ \\
\hline
\end{tabular}

Coefficient of Correlation, Standard Error, and Coefficlent of Variation for Shear Load. Sample KR1OF4 tested under initial normal load $3.6 \mathrm{kips}$ and applied stiffness $179.9 \mathrm{kips} / \mathrm{in}$.

\begin{tabular}{||c|c|c|c||}
\hline Sample & $\begin{array}{c}\text { Coefficient of } \\
\text { Correlation } \\
\text { KR10F4 }\end{array}$ & $\begin{array}{c}\text { Standard } \\
\text { Error } \\
(\mathbf{s}) \\
\text { (kips) }\end{array}$ & $\begin{array}{c}\text { Coefficient of } \\
\text { Variation } \\
\text { v })\end{array}$ \\
\hline Forward & 1.00 & & \\
1st cycle & 1.00 & 0.67 & 0.13 \\
2nd cycle & 0.99 & 0.24 & 0.07 \\
3rd cycle & 0.98 & 0.23 & 0.07 \\
4th cycle & 1.00 & 0.42 & 0.14 \\
5th cycle & & 0.33 & 0.11 \\
\hline Reverse & 0.96 & & \\
1st cycle & 1.00 & 1.07 & 0.22 \\
2nd cycle & 0.99 & 1.00 & 0.27 \\
3rd cycle & 0.98 & 0.98 & 0.29 \\
4th cycle & 1.00 & 0.95 & 0.29 \\
5th cycle & 0.96 & 0.30 \\
\hline
\end{tabular}


Coefflcient of Correlation, Standard Error, and Coefficient of

Variation for Dilatancy. Sample KR11F4 tested under initial normal load $7.2 \mathrm{kips}$ and applied stiffness $54.0 \mathrm{kips} / \mathrm{in}$.

\begin{tabular}{|c|c|c|c|}
\hline Sample & $\begin{array}{c}\text { Coefficient of } \\
\text { Correlation } \\
\text { KR11F4 }\end{array}$ & $\begin{array}{c}\text { Standard } \\
\text { Error } \\
(\text { s })\end{array}$ & $\begin{array}{c}\text { Coefficient of } \\
\text { Variation } \\
\left(10^{-3} \text { in. }\right)\end{array}$ \\
\hline Forward & 1.00 & 5.6 & 0.28 \\
1ot cycle & 1.00 & 5.3 & 0.58 \\
2nd cycle & 1.00 & 5.8 & 1.01 \\
3rd cycle & 1.00 & 6.8 & 1.64 \\
4th cycle & 1.00 & 7.4 & 2.88 \\
5th cycle & & & 0.39 \\
\hline Reverse & 1.00 & 3.4 & 1.60 \\
18t cycle & 1.00 & 4.4 & 3.79 \\
2nd cycle & 0.97 & 7.0 & 8.94 \\
3rd cycle & 1.00 & 6.3 & 3.67 \\
4th cycle & 1.00 & 7.2 & \\
5th cycle & & & \\
\hline
\end{tabular}

Coefflcient of Correlation, Standard Error, and Coefficient of Varlation for Shear Load. Sample KR11F4 tested under initial normal load $7.2 \mathrm{kips}$ and applied stiffness $54.0 \mathrm{kips} / \mathrm{in}$.

\begin{tabular}{||c|c|c|c||}
\hline Sample & $\begin{array}{c}\text { Coefficient of } \\
\text { Correlation } \\
\text { KR11F4 }\end{array}$ & $\begin{array}{c}\text { Standard } \\
\text { Error } \\
(\text { S }) \\
\text { (kips) }\end{array}$ & $\begin{array}{c}\text { Coefficient of } \\
\text { Variation } \\
\text { ( v) }\end{array}$ \\
\hline Forward & 0.90 & 1.45 & 0.17 \\
1st cycle & 0.92 & 1.25 & 0.21 \\
2nd cycle & 0.95 & 1.46 & 0.25 \\
3rd cycle & 0.95 & 1.70 & 0.29 \\
4th cycle & 0.98 & 1.80 & 0.31 \\
5th cycle & & & 0.09 \\
Reverse & 0.70 & 0.62 & 0.05 \\
1st cycle & 0.82 & 0.30 & 0.09 \\
2nd cycle & 0.87 & 0.52 & 0.10 \\
3rd cycle & 0.91 & 0.58 & 0.11 \\
4th cycle & 0.94 & 0.58 & \\
5th cycle & & & \\
\hline
\end{tabular}


Coefficient of Correlation, Standard Error, and Coefficient of Variation for Dilatancy. Sample KR12F4 tested under initial normal load $7.2 \mathrm{kips}$ and applied stiffness $179.9 \mathrm{kips} / \mathrm{in}$.

\begin{tabular}{|c|c|c|c|}
\hline Sample & $\begin{array}{c}\text { Coefficient of } \\
\text { Correlation } \\
\text { KR12F4 }\end{array}$ & $\begin{array}{c}\text { Standard } \\
\text { Error } \\
(\text { s })\end{array}$ & $\begin{array}{c}\text { Coefficient of } \\
\text { Variation } \\
\left(10^{-3} \text { in. }\right)\end{array}$ \\
\hline Forward & 1.00 & 4.0 & 0.28 \\
1st cycle & 1.00 & 1.8 & 0.70 \\
2nd cycle & 1.00 & 2.0 & 3.42 \\
3rd cycle & 1.00 & 2.5 & 1.05 \\
4th cycle & - & - & - \\
5th cycle & 1.00 & 0.7 & 0.21 \\
Reverse & 1.00 & 0.8 & 0.25 \\
1st cycle & 1.00 & 0.7 & 0.12 \\
2nd cycle & 1.00 & 0.9 & 0.12 \\
3rd cycle & - & - & - \\
4th cycle & & & \\
5th cycle & & & \\
\hline
\end{tabular}

Coefficient of Correlation, Standard Error, and Coefficient of Variation for Shear Load. Sample KR12F4 tested under initial normal load $7.2 \mathrm{kips}$ and applied stiffness $179.9 \mathrm{kips} / \mathrm{in}$.

\begin{tabular}{||c|c|c|c|}
\hline Sample & $\begin{array}{c}\text { Coefficient of } \\
\text { Correlation } \\
\text { KR12F4 }\end{array}$ & $\begin{array}{c}\text { Standard } \\
\text { Error } \\
(\text { s }) \\
\text { (kips) }\end{array}$ & $\begin{array}{c}\text { Coefficient of } \\
\text { Variation } \\
\text { v })\end{array}$ \\
\hline Forward & 0.99 & 0.29 & 0.03 \\
1st cycle & 1.00 & 0.18 & 0.03 \\
2nd cycle & 0.99 & 0.30 & 0.06 \\
3rd cycle & 0.99 & 0.39 & 0.07 \\
4th cycle & - & - & - \\
5th cycle & 0.94 & 1.25 & 0.18 \\
\hline Reverse & 1.00 & 1.14 & 0.21 \\
1st cycle & 1.00 & 0.97 & 0.19 \\
2nd cycle & 1.00 & 0.94 & 0.19 \\
3rd cycle & - & - & - \\
4th cycle & & & \\
5th cycle & &
\end{tabular}


Coefficient of Correlation, standard Error, and Coefficient of Variation for Dilatancy. Sample KR7F3 tested under initial normal load $3.8 \mathrm{kips}$ and applied stiffness $18.8 \mathrm{kips} / \mathrm{in}$.

\begin{tabular}{||c|c|c|c|}
\hline Sample & $\begin{array}{c}\text { Coefficient of } \\
\text { Correlation } \\
\text { KR7F3 }\end{array}$ & $\begin{array}{c}\text { Standard } \\
\text { Error } \\
(\text { s })\end{array}$ & $\begin{array}{c}\text { Coefficient of } \\
\text { Variation } \\
\left(10^{-3} \text { in. }\right)\end{array}$ \\
\hline Forward & 1.00 & & 0.19 \\
1st cycle & 1.00 & 5.6 & 0.24 \\
2nd cycle & 1.00 & 6.1 & 0.27 \\
3rd cycle & 1.00 & 6.2 & 0.26 \\
4th cycle & 0.99 & 5.8 & 0.23 \\
5th cycle & & 5.1 & 0.12 \\
Reverse & 1.00 & & 0.20 \\
1st cycle & 1.00 & 3.1 & 0.26 \\
2nd cycle & 1.00 & 4.2 & 0.32 \\
3rd cycle & 1.00 & 4.9 & 0.32 \\
4th cycle & 1.00 & 5.7 & 5.7 \\
5th cycle & & & \\
\hline
\end{tabular}

Coefficient of Correlation, Standard Error, and Coefficient of Variation for Shear Load. Sample KR7F3 tested under initial normal load $3.8 \mathrm{kips}$ and applied stiffness $18.8 \mathrm{kips} / \mathrm{in}$.

\begin{tabular}{|c|c|c|c|}
\hline $\begin{array}{l}\text { Sample } \\
\text { KR7F3 }\end{array}$ & $\begin{array}{c}\text { Coefficient of } \\
\text { Correlation } \\
(r)\end{array}$ & $\begin{array}{c}\text { Standard } \\
\text { Error } \\
\text { ( s ) } \\
\text { (kips) }\end{array}$ & $\begin{array}{c}\text { Coefficient of } \\
\text { Variation } \\
(v)\end{array}$ \\
\hline $\begin{array}{l}\text { Forward } \\
\text { 1st cycle } \\
\text { 2nd cycle } \\
3 \mathrm{rd} \text { cycle } \\
4 \mathrm{th} \text { cycle } \\
5 \mathrm{th} \text { cycle }\end{array}$ & $\begin{array}{l}0.04 \\
0.92 \\
0.80 \\
0.54 \\
0.54 \\
\end{array}$ & $\begin{array}{l}0.36 \\
0.50 \\
0.61 \\
0.53 \\
0.46 \\
\end{array}$ & $\begin{array}{l}0.12 \\
0.23 \\
0.31 \\
0.28 \\
0.23 \\
\end{array}$ \\
\hline $\begin{array}{l}\text { Reverse } \\
\text { 1st cycle } \\
\text { 2nd cycle } \\
3 \text { rd cycle } \\
4 \text { th cycle } \\
5 \text { th cycle }\end{array}$ & $\begin{array}{l}0.34 \\
0.80 \\
0.62 \\
0.60 \\
0.72 \\
\end{array}$ & $\begin{array}{l}0.53 \\
0.24 \\
0.16 \\
0.14 \\
0.09 \\
\end{array}$ & $\begin{array}{l}0.15 \\
0.09 \\
0.06 \\
0.05 \\
0.03 \\
\end{array}$ \\
\hline
\end{tabular}


Coefficient of Correlation, Standard Error, and Coefficient of Variation for Dilatancy. Sample KR8F3 tested under initial normal load $3.8 \mathrm{kips}$ and applied stiffness $56.3 \mathrm{kips} / \mathrm{in}$.

\begin{tabular}{||c|c|c|c||}
\hline Sample & $\begin{array}{c}\text { Coefficient of } \\
\text { Correlation } \\
\text { KR8F3 }\end{array}$ & $\begin{array}{c}\text { Standard } \\
\text { Error } \\
(\text { s }) \\
\left(10^{-3} \text { in. }\right)\end{array}$ & $\begin{array}{c}\text { Coefficient of } \\
\text { Variation } \\
\text { v })\end{array}$ \\
\hline Forward & 1.00 & 2.2 & 0.07 \\
1st cycle & 1.00 & 1.4 & 0.06 \\
2nd cycle & 1.00 & 3.7 & 0.16 \\
3rd cycle & 1.00 & 4.5 & 0.20 \\
4th cycle & 1.00 & 5.1 & 0.23 \\
5th cycle & & & 0.09 \\
\hline Reverse & 1.00 & 2.4 & 0.18 \\
1st cycle & 1.00 & 3.3 & 0.22 \\
2nd cycle & 0.99 & 3.6 & 0.27 \\
3rd cycle & 0.99 & 4.2 & 0.28 \\
4th cycle & 0.99 & 4.1 & \\
5th cycle & & & \\
\hline
\end{tabular}

Coefficient of Correlation, Standard Error, and Coefficient of

Variation for shear Load. Sample KR8F3 tested under initial normal load $3.8 \mathrm{kips}$ and applied stiffness $56.3 \mathrm{kips} / \mathrm{in}$.

\begin{tabular}{||c|c|c|c||}
\hline Sample & $\begin{array}{c}\text { Coefficient of } \\
\text { Correlation } \\
\text { KR8F3 }\end{array}$ & $\begin{array}{c}\text { Standard } \\
\text { Error } \\
\text { s }) \\
\text { (kips) }\end{array}$ & $\begin{array}{c}\text { Coefficient of } \\
\text { Variation } \\
\text { v })\end{array}$ \\
\hline Forward & 0.98 & 0.71 & 0.20 \\
1st cycle & 0.99 & 0.55 & 0.20 \\
2nd cycle & 0.98 & 0.55 & 0.22 \\
3rd cycle & 1.00 & 0.49 & 0.20 \\
4th cycle & 1.00 & 0.50 & 0.21 \\
5th cycle & & & 0.25 \\
\hline Reverse & 0.92 & 0.94 & 0.24 \\
1st cycle & 0.94 & 0.72 & 0.23 \\
2nd cycle & 0.96 & 0.63 & 0.20 \\
3rd cycle & 0.96 & 0.54 & 0.20 \\
4th cycle & 0.98 & 0.53 & \\
5th cycle & &
\end{tabular}


Coefficient of Correlation, standard Error, and Coefficient of Variation for Dilatancy. Sample KR9F3 tested under initial normal load $3.8 \mathrm{kips}$ and applied stiffness $187.5 \mathrm{kips} / \mathrm{in}$.

\begin{tabular}{|c|c|c|c|}
\hline Sample & $\begin{array}{c}\text { Coefficient of } \\
\text { Correlation } \\
\text { KR9F3 }\end{array}$ & $\begin{array}{c}\text { Standard } \\
\text { Error } \\
(\text { s })\end{array}$ & $\begin{array}{c}\text { Coefficient of } \\
\text { Variation } \\
\left(10^{-3} \text { in. }\right)\end{array}$ \\
\hline Forward & 0.99 & 4.3 & 0.19 \\
1st cycle & 1.00 & 3.5 & 0.22 \\
2nd cycle & 0.99 & 3.3 & 0.22 \\
3rd cycle & 1.00 & 3.2 & 0.24 \\
4th cycle & 1.00 & 3.4 & 0.27 \\
5th cycle & & & \\
\hline Reverse & 0.99 & 3.5 & 0.22 \\
1st cycle & 0.98 & 5.0 & 0.64 \\
2nd cycle & 0.98 & 4.8 & 0.71 \\
3rd cycle & 0.97 & 4.7 & 0.81 \\
4th cycle & 0.99 & 4.6 & \\
5th cycle & & & \\
\hline
\end{tabular}

Coefficient of Correlation, Standard Error, and Coefficient of Variation for Shear Load. Sample KR9F3 tested under initial normal load $3.8 \mathrm{kips}$ and applied stiffness $187.5 \mathrm{kips} / \mathrm{in}$.

\begin{tabular}{||c|c|c|c||}
\hline Sample & $\begin{array}{c}\text { Coefficient of } \\
\text { Correlation } \\
\text { KR9F3 }\end{array}$ & $\begin{array}{c}\text { Standard } \\
\text { Error } \\
(\text { s }) \\
\text { (kips) }\end{array}$ & $\begin{array}{c}\text { Coefficient of } \\
\text { Variation } \\
\text { ( v ) }\end{array}$ \\
\hline Forward & 0.97 & 2.12 & $0.5 r$ \\
1st cycle & 0.94 & 1.62 & 0.5 \\
2nd cycle & 0.97 & 1.46 & 0.54 \\
3rd cycle & 1.00 & 1.23 & 0.47 \\
4th cycle & 1.00 & 1.22 & 0.48 \\
5th cycle & & & \\
\hline Reverse & 0.96 & 2.69 & 0.64 \\
1st cycle & 0.91 & 1.89 & 0.61 \\
2nd cycle & 0.95 & 1.59 & 0.55 \\
3rd cycle & 0.97 & 1.34 & 0.47 \\
4th cycle & 0.99 & 1.33 & 0.49 \\
5th cycle & & & \\
\hline
\end{tabular}


Coefficient of Correlation, standard Error, and Coefficient of Variation for Dilatancy. Sample KR1OF3 tested under initial normal load $7.5 \mathrm{kips}$ and applied stiffness $56.3 \mathrm{kips} / \mathrm{in}$.

\begin{tabular}{|c|c|c|c|}
\hline $\begin{array}{l}\text { Sample } \\
\text { KR10F3 }\end{array}$ & $\begin{array}{c}\text { Coefficient of } \\
\text { Correlation } \\
(r)\end{array}$ & $\begin{array}{c}\text { Standard } \\
\text { Error } \\
(\mathrm{s}) \\
\left(10^{-3} \text { in. }\right)\end{array}$ & $\begin{array}{c}\text { Coefficient of } \\
\text { Variation } \\
(v)\end{array}$ \\
\hline $\begin{array}{l}\text { Forward } \\
\text { 1st cycle } \\
\text { 2nd cycle } \\
3 \text { rd cycle } \\
4 \text { th cycle } \\
5 \text { th cycle }\end{array}$ & $\begin{array}{l}1.00 \\
1.00 \\
1.00 \\
1.00 \\
1.00 \\
\end{array}$ & $\begin{array}{l}12.2 \\
12.6 \\
12.0 \\
12.0 \\
12.2 \\
\end{array}$ & $\begin{array}{l}0.65 \\
1.31 \\
1.82 \\
3.02 \\
6.98 \\
\end{array}$ \\
\hline $\begin{array}{l}\text { Reverse } \\
\text { 1st cycle } \\
2 \text { nd cycle } \\
3 \text { rd cycle } \\
4 \text { th cycle } \\
5 \text { th cycle }\end{array}$ & $\begin{array}{l}1.00 \\
1.00 \\
1.00 \\
1.00 \\
1.00\end{array}$ & $\begin{array}{r}9.7 \\
9.7 \\
10.6 \\
10.6 \\
11.1 \\
\end{array}$ & $\begin{array}{r}0.76 \\
2.12 \\
11.08 \\
7.26 \\
3.17 \\
\end{array}$ \\
\hline
\end{tabular}

Coefficient of Correlation, Standard Error, and Coefficient of Variation for Shear Load. Sample KR1OF3 tested under initial normal load $7.5 \mathrm{kips}$ and applied stiffness $56.3 \mathrm{kips} / \mathrm{in}$.

\begin{tabular}{|c|c|c|c|}
\hline $\begin{array}{l}\text { Sample } \\
\text { KR10F3 }\end{array}$ & $\begin{array}{c}\text { Coefficient of } \\
\text { Correlation } \\
(r)\end{array}$ & $\begin{array}{c}\text { Standard } \\
\text { Error } \\
(\text { s ) } \\
\text { (kips) }\end{array}$ & $\begin{array}{c}\text { Coefficient of } \\
\text { Variation } \\
(v)\end{array}$ \\
\hline $\begin{array}{l}\text { Forward } \\
\text { 1st cycle } \\
\text { 2nd cycle } \\
3 \text { rd cycle } \\
4 \text { th cycle } \\
5 \text { th cycle }\end{array}$ & $\begin{array}{l}0.27 \\
0.93 \\
0.68 \\
0.52 \\
0.46 \\
\end{array}$ & $\begin{array}{l}0.71 \\
0.11 \\
0.20 \\
0.28 \\
0.38 \\
\end{array}$ & $\begin{array}{l}0.10 \\
0.02 \\
0.04 \\
0.06 \\
0.08 \\
\end{array}$ \\
\hline $\begin{array}{l}\text { Reverse } \\
\text { 1st cycle } \\
2 \text { nd cycle } \\
3 \text { rd cycle } \\
4 \text { th cycle } \\
5 \text { th cycle }\end{array}$ & $\begin{array}{l}0.62 \\
0.05 \\
0.50 \\
0.73 \\
0.83\end{array}$ & $\begin{array}{l}2.36 \\
1.76 \\
1.75 \\
1.84 \\
1.67\end{array}$ & $\begin{array}{l}0.25 \\
0.25 \\
0.26 \\
0.28 \\
0.27\end{array}$ \\
\hline
\end{tabular}


Coefficient of Correlation, standard Error, and Coefficient of Variation for Dilatancy. Sample KR11F3 tested under initial normal load $7.5 \mathrm{kips}$ and applied stiffness $187.5 \mathrm{kips} / \mathrm{in}$.

\begin{tabular}{||c|c|c|c||}
\hline Sample & $\begin{array}{c}\text { Coefficient of } \\
\text { Correlation } \\
\text { KR11F3 }\end{array}$ & $\begin{array}{c}\text { Standard } \\
\text { Error } \\
(\text { s }) \\
\left(10^{-3} \text { in. }\right)\end{array}$ & $\begin{array}{c}\text { Coefficient of } \\
\text { Variation } \\
(\mathrm{v})\end{array}$ \\
\hline Forward & & & \\
1st cycle & 0.99 & 4.5 & 0.26 \\
2nd cycle & 0.99 & 4.6 & 0.46 \\
3rd cycle & 0.99 & 5.1 & 0.74 \\
4th cycle & 0.99 & 4.6 & 0.86 \\
5th cycle & 1.00 & 4.3 & 1.07 \\
\hline Reverse & & & 0.49 \\
1st cycle & 0.99 & 5.4 & 1.68 \\
2nd cycle & 0.99 & 5.4 & 26.38 \\
3rd cycle & 0.99 & 6.2 & 3.44 \\
4th cycle & 0.99 & 6.2 & 1.88 \\
5th cycle & 0.99 & 6.5 & \\
\hline
\end{tabular}

Coefficient of Correlation, Standard Error, and Coefficient of Variation for Shear Load. Sample KR11F3 tested under inltial normal load $7.5 \mathrm{kips}$ and applied stiffness $187.5 \mathrm{kips} / \mathrm{in}$.

\begin{tabular}{|c|c|c|c|}
\hline Sample & $\begin{array}{c}\text { Coefficient of } \\
\text { Correlation } \\
\text { KR11F3 }\end{array}$ & $\begin{array}{c}\text { Standard } \\
\text { Error } \\
(\text { s }) \\
\text { (kipg) }\end{array}$ & $\begin{array}{c}\text { Coefficient of } \\
\text { Variation } \\
(\mathrm{v})\end{array}$ \\
\hline Forward & 1.00 & 0.79 & 0.09 \\
1st cycle & 0.97 & 0.76 & 0.12 \\
2nd cycle & 0.99 & 0.68 & 0.12 \\
3rd cycle & 0.99 & 0.70 & 0.12 \\
4th cycle & 0.99 & 0.68 & 0.12 \\
5th cycle & & & 0.09 \\
Reverse & 0.99 & 0.79 & 0.08 \\
1st cycle & 0.93 & 0.54 & 0.08 \\
2nd cycle & 0.98 & 0.46 & 0.08 \\
3rd cycle & 0.99 & 0.45 & 0.07 \\
4th cycle & 1.00 & 0.38 & \\
5th cycle & & & \\
\hline
\end{tabular}


Coefficient of Correlation, standard Error, and Coefficient of Variation for Dilatancy. Sample KR6F2 tested under initial normal load $3.0 \mathrm{kips}$ and applied stiffness $14.8 \mathrm{kips} / \mathrm{in}$.

\begin{tabular}{|c|c|c|c|}
\hline $\begin{array}{l}\text { Sample } \\
\text { KR6F2 }\end{array}$ & $\begin{array}{c}\text { Coefficient of } \\
\text { Correlation } \\
(r)\end{array}$ & $\begin{array}{c}\text { Standard } \\
\text { Error } \\
(\mathrm{s}) \\
\left(10^{-3} \text { in. }\right)\end{array}$ & $\begin{array}{c}\text { Coefficient of } \\
\text { variation } \\
(v)\end{array}$ \\
\hline $\begin{array}{l}\text { Forward } \\
1 \text { st cycle } \\
2 \text { nd cycle } \\
3 \text { rd cycle } \\
4 \text { th cycle } \\
5 \text { th cycle }\end{array}$ & $\begin{array}{l}1.00 \\
1.00 \\
1.00 \\
1.00 \\
1.00 \\
\end{array}$ & $\begin{array}{l}2.6 \\
4.0 \\
4.0 \\
8.4 \\
8.9 \\
\end{array}$ & $\begin{array}{l}0.09 \\
0.18 \\
0.19 \\
0.68 \\
0.83 \\
\end{array}$ \\
\hline $\begin{array}{l}\text { Reverse } \\
\text { 1st cycle } \\
\text { 2nd cycle } \\
3 \text { rd cycle } \\
4 \text { th cycle } \\
5 \text { th cycle }\end{array}$ & $\begin{array}{l}0.99 \\
0.99 \\
0.99 \\
0.99 \\
0.99 \\
\end{array}$ & $\begin{array}{c}5.7 \\
10.3 \\
11.2 \\
17.5 \\
18.4 \\
\end{array}$ & $\begin{array}{l}1.28 \\
3.00 \\
2.20 \\
1.54 \\
1.45 \\
\end{array}$ \\
\hline
\end{tabular}

Coefficient of Correlation, standard Error, and Coefficient of Variation for Shear Load KR6F2 tested under initial normal load $3.0 \mathrm{kips}$ and applied stiffness $14.8 \mathrm{kips} / \mathrm{in}$.

\begin{tabular}{|c|c|c|c|}
\hline $\begin{array}{l}\text { Sample } \\
\text { KR6F2 }\end{array}$ & $\begin{array}{c}\text { Coefficient of } \\
\text { Correlation } \\
(r)\end{array}$ & $\begin{array}{c}\text { Standard } \\
\text { Error } \\
(\mathrm{s}) \\
\text { (kips) }\end{array}$ & $\begin{array}{c}\text { Coefficient of } \\
\text { variation } \\
(\mathrm{v})\end{array}$ \\
\hline $\begin{array}{l}\text { Forward } \\
\text { 1st cycle } \\
2 \text { nd cycle } \\
3 \text { rd cycle } \\
4 \text { th cycle } \\
5 \text { th cycle }\end{array}$ & $\begin{array}{l}0.76 \\
0.07 \\
0.53 \\
0.78 \\
0.47 \\
\end{array}$ & $\begin{array}{l}0.41 \\
0.31 \\
0.28 \\
0.21 \\
0.15 \\
\end{array}$ & $\begin{array}{l}0.19 \\
0.18 \\
0.18 \\
0.14 \\
0.10 \\
\end{array}$ \\
\hline $\begin{array}{l}\text { Reverse } \\
\text { 1st cycle } \\
\text { 2nd cycle } \\
3 \text { rd cycle } \\
4 \text { th cycle } \\
5 \text { th cycle }\end{array}$ & $\begin{array}{l}0.97 \\
0.94 \\
0.89 \\
0.94 \\
0.99\end{array}$ & $\begin{array}{l}0.22 \\
0.17 \\
0.17 \\
0.16 \\
0.22\end{array}$ & $\begin{array}{l}0.13 \\
0.11 \\
0.12 \\
0.12 \\
0.16\end{array}$ \\
\hline
\end{tabular}


Coefficient of Correlation, standard Error, and Coefficient of Variation for Dilatancy. Sample KR7F2 tested under initial normal. load $3.0 \mathrm{kips}$ and applied stiffness $44.3 \mathrm{kips} / \mathrm{in}$.

\begin{tabular}{|c|c|c|c|}
\hline $\begin{array}{l}\text { Sample } \\
\text { KR7F2 }\end{array}$ & $\begin{array}{c}\text { Coefficient of } \\
\text { Correlation } \\
(r)\end{array}$ & $\begin{array}{c}\text { Standard } \\
\text { Error } \\
(\mathrm{s}) \\
\left(10^{-3} \text { in. }\right)\end{array}$ & $\begin{array}{c}\text { Coefficient of } \\
\text { Variation } \\
(v)\end{array}$ \\
\hline $\begin{array}{l}\text { Forward } \\
\text { 1st cycle } \\
\text { 2nd cycle } \\
3 \text { rd cycle } \\
4 \text { th cycle } \\
5 \text { th cycle }\end{array}$ & $\begin{array}{l}1.00 \\
1.00 \\
0.99 \\
0.97 \\
- \\
\end{array}$ & $\begin{array}{l}1.9 \\
1.9 \\
3.9 \\
9.4 \\
-\end{array}$ & $\begin{array}{l}0.07 \\
0.10 \\
0.19 \\
0.40 \\
- \\
\end{array}$ \\
\hline $\begin{array}{l}\text { Reverse } \\
\text { 1st cycle } \\
\text { 2nd cycle } \\
3 \text { rd cycle } \\
4 \text { th cycle } \\
5 \text { th cycle }\end{array}$ & $\begin{array}{l}1.00 \\
0.99 \\
0.98 \\
0.98 \\
-\end{array}$ & $\begin{array}{c}2.1 \\
7.2 \\
14.7 \\
22.0 \\
-\end{array}$ & $\begin{array}{l}0.19 \\
0.58 \\
0.78 \\
0.92 \\
-\end{array}$ \\
\hline
\end{tabular}

Coefficient of Correlation, standard Error, and Coefficient of Variation for Shear Load. Sample KR7F2 tested under initial normal load $3.0 \mathrm{kips}$ and applied stiffness $44.3 \mathrm{kips} / \mathrm{in}$.

\begin{tabular}{|c|c|c|c|}
\hline $\begin{array}{l}\text { Sample } \\
\text { KR7F2 }\end{array}$ & $\begin{array}{c}\text { Coefficient of } \\
\text { Correlation } \\
(r)\end{array}$ & $\begin{array}{c}\text { Standard } \\
\text { Error } \\
\text { (s) } \\
\text { (kips) }\end{array}$ & $\begin{array}{c}\text { Coefficient of } \\
\text { Variation } \\
(v)\end{array}$ \\
\hline $\begin{array}{l}\text { Forward } \\
\text { 1st cycle } \\
\text { 2nd cycle } \\
3 \text { rd cycle } \\
4 \text { th cycle } \\
5 \text { th cycle }\end{array}$ & $\begin{array}{l}0.32 \\
0.97 \\
0.96 \\
0.76 \\
-\end{array}$ & $\begin{array}{l}0.33 \\
0.18 \\
0.28 \\
0.55 \\
.\end{array}$ & $\begin{array}{l}0.13 \\
0.09 \\
0.16 \\
0.40\end{array}$ \\
\hline $\begin{array}{l}\text { Reverse } \\
\text { 1st cycle } \\
\text { 2nd cycle } \\
3 \text { rd cycle } \\
4 \text { th cycle } \\
5 \text { th cycle }\end{array}$ & $\begin{array}{l}0.96 \\
0.94 \\
0.62 \\
0.60\end{array}$ & $\begin{array}{l}0.18 \\
0.16 \\
0.16 \\
0.56 \\
.\end{array}$ & $\begin{array}{l}0.10 \\
0.10 \\
0.11 \\
0.32 \\
.\end{array}$ \\
\hline
\end{tabular}


Coefficient of Correlation, standard Error, and Coefficient of Variation for Dilatancy. Sample KR8F2 tested under initial normal load $3.0 \mathrm{kips}$ and applied stiffness $147.8 \mathrm{kips} / \mathrm{in}$.

\begin{tabular}{||c|c|c|c|}
\hline Sample & $\begin{array}{c}\text { Coefficient of } \\
\text { Correlation } \\
(\mathrm{r})\end{array}$ & $\begin{array}{c}\text { Standard } \\
\text { Error } \\
(\text { sR8 }) \\
\left(10^{-3} \text { in. }\right)\end{array}$ & $\begin{array}{c}\text { Coefficient of } \\
\text { Variation } \\
\text { v })\end{array}$ \\
\hline Forward & & & \\
1st cycle & 1.00 & 8.4 & 0.33 \\
2nd cycle & 1.00 & 7.7 & 0.39 \\
3rd cycle & 1.00 & 8.9 & 0.50 \\
4th cycle & 1.00 & 8.5 & 0.51 \\
5th cycle & 1.00 & 10.6 & 0.66 \\
\hline Reverse & & & 0.41 \\
1st cycle & 0.95 & 2.4 & 2.60 \\
2nd cycle & 0.96 & 4.0 & 20.23 \\
3rd cycle & 0.93 & 4.8 & 10.83 \\
4th cycle & 0.92 & 5.6 & 4.45 \\
5th cycle & 0.92 & 5.3 & \\
\hline
\end{tabular}

Coefficient of Correlation, standard Error, and Coefficient of Variation for Shear load. Sample KR8F2 tested under initial normal load $3.0 \mathrm{kips}$ and applied stiffness $147.8 \mathrm{kips} / \mathrm{in}$.

\begin{tabular}{|c|c|c|c|}
\hline $\begin{array}{l}\text { Sample } \\
\text { KR8F2 }\end{array}$ & $\begin{array}{c}\text { Coefficient of } \\
\text { Correlation } \\
\left(\begin{array}{c}r \\
)\end{array}\right.\end{array}$ & $\begin{array}{c}\text { Standard } \\
\text { Error } \\
(\mathrm{s}) \\
(\mathrm{k} \perp \mathrm{ps})\end{array}$ & $\begin{array}{c}\text { Coefficient of } \\
\text { Variation } \\
(v)\end{array}$ \\
\hline $\begin{array}{l}\text { Forward } \\
\text { 1st cycle } \\
\text { 2nd cycle } \\
3 \text { rd cycle } \\
4 \text { th cycle } \\
5 \text { th cycle }\end{array}$ & $\begin{array}{l}0.98 \\
1.00 \\
0.99 \\
0.91 \\
0.99 \\
\end{array}$ & $\begin{array}{l}0.17 \\
0.21 \\
0.42 \\
0.56 \\
0.73 \\
\end{array}$ & $\begin{array}{l}0.04 \\
0.08 \\
0.16 \\
0.22 \\
0.28 \\
\end{array}$ \\
\hline $\begin{array}{l}\text { Reverse } \\
\text { 1st cycle } \\
\text { 2nd cycle } \\
3 \mathrm{rd} \text { cycle } \\
4 \mathrm{th} \text { cycle } \\
5 \mathrm{th} \text { cycle }\end{array}$ & $\begin{array}{l}0.84 \\
0.42 \\
0.79 \\
0.72 \\
0.50\end{array}$ & $\begin{array}{l}0.18 \\
0.15 \\
0.18 \\
0.21 \\
0.18\end{array}$ & $\begin{array}{l}0.08 \\
0.10 \\
0.12 \\
0.14 \\
0.13\end{array}$ \\
\hline
\end{tabular}


Coefficient of Correlation, Standard Error, and Coefficient of Variation for Dilatancy. Sample KR5'2 tested under initial normal load $1.3 \mathrm{kips}$ and applied stiftness $32.0 \mathrm{kips}$ ! in.

\begin{tabular}{|c|c|c|c|}
\hline $\begin{array}{l}\text { Sample } \\
\text { KR5G2 }\end{array}$ & $\begin{array}{c}\text { Coefficient of } \\
\text { Correlation } \\
(r)\end{array}$ & $\begin{array}{c}\text { Standard } \\
\text { Frror } \\
(\mathrm{s}) \\
\left(10^{-3} \text { in. }\right)\end{array}$ & $\begin{array}{c}\text { Coefficient of } \\
\text { variation } \\
(v)\end{array}$ \\
\hline $\begin{array}{l}\text { Forward } \\
\text { 1st cycle } \\
\text { 2nd cycle } \\
3 \text { rd cycle } \\
4 \text { th cycle } \\
5 \mathrm{th} \text { cycle }\end{array}$ & $\begin{array}{c}1.00 \\
1.00 \\
- \\
- \\
- \\
\end{array}$ & $\begin{array}{r}5.9 \\
17.2 \\
- \\
- \\
- \\
\end{array}$ & $\begin{array}{c}0.21 \\
0.88 \\
- \\
- \\
- \\
\end{array}$ \\
\hline $\begin{array}{l}\text { Reverse } \\
\text { 1st cycle } \\
\text { 2nd cycle } \\
\text { 3rd cycle } \\
4 \text { th cycle } \\
5 \text { th cycle }\end{array}$ & $\begin{array}{c}0.99 \\
0.93 \\
- \\
- \\
-\end{array}$ & $\begin{array}{c}37.6 \\
56.7 \\
- \\
- \\
- \\
\end{array}$ & $\begin{array}{c}4.59 \\
3.54 \\
- \\
- \\
- \\
\end{array}$ \\
\hline
\end{tabular}

Coefficient of Correlation, Standard Error, and Coefficient of Variation for Shear Load. Sample KR5G2 tested under initial normal load $1.3 \mathrm{kips}$ and applied stiffness $32.0 \mathrm{kips} / \mathrm{in}$.

\begin{tabular}{|c|c|c|c|}
\hline $\begin{array}{l}\text { Sample } \\
\text { KR5G2 }\end{array}$ & $\begin{array}{c}\text { Coefficient of } \\
\text { Correlation } \\
(r)\end{array}$ & $\begin{array}{c}\text { Standard } \\
\text { Error } \\
(\mathrm{s}) \\
\text { (kips) }\end{array}$ & $\begin{array}{c}\text { Coefficient of } \\
\text { variation } \\
(\mathrm{v})\end{array}$ \\
\hline $\begin{array}{l}\text { Forward } \\
\text { 1st cycle } \\
\text { 2nd cycle } \\
3 \text { rd cycle } \\
4 \text { th cycle } \\
5 \text { th cycle }\end{array}$ & $\begin{array}{c}0.98 \\
0.99 \\
. \\
- \\
- \\
\end{array}$ & $\begin{array}{c}0.56 \\
0.29 \\
- \\
- \\
- \\
\end{array}$ & $\begin{array}{c}0.28 \\
0.16 \\
- \\
- \\
- \\
\end{array}$ \\
\hline $\begin{array}{l}\text { Reverse } \\
\text { 1st cycle } \\
\text { 2nd cycle } \\
3 \text { rd cycle } \\
4 \text { th cycle } \\
5 \text { th cycle }\end{array}$ & $\begin{array}{c}0.99 \\
0.76 \\
- \\
- \\
-\end{array}$ & $\begin{array}{c}0.36 \\
0.30 \\
- \\
- \\
-\end{array}$ & $\begin{array}{c}0.39 \\
0.39 \\
. \\
. \\
-\end{array}$ \\
\hline
\end{tabular}


Coefficient of Correlation, Standard Error, and Coefficient of Variation for Dilatancy. Sample KR6G2 tested under initial normal lcad $6.4 \mathrm{kips}$ and applied stiffness $64.0 \mathrm{kips} / \mathrm{in}$.

\begin{tabular}{|c|c|c|c|}
\hline $\begin{array}{l}\text { Sample } \\
\text { KR6G2 }\end{array}$ & $\begin{array}{c}\text { Coefficient of } \\
\text { Correlation } \\
(r)\end{array}$ & $\begin{array}{c}\text { Standard } \\
\text { Error } \\
(\mathrm{s}) \\
\left(10^{-3} \text { in. }\right)\end{array}$ & $\begin{array}{c}\text { Coefficient of } \\
\text { Variation } \\
(v)\end{array}$ \\
\hline $\begin{array}{l}\text { Forward } \\
\text { 1st cycle } \\
\text { 2nd cycle } \\
3 \text { rd cycle } \\
4 \text { th cycle } \\
5 \text { th cycle }\end{array}$ & $\begin{array}{c}1.00 \\
0.83 \\
- \\
- \\
- \\
\end{array}$ & $\begin{array}{r}4.6 \\
19.4 \\
- \\
- \\
- \\
\end{array}$ & $\begin{array}{c}0.23 \\
8.84 \\
- \\
- \\
- \\
\end{array}$ \\
\hline $\begin{array}{l}\text { Reverse } \\
\text { 1st cycle } \\
\text { 2nd cycle } \\
3 \text { rd cycle } \\
4 \text { th cycle } \\
5 \text { th cycle }\end{array}$ & $\begin{array}{c}0.23 \\
0.64 \\
- \\
- \\
-\end{array}$ & $\begin{array}{l}22.4 \\
27.6 \\
- \\
- \\
-\end{array}$ & $\begin{array}{l}1.12 \\
0.91 \\
- \\
- \\
-\end{array}$ \\
\hline
\end{tabular}

Coefficient of Correlation, standard Error, and Coefficient of Variation for Shear Load. Sample KR6G2 tested under initial normal load $6.4 \mathrm{kips}$ and applied stiffness $64.0 \mathrm{kips} / \mathrm{in}$.

\begin{tabular}{|c|c|c|c|}
\hline $\begin{array}{l}\text { Sample } \\
\text { KR6G2 }\end{array}$ & $\begin{array}{c}\text { Coefficient of } \\
\text { Correlation } \\
(r)\end{array}$ & $\begin{array}{c}\text { Standard } \\
\text { Error } \\
(\text { s }) \\
(\text { kips })\end{array}$ & $\begin{array}{c}\text { Coefficient of } \\
\text { Variation } \\
(v)\end{array}$ \\
\hline $\begin{array}{l}\text { Forward } \\
\text { 1st cycle } \\
\text { 2nd cycle } \\
3 \text { rd cycle } \\
4 \text { th cycle } \\
5 \text { th cycle }\end{array}$ & $\begin{array}{c}0.99 \\
0.71 \\
- \\
- \\
-\end{array}$ & $\begin{array}{c}0.34 \\
0.91 \\
- \\
- \\
-\end{array}$ & $\begin{array}{l}0.05 \\
0.15 \\
- \\
- \\
-\end{array}$ \\
\hline $\begin{array}{l}\text { Reverse } \\
\text { 1st cycle } \\
\text { 2nd cycle } \\
3 \text { rd cycle } \\
4 \text { th cycle } \\
5 \text { th cycle }\end{array}$ & $\begin{array}{l}0.99 \\
0.73 \\
- \\
- \\
-\end{array}$ & $\begin{array}{l}1.62 \\
1.22 \\
- \\
- \\
-\end{array}$ & $\begin{array}{l}0.38 \\
0.31 \\
- \\
-\end{array}$ \\
\hline
\end{tabular}




\title{
APPENDIX \\ Information from the Reference Information Base \\ Used in this Report
}

This report contains no information from the Reference Information Base.

\author{
Candidate Information \\ for the \\ Reference Information Base
}

This report contains no candidate information for the Reference Information Base.

\author{
Candidate Informalion \\ for the \\ Geographic Nodal Information Study \\ and Evaluation System
}

This report contains no candidate information for the Geographic Nodal Information Study and Evaluation System. 


\section{YUCCA MOUNTAIN SITE CHARACTERIZATION PROJECT}

\section{DISTRIHUTION LIST}

1

L. H. Barrett (RW-1)

Acting Director

OCRWM

US Department of Energy

1000 Independence Avenue SW

Washington, DC 20585

$1 \quad$ J. D. Saltzman (RW.2)

Acting Deputy Director

OCRWM

US Department of Energy

1000 Independence Avenue SW

Washington, DC 20585

1 C. Kouts (RW-4)

Omce of Strategle Plunning and

International Programs

OCRWM

US Department of Enerzy

1000 Independence Avenue SW

Washington, DC: 20585

1 A. Benson (RW-5)

Omce of External kelations

OCRWM

US Department of Energy

10MO Independence Avenue SW

Washington, DC 20585

1 Samuel Rousso (RW-10)

Omce of Program and Resource Mgt.

OCRWM

US Department of Eneryy

1000 Independence Avenue SW

Washington, DC: 20585

1
J. C. Bresee (RW-1(1))

OCRWM

US Department of Energy

1000) Independence Avenue SW

Wast.Ington, DC 20585
1 L. M. Smlth (RW.20)

Omce of Geolougle Disposul

OCRWM

US Department of Enerwy

1000 Independence Avenue, SW

Washington, DC 20885

1 S. J. Brocoum (RW.22)

Analywis and Verincution Division

OCRWM

US Depurtment of Enervy

10OO Independence Avenue SW

Washington, DC 2585

1 D. Shelor (RW-30)

Omce of Systems and Compllance

OCRWM

US Department of Enervy

100) Independence Avenue, SW

Wushington, DC 2058s

I J. Roberts (RW-33)

Director, Regulatory Compllunce

Divislon

OCRWM

US Depurtment of Energy

IOMO Independence Avenue, sW

Washington, DC 2058s

1

(j. J. Purker (RW.3.32)

OCRWM

US Depurtment of Enerwy

1000) Independence Avenue, sW

Wushington, DC 20585

1 R. A. Milner (RW-40)

(OMce of Storuge und

Trunsporation

OCRWM

US Department of Eneruy

IMOO Independence Avenue, SW

Wushington, DC 20585 
S. Rousso (RW-50)

Omce of Contract Business

Management

OCRWM

US Department of Energy

1000 Independence Avenue, SW

Washington, DC 20585

1 T. Wood (RW-52)

Director, M\&O Management Division

OCRWM

US Department of Energy

1000 Independence Avenue, SW

Washington, DC 20585

4 Victoria F. Reich, Librarian

Nuclear Waste Technical Review Board

1100 Wilson Blvd, Suite 910

Arlington, VA 22209

5 C. P. Gertz, Project Manager

Yucca Mountain Site

Characterization Project Omice

US Department of Energy

P.O. Box 98608--MS 523

Las Vegas, NV 89193-8608

1 C. L. West, Director

Omce of External Affairs

DOE Nevada Field Omce

US Department of Energy

P.O. Box 98518

Las Vegas, NV 89193-8518

8 Technical Infurmation Omicer

DOE Nevada Field Omce

US Department of Energy

P.O. Box 98518

Las Vegas, NV 89193-8518

1 P. K. Fitzsimmons, Technical Advisor

Omce of Assistant Manager for

Environmental Safety and

Health

DOE Nevada Field Office

US Department of Energy

P.O. Box 98518

Las Vegas, NV 89193-8518
1

D. R. Elle, Director

Environmental Protection and Division DOE Nevada Field Omce

US Department of Energy

P.O. Box 98518

Las Vegas, NV 89193-8518

$1 \quad$ Repository Licensing \& Quality

Assurance

Project Directorate

Division of Waste Management

US NRC

Washington, DC 20555

1 Senior Project Manager for Yucca

Mountain

Repository Project Branch

Division of Waste Management

US NRC

Washington, DC 20555

$1 \quad$ NRC Document Control Desk

Division of Waste Management

US NRC

Washington, DC 20555

$1 \quad$ Philip S. Justus

NRC Site Representive

301 E Stewart Avenue, Room 203

Las Vegas, NV 89101

1 E. P. Binnall

Field Systems Group Leader

Building 50B/4235

Lawrence Berkeley Laboratory

Berkeley, CA 94720

1

Center for Nuclear Waste

Regulatory Analyses

6220 Culebra Road

Drawer 28510

San Antonio, TX 78284

3

W. L. Clarke

Technical Project Officer - YMP

Attn: YMP/LRC

Lawrence Livermore National

Laboratory

P.O. Box 5514

Livermore, CA 94551

Distribution - 2 
1

J. A. Blink

Deputy Project Leader

Lawrence Livermore National

Laboratory

101 Convention Center Drive

Suite 820, MS 527

Las Vegas, NV 89109

4

J. A. Canepa

Technical Project Oficer - YMP

N-5, Mail Stop J521

Los Alamos National Laboratory

P.O. Box 1663

Los Alamos, NM 87545

$1 \quad$ H. N. Kalia

Exploratory Shan Test Manager

Los Alamos National Laboratory

Mail Stop 527

101 Convention Center Dr., \#820

Las Vegas, NV 89101

$1 \quad$ N. Z. Elkins

Deputy Technical Project Omcer

Los Alamos National Laboratory

Mail Stop 527

101 Convention Center Dr., $\# 820$

Las Vegas, NV 89101

5

L. E. Shephard

Technical Project Ofincer - YMP

Sandia National Laboratories

Organization 6302

P.O. Box 5800

Albuquerque, NM 87185

1

J. F. Devine

Asst Director of Engineering Geology

US Geological Survey

106 National Center

12201 Sunrise Valley Drive

Reston, VA 22092

1 L. R. Hayes

Technical Project Officer

Yucca Mountain Project Branch

MS 425

US Geological Survey

P.O. Box 25046

Denver, CO 80225
V. R. Schneider

Asst. Chief Hydrologist--MS 414

Omce of Program Coordination

and Technical Support

US Geological Survey

12201 Sunrise Valley Drive

Reston, VA 22092

1

J. S. Stuckless

Geologic Division Coordinator

MS 913

Yucca Mountain Project

US Geological Survey

P.O. Box 25046

Denver, CO 80225

1 D. H. Appel, Chief

Hydrologic Investigations Program

MIS 421

US Geological Survey

P.O. Box 25046

Denver, CO 80225

1

E. J. Helley

Branch of Western Regional Geology

MS 427

US Geological Survey

345 Middlefield Road

Menlo Park, CA 94025

1

R. W. Craig, Chief

Nevada Operations Omce

US Geological Survey

101 Convention Center Drive

Suite 860, MS 509

Las Vegas, NV 89109

1

D. Zesiger

US Geological Survey

101 Conventional Center Drive

Suite 860, MS 509

Las Vegas, NV 89109

1

G. L. Ducret, Associate Chief

Yucca Mountain Project Division

US Geological Survey

P.O. Box 25046

421 Federal Center

Denver, CO 80225 
A. L. Flint

US Geological Survey

MS 721

P.O. Box 327

Mercury, NV 89023

1 D. A. Beck

Water Resources Division, USGS

6770 S Paradise Road

Las Vegas, NV 89119

1 P. A. Glancy

US Geological Survey

Federal Building, Room 224

Carson City, NV 89701

1 Sherman S.C. Wu

Branch of Astrogeology

US Geological Survey

2255 N Gemini Drive

Flagstafr, AZ 86001

1

J. H. Sass - USGS

Branch of Tectonophysics

2255 N Gemini Drive

Flagstaff, AZ $\mathbf{8 6 0 0 1}$

1 DeWayne Campbell

Technical Project Omcer - YMP

US Bureau of Reclamation

Code D-3790

P.O. Box 25007

Denver, CO 80225

1

J. M. LaMonaca

Records Specialist

US Geological Survey

421 Federal Center

P.O. Box 25046

Denver, CO 80225

1 W. R. Keefer - USGS

913 Federal Center

P.O. Box 25046

Denver, CO 80225

1

M. D. Voegele

Technical Project Omcer - YMP

SAIC

101 Convention Center Drive

Suite 407

Las Vegas, NV 89109
L. D. Foust

Nevada Site Manager

TRW Environmental Safety

Systems

101 Convention Center Drive

Suite 540, MS 423

Las Vegas, NV 89109

1

C. E. Ezra

YMP Support Omce Manager

EG\&G Energy Measurements Inc MS V -02

P.O. Box 1912

Las Vegas, NV 89125

E. L. Snow, Program Manager

Roy F. Weston Inc

955 L'Enfant Plaza SW

Washington, DC 20024

1 Technical Information Center

Roy F. Weston Inc

955 L'Enfant Plaza SW

Washington, DC 20024

1 D. Hedges, Vice President, QA

Roy F. Weston Inc

4425 Spring Mountain Road

Suite $\mathbf{3 0 0}$

Las Vegas, NV 89102

1 D. L. Fraser, General Manager

Reynolds Electrical \&

Engineering $\mathrm{Co}$, Inc

MS 555

P.O. Box 98521

Las Vegas, NV 89193-8521

1

B. W. Colston, President and

General Manager

Las Vegas Branch

Raytheon Services Nevada

MS 416

P.O. Box 95487

Las Vegas, NV 89193-5487

1

R. L. Bullock

Technical Project Officer - YMP

Raytheon Services Nevada

Suite P-250, MS 403

101 Convention Center Drive

Las Vegas, NV 89109 
PASS Program

Pacific Northwest Laboratories

P.O. Box 999

Richland, WA 99352

1

A. T. Tamura

Science and Technology Division

OSTI

US Department of Energy

P.O. Box 62

Oak Ridge, TN 37831

1 Carlos G. Bell Jr

Professor of Civil Engineering

Clvil and Mechanical Engineering Dept.

University of Nevada, Las Vegas

4505 S Maryland Parkway

Las Vegas, NV 89154

1 P. J. Weeden, Acting Director

Nuclear Radiation Assessment Div.

US EPA

Environmental Monitoring

Systems Lab

P.O. Box 93478

Las Vegas, NV 89193-3478

$1 \quad$ ONWI Library

Battelle Columbus Laboratory

Omce of Nuclear Waste Isolation

505 King Avenue

Columbus, OH 43201

1 T. Hay, Executive Assistant

Omce of the Governor

State of Nevada

Capitol Complex

Carson City, NV 89710

R. R. Loux

Executive Director

Agency for Nuclear Projects

State of Nevada

Evergreen Center, Suite 252

1802 N. Carson Street

Carson City, NV 89710
1

C. H. Johnson

Technical Program Manager

Agency for Nuclear Projects

State of Nevada

Everyreen Center, Suite 252

1802 N. Carson Street

Carson City, NV 89710

1 John Fordham

Water Resources Center

Desert Research Institute

P.O. Box 60220

Reno, NV 89506

1 David Rhode

Desert Research Institute

P.O. Box 60220

Reno, NV 89506

$1 \quad$ Eric Anderson

Mountaln West Research-

Southwest Inc

2901 N Central Avenue \#1000

Phoenix, AZ 85012-2730

I The Honorable Cyril Schank

Chairman

Churchill County Board of

Commissioners

190 W First Street

Fallon, NV 89406

1 Dennis Bechtel, Coordinator

Nuclear Waste Division

Clark County Department of

Comprehensive Planning

301 E Clark Avenue, Suite 570

Las Vegas, NV 89101

1 Juanita D. Hofrman

Nuclear Waste Repository

Oversight Program

Esmeralda County

P.O. Box 490

Goldmeld, NV 89013

1 Eureka County Board of Commissioners

Yucca Mountain Information

Omce

P.O. Box 714

Eureka, NV 89316

Distribution - 5 
Brad Mettam

Inyo County Yucca Mountuin Repository Assessment Omce

Drawer L

Independence, CA 93526

1 Lander County Bourd of Commissioners

315 South Humbolt

Battle Mountain, NV 89820

1 Vernon E. Poe

Omce of Nuclear Projects

Mineral County

P.O. Box 1026

Hawthorne, NV 89415

1 Les W. Bradshaw

Program Manager

Nye County Nuclear Waste

Repository Program

P.O. Box 153

Tonopah, NV 89(1)49

$1 \quad$ Florindo Mariani

White Pine County Nuclear

Waste Project Omce

457 Finth Street

Ely, NV 89301

1 Judy Foremaster

City of Caliente Nuclear Waste

Project Omce

P.). Box 158

Caliente, NV 89408

1 Phillip A. NledzielskJ-Eichner

Nye County Nuclear Waste

Repository Project Ofince

P.O. Box 221274

Chantllly, VA 22022.1274

1 Jason Pitts

LIncoln County Nuclear Waste

Project Omce

Lincoln County Courthouse

Pioche, NV 89(1)43
1 Economic Development Dept.

City of Las Vegas

400 E. Stewart Avenue

Las Vegas, NV 89101

1 Commmunity Planning and

Development

Clty of North Las Vegas

P.O. Box 4086

North Las Vegas, NV 89030

1 Community Development and

Planning

City of Boulder City

P.O. Box 61350

Boulder City, NV 89M06

1 Commission of the European

Communities

2(X) Rue de la Lol

B-1(1)49 Brussells

BELGiIUM

6 M. J. Dorsey, Llbrarian

YMP Reseurch and Study Center

Reynolds Electricul \&

Englneering Co Inc

MS 4107

P.(). Box 98521

Las Vegus, NV 89193-8521

1 Amy Anderson

Argonne Nutlonal Laboratory

Bullding 362

9700 S Cass Avenue

Argonne, IL 61)439

$1 \quad$ Steve Bradhurst

P.(). Box 1510

Reno, NV 895015

1 Mlchuel L. Huughmun

35 Clurk Roud

Fiskdule, MA (01518

1 Gienn Van Roekel

Director of Community

Development

City of Cullente

P.(). Box 158

Cullente, NV $89(M) 8$ 
1 Ray WIlllams, Jr

P.O. Box 10

Austin, NV 89310

1 Charles Thistlethwalte, AICP

Associate Planner

Inyo County Planning Department

Druwer L

Independence, CA 93526

$1 \quad$ Nye County District Attorney

P.0. Box 593

Tonopah, NV 89049

1 William Omutt

Nye County Manayer

Tonopah, NV 89049

1 R. F. Pritchett

Technicul Project Omcer - YMP

Reynolds Electrical \&

Engineering Company Inc

MS 408

P.(). Box 98521

Las Vegas, NV 89193-8521

1 Dr. Moses Karukouzlun

1751 E Reno $\$ 125$

Las Veuas, NV 89119

30 Dr. Bernurd Amudel

University of Colorado

Department of Civll Englueering

Campus Box 428

Boulder, (C) B(1)3(19-142X
6300 D.E. Ellis

6302 L.E. Shephard

6312 H.A. Dockery

6313 L.S. Costin

6313 R.H. Price

$20 \quad 6313$

26352

6352 G.M. (ierstner-MIller for DRMS nles

$20 \quad 6352 \quad$ WMT Llbrury

16319 R.R. Rlchards

16115 P.H. Duvles

$1 \quad 1502$ PJ. Hommert

I 6410 D.A. Dahlyren

57141 Technical Library

17151 Technicul Publlcutlons

10 7613.2 Document Processing for DOE/()STI

1 8523-2 Centrul Technicul Files 
SAND92-2247

The number in the lower right-hand corner is an accession number used for Omce of Civilian Radioactive Waste Management purposes only. It should not be used when ordering this publication. 


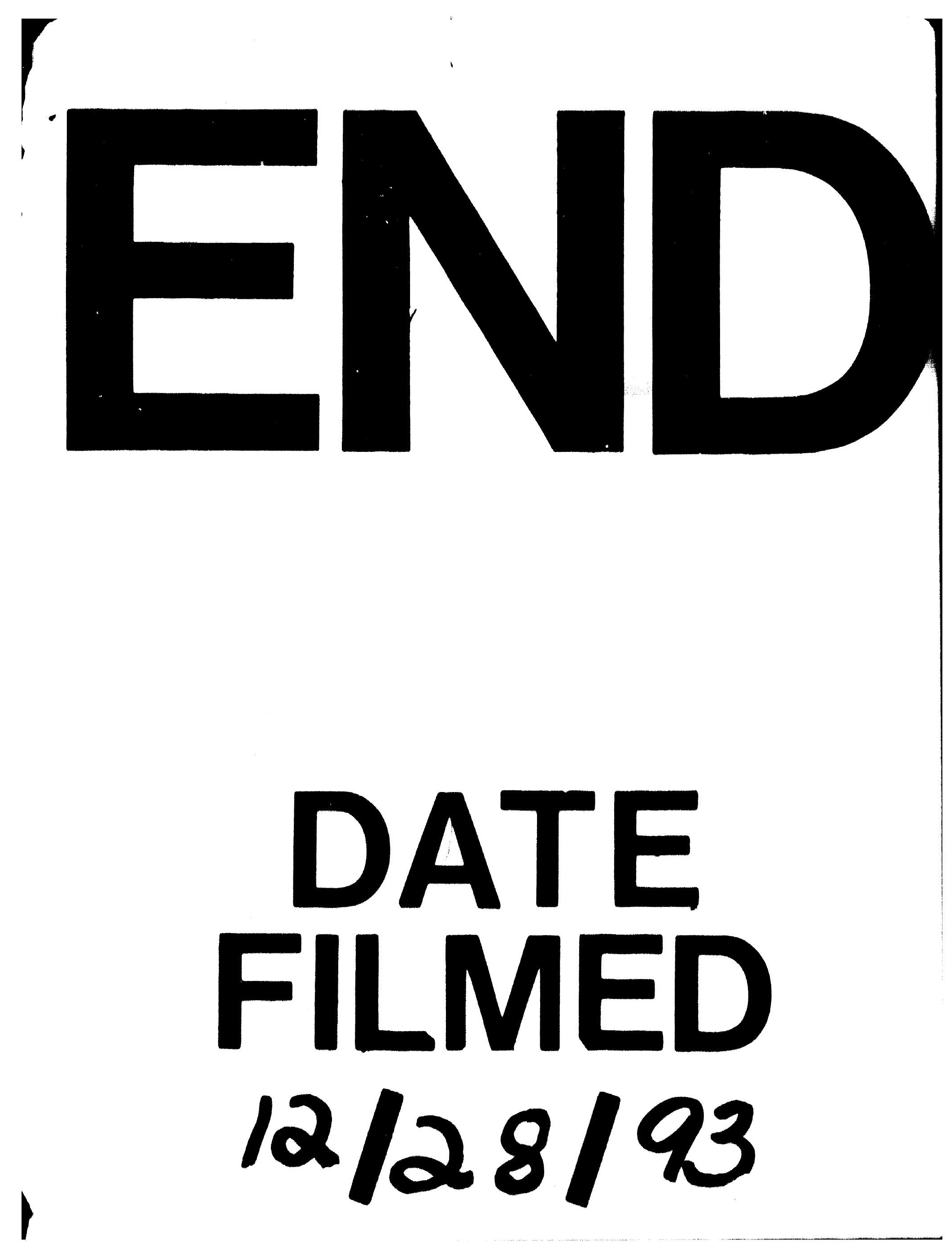



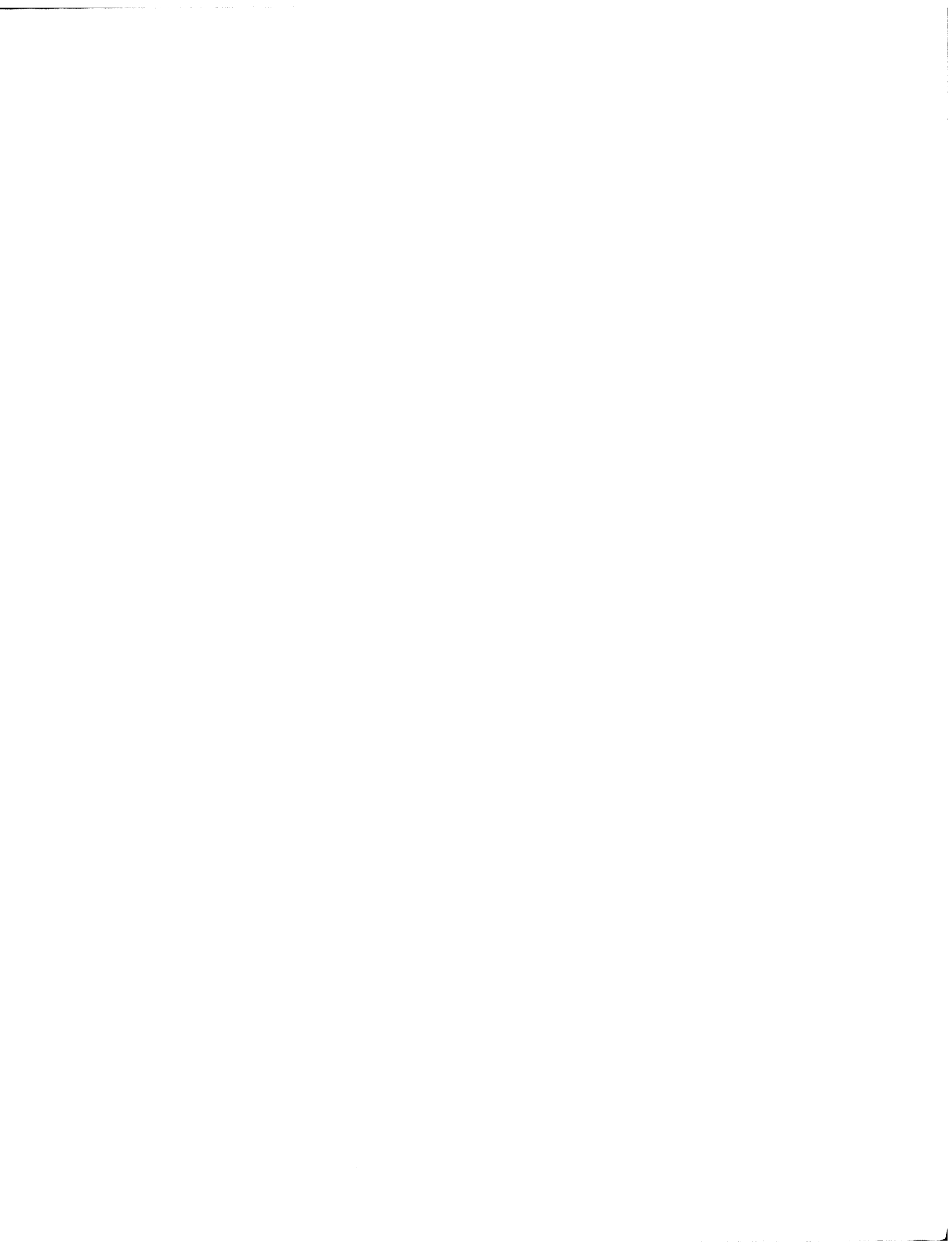